UNIVERSIDADE DE SÃO PAULO

FACULDADE DE FILOSOFIA, LETRAS E CIENCIAS HUMANAS

DEPARTAMENTO DE GEOGRAFIA

JOSÉ GUILHERME SCHUTZER

DISPERSÃO URBANA E APROPRIAÇÃO DO RELEVO NA

MACROMETRÓPOLE DE SÃO PAULO

São Paulo 
JOSÉ GUILHERME SCHUTZER

\section{DISPERSÃO URBANA E APROPRIAÇÃO DO RELEVO NA MACROMETRÓPOLE DE SÃO PAULO}

Tese apresentada ao Departamento de Geografia da Faculdade de Filosofia, Letras e Ciências Humanas da Universidade de São Paulo para a obtenção do título de Doutor em Geografia.

Área de Concentração: Geografia Física Geomorfologia

Orientador: Prof. Dr. Adilson Avansi de Abreu

São Paulo 
AUTORIZO A REPRODUÇÃO E DIVULGAÇÃO TOTAL OU PARCIAL DESTE TRABALHO, POR QUALQUER MEIO CONVENCIONAL OU ELETRÔNICO, PARA FINS DE ESTUDO E PESQUISA, DESDE QUE CITADA A FONTE.

\author{
Catalogação na Publicação \\ Serviço de Documentação \\ Faculdade de Filosofia, Letras e Ciências Humanas \\ da Universidade de São Paulo
}

Schutzer, José Guilherme

Dispersão Urbana e Apropriação do Relevo na Macrometrópole de São Paulo. José Guilherme Schutzer. Orientador: Prof. Dr. Adilson Avansi de Abreu. São Paulo, 2012.

Tese (doutorado, Programa de Pós-graduação em Geografia - Área de Concentração: Geografia Física - Geomorfologia) - Faculdade de Filosofia Letras e Ciencias Humanas da Universidade de São Paulo.

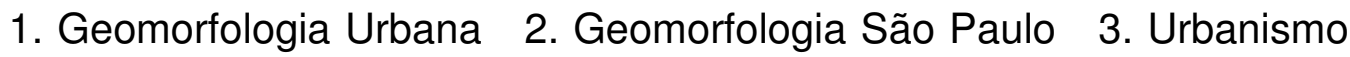
I - Título 


\section{FOLHA DE APROVAÇÃO}

José Guilherme Schutzer

Dispersão Urbana e Apropriação do Relevo na Macrometrópole de São Paulo.

Tese apresentada ao Departamento de Geografia da Faculdade de Filosofia, Letras e Ciências Humanas da Universidade de São Paulo para a obtenção do título de Doutor em Geografia.

Área de Concentração: Geografia Física Geomorfologia

Aprovado em:

Banca Examinadora

Prof. Dr.

Instituição Assinatura

Prof. Dr.

Instituição Assinatura

Prof. Dr.

Instituição Assinatura

Prof. Dr.

Instituição Assinatura

Prof. Dr. Instituição Assinatura 
Dedicatória

À minha esposa Ana Cecília, aos meus filhos Ana Carolina e Marcelo, e a Ana Schutzer, minha mãe. 


\section{AGRADECIMENTOS}

Ao Prof. Dr. Adilson Avansi de Abreu, pela atenção e apoio durante o processo de definição do trabalho e orientação.

Ao Departamento de Geografia da Faculdade de Filosofia Letras e Ciências Humanas pela oportunidade de realização do doutorado. 


\section{RESUMO}

Schutzer, José Guilherme. Dispersão Urbana e Apropriação do Relevo na Macrometrópole de São Paulo. 2012. Tese (Doutorado) - Departamento de Geografia da Faculdade de Filosofia Letras e Ciencias Humanas, Universidade de São Paulo, 2012.

Esta pesquisa apresenta um retrato da dispersão urbana que ocorre na região da Macrometrópole de São Paulo sobre a ótica da apropriação do relevo. Quais são os compartimentos de relevo que estão sendo ocupados pelas peças urbanas que se dispersam sobre a área anteriormente utilizada pelos usos relativos ao mundo rural, e em que medida essas peças urbanas residenciais, industriais ou mistas, diferem da morfologia de suas congêneres da cidade compacta, e as consequências ambientais decorrentes dessa forma de apropriação. A partir de uma proposta metodológica de abordagem estratégica do relevo na escala regional, e tendo como base categorias de análise da geomorfologia, este trabalho identifica no processo de dispersão, além de uma tendência de ocupação indiscriminada, e sem critérios ambientalmente claros, de todos os tipos de compartimento de relevo, inclusive daqueles que se pode considerar como compartimentos ambientais estruturantes da paisagem regional para a regulação dos processos naturais e de sua ocorrência não conflituosa com os usos urbanos. Essa ocupação dispersa, que impacta esses compartimentos ambientais estruturantes, é realizada tanto pelas camadas de alta e de baixa renda, como também pelos usos industriais e de comércio atacadista, embora esses grupos apresentem predominância em vetores de dispersão diferentes.

Palavra-chave: Geomorfologia. Geomorfologia Urbana. Urbanismo. 


\begin{abstract}
Schutzer, José Guilherme. Urban Dispersion and Relief Appropriation in the Large Metropolitan Concentration of São Paulo. 2012. Thesis (Ph.D.) -

Department of Geography, Faculty of Philosophy, Letters and Human Sciences, University of São Paulo, 2012.
\end{abstract}

This research presents a portrait of the urban sprawl that occurs in the large metropolitan area of São Paulo, in view of the allocation of relief. Which relief sectors are occupied by urban works that disperse over the region formerly used by the rural area, and to what extent these residential, industrial or mixed urban works differ from the morphology of its equivalents in a compact city, and the environmental consequences resulting from this form of allocation. From a methodological proposal for a strategic approach to relief on a regional scale, and based on analytical categories of geomorphology, this paper identifies the dispersion process and a trend of indiscriminate occupation, without clear environmental criteria, of all types of relief sectors, including those that can be considered as environmental zones of regional landscape designated for the regulation of natural processes and their occurrence without conflict with urban uses. This dispersed occupation, which impacts these environmental zones is performed by both levels of high and low income, but also by industrial uses and wholesale trade, although these groups predominate in different dispersal vectors.

Keyword: Geomorphology. Urban Geomorphology. Urbanism. 


\section{LISTA DE ILUSTRAÇÕES}

Figura 2.1 - Expansão linear da cidade de São Paulo em quatro séculos, segundo Aroldo de Azevedo, e sua relação com os compartimentos de relevo.

Figura 2.2 - Mapa esquemático da ocupação urbana de São Paulo e arredores em 1962, segundo Langenbuch.

Figura 2.3 - Diagramas esquemáticos da proposta de Cidades Jardins de Amanhã, de Howard, em 1898.

Figura 2.4 - Anéis agrários de Thünen - "Teoria do Estado Isolado".

Figura 3.1 - Estudos de compartimentação topográfica e ambiental organizados por Mcharg para a região de The Valleys, em Baltimore (EUA) - 1962.

Figura 3.2 - Esquemas utilizados na abordagem espacial da Ecologia da Paisagem

Figura 5.1 - Condomínio fechado de Aldeia da Serra, em Barueri/SP, na vertente norte da Serra do Itaqui.

Figura 5.2 - Detalhe da ocupação das quadras do condomínio fechado de Aldeia da Serra, em Barueri/SP.

Figura 5.3 - Detalhe da tipologia de ocupação de uma quadra do condomínio fechado de Aldeia da Serra, em Barueri/SP.

Figura 5.4 - Condomínio fechado Tamboré 10 - Terras Altas, em Barueri/SP, na vertente sul do divisor de águas Tietê-Juqueri. Vista geral e detalhe de quadra e lotes.

Figura 5.5 - Detalhe do padrão de ocupação de Alphaville, Barueri/SP.

Figura 5.6 - O padrão de ocupação Tamboré: Condomínio Resorte Tamboré (edifícios) e condomínio fechado horizontal, Barueri/SP.

Figura 5.7 - Condomínio fechado de alta renda em Ibiúna/SP. Vista geral e detalhe interno.

Figura 5.8 - Condomínio fechado Morada do Sol, em Santana do Parnaíba/SP, situado no vetor de expansão da Rod. Castelo Branco. Vista geral e detalhe interno.

Figura 5.9 - Condomínio fechado em Caucaia do Alto, Município de Cotia/SP.

Figura 5.10 - Condomínios fechados de alta renda em Vinhedo/SP: Marambaia e Vinhas Vista Alegre.

Figura 5.11 - Vista geral do condomínio fechado de alta renda Fazenda Vila Real, em Itú/SP.

Figura 5.12 - Detalhe do parcelamento e da ocupação interna dos lotes do condomínio fechado de alta renda Fazenda Vila Real, em Itú/SP.

Figura 5.13 - Condomínio fechado de chácaras de alta renda Alpes da Cantareira, Mairiporã/SP.

Figura 5.14 - Condomínio fechado de chácaras de alta renda na Região dos 5 Lagos e Jd. Maria Antonina, Mairiporã/SP.

Figura 5.15 - Condomínio loteamento de chácaras na região de Guacuri, Itupeva/SP.

Figura 5.16 - Loteamento de chácaras de alta renda em Ibiúna/SP.

Figura 5.17 - Condomínios e loteamentos de chácaras de alta renda no entorno da represa Paiva Castro, Mairiporã/SP. 
Figura 5.18 - Condomínios e loteamentos de chácaras de alta renda no entorno da represa de Jaguari, Igaratá/SP.

Figura 5.19 - Tecido urbano misto na divisa de Santana do Parnaíba com Cajamar/SP. Loteamentosde baixa renda ao longo da Estrada Tenente Marques.

Figura 5.20 - Loteamentos de baixa renda na divisa de Santana do Parnaíba (Bairro Cidade São Pedro e Colinas de Anhanguera) ao sul; e Cajamar(Parque Residencial Cajamar) a norte.

Figura 5.21 - Loteamento baixa renda e média-baixa em Cotia/SP (Vale Verde Cotia: Cond. Andorinha, Cond. Recanto das Graças I e II).

Figura 5.22 - Detalhe de loteamentos de baixa renda em Cotia/SP, situados na Estrada dos Fischers.

Figura 5.23 - Loteamento de baixa e média renda em Jundiaí/SP: Bairro e CDHU Novo Horizonte, Bairro Almerinda Chaves.

Figura 5.24 - Loteamentos de baixa renda em Jundiaí/SP: favela ao longo do bairro e CDHU Novo Horizonte.

Figura 5.25 - Loteamentos de baixa e média renda em Guarulhos/SP, Distrito de Fortaleza.

Figura 5.26 - Loteamento de /SP. Dispersão de loteamentos de média e baixa renda em Ribeirão Pires, nos contrafortes da Serra do Mar.

Figura 5.27 - Mineração e ocupação urbana de baixa renda na várzea do Tietê, em Itaquaquecetuba/SP.

Figura 5.28 - Morfologia da ocupação de quadras em loteamentos dispersos de baixa renda em Ribeirão Pires/SP.

Figura 5.29 - Ocupação de uso industrial/comércio atacadista (em vermelho) na região de Jundiaí/SP.

Figura 5.30 - Áreas industriais ao longo da Rod. Castelo Branco, em Barueri/SP.

Figura 5.31 - Distrito industrial Tamboré, Barueri/SP.

Figura 5.32 - Padrão de ocupação industrial de tecidos urbanos mistos, associados a loteamentos de baixa e média renda, sempre ao longo dos principais eixos viários de acesso a São Paulo/Campinas. Local da imagem: Rod. Raposo Tavares, entre Cotia e São Paulo.

Figura 5.33 - Pedreiras da mineradora Serveng na região próxima a Aldeia da Serra, Barueri/SP.

Figura 5.34 - Áreas de mineração em Santa Isabel, entre Rod. Dutra e Airton Senna.

Figura 5.35: Áreas de mineração entre Arujá e Santa Isabel, nos eixos de expansão urbana das rodovias Dutra e Airton Senna.

Figura 6.1: Arredores de São Paulo em meados do Século XIX.

Figura 6.2: Linhas de transporte coletivo rodoviário que se irradiam de São Paulo, 1951.

Figura 6.3 - Regiões metropolitanas no Brasil.

Figura 6.4 - Configuração da Macrometrópole Paulista em 1992, segundo a Emplasa.

Figura 6.5 - Configuração da Macrometrópole Paulista em 2011, segundo a Emplasa. 
Figura 6.6 - Área de estudo: Macrometrópole de São Paulo.

Figura 6.7 - Dispersão Urbana na macrometrópole paulista

Figura 6.8 - Vetores principais da dispersão urbana na macrometrópole paulista.

Figura 6.9 - Dispersão Urbana no vetor norte de São Paulo. Eixo da Rodovia Fernão Dias, entre São Paulo e Mairiporã.

Figura 6.10 - Dispersão Urbana no eixo da Rodovia Fernão Dias, região de Atibaia.

Figura 6.11 - Dispersão Urbana no eixo da Rodovia Fernão Dias, região de Bragança Paulista.

Figura 6.12 - Dispersão Urbana no Eixo Anhanguera- Bandeirantes, na saída de São Paulo, Cajamar e Caieiras.

Figura 6.13 - Dispersão Urbana no Eixo Anhanguera- Bandeirantes, região de Franco da Rocha, Francisco Morato, Cajamar e Várzea Paulista.

Figura 6.14 - Dispersão Urbana noEixo Anhanguera- Bandeirantes, região de Jundiaí.

Figura 6.15 - Dispersão Urbana noEixo Anhanguera- Bandeirantes, região de Vinhedo e Valinhos.

Figura 6.16 - Dispersão Urbana no Eixo Anhanguera- Bandeirantes, região de Campinas a Americana.

Figura 6.17 - Dispersão Urbana na região entre São Paulo, Barueri e Santana do Parnaíba. Eixo Castelo Branco.

Figura 6.18 - Dispersão Urbana na região entre Araçariguama e Pirapora do Bom Jesus. Eixo Castelo Branco.

Figura 6.19 - Dispersão Urbana na região entre Araçariguama, Itu e Sorocaba. Eixo Castelo Branco.

Figura 6.20 - Dispersão urbana na região de Itu - Eixo Castelo Branco.

Figura 6.21 - Dispersão urbana na região de Cotia e Vargem Grande Paulista - Eixo Raposo Tavares.

Figura 6.22 - Dispersão urbana na região de Vargem Grande Paulista e Ibiúna- Eixo Raposo Tavares.

Figura 6.23 - Dispersão urbana na região de São Roque, Ibiúna e Alumínio- Eixo Raposo Tavares.

Figura 6.24 - Dispersão urbana na região de Sorocaba - Eixo Raposo Tavares.

Figura 6.25 - Dispersão urbana na região de Embu e Itapecerica da Serra - Eixo Régis Bittencourt .

Figura 6. 26 - Dispersão urbana na região de São Lourenço da Serra e Embu-Guaçu - Eixo Régis Bittencourt.

Figura 6.27 - Dispersão Urbana na região sul de São Paulo e São Bernardo. Eixo AnchietaImigrantes.

Figura 6.28 - Dispersão urbana na região de Mauá, Rio Grande da Serra e Suzano - Eixo Anchieta-Imigrantes (Rod. Índio Tibiriçá).

Figura 6.29 - Dispersão urbana na região deArujá, Itaquaquecetuba e Santa Isabel - Eixo Dutra-Airton Senna. 
Figura 6.30 - Dispersão urbana na região do Vale do Paraíba entre Jacareí e Pindamonhangaba - Eixo Dutra-Airton Senna.

Figura 7.1 - Esquema Geomorfológico do Estado de São Paulo, elaborado por Ab'Saber em 1956, com destaque para a área da Macrometrópole de São Paulo.

Figura 7.2 - Mapa Geomorfológico do Estado de São Paulo, IPT-1981, com destaque para a área da Macrometrópole de São Paulo.

Figura 7.3 - Mapa Geomorfológico do Estado de São Paulo, IBGE-2000, com destaque para a área da Macrometrópole de São Paulo.

Figura 7.4 - Mapa Geomorfológico do Estado de São Paulo ,FFLCH/USP-Depto Geografia1993 (Ross \& Moroz), com destaque para a área da Macrometrópole.

Figura 7.5 - Mapa Topográfico da Província de São Paulo - 1875.

Figura 7.6 - Hipsometria da região de São Paulo e áreas vizinhas (1958)

Figura 7.7 - Serra da Cantareira, na vertente de Mairiporã,e Serra do Boturuju, região de Franco da Rocha, em 1940. Notar a ocupação esparsa, ainda, nessa época.

Figura 7.8 - Morro do Jaraguá, em São Paulo, e Morro do Saboó, em São Roque, sustentado por quartzitos, em fotos de 1940, ainda com ocupação urbana esparsa ou inexistente nas redondezas.

Figura 7.9 - desenho esquemático dos principais compartimentos ambientais estruturantes da paisagem - lineamento de divisores de água.

Figura 7.10 - Geologia da região da Macrometrópole de São Paulo. Notar a relação das serras existentes com a rochas graníticas (cor ver,elha no mapa).

Figura 7.11 - Unidades de conservação na área de estudo, 2008.

Figura 7.12 - O trecho de várzea do Rio Tietê, em São Paulo, durante a cheia de 1929; e o Rio Tietê nas proximidades de Itú (1940), em seu trecho de vale encaixado nos morros do Planalto Atlântico. Ao fundo, vê-se a silhueta da Serra do Japi.

Figura 7.13 - Desenho esquemático dos principais compartimentos ambientais estruturantes da paisagem - lineamento de fundos de vale.

Figura 7.14 - Foto e esquema topográfico que consta do livro "O Fato Urbano na Bacia do Paraíba" de Nice L. Müller. Análise de compartimentos ambientais urbanos em São José dos Campos e em várias cidades do Vale.

Figura 8.1 - Eixos estruturantes dos processos naturais na Macrometrópole de São Paulo.

Figura 8.2 - Alinhamento do divisor de águas do Tietê-Juqueri, Pico do Jaraguá, Serra da Cantareira e Serra do Itaberaba.

Figura 8.3 - Dispersão urbana sobre divisor Tietê-Juqueri, setor Região de Alphaville, Barueri e Santana do Parnaíba/SP.

Figura 8.4 - Morro do Botucavarú no trecho cortado pelo Rodoanel; e setor do Morro do Vacanga em Alphaville, e o Condomínio Genesis II.

Figura 8.6 - Condomínio Alpes da Cantareira e Jd. Samambaia, ocupando anfiteatro de nascentes no alto da Serra da Cantareira. Na foto ao lado, o reservatório Águas Claras e os condomínios do entorno, em setor de alta vertente da serra, no município de Mairiporã.

Figura 8.7 - Ocupação dispersa na baixa vertente da Serra da Cantareira, na região de Tremembé, São Paulo. 
Figura 8.8 - Ocupações dispersas de baixa renda na Serra da Cantareira em Guarulhos: à esquerda, bairros do Cabuçu e Recreio S. Jorge; à direita o Jardim Fortaleza.

Figura 8.9 - Dispersão urbana e adensamento da ocupação sobre divisor Tietê-Juqueri, setor Serra da Cantareira, São Paulo e Mairiporã/SP.

Figura 8.10 - Detalhe de ocupação de alta renda nos contrafortes da Serra da Cantareira, Mairiporã/SP: Jarim Samambaia e Alpes da Cantareira.

Figura 8.11 - Detalhe de embrião de ocupação de baixa renda nos contrafortes da Serra da Cantareira em meio aos condomínios de alta renda, Mairiporã/SP.

Figura 8.12 - Ocupação urbana dispersa de baixa renda na Serra da Cantareira, Guarulhos/SP: Cabuçu e Recreio São Jorge.

Figura 8.13 - Detalhe da ocupação urbana dispersa de baixa renda na Serra da Cantareira, Guarulhos/SP. Estrada do Cabuçu - Bairro Cabuçu e Sítio Pirucaia.

Figura 8.14 - Alinhamento de divisores dos rios Juqueri-Jundiaí.

Figura 8.15 - Detalhe de casas do Condomínio Chácaras da Ermida, situado no topo da Serra do Japi.

Figura 8.16 - Dispersão na Serra do Itaqui.

Figura 8.17 - Dispersão nas encostas da Serra da Caucaia.

Figura 8.18 - Dispersão no alinhamento de divisores dos rios Jundiaí e Atibaia.

Figura 8.19 - Várzea do Tietê, antes de chegar em São Paulo, e principais divisores de águas regionais.

Figura 8.20 - Ocupação urbana de baixa renda na várzea do Tietê, no Itaim Paulista, Zona leste de São Paulo/SP. O perímetro de linha amarela corresponde ao compartimento de várzea.

Figura 8.21 - Ocupação urbana de baixa renda na várzea do Tietê, Jardim Romano/ttaim Paulista, Zona leste de São Paulo/SP.

Figura 8.22 -Detalhe da morfologia interna do loteamento no Jardim Romano/Itaim Paulista, Zona leste de São Paulo/SP.

Figura 8.23 - Ocupação urbana de baixa renda na várzea do Tietê, Itaquaquecetuba e Poá/SP. O perímetro de linha amarela corresponde ao compartimento de várzea.

Figura 8.24 - Ocupação urbana de baixa renda na várzea do Tietê, entre Mogi das Cruzes e represas de Ponte Nova e de Paraitinga. O perímetro de linha amarela corresponde ao compartimento de várzea.

Figura 8.25 - Planície Aluvial do Rio Jundiaí e principais divisores de águas locais. Jundiaí/SP.

Figura 8.26 - Ocupação urbana na planície aluvial do Rio Jundiaí entre Várzea Paulista e Itupeva (delimitada pela linha amarela).

Figura 8.27 - Conjunto dop CDHU construído nas várzeas do Rio Jundiaí, em Jundiaí, e trecho da várzea ainda não ocupada por usos urbanos.

Figura 8.28 - Planície aluvial do Rio Atibaia (delimitada pela linha amarela)

Figura 8.29 - Condomínio Shambala II, ocupando trechos de várzeas do Atibaia.

Figura 8.30 - Enchente do Rio Atibaia em 2009, que alagou o setor de várzeas situadas ao lado do Jd. Suely, em Atibaia. 
Figura 8.31 - Entorno da represa de Jaguari, Rio Jaguari, em Igaratá.

Figura 8.32 - Entorno da represa Paiva Castro, Rio Juqueri, em Mairiporã.

Figura 8.33 - Entorno da represa Itupararanga, Rio Soirocaba, em Ibiúna.

Figura 8.34 - Entorno da represa de Billings, em São Paulo, São Bernardo e Santo André. 


\section{LISTA DE TABELAS}

Tabela 6.1 - Quadro síntese da dispersão das peças urbanas na macrometrópole de São Paulo. Comparação horizontal - número absoluto e percentual das tipologias segundo cadaeixo rodoviário, 2010-2011.

Tabela 6.2 - Quadro síntese da dispersão das peças urbanas na macrometrópole de São Paulo. Comparação dos eixos segundo cada tipologia de dispersão, 2010-2011.

Tabela 6.3 - Evolução da população total e \% relativo ao total da Macrometrópole nos

Tabela 6.4 - Percentual de crescimento nos períodos entre 1970-2010, segundo os eixos rodoviários de dispersão urbana.

Tabela 6.5 - Evolução da taxa de crescimento anual da população total nos períodos entre 1970-2010, segundo os eixos rodoviários de dispersão urbana.

Tabela 6.6 - Evolução da população total dos municípios do eixo de dispersão da Rodovia Fernão Dias, nos períodos censitários entre 1970-2010.

Tabela 6.7 - Evolução da população total dos municípios do eixo de dispersão da Rodovia Anhanguera-Bandeirantes, nos períodos censitários entre 1970-2010.

Tabela 6.8 - Evolução da população total dos municípios do eixo de dispersãoda Rodovia Castelo Branco, nos períodos censitários entre 1970-2010.

Tabela 6.9 - Evolução da população total dos municípios do eixo de dispersãoda Rodovia Raposo Tavares, nos períodos censitários entre 1970-2010.

Tabela 6.10 - Evolução da população total dos municípios do eixo de dispersãoda Rodovia Régis Bittencourt, nos períodos censitários entre 1970-2010.

Tabela 6.11 - Evolução da população total dos municípios do eixo de dispersão da Rodovia Anchieta-Imigrantes, nos períodos censitários entre 1970-2010.

Tabela 6.12 - Evolução da população total dos municípios do eixo de dispersão da Rodovia Dutra-Airton Senna, nos períodos censitários entre 1970-2010.

Tabela 6.13 - Evolução da taxa de crescimento anual da população total dos municípios no eixo de dispersão da Rodovia Fernão Dias, nos períodos entre 1970-2010.

Tabela 5.14 - Evolução da taxa de crescimento anual da população total dos municípios no eixo de dispersão da Rodovia Anhanguera-Bandeirantes, nos períodos entre 1970-2010.

Tabela 6.15 - Evolução da taxa de crescimento anual da população total dos municípios no eixo de dispersão da Rodovia Castelo Branco, nos períodos entre 1970-2010.

Tabela 6.16 - Evolução da taxa de crescimento anual da população total dos municípios no eixo de dispersão da Rodovia Raposo Tavares, nos períodos entre 1970-2010.

Tabela 6.17 - Evolução da taxa de crescimento anual da população total nos períodos entre 1970-2010.

Tabela 6.18 - Evolução da taxa de crescimento anual da população total dos municípios no eixo de dispersão da Rod. Anchieta-Imigrantes, nos períodos entre 1970-2010.

Tabela 6.19 - Evolução da taxa de crescimento anual da população total dos municípios no eixo de dispersão da Rodovia Dutra-Airton Senna, nos períodos entre 19702010.

Tabela 7.1 - Lançamentos imobiliários e a exploração da paisagem natural 


\section{LISTA DE QUADROS}

Quadro 4.1 - Taxa de crescimento anual da população de São Paulo e Campinas, comparadas às suas regiões metropolitanas entre 1970 e 2010.

Quadro 5.1 - Tipologias de padrão de ocupação urbana dispersa de uso residencial.

Quadro 5.2 - Tipologias de padrão ocupação de uso produtivo associado à indústria e disperso em meio rural.

Quadro 7.1 - Indicadores de análise e atributos da dinâmica climática. 


\section{LISTA DE SIGLAS}

APA - Área de Proteção Ambiental

APP - Área de Preservação Permanente

A.U. - Aglomeração Urbana

CDHU - Companhia de Desenvolvimento Habitacional e Urbano do Estado de São Paulo.

EMPLASA - Empresa Paulista de Planejamento Metropolitano

IBGE - Instituto Brasileiro de Geografia e Estatística

IPT - Instituto de Pesquisa Tecnológica

R.M. - Região Metropolitana

RMSP - Região Metropolitana de São Paulo

ZEE - Zoneamento Econômico Ecológico 


\section{SUMÁRIO}

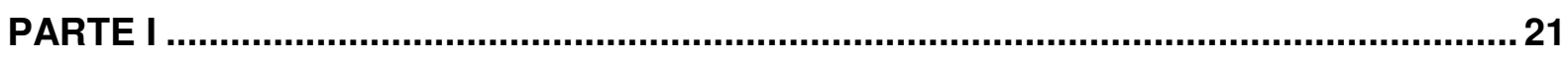

1. APRESENTAÇÃO

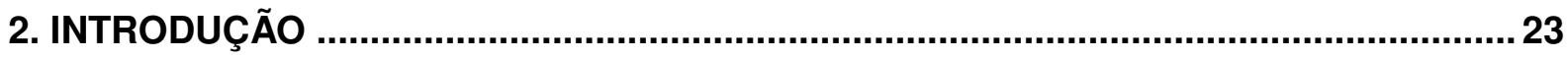

2.1. Justificativa

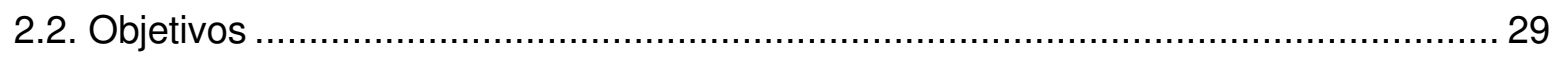

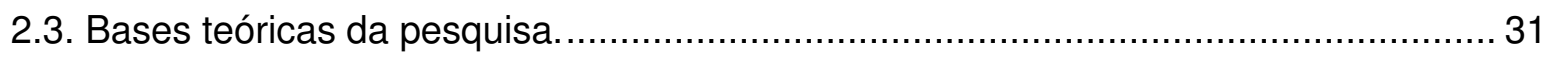

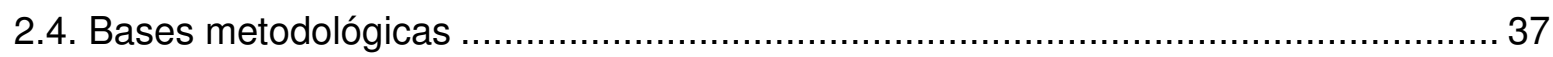

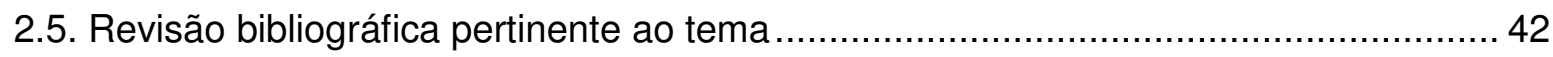

3. A ABORDAGEM DO RELEVO

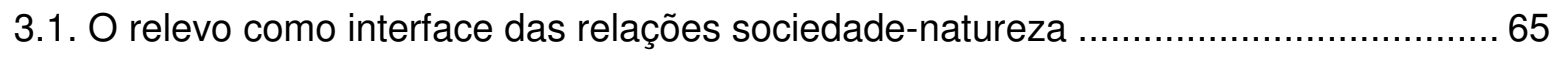

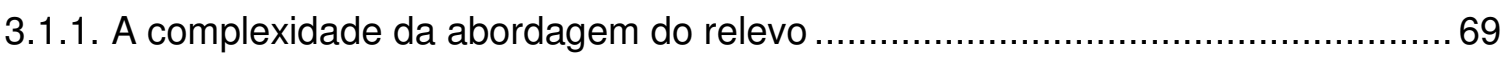

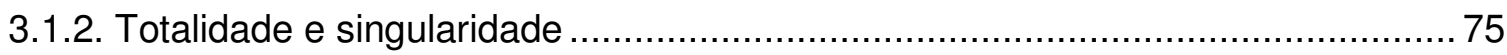

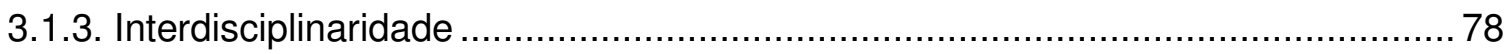

3.2. Fundamentação teórica no campo da Geomorfologia ......................................... 80

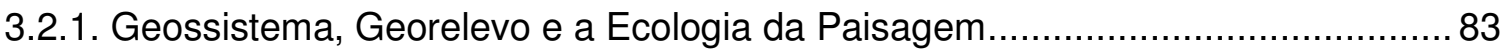

3.2.2. Geomorfologia Ambiental e Geomorfologia Urbana ..........................................93

4. DISPERSÃO URBANA E OCUPAÇÃO TERRITORIAL ...............................................95

4.1. Dispersão urbana: o conceito e evidências …………………………………........ 95

4.1.1. A urbanização contemporânea: entre a concentração e a dispersão ....................99

4.1.2. Cidade dispersa $\mathrm{x}$ cidade difusa ................................................................... 99

4.1.3. Concentração e dispersão: tendências opostas ou complementares................. 103

4.1.4. Em longo prazo o crescimento disperso é sustentável? ................................... 110

4.2. Dispersão e apropriação do relevo: sítio urbano e território urbanizado ................... 113

4.2.1. O novo rural que emerge ......................................................................... 114

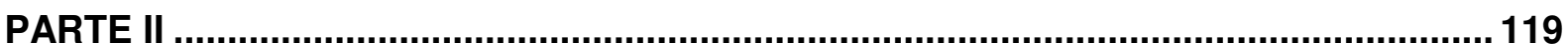

5. MORFOLOGIA DAS PEÇAS URBANAS QUE SE DISPERSAM NO TERRITÓRIO......119

5.1. Semelhança das Morfologias das peças dispersas com as da cidade

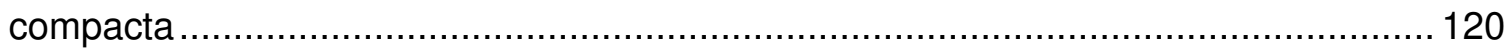

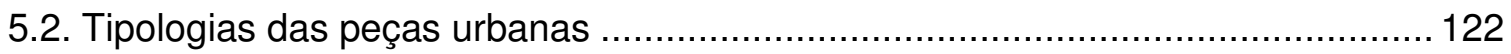

5.3. O padrão de condomínios fechados de média e alta renda ............................... 124

5.4. O padrão de condomínios e/ou loteamentos de chácaras de média e alta

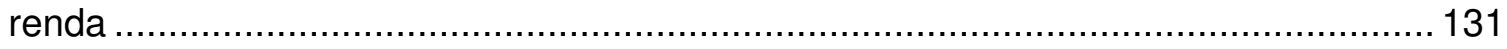

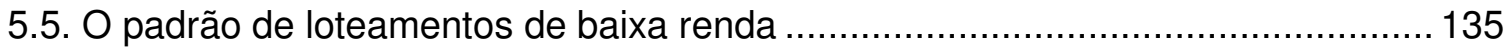




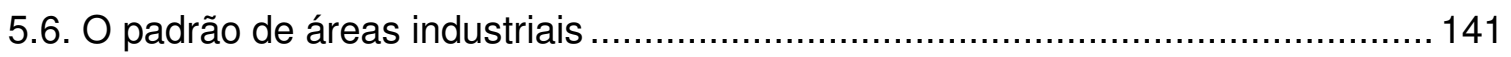

5.7. O padrão de outras atividades produtivas ................................................... 144

5.8. A dispersão das tipologias da cidade compacta.............................................. 147

6. A DISPERSÃO URBANA NA MACROMETRÓPOLE DE SÃO PAULO ........................ 150

6.1.1. Método de identificação do fenômeno e análise da dispersão. .......................... 162

6.2. Os eixos da Dispersão Urbana................................................................ 163

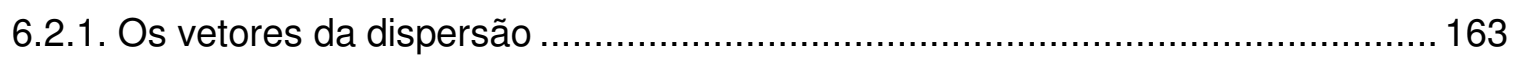

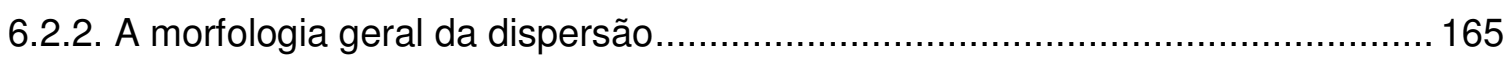

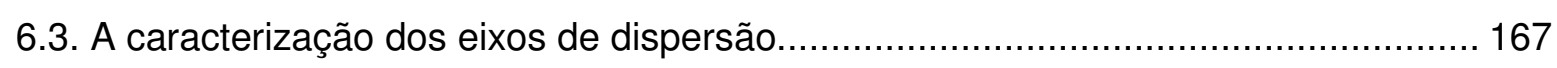

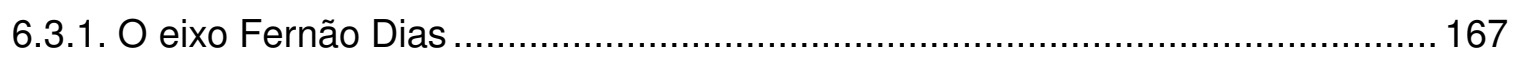

6.3.2. O Eixo Anhanguera-Bandeirantes............................................................ 172

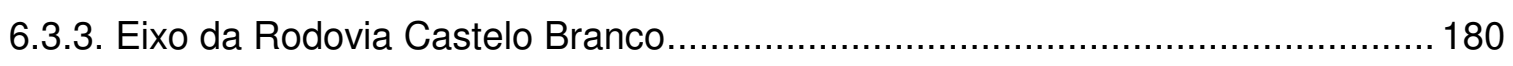

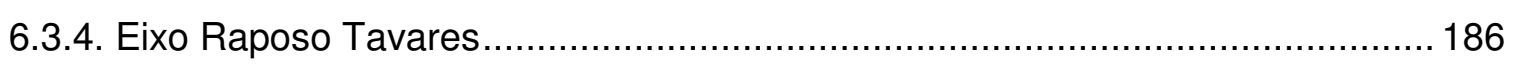

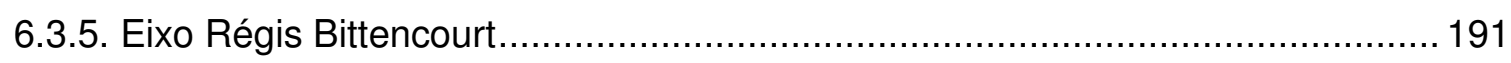

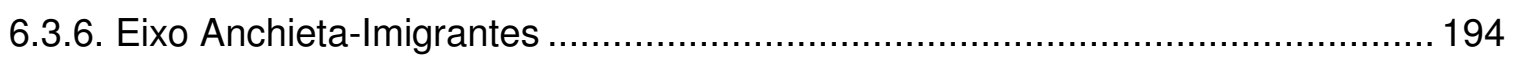

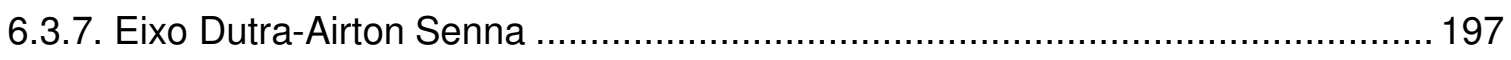

6.3.8. O quadro geral da dispersão na Macrometrópole: a realidade como

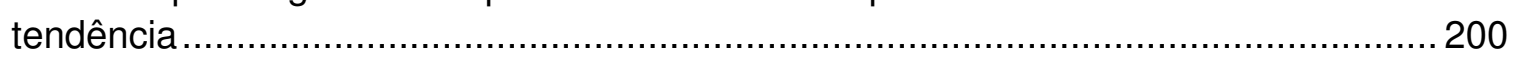

6.4. Os eixos da dispersão urbana e a desconcentração populacional......................... 203

6.4.1. As taxas de crescimento anual da população .................................................206

6.4.2. O tamanho populacional dos municípios..................................................... 208

6.4.3. A evolução populacional e tendências no eixo Fernão Dias..............................214

6.4.4. A evolução populacional e tendências no eixo Anhanguera-Bandeirantes.........215

6.4.5. A evolução populacional e tendências no eixo Castelo Branco.........................2 219

6.4.6. A evolução populacional e tendências no eixo Raposo Tavares.......................220

6.4.7. A evolução populacional e tendências no eixo Régis Bittencourt...................... 221

6.4.8. A evolução populacional e tendências no eixo Anchieta-Imigrantes................... 222

6.4.9. A evolução populacional e tendências no eixo Dutra-Airton Senna.................... 224

7. COMPARTIMENTOS AMBIENTAIS ESTRUTURANTES NA MACROMETRÓPOLE

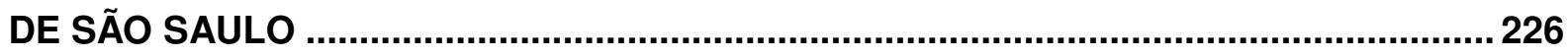

7.1. A Compartimentação da paisagem como etapa para a síntese da paisagem e

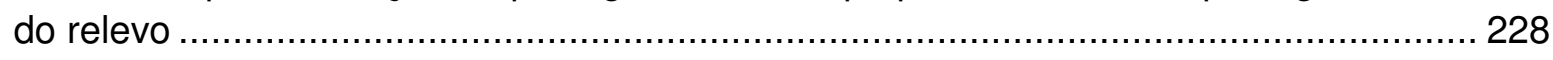

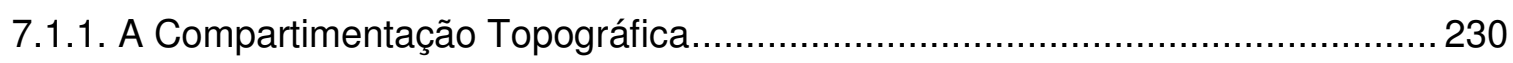

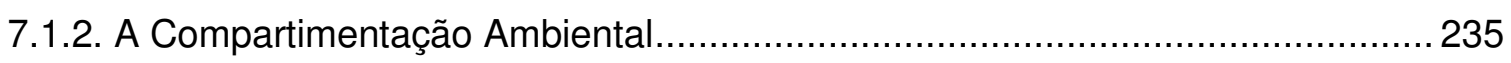

7.1.3. Compartimentos ambientais estruturantes ................................................ 239

7.1.4. Compartimentos ambientais estruturantes da macrometrópole.......................243 
7.2. A Dispersão dos efeitos da urbanização nos processos naturais ........................... 258

7.2.1. Dispersão e apropriação do relevo: a interferência nos processos naturais ......260

7.2.2. A dispersão dos efeitos na dinâmica climática da paisagem ............................ 263

7.2.3. A dispersão dos efeitos na hidrodinâmica da paisagem...................................269

7.3. O ideal de vida saudável próxima ao campo: o marketing verde imobiliário e a

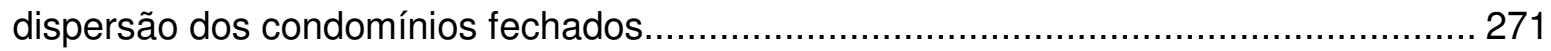

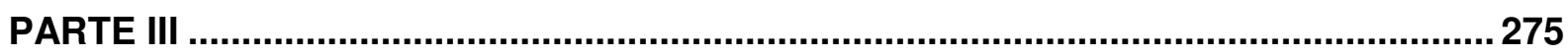

8. A DISPERSÃO URBANA NOS COMPARTIMENTOS AMBIENTAIS

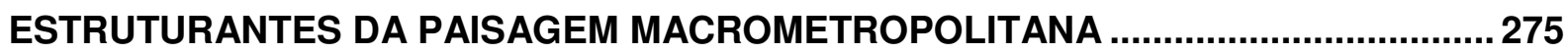

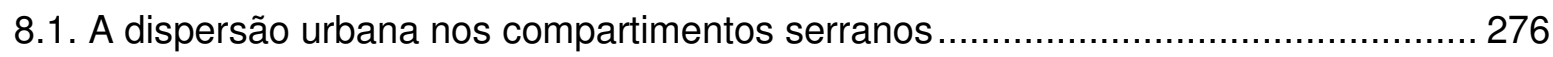

8.1.1. O alinhamento da Serra da Cantareira (Divisor Tietê-Juqueri) ......................... 277

8.1.2. O alinhamento do Divisor Juqueri-Jundiaí................................................... 289

8.1.3. A dispersão nos divisores de menor abrangência regional. .............................. 290

8.2. A dispersão urbana nos compartimentos de fundos de vale................................ 293

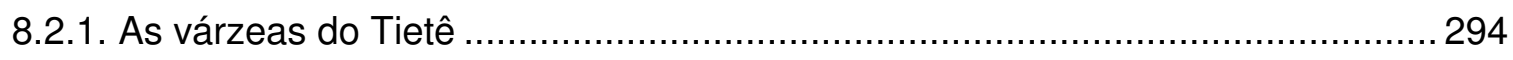

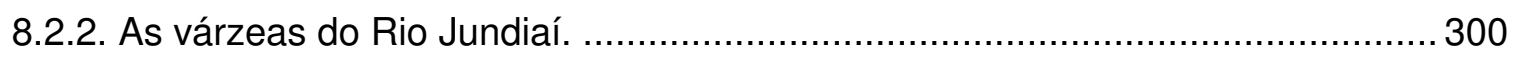

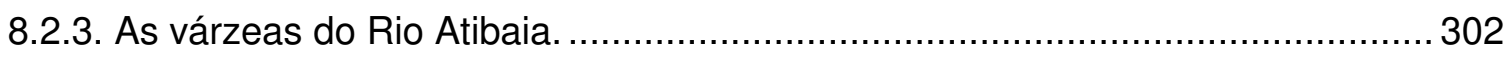

8.2.4. As várzeas do Rio Paraíba do Sul............................................................. 305

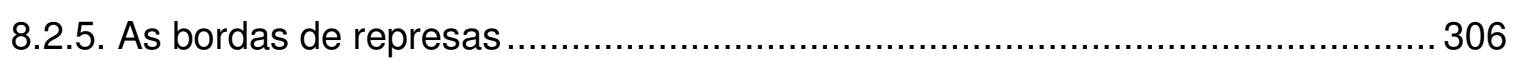

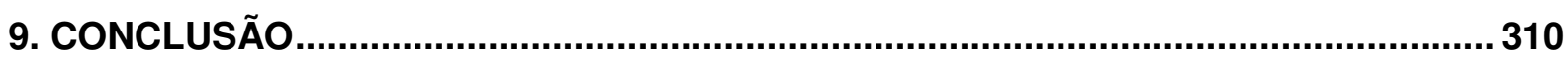

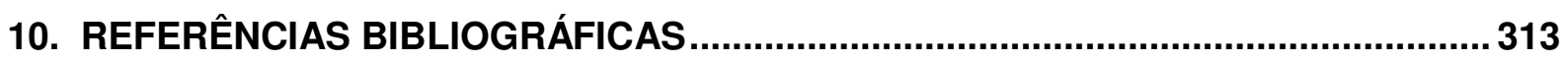




\section{PARTE I}

\section{APRESENTAÇÃO}

Este trabalho, apresentado em nove capítulos que desenvolvem a sequência de abordagem da dispersão urbana na Macrometrópole de São Paulo e sua vinculação com o relevo regional, está estruturado em três partes.

Na primeira, constituída pelos capítulos 1 a 4, apresenta-se o problema a ser investigado, o escopo do trabalho e a metodologia empregada para desvendar a hipótese assumida. Relata, no capítulo 2 , os objetivos e as bases teóricas e metodológicas da pesquisa, bem como realiza uma revisão bibliográfica do tema. Nos capítulos 3 e 4 discorre, de maneira pormenorizada, os aspectos teóricos que balizam a abordagem sobre o relevo, bem como realiza uma discussão dos conceitos e evidências que sustentam a tendência de dispersão urbana, na forma como vem sendo discutida nas análises do urbanismo atual sobre a cidade contemporânea. Teorias, tendências, estudos e principais questões sobre dispersão urbana estão referenciados no capítulo 4.

$\mathrm{Na}$ segunda parte, que compreende os capítulos 5 a 7 , apresentam-se os resultados da investigação, ou seja, o que se observou em relação às morfologias urbanas em dispersão (capítulo 5), os aspectos e tendências de expansão da dispersão na Macrometrópole de São Paulo em sua dimensão espacial e populacional, e em cada vetor de dispersão diagnosticado, além da identificação dos compartimentos ambientais considerados estruturantes da paisagem e os fundamentos dessa seleção.

$\mathrm{Na}$ terceira parte, capítulos 8 e 9, finaliza-se a pesquisa com a discussão dos resultados apresentados, em que se buscou contrapor a dispersão urbana atual aos compartimentos ambientais estruturantes da macrometrópolede São Paulo, e apresentar as conclusões sobre a dialética assumida na hipótese inicial.

Assim estruturada a pesquisa e sua apresentação, entendeu-se que facilitaria a compreensão do leitor sobre as análises e fatos identificados, a partir dos dados 
selecionados sobre esse fenômeno relativo às formas de espacialização da sociedade no momento atual, com base na experiência vivida em São Paulo. 


\section{INTRODUÇÃO}

As novas tendências da urbanização brasileira e mundial, passando de seu caráter de apropriação do relevo espacialmente concentrado para formas de ocupação mais dispersas, podem se constituir em padrões de ocupação sustentáveis ambientalmente, segundo se preconizava há décadas atrás nas críticas à cidade compacta?

A fragmentação do tecido urbano metropolitano, deixando interstícios verdes não ocupados, pode configurar um caminho para o equilíbrio entre os processos naturais e urbanos, produzindo efeitos de amenização dos rigores ambientais, climáticos e geomorfológicos?

A cidade dispersa produz um maior equilíbrio ambiental que a cidade compacta, ou conforme preconiza Coelho (2011) conduz a um estado de relativa estabilidade ambiental?

Os compartimentos ambientais estruturantes de uma região que se metropoliza, geralmente consumidos pela ocupação urbana da cidade compacta estão, ou estarão, a salvo na forma de ocupação da cidade dispersa, ou seja, livres de ocupação e desempenhando suas funções ambientais que favoreçam a manutenção dessa condição de relativa estabilidade?

Essas são questões que se imbricam e se completam, ou ainda se complementam, pois as duas formas de ocupação, a concentrada e a dispersa, tendem a conviver mutuamente. Entre núcleos urbanos densamente ocupados e edificados, onde antes existiam formas de ocupação estrita ou predominantemente rurais, instala-se a dispersão de formas ou peças urbanas, configurando um cenário multifacetado de usos e de funções sociais e ambientais. E isso se reflete no território em padrões de apropriação de relevo que se implantam sobre os compartimentos ambientais sensíveis aos processos naturais de uma determinada região, conforme se buscará analisar neste trabalho.

As hipóteses levantadas até aqui apresentam conceitos e termos que apresentam definição muitas vezes dúbia, pois refletem categorias de análise do território que têm origem tanto na geografia e na geomorfologia, como nos estudos 
sobre a urbanização da sociedade derivados do urbanismo. Um esforço nesse sentido será dado com vistas a circunscrever os limites de interpretação para cada um deles, ao menos no que se refere ao significado que o autor quer transmitir no uso do termo ou conceito.

O primeiro, e talvez o mais forte, é o conceito relativo à apropriação do relevo. Termo pouco conhecido em outras esferas de estudos territoriais, sobretudo dos que derivam do urbanismo, que preferem expressar a ocupação urbana ou o uso e ocupação do solo. Na geomorfologia foi utilizado por Casseti (1995, p.8) que correlacionou a ênfase dada pela análise marxista na "apropriação privada da natureza" do modo de produção capitalista com o relevo, como a superfície apropriada nesse processo. Este aspecto também foi trabalhado na dissertação de mestrado desenvolvida na FAU/USP (Schutzer, 2005), e no livro "Cidade e Meio Ambiente: a apropriação do relevo no desenho ambiental urbano" (Schutzer, 2012), onde se procurou estender o termo para a apropriação também dos processos naturais que ocorrem na superfície ou têm nela a sua interface. Caracteriza-se, assim, a apropriação privada da natureza em todos os seus aspectos, inclusive dos quais derivam hoje as resultantes ambientais deste processo de apropriação e transformação do relevo. Trata-se, dessa forma, do termo central deste trabalho, no qual se buscará elencar os padrões de dispersão urbana segundo seus modos de apropriação do relevo e as possíveis derivações ambientais futuras.

O segundo termo chave do trabalho é a conceituação dos compartimentos ambientaisestruturantesde uma paisagem metropolitana. Este conceito, embora oriundo de uma análise geomorfológica sintética, está carregado de um conteúdo social, pois reflete as necessidades ambientais de um território sob o enfoque de seu uso pela sociedade, que reflita uma ocupação urbana economicamente mais racional, e ambientalmente confortável. A análise perpassa a questão da finalidade do território para o uso humano.

A postura ambiental na geomorfologia recebeu grande impulso com a contribuição que Kugler (1976) ofereceu ao definir o conceito de "georelevo". Este conceito visava integrar a análise do relevo com a de território, por meio da definição da superfície como interface de processos geoecológicos com as funções sócioreprodutoras da sociedade. Assim, a evolução de cada um desses processos 
perpassava por esse limiar constituído por uma superfície. Portanto, em última instância, as funções sócio-reprodutoras resultam do uso que se faz dessas propriedades geoecológicas (Abreu, 1985 p.159; Casseti, 1995 p.51). Nesse sentido, a geomorfologia atual não pode deixar de dar relevância às derivações ambientais do processo de ocupação ou, melhor definindo, de apropriação do relevo.

Em face disso, pode-se argumentar que existem estruturas ambientais e/ou compartimentos ambientais que possuem um maior poder regulador dos processos naturais/ambientais que ocorrem em um determinado território. Os mais significativos devem possuir área de influencia considerável, a proteção de funções geoecológicas; a garantia de funções geoecológicas e sócio-reprodutoras para a sociedade (proteção de mananciais, regulação microclimática, proteção dos processos erosivos de grande impacto, etc.). Se existem essas estruturas ambientais, é importante verificar como elas já estão ocupadas ou estão sendo ocupadas e questionar quais são as tendências de expansão da urbanização sobre elas?

Entram questões de método de como delimitar tais estruturas, qual o seu suporte conceitual e metodológico; mas também questões de caráter subjetivo, que tem muito de pessoal e de arbitrário, pois envolvem aspectos físico-ecológicos, etambém as necessidades de uso do território segundo o momento histórico da sociedade.

$O$ terceiro elemento chave da abordagem passa pela abordagem do fenômeno da dispersão urbana, que recebeu até o presente variadas definições como cidade dispersa, cidade difusa, urbanização espraiada, dentre outras.

Não se tratará apenas de apresentar uma caracterização da relação entre a dispersão urbana e suas formas de apropriação do relevo, e, sim, ressaltar as potencialidades de utilização das categorias de análise consubstanciadas na teoria geomorfológica para os estudos ambientais urbanos, sobretudo como elemento chave nas análises relativas às formas de urbanização da sociedade, ou seja, nas formas de expansão urbana sobre um território, sem se discutir a qualidade destes espaços verdes ou rurais. 


\subsection{Justificativa}

A abordagem ambiental se desenvolveu mais intensamente na escala mundial e nacionais nas últimas décadas do século passado, justamente no período em que se observou uma maior flexibilização da localização das empresas, do trabalho e das moradias, decorrente do fato de que as distâncias se encurtam, não no sentido métrico, mas no tempo. Essa flexibilização vem acompanhada de uma evolução técnica que também encurta o tempo necessário para a elaboração das obras humanas.

Nesse sentido, a utilização do território ganha dimensões até então não verificadas o que, em termos de urbanização do território, opera-se uma intensa mobilidade e dispersão das atividades, dos investimentos, sobre um território mais vasto. As opções locacionais se ampliam, resultando, assim, também, numa flexibilização do conceito de um mundo urbano separado do mundo rural. A dicotomia rural-urbano, sobretudo nas regiões mais densamente ocupadas, se dilui em uma variedade de situações, configurações paisagísticas, e formas de se relacionar com a natureza. As formas de uso do solo que resultam desse processo também revelam também padrões de apropriação do relevo diferentes do modelo anterior, caracterizado pela cidade compacta.

Neste contexto, o tema revela-se extremamente atual e importante por implicar na imbricação da relação entre formas de ocupação urbana e qualidade ambiental daí resultante. $\mathrm{O}$ tema da sustentabilidade ambiental torna-se absoluto, no entanto, ainda pouco definido e preciso. As formas dispersas assumem uma ideologia de serem ambientalmente mais saudáveis por favorecerem um maior contato do homem com a natureza, seja o bioma natural do local ou a cobertura nativa já transformada em paisagem rural. As duas questões, dispersão urbana e relação cidade-meio ambiente, são discutidas hoje em todos os continentes, e muito mais intensamente nas áreas densamente povoadas.

Como antítese ambiental do modelo da cidade compacta, há que se perguntar se os fenômenos que conduzem a uma cidade dispersa têm revelado uma prática de apropriação do relevo que garanta sustentabilidade ou estabilidade ambiental, ou se ainda são capazes de preservar áreas ambientalmente sensíveis sob o ponto de 
vista do interesse público, para uma melhor relação entre cidade e natureza, e para uma melhor economia de recursos por meio da preservação dos serviços ambientais desenvolvidos pelo ambiente natural.

As formas de dispersão urbana, embora deixem áreas verdes intersticiais em meio às peças urbanas, em alguns casos também têm se apropriado de compartimentos de relevo sensíveis aos processos naturais, e que podem ser considerados como compartimentos estruturantes sob o ponto de vista do conjunto de serviços ambientais desempenhados pela natureza e que garantam uma melhor relação entre ocupação urbana e processos naturais. Portanto, argumenta-se acerca da importância de investigar se o modelo que vem se configurando nas áreas densamente urbanizadas das regiões metropolitanas, ou entre áreas metropolitanas distintas, se constitui em uma alternativa ambientalmente sustentável ao modelo da cidade compacta, ou cidade espacialmente bem definida.

O fato de não ser observado no planejamento urbano territorial uma visão de conjunto, nem sob o ponto de vista dos recursos naturais e suas potencialidades e fragilidades, nem sob o enfoque do planejamento territorial metropolitano, se apresenta como uma fragilidade importante para a sustentabilidade ambiental dos espaços metropolitanos. Os interesses fragmentados operados pela lógica do mercado imobiliário, bem com a fragmentação das políticas de expansão urbana operadas pelos municípios, imbricam-se e implicam-se no território que é analisado e apropriado segundo esses limites de atuação, gerando uma visão também fragmentada do ambiente natural.

De outro lado, também se observa que, mesmo nos modelos de ocupação menos densos e que chegam a preservar ou deixar áreas mais significativas, estas geralmente representam pequenos pedaços de compartimentos ambientais sensíveis, ou até nem chegam a significar áreas relevantes para a preservação.

Sob o ponto de vista da geomorfologia, conforme já discutido na dissertação de mestrado (Schutzer, 2005), essa apresenta instrumentos de análise da paisagem extremamente operativos ao planejamento territorial e urbano. Nesse sentido, suas categorias de análise propostas configuram-se em pontos de apoio importantes para 
a integração e síntese nos estudos sobre as potencialidades e fragilidades ambientais de um território.

Porém, aqui será utilizado o conceito de "compartimentos ambientais" da paisagem. Esse conceito se diferencia do termo "compartimentos de relevo" ou "compartimentação topográfica", comumente utilizado na Geomorfologia. Ele também será estendido para "compartimentos ambientais estruturantes" de uma paisagem. Na dissertação de mestrado, para as mesmas condições analisadas foi utilizado o termo "unidades ambientais estruturantes" (Schutzer, 2005), mas que guardava a mesma conotação deste. O que diferencia a compartimentação ambiental da compartimentação topográfica ou do relevo é que, na primeira, na delimitação das unidades inclui-se um juízo de valor para fins urbanos sobre as potencialidades e fragilidades para a ocupação e utilização do solo. Não se trata de analisar somente a fisiologia da paisagem natural ou mesmo que já incluamos as alterações de intensidade dos processos naturais provocadas pela urbanização. A compartimentação ambiental agrega à compartimentação topográfica premissas para a utilização e ocupação urbana daquele espaço. Por "compartimentos ambientais estruturantes" ou "unidades ambientais estruturantes", entemdem-se os espaços mais importantes sob o ponto de vista ambiental para um equilíbrio satisfatório entre os processos naturais e urbanos de um território, que devem ser objeto de uma eficaz ação regeneradora na cidade compacta ou preservacionista nas áreas ainda não ocupadas.

Sob o enfoque da natureza, todos os espaços de um território executam uma função dentro do sistema ambiental local e regional. Esses espaços não são iguais quanto às suas características físicas, locacionais, tampouco quanto às funções que desempenham ou às quais foram chamados a desempenhar. Alguns deles são mais frágeis ou apresentam uma morfodinâmica ativa, outros guardam funções ambientais mais relevantes para a sociedade. Para um ambiente urbanizado, ou a ser urbanizado, é sempre conveniente investigar, em primeiro lugar, quais são esses espaços naturais mais importantes para a sustentabilidade ambiental do território, quais são aqueles que apresentam maior influência sobre as condições ambientais locais, como primeiro indicador a orientar o planejamento do território urbano (Schutzer, 2012 p.183-184). 


\subsection{Objetivos}

Propor trabalhar com essa nova tendência da urbanização que vêm se verificando mais expressivamente nas duas últimas décadas, e que se caracteriza pela passagem de um desenho de cidade mais compacto e impermeabilizador do território para uma forma de cidade com suas peças urbanas fragmentadas e dispersas por um território mais vasto, anteriormente domínio exclusivo de formas de uso do solo de caráter rural, foi resultado de reflexões sobre os impactos ambientais causados pela urbanização concentrada, o que sugeria que uma urbanização mais equilibrada em relação aos processos naturais e ao equilíbrio ambiental deveria ser necessariamente menos compacta, entremeada, assim, por espaços verdes intersticiais.

No entanto, a observação de determinadas tendências de apropriação do relevo inseridas na ideologia das novas tipologias urbanas que almejam uma melhor relação com a natureza, com espaços de vida saudável, próximos ao campo, e distante do stress urbano causado pelo trânsito e pelo adensamento construtivo, revelavam também a insustentabilidade ambiental que essas novas formas de desenho da cidade deverão impor ao território.

Três aspectos dessa nova tendência parecem relevantes a serem investigados com maior rigor nesse duelo entre a antiga tendência à conurbação das manchas urbanas fragmentadas no passado com a nova tendência caracterizada pela dispersão urbana.

O primeiro objetivo deste trabalho, também objeto de reflexão e interrogação de Limonad (2008), refere-se a discutir até que ponto esse processo de dispersão não passa somente de mais uma etapa do processo de conurbação e adensamento urbano. Não se pode deixar de lembrar que data do início do século XX em São Paulo essa estratégia de crescimento periférico aos saltos: bairros novos eram lançados em descontínuo com a macha urbana compacta como estratégia de valorização das glebas que separavam esses bairros isolados da cidade. $O$ trabalho de Langenbuch (1971) - "Estruturação da Grande São Paulo" - ilustra exemplarmente esse processo. Também o de Odete Seabra (1987) - "Os meandros dos rios nos meandros do poder - Tietê e Pinheiros: a valorização dos rios e das 
várzeas na cidade de São Paulo" - aborda os interesses imobiliários de grupos econômicos paulistas e estrangeiros para a ocupação da várzea do Pinheiros, processo que visava, entre outros objetivos, unir o tecido urbano da cidade compacta com a ocupação que se desenvolvia nos bairros Butantã e Cidade Jardim.

O segundo objetivo diz respeito à avaliação da ideia de vida saudável fora da agitação da cidade, à sustentabilidade dos empreendimentos e à melhor relação com o meio ambiente que as peças urbanas dispersas apresentam em comparação com a cidade compacta. São muito variadas as tipologias dessas peças urbanas que se dispersam pelo meio rural. Até que ponto essas peças urbanas revelam uma nova relação com o ambiente? Como elas se comportam em relação aos processos naturais, às dinâmicas do clima e da água, e como se relacionam com a preservação dos biomas e da biodiversidade? O que diferenciam as peças urbanas dispersas das tipologias de loteamentos desenvolvidos historicamente na cidade compacta? Portanto, é fato que os tecidos urbanos dispersos apresentam qualidade ambiental muito superior ao que ocorre na cidade compacta?

O terceiro objetivose preocupa com a forma de apropriação do relevo resultante do processo de dispersão urbana. A questão que se coloca, hoje, à sociedade é verificar se houve mudança na forma de encarar as questões ambientais associadas a cada tipo de forma de relevo, a cada compartimento ambiental. Dois aspectos são relevantes nessa averiguação. Um deles indaga como as tipologias das peças urbanas, em seu desenho interno, se relacionam com o relevo, com o seu sítio urbano, ou com a vertente que ocupa. A forma de apropriação do relevo, neste caso, diferencia-se do que acontece na cidade compacta?

O outro indaga se as peças urbanas dispersas dirigem-se ou não aos compartimentos ambientais mais sensíveis desse sítio urbano-rural. Hoje, já é possível afirmar, sem grande contestação, que a grande cidade compacta tendeu a ocupar todos os compartimentos de relevo de seu sítio urbano, sendo este um dos principais motivos dos desajustes ambientais que provocam perdas de qualidade de vida, de vidas propriamente dito, e muitas perdas materiais, sobretudo para as camadas sociais de mais parcos recursos. A dispersão urbana, em sua forma tendencial, diferencia-se deste modelo de apropriação do relevo? 
Dessa forma, a hipótese objetiva testar o conteúdo ambiental da dispersão urbana sob a ótica da apropriação do relevo. A cidade dispersa, que no imaginário atual é percebida como uma melhor relação entre vida urbana e o meio ambiente, tem se revelado uma prática de apropriação do relevo ambientalmente sustentável para o equilíbrio do funcionamento da paisagem de territórios densamente urbanizados?

\subsection{Bases teóricas da pesquisa.}

Duas linhas de abordagem teórica dão suporte à pesquisa em desenvolvimento. De um lado, faz-se necessário considerar os aportes teóricos que subsidiam a interpretação da paisagem e do relevo oriundos da Geografia Física, e mais particularmente da Geomorfologia. De outro, os aportes relativos à ação antrópica, derivados das questões socioeconômicas e culturais, serão tratados por meio da análise da expressão territorial da urbanização, através das suas dinâmicas em desenvolvimento, do desenho urbano que se instala e das relações que estabelecem com o relevo no território estudado. Em ambas as análises empreendidas o foco central é a busca da síntese das relações que estão em desenvolvimento entre os processos naturais e os processos urbanos sobre territórios densamente urbanizados no âmbito da dispersão urbana.

$\mathrm{Na}$ abordagem geográfica-geomorfológica os aspectos analisados dirigem-se para uma compartimentação ambiental da paisagem, e mais especificamente, para a identificação dos compartimentos ambientais estruturantes da paisagem e que condicionam em maior grau os processos naturais relativos às dinâmicas do clima $\mathrm{e}$ da água. Desta forma, apresenta-se de antemão uma abordagem influenciada pela concepção sistêmica em voga nos estudos de geografia física. Já para as implicações relativas à ocupação urbana e sua expansão em curso, a identificação e constatação de sua situação atual é de extrema relevância ao planejamento urbano, pois considera os setores do território que, se continuadamente alterados, mais influenciam nos desajustes ambientais dessa ocupação urbana e que causam prejuízos materiais e riscos à população. 
As bases teóricas que dão suporte a essas análises geográficogeomorfológicas, todas da linhagem sistêmica, assentam-se na abordagem dos geossistemas que atualmente se delineiam como o objeto formal de estudo da Geografia Física; do georelevo, conforme concepção delineada por Kugler; e, mais especificamente, das categorias de análise para os estudos em geomorfologia conforme organizadas por Ab'Saber, em 1969, no texto "Um conceito de Geomorfologia a serviço das pesquisas sobre o Quaternário (Ab’Saber, 1969).

A concepção teórico-metodológica do geossistema foi formulada inicialmente pelo russo Sotchava (1977), em meados da década de 1960, e foi difundida no Brasil por G. Bertrand (1968). Essa concepção é derivada da ciência da paisagem, muito desenvolvida na escola alemã de Geomorfologia; da teoria geral dos sistemas; e da noção de ecossistemas. Assim, o suporte teórico do geossistema vem da noção de "paisagem ecológica" de Troll, apresentada em 1930, e da ampliação do termo e conceito de ecossistema de Tansley, em 1935.

Os princípios básicos do geossistema, segundo Sotchava (1977), se estruturam na visão da natureza como sistemas dinâmicos abertos e hierarquicamente organizados, passíveis de delimitação, ou de serem circunscritos espacialmente em sua tridimensionalidade; e na noção de dinâmica, na qual é possível classificar os geossistemas de acordo com seu estado ou estados sucessivos, assim como é possível assumir hipóteses sobre sua dinâmica futura. Esse caráter preditivo o torna um bom instrumento de apoio para a sua aplicação no planejamento territorial e urbano.

Já a especificação do termo "apropriação do relevo", utilizado nas abordagens sobre a expressão da urbanização do território, dá ênfase ao aspecto fundamental da pesquisa que é a importância da análise do relevo, e das dinâmicas que concorrem para a sua esculturação, para fins de planejamento territorial, sobretudo nas áreas densamente ocupadas. Assim, o termo "apropriar-se do relevo" visa realçar que a sociedade não somente usa uma superfície e ocupa um solo, como interfere nos processos naturais que por esse relevo perpassam e contribuem para a sua modelagem. 
É nesse sentido que o aporte teórico-metodológico também se aproxima do conceito de georelevo, conforme delineado por Kugler (1976). Como as paisagens metropolitanas sempre apresentam um elevado grau de humanização e de interferências no território, segundo Kugler, o relevo e o território são, assim, "cunhados em uma interface extremamente dinâmica e produzem uma paisagem fortemente marcada pela sociedade e por sua estrutura econômica" (Abreu, 1985 p. 158). Kugler dá ênfase à importância em associar ao estudo da evolução do relevo as dinâmicas da sociedade, fato até então pouco disseminado na pesquisa geomorfológica. $O$ autor, alemão de origem, trabalha o conceito de landschaftshülle, oriundo da visão clássica alemã, que visa articular a compreensão das dinâmicas da sociedade e as da natureza que se constitui em diferentes esferas que se interseccionam e desenham, ou definem uma epiderme de pouca espessura constituída pela superfície do relevo (epiderme) originando a paisagem. Nela se articulam as estruturas de análise vertical e horizontal da paisagem, podendo propiciar sínteses mais integradoras da paisagem.

A postulação metodológica, talvez a mais clara, para as pesquisas geomorfológicas foi estabelecida por Ab'Saber (1969, p.1-2) e emoldura o escopo de abordagem do relevo que se irá apresentar no decorrer deste trabalho. No artigo já mencionado acima, Ab'Saber delineia os três níveis de tratamento que considera essenciais: 1) o estudo da compartimentação da topografia regional e a caracterização e descrição das formas de relevo de cada um dos compartimentos estudados; 2) o estudo da estrutura superficial das paisagens referentes a esses compartimentos e formas de relevo observadas; e 3) o entendimento dos processos morfoclimáticos e pedogêncios atuais, em sua plena atuação, ou seja, a compreensão da fisiologia da paisagem.

O primeiro nível de tratamento, apesar de ser considerado elementar nas pesquisas geomorfológicas, não vinha tendo grande apelo dentre os pesquisadores, no entanto se trata de uma abordagem essencial para o planejamento da ocupação do solo urbano e rural. Associado aos demais, Ab'Saber (1969, p.4) entendia que só assim os estudos geomorfológicos poderiam "servir às disciplinas vizinhas e atingir a alguma coisa de mais objetivo para a restauração dos esventos que responderam 
pela evolução do relevo e pelas transformações globais e locais da própria paisagem"

Embora o próprio autor considerasse a importância de tais estudos para a pesquisa geomorfológica, entendia claramente as diferenças radicais e limitações operacionais de escala, de técnicas e de conteúdos para a abordagem de cada um desses níveis, que extrapolam as raízes da própria formação científica de cada pesquisador e das possibilidades das instituições as quaispertencem, daí a necessidade de projetos interdisciplinares. Mesmo assim, a proposição metodológica de Ab'Saber apresenta um ordenamento da análise da paisagem que introduz alguns procedimentos práticos que facilitam inferir sínteses dessa paisagem válidas, também, para se planejar o uso e a ocupação do espaço. Na dissertação de mestrado apresentada à FAU/USP em 2005, e na recente publicação de 2012 (Schutzer, 2012. Cidade e Meio Ambiente: a apropriação do relevo no desenho ambiental urbano), são utilizados esses instrumentos na análise da apropriação do relevo na cidade de São Paulo, transportando-os para servir ao interesse do planejamento ambiental e territorial urbano, facilitando, assim, o entendimento do relevo a partir de uma visão estratégica de sua ocupação.

De outro lado, há que se salientar também a aproximação com as referências utilizadas nas correntes de Ecologia da Paisagem / Landscape Ecology e Biogeografia. A escola da Ecologia da Paisagem tem dado suporte teórico a arquitetos e urbanistas, além de outros profissionais que atuam em planejamento territorial urbano. Sua ênfase na conservação da biodiversidade estabelece conceitos de preservação de ecossistemas e biomas que orientam procedimentos de ordenação do espaço. Nesse sentido, a abordagem que se realiza neste trabalho traz implícitos alguns desses conceitos, como o de conectores ou corredores ecológicos, da preservação de habitats, dos biomas locais e da biodiversidade, mesmo que em ambientes densamente urbanizados. Entretanto, não será foco de detalhamento nesse sentido, pois se pretende orientar a análise mais pela contribuição teórico-metodológica ao processo de planejamento urbano e regional pelo olhar do relevo - geomorfologia - do que sugerir uma proposta de desenho ambiental. 
Quanto aos aportes teóricos relativos às influências antrópicas na paisagem, conforme já mencionado, a ênfase será dada às questões relativas ao processo de urbanização em desenvolvimento no território. Duas correntes serão trabalhadas. A corrente dos pesquisadores e profissionais que estudam a urbanização em seu viés tradicional (Urbanismo tradicional) e aquela que aborda a inserção dos processos da natureza no desenho das cidades e no planejamento urbano, conhecida atualmente como Desenho Ambiental ou Landscape Ecology.

Na visão do urbanismo tradicional, a ênfase será dada às questões relativas à dispersão urbana, que se inserem nas discussões entre a cidade do século XX e do século XXI; cidade moderna e cidade contemporânea. Em ambas está implícita a passagem para o período técnico-cientifico-informacional (Santos, 1996) conforme explicitado por Milton Santos em "A natureza do espaço", além de diversos outros autores que estudaram o processo de globalização e a flexibilização das atividades produtivas em operação nas três últimas décadas mais intensamente. Dentre eles podemos destacar Harvey (1989), Soja(1989), Berman(1986) e Castells(1999).

Essa passagem do modernismo para o pós-modernismo, do regime de acumulação fordista para outro mais flexível, do que decorre uma compressão do tempo-espaço, conforme argumentou Harvey em "A condição pós-moderna" (1989), são elementos que Bernardo Secchi analisa, sob o ponto de vista do urbanismo e do projeto urbano, num excursus sobre a dissolução da cidade moderna e a emergência da cidade contemporânea. Sob o ponto de vista do urbanismo, avalia-se que Secchi é quem melhor explora o tema sobre como o conceito de cidade vem se alterando nas últimas décadas, e onde o tema da dispersão urbana aparece com maior substância. Nesse sentido, de suas duas publicações - "Primeira Lição de Urbanismo" e "A Cidade do Século Vinte" aportam elementos para a discussão acerca das repercussões da dispersão urbana na forma de expansão da cidade contemporânea (Secchi, 2006 e 2009).

O tema dispersão urbana é bastante rico e vem sendo analisado sob variados aspectos, que sugerem inclusive a criação de outras formas de expressar o fenômeno de explosão ou fragmentação das manchas urbanas concentradas. Alguns autores têm utilizado o conceito de "cidade difusa" para os casos em que todos os valores urbanos estejam presentes nas células dispersas, dentre eles 
Dematteis (1998) e Indovina(1990). De outro lado, Monte-Mór (2006, p. 10), apoiado em Lefebvre, utiliza o termo "urbanização extensiva" para se referir à disseminação da lógica dos valores urbanos ligados à produção industrial e consumo que são estendidas para além das aglomerações urbanas, ou seja, ao espaço social como um todo.

Nesse sentido, o autor cita Lefebvre, para explicar as facetas dessa penetração das lógicas urbanas que transformam as relações cidade-campo:

"O tecido urbano prolifera, estende-se, corrói os resíduos de vida agrária. Estas palavras, 'o tecido urbano', não designam, de maneira restrita, o domínio edificado nas cidades, mas o conjunto das manifestações do predomínio da cidade sobre o campo. Nessa acepção, uma segunda residência, uma rodovia, um supermercado em pleno campo, fazem parte do tecido urbano." (Lefebvre, 1999: 17) (Monte-Mór, 2006, p. 10)

Embora não seja foco do trabalho aprofundar a análise do caráter da cidade resultante do processo de dispersão, e dos valores urbanos inseridos nas peças que se dispersam, isoladamente ou em seu conjunto, considera-se importante levantar um pouco a discussão sobre qual é o caráter que se estabelece entre a antiga dicotomia entre o rural e o urbano, visto que isso tem relação com as formas de utilização da terra que se estabelecem, portanto, com repercussões ambientais nos diversos compartimentos que compõem a paisagem. Ou seja, qual é o rural que emerge do processo de dispersão nas áreas densamente ocupadas?

Outro importante aspecto que será utilizado como referencial das análises sobre a dispersão urbana se refere à já razoável produção acadêmica sobre o tema, sobretudo a vinculada aos estudos de caso realizados em diversas cidades brasileiras. Linhas de pesquisa coordenadas por Nestor Goulart Reis Filho (FAU/USP), Ester Limonad (Universidade Federal Fluminense) e Heloísa Soares Costa (UFMG), têm produzido reflexões e análises de casos que são de extrema valia para a consolidação desse conteúdo da expressão urbana derivada desse processo de dispersão.

A segunda corrente de urbanistas se orienta pela inclusão de forma mais enfática de princípios ecológicos e ambientais na análise do planejamento urbano. Vários autores têm trabalhado esse conceito de um desenho urbano de caráter ambiental, do ato de se projetar orientando-se pelos processos da natureza. Talvez 
o expoente mais marcante ainda dessa corrente, embora não o pioneiro e precursor, venha a ser I. Mcharg, que na década de 1960 elaborou, com uma equipe multidisciplinar, trabalhos de ordenamento territorial em várias cidades americanas, dentre elas Nova York e Baltimore. O livro "Design with Nature" (Mcharg, 1967) se transformou em referência importante para a geração de urbanistas das últimas quatro décadas. Seguindo uma metodologia já reconhecida há tempos na Geografia Física e nas Ciências da Terra - a sobreposição de cartas básicas e temáticas Mcharg incorpora à análise do meio físico a sobreposição de informações mapeadas dos elementos urbanos e da urbanização, além da inserção de prognósticos de expansão da ocupação e da criação de cenários tendenciais dessa expansão.

O objetivo final desse método é orientar os melhores lugares para a ocupação e expansão urbana, além da definição dos melhores espaços para lazer e fruição e para a preservação ecológica. É nesse sentido que essa pesquisa se aproxima da escola da Landscape Ecology, contudo, dando mais relevância ao relevo como elemento importante na organização do espaço, como um dos elementos que condicionam os desenhos da ocupação urbana.

\subsection{Bases metodológicas}

A abordagem metodológica foi estruturada em três fases de trabalho nas quais se buscou levantar dados e selecionar informações, correlacioná-los entre si e com as teorias vigentes, e, por fim, interpretá-los à luz dos conceitos dominantes a fim de estabelecer as generalizações possíveis ante as hipóteses preliminarmente assumidas, baseadas na tendência crescente de impactos ambientais do fenômeno de dispersão urbana sob a ótica da apropriação do relevo.

A metodologia adotada se apoia na proposta de Libault (1971) descrita por Ross (2000), que seleciona os quatro principais níveis de abordagem de uma pesquisa geográfica: o nível compilatório; o correlativo; o Semântico e o Normativo. Em face de seu potencial analítico para pesquisas de qualquer conteúdo, conforme relata Ross (2000), e não somente para as pesquisas de bases predominantemente quantitativas, faz parecer que esse método facilitaria o entendimento da interpretação analítico-dedutiva a ser empreendida neste trabalho. 
$\mathrm{Na}$ primeira fase realizou-se o levantamento das informações de base do meio físico, do mapeamento do fenômeno abordado, dos dados quantitativos socioeconômicos e das bases conceituais que suportam a análise do fenômeno a ser empreendida.

A observação dos fatos que consubstanciam a hipótese deste trabalho iniciou-se pela seleção das informações de base do território já estudadas e mapeadas pelas instituições oficiais como:

Mapa topográfico - Uso e ocupação do solo da Região Metropolitana de São Paulo (RMSP) e Bacia Hidrográfica do Alto Tietê - EMPLASA, 2005: nesta base foram identificados os níveis topográficos dos principais divisores de água do relevo, a rede de drenagem principal e mapeados os principais níveis topográficos onde se instalam as mais expressivas planícies aluviais.

$\checkmark$ Mapa geomorfológico do estado de São Paulo - IPT (1:500.000): a análise deste mapa visou correlacionar a topografia, as peças urbanas dispersas identificadas com as formas de relevo predominantes na região da Macrometrópole de São Paulo.

$\checkmark$ Mapa geológico do estado de São Paulo - IPT (1:500.000): a análise deste mapa visava correlacionar os fatos geológicos aos dados geomorfológicos e topográficos, como também à ocupação urbana dispersa mapeada na base do Google Earth.

O fenômeno de dispersão urbana na Macrometrópole de São Paulo foi mensurado por meio da análise de sua ocorrência observando-se as imagens do Google Earth. Utilizando-se as ferramentas disponíveis no próprio programa, foram mapeados os perímetros da ocupação urbana compacta e dispersa. A mancha urbana compacta das sedes dos municípios das regiões metropolitanas e aglomerações urbanas que compõem a Macrometrópole de São Paulo, e as peças urbanas dispersas foram mapeadas por meio da identificação do perímetro visual e aproximado do loteamento, do condomínio ou da área industrial. Esse perímetro não obedeceu aos limites rígidos dos loteamentos e dos terrenos correlatos, pois não foram levantados mapas das plantas cadastrais dos mesmos. Mesmo assim, foi possível dimensionar a porção espacial aproximada da imagem da superfície para 
ser confrontada com os dados topográficos e linhas estruturantes da paisagem a ser objeto de análise e cruzamentos necessários.

A identificação das áreas objeto de ocupação urbana se baseou em dois critérios iniciais de separação: as áreas de ocupação urbana compacta relativa à sede do município e chamada de cidade compacta foi diferenciada das manchas urbanas dispersas e alcunhadasneste trabalho de peças urbanas. Essas peças urbanas dispersas foram separadas segundo o seguinte parâmetro de diferenciação de morfologia:

$\checkmark$ Loteamentos e condomínios de média-alta e alta renda;

$\checkmark$ Loteamentos de chácaras de média e alta renda;

$\checkmark$ Loteamentos de média e de baixa renda similares ao padrão da mancha compacta;

$\checkmark$ Áreas produtivas relacionadas à indústria/comércio/serviços, bem como os equipamentos polarizadores como aeroportos, campus universitários;

$\checkmark$ Áreas de mineração e reflorestamento comercial;

A utilização dos recursos de mapeamento temático sobre as imagens do Google Earth possibilitou a observação das várias camadas e tipologias mapeadas, de modo conjunto, isoladamente ou por meio de comparações eletivas e/ou alternadas, e possibilitou o reconhecimento mais aprofundado das relações que elas estabeleciam entre si, com a mancha urbana compacta e com os demais aspectos físicos e de infraestrutura viária relacionada.

Foram também mapeadas sobre as imagens do Google Earth, informações sintéticas da paisagem física que subsidiassem a elaboração de uma leitura estratégica da superfície e a correlação dos dados topográficos, geológicos e geomorfológicos dos mapas-base citados. Essas informaçõescorresponderam a:

$\checkmark$ Identificar a rede hídrica principal que drena o território da macrometrópole: foram mapeados apenas os canais principais da Bacia do Rio Tietê (Pinheiros, Tamanduateí, Juqueri, Jundiaí, Atibaia, etc) e do Paraíba do Sul. 
$\checkmark$ Identificar os principais divisores de água deste relevo: foram mapeadas as linhas desses divisores principais que conformam as principais serras da região e os alinhamentos de morros e colinas que separam as principais subbacias.

$\checkmark$ Identificar a constituição geológica dos principais maciços que estruturam a drenagem da região, mais especificamente dos principais divisores da água mapeados.

Para melhor lastrear a identificação do fenômeno de dispersão foi realizado um levantamento de dados populacionais e socioeconômicos dos municípios das regiões metropolitanas e aglomerações urbanas que configuram a Macrometrópole de São Paulo. Os principais dados levantados foram os seguintes:

$\checkmark$ Populacionais: Evolução da população total, urbana e rural dos municípios e taxa geométrica de crescimento anual da população no período censitário compreendido entre 1970 e 2010. A fonte principal se baseou nos dados censitários do IBGE.

$\checkmark$ Econômicos - Agropecuária: levantamento da produção agrícola e pecuária municipal, por produção e área plantada. Os dados relativos às lavouras permanente e temporária e da produção pecuária visaram mensurar o potencial de produção das áreas rurais de cada município e região da macrometrópole para propiciar inferências quanto às tendências futuras de acentuação da passagem de uma vida agrária para uma economia marcadamente de caráter e influência urbana. A base das informações veio da Pesquisa Agrícola Municipal do IBGE. A presença da produção de madeira para papel e celulose também foi objeto de levantamento em virtude da presença de áreas de reflorestamento significativas em alguns municípios, produção que eventualmente pode servir como freio à expansão de loteamentos dispersos em virtude da valorização do território rural proporcionado pela atividade agroindustrial.

$\checkmark$ Ambientais: levantamento das áreas protegidas incidentes na região da Macrometrópole de São Paulo a fim de correlacionar com as tendências da ocupação urbana e com as linhas estruturantes da paisagem a serem objeto de interpretação.

A fundamentação teórico-conceitual também foi objeto de levantamento e sistematização, iniciando-se pelo rastreamento dos estudos de caso sobre a 
dispersão urbana no Brasil e no mundo, bem como sobre os trabalhos analíticoconceituais deste fenômeno sob o enfoque da urbanização do território e do urbanismo contemporâneo. Essas informações foram descritas mais detalhadamente no tópico anterior deste capítulo. Nesse tópico os levantamentos se basearam nos seguintes aspectos:

$\checkmark$ Identificação do estado da arte de fundamentação das tendências teóricas do urbanismo contemporâneo e sua leitura sobre o fenômeno da dispersão urbana.

$\checkmark$ A identificação dos conceitos utilizados e das diversas denominações do fenômeno.

$\checkmark$ A identificação da contradição dos conceitos e das análises ante a leitura dos impactos ambientais ou das vantagens ambientais da dispersão urbana, comparativamente ou não em relação aos impactos da cidade compacta.

Numa segunda fase do trabalho procedeu-se uma análise comparativa dos dados e das regiões analisadas, realizando-se cruzamentos seletivos das informações, a fim de se encontrarem correlações e tendências evolutivas do fenômeno de dispersão e suas relações com o ambiente físico-natural. Os mapeamentos e informações levantadas na fase anterior, cruzados e correlacionados nesta fase visaram estabelecer os níveis de comparação entre as regiões, ou seja, em que bases esses dados poderiam ser correlacionados a fim de possibilitar a interpretação do fenômeno sob o ponto de vista dos possíveis impactos ambientais decorrentes das tendências evolutivas diagnosticadas.

Em uma terceira fase procedeu-se a interpretação do fenômeno analisado frente às hipóteses levantadas inicialmente, a fim de estabelecer possíveis generalizações, por meio do reconhecimento do mecanismo de funcionamento do processo em questão. Para isso optou-se por selecionar duas áreas-exemplo para um detalhamento e observação mais detalhada das ocorrências de ocupação dispersa que se direcionavam a compartimentos ambientais eleitos como estruturantes da ocorrência dos processos naturais na região. Nesse sentido, foi realizada uma abordagem estratégica sobre o relevo regional buscando selecionar aqueles setores onde prevalecem as principais linhas e compartimentos estruturantes da paisagem macrometropolitana. 
Concorreu para a interpretação dessa fase um lastreamento teóricometodológico utilizados na pesquisa geomorfológica e em sua base conceitual de leitura da paisagem e de suas respostas ante a ação antrópica.

\subsection{Revisão bibliográfica pertinente ao tema}

Conforme já alinhavado no item anterior, sobre as bases teóricas e metodológicas, esta pesquisa se desenvolve em duas linhas de abordagem distintas: uma de caráter nitidamente voltado para o urbanismo e geografia urbana, discutindo a urbanização contemporânea e a forma como vem se desenvolvendo nas metrópoles e nas áreas densamente urbanizadas sua relação com o sítio; e outra visa analisar a paisagem sob o aspecto da identificação de unidades de relevo, ou seja, das implicações ambientais da urbanização contemporânea, tendo como ponto de interface o relevo.

Quanto à primeira linha, o tema central dirige-se para as mudanças que vêm ocorrendo nas últimas três décadas quanto ao desenvolvimento tecnológico e da informação, que se traduz em uma grande flexibilização das atividades produtivas e de uso do território. Isso vem se refletindo, na urbanização mundial e brasileira, numa tendência a construção de uma cidade fragmentada, que tem nos conceitos de dispersão urbana, cidade difusa, urbanização extensiva, entre outros, expressões para justificar o processo em desenvolvimento.

O arquiteto e urbanista Bernardo Secchi abordou esse tema, especialmente nos seus dois livros traduzidos para o português, "Primeira lição de urbanismo" e "A cidade do século XX”. Segundo o autor,

"[...] alguns dos mais evidentes aspectos visíveis da cidade contemporânea fragmentação, heterogeneidade e dispersão - têm sido muitas vezes atribuídos às numerosas e sucessivas ondas de progresso técnico ocorridas no campo das comunicações e do transporte: seja do transporte dos corpos e da matéria, seja do tipo imaterial" (Secchi, 2006 - p 94).

Em sua análise sobre a passagem da cidade moderna para a contemporânea, Secchi assinala que 
"[...] à medida que as técnicas de transporte, a construção de ferrovias, de bondes e, mais tarde, a difusão do automóvel o permitiram, a pressão nas áreas centrais foi atenuada pela expansão de uma vasta periferia frequentemente identificada como sendo o produto mais evidente do crescimento urbano do século $X X$, o setor no qual o século produziu formas de ocupação que mudaram a fisionomia de territórios inteiros, construindo novas geografias sociais, funcionais ou simbólicas" (Secchi, 2009 - p 36).

Dematteis (2008) e Indovina (1990) abordam o tema da fragmentação e suas tipologias. O primeiro estuda as dinâmicas da desurbanização e contraurbanização, preferindo chamar a fragmentação dos tecidos urbanos como uma "difusão reticular"1 no lugar de cidade difusa.

O segundo autor atenta para a diferenciação entre as novas periferias urbanas - a periurbanização e a cidade difusa - com as periferias urbanas da fase precedente, diferença essa que se expressa não somente na forma, mas sim nas modalidades de organização territorial, de composição social e de desenvolvimento. A flexibilização das relações hierárquicas, da organização produtiva e do trabalho, operadas na passagem das relações de produção "fordista" para a "pós-fordista" ocorridas entre as décadas 1960 e 1970, modificaram formal e funcionalmente estes novos espaços periféricos, fazendo surgir novas identidades, centralidades ou especificidades locais ou outras tantas vantagens competitivas, em um contexto tendencialmente global (Dematteis, $2008-p$ 6).

Já Limonad (2008) acentua seu foco na dúvida se a dispersão não carrega em si apenas uma etapa de novas concentrações do tecido urbano compacto. Segundo a autora, "nas duas últimas décadas a urbanização contemporânea no Brasil caracteriza-se por duas tendências diversas: concentração e dispersão, que estariam a se desenvolver de forma complementar" (Limonad, 2007c). Enquanto o movimento de concentração dá origem a grandes aglomerações urbanometropolitanas, a um tecido urbano coeso e contínuo, com áreas rurais e urbanas bem definidas; a dispersão caracteriza-se por uma disseminação difusa das indústrias e atividades produtivas no território e por uma multiplicação de núcleos e aglomerações urbanas. Toma forma, assim, um tecido esgarçado, descontínuo, que dá origem a uma estruturação territorial dispersa. Aí, segundo a autora, não há contiguidade de usos e de atividades. Rural e urbano se tornam indistintos, embora

\footnotetext{
${ }^{1}$ Esse tema será abordado com mais detalhe no Capítulo 4.
} 
se agucem as contradições entre a urbanidade e a ruralidade. (Limonad, 2008, p. 4). Limonad também questiona muito sobre os impactos ambientais desse consumo expressivo do território.

Do ponto de vista conceitual, Font (2007) também se preocupa com a clareza das terminologias utilizadas para expressar o fenômeno de dispersão que vem se desenvolvendo. Segundo o autor, "dispersão é um conceito de natureza topológica, diz respeito às relações das distâncias entre as coisas mais do que um fenômeno de densidade, mais do que um fenômeno de difusão" (Font, 2007 - p 63). Para ele, a difusão expressa efetivamente "a extensão de alguns valores urbanos pelo território, que fazem com que pareçam urbanóides, como ocorre, por exemplo, no Vêneto Central, na Média Ave em Portugal, no Sul de Alicante na Espanha, onde esses valores de construção da cidade difundem-se pelo território" (Font, 2007 - p 64). Os impactos ambientais da dispersão também são questionados por esse autor, porém sem grande aprofundamento nesse tema.

Monte-Mór (2006) em vários artigos carrega as tintas na extensividade do fenômeno urbano, trazendo muitos elementos para a discussão da antiga dicotomia rural-urbano. Segundo ele,

"[...] cada vez mais as fronteiras entre o espaço urbano e o espaço rural são difusas $e$ de difícil identificação. Pode-se supor que isto acontece porque hoje esses adjetivos carecem da sua referência substantiva original, na medida em que tanto a cidade como o campo não são mais conceitos puros, de fácil identificação ou delimitação" (Monte-Mór, 2006, p. 6).

No Brasil, vale ressaltar a contribuição de Nestor Goulart Reis, Ester Limonad e Heloísa Soares M. Costa na organização de linhas de pesquisa sobre o tema da dispersão urbana, as quais aportam uma grande quantidade de estudos de caso de várias regiões e cidades brasileiras ${ }^{2}$.

N. G. Reis (Reis, 2006 e 2007), procura sistematizar a discussão e os vários estudos de caso em investigação no Brasil e na Europa, nos artigos "Sobre a dispersão urbana em São Paulo" e "Notas sobre a urbanização dispersa e novas

\footnotetext{
${ }^{2}$ Ver referências bibliográficas sobre estudos de caso em dispersão urbana em Assis (2009); Caiado \& Perillo (2008); Costa (2004 e 2006); Costa \& Monte-Mór (2007); Finati (2009); Honda (2008); Larrabure (2009); Magalhães, Linhares e Monte-Mór (2006); Martins (2006); Mitica (2007); Tanaka (2007); Tatsch (2008); Tineu (2009); Trindade Júnior (1998) e Wendel (2006).
} 
formas de tecido urbano", e na organização do seminário "Urbanização Dispersa e Mudanças no Tecido Urbano", realizado na FAU/USP em 2006. Nestes trabalhos Reis retrata as peculiaridades do processo de dispersão em São Paulo, analisando vetores de dispersão e os tecidos urbanos elaborados neste processo, buscando verificar o conteúdo dessas novas formas de tecido urbano em dispersão. Estudos sobre a dispersão urbana realizados por colaboradores para o seminário discutiram as tendências verificadas em Campinas (Caiado e Pires, 2007), São José dos Campos (Tanaka, 2007) e Sorocaba (Debrassi, 2007), que trazem olhares sobre questão na macrometrópole de São Paulo. Além destes, trabalhos sobre Brasília, Belo Horizonte, Maceió, Fortaleza, no litoral de Santa Catarina e litoral do Nordeste, demonstram que a tendência à dispersão atinge aglomerados dos mais variados portes.

No livro "Novas Periferias Metropolitanas", organizado por H.S.M. Costa (2006), artigos de diversos pesquisadores estão reunidos e realçam a especificidade da expansão urbana no Eixo Sul da Região Metropolitana de Belo Horizonte. Ali, expansão e dispersão se diferenciam do que ocorre em outras regiões metropolitanas pela associação de interesses entre as camadas de alta renda e o negócio da mineração, predominantemente de minério de ferro. Segregação socioespacial e mercantilização da natureza dá o tom da dispersão que ocorre nos municípios de Nova Lima, Brumadinho, Rio Acima e Itabirito, em um contexto de elevada concentração fundiária nas mãos das empresas mineradoras e do mercado imobiliário (Costa, 2006). A ocupação por condomínios horizontais das camadas de alta renda de compartimentos ambientais estruturantes daquela paisagem (a Sinclinal Moeda e nascentes do Rio das Velhas), responsáveis pela maior parte do abastecimento de água da região metropolitana e por abrigar inúmeras nascentes e biomas diversificados, com espécies endêmicas e ameaçadas de extinção, evidencia uma apropriação do relevo pouco adequada dentro do contexto de uma abordagem estratégica do relevo para efeitos de preservação ambiental.

Já a dispersão urbana nas cidades praianas é discutida com maior ênfase por Limonad. A implantação de condomínios fechados e resorts ao longo do litoral do 
Nordeste, sobretudo na Bahia ${ }^{3}$ e Pernambuco, evidencia uma ocupação em que se misturam elementos de dispersão e tendência de continuidade de um tecido urbano homogêneo ao longo da costa. A ocupação de distintos compartimentos de relevo entre as camadas de alta e baixa renda revela a emergência de sítios sociais, entre costa e interior, entre áreas inundáveis e áreas secas, áreas com e sem infraestrutura urbana adequada, e outras disparidades e anomalias, em evidente processo de segregação socioespacial e socioambiental que tem contribuído para a degradação dos ecossistemas litorâneos.

É extensa a bibliografia sobre as estruturas urbanas segregadas do tipo condomínios fechados, um dos principais motores da dispersão urbana. Autores como Borsdorf (2003), Costa e Monte-Mór (2007), Honda (2008), Larrabure (2009), Bhering (2002), Peixoto (2005), Mendonça (2002), entre outros, abordaram, sob diversos olhares, essa forma de segregação espacial em seus aspectos sociais, urbanísticos, imobiliários e jurídicos. A fragmentação do tecido urbano e as barreiras criadas à acessibilidade dos bairros, a homogeneização social, a criação de espaços livres privados, são aspectos considerados, juntamente com a leniência da regulação na esfera pública.

De outro lado, são poucas as referências que se faz quanto às relações dos condomínios fechados com o ambiente e, sobretudo, com o relevo, ou seja, a escolha do sítio em que são isntalados. Nesse sentido, cabe destaque a Costa (2004), pois em alguns trabalhos busca colocar em evidência os impactos ambientais e as estratégias de privatização da natureza inseridas na ideologia imobiliária para as camadas de alta renda. A autora analisa os conflitos de uso associados à mineração, à produção imobiliária para assentamentos residenciais ou à preservação do patrimônio natural metropolitano na Região Metropolitana de Belo Horizonte. No eixo-sul de expansão metropolitana desta capital, um ingrediente

\footnotetext{
${ }^{3}$ Costa dos Coqueiros, no litoral norte do estado da Bahia, nas duas últimas décadas assistiu, de um lado, a expansão de condomínios fechados ao longo da costa dos municípios de Camaçari e Mata de São João, com a quase extinção dos biomas de restinga, colmatação e aterro de lagoas, e desmatamento de remanescentes de Mata Atlântica. De outro, no interior dos municípioso incremento da industrialização, o pólo petroquímico de Camaçari e a expansão/dispersão de loteamentos regulares e/ou irregulares para as camadas populares. Ver Limonad, 2008. A mesma situação pode ser encontrada em Pernambuco, nos municípios de Cabo de Santo Agostinho e Ipojuca, ao sul de Recife. Condomínios fechados, resorts, turismo de massa em Porto de Galinhas, no litoral, e polo industrial e Portuário de Suape, na porção interiorana ao longo dos eixos rodoviários, por onde se desenvolve a dispersão de loteamentos para as camadas populares.
} 
contraditório é a busca da qualidade ambiental do empreendimento imobiliário por meio da apropriação de unidades de conservação (RPPNs) e/ou das vizinhanças das reservas estaduais, transformando, assim, valor de uso coletivo inerente à preservação ambiental, em valor de troca, materializado, por exemplo, na elevação dos valores fundiários e na elitização do acesso à moradia (Costa, 2004, p. 3).

Também a Região Metropolitana de Belo Horizonte serve de estudo de caso para Peixoto analisar a questão do licenciamento ambiental em relação à expansão urbana, especialmente dos grandes projetos de condomínios residenciais fechados para as camadas de alta renda. Tendo como cenário o município de Nova Lima, a autora ressalta as dificuldades da introdução da análise ambiental no controle da expansão urbana, que deve ser considerada, também, a partir da avaliação da capacidade de suporte dos ecossistemas natural e construído (Peixoto, 2005, p.147). Como a legislação ambiental federal dispensa o licenciamento ambiental de loteamentos em área rural e ainda questiona a situação legal dos condomínios ou loteamentos fechados, criou-se um impasse regulatório cuja alternativa frequentemente utilizada pelos empreendedores imobiliários é manter a gleba, objeto do projeto de loteamento fechado, como área rural. Embora extremamente relevante essa abordagem sobre a legalidade jurídica não foi objeto de aprofundamento neste trabalho, mesmo em se considerando a expressão dos condomínios fechados no processo de dispersão urbana na macrometrópole. Nesse assunto, cabe destacar o trabalho de P.M. Bicudo (2007) - Loteamentos fechados e condomínios deitados - em que analisa essa lacuna jurídica quanto a regulamentação dessa forma de loteamento residencial no Brasil.

Ainda sobre o tema urbanização e geografia urbana vale mencionar os trabalhos de Aroldo de Azevedo (1958), Langenbuch (1971) e Meyer (2004) que fazem, cada um a seu tempo, uma radiografia do processo de expansão metropolitana de São Paulo, e que trazem muitos insumos às pesquisas sobre a metrópole e sua relação com o sítio urbano.

O trabalho organizado por Aroldo de Azevedo (1958) - A cidade de São Paulo: estudos de geografia urbana - trata-se de uma obra referencial para, não somente caracterizar física, social e economicamente a região de São Paulo, evidenciar as relações entre a cidade e seu sítio (Ver Figura 2.1). Para entender a 
metrópole, como ela se apresenta hoje sob o viés da incrível expansão urbana e sua dispersão, e da consequente apropriação do relevo, é importante um retorno a essa obra que, em quatro volumes disseca a evolução da cidade e da futura metrópole. Além de Aroldo de Azevedo, eminentes geógrafos escreveram capítulos sobre São Paulo, como Aziz Ab'Saber, Ary França, Fernando de Almeida, Pasquale Petrone, Odilon Nogueira de Matos, J. R. de Araújo Filho, Nice Lecocq Müller, entre outros.

Figura 2.1 - Expansão linear da cidade de São Paulo em quatro séculos, segundo Aroldo de Azevedo, e sua relação com os compartimentos de relevo.

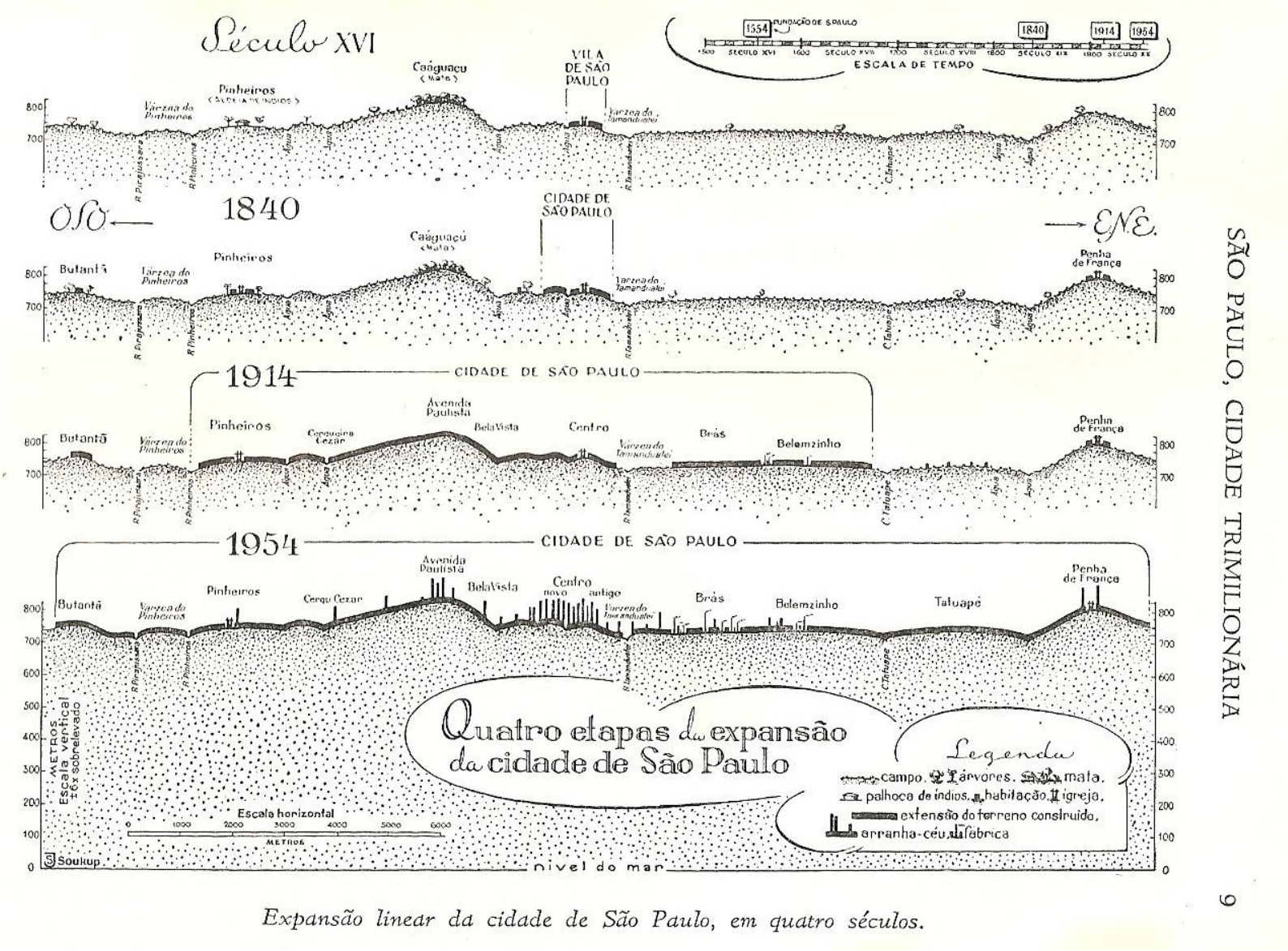

Fonte: Azevedo (1958).

O Volume I retrata a região de São Paulo em seus aspectos físicos, mas fazendo relações importantes com a ocupação humana, rural e urbana, em um típico trabalho de análise geográfica do território. Os capítulos de Ab'Saber - O sítio urbano de São Paulo - e de Fernando de Almeida - O Planalto Paulistano - são de extrema importância para a análise do relevo e da paisagem original do sítio urbano, hoje, imensamente alterada pela urbanização. As fotografias de uma cidade em expansão, e também dispersão à moda da época, a que Ab"Saber se referiu como 
crescimento aos saltos, realçam a ocupação dos diferentes compartimentos de relevo, com uma nitidez impossível hoje de ser percebida em face da volumetria diferenciada das construções de cada bairro ou porção da cidade e da metrópole.

Já o Volume 4 analisa os subúrbios paulistanos, onde se pode verificar a consolidação dos vetores da expansão metropolitana e, hoje, também os vetores da dispersão urbana que se dá a partir da cidade de São Paulo.

Trabalho também referencial para o estudo da apropriação do relevo na região de São Paulo é a tese de doutoramento de Ab'Saber, apresentada em 1958, em que o autor detalha, em maior grau, o texto sobre o sítio urbano de São Paulo publicado na obra de Azevedo (1958), já mencionada. Ab'Saber realiza uma instigante análise geomorfológica dos compartimentos de relevo, da estrutura superficial da paisagem e correlações com os processos naturais por meio do relato dos fatos marcantes da história da paisagem paulista, como as enchentes ou as cheias dos rios Tietê, Pinheiros e Tamanduateí, das alterações climáticas, da resistência dos solos aos processos erosivos, da alteração da cobertura vegetal, aspectos que realçam a fisiologia da paisagem, completando assim a metodologia de Ab'Saber nas suas análises geomorfológicas.

Pouco mais de dez anos depois Langenbuch (1971) retratou a estruturação da Grande São Paulo, em um trabalho também referencial para geografia urbana de São Paulo. Disseca, em períodos, o processo de evolução metropolitana, realçando as ligações entre a cidade de São Paulo, subúrbios e aglomerados, com a estruturação dos vetores da expansão urbana, a que se poderia chamar dispersão, como uma etapa de uma posterior compactação da mancha urbana. Distinguiu o autor dois períodos em que predominaram meios de transporte e variações de trajeto distintos: o comando da expansão pela ferrovia até meados da década de 1940; e, posteriormente, o comando da rodovia, que se mantém até hoje. Embora não faça alusão e correlação nítida da relação dessa expansão com o relevo, Langenbuch retrata a evolução das alterações fisiográficas do relevo operadas pela engenharia (represas, rodovias, etc), bem como a especialização dos arredores de São Paulo em suprir a metrópole de recursos retirados da natureza (madeira, água, produtos agrícolas, etc.), de clima apto à saúde, de opções de lazer, entre outros 
aspectos que revelam a dinâmica do uso e da alteração da paisagem local e regional.

Figura 2.2 - Mapa esquemático da ocupação urbana de São Paulo e arredores em 1962, segundo Langenbuch.

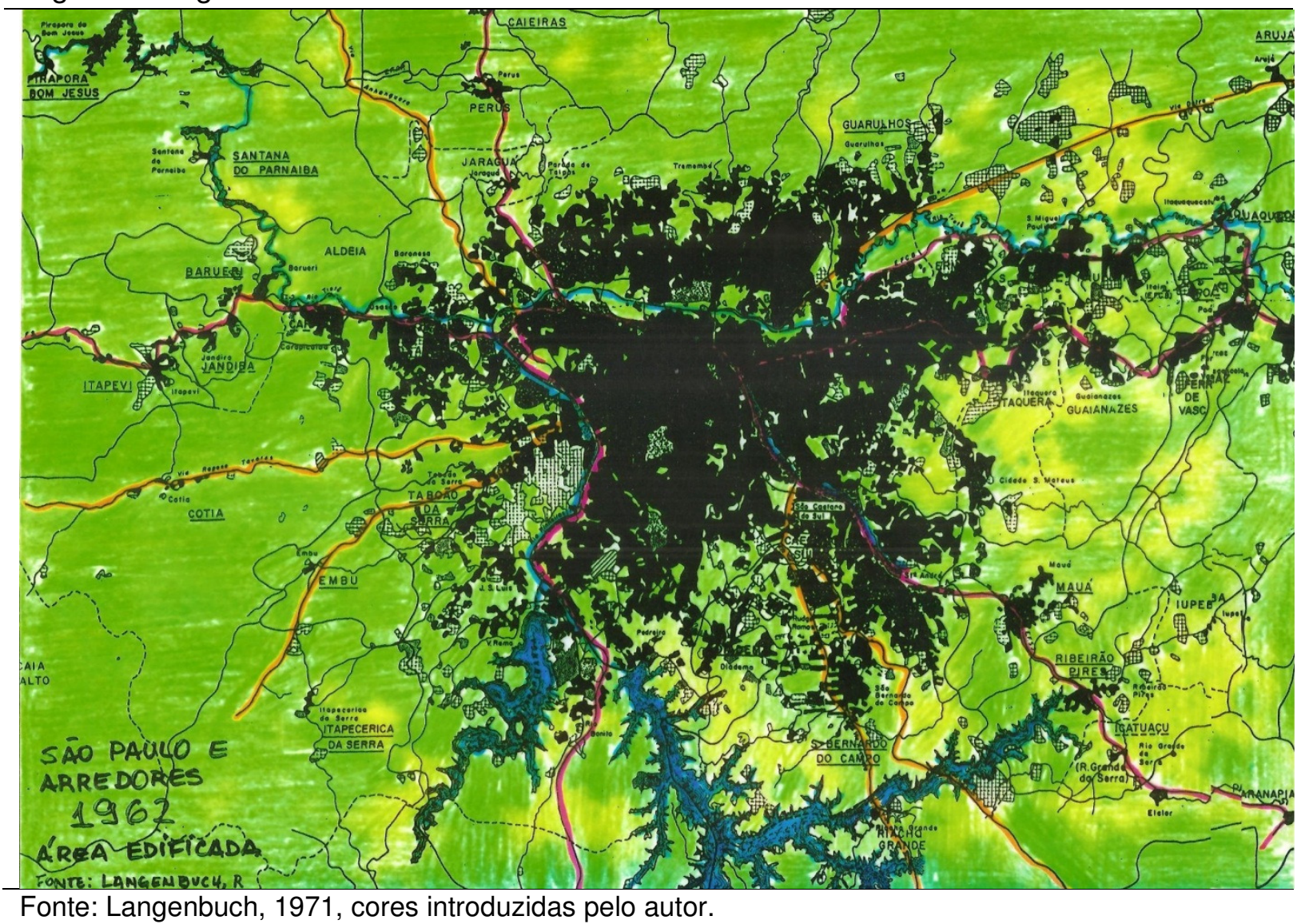

Já o trabalho de Meyer (2004) - São Paulo Metrópole - nos traz as dinâmicas urbanas recentes e a consolidação dos vetores da expansão urbana, além de demonstrar a relocalização da população dentre os municípios metropolitanos e também da atividade industrial. $O$ surgimento de novas centralidades e as novas dinâmicas da cidade informal retrata essa nova etapa do percurso metropolitano. Algumas alusões aos problemas ambientais derivados dessa urbanização são feitas. No entanto, não é dada ênfase no trabalho ao fenômeno da dispersão urbana, pelo menos no que se refere aos termos e conceitos explicativos desse processo.

Em outro importante trabalho de geografia urbana sobre a área foco deste estudo cabe mencionar também o de Nice Lecocq Müller (Müller, 1969), referente ao processo de urbanização no Vale do Paraíba. Em "O fato urbano na bacia do Rio 
Paraíba - São Paulo" a autora faz importante análise do uso e da ocupação dos diversos compartimentos de relevo que caracterizam a paisagem do Vale do Paraíba, em São Paulo. A abordagem que faz sobre o traçado urbano em relação ao sítio utilizado de cada cidade estudada é de riqueza ímpar em termos de análise geográfica e hoje muito importante que se faça para a análise ambiental urbana. Trata-se de um tipo de trabalho e análise de conjunto da paisagem que a própria geografia não tem dado o merecido destaque. É possível verificar neste estudo de Müller, já um embrião do processo de dispersão urbana, ou de crescimento da mancha urbana aos saltos, na maior cidade da região à época - São José dos Campos. Trata-se da expansão de bairros de baixa renda, desgarrados da mancha urbana compacta, que vão ocupar os terrenos baixos às margens do Rio Paraíba e sujeitos a inundação, segregados pelo rio de um lado, e pela ferrovia de outro. Significa mais um exemplo de sítio social em que para as camadas de baixa renda reservam-se os compartimentos mais vulneráveis e sem infraestrutura adequada.

No que se refere às experiências urbanísticas que se implicam com o tema tratado nesta pesquisa, cabe citar o trabalho de Fishman (1982) sobre as utopias urbanas no século $\mathrm{XX}$, em que analisa e compara as propostas de Ebenezer Howard (Cidades Jardim), Frank Lloyd Wright (Broadacre City) e de Le Corbusier (Cidade Moderna). O que elas apresentam em comum, ao menos em relação ao que interessa a esta pesquisa, é a tentativa de estabelecer uma nova relação da cidade com o seu meio ambiente, diferente da cidade compacta tradicional daquela época ${ }^{4}$. Todas elas propõem uma maior inserção de espaços livres públicos ou privados e uma vegetação mais densa dentro do perímetro urbano. Novos formatos de traçado urbano e de quadras indicam a configuração de uma cidade mais verde, permeável e ensolarada. Tratava-se de, efetivamente, de proposição de novas morfologias de tecido urbano. Nesse sentido há que se perguntar se a dispersão urbana, da forma como se desenvolve atualmente, traz em seu bojo nova morfologia de tecido urbano, principalmente no que se relaciona com a ocorrência dos processos naturais.

A experiência de implantação das "cidades-jardim" inglesas, do início do século XX, pode ser considerada um marco em termos de concepção de projeto urbano-ambiental, se não do ponto de vista funcional, pois elas não vingaram

\footnotetext{
${ }^{4}$ Teorias e experiências desenvolvidas entre 1890 e 1930. A experiência de Howard (cidade-jardim) se concretizou nas duas primeiras décadas desse século XX.
} 
totalmente conforme o planejado, pelo menos no que tange o lado ambiental. Em sua origem, a concepção trazia elementos de desconcentração urbana, de sustentabilidade ambiental (embora não com esse nome, e sim "vida saudável") e de sustentabilidade econômica. Tratava-se de uma dispersão planejada, mas bem diferente da atual, pois se caracterizava pela construção de cidades em toda a sua essência, e não simplesmente a dispersão de peças urbanas monofuncionais. Apresentava também como premissa uma relação intrínseca entre cidade e campo circundante, o que não se dá no fenômeno atual da dispersão. No entanto, trata-se de uma referência importante para a análise da apropriação do relevo, em face do grau de permeabilidade do solo que buscava manter, mesmo que oriunda de uma baixa densidade de ocupação populacional.

Nesse sentido, o livro de Ottoni (1996) - "Cidades-jardins de amanhã" ilustra a concepção original do criador desse modelo, Ebenezer Howard, apresentado em 1898, e implantado nas cidades de Letchworth (1902) e Welwyn (1920). A busca de um equilíbrio social e ambiental e de viabilidade econômica eram as premissas do projeto. Parte deste conceito foi disseminado em outros países, e em São Paulo apenas alguns elementos de seu aspecto formal foram introduzidos em bairros da cidade, os bairros-jardim: Jd. América, Jd. Europa, Pacaembú, entre outros. Mesmo assim, pode-se dizer que essa configuração de bairros-jardim representou, e representa hoje, formas de apropriação do relevo urbano menos impactantes aos processos naturais do que as demais formas implantadas na cidade ${ }^{5}$.

Para a divulgação do modelo teórico das cidades-jardim Howard utilizava-se de desenhos esquemáticos das funções e localizações de cada parte da cidade e das áreas rurais, uma técnica muito referendada nos estudos de urbanismo, que visa a organização mental dos planos de urbanização, mas na qual se abstrai as interferências do relevo. Este elemento vem a ser considerado somente no momento de projetar a implantação do esquema em um espaço determinado.

\footnotetext{
${ }^{5}$ Em 1997, na 3a bienal Internacional de Arquitetura de São Paulo foi lançado o livro "Cidades Jardins, a busca do equilíbrio social e ambiental 1898-1998" , livro este que analisa as contribuições e os reflexos desse conceito em outros países da Europa, nos EUA e no Brasil. Em todos eles pode-se verificar exemplificações de peças urbanas que foram inseridas ou propostas para as cidades, e que muitas, hoje, servem de modelo para o desenho urbano.
} 
Figura 2.3 - Diagramas esquemáticos da proposta de Cidades Jardins de Amanhã, de Howard, em 1898.

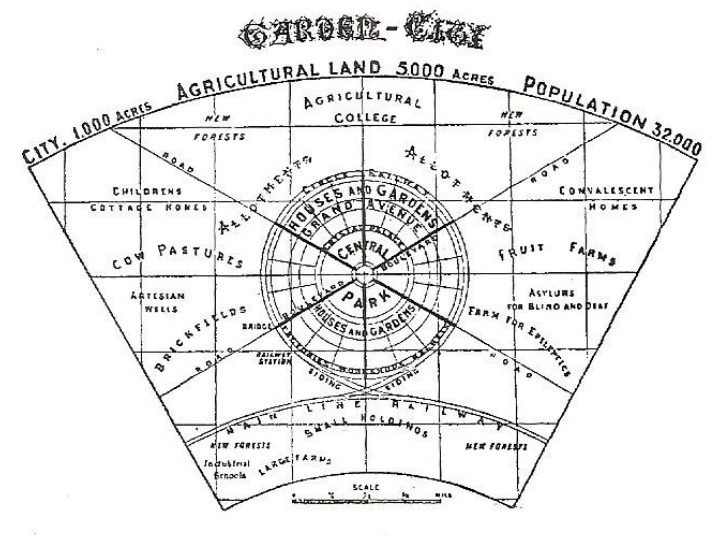

Diagrama $n^{\circ} 2$

Fonte: PURDOM, C. B.; The Building of Satelite Towns.

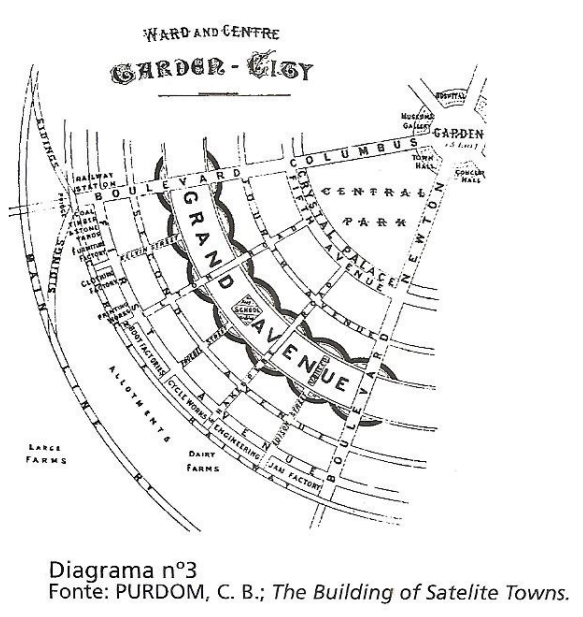

Modelo do núcleo central - Cidade

Modelo da relação cidade a área rural

Fonte: FAU/USP (1998)

Nesse mesmo sentido, essa referência à modelização de ideias de organização do espaço serve para introduzirmos outra referência interessante para a geografia urbana, a teoria de Thünen do "Estado Isolado"6 (Waibel, 1958). Essa teoria introduzia uma abstração de natureza espacial, natural e econômica, de um Estado que tem uma forma circular e que estaria completamente isolado do restante do mundo por uma floresta impenetrável. Natural porque o modelo está situado em uma planície, portanto, sem interferências marcantes do relevo, com mesmo tipo de solo e clima, e sem nenhum rio de grande porte. A abstração econômica se baseaia na pré-determinação das funções, nas quais a população rural se dedica à agricultura e silvicultura, utilizando-se das técnicas mais produtivas àquela época; enquanto a população urbana se dedicava a fornecer serviços, produtos industrializados e tecnologia ao campo, e ambas com um nível de educação igual e elevado a ponto de, na necessidade, mudar de um sistema econômico a outro sem dificuldades.

\footnotetext{
${ }^{6}$ A obra de Thünen divide-se em três volumes, surgidos entre 1826 e 1875, com o último editado já após a morte do autor. O primeiro tem o título de "Análise da influência que exercem sobre a agricultura o preço dos cereais, a fertilidade do solo e os impostos". O segundo trata do "salário adequado e sua relação com a taxa de juros e a renda"; e o terceiro trata das "Bases para a determinação do rendimento do solo, da época de circulação mais favorável e do valor das reservas de madeira de diferentes idades no reflorestamento com pinheiros". Léo Waibel (1979) faz referência a essa teoria e acrescenta observações sobre sua aplicação à realidade, citando experiências de aplicação na 1a metade do século XX na Europa, e o reconhecimento que teve no meio acadêmico pela geografia agrária e economia política. Ver a análise de Waibel no livro "Capítulos de Geografia Tropical e do Brasil. (Waibel, 1958)
} 
O ponto marcante dessa teoria é a distinção entre seis sistemas de organização do espaço agrícola em anéis agrários em torno da grande cidade que polariza essa região, em uma alusão para a situação existente na Europa Central. As seis faixas são, do centro para a periferia: Horticultura, Silvicultura, Sistema Rotativo de Cereais e Raízes, Sistema Rotativo de Culturas e Pastagens, Sistema de Três Campos, e faixa de Criação de Gado (Figura 2.4). Essa distinção fazia referência às imposições de perecibilidade dos produtos agrícolas; às distâncias e ao custo do transporte e volume de carga transportado; à necessidade de produção intensiva e/ou extensiva em face do custo da terra e tamanho de propriedade necessária ao tipo de produção, etc.

Embora de aplicação prática duvidosa e difícil, mesmo na época de sua formulação, essa teoria de Thünen pode provocar interessantes reflexões acerca da organização desse novo espaço rural que se delineia na cidade dispersa.

Figura 2.4 - Anéis agrários de Thünen - "Teoria do Estado Isolado".
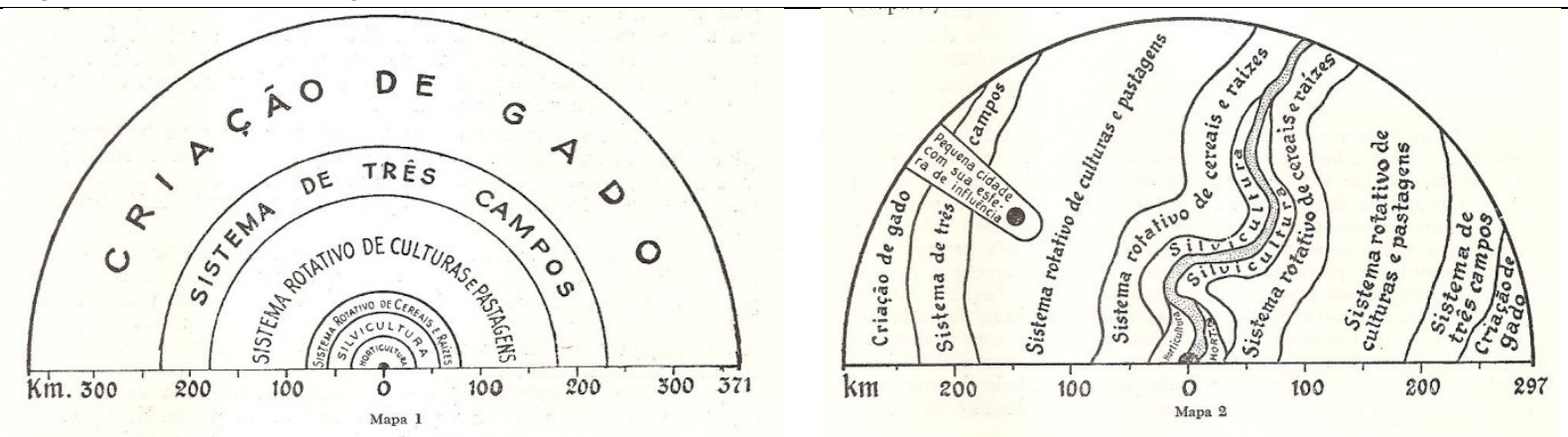

Mapa 1: Esquema teórico, sem interferências, grande cidade no centro (marco zero).

Mapa 2: Situação da cidade grande ou capital do Estado situada à margem de um grande rio, muda a configuração das faixas e como uma cidade menor desenvolve uma área sob sua própria influência.

Fonte: Waibel (1958)

Outro tema de grande relevância para este trabalho é o desenho ambiental, ou seja, o desenho urbano que busca integrar as questões da natureza no planejamento e projeto dos espaços urbanos. Dentre vários autores dessa linha vale destacar lan Mcharg, um dos primeiros arquitetos a ressaltar o uso de camadas de informação do território na construção do planejamento urbano. Dentre essas camadas, havia grande destaque às camadas físicas do território. No livro "Design with Nature", publicado em 1967 em sua $1^{\text {a }}$ edição, Mcharg (2000) ressalta a importância da inclusão dos processos naturais, tomados como valores da paisagem, nos estudos de planejamento territorial para fins urbanos. $O$ autor 
apresenta os estudos de caso realizado para as cidades de Nova York e Baltimore na década de 1960. Faz uso de técnicas muito comuns na Geografia, particularmente na Geografia Física, de sobreposição de camadas da base física (topografia, hipsometria, geologia, geomorfologia, hidrografia, vegetação, solos, etc) com a inclusão de mapas das camadas relativas à urbanização do território. Os conceitos de ecologia da paisagem estão incorporados nas interpretações de Mcharg e sua equipe.

Seguindo a mesma linha de abordagem podem ser lembrados os também arquitetos M. Hough (1998), J.T.Lyle (1985), Franco (2000), Sabaté (2009) que visam incorporar ao desenho urbano a análide dos processos naturais e princípios ecológicos, seguindo a linha de um desenho ambiental urbano. Abordam, assim, em suas análises, questões práticas de projeto urbano que trazem críticas à ausência de critérios ambientais ou soluções que agregam premissas ambientais no desenho dos espaços urbanos. Em todos eles evidencia-se uma crítica às tipologias das peças urbanas existentes na cidade tradicional compacta.

Hough, no livro "Naturaleza y Cyudad" trabalha a escala de uma planificação urbana que considere os processos ecológicos, acreditando no estudo da ecologia urbana como uma base para a remodelação das cidades. Analisa didaticamente a relação da cidade com a água, as plantas, a fauna, o clima e propõe uma agricultura urbana. Em cada uma dessas análises separadas, Hough tenta dissecar os processos naturais e os processos urbanos, valores culturais e princípios de desenho urbano passíveis para uma melhor conformação ambiental da cidade. Trabalha questões que implicam em uma nova relação entre espaços construídos e espaços livres, bem como a percepção e os valores ambientais para a população urbana.

Lyle (1985) segue a mesma linha de abordagem de Hough, no entanto, mais detidamente na proposição de desenhos de espaços urbanos, ou mesmo periurbanos e rurais, em um viés mais rigorosamente marcado por concepções ecossistêmicas.

\footnotetext{
${ }^{7}$ Título original "Cities and natural process", publicado originalmente em 1995.
} 
Já Franco (2000) centra o foco no planejamento ambiental na escala urbana e territorial, e por meio de princípios ecossistêmicos e proposição de cenários trabalha a ideia de sustentabilidade ambiental das cidades. Em estudo de caso de planejamento e desenho ambiental para a área das marginais dos rios Pinheiros e Tietê, em São Paulo, introduz o conceito de APA Urbana, ou seja, uma área de proteção ambiental dentro do perímetro urbano e incorporando faixas de preservação e de uso urbano que implicam em um desenho urbano de quadras e lotes diferenciados em relação à proximidade da área de proteção máxima, que, no caso, se trata de um compartimento ambiental relevante para a ocorrência dos processos naturais.

$\mathrm{Na}$ Europa a produção acadêmica e prática em análises e projetos de ordenamento territorial é vasta em países como Holanda, Alemanha e Espanha, e que seguem, em parte, os princípios da ecologia da paisagem.

Buscando sistematizar o conteúdo metodológico de diversas experiências empreendidas no âmbito da universidade e da prática em consultorias de planejamento territorial na Espanha e na América Latina, incluindo o Brasil, J. Sabaté Bel (2009) reconhece quinze princípios básicos que devem balizar a gestão do território. Dentre eles serão destacados aqueles que se implicam com o tema da dispersão urbana e da preservação ambiental, como o de moderar o consumo de solo e velar pelo caráter compacto e contínuo do crescimento.

São premissas citadas por Sabaté totalmente contrárias a tendência atual da urbanização em pleno processo de dispersão. Moderar o consumo de solo significa moderar o consumo do relevo, e consequentemente preservar compartimentos de relevo e processos naturais do impacto da urbanização. Sabaté sugere ainda, adotar medidas de regulação e orientação espacial da $2^{\underline{a}}$ residência, ou seja, a ordenação territorial do mercado imobiliário.

O que se observa na Macrometrópole de São Paulo, pela ampla dispersão de loteamentos (condomínios fechados) com esse fim é, de fato, a ausência de qualquer regulação nesse sentido proposto por Sabaté. Outros princípios de conteúdo mais genérico relativos à preservação da paisagem são citados, como o de favorecer a biodiversidade e manter a matriz biofísica do território; o de proteger 
os espaços naturais, agrários e não urbanizáveis como componentes da ordenação do território e preservar a paisagem como valor social e ativo econômico.

A segunda linha de abordagem desta pesquisa referencia o instrumental teórico-metodológico da geomorfologia nas análises territoriais urbanas, e os estudos de geomorfologia que se direcionam para as abordagens de cunho ambiental e urbano.

No aspecto teórico-conceitual sobre geomorfologia, há que se destacar, preliminarmente, o trabalho de Abreu (1983) - "A teoria Geomorfológica e sua edificação: análise crítica" - um dos poucos trabalhos acadêmicos em língua portuguesa que buscou fontes originais, sobretudo alemãs, sobre as duas linhas mestras da evolução das teorias geomorfológicas, a corrente inglesa, derivada de Davis (1899), e a alemã, de Penck (1953). Nesse trabalho é possível verificar com maior clareza as diferentes posturas assumidas pelos geomorfólogos no decorrer do tempo e situar as tendências atuais assumidas, bem como a própria abordagem deste trabalho.

Dessas duas correntes originaram teorias que de alguma forma contribuíram para embasar o campo das pesquisas geomorfológicas, os quais aportam referências para a abordagem aqui realizada como as teorias do ciclo geográfico (Davis, 1899); do equilíbrio dinâmico (Hack) e da pediplanação (King, 1956); e da abordagem de uma geomorfologia climática (Büdell e Wilhelmy) e climatogenética (Kugler) (Abreu, 1983).

Em 1985, no artigo "Significado e propriedades do relevo na organização do espaço", Abreu (1985) destaca os geomorfólogos que contribuíram para os estudos sobre o papel da geografia física e da própria geomorfologia como fontes de obtenção de leis e padrões de comportamento espacial. Nesse artigo, destaca a contribuição de Kluger na formulação do conceito de georelevo, o qual insere de forma mais enfática e contundente a influência do homem na gênese das formas da paisagem e do relevo, dando suporte às abordagens atuais de cunho ambiental e de uma geomorfologia ambiental, urbana ou antropogenética.

De Ab'Saber (1969 e 1977) ressalta-se a ênfase das categorias de análises paisagem e integração de seus elementos. No artigo "Um conceito de geomorfologia 
a aerviço das pesquisas sobre o Quaternário", Ab'Saber sintetiza os três elementos básicos para uma pesquisa em geomorfologia: a compartimentação topográfica; a estrutura superficial e a fisiologia da paisagem. Importante destacar também sua tese de livre docência - "Da participação das depressões periféricas e superfícies aplainadas na compartimentação do Planalto Brasileiro" (Ab'Saber, 1965), como contribuição para a análise do relevo na região de Campinas, Sorocaba e arredores.

Ainda de Ab'Saber (1958), o clássico "O sítio urbano de São Paulo", traz elementos importantes para se entender a compartimentação da paisagem do território da cidade de São Paulo e a gênese de sua formação. No mesmo ano de 1958, Fernando de Almeida (Almeida, 1958) traz um relato sobre a geomorfologia do Planalto Paulistano, abordando detalhes da gênese e da morfologia do reelvo da região de São Paulo, que hoje coincide praticamente com a área da Região Metropolitana de São Paulo.

Pesquisas mais recentes sobre a geomorfologia de São Paulo têm ajustado o foco para as influências antropogenéticas na configuração da paisagem atual da macrometrópole. Nessa linha cabe destacar os trabalhos Cleide Rodrigues (Rodrigues, 1990, 1997, 2001 e 2005) que trazem importantes aportes na análise geomorfológica de ambientes densamente urbanizados, com ênfase na cidade de São Paulo, na região da Represa de Guarapiranga, no setor de contato da Bacia Sedimentar de São Paulo com o embasamento cristalino do Planalto Atlântico. As categorias de análise e técnicas revelam o aparelhamento da Geomorfologia nas abordagens ambientais urbanas, trabalhando, de forma comparada, a apropriação do relevo em bairros consolidados e não consolidados, e a fisiologia da paisagem decorrente dessa relação entre o uso urbano e o relevo, de onde decorrem os efeitos ambientais para a cidade e para rede hídrica, no caso a represa citada.

Vários trabalhos entre livros, artigos e pesquisas de mestrado e doutorado têm se direcionado para essa vertente antropogenética, de uma geomorfologia que se orienta para o estudo do homem como um agente geomorfológico, enquanto a geologia afirma o caráter de agente geológico. Essa linhagem de estudos recebe denominações diversas, ora de Geomorfologia Ambiental, ora Geomorfologia Urbana, ou simplesmente relacionando os impactos ambientais urbanos ou a questão ambiental que tem origem nessa ação do homem sobre o relevo. Nessa 
frente destacam-se os trabalhos de Rodrigues (1990), Christofolletti (1994), Silva e Rodrigues (2006), Guerra (2007), Cunha (2007), Coelho (2011) e Guerra \& Marçal (2012).

Outra variante dessa abordagem relaciona a importância da geomorfologia para o planejamento territorial, mas sobretudo ambiental. A maior produção vem de Ross (1995, 1998, 2000, 2000a, 2000b, 2006), além de Rodrigues (1997, 2005), Christofoletti (2001), Coelho Neto (2005) e Schutzer (2012).

São também intensos e variados os trabalhos que analisam aspectos da fisiologia da paisagem em ambiente urbano, tanto em relação à dinâmica da água quanto em relação à dinâmica do clima. No primeiro caso podem ser lembrados Coelho Neto (2001), Meneghasse (1996), Rebouças (1992 e 1999), Cunha (2007), versando sobre a hidrologia de encostas, impactos nas águas superficiais e subterrâneas, em face das intensas alterações no regime hídrico local e regional promovidas pro represamentos, retificação e tamponamento de rios, etc.

Na dinâmica do clima são importantes os estudos de clima urbano de Oke (1973, 1973b), Monteiro (1976), Tarifa (2001), Azevedo (2001) e Lombardo (1985), entre outros, todos versando sobre os efeitos da urbanização sobre o aumento de temperatura nos recintos densamente urbanizados e a formação de "ilhas de calor".

Cabe mencionar dois trabalhos importantes realizados ainda na década de 1950 por eminentes pesquisadores americanos e europeus, que visavam avaliar de maneira abrangente e multidisciplinar os impactos causados pelo homem ao meio ambiente.

O primeiro se refere à publicação do simpósio internacional realizado em Chicago, em 1956, pela Wernner-Gren Foundation for Anthropological Research, com o tema "Man's Role in Changing the face of the Earth" (Thomas, 1956), que contou com a coordenação de Carl Sauer, Marston Bates e Lewis Mumford. A análise do papel do homem nas mudanças da face de Terra compreendeu desde uma abordagem histórica das civilizações e do seu uso do ambiente até os efeitos atuais acumulados nas mudanças climáticas, na linha da costa, na rede hídrica, no mar, incluindo os efeitos nas comunidades biótica e na fauna. Trata-se de um retrato minucioso sobre os impactos do homem sobre o meio ambiente, que antecipou em 
20 anos as questões que emergiram mundialmente na mídia a partir da Conferência de Estocolmo, de 1972.

O segundo é um trabalho de fôlego de Edwin Fels (Fels, 1955), cuja versão em espanhol teve o nome de "El hombre economizante como estructurador de laTierra", em que relata criteriosa e detalhamente importantes aspectos das mudanças promovidas pelo homem na superfície (relevo), no reino vegetal, na fauna, nas águas, e aumento da explotação mineral e de outros recursos naturais. Estes dois trabalhos demonstram que os estudos sobre os impactos do homem no ambiente, incluindo os da urbanização não são recentes.

O próximo capítulo procura realçar a difícil tarefa de abordar o relevo, em face da complexidade de processos que interferem em sua esculturação, desde a complexidade dos processos naturais à dos processos sociais de um homem economizante, a que aludiu Fels (1955). 


\section{A ABORDAGEM DO RELEVO}

A ocupação humana em um território qualquer sempre implica na alteração plástica da fisionomia da paisagem e na modificação, sutil ou mais drástica, da intensidade dos processos de funcionamento da natureza. A história da relação entre sociedade e natureza tem sido, assim, a história da substituição de um meio natural herdado por uma sociedade para um meio cada vez mais artificializado (Santos, 1999). A ocupação humana, dessa maneira, sempre implica em impactos no meio físico, e esse impacto é mais intenso quanto maior o adensamento populacional e o padrão tecnológico dessa sociedade. A essa modificação da morfologia da paisagem humanizada e dos processos naturais que nela ocorrem é que se denomina hoje "impactos ambientais", ou seja, as alterações no ambiente de utilização do homem que, hoje, em face de sua intensidade, interferem na qualidade desse ambiente.

Todas essas modificações acontecem sobre uma superfície de contato que plasticamente é conhecida como relevo. Assim, como afirmava Ab'Saber (1994, p.34), "a produção de um espaço humanizado não é feita no ar". Todos os objetos artificiais introduzidos na paisagem pelo homem, como estradas, cidades, complexos industriais, represas e hidrelétricas, se dão sobre um suporte material que tem uma base física e uma condição ecológica. Toda uma série de alterações plásticas nessa superfície, aliadas às alterações na roupagem natural de sua cobertura para uma outra artificial, ou mesmo agrária, modificam a qualidade dos processos de funcionamento dessa paisagem.

É por isso que podemos admitir uma imbricação importante no estudo do relevo com os estudos de impactos ambientais na atualidade. A influência do homem sobre o ambiente é percebida de maneira cada vez mais intensa, na medida em que a informação se difundiu mundialmente e quase instantaneamente, e os movimentos de cada sociedade na relação com seu território puderam ser conhecidos e analisados em seu conjunto. Isso demonstrou a convergência dos momentos dessas ações de intervenção humana em cada porção da superfície da Terra, se realizando como um modo de organização do espaço que edifica um sistema mundo em que se confundem os sistemas naturais com os sistemas da sociedade. 
Antes da emergência das questões ambientais, da forma em que se compreende hoje, e que se deu mais intensamente a partir de meados do século $X X$, a poluição e outras ofensas ambientais, que ainda não tinham esse nome, já eram percebidas no século XIX e anteriores. A poluição do ar e da água das cidades industriais inglesas e os problemas vinculados à saúde dos trabalhadores na Revolução Industrial são hoje bem documentados e conhecidos. Os problemas de falta d'água potável no Rio de Janeiro em fins do século XIX, em virtude do desmatamento dos morros da Tijuca pela economia cafeeira, é um exemplo nacional de que essas agressões ao ambiente, que implicavam em alterações nos processos da natureza, já ocorriam há tempos. Entretanto, era ainda um fenômeno limitado a poucos países ou regiões mais intensamente ocupadas e produtivas, e tinham igualmente uma percepção também limitada.

Em conformidade a essa condição, os estudos das Ciências da Terra na primeira metade do século XX ainda buscavam compreender esse mundo natural, os seus recursos e mistérios, bem como a sua forma de funcionar. A Geomorfologia se orientava pelo estudo da morfologia do relevo e compreensão da gênese de sua formação. Para isso centrava seus esforços de pesquisa nas paisagens menos alteradas ou menos impactadas pelas ações humanas. Buscava compreender os processos naturais que concorriam para a elaboração do relevo em sua essência primária como modelo de comparação entre as regiões da Terra e, posteriormente, com as regiões mais densamente impactadas.

A partir do aprimoramento conceitual e prático de uma geomorfologia climática é que a fisiologia da paisagem vai aparecer como uma categoria relevante nos estudos geomorfológicos. E, com a teoria geral dos sistemas, tanto a geografia física como a geomorfologia passam a produzir análises integradas do meio físico em que, pari-pasu, vai se introduzindo mais incisivamente o papel das ações humanas como elemento importante no sistema de paisagem atual. $O$ aprimoramento do conceito de ecossistema, efetuado a partir do surgimento dos estudos de ecologia da paisagem, que visam espacializar esse conceito e introduzilo no espaço do homem geograficizado, vai dar a base necessária para a produção de análises dos impactos ambientais do homem sobre o território ocupado. 
Como já mencionado, muito antes do reconhecimento da questão ambiental em termos mundiais que se deu a partir da Conferência de Estocolmo em 1972, duas obras editadas na década de 1950 foram fundamentais no reconhecimento do papel do homem na transformação da natureza, uma nos EUA e outra na Alemanha.

Uma delas foi editada por Willian L. Thomas, patrocinada pela Wenner-gren Foundation For Anthtopological Research e National Science Foundation da Universidade de Chicago - "Man's role changing the face of the earth". Foi o resultado de um simpósio internacional realizado em Chicago em 1956, com trabalhos encomendados a grandes autores, em sua maioria professores de universidades dos EUA e da Europa, dentre eles os geógrafos Carl O. Sauer e Artthur Strahler, e o urbanista Lewis Munford. Mais de 1.000 páginas e 50 artigos e rodadas de discussão, esmiuçaram os efeitos da ação do homem sobre a Terra, revelando já naquele momento a certeza do homem como o principal agente geomorfológico e geológico, rivalizando com os efeitos dos processos naturais, não na escala, mas no tempo, em razão da aceleração de processos e alteração rápida da intensidade dos processos naturais. Fato marcante é que o simpósio foi estruturado para engendrar uma visão multidisciplinar do papel do homem sobre a Terra, um avanço em termos conceituais e metodológicos das abordagens feitas até então, já dirigindo análises para a capacidade de suporte do planeta em face das demandas crescentes por recursos das atividades econômicas e pelo crescimento populacional.

O outro é o do alemão Edwin Fels, "Der Wirtschaftende mensch als gestalter der erde", editada em 1935 na Alemanha, e traduzida para o espanhol em 1954, com o título "El hombre economizante como estructurador de la Tierra" (Fels, 1954). Neste trabalho Fels analisa a intervenção do homem nos acontecimentos naturais se dá, em primeiro lugar, por razões econômicas, e haviam aumentado de tal maneira, e seus efeitos e consequências haviam agudizado de tal sorte, que muitas vezes não tão somente haviam mudado o quadro da paisagem até então conhecido, e sim também todos os seus efeitos em conjunto. Fels analisa espaços territoriais em franco processo de alteração e já densamente ocupados, na Europa e nos EUA, reconhecendo as expressivas alterações na morfologia das paisagens artificializadas pela atividade industrial, pela mineração, pela agropecuária, e pelas grandes obras 
de engenharia para a produção de energia, instalação de infraestrutura e expansão das grandes cidades. A estrutura e a forma de abordagem e análise empreendida por Fels pode ser considerada como precursora das metodologias posteriormente utilizadas pela escola da Ecologia da Paisagem, assim como o fez Mcharg na década de 1960 (2000). A diferença é que Fels não realiza uma abordagem de caráter propositivo para efeitos de planejamento de ocupação, e, sim, como uma constatação dos efeitos e dos impactos do homem sobre a paisagem.

Neste trabalho de Fels é possível verificar os exemplos de intervenções que posteriormente foram disseminados no Brasil e em São Paulo, como a retificação de rios que correm em várzeas, e o aterramento e ocupação destas várzeas, os represamentos da rede de drenagem para a formação de represas para produção de energia e abastecimento público. Além disso, as morfologias de ocupação agrícola e industrial altamente extensivas sobre vários compartimentos de relevo e o consequente desmatamento quase que absoluto destas paisagens, fatos muito similares ao que ocorreu em São Paulo.

Em 1956, Fels (1958) apresentou no Congresso Internacional de Geografia do Rio de Janeiro a comunicação intitulada Geomorfologia Antropogenética, na qual enfatiza, já naquela época, o caráter antropogenético da elaboração do relevo nas áreas densamente ocupadas. $\mathrm{O}$ autor enfatiza os aspectos da fisiologia da paisagem induzidos pelo homem, como os intensos processos erosivos que se dão após o desmatamento intenso de uma área e de uma ocupação urbana não consolidada como erosão antropogenética. Trata-se de uma imagem altamente educativa para a conscientização ambiental na atualidade, pois no senso comum ainda persiste a imagem de que os processos de erosão, de assoreamento, de deslizamento de encostas, de inundação, etc, são processos naturais, e derivados de causas também naturais.

É assim, neste contexto, que podemos afirmar a relação intrínseca entre relevo e impactos ambientais, analisados a partir do comportamento espacial das sociedades, assim como o papel do relevo na organização do espaço, seu significado e propriedades (Abreu, 1985). Nesse sentido, a abordagem do relevo assume papel importante nas análises ambientais e na previsão de impactos, o que realça o papel na Geomorfologia para a compreensão das relações sociedade- 
natureza, sobretudo na organização do espaço territorial em apoio a outras disciplinas. Essa vinculação é importante reconhecer para que se possa compreender que a abordagem do relevo envolve graus de complexidade e de interdisciplinaridade que nos obriga a circunscrever o parâmetro de sua análise em cada pesquisa, dirigindo o olhar para realçar aspectos que contribuam para a compreensão coletiva dos resultados da ação do homem que, estampados no relevo, conduzam a antever os processos futuros e seus impactos.

Este capítulo visa delimitar a abordagem do relevo que dá suporte à compreensão dos efeitos ambientais decorrentes do fenômeno atual de dispersão urbana, por meio de uma das categorias mais relevantes para a organização do espaço, que é a forma de relação da sociedade com o sítio urbano local e regional.

\subsection{O relevo como interface das relações sociedade-natureza}

Como interface das relações sociedade-natureza, o relevo é objeto de trabalho e de estudo de diversas áreas profissionais e acadêmicas, pois se insere num quadro concreto de intervenção de várias disciplinas. O que diferenciam as diversas abordagens que de uma forma ou de outra se implicam com a superfície denominada relevo, são os graus de aprofundamento e as óticas distintas impressas nas análises e nas proposições de ação sobre essa superfície, que perpassam não somente os aspectos do meio físico relacionados à Geologia e Geotecnia, Geografia Física e Geomorfologia, Pedologia ou Ciências do Solo, Biologia e Ecologia, como os assuntos relacionados à intervenção do homem ligados à Geografia, Arquitetura e Urbanismo, Engenharia e seus diversos ramos (Hidrologia, Mecânica dos Solos, Topografia, etc), Ciência Ambiental e Ciências Sociais.

Para a Geografia, o relevo é a superfície de contato entre as esferas biofísica e humana, por meio do qual as ações do homem se espacializam, e segundo Kugler (1976, p. 154, apud Abreu, 1985, p. 159), é o resultado das relações dinâmicas que ocorrem dentro da epiderme da paisagem ${ }^{8}$, na forma de troca de energia e matéria

\footnotetext{
${ }^{8}$ Epiderme da paisagem, para Kugler, segundo o conceito de Georelevo, corresponde aos componentes da atmosfera, da parte superior da crosta e das águas superficiais, assim como o mundo vegetal e animal integrados no invólucro ou epiderme da paisagem (landschaftschülle). Esses subsistemas naturais gerais que
} 
que concorrem para a sua elaboração. O conceito de epiderme da paisagem corresponde para Kugler, além do relevo, que é a expressão plástica da paisagem, os conteúdos da base física (endógenas e exógenas), biológica e social responsáveis pela cobertura paisagística (objetos naturais e artificiais) e pelo uso do território e dos recursos naturais ${ }^{9}$.

As análises sobre a crescente intensificação dos impactos ambientais ocasionados pela ocupação humana, realizadas a partir dos anos 1930, como vimos anteriormente, direcionaram o olhar das pesquisas realizadas a partir de 1970, para as reações que ocorrem nessa superfície de contato entre as ações humanas e as da natureza. Assim, a abordagem do relevo foi direcionada predominantemente para a ótica dos impactos e riscos ambientais que se relacionam com o uso e ocupação do solo urbano, com a qualidade ambiental urbana, com o uso da terra agrícola, e com as grandes obras de engenharia (hidrelétricas, estradas, ferrovias, mineração, etc). Com isso, já tem sido frequente a elaboração e utilização de mapas de zoneamento econômico-ecológico, cartas de aptidão da terra, cartas geotécnicas para fins de uso urbano, entre outras.

Entretanto, segundo Guerra e Marçal (2012, p. 13), nota-se que, a par de uma crescente preocupação com os estudos relacionados às análises ambientais, o que acontece nas ciências em geral é um excesso de especialização, em que se procura adequar trabalhos de ordem tão vasta e genérica, a ponto de não poder se concluir que o ambiente é somente "um simples somatório desses fatores, e que analisados individualmente, levaria à sua compreensão total'.

No que se relaciona ao planejamento territorial, geral e urbano, a intensificação do uso e a consequente tecnificação do território se apoiaram em experiências, ora mais ou ora menos, multidisciplinares, resultando em alterações na superfície e incorporação de novos objetos artificiais sobre o relevo - as próteses a que se referiu Milton Santos em a Natureza do Espaço (1999), que configuravam nova paisagem e novos processos, que contribuíam para aumentar a complexidade

cunham a estrutura vertical da paisagem, "são definidos através de manifestações materiais específicase por um conjunto de leis de movimentos específicos da matéria", unidos entre si por um conjunto de relações estáticas e dinâmicas, nas quais as primeiras são o resultado das segundas.

${ }^{9}$ Casseti $(1995$, p. 34), no mesmo sentido, se refere ao relevo como a interface das interações naturais e sociais, e produto do antagonismo entre as forças endógenas e exógenas. 
do objeto de estudo - o território. Santos, aludiu a esse espaço criado pela interação sociedade-território como uma totalidade, produto sempre em movimento, em constante transformação e elaboração pelas ações da sociedade e da natureza. Coelho (2011, p. 41-42), falando sobre impactos ambientais urbanos, argumentou sobre a necessidade de busca de uma teoria unificadora em que natureza e sociedade apresentem-se inseparáveis, e que reúnam ao mesmo tempo e de forma inseparável o físico, biológico, químico, social, político e cultural.

Nesse sentido, como a sociedade estabelece interface com esses recursos e dinâmicas da natureza, o relevo se apresenta como um limiar entre essas forças, endógenas e exógenas da natureza, e um limiar entre o uso dos recursos da subsuperfície, da superfície e da atmosfera. Abordar, então, o relevo significa abordar o território e o espaço, dentro das categorias da análise geográfica, pois ele é o suporte e resultado da configuração espacial e territorial constituída na interação dos processos da natureza com os da sociedade.

Abordar o relevo também não deixa de ser, assim, uma tarefa interdisciplinar. Neste contexto, a geografia e a geomorfologia se apresentam como importantes aportes, como uma das possíveis ferramentas que visam articular visões específicas, pontuais/locais, às questões espaciais mais abrangentes - regionais e globais - na busca dessa totalidade que só poderá ser atingida em abordagens transdisciplinares ${ }^{10}$. Assim, a síntese das respostas geológicas, geomorfológicas, biológicas, sociológicas, econômicas, urbanísticas e territoriais em geral, perpassa pelo relevo como superfície-resultado destes processos, e que pode ser apreendida nas relações que a sociedade estabelece com esse relevo, em suas diversas escalas de abordagem - local, regional, continental e global.

A leitura dos impactos ambientais vem sendo uma das possibilidades e tentativas de se aproximar dessa síntese das relações sociedade-natureza, entretanto, corroborando com as afirmações de Coelho (2011, p. 20), ainda faltam instrumentos teórico-metodológicos mais adequados a esse fim no momento atual. Como bem afirmou Ross (1995, p. 66), os geógrafos sempre fizeram estudos sobre

\footnotetext{
${ }^{10}$ Guerra e Marçal (2012, p.13-14) enfatizam a complexidade da abordagem ambiental afirmando que "o que existe é uma combinação infinita e aleatória destes fatores que torna a estrutura, o estudo e o encaminhamento de soluções, tarefa para uma abordagem não mais multidisciplinar, mas, sim, transdisciplinar".
} 
a natureza e a sociedade, mesmo que com enfoques e metodologias diferentes das atuais. Os estudos sobre o homem e o meio em suas diversas abordagens pela geografia física e humana, de maneira estanque ou integrada, sempre foram uma tentativa de interpretação da realidade de uma paisagem, de um território ou de um lugar, muito parecida ao que hoje se tenta aborda nos estudos integrados das análises ambientais. O trabalho de Fels, já mencionado anteriormente, é um exemplo dessa aproximação de uma síntese da paisagem.

Entretanto, se a geografia/geomorfologia desenvolveram metodologias e conceitos que favoreciam uma leitura sintética da paisagem, elas ainda apresentavam um caráter especificamente mais multidisciplinar do que transdisciplinar. A interpretação geográfica para as questões ambientais também não deixa de ser uma interpretação setorial, mesmo que abrangente e que incorpore aportes de outras disciplinas. Em relação à geomorfologia, mesmo que conceitual, teórica e metodologicamente os estudos e pesquisas envolvam o estrato geográfico superficial, contendo tanto as dimensões biofísicas quanto as sociais, o resultado analítico provinha de uma síntese elaborada por geógrafos-geomorfólogos, longe de significar uma real leitura integrada da realidade analisada sob o enfoque ambiental de hoje. Assim como Fels, Neef, já em 1972, defendia uma ciência geográfica mais voltada ao aprofundamento da relação homem-meio que a colocasse como uma ciência ambiental (Abreu, 1985, p. 158), mais afinada com a resolução dos problemas ambientais mundiais. Neef também destacou a importância do relevo "como veículo de articulação material dos elementos ecológicos e sociais que, através de impulsos de diferentes ordens, definem o sistema territorial operado pela sociedade, face a seus objetivos e condições" (Abreu, 1985, p. 158).

Para Coelho (2011, p. 20), a incorporação das questões sociais na análise de impactos ambientais é ainda incipiente. Tanto a Geografia Física como a Geografia Humana ainda carecem de aperfeiçoamento nesse sentido, para se falar apenas dentro do campo da Geografia. Nas demais ciências a situação é similar. As abordagens dos impactos ambientais que repercutem na superfície (Georelevo) são abordadas de maneira setorial, por mais que procurem agregar outras visões disciplinares. 
Nessas condições, pode-se afirmar que, assim como nas análises ambientais, a abordagem do relevo expressa também conteúdos de complexidade, de totalidade e de singularidade, dos quais decorre a necessidade de inter e transdisciplinaridade analítica, em face de suas interfaces múltiplas. É certo que, conforme nos lembrou Abreu (1985, p.154), "a reflexão científica sobre o relevo emergiu no campo do conhecimento principalmente a partir do trabalho de geógrafos e geólogos", ficando assim o seu estudo - a geomorfologia - ora alinhado à abordagem geológica, ora à abordagem geográfica, abordagens essas que, dependendo das perspectivas de análise, tendem a se distanciar em função de suas escalas têmporo-espaciais divergentes. No entanto, a abordagem do relevo extrapola, em muito, esses limites de uma realidade filtrada por uma estrutura acadêmica e curricular do conhecimento. É nesse sentido que se pode afirmar que, em face desses elementos de complexidade, totalidade e singularidade, é possível acessar o estudo do relevo por meio de outras perspectivas, e por isso a necessidade de visões multidisciplinares.

De outro lado, assim como enfatizou Abreu (1985, p.154), é também relevante insistir sobre a "pertinência da consideração do relevo e suas propriedades na organização do espaço, posto que ele e sua dinâmica fornecem para a geografia uma das mais ricas fontes de leis espaciais e de movimentos de transformação da matéria na superfície do planeta", e este trabalho caminha nessa perspectiva de que, a par de toda a complexidade inserida no estudo do relevo, o instrumental teórico-metodológico da geomorfologia pode colaborar para o entendimento da organização do espaço geográfico de um território, sobretudo no aspecto ambiental. Entretanto, considera-se prudente realçar, com mais algumas linhas neste texto, as questões que expressam essa complexidade da abordagem do relevo, com o intuito de circunscrever com maior clareza, ao leitor, o enfoque que realizará sobre o relevo em sua relação com o tema da organização do espaço na macrometrópole paulista, em face da dispersão urbana em processo.

\subsubsection{A complexidade da abordagem do relevo}

Pode-se afirmar, mesmo que simplificadamente, que a complexidade teóricometodológica da abordagem do relevo se expressa em três fatores que podem ser considerados relevantes. O primeiro corresponde às dificuldades intrínsecas da inserção da problemática social derivada da própria dicotomia das abordagens física 
e humana. Um segundo fator corresponde aos problemas das escalas interpretativas, sejam elas espaciais ou temporais; e o terceiro se relaciona às limitações que a complexidade das condições biofísico-químicas e das ações sociais colocam para as categorias de pesquisa ainda vigentes, relativas aos conceitos de equilíbrio, de evolução determinística e da capacidade auto-organizativa dos sistemas ecológicos (Coelho, 2011).

Em relação ao problema da inserção da abordagem social, tanto nos estudos do relevo como nos de impactos ambientais, pode-se afirmar que este deriva, historicamente, da própria evolução conceitual das ciências em sua necessidade de especialização, de verticalização das análises setoriais, o que levou a uma dicotomia das abordagens, ainda presente em várias delas. Essa dicotomia físico-humano perpassa, ainda, a própria estrutura do ensino regular e acadêmico na separação entre Ciências da Terra e Ciências Sociais, Ciências Exatas-Ciências Humanas, Geografia Física-Geografia Humana, etc.

Para Coelho (2011, p.19), tanto a Geografia Física permanece alheia à dinâmica da sociedade, embora a inclua em suas abordagens conceituais e de forma incipiente nas investigações técnicas, como a Geografia Humana permanece distante da abordagem das dinâmicas da natureza, inserindo o ambiente apenas como substrato físico, que é passivamente transformado pela sociedade. Para a mesma autora (p. 20), as análises realizadas no campo dos impactos ambientais falham pela falta de profundidade teórica e pelo seu reduzido poder explicativo. Para ela a complexidade dos processos urbanos solicita a articulação de uma interpretação coerente dos processos ecológicos (biofísico-químicos) e sociais ante a degradação do ambiente urbano.

De outro lado, a ausência de teorias sintéticas dos processos sociais e que articulem a dimensão espaço-territorial e temporal implica, segundo Coelho (2011, p.31), na superficialidade da compreensão social e de suas inter-relações como o meio biofísico.

Embora ainda pouco utilizada nas análises ambientais e na produção geomorfológica de cunho ambiental e urbana, a teoria dos sistemas sociais de Luhmann merece ser lembrada, pois visa reduzir a complexidade infinita do mundo 
social através da seleção daquilo que é atualmente relevante e a ser considerado na relação com o ambiente (Stockinger, 1997). Esta teoria se insere no âmbito da teoria geral de sistemas, teoria utilizada também nas abordagens das ciências biofísicas, da ecologia, da geografia, e em especial pela geomorfologia. A abordagem interdisciplinar da teoria dos sistemas sociais proposta por Luhmann abrange desde a termodinâmica física e biogenética até a cibernética e a teoria da informação.

Segundo Stockinger (1997), Luhmann baseia sua teoria numa concepção particular de comunicação enquanto processo fundamental - ou matéria genética que constitui a sociedade. Trata-se de uma teoria da sociedade enquanto sociologia da comunicação. Enquanto Weber constituía sua teoria da ação social na compreensão do indivíduo, para Luhmann o sistema social emerge dos acórdãos resultantes da interação dos processadores - os indivíduos em relação que produzem uma comunicação, que se realiza a partir de três elementos: informação, mensagem e compreensão. Assim, para Luhmann, "a estrutura social não representa, portanto, uma rede ou caminho que regula diretamente as ações humanas. Ela orienta apenas a comunicação que tornará determinadas ações mais prováveis do que outras"11 (Stockinger, 1997) ${ }^{12}$.

A sociedade, dessa forma, é mostrada como um sistema complexo, não determinado, exposto a flutuações casuísticas, baseado em "sentido", ou seja, na seleção do "aquilo que faz sentido". Este é capaz de transformar diferenças emergentes no âmbito do sistema em "informação" - novidades, mas que não se transformaram ainda em comunicação. Seguindo a teoria geral de sistemas, sistemas autoorganizadores processam essa informação, selecionam aquelas que irão se transformar em mensagem que, compreendidas, se transformam em comunicação - o processo social em movimento, "guiando-se através de um processo evolucionário não linear que leva a uma sociedade mundial funcionalmente diferenciada" (Stockinger, 1997). Assim como nas teorias sistêmicas das ciências físicas se sintetizam as dinâmicas da natureza em processos naturais (com seus

\footnotetext{
${ }^{11}$ Essa definição de Luhmann se orienta também na formulação de Prigogine sobre a existência de sistemas complexos não lineares e longe do equilíbrio, caracterizados por conter parcelas de instabilidade que geram um aumento das possibilidades, das probabilidades de não seguir a linearidade predominante. Disso resulta a imprevisibilidade das mudanças no contexto evolutivo do sistema. Esse aspecto será abordado adiante.

12 Para melhor entendimento do assunto, verificar também “O Pensamento de Niklas Luhmann, de José Manuel Santos (org), 2005, Universidade da Beira Interior/Portugal, disponível em www.lusosofia.net.
} 
subsistemas), a teoria sistêmica de Luhmann visa chegar à síntese dos processos sociais para as ciências sociais, que podem ser estendidos para a compreensão do termo "processos urbanos" comumente utilizados nos estudos sobre o meio ambiente urbano atualmente.

A sistematização de uma teoria dos sistemas sociais, assim como propôs Luhmann, poderá proporcionar importante instrumento analítico para a integração das abordagens entre sociedade e natureza, no entanto, ainda permanece como um caminho pouco percorrido no âmbito das pesquisas ambientais e também das pesquisas em geografia e geomorfologia, e inclusive nas próprias pesquisas em sociologia, em que pese a sua lógica argumentativa.

Nesse sentido, é importante considerar que o presente estudo não pretendeu entrar nessa complexa discussão acerca da inserção dos processos sociais na relação que o processo de dispersão da sociedade urbana estabelece com o relevo. Pretendeu apenas realçar um dos aspectos em que o instrumental teóricometodológico da análise geomorfológica pode contribuir para ampliar o entendimento da espacialização da sociedade urbana sobre o território e de seus impactos sobre o ambiente, como referenciais para o planejamento territorial urbano. Por isso, não se entrou no mérito das forças de produção do espaço que levam à dispersão urbana, e nem aos seus subsistemas econômicos, sociais (de estrutura de classes, culturais, etc) e políticos. A complexidade da abordagem do relevo, neste contexto, foi sintetizada por meio da análise dos resultados dos processos naturais e urbanos que estão configurados no relevo atual da macrometrópole paulista.

O segundo fator que expressa a complexidade teórico-metodológica da abordagem do relevo se direciona às escalas interpretativas. A noção de escala é fundamental para as ciências que lidam com o espaço, e, sobretudo, para as que se utilizam do recurso de cartografar os fatos verificados. A definição de escala interpretativa é também importante como fator de decisão na escolha de técnicas e estratégias de pesquisa (Abreu, 1986). Alguns autores resvalam na variação de escalas de abordagem utilizando métodos e técnicas que muitas vezes se contrapõem à própria essência conceitual do objeto estudado. Segundo Abreu (1986, p.54), a concepção de um objeto, apoiado em uma mesma premissa teórica, não deve se alterar mediante a escolha de diferentes escalas de abordagem. Trata- 
se de uma questão de método, em se utilizar técnicas e representação gráfica adequadas às escalas de abordagem.

Segundo Coelho (2011, p.30), muitos estudos sobre impactos ambientais apresentam uma maior preocupação em identificar os efeitos imediatos e locais do que o estudo da interpretação dos processos. É certo que a análise das dinâmicas em processo é uma tarefa que apresenta dificuldades intrínsecas, tanto em relação aos fatos da base física quanto aos da base social, e segundo Ab'Saber (1969, p.4), parece ser o setor mais difícil da pesquisa geomorfológica. Para Coelho (2011, p.43), compreender a singularidade dos processos locais requer um esforço permanente e uma interpretação articulada dos micro e macroprocessos de mudança, e da articulação da micro, média e macroescala de análise. Para a autora, "na compreensão dos impactos ambientais em áreas urbanas nem sempre se considera impacto como parte de um problema ambiental dos espaços mais amplos". De modo geral, os estudos realizam a mensuração de um processo, fundamentado em medições empíricas, na microescala, o que não deixa de refletir uma visão limitada e fragmentada dos processos atuantes. Assim, as análises ambientais e das dinâmicas que esculturam o relevo exigem uma permanente atitude de correlação entre os fatos locais e regionais, e segundo Ab'Saber (1968, p. 5) se referindo às análises da fisiologia da paisagem, entre os fatos dito areolares e lineares. Basta lembrar que a análise dos processos erosivos, do assoreamento, da hidrologia, estão associados a causas múltiplas, temporal e espacialmente, ainda que interligadas.

Milton Santos (1999, p. 121), em a "Natureza do Espaço", tratando dos processos (eventos) - no tempo e no espaço - nos fala da escala das forças operantes e da escala dos fenômenos, que colaboram para a compreensão da complexidade das abordagens ambientais e do relevo em termos espaço-temporais. $\mathrm{Na}$ primeira deve-se levar em conta o lugar geográfico, econômico ou político de onde atuam as variáveis, e acrescentaríamos aqui o lugar das forças biofísicas da natureza, que podem ir muito além da escala local e tem a ver com a força de seu emissor. A escala do fenômeno se refere à sua área efetiva de ocorrência e é dada pela extensão dos eventos. Corresponde, dessa forma, à escala do seu impacto, de sua realização. Assim, podemos dizer que na relação dos processos urbanos com 
os naturais sobre o relevo existem implicações que interconectam a escala local com a regional, e até com espaços mais abrangentes. Os métodos, técnicas e representação gráfica devem corresponder às hipóteses assumidas na abordagem conceitual, tarefa com suas dificuldades inerentes, pois multi ou transdisciplinares.

O terceiro fator que expressa essa complexidade teórico-metodológica da abordagem ambiental, e consequentemente de uma abordagem do relevo que inclua toda a dimensão sócio-ambiental, se relaciona às limitações que a complexidade das condições biofísico-químicas, de um lado, e a complexidade do espaço urbano e das ações sociais, de outro, colocam para as categorias de pesquisa ainda vigentes, relativas aos conceitos de equilíbrio, de evolução determinística e da capacidade auto-organizativa dos sistemas ecológicos (Coelho, 2011, p.21). As noções de sustentabilidade ambiental, de equilíbrio ambiental, de equilíbrio morfodinâmico, de biostasia, encontram-se ainda carregadas de um objeto de ciências da natureza que dava ênfase nas situações estáveis, nas permanências e nos fenômenos imutáveis. Hoje, se considera também que são os fenômenos imprevisíveis, as crises e as instabilidades que podem ser a chave de explicação dos processos evolutivos, como por exemplo, as perturbações geológicas e climáticas que concorrem para as modificações morfodinâmicas do relevo, a gênese das normas que interferem nos comportamentos sociais, a evolução das espécies.

Para Coelho (2011, p.32), da dificuldade de incorporar às análises ambientais as noções de ruptura, irreversibilidade, imprevisibilidade das mudanças e autorregulação dos sistemas abertos resultantes das relações e interação entre sociedade e natureza, é que se deve o pouco avanço nos estudos de impacto ambiental. A autora baseia sua formulação nas análises de Prigogine e Stengers (1992) sobre a renovação da dinâmica com a descoberta dos sistemas dinâmicos instáveis.

Para Prigogine existe na natureza toda uma classe de sistemas complexos não lineares que conseguem permanecer, no tempo, bem afastados da estabilidade e do equilíbrio, sofrendo crises onde as flutuações que os perturbam são amplificadas, em vez de serem superadas (organizadas ou reorganizadas) pelo sistema. Isso os conduz a uma evolução crítica, porque instável, em busca de um novo estado de metaestabilidade, sofrendo, para isso, uma reestruturação e 
reorganização (Vieira, 2003, p.294-295). Daí a ideia de irreversibilidade, que pode ser transposta às dinâmicas sociais e, consequentemente, às abordagens sobre 0 relevo e sobre impactos ambientais. Segundo Prigogine, essas condições de afastamento do equilíbrio eram impostas por certas propriedades sistêmicas, quando os valores de suas intensidades ultrapassavam algum valor crítico. Quando as perturbações são amplificadas, elas tendem a envolver todo o sistema, gerando um processo em larga escala, não mais localizado. Ou seja, o que ele chamou "correlações de longo alcance". (Vieira, 2003, p.294)

Coelho (2011, p. 21) sugere, então, para a abordagem dos impactos ambientais nas áreas densamente urbanizadas, a necessidade de mudanças na noção de sistemas dinâmicos na direção da concepção dos sistemas complexos, não lineares e, ainda, distantes do equilíbrio. Segundo a autora,

"[...] os estudos urbanos de impacto ambiental relacionam-se a um conhecimento insuficiente dos processos ambientais, pautado numa noção defasada de equilíbrio e na ausência de uma teoria dos processos ambientais integradora das dimensões físicas, político-sociais, socioculturais e espaciais. Por outro lado, sendo a urbanização uma transformação da sociedade, os impactos ambientais promovidos pelas aglomerações urbanas são, ao mesmo tempo, produto e processo de transformações dinâmicas e recíprocas da natureza e da sociedade estruturada em classes sociais".

Como exposto até aqui, afora a dificuldade de inserção destas complexas questões que se implicam na abordagem ambiental e do relevo, é também relevante considerar os conceitos de totalidade e singularidade pelos quais se pode alcançar 0 estudo do relevo e das questões ambientais por meio de outras lentes e perspectivas que realçam a necessidade de integração disciplinar analítica.

\subsubsection{Totalidade e singularidade}

Conforme já mencionado, na abordagem do relevo, tanto quanto na análise ambiental, impera a necessidade de apreender uma síntese da realidade do lugar como um todo, pois para a gênese do relevo e sua evolução concorrem dinâmicas que proveem da natureza e da sociedade. Segundo M. Santos (1988, p.57), a análise geográfica impõe ao geógrafo apreender objetos e relações como um todo, na perspectiva de se aproximar de uma visão holista. Em 1999 (p.92), o mesmo autor citando R. Brunet (1962, p.13), quando este diz que "o geógrafo se esforça por 
realizar o velho sonho de filósofo: apreender o real em sua totalidade", lembra que essa não é a ambição correta, e sim a de propor uma visão sintética do mundo, a partir de sua própria província do saber.

Para M. Santos a primeira tarefa é a construção de um sistema de conceitos capaz de reproduzir, na inteligência, as situações reais enxergadas do ponto de vista dessa província do saber. Embora para ele $(1999$, p.92) essa questão da totalidade tenha sido enfrentada de maneira tímida pela Geografia, esforços têm sido feitos para incorporar essa ideia à análise geográfica por autores como Johnston \& Taylor (1986), R. Brunet \& O. Dolfus (1990), R. Peet (1991) e os de Durand, Lévy, Retaillé (1992)13.

De outro lado, no campo da formulação teórica da Geomorfologia essa preocupação totalizante no sentido da inclusão das dinâmicas sociais na evolução da paisagem e do relevo, vem sendo absorvida de maneira mais contundente na conceituação dos Geossistemas (Sotchava, Bertrand, Tricart) e do Georelevo (Kugler). Entretanto, ainda é importante reconhecer que a dificuldade em romper a dicotomia Geografia Física - Geografia Humana ainda persiste, mesmo com o reconhecimento de ambas as correntes da necessidade de uma visão integrada dos fenômenos espaciais.

O conceito de totalidade favorece a apreensão da necessidade das articulações das escalas de análise geográfica nas abordagens ambientais e também do relevo, constituindo em elemento fundamental para o conhecimento e análise da realidade. Este conceito trabalha com a ideia de que todas as coisas presentes no universo formam uma unidade, e que cada coisa é apenas parte dessa unidade. Cada coisa é, assim, parte do todo, da totalidade. Mas a totalidade não se explica pela simples soma das partes. Estas não bastam para explicá-la, ao contrário, é a totalidade que explica as partes (Santos, 1999, p.93). Isto implica em analisar e relacionar constantemente a apreensão das realidades das escalas locais,

\footnotetext{
13 Johnston, R. J. e P. J. Taylor (eds). A world in crisis?Geographical perspectives. Basil Blackwell. Oxford, 1986.Brunet, Roger e Olivier Dollfus.Mondes Nouveaux, 1ㅇvol. Da Géographie Universelle (R. Brunet, dir.), Hachette-Reclus, Paris, 1990.Peet, Richard. Global capitalism, theories of societal development. Routledge, London. 1991. Durand, M.F., Lévy, J., Retaillé, D. Le monde, espaces et systèmes. Presses de la Fondation Nationale des Sciences Politiques et Dalloz. Paris, 1992.
} 
que podem ser consideradas como partes, com as regionais, nacionais ou globais, que abrangem as estruturas globais, sejam elas da natureza ou da sociedade.

Portanto, a formulação do conceito de totalidade nas análises geográficas implica nas relações de escala entre o local e o global, entre lugar e região, e na abordagem do relevo entre os diversos compartimentos topográficos e estruturas superficiais inseridos em totalidades sucessivas, como sítios urbanos, bacias hidrográficas, domínios climáticos, etc.

Para as análises de impactos ambientais Ab'Saber (1994, p.30) sugere a utilização do conceito de "espaço total". Para esse autor, o espaço total significa "o arranjo e o perfil adquiridos por uma determinada área em função da organização humana que Ihe foi imposta ao longo dos tempos". Sua gênese é explicada pela análise da estruturação espacial da sociedade sobre os atributos remanescentes de um espaço herdado da natureza. Por essa razão, o autor entende que há que se reconhecer o funcionamento dos fluxos vivos da natureza - os processos naturais mesmo que perturbados, mas não inteiramente eliminados, e toda a história e formas de ocupação dos espaços criados pelo homem. Exemplificando, Ab'Saber, explica que esse conceito envolve os componentes dos agroecossistemas regionais, os ecossistemas urbanos da região em sua plenitude e os eventuais remanescentes, bem preservados ou muito perturbados, dos ecossistemas naturais.

Por outro lado, se a noção de totalidade nos obriga a considerar objetos e relações como um todo, e que as relações são orientadas por forças que geralmente extrapolam o local em que estes objetos se encontram, a noção de singularidade, e em nosso caso, a singularidade do relevo em cada lugar, nos remete a considerar a singularidade do cotidiano, que interpreta o sistema mundo por meio de ações que constroem a configuração desse relevo local.

Esse aspecto realça a importância que os estudos aprofundados de uma localidade têm para a construção de uma interpretação holista do território. Voltamos aqui à questão das escalas de abordagem do relevo e das questões ambientais que exigem um esforço de articulação do local ao global. "Cada lugar é, à sua maneira, o mundo", afirmou M. Santos (1999, p.252), ou "a uma maior globalidade, corresponde uma maior individualidade". Nesse sentido, a configuração de um sítio urbano, em 
qualquer escala de tamanho de uma cidade, decorre de uma interação de singularidades - a do relevo e seus processos de esculturação e a do cotidiano da sociedade local - que constroem uma materialidade que é o componente imprescindível para a análise do espaço geográfico. Como, segundo M. Santos (1999, p. 257), "nada fazemos hoje que não seja a partir dos objetos que nos cercam" essa materialidade do relevo e dos objetos nele implantados são uma estrutura de controle e uma condição, um limite e um convite à ação. O lugar é o quadro que dá uma referência pragmática ao mundo, é a partir dele que conseguimos nos aproximar da compreensão do funcionamento do mundo, tanto em seus aspectos físicos como humanos. Daí a necessidade e importância dos estudos verticais em cada uma das ciências envolvidas com a interpretação do território, e dos estudos de geomorfologia aplicada dentre outros, como subsídios a uma compreensão mais holista do território. Disso decorre a compreensão, mais difundida na Geografia, da necessidade de integração disciplinar em abordagens multi, inter e transdisciplinares acerca da compreensão dessa expressão territorial das sociedades materializada na superfície plástica do relevo.

\subsubsection{Interdisciplinaridade}

Partindo-se desse reconhecimento da complexidade das abordagens ambientais, e consequentemente da abordagem do relevo; e também da necessidade de uma visão holista e integrada acerca dos fatores naturais e sociais que concorrem para a gênese do relevo em sua configuração plástica atual, é necessário reconhecer que da diversidade de questões que emergem no processo de trabalho, a que Coelho (2011, p. 30) referiu como multidimensionalidade, implica no reconhecimento da interdisciplinaridade como prática de pesquisa (Coelho, 2011, p.42).

No entanto, como a produção acadêmica exige a delimitação do olhar sob o enfoque de uma província de saber, a análise elaborada sobre o relevo nesta pesquisa visou explorar, apenas, algumas das categorias de análise da geomorfologia como instrumentos de leitura para subsidiar a compreensão dos processos de ocupação territorial, ou seja, trazer alguns elementos para compreender a organização dos espaços densamente urbanizados. 
Portanto, se tratou de delimitar uma estratégia de abordagem do relevo ante os processos de ocupação relacionados à forma atual de dispersão urbana, ou seja, a dispersão de peças da cidade pelo espaço anteriormente rural. Portanto, na análise da dispersão urbana, conforme já mencionado, não foi objetivo aprofundar uma análise dos processos de produção do espaço que induzem a dispersão, e sim à sua expressão territorial assumida e sua vinculação com o relevo.

A abordagem geomorfológica também ficou predominantemente circunscrita às questões que se implicam com o planejamento territorial da ocupação do relevo e suas vinculações referentes aos impactos ambientais. A abordagem do relevo assumiu assim, propositadamente, um enfoque estratégico, uma leitura estratégica do espaço a se ocupar pela perspectiva das respostas ambientais que possuem interface com o relevo. Por isso, essa vinculação entre relevo e impactos ambientais. O enfoque estratégico do relevo abordado na sequência deste trabalho é realizado por meio da análise dos compartimentos ambientais estruturantes de uma paisagem. Para isso, faz-se necessário primeiramente delimitar essa pesquisa no campo teórico-metodológico da abordagem geomorfológica. Só após, poderemos discorrer em relação à conceituação de compartimentos a que estamos nos referindo.

Assim como realçou Kalesnik (1958, apud Casseti, p. 31), a geomorfologia inserida dentro da Geografia Física colabora para a configuração desta ciência como uma ciência de integração e de síntese dos aspectos físicos, em face da interdependência das unidades dos sistemas biológicos, hidrológicos, atmosféricos, acrescidos da litosfera mais as fontes de energia interna e externa. Essa integração é dada por leis geográficas gerais da Terra, de integridade de sua composição e estrutura; de existência de fenômenos circulares da matéria e energia; da presença de ritmo em seus fenômenos; da coexistência na estrutura de particularidades zonais e azonais; e da continuidade de sua evolução, cujo resultado é a dialética dos processos endógenos e exógenos de esculturação do relevo.

De outro lado, a geomorfologia, entendida como ciência que busca explicar dinamicamente as transformações geográficas do relevo em toda a sua dinâmica, portanto, não apenas quanto a forma (morfologia), mas também quanto às funções que abriga (fisiologia), se vincula à Geografia como um todo, pois nessa análise necessita incorporar o movimento histórico da sociedade, ou seja, a sua 
geograficização. Essa análise, que busca sintetizar os principais fatores que concorrem para a expressão territorial da ocupação humana sobre a Terra, em uma integração multidisciplinar (e não inter, e muito menos transdisciplinar), vê-se potencializada hoje pela temática ambiental, pois esta exige dois movimentos simultâneos para a compreensão dos fenômenos: 0 da verticalização (aprofundamento setorial) e o da horizontalização (a síntese integrada da paisagem). $\mathrm{Na}$ análise vertical, como já enfatizado acima, os estudos de geomorfologia aplicada são importantes meios de mensuração das respostas ambientais dos processos naturais e processos sociais que impactam o relevo. $\mathrm{Na}$ análise horizontal, configura-se como importante apoio à construção de sínteses interpretativas para o planejamento territorial e urbano, por meio das análises espaciais que integram informações de diferentes campos do conhecimento a fim de compreender a situação atual e realizar prognósticos, que serão tanto mais assertivos quanto mais multi e transdisciplinares.

Conforme Ross (2000a, p.307) assinalou, a aplicação das pesquisas geográfico-geomorfológicas nos estudos ambientais voltam-se atualmente para os campos do planejamento ambiental e regional; para a participação na produção de planos diretores municipais (ordenamento territorial), bem como para os estudos de impactos ambientais (EIAs-RIMAs); como para a subsidiar os projetos de implantação de grandes obras de engenharia civil, complexos industriais, instalação de núcleos urbanos, complexos portuários e aeroviários, entre outros (Ross, 2000a, p. 334).

No campo específico da Geomorfologia esta pesquisa se vincula às recentes correntes voltadas aos estudos de geomorfologia ambiental e urbana e, de certa forma, tem implicações com os estudos de ecologia da paisagem utilizados nas abordagens de urbanistas e outros profissionais ligados ao planejamento urbano.

\subsection{Fundamentação teórica no campo da Geomorfologia}

$\mathrm{Na}$ abordagem geográfica-geomorfológica deste trabalho, os aspectos a serem analisados se dirigem para uma compartimentação ambiental da paisagem, e mais especificamente, para a identificação dos compartimentos (ou unidades) 
ambientais estruturantes da paisagem que condicionam, em maior grau, os processos naturais das dinâmicas do clima e da água. Verifica-se aí, já de antemão, uma abordagem da paisagem influenciada pela concepção sistêmica. Nesse sentido, para as implicações relativas à ocupação urbana e sua expansão, a constatação de sua situação atual, e do que se aponta como tendência, é de extrema relevância ao planejamento urbano, pois considera os setores do território que, se alterados pela ocupação, mais influenciarão nos desajustes ambientais da expansão urbana e que poderão causar prejuízos ambientais e materiais e, consequentemente, trazer riscos à população.

Dessa maneira, as bases teóricas que dão suporte as análises a serem empreendidas estão influenciadas pela abordagem dos geossistemas, que na atualidade se delineia como o objeto formal de estudo da Geografia Física. Embora ainda venha sofrendo ampla discussão em termos de sua aplicação e reconhecimento escalar, e em relação à inclusão da abordagem antrópica dentro do conceito, o geossistema permanece como uma construção teórica importante, sobretudo para a Geografia Física, pois possibilitou considerar a interação e a integração dos elementos abióticos (solo, relevo, clima, hidrografia), bióticos (vegetação e animais) e antrópicos e não abordá-los de maneira isolada.

A linha de abordagem deste trabalho também se aproxima do conceito de georelevo, conforme delineado por Kugler (1976). Este deu ênfase à interação que ocorre na superfície entre os processos de funcionamento da natureza com os da sociedade e que envolvem a epiderme da Terra, composta por todos os elementos que participam dessa interação, os mesmos elementos abióticos, bióticos e antrópicos do Geossistema. Entretanto, teoricamente, Kugler não posicionou o georelevo como um sistema natural que sofre influência antrópica e, sim, como um sistema complexo, interativo, pois fortemente marcado pela estrutura social e econômica. Pode-se associar, então, a esta definição o conceito de Formação Econômico Social ${ }^{14}$ como um possível delineador espacial de georelevo ou de suas unidades tipológicas, em face da forte correlação que quer fazer com a influência da sociedade na evolução do georelevo.

\footnotetext{
${ }^{14}$ Segundo Santos (2012) a noção de Formação Economica e Social foi elaborada por Marx e Engels, no entanto o autor prefere utilizar como categoria de análise o termo Formação Social como apoio à construção de uma teoria do espaço.
} 
De outro lado, a opção metodológica da abordagem que se realiza também se aproxima, embora menos enfaticamente, dos aportes que a corrente da ecologia da paisagem sugere para a análise de planejamento territorial, pelo caráter operativo e propositivo que esta alcança na formulação de unidades de paisagem, visando a síntese da paisagem para a formulação de propostas de uso e ocupação do solo e de preservação de ecossistemas ou biomas importantes à biodiversidade local, visando promessas de sustentabilidade e equilíbrio ambiental de uma paisagem. Nesse sentido, a principal formulação desta corrente vem das experiências empreendidas por Mcharg entre 1960 e 1980.

Esta visão propositiva em abordar o território a partir de seu uso e, consequentemente, de uma valoração dos melhores espaços a ocupar ou a preservar, vincula esta pesquisa aos estudos no campo de abordagem da Geomorfologia Ambiental e da Geomorfologia Urbana, e das correntes que trabalham com uma visão antropogeomorfológica da geografia ${ }^{15}$, que inserem o homem atual como o principal agente geomnorfológico e geológico nos destinos no planeta.

Neste sentido, é relevante trazer a essa discussão algumas considerações a mais sobre essas correntes metodológicas a fim de balizar as perspectivas adotadas neste trabalho para com o território, ou mais especificamente, a partir do uso que uma sociedade urbana faz deste território, tendo o relevo como um dos parâmetros dessa relação de uso. No capítulo 3.2.1 os conceitos de Geossistema, Georelevo e Ecologia da Paisagem serão apresentados em sua aproximação com esta pesquisa, e no seguinte (3.2.2) abordaremos a importância do desenvolvimento dos estudos de geomorfologia urbana e geomorfologia ambiental como instrumentos de estudo e de reflexão para subsidiar o planejamento territorial e planejamento urbano em face das evidências que trazem do conjunto de interferência do homem na construção da paisagem e do relevo.

\footnotetext{
${ }^{15}$ Incluindo a Geomorfologia antropogenética de Fels (1958), como já mencionado anteriormente.
} 


\subsubsection{Geossistema, Georelevo e a Ecologia da Paisagem}

A concepção teórico-metodológica do Geossistema foi formulada inicialmente pelo russo Sotchava, em meados da década de 1960, e foi difundida no Brasil por G. Bertrand. Essa concepção deriva da ciência da paisagem desenvolvida na escola alemã de geomorfologia; da teoria geral dos sistemas e da noção de ecossistemas. O suporte teórico do Geossistema vem da noção de "paisagem ecológica" introduzida por Troll na década de 1930, e da ampliação do termo e conceito de ecossistema de Tansley (em 1935) (Ross, 2006, p.28).

O termo Geossistema, conforme definido por Sotchava, possuía o caráter de um conceito teórico e, assim como o de ecossistema, não teria uma existência real na superfície terrestre ${ }^{16}$. Tinha por objetivo significar a epiderme da Terra onde se misturam as dinâmicas da natureza em seus diversos elementos constituintes (litosfera, hidrosfera, atmosfera, biosfera) que estabelecem relações de simultaneidade. Em outras palavras, Sotchava (1978, p.3) afirma que o meio natural organiza-se em termos de hierarquias funcionais. O termo visava dar um conteúdo geográfico ao conceito de ecossistema, a fim de que incorporasse a espacialidade humana. Assim, o conceito de geossistema incluiria o de ecossistema e, segundo Ab'Saber (2003, p. 139), seria o "espaço original de abrangência de um ecossistema no entremeio de uma zona, domínio ou região morfoclimática e fitogeográfica".

Os princípios básicos do Geossistema, segundo Sotchava (1978), se estruturam na visão da natureza como sistemas dinâmicos abertos e hierarquicamente organizados, que são passíveis de delimitação ou de serem circunscritos espacialmente em sua tridimensionalidade; e na noção de dinâmica, em que se permite avaliar a evolução dos estados sucessivos dos geossistemas e classificá-los, bem como assumir hipóteses sobre sua dinâmica futura. É esse caráter preditivo que o torna um importante instrumento de apoio para a sua

\footnotetext{
${ }^{16}$ Segundo Bolòs y Capdevila (1977), "La palabra geosistema fue definida por el geógrafo soviético Sochava em 1953, como un modelo teórico y por tanto como a tal no tendría existencia real en la superficie terrestre, de la misma manera que no la tiene el ecosistema. Queremos subrayar que la palabra geosistema ha sido utilizada por G. Bertrand con carácter de unidad taxocorológica, cosa que hay que ten en cuenta para la buena comprensión de los trabajos realizados en Toulouse y en Barcelona hasta 1978 aproximadamente. Como dice el mismo autor "en un deseo de uniformización conceptual y de simplificación de lenguaje es mejor utilizar siempre el sentido inicial dado por Sochava que hace del geosistema, paralelamente al ecossistema una abstracción y un concepto". Bolos I Capdevila (1977), baseando-se no texto de BERTRAND, 1978 - Le paysage entre la nature et la societé. Revue Géographique des Pyreneés et du Sud-Ouest. no 2, pp.239-258.
} 
aplicação no planejamento territorial e urbano e no planejamento ambiental. Entretanto, a sua aplicação escalar e a incorporação da variável antrópica foram, até agora, questões que dificultaram a sua aplicação prática (Monteiro, 2000; Rodrigues, 2001). No Brasil, Monteiro (2000) foi um dos poucos pesquisadores que tentaram concretizar essa proposta de Sotchava em estudos realizados na Bahia e na região de Ribeirão Preto/SP. Com base nessas experiências visou também difundir no mundo acadêmico e profissional a perspectiva do Geossistema como elemento de integração na síntese geográfica e fator de promoção interdisciplinar na compreensão do ambiente (Rodrigues, 2001).

Na proposição de Sotchava o geossistema de nível planetário se divide em subsistemas de várias ordens dimensionais, nas escalas regional e local, que formam complexos físico-geográficos (geossistemas) constituídos de componentes naturais inter-condicionados e inter-relacionados em sua distribuição, desenvolvendo-se, no tempo, como parte do todo. Essas condições naturais são caracterizadas por seu funcionamento que envolve a estrutura superficial da paisagem em sua base lito-estrutural, o relevo, os solos, as águas superficiais e subsuperficiais, as comunidades vegetais e animais e as dinâmicas do clima e da água que promovem essa interação complexa de um sistema aberto, podendo incluir ou não o fator da ação e da presença humana. Assim, verifica-se que o autor denominou o processo de funcionamento da paisagem que origina um Geossistema como um sistema natural, mesmo levando-se em conta a interferência humana neste processo. Inclusive nas áreas densamente povoadas poderá se identificar geossistemas em evolução.

Bertrand tentou tornar mais preciso esse conceito ao otimizar a classificação das paisagens naturais delineada por Sotchava, atribuindo hierarquia das paisagens com uma tipologia às ordens taxionômicas do relevo, definindo as unidades de paisagem, conforme a escala espaço-temporal anteriormente proposta por Tricart e Cailleux, em unidades superiores - Zona, Domínio e Região Natural - e unidades inferiores - Geossistemas, Geofácies e Geótopo. Nas unidades superiores os elementos fundamentais da análise se baseiam nos fatores climáticos e estruturais. Nas inferiores são os elementos biogeográficos e antrópicos os determinantes. No entanto, para os profissionais que a experimentaram em suas pesquisas tiveram 
dificuldades em trabalhar com a escala das unidades inferiores, pois quando transposta para dimensionar paisagens de expressão continental como as brasileiras se mostraram inadequadas ${ }^{17}$.

Portanto, como afirma Bolós y Capdevilla (1977), é melhor continuar utilizando o geossistema no sentido inicialmente proposto por Sotchava, como uma abstração, um conceito, assim como o conceito de ecossistema, uma área ou região, não efetivamente delimitada, em que se desenvovem processos de interação dos elementos que constroem e modelam a paisagem. A aproximação da abordagem deste trabalho ao conceito de geossitema se relaciona à avaliação dos processos de funcionamento da natureza e da sociedade que interagem em um espaço determinado, e concorrem para a conformação dos atributos ambientais da paisagem local, mensurados pelos indicadores de temperatura e umidade relativa do ar, vazão da rede hídrica, taxas de erosão do solo e de assoreamento da rede de drenagem, etc.

A especificação do termo "apropriação do relevo" utilizado nas abordagens sobre a expressão da urbanização do território dá ênfase ao aspecto fundamental da pesquisa que é a importância da análise do relevo e sua dinâmica para o planejamento territorial, sobretudo nas áreas densamente ocupadas. Nesse sentido, o aporte teórico-metodológico também se aproxima do conceito de georelevo, conforme delineado por Kugler (1976). Como as paisagens metropolitanas sempre apresentam um elevado grau de humanização e de interferências no território, segundo Kugler, o relevo e o território são, assim, "cunhados em uma interface extremamente dinâmica e produzem uma paisagem fortemente marcada pela sociedade e por sua estrutura econômica" (Abreu, 1985 p. 158).

Para Kugler, o georelevo é resultado da dinâmica endógena da paisagem mais a epiderme (Landschaftshülle), especialmente da troca de energia e matéria entre a geoderme e os outros elementos sistêmicos (subsistemas), e da influência exógena, ou seja, telúrica, solar, social que de fora penetra a paisagem e a epiderme (Abreu, 1985, p. 158). O conceito de Landschaftshülle, oriundo da visão

\footnotetext{
${ }^{17}$ RIBEIRO de Melo, Dirce. Geossistemas: sistemas territoriais naturais. Belo Horizonte: UFMG. Texto disponível em: http://w.sites.uol.com.br/ivairr/dirce.htm. Acesso em 04/06/2011.
} 
clássica alemã, visa articular a compreensão das dinâmicas da sociedade e as da natureza, que se constituem em diferentes esferas e que se interseccionam e desenham, ou definem, uma epiderme de pouca espessura visualizada plasticamente por sua superfície - o relevo - originando, assim, a paisagem. Nela se articulam as estruturas de análise vertical e horizontal da paisagem, podendo propiciar sínteses mais integradoras da paisagem.

O conceito de georelevo parece ser o mais próximo a subsidiar a análise dos efeitos ambientais da urbanização dispersa, pelo fato de que a partir dele pode-se salientar as relações que se estabelecem entre as funções geoecológicas (processos naturais) e as funções sócio-reprodutoras (processos sociais ou urbanos). Pode-se dizer que as formas da reprodução social resultam do uso das propriedades geoecológicas relevantes e das influências diretas da esculturação e da dinâmica do relevo, face à intensidade e modos de uso e face à efetividade e custos sociais de reprodução. No entanto, deve-se deixar claro que, a pesquisa não tem o intuito de abarcar a totalidade desses aspectos e sim, apenas, avaliar os prováveis conteúdos e riscos ambientais do processo de dispersão urbana na macro-metrópole paulista, tomados a partir das suas formas-conteúdo, seguindo a conceituação de Santos (1999), dispostas no espaço intersticial dos diversos centros urbanos compactos dessa macrometrópole. As formas-conteúdo citadas correspondem nesta pesquisa aos agrupamentos de objetos dispersos artificiais, as peças urbanas que contem casas, bairros, ruas, indústrias, estradas, etc., que se sobrepõem às formas-conteúdo naturalizadas do mundo rural (fazendas, parques, áreas de preservação, produção agrária, matas, campos, etc).

É certo que, em um estudo interdisciplinar, essas relações entre as funções geoecológicas e as socioreprodutoras poderiam ser tratadas mais verticalmente na análise da influência antrópica sobre o relevo, incluindo, conforme mencionado acima, parâmetros ligados à formação social que caracteriza mais profundamente os processos urbanos em desenvolvimento na macrometrópole. Como já mencionado, optou-se por utilizar as formas-conteúdo da urbanização como síntese dessa formação, na hipótese de se configurar a abordagem espacial na acepção que condicionou Santos em variados trabalhos (1982, 1988, 1999) - o espaço constituído pela paisagem mais a sociedade que a anima. 
Nesse contexto, é importante salientar que, embora as abordagens desenvolvidas na pesquisa sobre as respostas ambientais originadas da análise da relação entre os processos naturais e os urbanos muitas vezes se aproximem das referências utilizadas na Ecologia da Paisagem (Lanscape Ecology), a sua pouca profundidade em relação à abordagem do relevo e da espacialização da sociedade, a nosso ver, conduzem a uma dificuldade em operar com um aspecto fundamental em planejamento territorial que se traduz na valorização das funções desempenhadas pelo relevo em relação às demandas urbanas. Por isso, a ênfase dessa pesquisa para a análise da apropriação do relevo e da compartimentação topográfica e ambiental da paisagem.

Entretanto, a abordagem da Ecologia da Paisagem adotada no planejamento urbano, introduzida pelos arquitetos-urbanistas, apresenta um caráter eminentemente pragmático e propositivo em colaborar para o desenho dos espaços de ocupação, de proteção ecológica e de regeneração ambiental, tendo em vista a regulação e o ordenamento do território, fato que se coloca como um importante instrumento de planejamento urbano e também ambiental, nas áreas mais densamente povoadas. Nessas abordagens, embora as questões geográficas, geomorfológicas, geológicas e climáticas estejam presentes, elas o estão de maneira sintética e pouco integradas, aparecendo subjugadas às questões ligadas ao mundo biótico.

Como mencionado, a Ecologia da Paisagem dá suporte teórico aos arquitetos, urbanistas e outros profissionais que estudam e atuam nas discussões sobre planejamento territorial urbano. Dentre eles destacam-se I. Mcharg, M. Hough, J.T. Lyle, M. Franco, A. Spirn, J. Sabaté. O grande disseminador do método de abordagem denominado como "projetar com a natureza" foi lan Mcharg (1967). Ele utilizou dois métodos muito próximos e que foram extraídos de técnicas comuns já utilizadas nos estudos de Geografia Física, Geomorfologia e Geologia. Um deles era a superposição de cartas com os dados da base física, biótica e da urbanização. $O$ outro, essa superposição usava como método preliminar a compartimentação do relevo.

A técnica de superposição de camadas para a leitura dos fatores físicos e de uso do solo foi utilizada nos estudos que a equipe de Mcharg realizou para o 
Departamento de Parques de New York, em State Island, em 1967. Tinha como objetivo extrair diretrizes de ordenamento da ocupação do solo, segundo avaliação de aptidão para as diferentes demandas de uso do solo. A hipótese utilizava um conceito comum à geomorfologia - a análise da fisiologia da paisagem - que na acepção de Mcharg se direcionou a entender os processos naturais e urbanos como valores. A justificativa era a de que a natureza é um conjunto de processos e valores que implicam oportunidades e limitações para o uso humano.

Para categorizar e dar valores aos fatores, todos os mapas foram feitos sobre transparências e se reuniu e fotografou o grupo de fatores relevantes para cada uso do solo. O resultado eram gradientes de valor que incorporavam todos os fatores apropriados e se analisava as áreas de coincidência de maior número de fatores positivos e onde se davam as mínimas restrições. Assim, os processos, reorganizados como valores, indicavam as zonas aptas para cada um dos usos do solo considerados: recreativo, conservação e urbanização, tanto para as zonas residenciais como para as áreas de uso industrial e comercial. Como síntese chegou-se à confecção de mapas de aptidão para uso do solo e de aptidão para urbanização.

Uma grande série de mapas foram analisados e superpostos, desde os da base física (geologia, geologia superficial, geomorfologia, topografia, hidrologia, áreas inundáveis, drenagem subterrânea, hidrogeologia, solos, limitações do solo) e da base biótica (vegetação, bosques/reflorestamentos e associações ecológicas, fauna selvagem, hábitats para a fauna, etc), incluindo posteriormente os mapas de valoração em: valor cênico da terra e da água, valor fisiográfico, valor histórico, valor geológico, valor das associações ecológicas, etc, e de qualidade das praias, das correntes de água, bosques, etc.

Anteriormente, em 1962, na cidade de Baltimore - Região de The Valleys, Mcharg havia utilizado a estratégia inicial de compartimentação topográfica da paisagem e inferências de uma compartimentação ambiental. Tratou-se de um estudo de ordenamento territorial urbano em face da expansão urbana galopante para a região conhecida como The Valleys. O processo de expansão urbana era intenso e impulsionado pela implantação de autopistas. A técnica utilizada neste caso também já era de utilização na Geografia Física, que era a da 
compartimentação topográfica, reconhecendo-se e mapeando, preliminarmente, os fundos de vale, as vertentes e as mesetas (ou platôs). A partir deste reconhecimento se partia para a caracterização fisiográfica e qualificação dos compartimentos por meio da análise dos processos e propriedades geoecológicas e, após, a análise das propriedades socioreprodutoras da paisagem, embora o autor não utilizasse essa denominação.

Figura 3.1 - Estudos de compartimentação topográfica e ambiental organizados por Mcharg para a região de The Valleys, em Baltimore (EUA) - 1962.

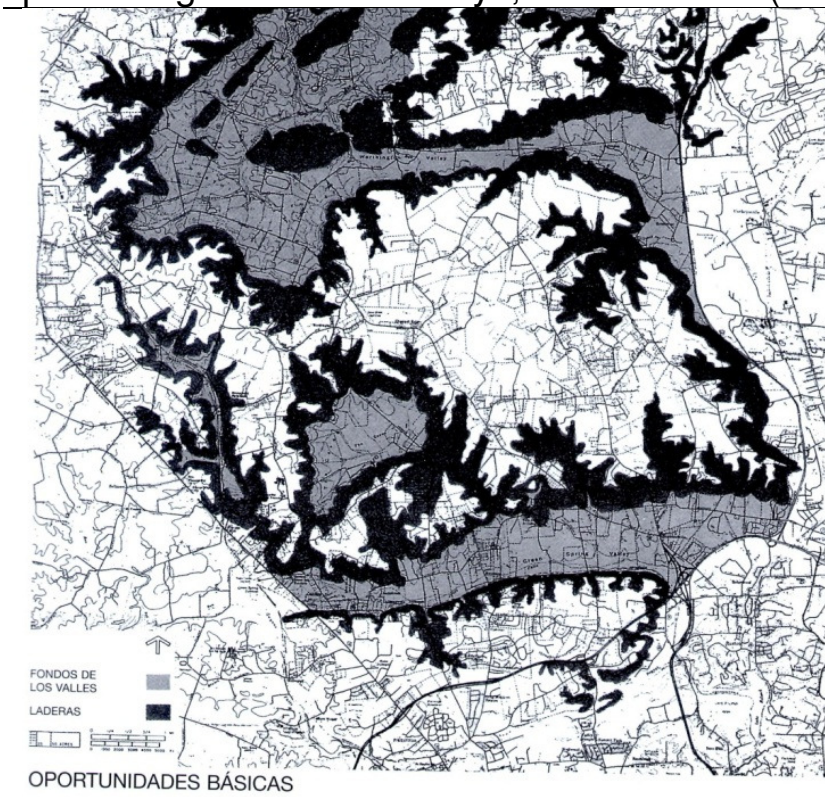

Compartimentação Topográfica

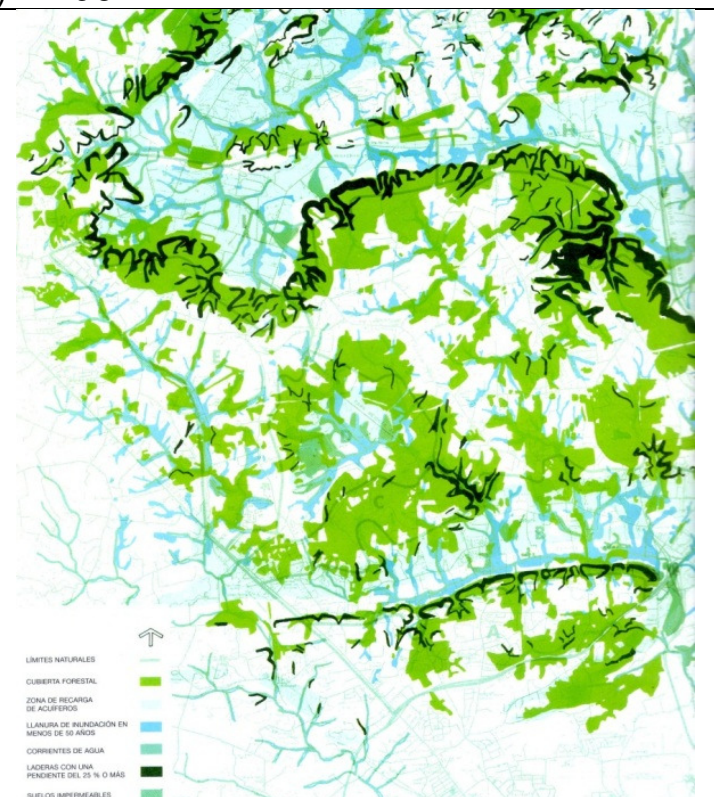

Fatores ambientais limitantes

Fonte: Mcharg (2000)

O resultado se dirigia para o estabelecimento de prognoses, prognósticos de crescimento da expansão urbana, de modelos de crescimento alternativos, e criação de cenários de crescimento, para se chegar à determinação de um uso do solo ótimo proposto. Neste trabalho em Baltimore a superposição de cartas também se realizou como método básico, porém antecedido pela análise da compartimentação do relevo.

Essa explanação nos parece importante, pois já evidencia a utilização de instrumentos metodológicos e de técnicas associadas que tem origem nas ciências físicas, particularmente na geografia física, na geomorfologia, geologia, e também na geografia em geral. A grande dificuldade talvez se dê na interpretação que se faz dos mapas e dos cruzamentos, pois requerem especialidades diversas, ou seja, equipes multidisciplinares. 
No entanto, pairam ainda diferenças de visões que os profissionais de cada corrente tem entre os objetos da Geografia Física e da Ecologia da Paisagem. A argumentação de Fusalba no artigo "O conceito de paisagem e sua aplicação no planejamento territorial e ambiental" parece esclarecedora dessa diferenciação que se produz nas sínteses propositivas. Segundo ele,

"[...] o que diferencia a Ecologia da Paisagem das outras escolas, é que ela analisa como a escala espacial e a heterogeneidade afetam os processos ecológicos que se dão na paisagem, de maneira que centra sua atenção nas relações horizontais entre os elementos que constituem o mosaico paisagístico, relações horizontais esquecidas até agora em favor da "análise vertical", quase fisiológica do chamado Geossistema, pelos geógrafos físicos, ou dos ecossistemas, por parte dos ecólogos" (Fusalba, 2009 p. 146).

Fusalba finaliza argumentando que "o enfoque central da Ecologia da Paisagem é a inter-relação entre o que se denomina estrutura (o tipo de elementos e sua distribuição espacial no território) e o funcionamento da paisagem" (Fusalba, 2009 p. 147).

Em decorrência disso, conforme o próprio autor analisa, sobretudo na corrente anglo-saxônica (Landscape Ecology), há uma nítida inflexão em dirigir o centro de interesse das análises de paisagem para a conservação da biodiversidade, enfatizando a influência da estrutura da paisagem sobre o funcionamento dos sistemas naturais. Disso decorrem algumas categorias de análise muito comuns nessa corrente como a fragmentação da paisagem e o estudo dos padrões de cobertura do solo.

Portanto, a ênfase dos estudos de ecologia da paisagem se dirige para o comportamento da flora e da fauna ante as pressões da ocupação humana, urbana e rural, como elementos indutores de um equilíbrio ambiental entre relações sociais e processos naturais (Figura 3.2). O comportamento do clima e dos solos são abordados tangencialmente, e pouca expressão é dada para as influências da estrutura superficial da paisagem e do relevo nas definições propositivas de preservação do ecossistema humano. O comportamento do relevo aparece, nessa escola da Ecologia da Paisagem como um elemento passivo, enquanto para a Geografia e para a Geomorfologia ele é indutor e receptor de processos. Por isso, abordá-lo com uma visão estratégica de seu potencial e suas fragilidades ante as 
necessidades de uso e de ocupação humana recoloca em outro patamar as análises propositivas da Ecologia da Paisagem.

Figura 3.2 - Esquemas utilizados na abordagem espacial da Ecologia da Paisagem
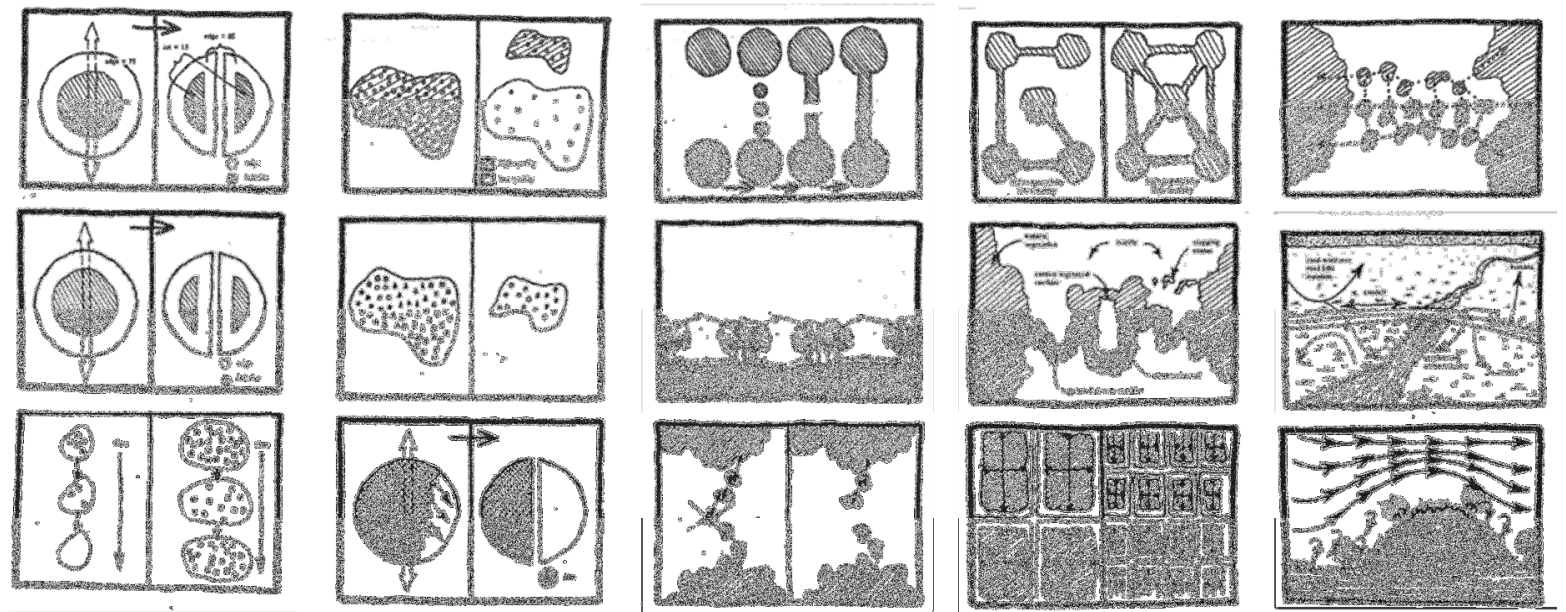

Fonte: DRAMSTAD, W.E., OLSON J.D. y FORMAN R.T.T., 1996.

Nesse sentido, a análise da compartimentação topográfica e do relevo nos permite reconhecer, em primeiro lugar, o estágio evolutivo daquele compartimento em sua relação de interdependência com os demais, e que se coloca como condição da evolução da paisagem e de suas formas de vida, em face das relações processuais do funcionamento da paisagem. Em segundo lugar, permite extrair elementos para orientar a escolha de sítios de ocupação, quando a essa análise se estende os fatores de previsão de impactos e de riscos ambientais para o uso humano.

Talvez a abordagem mais integradora dos elementos abióticos e bióticos na análise ambiental tenha sido trazida por Ab'Saber na formulação dos domínios morfoclimáticos e biogeográficos para as paisagens da América do Sul e do Brasil. Numa tentativa de cruzamento das interações entre relevo (geomorfologia e geologia), clima, biomas (vegetação e fauna) e solos, chegou a um grau de interpretação da paisagem, que até proporcionou, ou facilitou, a elaboração da teoria dos refúgios, proporcionando elementos de uma análise estratégica de preservação da paisagem, ou mais especificamente, dos biomas em sua evolução (ou involução/regressão).

É fato que a abordagem de geossistemas e de outras teorias geomorfológicas ainda carecem de uma mais ampla consideração da evolução dos biomas e de sua 
preservação, embora essa questão sempre estivesse presente nos estudos geográficos por meio da biogeografia e em algumas teorias geomorfológicas da paisagem como as delineadas nos estudos geoecológicos progressivamente amadurecidos na literatura alemã por H.J.Klink, H.Kugler, G.Haase e E.Neef ${ }^{18}$ (Abreu, 1985), e mais recentemente por Tricart (1977) e Ross (2006) nas formulações da ecodinâmica e da ecogeografia.

Parece evidente que uma aproximação mais efetiva dessas correntes e desses conceitos poderá trazer benefícios conceituais para a abordagem ambiental, pois elas antes se complementam do que se excluem. Essa visão integradora da paisagem, e do espaço, é ainda um caminho longo a percorrer, e carece de uma aproximação cada vez maior entre conceitos e sua experimentação prática na realidade. Por isso, a análise ambiental ainda permanece como um campo extremamente aberto de indagações, conceituações, proposições e experimentações das variadas visões profissionais e acadêmicas, mais ou menos integradoras, que somente uma integração mais radical desses estudos poderá conduzir à formulação de teorias e conceitos mais totalizantes para uma sociedade que é indivisível.

Dessa forma, o conceito de georelevo parece ser o mais próximo, no campo da geomorfologia, a subsidiar a análise dos efeitos ambientais da urbanização dispersa, pelo fato de que a partir do relevo pode-se elucidar e salientar as relações que se estabelecem entre as funções geoecológicas (processos naturais) e as funções sócio-reprodutoras (processos sociais ou urbanos). Pode-se afirmar que as formas originadas da reprodução social resultam do uso das propriedades geoecológicas relevantes e das influências diretas da esculturação e da dinâmica do relevo, face à intensidade e modos de uso e face à efetividade e custos sociais de reprodução. No entanto, deve-se deixar claro que, a pesquisa não tem o intuito de

\footnotetext{
${ }^{18}$ Conforme citado por Abreu (1985), os estudos em língua alemã de Klink, H.J. -1966 - Naturräumliche Gliederung des Ith-Hils-Berglandes. Art umd Anordnung der Physiotope und Oekotope. Forsch. Z. Dt. Landeskunde, no 159. Bad Godesberg.; e de 1972 - Geooekologie and Naturräumliche Gliederung. Grundlagen dr Umwltforschung. Gographisch Rundschau, no 24, p. 7-19. De Kugler - 1976 - Zur Aufgaben der geomorphologischen Forschung und Kartierung in der DDR. Petermanns Geographische Mitteilungen, Vol. 120, no 2, p. 154-160. De Haase - 1977 - Ziele und Aufgaben der geographischen Landschafts-forschung in der DDR. Geographische Berichte. Heft 82, no 1, p. 1-19. E de Neff - 1972 - Geographie und Umweltwissenschaft. Petermanns Geographische Mitteilungen, Vol. 116, № 2, p. 81-88.
} 
abarcar a totalidade desses aspectos e sim, apenas, avaliar os prováveis conteúdos e riscos ambientais do processo de dispersão urbana na macrometrópole paulista.

\subsubsection{Geomorfologia Ambiental e Geomorfologia Urbana}

Uma importante produção de pesquisas acerca dos impactos ambientais em áreas urbanas vem surgindo nos últimos 20 anos e revelam o olhar mais atento sobre as formas de ocupação desenvolvidas pelas cidades em sua relação com o sítio urbano. Os últimos eventos catastróficos ocorridos recentemente em Blumenau e Itajai (SC); Rio de Janeiro, Petrópolis, Teresópolis e Nova Friburgo (RJ); e as recorrentes enchentes em São Paulo e em muitas cidades brasileiras tem chamado a atenção para a investigação das causas e das estratégias e técnicas de prevenção dos riscos vinculados, principalmente às enchentes e deslizamentos, dentre outros.

$\mathrm{Na}$ Geografia, a produção relativa a esse tema vem ganhando espaço, direcionando as diversas pesquisas sobre os efeitos do clima, da hidrologia, da pedologia, da geomorfologia e até da biogeografia para linhas de abordagem que se intitulam como geomorfologia ambiental e geomorfologia urbana. Essa produção vem trazendo reflexões de ordem prática e teórica no sentido de problematizar as questões relativas à organização socioespacial. Eminentes pesquisadores que atuavam nessas sub-áreas da Geografia Física, estudando o comportamento dos processos naturais em áreas rurais ou ainda pouco afetadas pelo uso humano, começaram a focar suas pesquisas para o comportamento da natureza em áreas urbanas.

Talvez uma das primeiras áreas a introduzir mais incisivamente essa questão das alterações impulsionadas pela ocupação urbana tenha sido a área de climatologia, que desde os anos 1960 vem produzindo estudos sistemáticos sobre o clima urbano.

$\mathrm{Na}$ Geomorfologia esses estudos tem se direcionado na avaliação do caminho das águas e das enchentes em ambientes urbanos, de um lado, e na análise dos movimentos de massa e da produção de sedimentos derivados do escoamento superficial. 
Em relação ao primeiro caso, as pesquisas se concentram em duas linhas de abordagem: uma quanto ao estudo com base em bacias hidrográficas urbanas, no que se refere à análise das formas de ocupação do território pela cidade, e ligadas à questão de planejamento urbano; e outra sobre a drenagem urbana, no que se refere às técnicas de controle da água e do escoamento superficial.

Em relação aos movimentos de massa, os estudos se dirigem aos próprios movimentos de massa que se caracterizam por seu caráter esporádico, mais conhecidos na literarura técnica e no senso comum como deslizamentos e escorregamentos; e outra vertente de pesquisas analisam os movimentos contínuos, porém silenciosos, derivados do escoamento superficial cotidiano, mas que também causam, no tempo, estragos e prejuízos consideráveis, derivados da erosão e assoreamento, que provocam voçorocas e as enchentes.

Uma vasta literatura internacional é acessada nestes temas destacando-se Coates (1976) e Goudie (1990) cujas linhas de pesquisa agregam muitos pesquisadores nessa linha de geomorfologia urbana. Na produção nacional vem se destacando os trabalhos de Rodrigues (1990, 2005); Ross (2000, 2000a, 2000b, 2010), Guerra (2001, 2007, 2011), Cunha (2007) e Coelho (2001, 2005), com trabalhos importantes no estudo das mudanças na rede de drenagem urbana; na hidrologia de encostas urbanas; nos depósitos tecnogênicos e riscos de contaminação e deslizamentos; nos estudos de impactos ambientais e de planejamento ambiental urbano, entre outros.

Estes trabalhos servem de insumos práticos para as análises estratégicas de uso e ocupação do solo, portanto, para o planejamento urbano. De outro lado, possibilita mensurar, por meio de fatos da base empírica, os compartimentos ambientais mais suscetíveis a impactos semelhantes e que devem ser preservados de uma ocupação urbana indiscriminada, ou conter premissas restritivas ao adensamento. 


\section{DISPERSÃO URBANA E OCUPAÇÃO TERRITORIAL}

\subsection{Dispersão urbana: o conceito e evidências}

As grandes aglomerações urbanas que marcaram os territórios brasileiros nas décadas 1950 a 1990 assumiram um ar de homogeneidade caracterizado pela concentração de atividades e verticalização na área central, e pela expansão urbana horizontal contígua ou a pequenos saltos que deixavam vazios intersticiais à espera de valorização, como uma etapa do processo de concentração do tecido urbano. Nas duas últimas décadas essas aglomeraçõesassumem marcadamente um caráter disperso, com a fragmentação de peças urbanas sobre o antigo território rural, que podem constituir ou não diversificação de atividades que caracterizem pólos descentralizados de vida urbana.

Segundo Secchi (2009, p.45), a literatura anglo-saxônica utiliza, desde a metade do século dezenove, o termo sprawl, para se referir ao espraiamento urbano de baixa densidade (com casas de um ou dois pavimentos) que envolve área central de uma cidade cada vez mais concentrada e verticalizada. Sprawl deriva de um verbo, to prawl, que significa deitar-se. Essas duas imagens, a da cidade absolutamente vertical em um espaço limitado e a da cidade deitada, segundo esse autor, simboliza um ponto de passagem importante "na história urbana européia e ocidental, sempre interpretada como uma ruptura, uma passagem entre duas épocas distintas, ou uma dissolução, quase uma transferência de uma imagem para outra."

Entretanto, essa cidade horizontal que se espraia forma uma periferia que assume caráter muitas vezes distinto dentro dessa própria história urbana ocidental, e pouco referendada pelos estudiosos da urbanização, que não se ocuparam muito da periferia, da suburbanização e da dispersão, e conforme relata Secchi (2009 - p 45), "consideraram tanto uma como a outra consequência nefasta e sem importância para o crescimento urbano, fenômenos a serem condenados, mais do que estudados, com base em alguns juízos estereotipados." 
Se observarmos a dispersão urbana não somente pelas formas de habitar, mas também pelas formas de produção do espaço, a dispersão urbana na Europa surge como fenômeno diverso do suburbs norte-americano, e assume também diferencial marcante com o que ocorre no Brasil sob o ponto de vista social e de qualidade urbanística. Segundo Secchi (2009 - p 53), os fenômenos europeu e norte-americano, apesar de serem similares em muitos aspectos, têm uma história e uma dimensão diferente, pois diverso foi o papel dos atores que concorreram para suas realizações ediversas foram as retóricas que mantiveram as motivações de quem as escolheu como lugar de residência ou onde posicionar a própria atividade. Isso não exclui a possibilidade de que, em poucos anos, eles possam se desenvolver de maneira bem parecida. Já a dispersão brasileira, além daquela que tem nos extratos sociais de média e alta renda os seus protagonistas, apresenta uma perifização de baixa renda que também se espraia, seja vinculada à oferta de transporte para as áreas concentradas que oferecem os empregos, seja para se aproximar dos novos pólos de emprego, também dispersos, das moradias de $1^{\underline{a}}$ ou $2^{2}$ residência das camadas de mais elevada renda, e das indústrias e serviços que se descolam das áreas concentradas.

O processo de dispersão não é simples como aparenta ser, envolvendo apenas o deslocamento de moradia tipo condomínio fechado para as faixas de renda média a alta. Ele se apresenta complexo e diversificado, e inclui a formação de áreas destinadas a indústrias, inclusive condomínios para fábricas; bairros populares, também dispersos associados às áreas industriais e também para servir as áreas residenciais de média e alta renda. $O$ processo também inclui área para serviços, na forma de grandes equipamentos ou centros para comércio (shoppings, com suas variadas formas), para escritórios e para serviços de diversos tipos (campus para universidades, centros médicos, equipamentos para cultura, lazer e entretenimento). Além disso, ele aparece também expressivamente nas áreas com potencial turístico, onde se formam os equipamentos de usos turísticos e os loteamentos de chácaras e condomínios para 2ª residência (Reis Filho, 2007 p. 39).

As rodovias são os eixos principais por onde se estrutura a dispersão dessas diversas peças urbanas pelo território, que podem assumir um caráter mono ou multifuncional. Em São Paulo, segundo Reis Filho (2007, p. 38), as imagens de 
satélite de 1970, interpretadas pelo INPE, mostram que o processo ainda não havia se iniciado, mas que ficou demonstrado em 1980, e nas décadas seguintes.

O processo de dispersão é geral, ocorre em todos os países e é mais visível nas áreas metropolitanas ou ao redor de grandes cidades. No entanto, já ocorre também no entorno de cidades médias, como uma reprodução, em menor escala, das tendências de empreendimentos análogos ao padrão da grande cidade.

Nas áreas onde a urbanização se intensifica, a expansão da franja urbana e das áreas periféricas metropolitanas se encostam, o que tende a formar ao longo do tempo, segundo Limonad (2008. p.1), macroaglomerações urbano-metropolitanas na perspectiva da "cidade-região global" polarizadas por um núcleo forte, como São Paulo, Rio de Janeiro e Cidade do México, "da qual Los Angeles seria o exemplo paradigmático, conforme a proposição de Allen Scott, John Agnew, Edward Soja e Michael Storper (2001:11-14)".

\subsubsection{A urbanização contemporânea: entre a concentração e a dispersão ${ }^{19}$}

É facilmente observável, sobretudo num sobrevôo noturno sobre territórios mais densamente ocupados como o do estado de São Paulo, e também por meio das imagens aéreas observáveis no Google Earth, que a ocupação urbana periférica às aglomerações urbanas de maior porte e concentrada assume um caráter eminentemente espalhado, pulverizado por entre manchas verdes do antigo mundo rural ou áreas de vegetaçãonatural ainda preservadas da utilização humana. No Brasil esse processo assume maior intensidade ao redor das áreas metropolitanas, mas também pode ser observável ao redor de muitas cidades médias.

Segundo Limonad (2007, p.1), estão em curso duas grandes tendências de urbanização ocorrendo simultaneamente: a concentrada e a dispersa. Da primeira decorre a geração das grandes aglomerações metropolitanas, como São Paulo e Rio de Janeiro, no Brasil, ou Barcelona na Espanha. Da última, mais recente, tem gerado uma mancha urbana fragmentada, caracterizada pela dispersão das

\footnotetext{
19 “Novas Periferias Metropolitanas...” obra citada, discute a expansão metropolitana diferencial em Belo Horizonte, de alta renda e excludente no eixo sul da Metrópole.
} 
atividades produtivas e da população no território, seja nas periferias metropolitanas; seja em enclaves dinâmicos do interior do Brasil. Embora aparentemente contrapostas, existem diversos indícios de que essas tendências vêm se desenvolvendo de forma complementar (Limonad, 2007 - p 1). Este aspecto se analisado mais detalhadamente no próximo tópico.

É importante relembrar que a cidade industrial do final do século XIX e sua expressão durante quase todo 0 século $X X$ foi pautada pela tendência à concentração, urbana, industrial, populacional e, consequentemente, das atividades comerciais e de serviços. A cidade como lócus de relações sociais mais intensas, gerou um tecido urbano coeso que se fragmentava mais em função de características locais de relevo e hidrografia que por emergência de novos pólos urbanos, em função da necessidade de acessibilidade aos serviços da cidade, pois concentrados nas regiões centrais dos núcleos urbanos.

Dematteis (1998) constata que as cidades europeias ocidentais sofreram mudanças consideráveis, a partir do final dos anos de 1970, que se caracterizaram pela passagem de uma situação de suburbanização, com o crescimento maior das coroas periféricas que dos centros, para uma situação de desurbanização, por meio de um declive demográfico das áreas urbanas. $O$ autor reconhece a constituição de uma "desconcentração concentrada" marcada pela presença de duas dinâmicas: a periurbanização, que se manifesta como dilatação progressiva das coroas externas e das ramificações radiais dos sistemas urbanos, mas ainda fortemente ligados e dependentes da coroa central, pois se caracteriza por uma expansão das funções residências acompanhadas das de serviços, e eventualmente industriais, num contexto relativamente pobre. A segunda dinâmica é denominada por "cidade difusa", e se configura como formas de expansão urbana relativamente independentes dos campos de polarização dos grandes centros, formando tecidos mistos residenciais e produtivos, fazendo surgir novas centralidades imbricadas em uma malha de urbanização extensiva. Segundo Dematteis, onde estes dois tipos se fundem aparecem os contextos territoriais propícios ao desenvolvimento de níveis industriais e terciários mais avançados, geralmente dentro do contexto de áreas metropolitanas monocêntricas ou policêntricas. 


\subsubsection{Cidade dispersa $x$ cidade difusa}

O conceito urbanístico que visa se estabelecer nesse domínio da morfologia urbana intenta diferenciar os padrões funcionais das peças urbanas que se dispersam quanto a constituírem-se de fato "cidade", abrigando todas as funções necessárias à vida urbana, como o uso residencial, serviços correlatos, equipamentos públicos e sociais, empregos, num raio a se formar uma unidade de vizinhança. A esse fato, segundo Dematteis(1998), as peças urbanas seriam consideradas multifuncionais e constituiriam parte da cidade, uma porção de cidade desgarrada do núcleo central da sede urbana, assim, uma cidade difusa. Veja, não se trata se este novo núcleo forme uma outra cidade independente, e sim que apenas se configure como uma nova centralidade, pelo menos para uma vizinhança próxima.

Para Font (2007 - p 63-64) "dispersão é um conceito de natureza topológica, diz respeito às relações das distâncias entre as coisas mais do que um fenômeno de densidade, mais do que um fenômeno de difusão". Já difusão, em termos urbanísticos, significa se referir à extensão dos valores urbanos pelo território. Entretanto, existem outras tantas extensões das cidades que não têm esses valores de cidade, onde, portanto, não se produz a difusão. As periferias urbanas da metrópole de São Paulo, produzidas nas décadas de 1960 a 1980, dos loteamentos irregulares aos conjuntos habitacionais construídos pelo poder público, só para citar um exemplo, não incluíam esses valores de cidade.

O termo dispersão é frequentemente utilizado de maneira generalista, não fazendo distinção entre setores dispersos mono ou multifuncionais. Neste trabalho, também não se fará distinção quanto a isso, utilizando sempre o termo dispersão para se referir a qualquer peça urbana, ou conjunto de peças urbanas dispersas do núcleo central da cidade.

Nesse sentido, hoje, quando nos referimos à cidade estaremos nos referindo apenas ao núcleo central, ou seja, à mancha urbana compacta, ou a todos os setores urbanos, incluindo os núcleos dispersos? Anteriormente, a essa dispersão de núcleos dava-se o nome de vila ou distrito, que poderiam ser,no futuro, desmembradas, formando novo município e, consequentemente, nova cidade. 
Embora não se trate de um detalhe importante da argumentação deste trabalho, pois a ele interessam os impactos que as peças urbanas dispersas em seu conjunto promovem ao ambiente regional, e não ao seu conteúdo funcional intrínseco, entender como se conformam essas peças no espaço pode trazer inferências quanto aos processos de evolução da mancha urbana, sua possibilidade de expansão, de concentração e de adensamento.

Reis Filho (2007, p 38), discorrendo sobre o fenômeno da dispersão no Brasil e, particularmente, em São Paulo, afirma que nos projetos imobiliários de maior porte muitos empreendimentos apresentam novas formas de tecido urbano, incluindo infraestrutura, usos diversificados, serviços, áreas para esportes, e, em alguns poucos, áreas de vegetação nativa. A maioria desses projetos atende a faixas de renda média. Dentre os usos, além do residencial, novos projetos para condomínios industriais, para escritórios e comércio são objeto desses novos empreendimentos.

Deve-se levar em conta que essa tendência se observa apenas nos empreendimentos de maior valor e para os faixas de renda de média a alta. Nos casos dos condomínios residenciais, alguns desses serviços são oferecidos exclusivamente ao conjunto de condôminos. Em outros casos o núcleo comercial e de serviços fica em setor aberto ao público externo. Neste último caso, pode-se desenvolver um embrião de centralidade influenciando a expansão de novos loteamentos (empreendimentos) ao redor desse núcleo comercial, ampliando a dimensão dessa unidade de vizinhança dispersa.

Entretanto, conforme se poderá verificar na sequência desse trabalho, essas novas formas de tecido urbano dispersos ainda não são as formas predominantes, sobretudo no que se refereaos condomínios para as faixas de renda média a alta. Existe uma grande quantidade de condomínios e loteamentos construídos sem abranger nenhum tipo de serviço/comércio complementar. Essas necessidades tendem a ser abastecidas no distrito urbano comercial mais próximo ou na área urbana da sede mais próxima. Assim, a tendência à aglomeração das peças urbanas dispersas pode ocorrer em maior grau nas proximidades destes núcleos comerciais e de serviços. Essa proximidade será relativa à natureza das tipologias que se instalarem, podendo se dar de forma a compactar e concentrar esses novos 
loteamentos formando aglomerações, ou manter uma distância relativa, de acordo com a demanda e oferta dos negócios imobiliários e seu imaginário de vida urbana.

O que se verifica, ao certo, nas proximidades dos principais núcleos urbanos da macrometrópole de São Paulo é que na dispersão de baixa renda e na industrial a tendência a manter-se uma proximidade com os serviços da mancha compacta é evidente. $E$, como a atividade industrial, de comércio e de serviços ofertam empregos, essas induzem a aproximação da demanda de baixa renda para novos loteamentos populares. Portanto, há nessas áreas, condições de estabelecimento de setores urbanos polifuncionais e de se expandir a ocupação para uma configuração de área periurbana.

Secchi (2009), nas comparações entre cidade moderna e cidade contemporânea argumenta sobre essa distância precisa do efeito da dispersão em relação à cidade concentrada (moderna). A questão das unidades de vizinhança e da repartição funcional dos espaços urbanos, importantes no conceito da cidade moderna, ganha outra dimensão na cidade contemporânea em virtude do aumento da mobilidade e da acessibilidade física e virtual. Assim, Secchi prevê um cenário multifacetado de situações nessas franjas periurbanas dispersas:

"A dispersão e a fragmentação, a formação daquilo que em toda a Europa já vem indicado com os termos de "cidade difusa", são uma resposta parcial dos porcosespinhos de Schopenhauer a esses aspectos da cidade contemporânea e, provavelmente, representam a busca de uma distância precisa em um novo sistema de compatibilidades físicas, sociais e simbólicas. Nesse sentido, a cidade difusa é somente uma parte, nem autônoma nem independente, da cidade contemporânea, mas, ao mesmo tempo, não constitui uma evolução necessária da cidade moderna e tampouco, é provável que se desenvolva dando origem a algo que se lhe assemelhe ou, que se desenvolva ao longo de uma única trajetória."

Se a concentração urbana da cidade moderna chegava a transmitir essa ideia de homogeneidade morfológica e social, mesmo em se considerando todos os contrastes sociais internos a essa mancha compacta, com a explosão desses tecidos urbanos para as áreas rurais adjacentes resulta, ao olhar, a sensação de umaheterogeneidade caótica das situações urbanas em dispersão. Conforme argumenta Secchi (2009-p 53),

"A sociedade urbana, não mais interpretável como formada por grandes agregações homogêneas, se dissemina no inumerável, em uma dispersão de grupos sociais 
ciosos dos próprios estilos de vida, entre os quais, a dispersão da cidade difusa se torna representação concreta".

De fato, essa dispersão das peças urbanas no meio rural produz inumeráveis configurações morfológicas derivadas de misturas de usos urbanos distintos com as diversas morfologias rurais, além da surpresa de um retorno do relevo na configuração paisagística, totalmente apagado em muitas morfologias urbanas da cidade compacta. Assim, pode-se mesmo afirmar que a dispersão não é somente uma nova forma de habitar ou produzir no território, mas também uma nova forma de produção do espaço.

Ainda falando sobre a gênese das diferenças entre cidade compacta e cidade dispersa, Dematteis (2008 - p 6) num excursus sobre as novas periferias urbanas da cidade contemporânea e suas diferenças com a fase precedente, a da cidade moderna, sintetiza da seguinte forma:

"Si queremos identificar la periurbanización y la "ciudad difusa" con las nuevas periferias urbanas, hemos de reconocer su diferencia respecto de las periferias urbanas de la fase precedente, diferencia que no radica sólo en la forma (baja densidad, viviendas unifamiliares o pareadas, tramas reticulares...) sino también en las modalidades de organización territorial, de composiciones sociales y de desarrollo. Más en general, esta diferencia entre viejas y nuevas periferias se adscribe al gran cambio que se ha producido entre los años 1960 y 1970 en los países industrializados (con consecuencias de carácter indirecto a escala planetaria),marcado por el tránsito de la organización y la regulación social denominada "fordista" a la "posfordista", caracterizada por la relajación de las relaciones jerárquicas, por la flexibilidad de la organización productiva y del trabajo, por la multiplicación de las conexiones horizontales y por la aparición consiguiente de las identidades o especificidades locales como otras tantas "ventajas competitivas", en un contexto tendencialmente global.

No âmbito da escala local, onde o sistema de circulação e de acessibilidade favorece o movimento pendular para a realização da vida cotidiana, pode-se dizer que a urbanização espraiada decorre mais de uma redistribuição geográfica da população dentro de um contexto urbano marcado pelas relações de proximidade relativa. Spósito (2007) argumenta que

"nos países de economia industrial e urbanização consolidadas, esse fenômeno se explica pelo enorme desenvolvimento dos meios de circulação automotiva individuais ou coletivos, que vêm possibilitando deslocamentos entre pontos cada vez mais distantes em menor tempo, reforçando os interesses fundiários e imobiliários de produção de uma cidade mais dispersa, associada à busca da "periferia" identificada 
com uma idealização de vida no campo. Esse movimento é reforçado pela ampliação do uso de novas tecnologias de informação e comunicação, que aumentam as possibilidades técnicas de conexão e articulação entre diferentes pontos do território inclusos na escala intra-urbana."

Já nos países de industrialização recente, não consolidada ou dependente, o crescimento populacional explosivo não se fez acompanhar da implantação de uma infraestrutura de circulação e de habitabilidade minimamente em sintonia à demanda, gerando uma perifização impositiva para as parcelas da população de mais baixa renda e opcional para a alta renda, sendo que, em muitas situações dirigindo-se a vetores opostos e excludentes.

Dessa forma, a melhoria das condições de mobilidade no território e as novas possibilidades geradas pela tecnologia da informação, associadas ou não, vêm possibilitando o espraiamento urbano sobre a área antigamente associada exclusivamente ao mundo rural. Trata-se de um movimento não mais notadamente monofuncional, como já mencionado,associado às antigas periferias urbanas de baixa renda - as cidades ou bairros dormitórios - e sim abrangendo a dispersão industrial e de comércio e serviços, estes últimos também associados à dispersão dos condomínios fechados para média e alta renda. Fato é que este espraiamento da urbanização, embora estruturado pelos grandes eixos radiais de circulação intermunicipais e interregionais, não vem apresentando como regra a contigüidade e continuidade dos tecidos urbanos instalados, e sim a fragmentação e distanciamento relativo, deixando espaços verdes ou rurais intersticiais, produtivos ou não, congelados em determinados empreendimentos de alta renda ou à espera de uma futura valorização imobiliária.

\subsubsection{Concentração e dispersão: tendências opostas ou complementares}

O movimento de concentração-dispersão é próprio da dinâmica territorial em todos os tempos, conforme nos fala Milton Santos (2009 - p 99), mas ganha, todavia, expressões particulares segundo os períodos históricos. Na história da metropolização de São Paulo esses movimentos passam a atuar mais significativamente a partir do início do século XX, conforme nos relata Langenbuch (1970) no seu minucioso trabalho sobre a estruturação da Grande São Paulo em 
que analisa a vinculação da especulação fundiária e imobiliária com os negócios de transporte público no processo de perifização dos loteamentos populares na cidade de São Paulo. Odete Seabra (1987), acrescenta nessa análise da especulação com a terra em São Paulo a participação dos interesses ligados à produção de energia da empresa Light and Power com a especulação imobiliária no processo de retificação do Rio Pinheiros, que Ihe colocariam grandes glebas da antiga várzea para serem ofertados ao mercado imobiliário.

Se concentração e dispersão são tendências opostas ou complementares conforme pergunta Limonad (2007), o certo é que são processos que ganharam um novo significado nas duas últimas décadas com os desenvolvimentos tecnológicos da comunicação, informação e mobilidade urbana, e também, por certo, das inovações dos processos da construção civil que encurtaram ainda mais o tempo da construção de grandes empreendimentos urbanos.

Observando em um mapa ou foto aérea qualquer situação de mancha urbana com dispersão mais intensa a pergunta que vem à mente é: até que ponto a dispersão urbana observada não passa de uma etapa de uma nova concentração, conforme já se verificou no passado? Quais situações morfológicas, funcionais, da divisão territorial do trabalho, etc concorrem para afirmar que o processo de dispersão veio para ficar e construir essa nova morfologia urbana fragmentada?

É possível reconhecer hoje, em muitos casos, essa tendência a concentração da franja urbanizada compacta. Em nossa área de estudo, é possível verificar essa situação na região de Campinas, muito evidente, e em São Paulo, na região entre São Paulo e Cotia e entre Guarulhos e Arujá.

Analisando-se os dados demográficos dessas áreas metropolitanas de São Paulo e de Campinas fica evidente que ocorreu uma relocalização da população, com os municípios do entorno desses centros crescendo a taxas bem mais elevadas. O quadro 4.1 apresenta uma comparação das taxas de crescimento médio anual da população do município central dessas metrópoles com a média do entorno. Na Região Metropolitana de São Paulo os municípios do entorno cresciam a taxas que significavam o dobro do crescimento do município de São Paulo. O mesmo se verificou em Campinas, nos períodos analisados de 1970 a 2010. 
Quadro 4.1 - Taxa de crescimento anual da população de São Paulo e Campinas, comparadas às suas regiões metropolitanas entre 1970 e 2010.

\begin{tabular}{lcccc}
\hline \multicolumn{1}{c}{ Município Central e Região } & $\mathbf{1 9 7 0 - 1 9 8 0}$ & $\mathbf{1 9 8 0 - 1 9 9 1}$ & $\mathbf{1 9 9 1 - 2 0 0 0}$ & $\mathbf{2 0 0 0 - 2 0 1 0}$ \\
\hline Município de São Paulo & 3,67 & 1,28 & 0,79 & 0,75 \\
\hline Demais Municípios RM S.Paulo & 6,36 & 3,54 & 2,53 & 1,25 \\
\hline Município de Campinas & 5,86 & 2,24 & 1,50 & 1,10 \\
\hline Demais Municípios RM Campinas & 7,22 & 4.74 & 3,34 & 2,30 \\
\hline Fonte: IBGE & & &
\end{tabular}

Para Limonad (2008) a questão principal não é discutir ou contestar se existe mesmo essa tendência à relocalização da população, mas esclarecer se esse processo representa a expressão de novas formas de urbanização, de novas morfologias urbanas, ou se tratariam meramente de "variações de formas de expansão das áreas urbanas, que ao longo do tempo tenderiam a se incorporar e conurbar com a malha urbana mais densa e compacta adjacente aos centros urbanos de maior porte." A autora reconhece que, em face dos diversos estudos e observações realizadas no mundo todo, existem evidencias suficientes de que esses processos estão se desenvolvendo de forma complementar, uma vez que ambas promovem a expansão territorial do tecido urbano.

"Se puede observar en la periferia de las grandes áreas metropolitanas, en países avanzados o en desarrollo, un movimiento progresivo hacia la dispersión a través de la multiplicación de núcleos y aglomeraciones urbanas - leap-frogging, sin que esto resulte necesariamente en una interminable aglomeración urbana concentrada como Los Angeles." (Limonad, 2007 - p 15)

Já Dematteis (2008 - p 1) considera que os modelos de periurbanização e de difusão reticular da cidade (cidade difusa) estão dando origem a periferias urbanas muito distintas das que se formaram na Europa até a década de 1960, no contexto da cidade moderna industrial. Os modelos de suburbanização de tipo latinomediterrâneo e de tipo anglo-saxão, que durante muito tempo haviam seguido caminhos diferentes, tendem, na Europa, a se converter em um único modelo: o de "cidade sem centro" de estrutura reticular, que implica em importantes consequências para o planejamento urbano e para as modalidades de governo e de gestão do território. Dematteis acena para o reconhecimento efetivo de novas morfologias urbanas, não especificamente no sentido da morfologia interna das 
peças urbanas, mas, sobretudona configuração de uma nova morfologia metropolitana em seu conjunto, cujos nós dessa trama reticular formariam sistemas urbanos singulares, que conservam e acentuam sua identidade através de processos inovadores de competição e cooperação.

Se entendermos a desconcentração urbana como um fenômeno estrutural, assim como Dematteis (2008) questiona em seu artigo "Superurbanización y Periurbanización" das cidades anglo-saxônicas e das cidades latinas, será necessário abordá-la sobre as duas unidades escalares que se relacionam na sua definição: a escala da pendularidade e a da desconcentração espacial. A primeira ocorre em um raio de dezenas de quilômetros, o que permite a redistribuição geográfica dentro de um mesmo sistema urbano ou área urbana. Na segunda, começa-se a se trabalhar com distancias de centenas de quilômetros, mas que, em vista de fatores de melhor acessibilidade de transportes e tempo, não exclui a existência de movimento pendular também. (Sposito, 2007a)

Em ambas as situações a desconcentração urbana implica em um maior consumo do territorio. A diferença é que na primeira, a pendularidade, pode-se dizer que, guarda maior relação com as forças de concentração, pressão para ocupação dos espaços vagos intersticiais; enquanto a segunda, a desconcentração espacial, promove a formação de novas aglomerações, e possibilidades de constituírem-se novas centralidades. Nesse sentido, é possível afirmar que a desconcentração espacial apresenta maior interface para o desenvolvimento da difusão reticular do que a uma periurbanização ou suburbanização do território. Entretanto, esse movimento contínuo de desconcentração-concentração permanece vivo também internamente no território polarizado. Explicando melhor, a formação de novas aglomerações se dá por um movimento de desconcentração espacial do núcleo urbano maior, mas internamente esse novo lócus de concentração também desenvolve sua dispersão interna e seus movimentos pendulares intrínsecos.

De toda forma, ainda fica a questão a esclarecer se as formas de urbanização extensiva ou dispersa que vem se multiplicando em várias partes do mundo se constituem mesmo em uma nova forma de desenvolvimento urbano ou se se trata de mais um patamar do crescimento urbano rumo à cidade concentrada? 
Os movimentos de concentração e dispersão ocorrendo simultaneamente no momento presente dão origem às grandes aglomerações urbano-metropolitanas e a um território multifacetado. Enquanto o movimento de concentração atua para a formação de um tecido urbano contínuo e coeso, o de dispersão atua no sentido da fragmentação e da heterogeneidade, promovendo uma multiplicação de núcleos e aglomerações urbanas dando origem a um tecido esgarçado. As contradições entre o rural e o urbano, nesse processo, se acentuam, com prejuízo para a manutenção das atividades agrárias em virtude da valorização da terra urbana.

Talvez a análise de Milton Santos (2009) seja a que melhor define a organização interna atual das cidades brasileiras que tem implicações com esses movimentos de concentração e dispersão. Num breve relato sobre a organização interna das cidades, "a cidade caótica", nos relata a existência de uma grande interdependência de categorias espaciais relevantes desta época para a análise dessas cidades espraiadas, características de uma urbanização corporativa, em que a Macrometrópole de São Paulo é um exemplo mais que completo no Brasil. As categorias listadas são: "o tamanho urbano, modelo rodoviário, carência de infraestruturas, especulação fundiária e imobiliária, problemas de transporte, extroversão e perifização, gerando, graças à dimensão da pobreza e seu componente geográfico, um modelo específico de centro-periferia”, onde cada qual dessas realidades sustenta e alimenta as demais. Assim, o crescimento e a expansão urbana decorrem do crescimento sistêmico dessas características. (Santos, 2009 - p 106). O círculo não muito virtuoso do processo ele relata da seguinte maneira:

"As cidades são grandes porque há especulação e vice-versa; há especulação porque há vazios e vice-versa; porque há vazios as cidades são grandes. O modelo rodoviário urbano é fator de crescimento disperso e de espraiamento da cidade. Havendo especulação, há criação mercantil de escassez e acentua-se o problema do acesso à terra e à habitação. Mas o déficit de residências também leva à especulação, e os dois juntos conduzem à perifização da população mais pobre e, de novo, ao aumento do tamanho urbano. As carências em serviços alimentam a especulação, pela valorização diferencial das diversas frações do território urbano. $A$ organização dos transportes obedece a essa lógica e torna ainda mais pobres os que devem viver longe dos centros, não apenas porque devem pagar caro seus deslocamentos como porque os serviços e bens são mais dispendiosos nas periferias. $E$ isso fortalece os centros em detrimento das periferias, num verdadeiro círculo vicioso." 
Entretanto, convém lembrar que são as atividades mais dinâmicas e as populações de mais alta renda que se instalam nessas áreas privilegiadas ou em suas proximidades. É assim que certos pontos tornam-se mais acessíveis e que as diversas parcelas da cidade ganham ou perdem valor ao longo do tempo. Acrescente-se a isso, o planejamento urbano colabora para a organização desse mecanismo de mercado e o marketing urbano atua na geração de expectativas que influem nos preços (Santos, 2009 - p 107).

Dessa forma, conclui-se o primeiro momento desse processo especulativo por meio da extensão da cidade e da implantação diferencial dos serviços coletivos. 0 motor monopolista e corporativo do capitalismo na fase atual induz governantes e a sociedade nessa destinação desigual dos investimentos públicos alocando a maior parcela dos recursos, conforme argumenta Milton Santos (2009 - p 107), na "cidade econômica" em detrimento da "cidade social". Ampliam-se, assim, as diferenças existentes entre os lugares urbanos. O processo continua com a expansão das classes médias urbanas e com a chegada de numerosos pobres à cidade, que pressionam o interesse por sítios a habitar, e tornam a acirrar o processo especulativo. Dessa maneira, em face de uma crescente demanda, a terra urbana, dividida em loteamentos ou não, aparece como promessa de lucro futuro. No caso da metrópole paulista esse processo a partir dos anos 1980 passa a ser mais intenso nos municípios vizinhos de São Paulo.

Todavia, Milton Santos acrescenta que, "como as terras apropriadas (mas não utilizadas) são cada vez mais numerosas, a possibilidade de dotá-las dos serviçosrequeridos é sempre menor. Daí, e de novo, uma diferenciação no valor de troca entre as diversas glebas e assim por diante. É assim que a especulação se realimenta e, ao mesmo tempo, conduz a que as extensões incorporadas ao perímetro urbano fiquem cada vez maiores". (Santos, 2009 - p 107).

A atual discussão sobre a implantação do trem bala ligando Campinas-São Paulo-São José dos Campos e Rio de Janeiro nos dá um belo exemplo da reafirmação constante de investimentos sociais corporativos, pois visa mais uma vez a atender à "cidade econômica" e aos interesses dos de mais alta renda capazes de pagar pela tarifa do transporte, atualmenteem estudos e discussão. 
Nessa abordagem da organização interna da cidade, fica evidente também que os aspectos relacionados ao sítio natural embora tragam limitações importantes na determinação dessas variáveis no espaço, eles também atuam como indutores potenciais através de seus recursos mais notadamente paisagísticos do que produtivos nesse processo de valorização-desvalorização dos setores da cidade. Assim é que chama a atenção, na metrópole paulista, os sítios preferenciais da dispersão dos condomínios e loteamentos residenciais de média a alta renda. Estes ocupam e se dirigem, em maior profusão, os eixos das rodovias Fernão Dias (Mairiporã e Atibaia), Raposo Tavares (Cotia, Ibiúna) e Castelo Branco (Barueri/Alphaville-Aldeia da Serra). Na região de Campinas os vetores principais ocorrem ao longo da Via Anhanguera (até Jundiaí), D. Pedro I (até Itatiba) e SP 079 (até Itu e Sorocaba).

Como o movimento concentração-dispersão é inerente ao processo de ocupação territorial urbana, a questão que se coloca, então, é saber quais são as forças e as condições efetivas para a concentração e quais seriam aquelas que assegurariam um tecido urbano sempre disperso. A formação de polos multifuncionais com geração de emprego e a melhoria dos eixos viários são fatores que podem agir para a concentração urbana. De outro lado, a melhoria da acessibilidade também é um fator que impulsiona a dispersão, a fragmentação urbana. Não se pode deixar de acrescentar o ideário ambiental e o marketing verde muito em voga nas duas últimas décadas, que acentuou o modismo de viver no campo para o contato com a natureza.

Talvez a discussão dessa questão esteja mais bem colocada no campo oposto, ou seja, na discussão dos vazios intersticiais entre as peças urbanas, na discussão de sua função, na qualidade e na sobrevivência de usos e valores. Até que ponto poderá conviver usos urbanos, usos rurais e usos ambientais na configuração de uma cidade dispersa (ou difusa) com razoável sustentabilidade ambiental e de sua própria configuração que impeça uma nova concentração/compactação do tecido urbano?

Decerto, essa questão da dispersão-concentração não permite mais ser analisada apenas em uma escala local. A dispersão recoloca a questão urbana no patamar da discussão da urbanização do território. Sai da escala do sítio, da escala 
municipal, para uma escala regional, territorial. Este é aspecto que será abordado a seguir.

\subsubsection{Em longo prazo o crescimento disperso é sustentável?}

A questão da sustentabilidade do processo de dispersão urbana é um assunto que vem sendo abordado perifericamente nos estudos desenvolvidos atualmente por vários pesquisadores e urbanistas. A visão de sustentabilidade conforme vem sendo abordada nestes estudos, embora nos remeta à ideia inicial de uma sustentabilidade ambiental, ela tende a privilegiar mais os aspectos relativos à urbanidade e aos custos econômicos e sociais, do que à questão ambiental no que se refere à preservação dos biomas naturais e dos processos naturais relevantes.

Discutir essa questão é uma tarefa árdua, e nem é o objeto principal deste trabalho, pois este pretende apenas colocar em cena nesta questão do processo de dispersão apenas a faceta relativa à sua essência em relação ao relevo, à forma como a cidade dispersa vem se apropriando do relevo regional e os impactos derivados dessa forma.A sustentabilidade ambiental é ainda um conceito vago e geral, e inclui não apenas considerar a superfície, mas todas as condições socioeconômicas e culturais presentes naquele momento no território. Nesse sentido, várias perguntas elementares acabam por fazer sentido, pois o que cada cidadão ou cada conjunto social entende por sustentabilidade da ocupação urbana, seja ela compacta ou dispersa? Sustentabilidade do quê ou de quem? Neste discurso várias formas de sustentabilidade parciais emergem. Limonad (2008) e Costa (2007) lembram-nos bem quando enfatizam que em torno dessa faceta do conflito da produção social do espaço nas áreas de dispersão (residencial, de turismo e produtivas industriais e extração mineral) tanto nas metrópoles litorâneas, quanto nas do interior do Brasil como São Paulo e Belo Horizonte, o movimento para a defesa das florestas nativas e o desenvolvimento sustentável servem ao mesmo tempo como argumento para formar RPPNs (reservas particulares do patrimônio natural), privilegiando grupos econômicos e sociais que privatizam o uso do espaço e de paisagens naturais, muitas vezes criando territórios exclusivos e altamente valorizados por lidarem com a raridade do espaço natural. 
Retoma-se aqui uma questão do movimento ambientalista dos anos 1980 e 1990 quanto à tendência do discurso da sustentabilidade se direcionar para o que se chamava de capitalização da natureza, capitaneado por economistas ambientalistas que advogavam necessidade de valoração dos serviços ambientais e recursos da natureza e muito bem aceito pelos grandes empreendedores da iniciativa privada.

Mas, voltando aos estudos sobre dispersão urbana a discussão tende a alertar para os custos econômicos, sociais e ambientais decorrentes do processo. Os argumentos utilizados ora tentam se contrapor ao que acontece na ocupação da cidade compacta ora expressa uma situação ruim sem se ater que o mesmo ocorre na ocupação densa e compacta. Dentre as análises realizadas quanto aos aspectos ambientais mais corriqueiros são:

$\checkmark$ A acentuação do conflito preservação ambiental (avanço sobre áreas preservação permanente - APPs, matas nativas, etc) versus ocupação urbana e/ou exploração produtiva (industrial/extrativa);

$\checkmark$ O pouco peso das questões ambientais no embate técnico-político em relação às vantagens dos chamados impactos sociais positivos dos empreendimentos como a geração de emprego e renda em escala regional;

$\checkmark$ As áreas pouco povoadas ou os grandes vazios entre áreas urbanas são identificados como áreas potenciais pra urbanização com vistas ao desenvolvimento territorial sustentável;

$\checkmark$ A urbanização e a ocupação dispersa consomem de forma extensiva o meio ambiente e os recursos naturais, principalmente quando escassos.

$\checkmark$ E, mais especificamente, aparecem a perda da biodiversidade e a fragmentação da paisagem (rural, nativa, biomas, etc); degradação dos recursos naturais, em especial a água;

Sob o ponto de vista da sustentabilidade econômica os aspectos mais relevantes tratados são:

$\checkmark$ A dispersão exige muitos investimentos na extensificação de redes e suportes de infraestrutura de transportes, abastecimento e comunicações;

$\checkmark$ Desperdício do solo agrícola e mau uso dos solos e dos bens da natureza;

$\checkmark$ Comprometimento de recursos ambientais escassos (água e energia); 
$\checkmark$ Dependência da mobilidade individual (automóvel) e segregação socioespacial;

$\checkmark$ Subutilização do capital social fixo da cidade compacta tradicional;

$\checkmark$ As externalidades negativas como: a transferência de custos sociais para municípios vizinhos combaixa capacidade financeira e administrativa para responder com agilidade ao crescimento da demanda, com reflexos importantes na capacidade de ordenamento urbano;

Quanto aos custos sociais mais relevantes costumeiramente relacionados, aparecem os seguintes:

$\checkmark$ Perda de urbanidade, de habitabilidade e de sociabilidade e a consequente segregação sócio-espacial.

$\checkmark$ Transformação dos ritmos lentos da vida cotidiana regulada pelos ciclos naturais e dos espaços rurais em espaços abstratos pasteurizados, imateriais e impessoais, destinados ao consumo turístico ou típico de padrões urbanos da cidade grande (a transformação do consumo nos lugares para o consumo dos lugares, segundo Lefebvre, 1969).

Algumas questões gerais são abordadas também, como:

$\checkmark$ À medida que a urbanização avança para uma vivência próxima aos artefatos ambientais, compromete-se a capacidade de ofertar tais amenidades (Ojima: 2007 - p 286).

$\checkmark$ O disciplinamento e o controle do uso do solo ocorrem apenas em determinadas áreas. São reguladas principalmente nos setores ocupados pelos empreendimentos de grande porte e nas faixas de alta renda. Mas como essas áreas criam demandas (serviços e empregos) atraem para 0 entorno população pobre que vai estimular a especulação imobiliária e a ocupação de setores de risco, que possuem limitações ambientais para a ocupação urbana. (Limonad, 2008 - p16).

$\checkmark$ Para Font (2007 - p 66) coexistem duas lógicas contrapostas para a sustentabilidade: a visão de curto prazo das decisões oriundas da racionalidade privada; e a necessidade de uma visão de longo prazo para cobrir os custos coletivos dessas decisões. 


\subsection{Dispersão e apropriação do relevo: sítio urbano e território urbanizado}

O que se vê na atualidade e nos últimos 30 anos é uma total mudança de escala da vida urbana. A própria vida de cada cidadão se tornou mais abrangente no sentido espacial, no que se refere aos seus deslocamentos casa-trabalho-casa, casa-lazer, etc. As distâncias percorridas aumentaram em face do encurtamento do tempo de deslocamento, e também do próprio conforto. A dispersão urbana também foi um motor dessa mudança de escala em termos espaciais. Essa dispersão é diferente da que ocorreu na primeira metado do século XX. Não se trata somente de um crescimento aos saltos para uma posterior cerzidura do tecido urbano, como era a lógica do passado em São Paulo, estudada por diversos pesquisadores, dentre eles Langenbuch (1971) e Seabra (1987). Hoje, esse crescimento se pulveriza ao extremo pelo território que não é seguro afirmar que todas essas áreas dispersas estarão conurbadas no futuro com as cidades compactas de seu entorno.

Assim, de uma lógica de análise de sítio urbano conforme se realizava no passado, muda-se para uma lógica de território, que inclui o que é urbano e o que se denomina de rural. Em um exemplo puramente geomorfológico quanto à taxonomia do relevo, pode-se dizer que o urbano hoje deixa de ser analisado segundo o $4^{\circ}$ ou 50 táxon da classificação de Ross (2000) e passa a se relacionar com o $3^{\circ}$ e $2^{\circ}$ táxon. Pode-se perguntar, então, se a grande cidade moderna compacta ocupou todos os compartimentos de relevo de um sítio; a cidade contemporânea irá ocupar todos os sítios de um território?

A inundação de conceitos que invadiu a literatura urbanística especializada a partir dos anos 80 , buscando substituir os termos cidade, metrópole, região, ou, até mesmo território, por outros, que os descrevem de forma mais condizente com as novas características físicas dos espaços urbanos que estão se organizando, talvez confirme essa preocupação de que, hoje, discutir a cidade é discutir o território. Assim, segundo Meyer (2006) a afirmação de Marcel Roncayolo (1993, apud Meyer), segundo a qual "a cidade é um território que organiza territórios", faz sentido, e até serviu como uma luva para a renovação conceitual e para a reorganização da metodologia de trabalho do urbanismo. Dentre muitos conceitos que surgiram, alguns, tais como, exópolis, metápolis, heterópolis, que revelam a determinação dos estudiosos na reestruturação do território em termos funcionais, 
econômicos, sociais e até mesmo formais, segundo Meyer (2006), há que se considerar a necessidade da inclusão dessa mudança de escala territorial física de sítio urbano para território urbanizado.

Nessa mudança de escala, mesmo que oriunda no caso brasileiro de um efetivo crescimento populacional do território metropolitano, a questão urbana deve ser avaliada segundo a passagem de uma concentração absoluta, na cidade compacta, para uma concentração relativa, no território urbano ampliado. Nesse sentido, há que se considerar essa mudança de escala do impacto ambiental da ocupação urbana. A população é a mesma que estaria locada na cidade compacta. Só que agora ela se dispersa mais pelo território.

Se analisarmos sob a ótica da gestão estadual isso pouco importa, porém sob a ótica municipal a situação é outra. As taxas de crescimento anual da população analisadas no próximo capítulo demonstram que o que acontece em termos populacionais corresponde a uma relocalização populacional com crescimento, e não uma simples relocalização com aspectos de equalização das demandas e dos impactos.

Uma questão importante para a ótica ambiental, que deriva dessa mudança de escala de sítio para território, é a necessidade de se analisar o conjunto do território para os dois processos - naturais e urbanos - o que requer uma abordagem integrada do problema, entretanto, a gestão e o planejamento territorial continuam fragmentados por município.

\subsubsection{O novo rural que emerge}

A dispersão urbana vista sob a ótica rural, pode remeter à questão de até que ponto é o mundo urbano que se espraia pelo campo, ou é o mundo rural que se urbaniza? A desconcentração industrial, já existente em relação à indústria extrativa, está levando cada vez mais outras indústrias para perto da sua matéria prima, sobretudo a alimentícia (agroindústria). A localização preferencialmente urbana começa a se dirigir para o território inter-urbano, ao longo de eixos rodoviários importantes. As facilidades de acesso, tanto para o fluxo de mercadorias como de 
trabalhadores que moram na cidade ou na sua periferia, tendem a favorecer a uma economia de custos gerada por este fator locacional, sem, no entanto, que as pessoas se distanciem das relações com a cidade e seu mercado. O movimento pendular de trabalhadores se distende ainda mais pelo território na atualidade.

De acordo com Campos e Krahl (2006), mas trazendo a afirmativa especificamente para este território inter-urbano das grandes aglomerações urbanas aqui analisado, hoje,

"[...] nas regiões mais densamente povoadas, é preciso superar a visão de que o rural é a população dispersa no território, centrada no setor agropecuário, para passar à reconstrução do rural tanto como objeto de análise como de política pública, ao definir o âmbito do rural como o território construído a partir do uso e da apropriação dos recursos naturais, onde se originam processos produtivos, culturais, sociais e políticos".

Assim, a dimensão do rural hoje compreende uma diversidade de setores econômicos independentes e que envolve também outras dimensões nãoeconômicas que estabelecem relações funcionais com 0 urbano. Além da agropecuária e as diversas formas de extrativismo, o mundo rural abriga hoje funções que envolvem o consumo virtual de paisagens que se dá por meio do lazer, do turismo e de funções residenciais fixas (condomínios fechados) ou de finais de semana.

É interessante notar que atualmente em muitos planos diretores municipais o condomínio fechado ou o loteamento residencial disperso no meio rural são classificados como área urbana, como pertencentes ao mundo legal urbano, sobretudo para vias de arrecadação ${ }^{20}$. Esta distorção talvez venha colaborando para a manutenção do rural nas políticas públicas como simplesmente reserva de mercado para a especulação urbana. Acrescentando às proposições de Abramovay de que se deve reforçar o capital social do meio rural como forma de criação oportunidades com base no aperfeiçoamento do tecido institucional de cada região, estas novas funções, antigamente prioritariamente urbanas, devem ser entendidas como novas funções do mundo rural e incorporadas num processo de planejamento territorial para o desenvolvimento do meio rural enquanto esta totalidade funcional-

\footnotetext{
${ }^{20}$ Vimos em outros casos se dá o contrário, ou seja, as glebas que abrangem condomínios fechados continuam como rurais, com o mercado imobiliário aproveitando-se de oportunidades jurídicas.
} 
econômica-social. Segundo Steinberger e Amado (2006), "o uso do território vai muito além da expressão uso da terra, frequentemente utilizada nos documentos de ZEE, pois engloba as atividades com as quais um território é usado e as relações de poder que decidem sobre tais atividades". Assim, é necessário o deslocamento do enfoque de que o controle do mundo rural está no urbano, para este enfoque territorial de que o rural urbanizado também se constitui em uma instância de poder. Segundo Campos e Krahl (2006), o espaço rural deve ser pensado a partir de um esforço para se identificar a contribuição que um novo mundo rural pode dar à sociedade, e não somente pela sua valoração para a sociedade urbana, como um objeto de consumo. (Campos e Krahl, 2006, p. 88).

Este novo espaço que emerge entre a cidade compacta e o mundo predominantemente rural, ou simplesmente entre uma cidade e outra, vem recebendo diferentes denominações que vão desde 0 antigo conceito de "periurbano", passando por "rurbano", "inter-urbano", e agora pela associação à urbanização espraiada, cidade dispersa ou difusa, urbanização extensiva. Todos eles trazem uma grande carga de visão antropo-urbana, ou seja, da visão da cidade. Parece-nos que o espaço que vem surgindo, se não mais o é especificamente rural, também, ainda, não vem a ser especificamente urbano, na acepção da dicotomia comumente utilizada entre o urbano e o rural, cidade e campo. A análise da questão ambiental vinculada a estes dois universos talvez possa contribuir para a inserção de uma nova racionalidade na compreensão deste fenômeno da urbanização extensiva e espraiada, ou sob outra ótica, da emergência do "campo urbanizado".

Segundo Campos e Krahl (2006), o debate sobre o mundo rural no Brasil vem se dando segundo quatro perspectivas, que podem ilustrar a complexidade de visões e atores envolvidos, mesmo especificamente construídos segundo a ótica singular da dispersão urbana. Um primeiro enfoque sustenta a idéia do "continuum", de que a urbanização do campo se dá pela emergência de atividades não agrícolas - o chamado "rurbano". José Graziano da Silva em "O novo rural brasileiro" $(1999)^{21}$ aborda a influência do urbano sobre o rural como um processo parecido com o de aculturação dos indígenas absorvidos por uma sociedade culturalmente mais forte e hegemônica.

\footnotetext{
${ }^{21}$ J.Graziano da Silva, O novo rural brasileiro. Campinas, Unicamp, 1999.
} 
O segundo enfoque aborda a valorização das dimensões espaciais na análise do rural e da ruralidade brasileira, na qual vê que a "competitividade é um atributo do meio, antes mesmo de ser um trunfo de uma firma". Reconhece o tratamento do rural como paisagem a ser consumida. Esse enfoque Tem como expoente José Eli da Veiga ${ }^{22}$.

O enfoque da sociabilidade, o terceiro, opõe-se ao do continuum e propõe o fortalecimento da ruralidade, de suas especificidades, a partir das possibilidades de reestruturação de identidades e sociabilidades. Advoga a construção de novas territorialidades, ou seja, novas formas de produzir e existir coletiva e socialmente no meio rural.

O quarto enfoque argumenta sobre a necessidade de formação e fortalecimento do capital social no meio rural como instrumento capaz de abrir oportunidades com base no aperfeiçoamento do tecido institucional de cada região sob os auspícios de uma espécie de pacto territorial, apoiado pela formação de redes territoriais e suas articulações externas. Tem como expoente Abramovay, que acredita que a possibilidade de desenvolver novas funções: lazer, conservação ambiental, turismo rural, etc., facilitada pela democratização do acesso aos meios de comunicação e acessibilidade (melhoria das estradas) possa facilitar a construção de um capital social consistente neste novo mundo rural. E conclui que a condição básica para o desenvolvimento rural é 0 acesso à terra, visto que 0 trabalho assalariado mesmo nas regiões de grande expansão comercial agrícola é sinônimo de pobreza. E acrescente-se que o é também nas periferias metropolitanas sob diversas formas de emprego urbano.

Desta forma, pode-se afirmar que a dimensão do rural, hoje, incorpora áreas dispersas e concentrações urbanas que se explicam por sua relação com os recursos naturais. Compreende uma ampla diversidade de setores econômicos, interdependentes, envolvendo dimensões não-econômicas e estabelecendo relações funcionais com o urbano. Nesse sentido, se pergunta como considerar esse mundo rural que acolhe estas novas funções, antigamente exclusivas do mundo urbano? Muitos municípios brasileiros, em seus planos diretores, vêm relacionando

\footnotetext{
22 “Destinos da ruralidade no processo de globalização” in seminário n 16/2004. Programa de Seminários Acadêmicos, FEA/USP.
} 
juridicamente estas áreas como setores urbanos ou áreas de expansão urbana, frequentemente com ênfase arrecadatória. Deve-se considerar assim que as políticas públicas atuais têm colaborado também para a desarticulação do mundo e da produção rural nos territórios mais densamente povoados? 


\section{PARTE II}

\section{MORFOLOGIA DAS PEÇAS URBANAS QUE SE DISPERSAM NO TERRITÓRIO}

Entender a morfologia interna das peças urbanas dispersas na análise ambiental do território tem relevância em um sentido que vai além da verificação de seu traçado, largura de ruas, disposição de lotes, densidade construída, entre outros aspectos de caráter urbanístico. Essa verificação significa compreender que relações que esse desenho urbano estabelece com a fisiologia natural do sítio sobre o qual está assentado.

Se no senso comum e na especulação imobiliária a dispersão traz naturalmente vantagens ambientais pelos componentes de não aglomeração e não impermeabilização excessiva do solo, fatores que existem na cidade compacta e são os responsáveis por grande parte dos problemas ambientais vividos nas grandes metrópoles, é importante verificar em que montante as tipologias de uso e de desenho urbano da cidade dispersa se diferenciam dos modelos adotados na cidade compacta.

Questões importantes devem ser implicadas na análise morfológica das peças urbanas dispersas, dentre elas:

$\checkmark$ Que relações o traçado do loteamento estabelece com o sitio ocupado, no que se refere à vinculação dos arruamentos com a declividade do terreno, como a necessidade de corte/aterro, como a largura das ruas nas vertentes, como a ocupação de setores sensíveis com nascentes, anfiteatros e fundos de vale?

$\checkmark$ Que relações a estrutura do loteamento e a forma de ocupação projetada (tamanho dos lotes, área construída) estabelece com a dinâmica climática da fisiologia do sítio, naquilo que se refere à com a densidade construída e suas implicações com a emissividade de calor e com a umidade relativa do ar?

$\checkmark$ Que relações essa estrutura do loteamento estabelece com a dinâmica da água na fisiologia do sítio, naquilo que diz respeito à impermeabilização do solo, à indução de enchentes, e na diminuição da vazão de nascentes e córregos, etc? 
Essas questões têm relevância em dois aspectos que têm vinculação com o equilíbrio ambiental de uma paisagem regional. O primeiro deles tem relação com os compartimentos ambientais ocupados na implantação do desenho urbano proposto. $O$ segundo se refere à sobrecarga sobre o sistema ambiental regional que a ocupação urbana provoca, seja ela concentrada ou dispersa. Assim, pode-se afirmar que a questão da mudança de padrão de ocupação do solo e do sitio urbano se torna a questão chave sobre o equilíbrio ambiental de um território, e não somente os aspectos de sua concentração ou dispersão.

Dessa forma, o desenho urbano ganha outra expressão analítica e de projeto na discussão urbanística do fenômeno da dispersão urbana. Se na cidade compacta e concentrada há o predomínio da emergência de problemas ambientais de caráter local e decorrentes de uma gênese local (inerentes ou internos à mancha urbana compacta), na cidade dispersa os problemas ambientais passam a decorrer muito mais do contingente da ocupação regional do que da local.

Assim, entende-se que é importante observar as características do desenho das peças urbanas que se dispersam no território e o seu padrão de semelhança com as tipologias que ocorrem e são comuns na cidade compacta. Nesse sentido é que poderá se afirmar que a dispersão urbana guarda uma melhor relação ambiental com o território, ou que essa nova forma de ocupação do território, em seu conjunto, pouca contribuição trará ao equilíbrio regional da ocupação urbana em áreas densamente povoadas.

\subsection{Semelhança das Morfologias das peças dispersas com as da cidade compacta}

O senso comum observa como padrão predominante da dispersão urbana o modelo de bairro residencial em meio ao verde do campo. O mercado imobiliário difundiu muito bem essa ideia de viver em contato com a natureza, que passou pelo início de estreitar esse contato nos finais de semana (padrão de $2^{\underline{a}}$ residência) para a semana inteira, transformando essa $2^{2}$ residência na residência fixa. No entanto, esse contato com a natureza guarda grandes variações de morfologia e também de efetivo contato. 
Sem dúvida, o padrão predominante de peça urbana dispersa corresponde aos condomínios horizontais, fechados ou não, de média a alta renda, utilizados como moradia fixa ou segunda residência. Existem pequenas variações formais de padrão de ocupação relativos ao tamanho dos lotes, taxa de ocupação e de permeabilidade do solo. Salvo aqueles que tendem ao padrão de pequenas chácaras que só ocorrem na cidade dispersa, todos os demais são padrões de bairros residenciais da cidade compacta que se dispersam pelo território rural.

Em São Paulo, após essa intensificação da dispersão inicial do padrão de condomínios fechados de média a alta renda ocorrida nos anos 1970 e 1980, outras formas de dispersão ocorreram, sempre em menor escala de ocupação territorial quando comparadas aos primeiros exemplos, mas que no conjunto terminam por equilibrar e caracterizar o fenômeno da dispersão. Estas morfologias - loteamentos de média e baixa renda, áreas comerciais e industriais, conjuntos habitacionais de interesse social - pouco se diferenciam do padrão que ocorre na cidade compacta, mas carregam, no bojo de sua indução, essa ideia de contato com o mundo menos agitado do campo.

Assim é que, grande parte dessas morfologias de peças urbanas que se dispersam pouco se diferencia do padrão de ocupação existente na densificada e impermeabilizada cidade compacta. Em muitos casos, como se poderá verificar na descrição das tipologias dos padrões de ocupação, o contato que se estabelece com o campo e com a natureza é apenas visual, pois o que caracterizaria uma vivência com o verde e com a natureza se encontra fora dos domínios do loteamento. $\mathrm{Na}$ parte interna, a relação com os processos naturais se dá igualmente como ocorre na cidade compacta. Apenas como rápido exemplo, pois esse assunto será melhor tratado no capítulo 7 , pode-se lembrar as taxas de ocupação do lote que permitem uma intensa impermeabilização do solo; e a baixa cobertura vegetal, apenas restrita ao sistema viário, quando muito, que impulsiona os efeitos de aumento de calor à superfície.

A seguir são apresentadas as tipologias verificadas nos diversos loteamentos residenciais, industriais e comerciais que se dispersam na região da Macrometrópole de São Paulo. 


\subsection{Tipologias das peças urbanas}

Dois padrões predominantes de tipologia de uso do solo de caráter urbano ocorrem na dispersão da Macrometrópole de São Paulo. Um de uso residencial e outro de uso produtivo, geralmente associado à atividade industrial. Suas tipologias podem ser verificadas nos quadros 5.1 e 5.2 .

Quadro 5.1 - Tipologias de padrão de ocupação urbana dispersa de uso residencial.

Padrões de ocupação residencial

Classe de renda

\begin{tabular}{ll} 
Condomínios fechados & Alta \\
& Média \\
\hline \multirow{2}{*}{ Loteamentos (bairros) } & Alta \\
& Média \\
& Baixa \\
\hline \multirow{2}{*}{ Condomínios fechados de chácaras } & Alta \\
& Média \\
\hline \multirow{2}{*}{ Loteamentos de chácaras } & Alta \\
& Média \\
& Mistos (média e baixa) \\
\hline
\end{tabular}

Conjuntos Habitacionais de Interesse Social

Baixa

Loteamentos irregulares, habitação subnormal, favelas Baixa

Fonte: Elaborado pelo autor.

O padrão de uso residencial se caracteriza pela presença de condomínios fechados, de loteamentos que formam bairros, e de conjuntos habitacionais. No uso residencial diversos padrões de renda configuram essa dispersão das peças urbanas, desde as destinadas para as classes de mais alta renda como para as faixas de baixa renda, esta última, geralmente mais próxima dos principais núcleos de cidade compacta.

Os condomínios fechados, dominantemente para alta e média renda, que, dependendo do tamanho do lote, se diferenciam entre um de características de ocupação semelhante ao que ocorre na cidade compacta, com lotes que variam de 300 a $800 \mathrm{~m} 2$; e, outro com lotes entre 1000 e $2000 \mathrm{~m} 2$, conhecido popularmente como condomínio de chácaras, que só ocorrem fora da mancha compacta das cidades. 
Conjuntos habitacionais populares e loteamentos/ocupação irregular de baixa renda também ocorrem na dispersão urbana, entretanto sua localização não se desgarra muito da cidade compacta mais próxima.

Todas essas tipologias de ocupação residencial apresentam tamanhos diferenciados em área ocupada e em número de lotes. Muitas delas apresentam contiguidade espacial, separada normalmente pelos muros de divisa dos condomínios fechados, ou formando o embrião de nova compactação urbana, quando agrupam loteamentos abertos e áreas industriais/comerciais.

Os condomínios fechados e loteamentos de padrão de renda médio a alto ocorrem mais frequentemente nos eixos de expansão das rodovias Anhanguera/Bandeirantes, Castelo Branco, Raposo Tavares e Fernão Dias. Na região de Campinas é a SP 075, que liga Campinas a Itú e Sorocaba, o principal vetor de expansão de condomínios de médio a alto padrão.

O padrão de uso produtivo que se encontra disperso no território deve ser considerado sob a ótica das relações que esse uso estabelece com o entorno rural ou com as atividades agropecuárias. Assim, neste trabalho considerou-se como peças urbanas produtivas as de caráter industrial, comercial e atacadista que originariamente buscavam sua localização e concentração junto às manchas compactas da cidade.

Quadro 5.2 - Tipologias de padrão ocupação de uso produtivo associado à indústria e disperso em meio rural.

Tipologias Produtivas

\begin{tabular}{lcl}
\hline \multirow{2}{*}{ Industriais } & $\checkmark$ & Loteamentos abertos (distritos industriais/comerciais \\
& $\checkmark$ atacadistas); \\
& $\checkmark$ Condomínios industriais \\
\hline \multirow{2}{*}{ Exploração Mineral } & $\checkmark$ & Diversos tipos (atividade com rigidez locacional)
\end{tabular}

Fonte: Elaborado pelo autor.

Um segundo aspecto considerado nessa análise da dispersão urbana correspondeu a estabelecer como categoria de análise contraposta à dispersão aquilo que é inerente ao mundo rural. Ou seja, as atividades produtivas de caráter eminentemente rural não estão aqui computadas. De outro lado, entendeu-se 
necessário contabilizar as áreas de extração mineral, em que pese o seu caráter de rigidez locacional que a coloca frequentemente em meio às áreas rurais, mas que corresponde a um tipo de atividade industrial.

Dessa forma, considera-se que em seu conjunto as peças urbanas produtivas de caráter industrial/comercial/extrativa colaboram para a fragmentação do mundo rural e somam seus impactos ao meio ambiente aos impactos causados pelo uso residencial. Observar sua tipologia também deve ser analisado sob a ótica interna de sua morfologia em relação à fisiologia do sítio; naquilo que essa forma de ocupação se diferencia ou não dos modelos adotados na cidade compacta; e sob a ótica da forma com que ocupam os compartimentos ambientais do relevo regional.

A dispersão da tipologia industrial/comercial atacadista se dá predominantemente ao longo das principais estradas que partem de São Paulo e de Campinas. Em sua maior parte se configuram como distritos industriais que conformam um loteamento aberto. Os condomínios industriais fechados ainda ocorrem em pequena proporção, e é considerável a ocorrência de lotes industriais isolados ao longo das rodovias.

\subsection{O padrão de condomínios fechados de média e alta renda}

Este padrão se caracteriza por apresentar parcelamento em lotes que variam de 500 a 1.000m2, predominantemente, com casos que chegam aos 2.000 ou 3.000m2 (Cond. Terras de São José e Vila Real, em Itu/SP). A morfologia é semelhante à dos bairros-jardim e de loteamentos de média a alta renda, típicos da cidade compacta.

O padrão construtivo dessa faixa de renda e de negócios imobiliários correlatos induz a uma densificação de área construída no lote, que, aliado aos equipamentos de lazer internos como piscina, churrasqueiras e varandas, deixam pouco espaço para cobertura vegetal intra-lote. Assim, o caráter de bairro-jardim depende predominantemente da arborização existente no sistema viário interno, fato que, em muitos casos, não ocorre com a intensidade necessária para a amenização microclimática do conjunto do loteamento. 
Os espaços livres internos do condomínio correspondem a uma situação parecida à de praças e alguns parques urbanos de pequenas dimensões existentes nas tipologias semelhantes da cidade compacta. São pouco frequentes os casos de loteamentos que agregam em seu interior pequenas ou grandes reservas de matas nativas ou bosques. Quando, em virtude do tamanho do loteamento, agregam vários setores de morros ou colinas e contam com a presença de nascentes e córregos, estes são preservados como áreas verdes internas e os córregos represados para a formação de lagos.

Assim, embora a presença de pequenos jardins intra-lote, calçadas verdes e arborização urbana transmitam a ideia de uma aproximação com a natureza, esta se dá mais em virtude da proximidade com um entorno ainda predominantemente rural, ou campestre. O caso de Alphaville (Barueri/SP) parece exemplar para confirmar esse argumento, pois, após a profusão da expansão de loteamentos desta tipologia contíguos aos existentes, transformaram o que foi, um dia, um padrão imobiliário com apelo campestre em mais um conjunto de loteamentos conurbados à mancha urbana da cidade compacta. Esse aspecto pode ser observado nos exemplos inseridos nas figuras 5.1 (Aldeia da Serra) e 5.4 (Tamboré 10).

Figura 5.1 - Condomínio fechado de Aldeia da Serra, em Barueri/SP, na vertente norte da Serra do Itaqui.

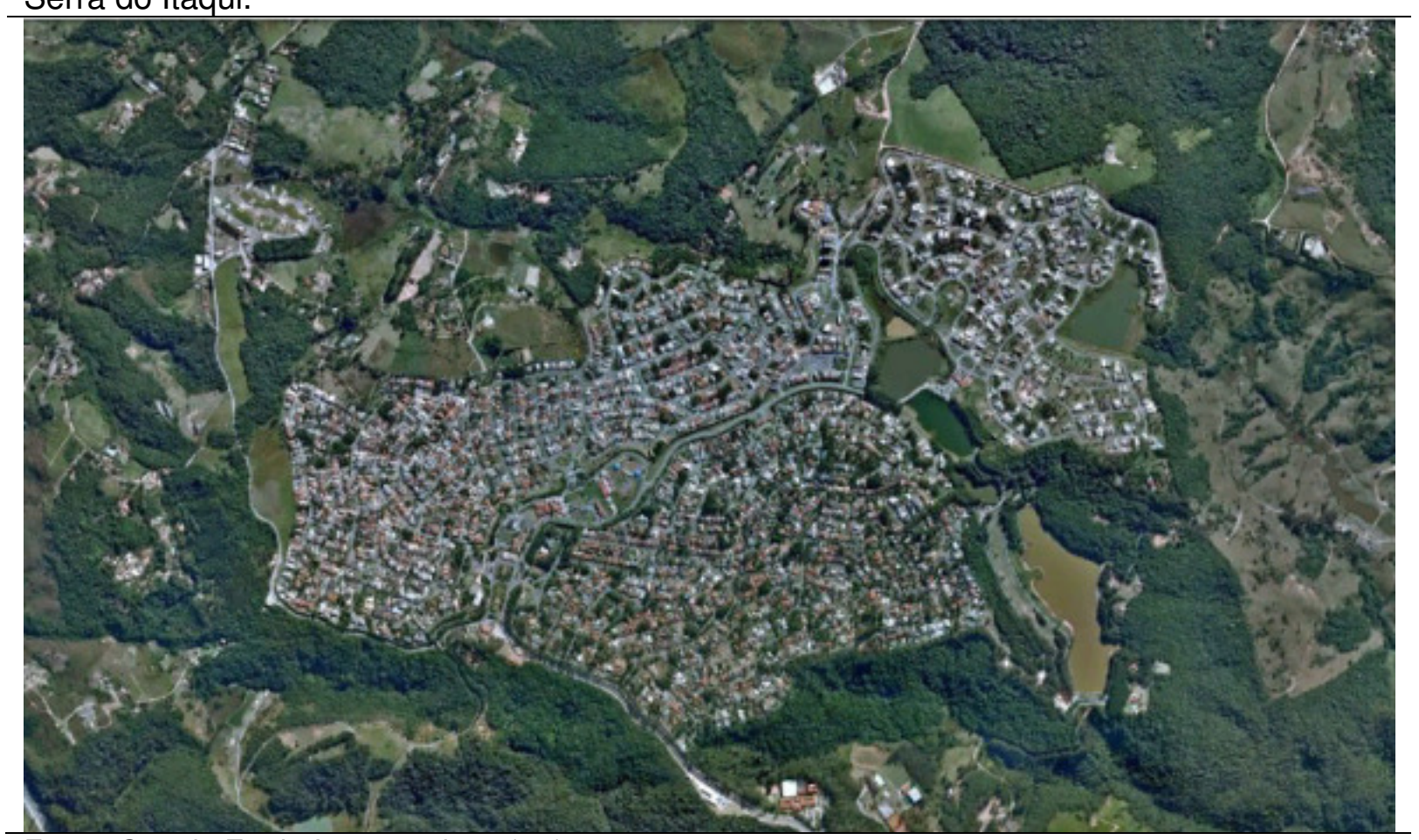

Fonte: Google Earth. Imagem de 17/11/2009 
O traçado da planta urbana nesta tipologia é predominantemente orgânico, com arruamentos curvilíneos que visam uma melhor apropriação da declividade do relevo e que também guardam relação com o ideário de cidade-jardim em face do forte apelo que este modelo apresenta para essa faixa de renda. Esse traçado orgânico é desenvolvido tanto nas áreas íngremes dos morros cristalinos do Planalto Atlântico quanto nas colinas sedimentares da Depressão Periférica, que apresentam vertentes suaves de baixa declividade.

Nos condomínios com lotes menores (500 a 1.000m2), é geralmente incipiente a arborização intra-lote e a taxa de impermeabilização torna-se elevada em decorrência do padrão construtivo, fator já mencionado anteriormente, e que pode ser verificado nos exemplos das figuras 5.4 a 5.10. Este padrão se instala em áreas já degradadas anteriormente pelas práticas agrícolas ou, quando em áreas com remanescentes de matas, a cobertura vegetal é inteiramente retirada para a definição das quadras e lotes.

Figura 5.2 - Detalhe da ocupação das quadras do condomínio fechado de Aldeia da Serra, em Barueri/SP.

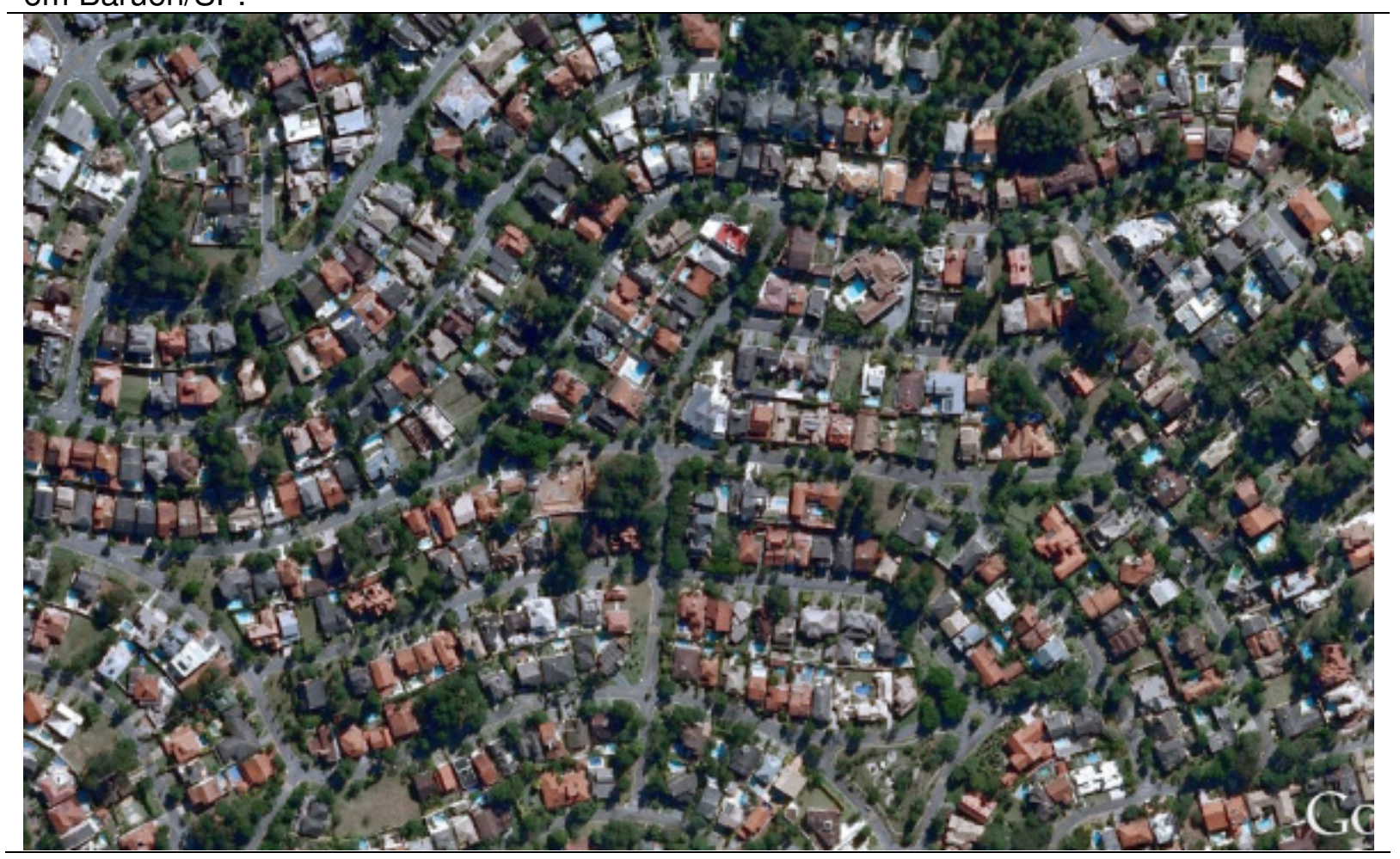

Fonte: Google Earth. Imagem de 17/11/2009 
Figura 5.3 - Detalhe da tipologia de ocupação de uma quadra do condomínio fechado de Aldeia da Serra, em Barueri/SP.

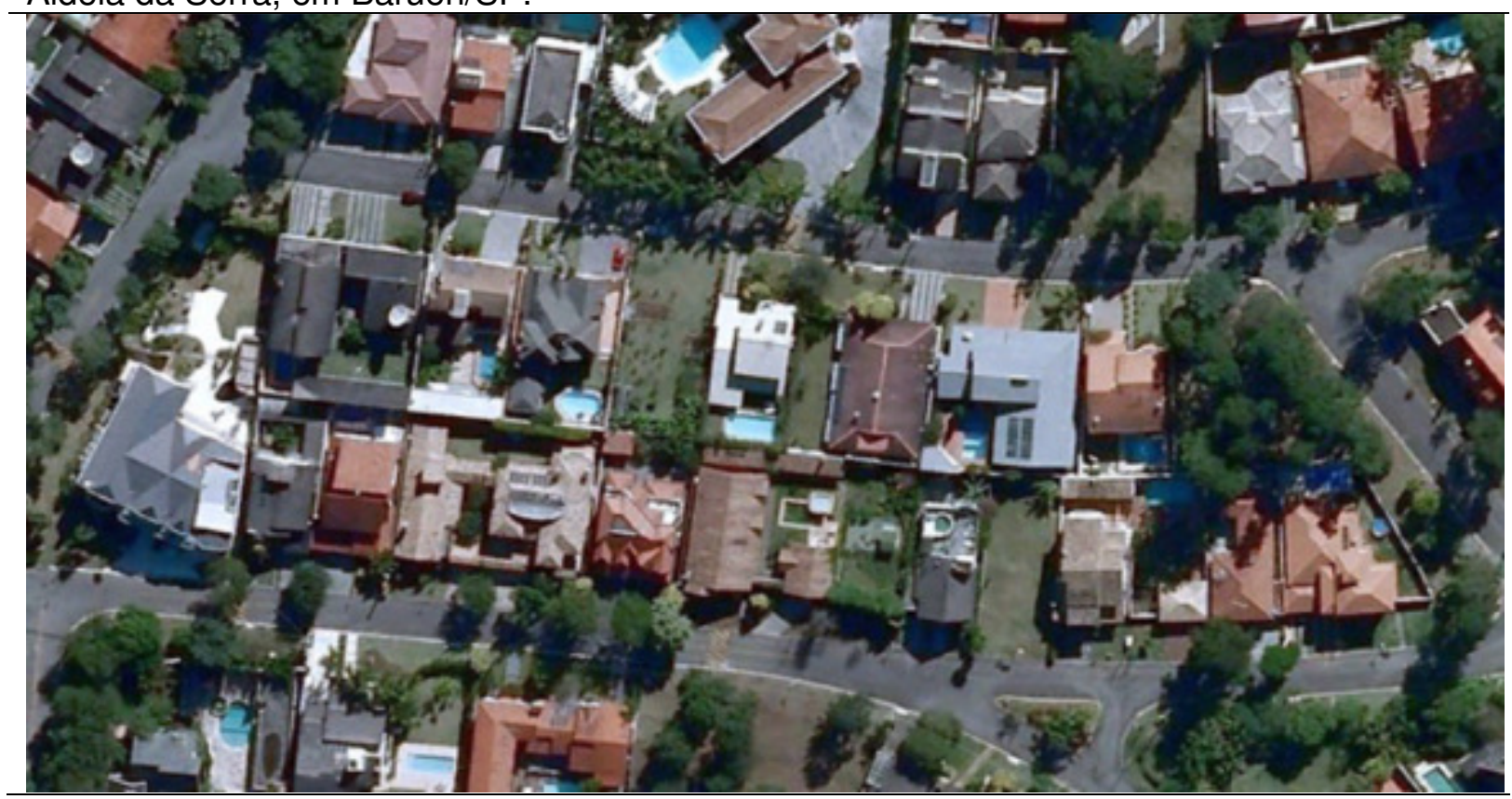

Fonte: Google Earth. Imagem de 17/11/2009

Figura 5.4 - Condomínio fechado Tamboré 10 - Terras Altas, em Barueri/SP, na vertente sul do divisor de águas Tietê-Juqueri. Vista geral e detalhe de quadra e lotes.

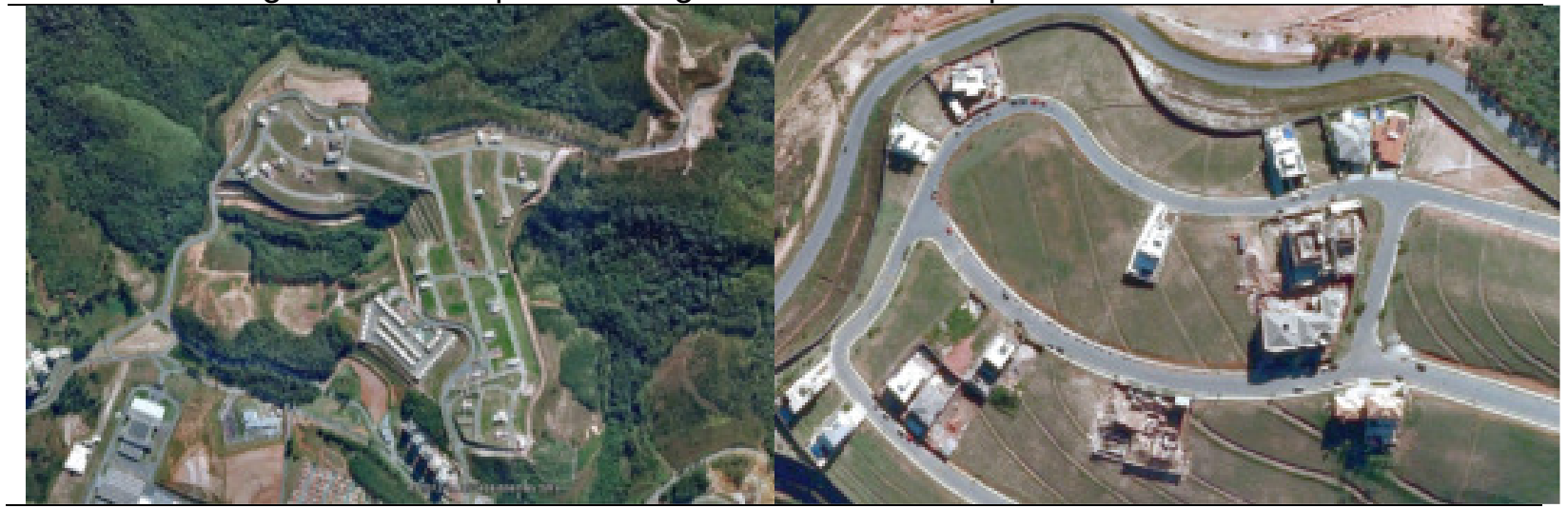

Fonte: Google Earth. Imagem de 17/11/2009 
Figura 5.5 - Detalhe do padrão de ocupação de Alphaville, Barueri/SP.

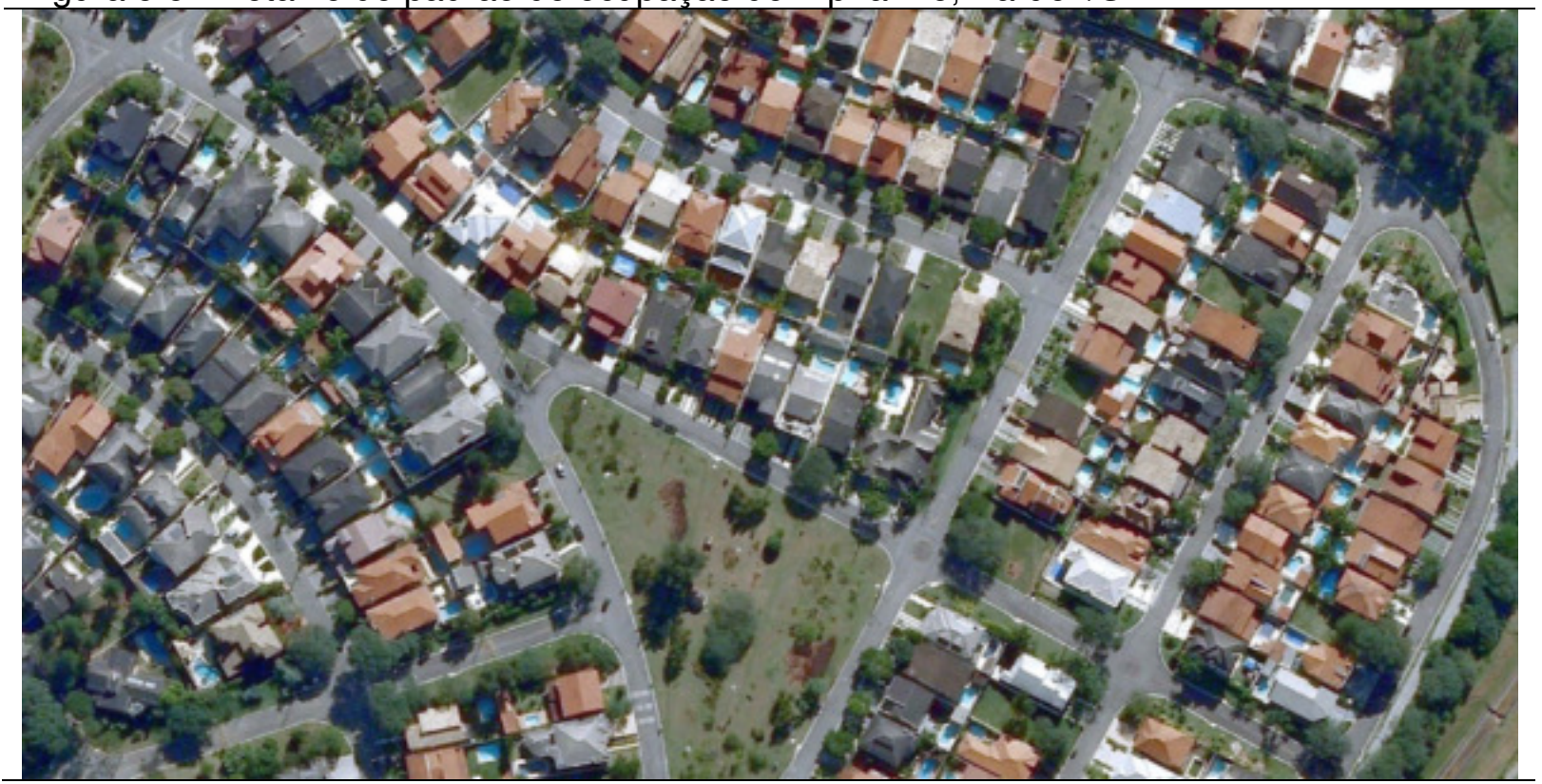

Fonte: Google Earth. Imagem de 17/11/2009

Figura 5.6 - O padrão de ocupação Tamboré: Condomínio Resort Tamboré (edifícios) e condomínio fechado horizontal, Barueri/SP.
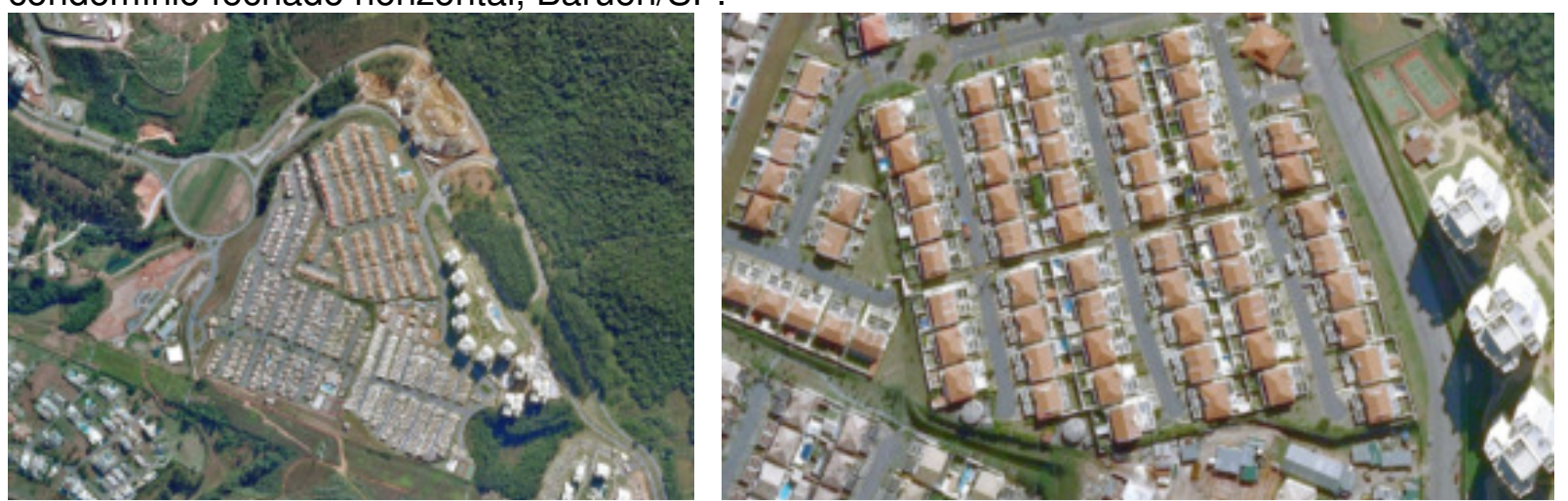

Fonte: Google Earth. Imagem de 17/11/2009

Figura 5.7 - Condomínio fechado de alta renda em Ibiúna/SP. Vista geral e detalhe interno.
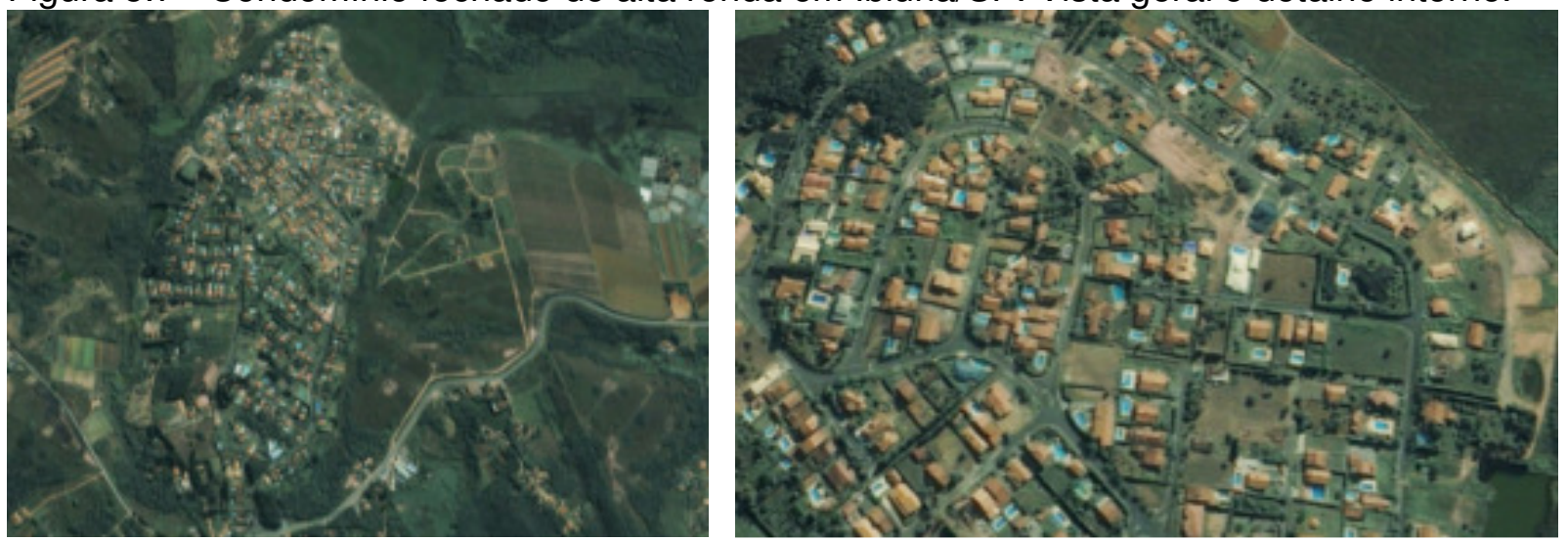

Fonte: Google Earth. Imagem de 17/11/2009 
Figura 5.8 - Condomínio fechado Morada do Sol, em Santana do Parnaíba/SP, situado no vetor de expansão da Rod. Castelo Branco. Vista geral e detalhe interno.

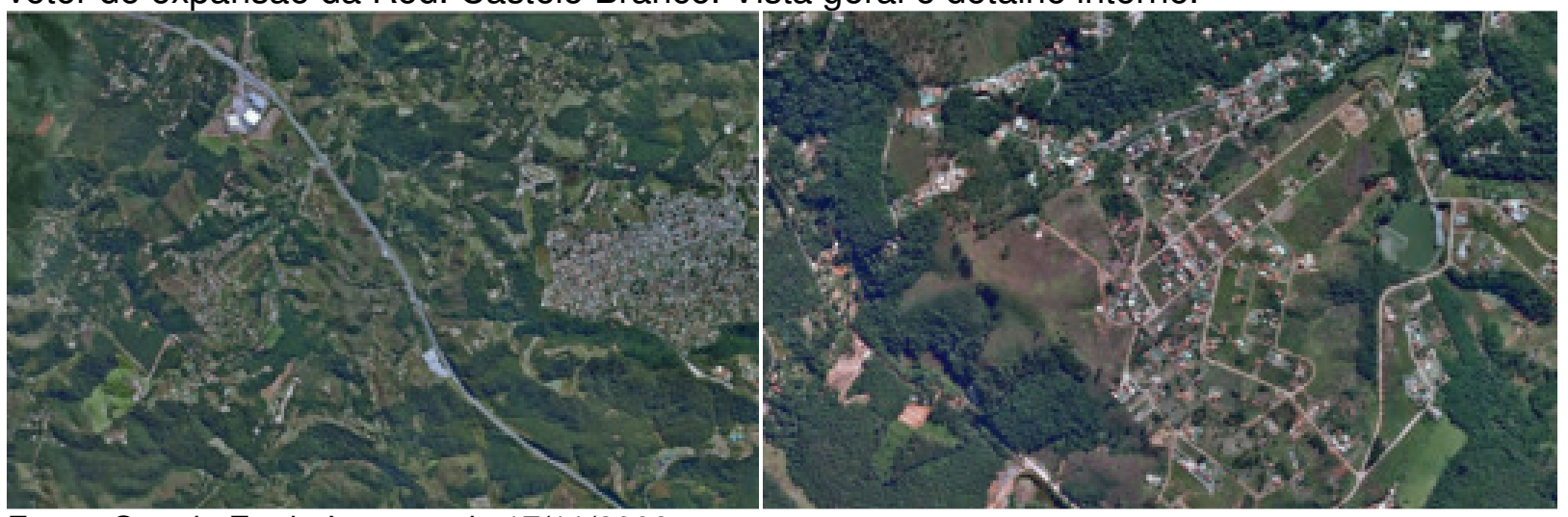

Fonte: Google Earth. Imagem de 17/11/2009

Figura 5.9 - Condomínio fechado em Caucaia do Alto, Município de Cotia/SP.

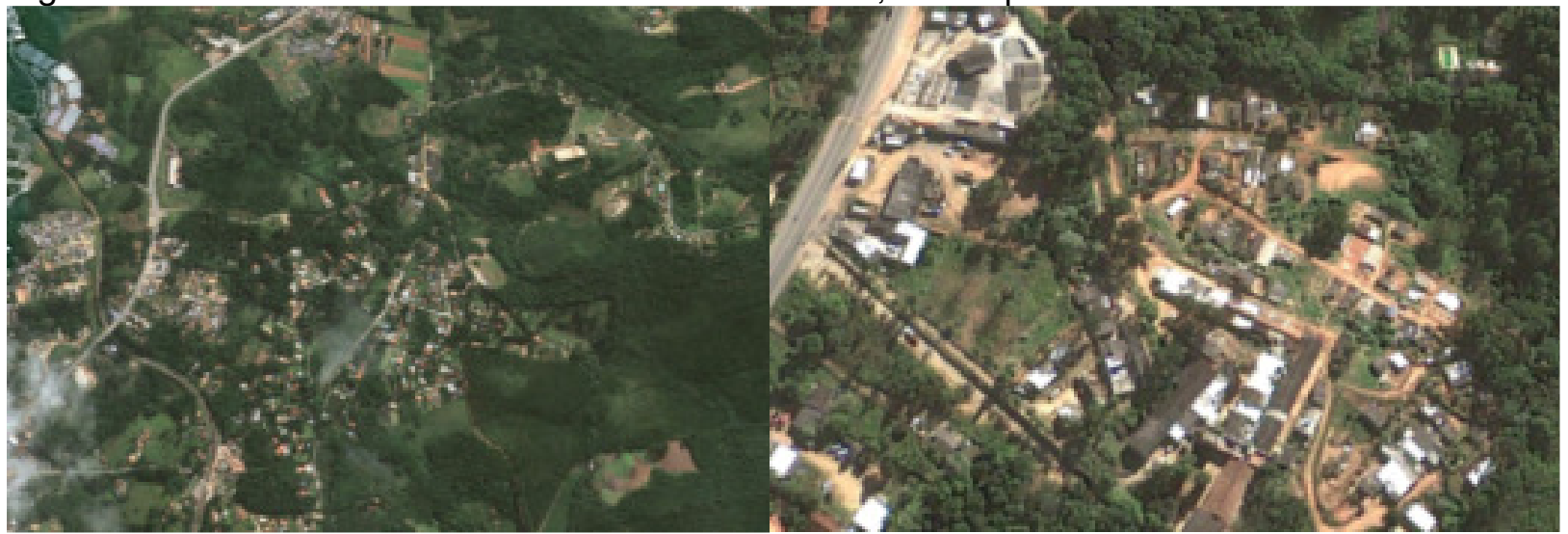

Fonte: Google Earth. Imagem de 17/11/2009

Figura 5.10 - Condomínios fechados de alta renda em Vinhedo/SP: Marambaia e Vinhas Vista Alegre.
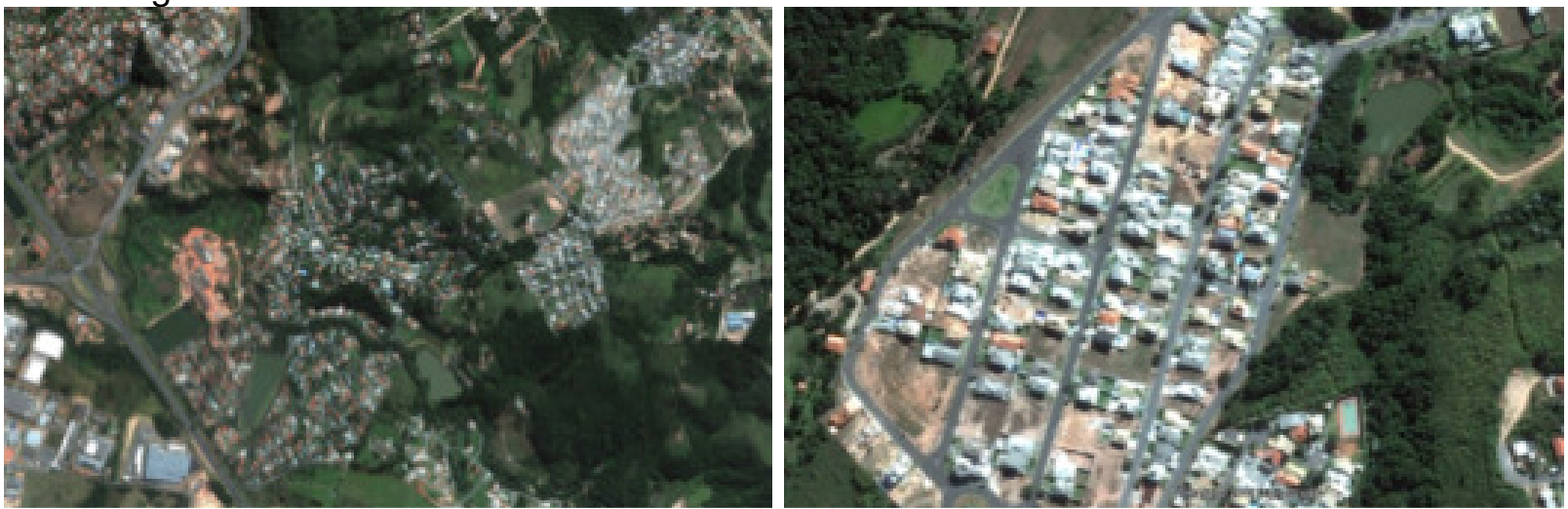

Fonte: Google Earth. Imagem de 17/11/2009 
Figura 5.11 - Vista geral do condomínio fechado de alta renda Fazenda Vila Real, em Itú/SP.

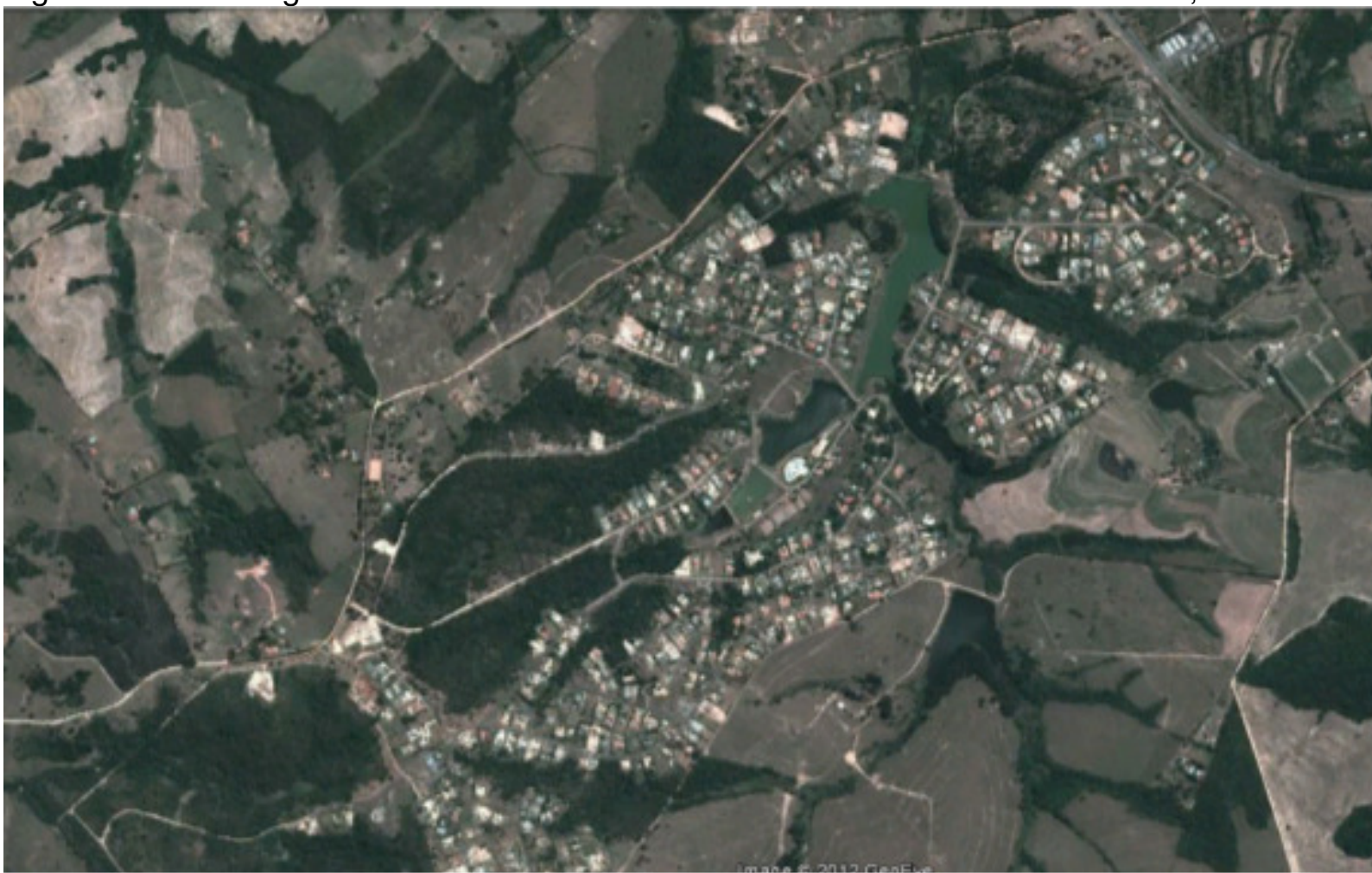

Fonte: Google Earth. Imagem de 31/05/2011

Figura 5.12 - Detalhe do parcelamento e da ocupação interna dos lotes do condomínio fechado de alta renda Fazenda Vila Real, em Itú/SP.

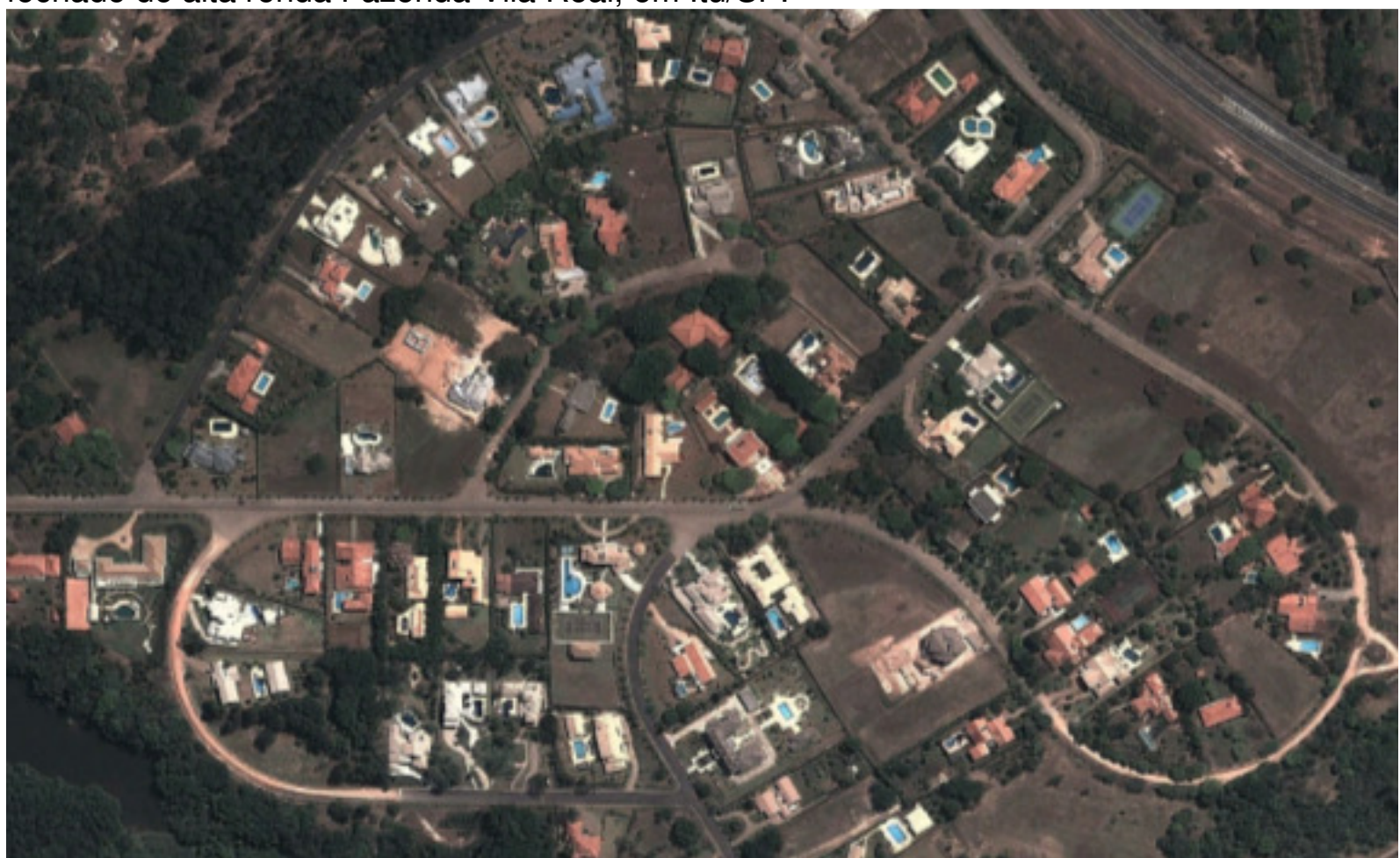

Fonte: Google Earth. Imagem de 31/05/2011 


\subsection{O padrão de condomínios e/ou loteamentos de chácaras de média e alta renda}

Esta tipologia de peça urbana dispersa é a que menos guarda relação com os padrões de ocupação existentes na cidade compacta. Quando ocorrem, tratam-se de loteamentos ou condomínios que tiveram seu traçado absorvido pela mancha urbana da cidade compacta por meio do processo de conurbação. Neste caso, é frequente a tendência ao reparcelamento dos lotes para o aumento da densidade da ocupação em decorrência da valorização do terreno.

O tamanho dos lotes nesta tipologia varia entre 2.000 a $5.000 \mathrm{~m} 2$. O traçado dos arruamentos é geralmente orgânico e guarda uma maior relação com o relevo, com o sistema de drenagem e com a vegetação remanescente. Ocorre tanto nos relevos dos morros cristalinos dos arredores de São Paulo, quanto nas colinas sedimentares da região de Campinas e Sorocaba, mas sua presença é mais frequente nos primeiros, nas regiões de Mairiporã, Atibaia e Ibiúna.

Figura 5.13 - Condomínio fechado de chácaras de alta renda Alpes da Cantareira, Mairiporã/SP.

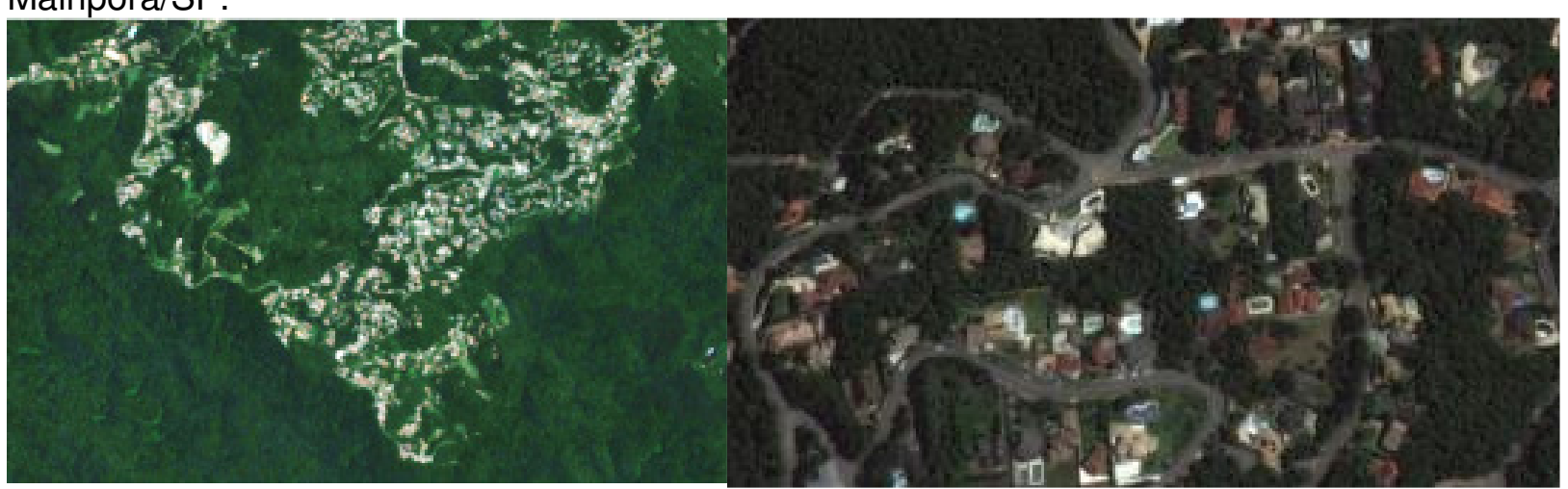

Fonte: Google Earth. Imagem de 21/12/2009

Figura 5.14 - Condomínio fechado de chácaras de alta renda na Região dos 5 Lagos e Jd. Maria Antonina, Mairiporã/SP.
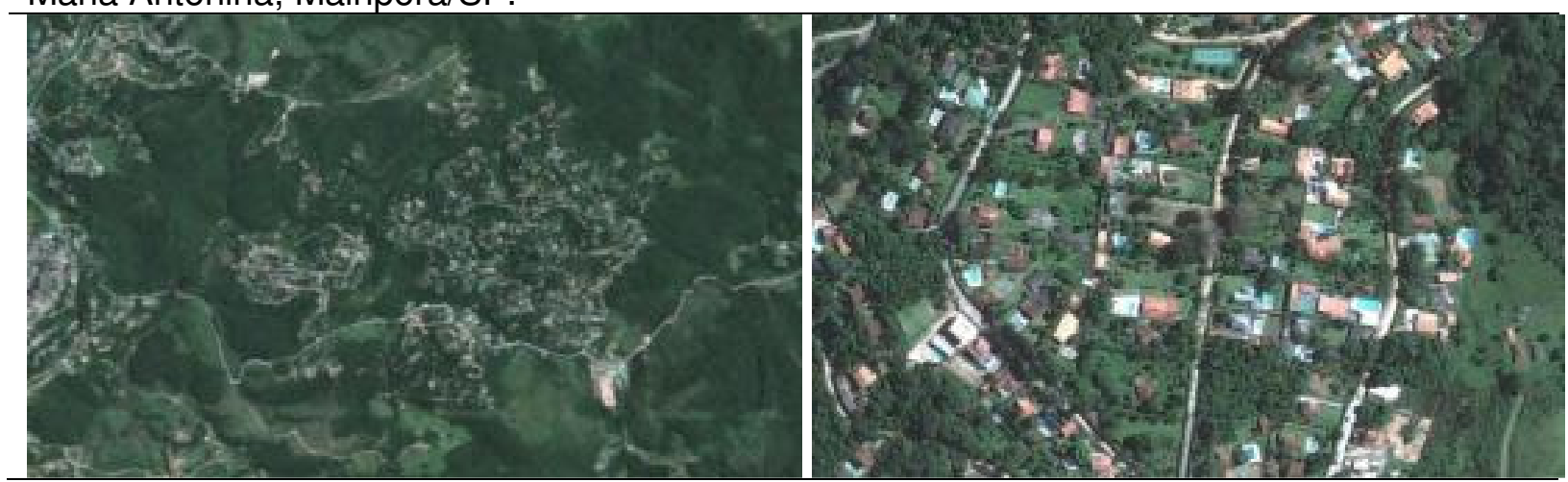

Fonte: Google Earth. Imagem de 2009 
Figura 5.15 - Condomínio loteamento de chácaras na região de Guacuri, Itupeva/SP.
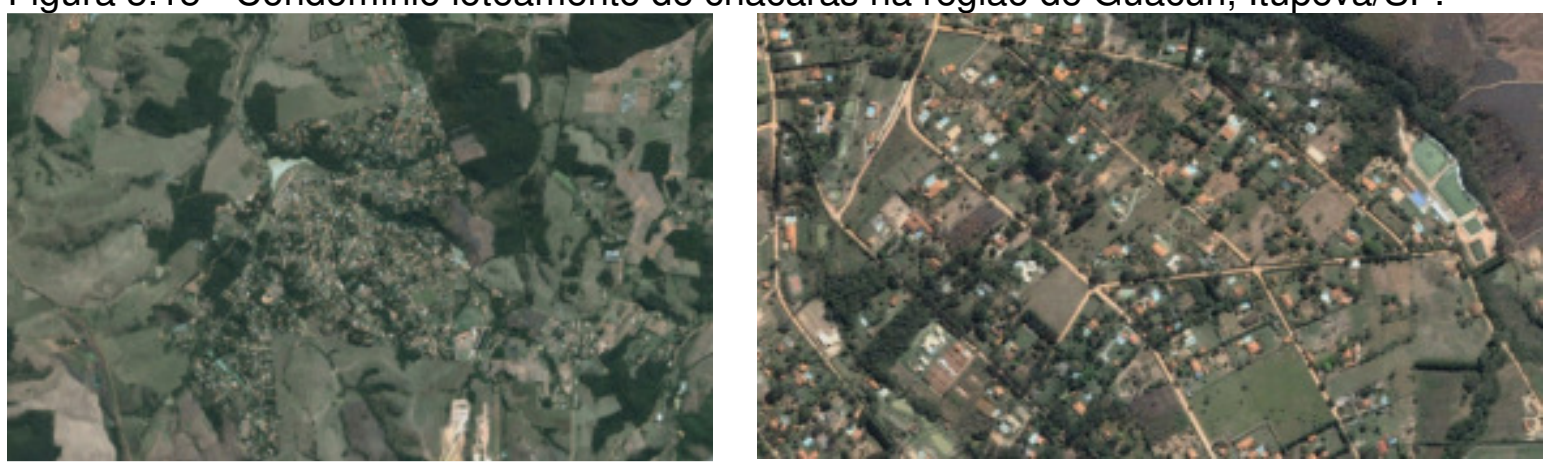

Fonte: Google Earth. Imagem de 2009

Figura 5.16 - Loteamento de chácaras de alta renda em Ibiúna/SP.
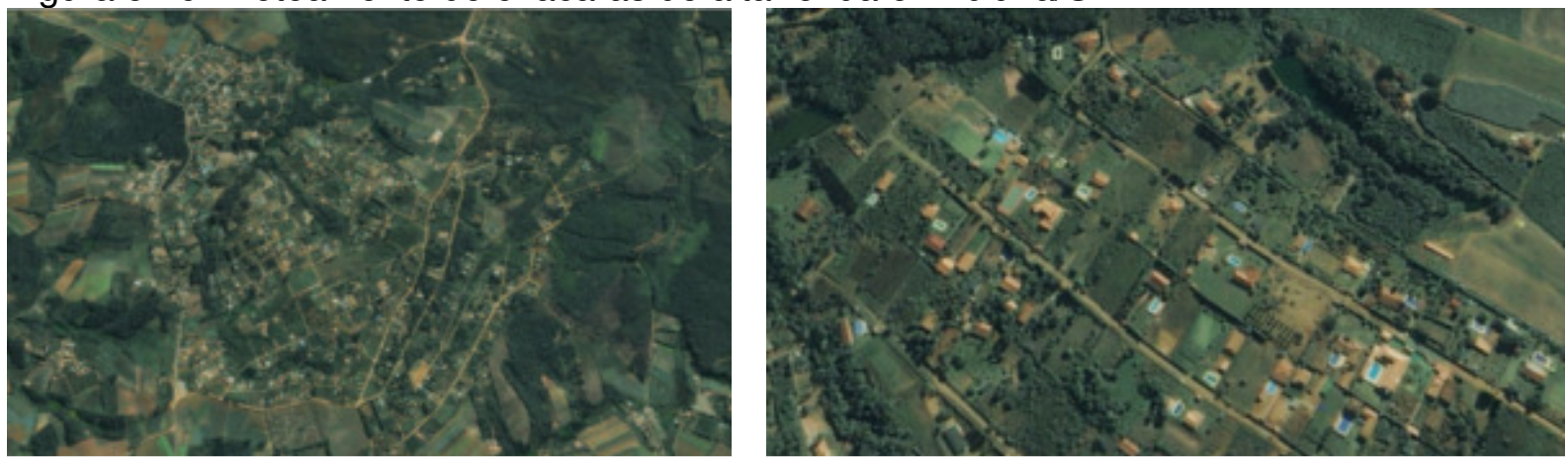

Fonte: Google Earth. Imagem de 2009

Ainda se configura na típica forma de $2^{\text {a }}$ residência, diferente da tendência dos condomínios fechados abordados no capítulo anterior. A ideia de contato com a natureza está mais presente, e impressa na própria característica de densidade construída das áreas de uso internas. A presença de verde, na forma de gramado, jardim, pomar etc,e de arborização intra-lote é dominante. Assim, a relação entre área construída e vazios internos garante uma alta taxa de permeabilidade do solo, e mesmo uma cobertura vegetal mais compatível aos usos urbanos.

Em virtude dessa baixa densidade a relação com o relevo permite uma baixa taxa de remoção da cobertura vegetal remanescente e baixa taxa de corte e aterro para assentar os arruamentos e as construções. Permite assim, em maior grau, a coexistência dos processos naturais das dinâmicas do clima e da água com a ocupação residencial. A relação com o sistema hídrico de drenagem tende a preservar nascentes e córregos e sua vegetação ciliar. As encostas muito íngremes são também preservadas com sua vegetação nativa ou em regeneração.

Esse tipo de parcelamento já foi pensado em termos urbanísticos como um anteparo, ou uma passagem gradual da cidade compacta para o mundo rural, ou 
seja, como um setor de transição entre aglomeração e paisagem rural. Nas áreas de preservação de mananciais essa forma de ocupação foi e é estimulada, no intuito de barrar a expansão de loteamentos periféricos de baixa renda.

O caso da lei de proteção dos mananciais da Billings-Guarapiranga ${ }^{23}$ de 1975 visava conteressa expansão periférica por meio da regulação de densidade ${ }^{24}$ e taxa de permeabilidade do lote que induzia a um parcelamento com lotes não inferiores a $3.000 \mathrm{~m} 2$, restringindo assim a ocupação para uma tipologia de chácaras. Na região sul de São Paulo, entre as represas Billings e Guarapiranga essa indução não logrou êxito, e não conseguiu evitar a expansão dos loteamentos periféricos de baixa renda e a persistência da dispersão urbana deste padrão de renda. É interessante notar que não se verifica nenhum caso de loteamento típico de chácaras desta tipologia analisada nessa região.

Ao contrário, na região norte da cidade São Paulo e em Mairiporã é onde se pode verificar a ocorrência mais significativa desta tipologia de loteamentos ou condomínios de chácaras. Situadas nos contrafortes da Serra da Cantareira, ela se expande sobre os últimos remanescentes de Mata Atlântica razoavelmente preservados. Se essa forma de ocupação garante uma relação mais satisfatória com o relevo, com os processos naturais e com a preservação de parcelas de vegetação nativa, ela, de outro lado acentua a fragmentação das áreas florestais, prejudicando a sustentabilidade do bioma local (flora e fauna associada).

Outra tendência atual importante deste tipo de ocupação é a sua localização no entorno de represas, como se pode verificar no entorno dos reservatórios de Paiva Castro (Mairiporã), de Jaguari (Igaratá) e Billings (Rio Grande da Serra). Nos dois primeiros casos essa ocupação é mais intensa e pode ser observada nas figuras 5.17 e 5.18 .

\footnotetext{
${ }^{23}$ Lei estadual 898 de 1975 e 1.172 de 1976. Ver Marcondes, 1999 (Cidade e Natureza: proteção dos mananciais e exclusão social. São Paulo: Studio Nobel, 1999). Citar artigo de Odete Seabra

${ }^{24}$ Previa-se densidade de 30 habitantes por hectare.
} 
Figura 5.17 - Condomínios e loteamentos de chácaras de alta renda no entorno da represa Paiva Castro, Mairiporã/SP.

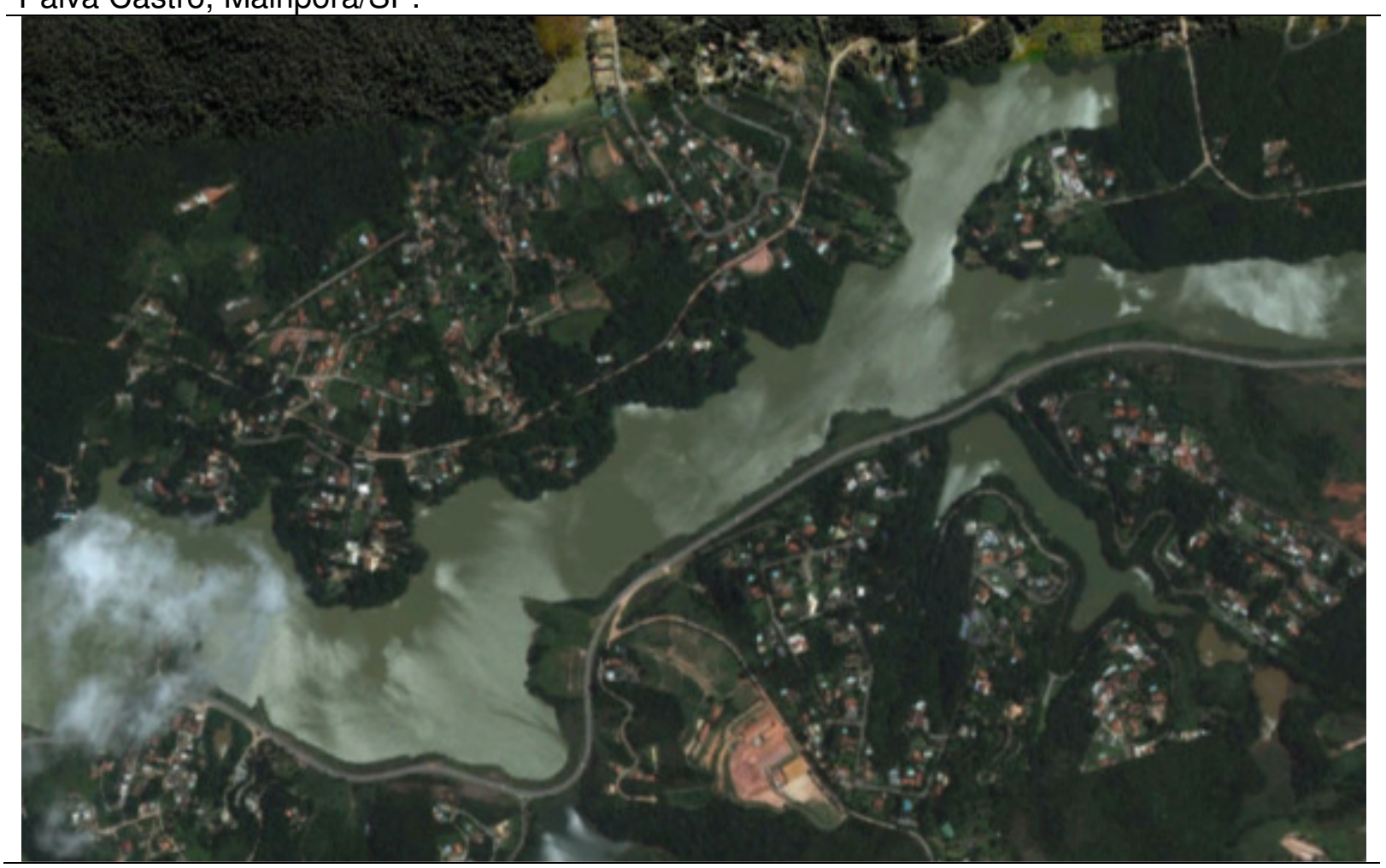

Fonte: Google Earth. Imagem de 21/12/2009

Figura 5.18 - Condomínios e loteamentos de chácaras de alta renda no entorno da represa de Jaguari, Igaratá/SP.

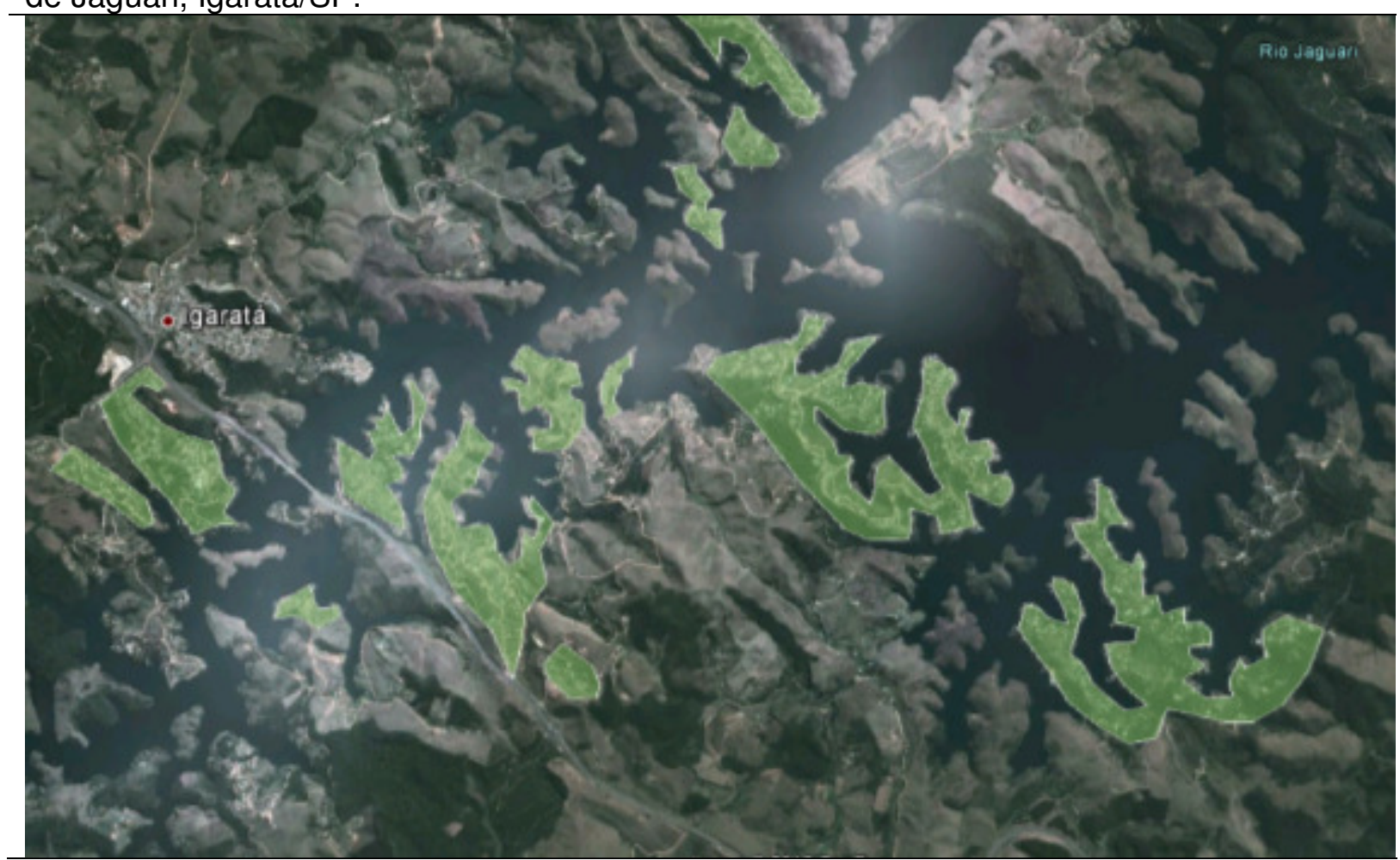

Fonte: Google Earth. Imagem de 04/10/2011 


\subsection{O padrão de loteamentos de baixa renda}

O padrão de loteamentos residências de baixa renda que se dispersam pelo território rural da Macrometrópole de São Paulo apresentam variações que não foram separadas na presente análise. Essas variações se referem aos diferentes espectros abordados em relação à baixa renda ou ao baixo padrão construtivo do loteamento. Em termos de renda essa classe $C$ pode ser dividida em faixas específicas que vão do $\mathrm{C}$ ao $\mathrm{E}$. Em termos de morfologia dos loteamentos para essas faixas de renda podem ocorrer desde bairros consolidados com habitações simples, mas ordenados e com todos os serviços, passando pelos conjuntos habitacionais e abrangendo os bairros de habitação subnormal e favelas. Loteamentos com padrão típico do que se alcunhou chamar de classe média baixa também ocorrem nesse fenômeno da dispersão urbana.

Como os loteamentos formados para essa camada da população apresentam elevado grau de similitude com as ocupações da mesma classe que ocorrem na cidade compacta, a análise optou por agrupá-los como peças urbanas semelhantes à cidade tradicional compacta. Assim, a tipologia aqui detalhada agrupa e ilustra os variados matizes desse tipo de ocupação residencial na franja dispersa das cidades compactas da Macrometrópole de São Paulo.

O que caracteriza esse tipo de dispersão de baixa renda é a tipologia de parcelamento das quadras. No padrão tipicamente baixo a área do lote regular varia de 125 a 160m2. Em muitos casos ocorre uma divisão deste lote em parcelas menores. No padrão baixo para médio os lotes são um pouco maiores e variam de 200 a $300 \mathrm{~m} 2$.

Essa tipologia ocorre em variadas maneiras, desde a forma isolada, comoloteamento individual, ou já agrupados, denotando um processo de expansão e adensamento. Esse agrupamento muitas vezes associa os diversos matizes de renda existentes dentro desta tipologia.

Ocorrem também geralmente associados a áreas industriais, como mostra a figura 5.19, que ilustra a forma de ocupação no eixo Via Anhanguera, na divisa de Santana do Parnaíba com Cajamar. Esta ocupação ocorre distante da sede dos dois 
municípios e encontra-se em franco processo de expansão e adensamento, misturando áreas residenciais de variados matizes e distrito industrial.

Essa forma de dispersão de baixa e médio-baixa renda tende a ocorrer nas imediações da cidade compacta sede do município e ao longo dos principais eixos viários, pois empre dependente da existência de transporte e dos serviços públicos.

Figura 5.19 - Tecido urbano misto na divisa de Santana do Parnaíba com Cajamar/SP. Loteamentosde baixa renda ao longo da Estrada Tenente Marques.

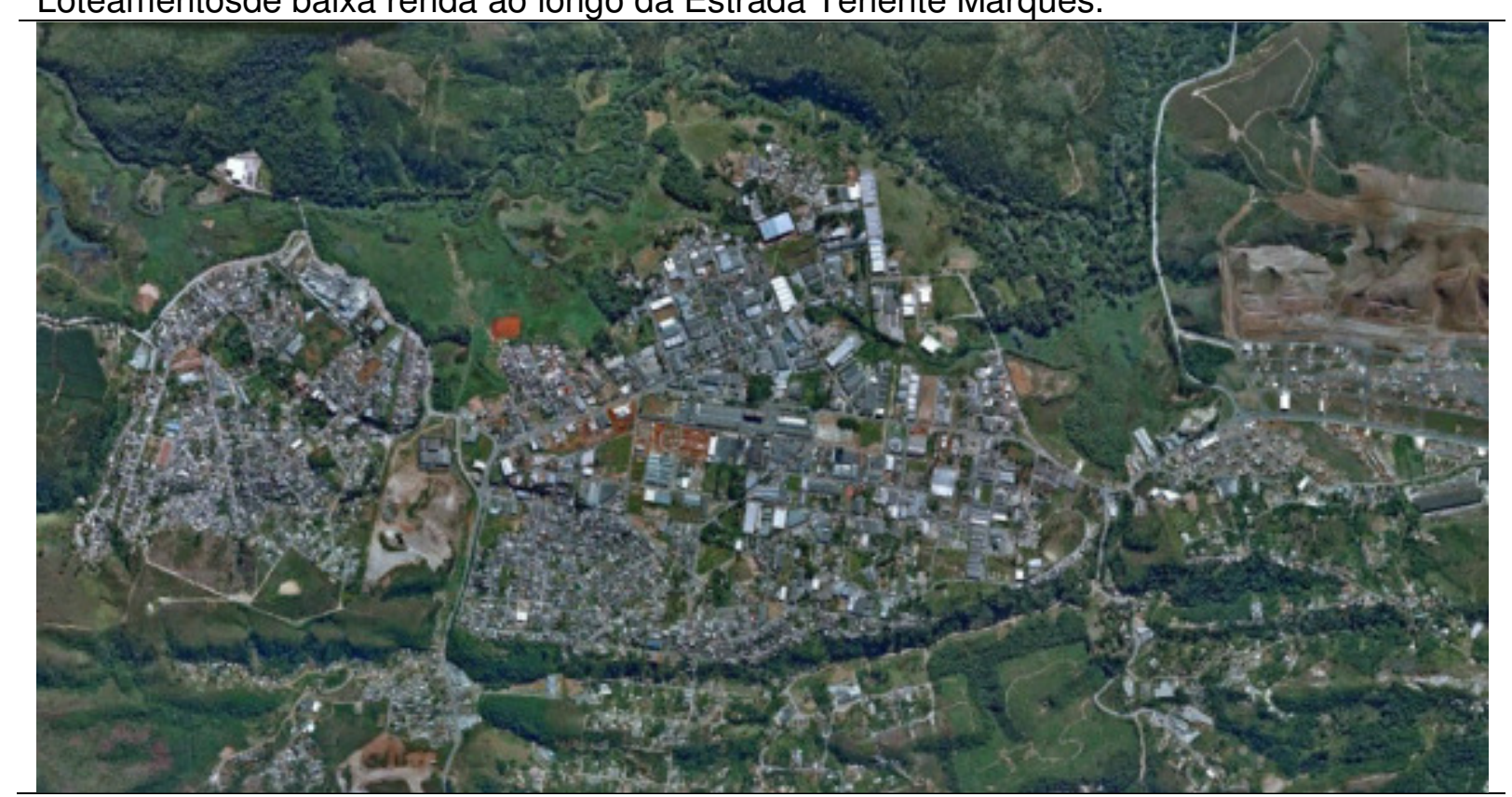

Fonte: Google Earth. Imagem de 30/06/2009

Neste padrão, assim como o parcelamento do solo é intenso, a impermeabilização do solo também expressiva em virtude das pequenas dimensões do lote. Disso decorre que os arruamentos e calçamentos tendem a ter dimensões menores e, consequentemente, quase não sobra espaço para ajardinamento e arborização urbana. Assim é que essa tipologia é totalmente semelhante às que ocorrem na cidade compacta adensada. Aqui a necessidade de morar a baixo custo supera qualquer ideário de localização campestre ou de sustentabilidade ambiental da ocupação. 
Figura 5.20 - Loteamentos de baixa renda na divisa de Santana do Parnaíba (Bairro Cidade São Pedro e Colinas de Anhanguera) ao sul; e Cajamar(Parque Residencial Cajamar) a norte.

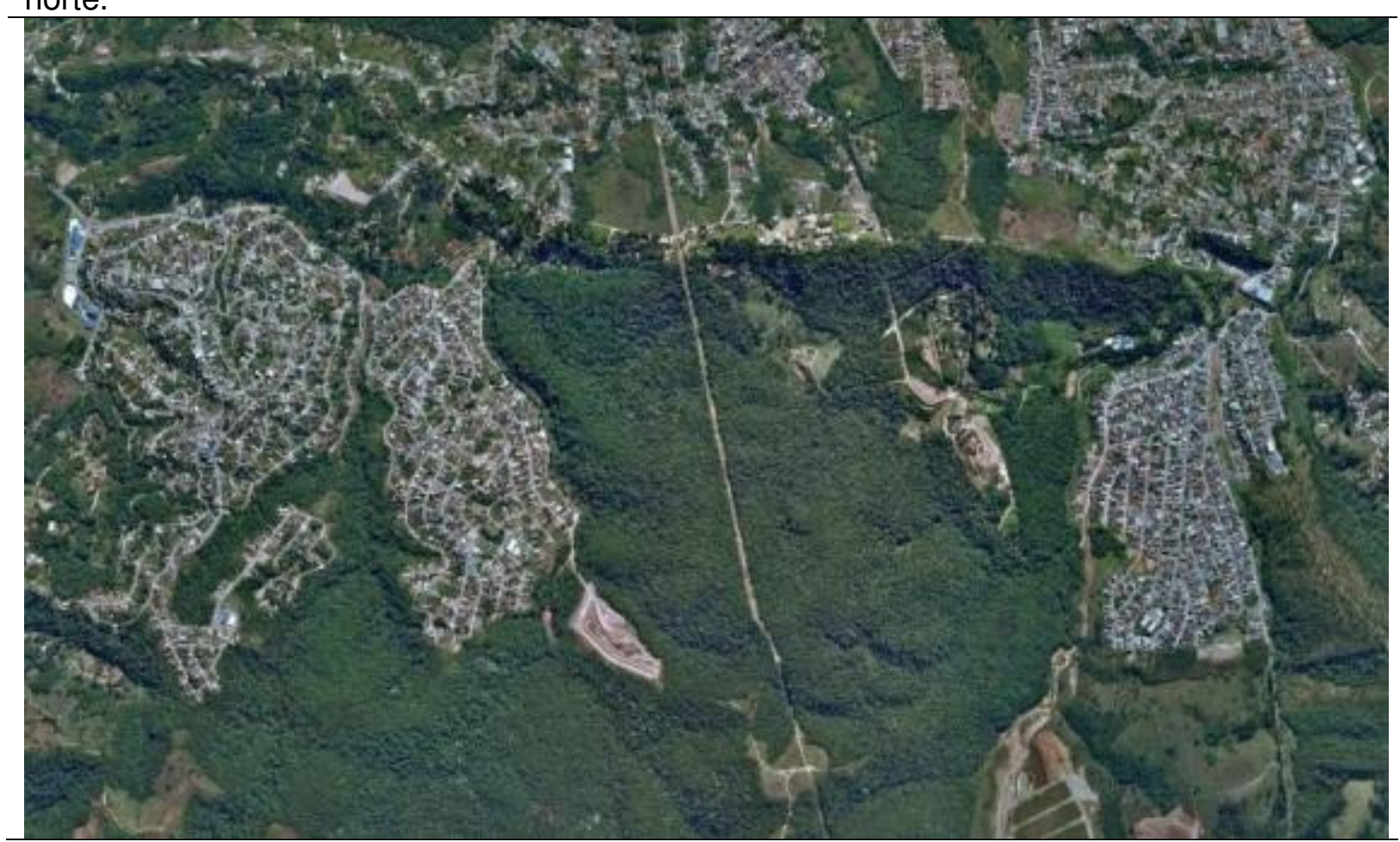

Fonte: Google Earth. Imagem de 30/06/2009

Figura 5.21 - Loteamento baixa renda e média-baixa em Cotia/SP (Vale Verde Cotia: Cond. Andorinha, Cond. Recanto das Graças I e II).

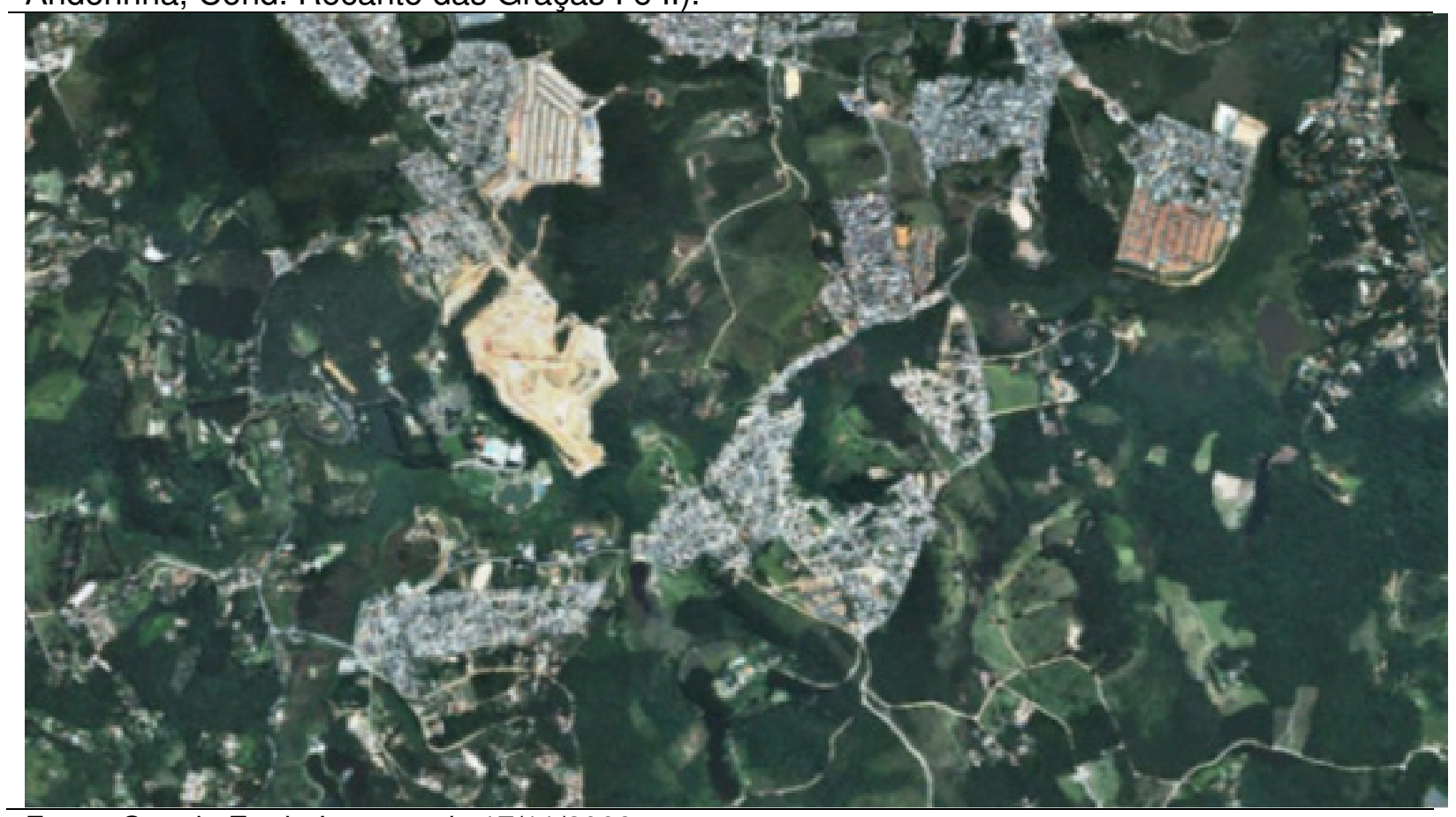

Fonte: Google Earth. Imagem de 17/11/2009. 
Figura 5.22 - Detalhe de loteamentos de baixa renda em Cotia/SP, situados na Estrada dos Fischers.

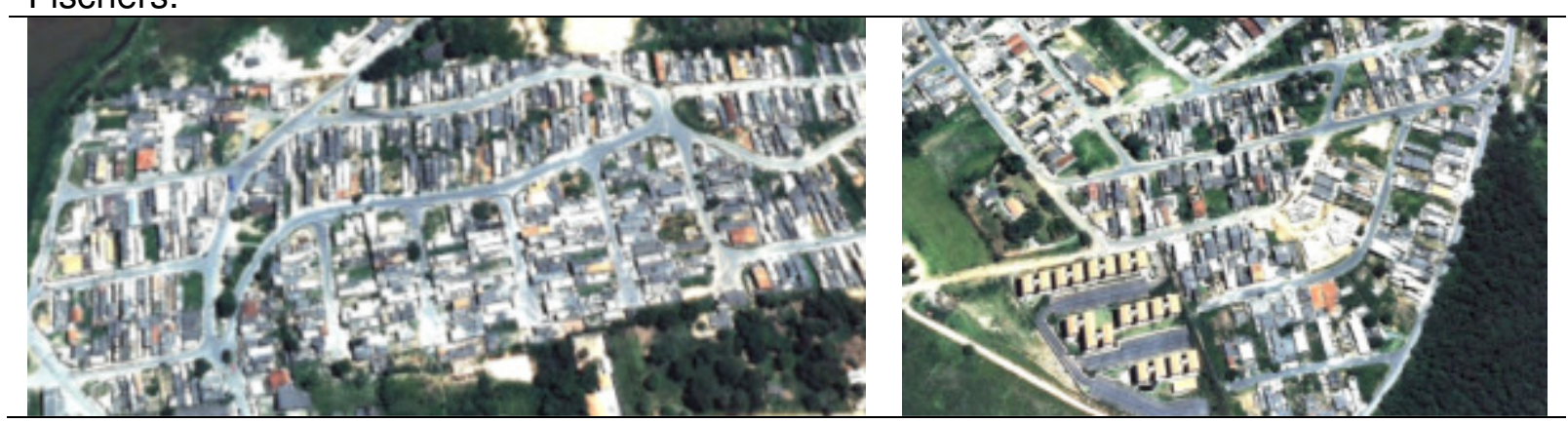

Fonte: Google Earth. Imagem de 17/11/2009

O que impressiona nesta ocupação periférica da Macrometrópole é a expressão do fenômeno de dispersão que ocorre em quase todos os quadrantes. Isto traz como resultado uma intensa fragmentação da paisagem rural, desarticulando os modos de vida vinculados à produção rural. Esse aspecto pode ser notado na região de Cotia e Vargem Grande, no vetor de dispersão da Rod. Raposo Tavares (Figuras 5.21) e na região de Ribeirão Pires, no eixo de ligação com Suzano (Figura 5.26).

Já quanto ao traçado dos loteamentos, o orgânico passa a ser menos frequente que o ortogonal-regular e que os modelos mistos. Na região de Jundiaí, junto à planície aluvial do Rio Jundiaí, os loteamentos de traçado regular-retilíneo predominam (Figuras 5.23 e 5.24). Nas porções da Depressão Periférica em Campinas, Itú e Sorocaba, essa forma também é dominante.

Os loteamentos dispersos de tipologia de baixa renda ocupam os mais variados compartimentos de relevo, desde áreas elevadas e de média a alta declividade dos morros cristalinos, como os terrenos planos dos terraços aluviais e várzeas. É expressiva a ocupação das várzeas do Tietê na região de Poá e Itaquaquecetuba, como se pode verificar na figura 5.27. 
Figura 5.23 - Loteamento de baixa e média renda em Jundiaí/SP: Bairro e CDHU Novo Horizonte, Bairro Almerinda Chaves.

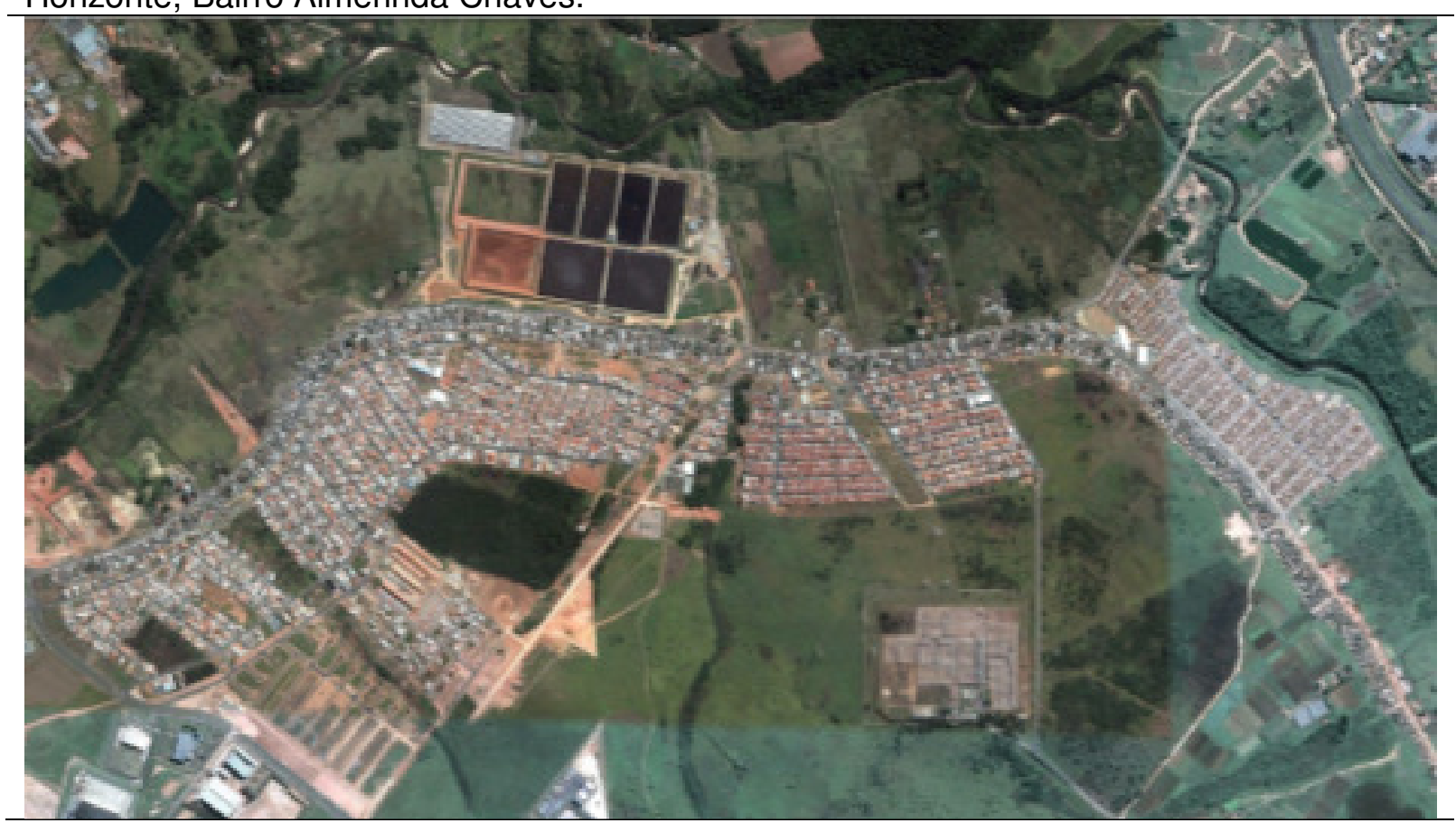

Fonte: Google Earth. Imagem de 04/09/2011

Figura 5.24 - Loteamentos de baixa renda em Jundiaí/SP: favela ao longo do bairro e CDHU Novo Horizonte.

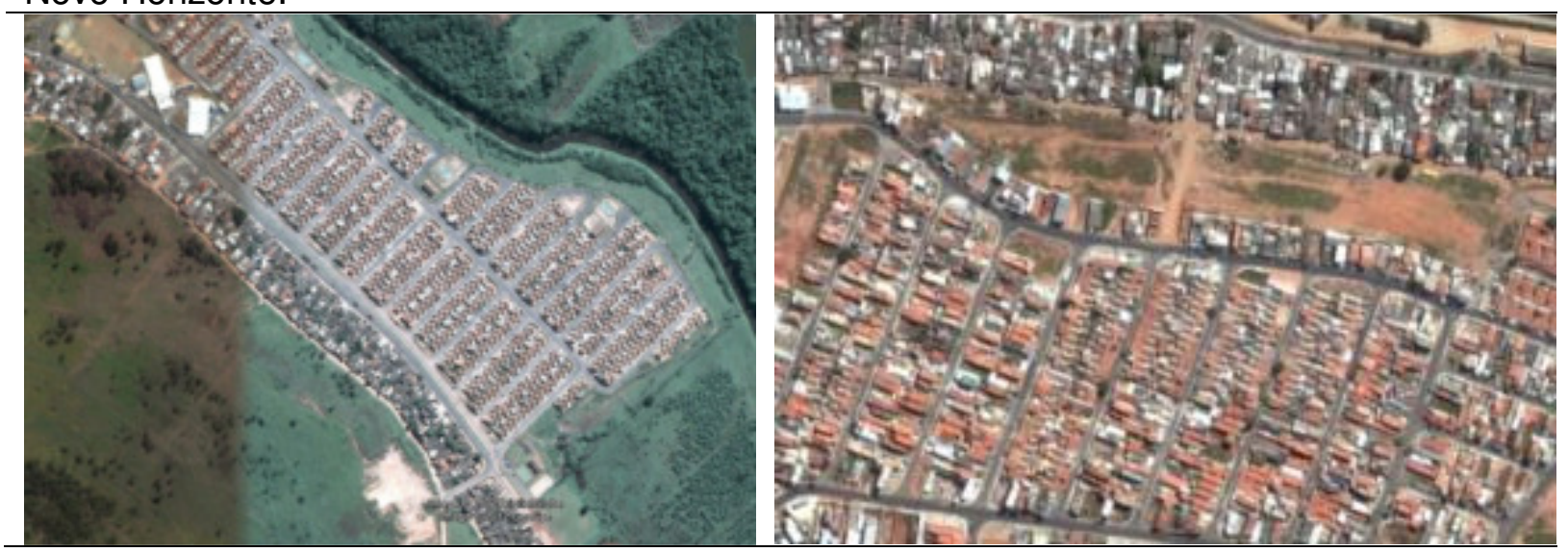

Fonte: Google Earth. Imagem de 04/09/2011

Figura 5.25 - Loteamentos de baixa e média renda em Guarulhos/SP, Distrito de Fortaleza.

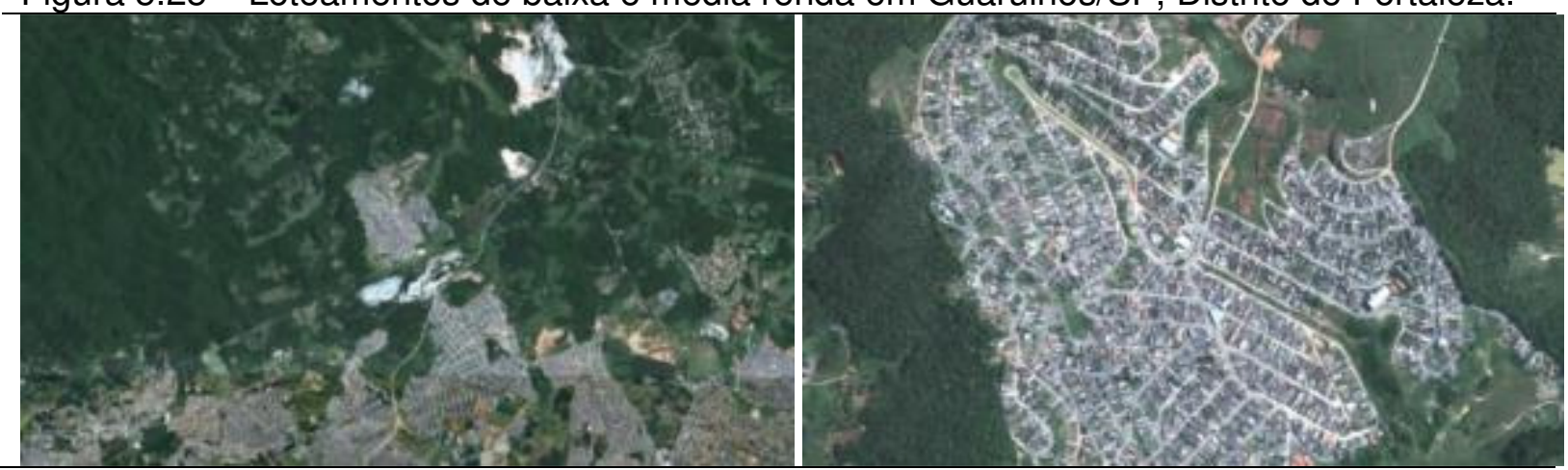

Fonte: Google Earth. Imagem de 03/07/2010 
Figura 5.26 - Loteamento de /SP. Dispersão de loteamentos de média e baixa renda em Ribeirão Pires, nos contrafortes da Serra do Mar.

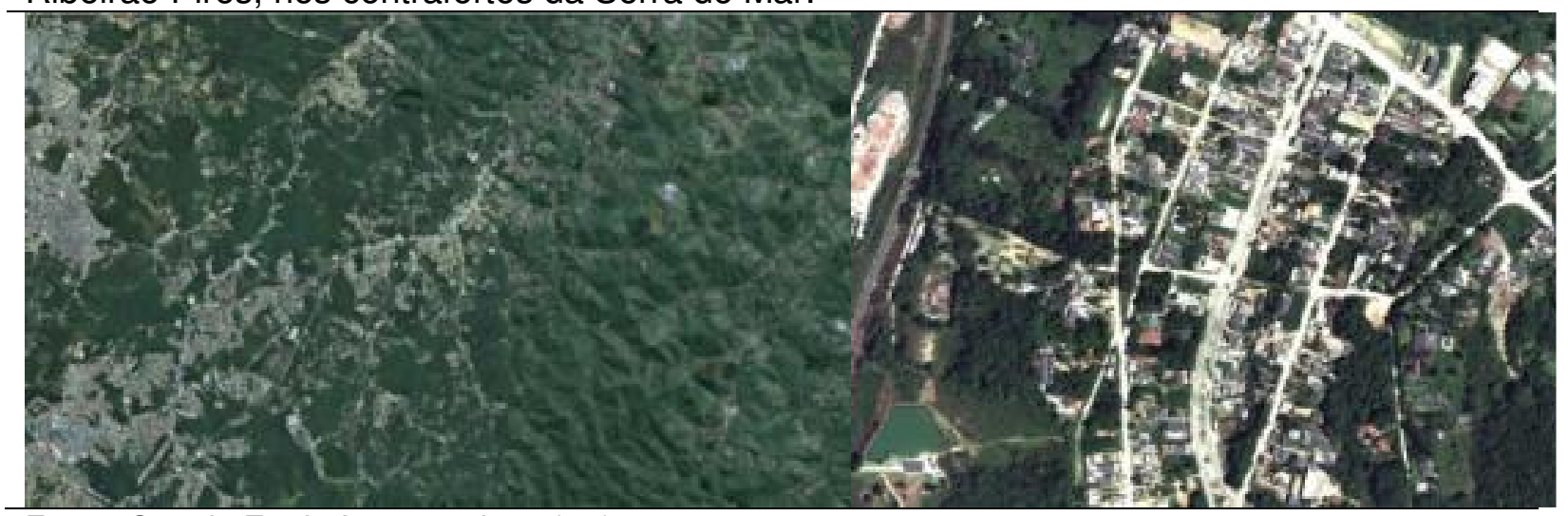

Fonte: Google Earth. Imagem de 21/12/2009

Figura 5.27 - Mineração e ocupação urbana de baixa renda na várzea do Tietê, em Itaquaquecetuba/SP.

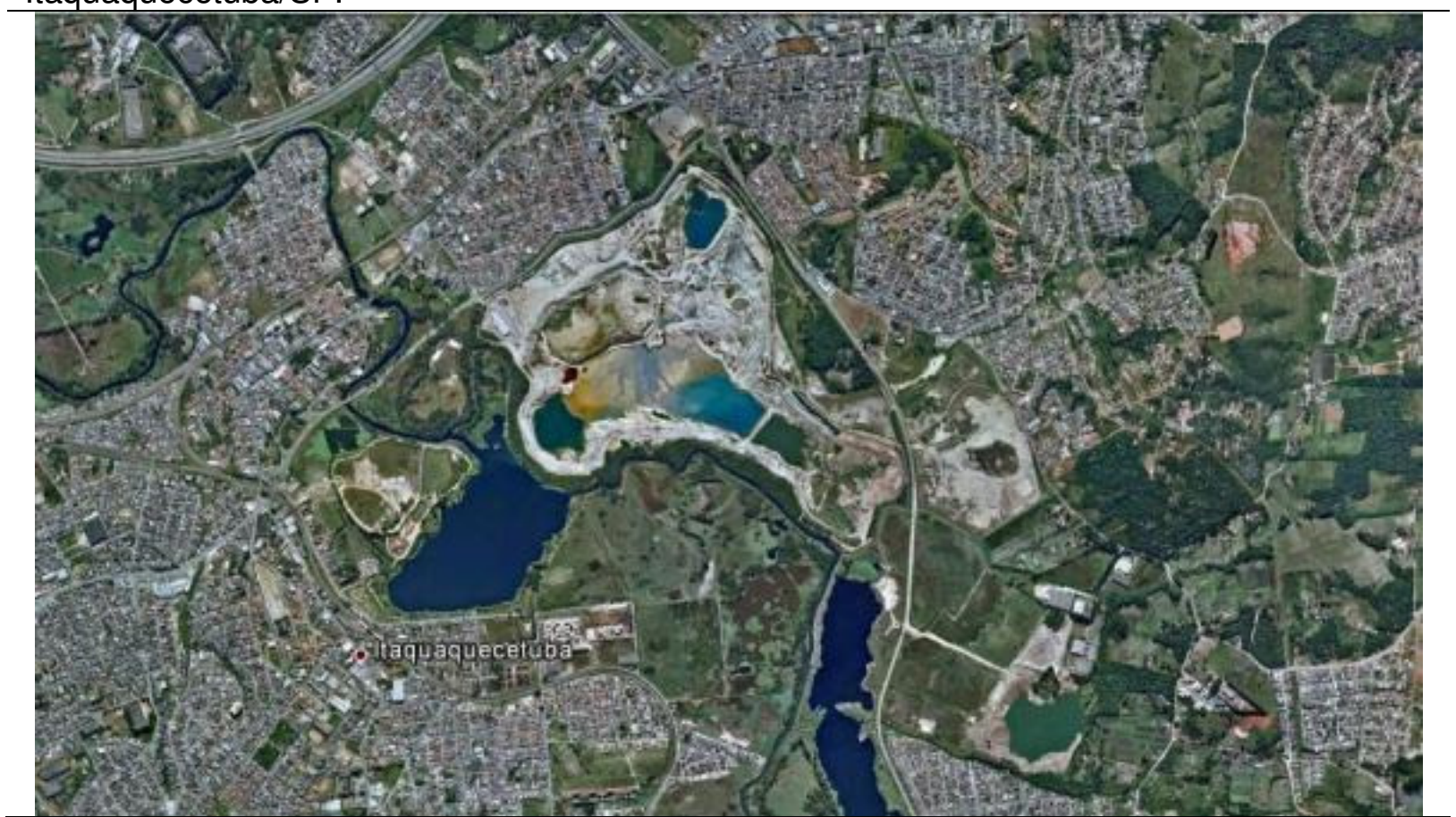

Fonte: Google Earth. Imagem de 04/03/2009

Figura 5.28 - Morfologia da ocupação de quadras em loteamentos dispersos de baixa renda em Ribeirão Pires/SP.

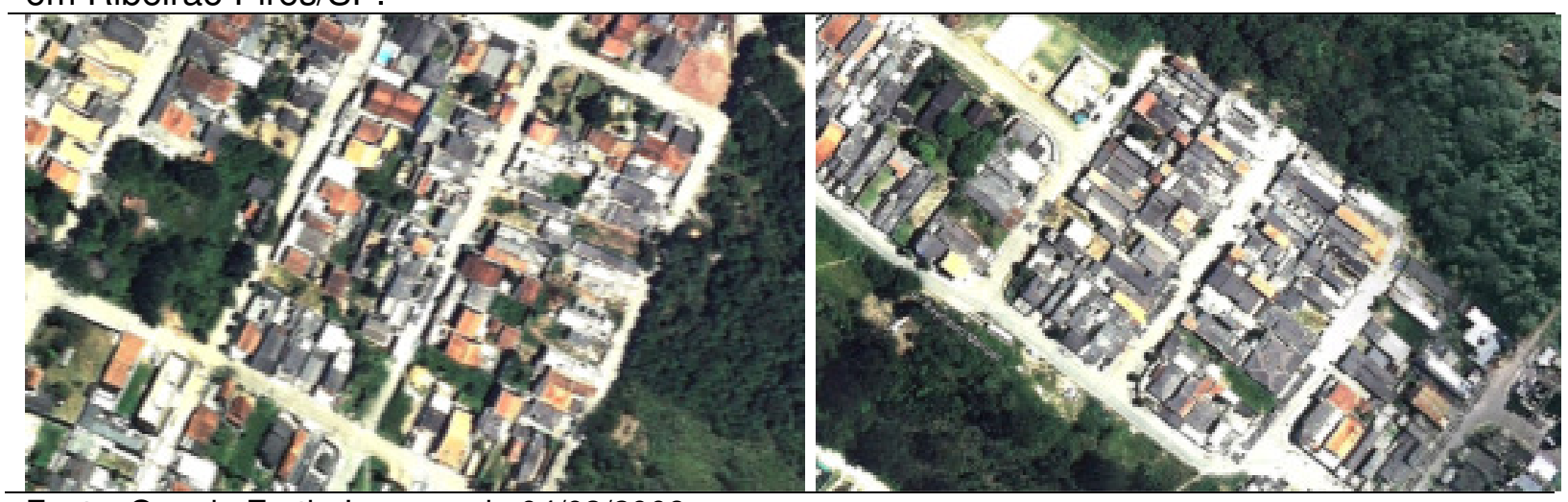

Fonte: Google Earth. Imagem de 04/03/2009 
5.6. O padrão de áreas industriais

Das peças urbanas dispersas a tipologia de áreas produtivas industrial/comercial atacadista é a que em menor grau ocorre desgarrada das demais ocupações dispersas. Elas tendem a se agrupar em linha ao longo das principais rodovias, com ou sem interrupções da sequência. É comum formar aglomerados, compondo verdadeiros distritos industriais. Outro aspecto que configura a sua localização é a tendência a agregar em sua vizinhança loteamentos de baixa e média renda, formando, assim, novos embriões de cidade compacta, perdendo o caráter monofuncional do aglomerado. O exemplo mostrado na figura 5.29 ilustra a ocupação industrial (em vermelho) na região de Jundiaí, Louveira e Itupeva, ao longo do vetor de dispersão do sistema de rodovias AnhangueraBandeirantes. Em amarelo, no mapa, observa-se os loteamentos de média e baixa renda típicos da cidade compacta (Jundiaí). Em verde aparecem os condomínios e loteamentos de média-alta e alta renda.

Figura 5.29 - Ocupação de uso industrial/comércio atacadista (em vermelho) na região de Jundiaí/SP.

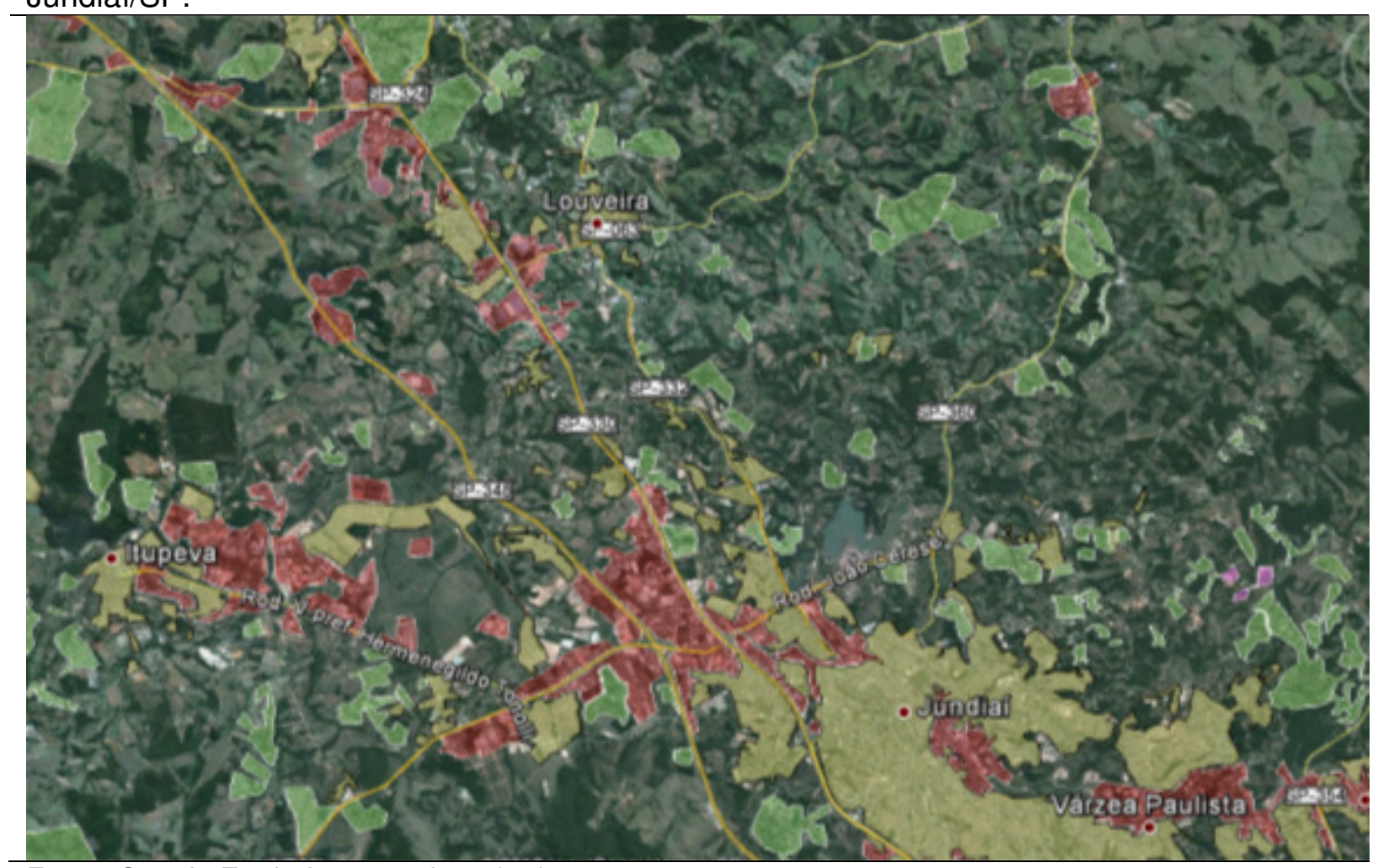

Fonte: Google Earth. Imagem de 31/05/2011 
É interessante notar que as manchas industriais e sua dispersão se localizam predominantemente nas saídas da metrópole paulistana, ao longo das rodovias Anhanguera, Castelo Branco, Raposo Tavares, Regis Bittencourt, AnchietaImigrantes e Dutra. Aglomeram-se no início destas rodovias e depois sua ocorrência vai espaçando e deixando vazios. A tendência a compor aglomerados é evidente formando densas áreas ocupadas pela tipologia e, frequentemente contíguas às ocupações residenciais.

A imagem da figura 5.28 ilustra uma tipologia padrão de áreas industriais da Macrometrópole no eixo de expansão da dispersão da rodovia Castelo Branco, em Barueri/SP. Nela pode-se observar que, mesmo em se tratando de uma região de relevo de morros, as plantas industriais necessitam de intensa terraplenagem do terreno a fim de aplainar e nivelar os platôs necessários aos empreendimentos. Promovem-se, assim, sucessivos patamares escalonados intermediados por taludes. O processo de raspagem da superfície é intenso, decorrendo uma total remoção da cobertura vegetal existente.

Figura 5.30 - Áreas industriais ao longo da Rod. Castelo Branco, em Barueri/SP.

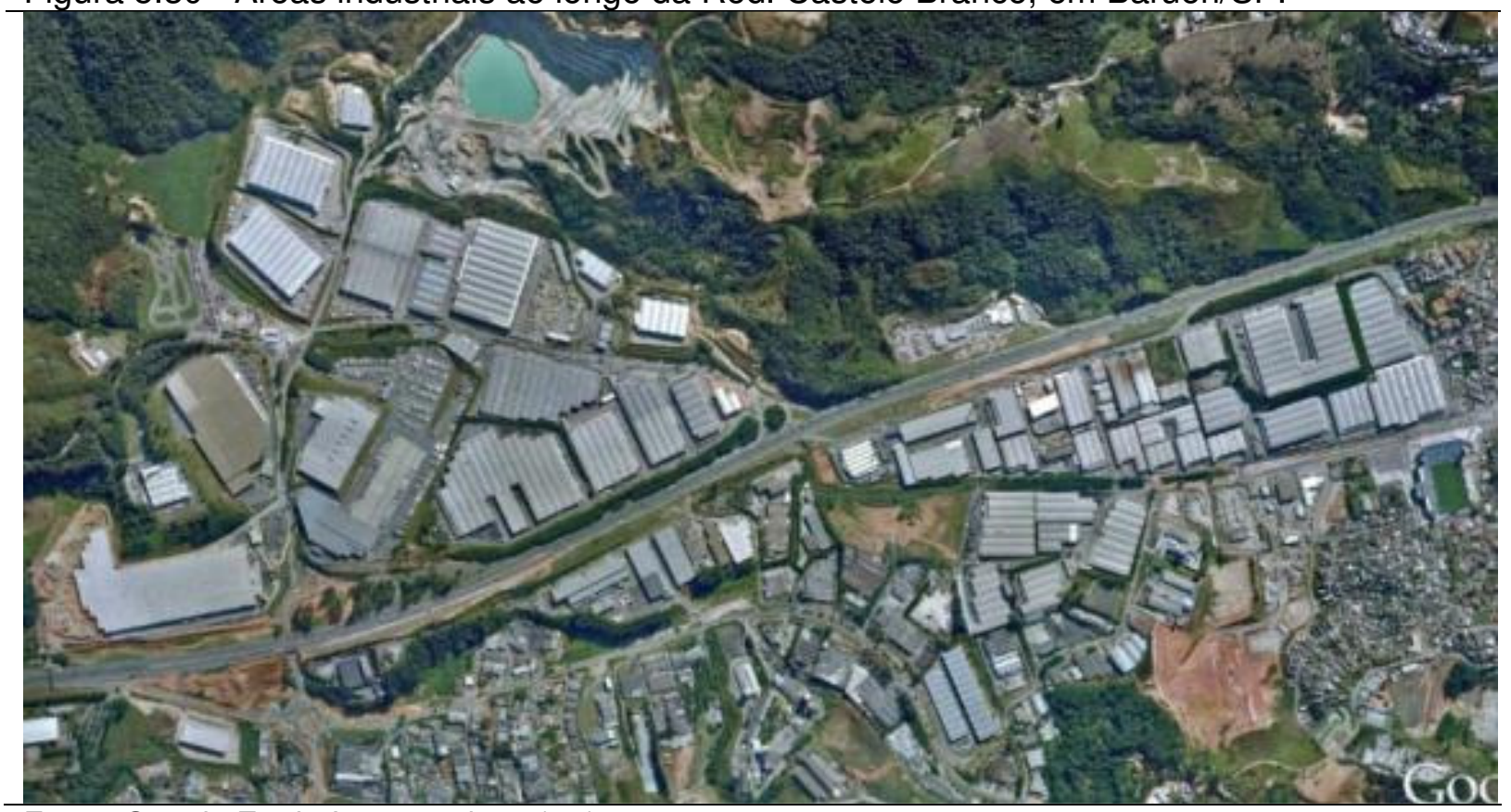

Fonte: Google Earth. Imagem de 17/11/2009

O padrão de áreas industriais existente tende a compor um espaço bastante impermeabilizado e, no interior dos lotes a ausência de arborização é quase absoluta. Em algumas unidades observa-se a ocorrência de arborização na divisa do lote, compondo uma barreira visual verde para a atenuação paisagística. Mas esse 
fato não é a regra. Segundo os variados estudos sobre ilhas de calor25, as áreas industriais conformam células quentes no clima urbano das metrópoles, onde a emissividade de calor das superfícies (telhados, pisos, asfalto, etc) é intensa, colaborando para o aumento significativo da temperatura a superfície.

Na figura 5.31 em Barueri, pode-se verificar a implantação de um novo distrito industrial na região de Tamboré, nas encostas do divisor de águas Tietê-Juqueri. Embora o processo de raspagem das áreas a serem ocupadas seja semelhante ao padrão normal de plantas industriais, percebe-se uma implantação menos agressiva ao relevo, buscando um traçado que evitasse as vertentes de maior declividade, diminuindo, assim, a necessidade de grande movimentação de solo. Verifica-se também que as encostas mais íngremes permaneceram arborizadas e recortam as áreas ocupadas pelas construções, introduzindo cunhas de verde que amenizam a paisagem tanto sob o aspecto visual quanto microclimático.

Figura 5.31 - Distrito industrial Tamboré, Barueri/SP.

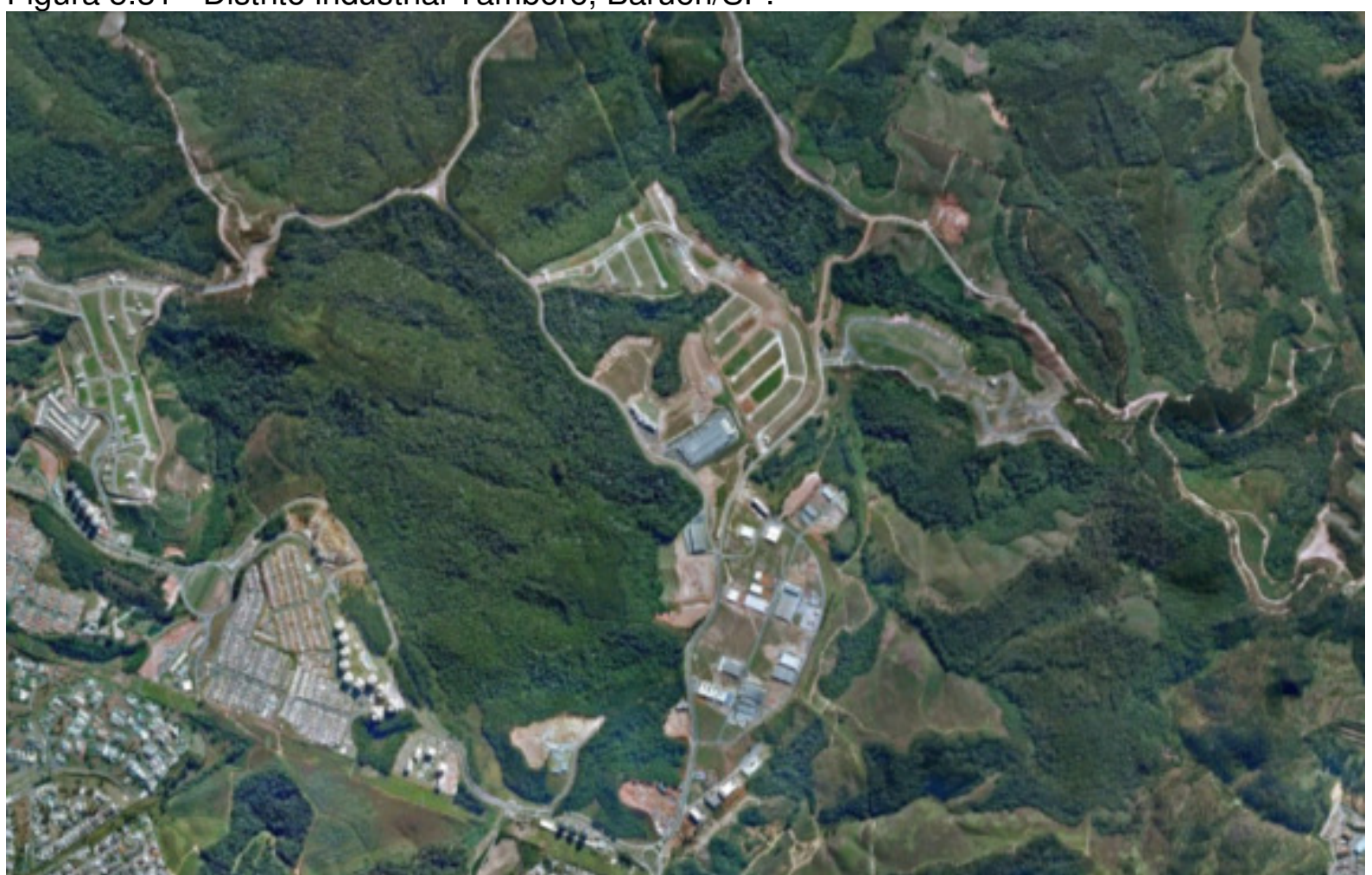

Fonte: Google Earth. Imagem de 04/03/2009

\footnotetext{
${ }^{25}$ Relacionar os estudos de Lombardo, Isa Garland e Tarifa. Citar bibliografia.
} 
A imagem da figura 5.32 demonstra uma outra tipologia comum de tecido de áreas industriais consorciadas a ocupação residencial predominantemente de baixa e média renda. Nessa região entre Cotia e São Paulo, as plantas industriais apresentam um porte menor e uma fragmentação mais intensa. Trata-se de uma área que apresenta uma grande tendência à compactação (conurbação) da mancha urbana. As áreas verdes resultantes apresentam-se intensamente fragmentadas, sem uma lógica de continuidade que possibilite reconhecer as principais linhas da paisagem (rede hídrica, fundos de vale, divisores de águas).

Figura 5.32 - Padrão de ocupação industrial de tecidos urbanos mistos, associados a loteamentos de baixa e média renda, sempre ao longo dos principais eixos viários de acesso a São Paulo/Campinas. Local da imagem: Rod. Raposo Tavares, entre Cotia e São Paulo.

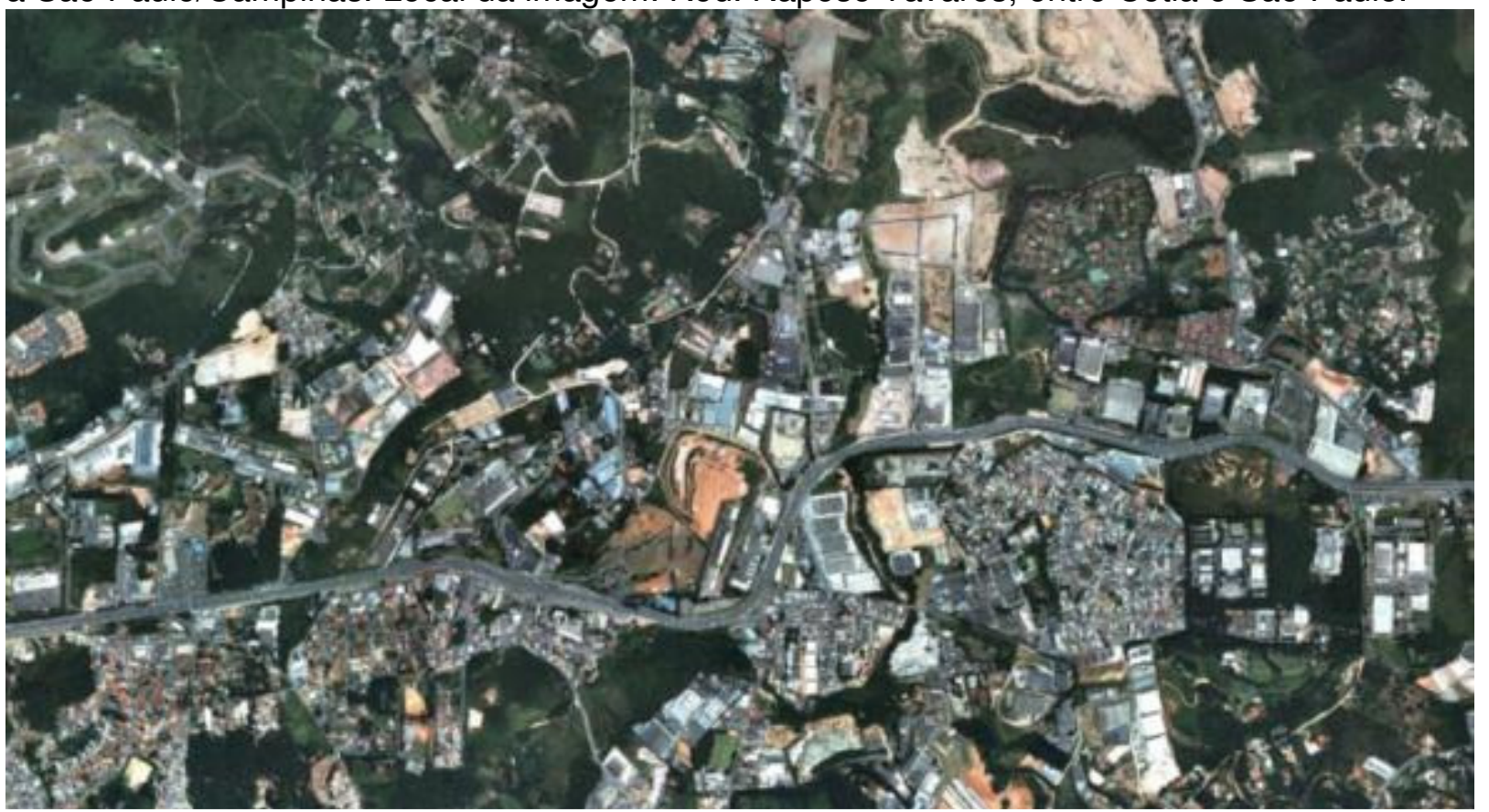

Fonte: Google Earth. Imagem de 17/11/2009

\subsection{O padrão de outras atividades produtivas}

É intensa a atividade de mineração nos arredores da metrópole de São Paulo. Um grande número de pedreiras são exploradas nas regiões dos vetores de expansão urbana e de dispersão da Rod. Castelo Branco, Anhanguera-Bandeirante, Dutra e Fernão Dias. Já nas várzeas do Tietê na região de Itaquaquecetuba é intensa a exploração de areia para construção. Esse produto também é retirado em Santa Isabel, nas áreas de colinas e terraços da Bacia Sedimentar de São Paulo. 
Os dois tipos de exploração provocam grandes marcas na paisagem e intensificam a fragmentação dos espaços rurais e vegetados, quando no entorno dessas áreas se associam outras peças urbanas residenciais e industriais dispersas. Essa atividade extrativa impacta dois setores de paisagem importantes para o equilíbrio ambiental de um território, quando se instalam em várzeas e nas cabeceiras de drenagem serranas.

Figura 5.33 - Pedreiras da mineradora Serveng na região próxima a Aldeia da Serra, Barueri/SP.

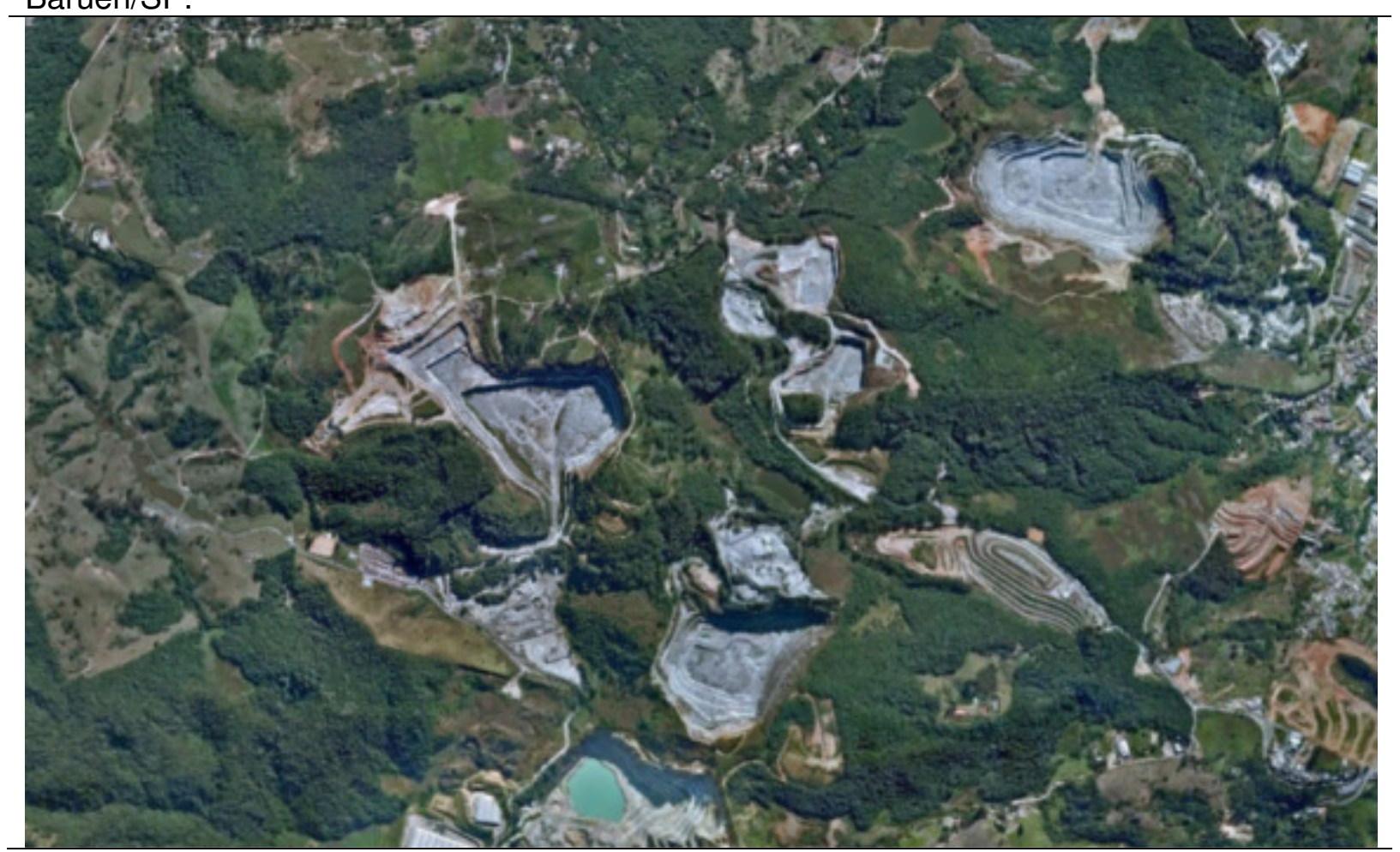

Fonte: Google Earth. Imagem de 17/11/2009 
Figura 5.34 - Áreas de mineração em Santa Isabel, entre Rod. Dutra e Airton Senna.

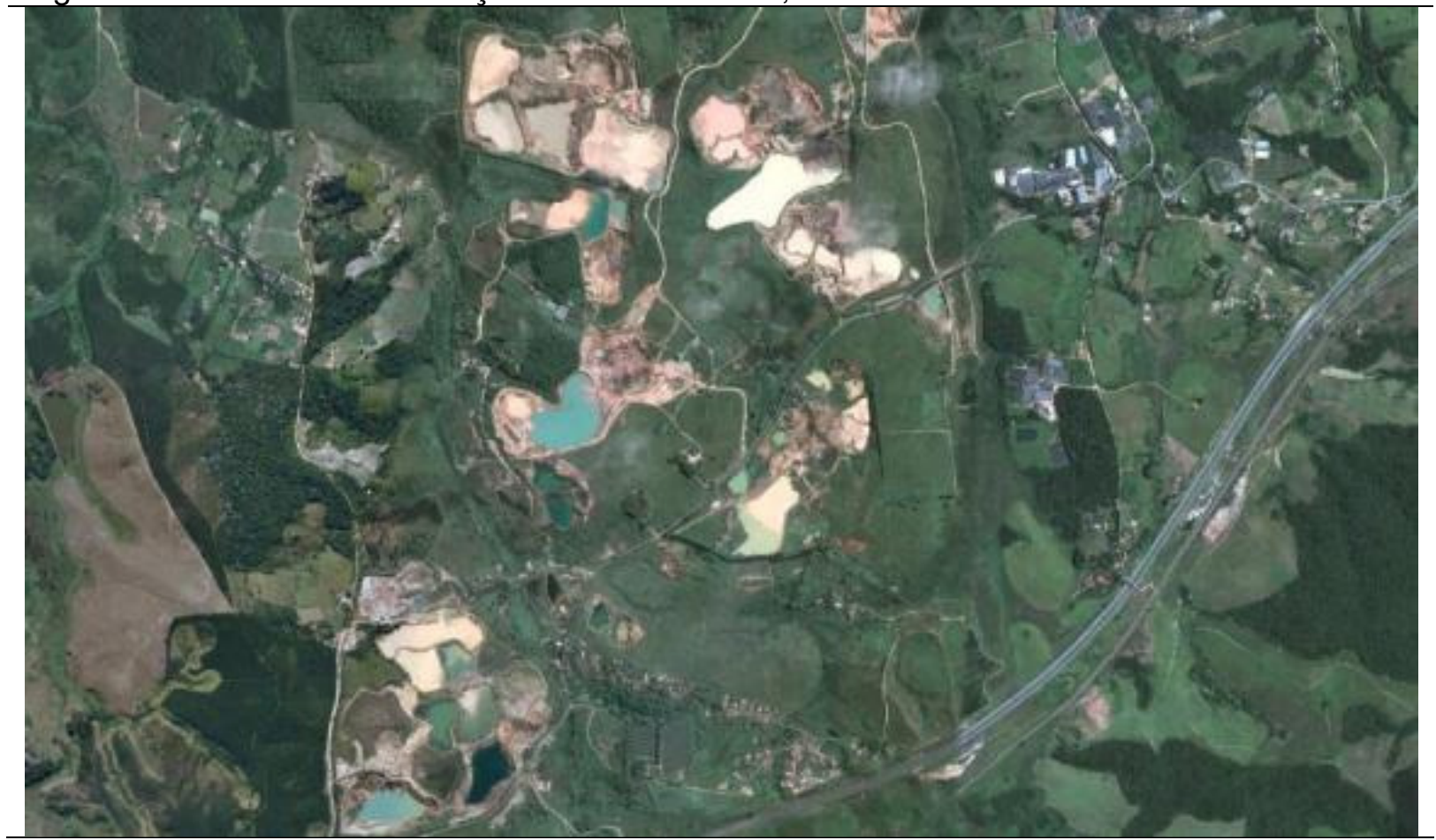

Fonte: Google Earth. Imagem de 04/09/2011

Figura 5.35: Áreas de mineração entre Arujá e Santa Isabel, nos eixos de expansão urbana das rodovias Dutra e Airton Senna.

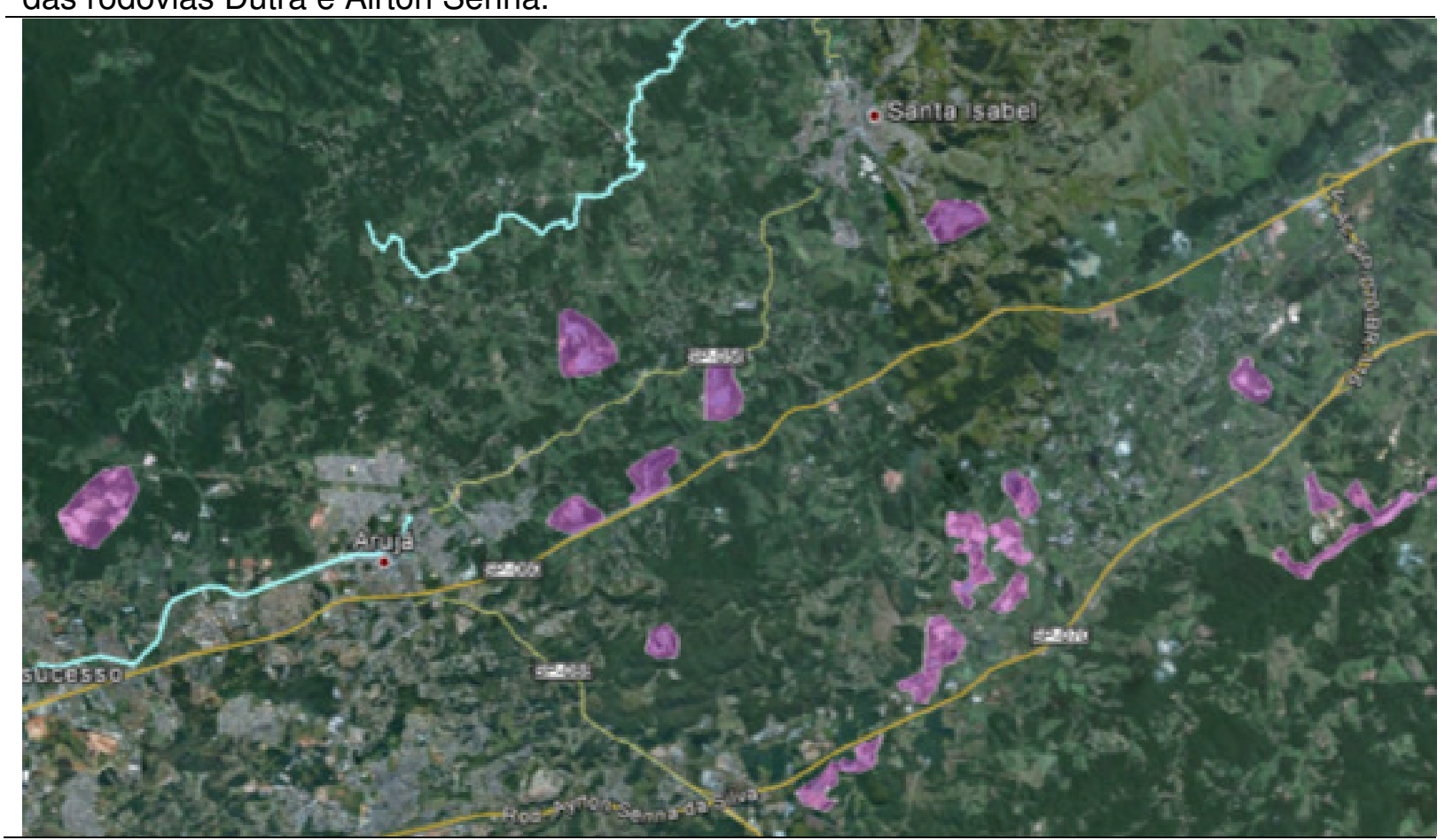

Fonte: Google Earth. Imagem de 04/09/2011 


\subsection{A dispersão das tipologias da cidade compacta}

A verificação dos modelos tipológicos das peças urbanas dispersas na Macrometrópole de São Paulo não deixa dúvidas de que é o padrão tipológico da cidade compacta que se dispersa pelo entorno rural. A semelhança é marcante, em todos os padrões de renda para as áreas residenciais, como nos padrões industriais. A única exceção se refere à tipologia de chácaras, que não ocorre na cidade compacta.

Se considerarmos que os grandes problemas ambientais da cidade compacta, conforme pudemos argumentar na dissertação de mestrado sobre a metrópole de São Paulo, derivam da concentração e adensamento destas tipologias que compõem a morfologia da cidade, pode-se argumentar que o processo atual dispersa o germe de problemas ambientais futuros que se encontram em estado latente em cada uma dessas peças dispersas.

O processo fica evidente em virtude da mesma relação que estes modelos dispersos estabelecem com o ambiente local em relação a 4 fatores:

A relação com o relevo: se o traçado urbano tende a acompanhar as curvas de nível, evitando cortar as áreas de grande declividade, o processo de implantação dos loteamentos continua impondo uma raspagem quase total da superfície, com remoção da vegetação existente e movimentação de corte e aterro das camadas superficiais do solo. Esse processo é mais intenso nas tipologias das peças produtivas industriais. Secundariamente ele se torna relevante em algumasformas tipológicas de baixa renda, dentre elas os conjuntos habitacionais verticais, e os loteamentos em área de morros cristalinos.

$\checkmark$ A relação com as águas: em quase todos os padrões tipológicos das peças urbanas dispersas verifica-se a mesma intensidade de impermeabilização do solo interno do loteamento. Tanto do lote quando das áreas internas do condomínio ou do bairro. Essa impermeabilização traz altera a relação infiltraçãoescoamento superficial pode induzir a ocorrência de enchentes a jusante, e redução mais intensa da vazão de nascentes e cursos d'água durante os meses de estiagem. 
$\checkmark$ A relação com o clima: também decorrente do adensamento construtivo interno das tipologias analisadas, tanto nos condomínios de mais alta renda como nos de baixa renda, inverte-se o padrão de emissividade de calor da superfície pela troca da cobertura vegetal, seja ela arbórea, arbustiva ou herbácea, por uma cobertura artificial de concreto, asfalto e telhas de cerâmica ou fibrocimento. $\mathrm{Na}$ cidade compacta o fenômeno das ilhas de calor sintetizaa alteração dos atributos climáticos que causa desconforto térmico às populações das áreas centrais das cidades. Nas áreas dispersas este é um problema latente, que espera a oportunidade colocada pelo adensamento urbano para se manifestar mais intensamente. Não se pode deixar de considerar, ainda dentro deste fator, a pequena expressividade da arborização interna das áreas das tipologias analisadas, semelhante ao que ocorre nas cidade compacta. Esta relação será tratada com mais detalhe no capítulo $\mathrm{xx}$.

$\checkmark$ A relação com o bioma local: em raros exemplos pode-se verificar a preocupação com a continuidade dos ambientes naturais. A fragmentação é, quase sempre, a regra. Os fundos de vale são seccionados, os principais divisores de água. As massas vegetais ciliares à rede de drenagem e os grandes remanescentes de mata atlântica, como pode muito bem ser observado nas ocupações dos contrafortes da Serra da Cantareira e da Serra do Mar.

Do que foi relatado, conclui-se que, sob a ótica do desenho urbano dos loteamentos dispersos em voga, a relação entre áreas construídas e áreas livres pouco se alterou em relação ao passado (da cidade compacta), bem como esse desenho urbano possa revelar uma nova postura em relação ao meio ambiente, seguindo o discurso atual de sustentabilidade ambiental e de uma melhor relação com os processos naturais.

Portanto, em relação ao conteúdo interno dos loteamentos e condomínios residenciais, e das áreas industriais que se dispersam, a forma de apropriação do sítio urbano continua não considerando fatores importantes para o equilíbrio ambiental da paisagem urbanizada. Se a dispersão urbana, por si só, é o remédio para os problemas ambientais da ocupação urbana, pois evita a conurbação e o adensamento da ocupação de um território, então o problema central colocado se 
dirige para a hipótese de que, em que grau, a tendência à conurbação e à compactação da ocupação urbana persiste. De outro lado, não há, também, uma mensuração da capacidade de carga do território e da natureza local em receber essa ocupação dispersa em seu conjunto.

Esse aspecto será abordado nos capítulos que se seguem. 


\section{A DISPERSÃO URBANA NA MACROMETRÓPOLE DE SÃO PAULO}

A estruturação da macrometrópole tem suas origens na estruturação da Grande São Paulo, bem analisadas nos documentos já mencionados de Aroldo de Azevedo - A Cidade de São Paulo: estudos de geografia urbana, datado de 1958, e de Juergen R. Langenbuch - A estruturação da Grande São Paulo, de $1971^{26 .}$

Segundo Langenbuch, essa estruturação se inicia no período compreendido entre 1875 - 1915, quando o cinturão de vilas e pequenos aglomerados do entorno se reorganiza em função e benefício de São Paulo, que passa a demandar produtos para o seu crescimento. Os vínculos funcionais se estreitam. A instalação ou ampliação de novas atividades econômicas visando o mercado da capital, baseadas na exploração dos recursos naturais locais (extrativismo mineral e vegetal, indústria de beneficiamento dos mesmos), se instalam nos arredores de São Paulo. Núcleos coloniais oficiais foram estabelecidos (São Caetano e São Bernardo) e as condições topográficas e hidrográficas favoreceram a instalação de equipamentos hidráulico e hidrelétrico (Represa Guarapiranga, Usina de Santana de Parnaíba). Órgãos militares se instalam próximos à capital, no município de Osasco. A capital impulsiona o repovoamento dos arredores, através de sua expansão centrífuga e da reorganização do espaço que promove e enseja.

A ferrovia, já implantada desde a década de 1870, funciona como instrumento dessa reorganização dos arredores de São Paulo, embora tivesse provocado o colapso do antigo sistema de transporte e das atividades a ele relacionadas. Por seguir trajeto diferente das antigas estradas provoca uma relativa desvalorização das áreas beneficiadas pelas mesmas, abrangendo grande número dos aglomerados preexistentes. Valorizou, dessa forma, as áreas que passou a servir. Ospovoados surgidos no entorno da estação ("povoados-estação") cresciam fazendo surgir o embrião das futuras cidades de São Caetano, Santo André, Mauá, Itaquera, Mogi das Cruzes, Osasco, Carapicuíba, Barueri,e de bairros de São Paulo como Itaquera; enquanto os aglomerados apartados da linha, de um modo geral,

\footnotetext{
${ }^{26}$ Ver também Richard M. Morse, “De Comunidade a Metropóle - Biografia de São Paulo", de 1954, publicado pela Comissão do IV Centenário da Cidade de São Paulo, em que o autor analisa a formação histórica de São Paulo pela ótica do planejamento urbano e da industrialização.
} 
estagnavam, casos de Embu, Itapecerica, Cotia, S. Bernardo, S. Miguel, Itaquaquecetuba, Guarulhos, Parnaíba.

Durante este período é que se definem as vocações de inúmeros setores dos arredores paulistanos, que posteriormente iriam influir, decisivamente, nas formas que assumiria a expansão metropolitana. As ferrovias conferiram às estações ferroviárias uma vocação de polarização da industrialização e do povoamento suburbano.

Figura 6.1: Arredores de São Paulo em meados do Século XIX.

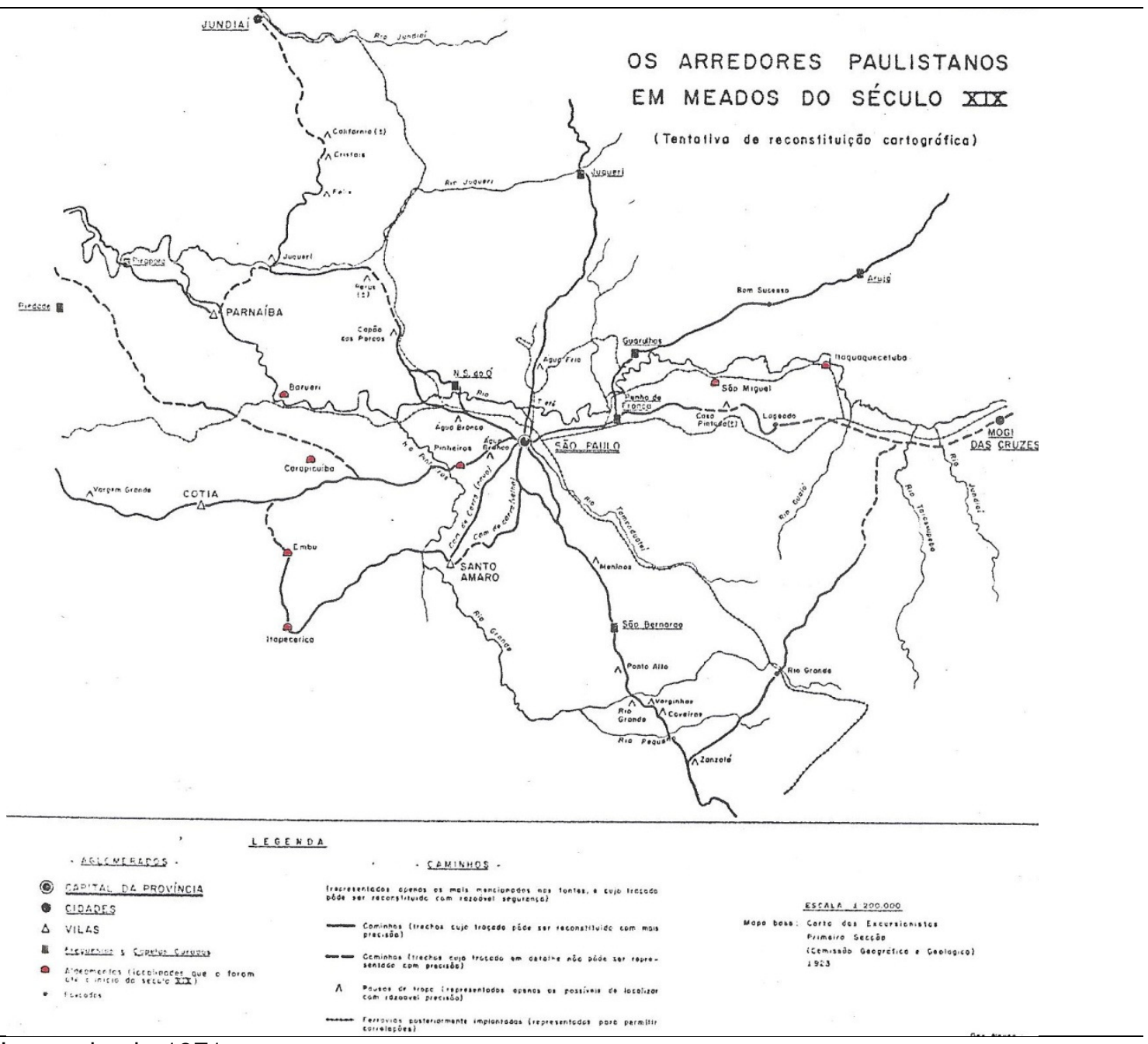

Fonte: Langenbuch, 1971.

No quadrante norte da cidade de São Paulo, a área compreendida entre Perus e a Estação Juqueri (atual Franco da Rocha) se especializa no extrativismo mineral, na fabricação de papel e cura psiquiátrica (Hospital de Juqueri), em face da proximidade da área serrana (Serra da Cantareira, Serra do Juqueri e Serra do 
Boturuju). Nos contrafortes da Cantareira também se definiu pela vocação de subúrbio hospitalar e recreativo, funções que a área ainda conserva, em parte.

No quadrante oeste, como já mencionado, na região de Osasco, cortada pela E.F. Sorocabana, são instalados os primeiros estabelecimentos militares, abrindo o caminho para a situação atual, em que grandes trechos da área pertencem ao exército; além do embrião de um subúrbio industrial.

A sul, a construção da Represa Guarapiranga, afogando as várzeas do rio, assentadas sobre terrenos da Bacia Sedimentar de São Paulo, firmou definitivamente a função recreativa dos arredores de Santo Amaro, que foi reforçada pela instalação do tramway elétrico. Ambos os empreendimentos conferiram forte vocação suburbana a Santo Amaro.

Já no quadrante Sul, a ferrovia comandou o surgimento dos subúrbios industriais de Santo André (então Estação S. Bernardo) e em escala menor, mas ainda expressiva, em São Caetano. Ribeirão Pires se definia como área de extrativismo e indústria oleira, característica que ainda se conserva, apesar da mais recente superposição das funções industrial e residencial.

Mesmo que ainda incipientes os aglomerados surgidos no entorno das estações e que datam desse período foram os seguintes: Pirituba, Taipas (hoje Jaraguá), Perus, Caieiras, Estação Juqueri (Franco da Rocha), Campo Limpo (da zona norte) e Várzea (hoje Várzea Paulista), situados no percurso que entremeia os morros, serras e colinas do Planalto Atlântico; e Barueri, Estação Cotia (hoje Itapevi), Itaquera, Poá, Guaió (hoje Suzano), São Caetano do Sul e São Bernardo (hoje Santo André), implantados no setor de terraços de várzeas dos rios Tietê e Tamanduateí; alé de Ribeirão Pires, Rio Grande (da Serra) e Paranapiacaba, já novamente ao longo de vales do Planalto Atlântico, nas proximidades da Serra do Mar.

Muitos destes povoados abrigariam também uma função industrial de beneficiamento e transformação de matérias primas extrativas (serrarias, móveis, cerâmica, cimento, cal, pedras, papel, etc.). O número de indústrias fora do núcleo principal foi diminuto, mas ocorreu em Osasco (tecido e frigorífico); São Caetano (sabão, graxa, velas); S. André (têxteis). 
Em termos residenciais de instalação da mão de obra necessária ao crescimento da cidade a função de subúrbio dormitório ainda é incipiente. A expansão residencial ainda se dava nos diversos loteamentos dispersos, que se ocupavam vagarosamente, ligados ao núcleo central por meio de bondes que possuíam maior disponibilidade de horários e trafegavam sem congestionamentos. Os trens de subúrbio ainda não haviam se generalizado (somente em 1911 ele chega até Mogi).

É no período 1915-1940 que, para Langenbuch, a metropolização dos arredores paulistanos vai ganhar impulso. Os vazios deixados pela anterior onda de dispersão de loteamentos seráocupado. Acentua-se o crescimento horizontal e periférico, não obstante ainda que vários loteamentos permanecerão desocupados à espera de valorização, continuando a manter separados bairros já estruturados.

Neste período aparecem os primeiros bairros-jardim, com o aproveitamento para fins residenciais de áreas rejeitadas anteriormente por ter topografia acidentada (Pacaembú e outros) ou se localizar em fundos de vale e nas várzeas, como ocorreu na Vila Maria, a primeira ocupação residencial do compartimento de várzeas do Rio Tietê. A tendência de industrialização dos terrenos dos baixos terraços e várzeas contíguos às ferrovias se manteve na cidade de São Paulo, principalmente entre as estações Lapa e Ipiranga. A Ferrovia Santos-Jundiaítorna-se no mais importante instrumento de suburbanização residencial, transportando cada vez mais operários.

Fato importante deste período foi o andamento da retificação e "saneamento", como se dizia à época, das várzeas do Tietê e Pinheiros, e a controversa enchente de 1929, como bem documentou Odete Seabra (1987) em "Os meandros dos rios nos meandros do poder - Tietê e Pinheiros: valorização dos rios e das várzeas na cidade de São Paulo" sobre a vinculação de interesses imobiliários, de empresas de ônibus e dos negócios da Ligth com energia.

Uma grande especulação imobiliáriapromove nova onda de dispersão de loteamentos residenciais suburbanos a certa distância da cidade compacta, ainda não necessários à expansão urbana da cidade, pois permanecem vazios ou com incipiente ocupação durante todo o período analisado. Somente os mais próximos às estações têm uma ocupação maior, e os situados ao longo da linha de Santo Amaro, 
evidenciando o crescimento para este vetor sul da cidade. Nesse sentido formam-se nítidos e definidos subúrbios industriais e residenciais. São Caetano e Santo André se firmam como a mais importante área suburbana de São Paulo.

As ferrovias continuam como os grandes eixos de desenvolvimento suburbano, apesar do progresso do transporte rodoviário, que participa do desenvolvimento suburbano como meio de transporte supletivo e complementador de percursos. A maiores distâncias, a circulação rodoviária ainda não gera subúrbios, mas originou ou revigorou os povoados-entroncamento da rede de circulação já existentes.

No meio rural forma-se um verdadeiro cinturão verdeou hortifrutigranjeiro de São Paulo, com desenvolvem inúmeras atividades agrícolas diretamente voltadas para o abastecimento de São Paulo como a horticultura, a fruticultura e floricultura, que se intensificam e se diversificam, e em muitos lugares permanecem até hoje.

No período seguinte, analisado por Langenbuch, de 1940 a 1970, é que se dá o intenso crescimento da cidade em área e em população. Basta dizer que a cidade cresce pula de um crescimento médio anual de população em torno de $90 \mathrm{mil}$ pessoas/ano na década 1940-50, para 220 mil na década de 1960-70. Acontece a compactação da cidade já urbanizada em 1940 e a proporção dos lotes não ocupados diminui sensivelmente, e ao mesmo tempo inicia-se a conurbação do tecido urbano de São Paulo com os vizinhos São Caetano, Santo André e São Bernardo.

A ferrovia continua a gerar novos subúrbios, enquanto os já existentes crescem extraordinariamente conservando a original polarização em torno da estação ferroviária, mas o ônibus passa a ter um papel cada vez mais destacado na circulação rodoviária e acentua-se a criação de novos subúrbios.

O surgimento dasauto-estradasfacilita o acesso a Guarulhos e São Bernardo, anteriormente não servidos pela ferrovia, passam a funcionar como os novos eixos de desenvolvimento suburbano em escala regional, mas não a distâncias tão grandes quanto o propiciado pelas ferrovias. Impulsionaram também a uma grande industrialização em suas bordas. 
O mapa da Figura 6.2 ilustra o esquema do desenvolvimento rodoviário no período, a partir do mapa do DER de 1951, que interliga, radialmente,toda as cidades polarizadas por São Paulo. Notar que o fluxo na direção de Campinas ainda não é tão intenso relativamente, em comparação com outras regiões, como o é hoje. Os eixos estruturantes da dispersão urbana atual já estão estabelecidos nesse período, salvo ligações complementares, como as rodovias Bandeirantes, Trabalhadores, Castelo Branco e Imigrantes.

Figura 6.2: Linhas de transporte coletivo rodoviário que se irradiam de São Paulo, 1951.

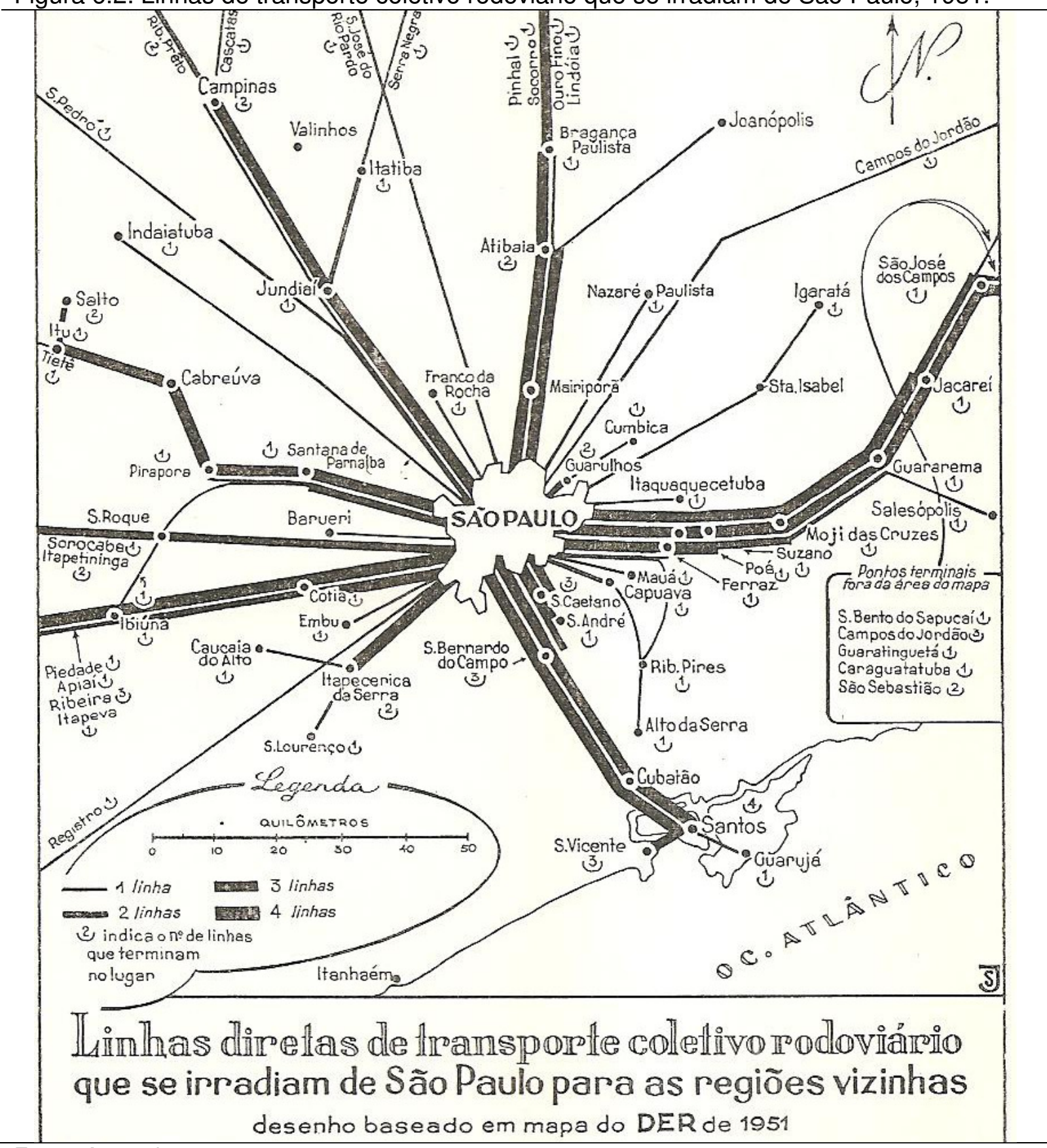

Fonte: Azevedo, 1958. 
Surgem os primeiros grandes conjuntos habitacionais de iniciativa oficial ou particular, que também promovem a urbanização periférica e a dispersão urbana. As grandes cidades da macrometrópole apresentam um crescimento extraordinário neste período e isso poderá ser verificado nos capítulos seguintes.

De outro lado, é importante destacar que no meio rural o cinturão hortifrutigranjeiro se amplia, aliado a uma notável expansão do reflorestamento de eucalipto e do desmatamento das florestas nativas.

\subsection{A Macrometrópole de São Paulo}

A área de estudo da pesquisa abrange a região aqui denominada de macrometrópole paulista, que engloba as regiões metropolitanas de São Paulo e Campinas, e as aglomerações urbanas de São José dos Campos, Sorocaba e Jundiaí. Além dessas, foram incluídas dentro do perímetro de investigação da dispersão urbana municípios próximos a essas regiões que fazem parte dos eixos rodoviários de dispersão, como a região de Atibaia, de Bragança Paulista, de Itu e do município de lbiúna.

O Mapa da Figura 6.3 ilustra o recorte territorial adotado nesta investigação. Mais do que considerar os recortes regionais e administrativos adotados pelo Governo do Estado de São Paulo, como a regiões metropolitanas e aglomerações urbanas oficializadas, a macrometrópole aqui considerada incluiu essas unidades regionais citadas e os municípios do entorno que se estendem ao longo dos eixos rodoviários que interligam essas aglomerações.

Assim, foram considerados, ao todo, neste estudo 87 municípios, sendo 38 correspondentes à R.M. de São Paulo, 19 da R.M. de Campinas, 10 da A.U de Sorocaba, 6 da A.U. de Jundiaí e 6 da A.U. de São José dos Campos. Além destes foram estudados mais 8 municípios do entorno não inseridos nessas aglomerações.

O termo "Macrometrópole" é ainda pouco preciso, e é utilizado segundo variados recortes territoriais. Na década de 1970, Maria Adélia de Sousa (1978, p.25) já empregava esse termo para designar a união das regiões metropolitanas de 
São Paulo e Campinas, embora esta segunda ainda não estivesse regulamentada na legislação federal.

Por "Metrópole" costuma-se designar uma grande cidade que possui os melhores equipamentos urbanos do país (metrópole nacional), ou de uma grande região do país (metrópole regional), e que polariza intensamente a vida socioeconômica do entorno, que pode abranger tanto as escalas regionais ou nacional. Pode-se apresentar conurbada com outras cidades territorialmente vizinhas ou não. Já o termo Região Metropolitana corresponde ao conjunto de municípios conurbados a uma metrópole e que desfrutam de infraestrutura e serviços em comum. No Brasil as regiões metropolitanas são regulamentadas por leis federais (constituição de 1988) ${ }^{27}$, embora, conforme Milton Santos (2009, p. 84), "o fenômeno de metropolização vai muito além da denominação legal". Hoje cada Estado define seus critérios específicos para regulamentar essas regiões, com a finalidade de articular um melhor processo de gestão metropolitana, tendo em vista as imbricações e implicações do uso compartilhado de infraestruturas e serviços públicos de interesse comum, que podem ser enfrentados a partir de uma perspectiva regional.

As regiões metropolitanas tem como ponto comum dois elementos essenciais, segundo Milton Santos (2009, p.84): a) são formadas por mais de um município e o considerado principal lhe dá o nome; b) são objeto de programas especiais de nível federal e estadual o que lhes proporciona recursos para projetos setoriais. São, assim, regiões de planejamento, e a perspectiva de acessar novos recursos tem acirrado, recentemente, os processos de criação dessas regiões, segundo critérios diversos que tem mais se prestado a descaracterizar o conceito até aqui adotado. Basta citar as regiões de Santarém (PA), Macapá (AP), Grande Teresina (PI), NorteNordeste Catarinense (SC), Cuiabá (MT), dentre outras que se pode visualizar no mapa da Figura 6.3. Em termos populacionais as atuais regiões metropolitanas do Brasil variam de 200 mil (RM Guarabira/PB) a 20 milhões de habitantes (São Paulo).

\footnotetext{
${ }^{27}$ A Constituição Federal de 1988 deixa a cargo dos estados a instituição de Regiões Metropolitanas, por meio de leis complementares. A definição legal é que as regiões metropolitanas seriam "constituídas por agrupamentos de municípios limítrofes, para integrar a organização, o planejamento e a execução de funções públicas de interesse comum". A finalidade é gerir os recursos econômicos e sociais do estado e realizar tarefas públicas que exigem a cooperação entre os municípios, como os serviços de saneamento básico e de transporte coletivo, legitimando, em termos político-institucionais, sua existência. Fonte: Parágrafo 3 do Art. 25 da Constituição de 1988.
} 


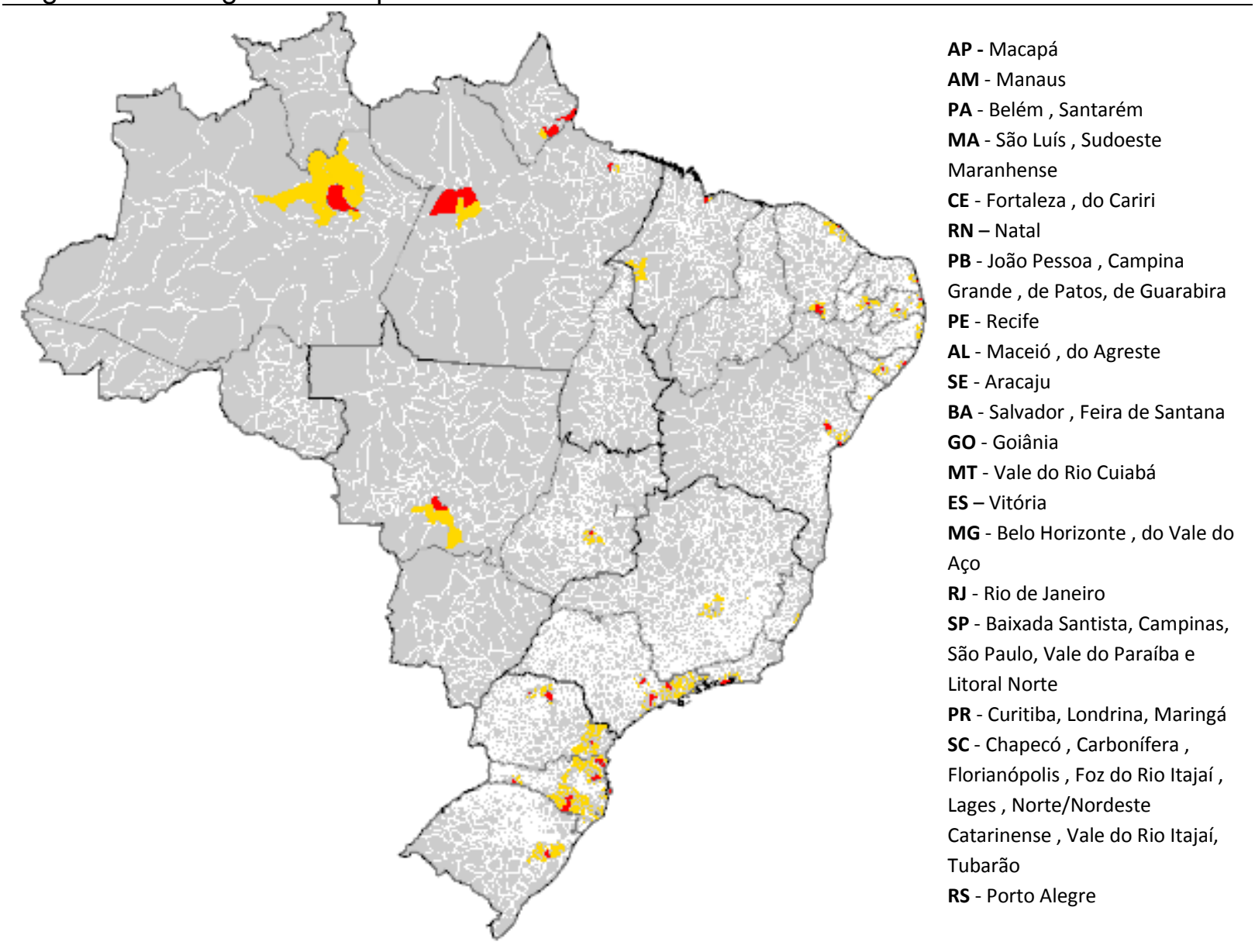

Fonte: Wikimedia Commons

O conceito de Aglomerações Urbanas também foi introduzido pela Constituição Federal de 1988, juntamente com os conceitos de regiões metropolitanas e de microrregiões, e também com a finalidade de planejamento e execução de funções públicas de interesse comum (Braga, 2005, p. 2250).Por aglomeração urbana entende-se constituída por um espaço urbano contínuo, resultante de um processo de conurbação ainda incipiente, e onde se verifica o embrião deste processo de conurbação e intensificação de relações.

Em São Paulo, segundo dados da Emplasa (2011, p. 36), estão instituídas três regiões metropolitanas (São Paulo, Campinas e Baixada Santista) e dez aglomerações urbanas (Ribeirão Preto, São José do Rio Preto, Araraquara/São Carlos, Sorocaba, Bauru, Araçatuba, Jundiaí, Mogi Guaçu/Mogi Mirim, Piracicaba). 
Figura 6.4 - Configuração da Macrometrópole Paulista em 1992, segundo a Emplasa.

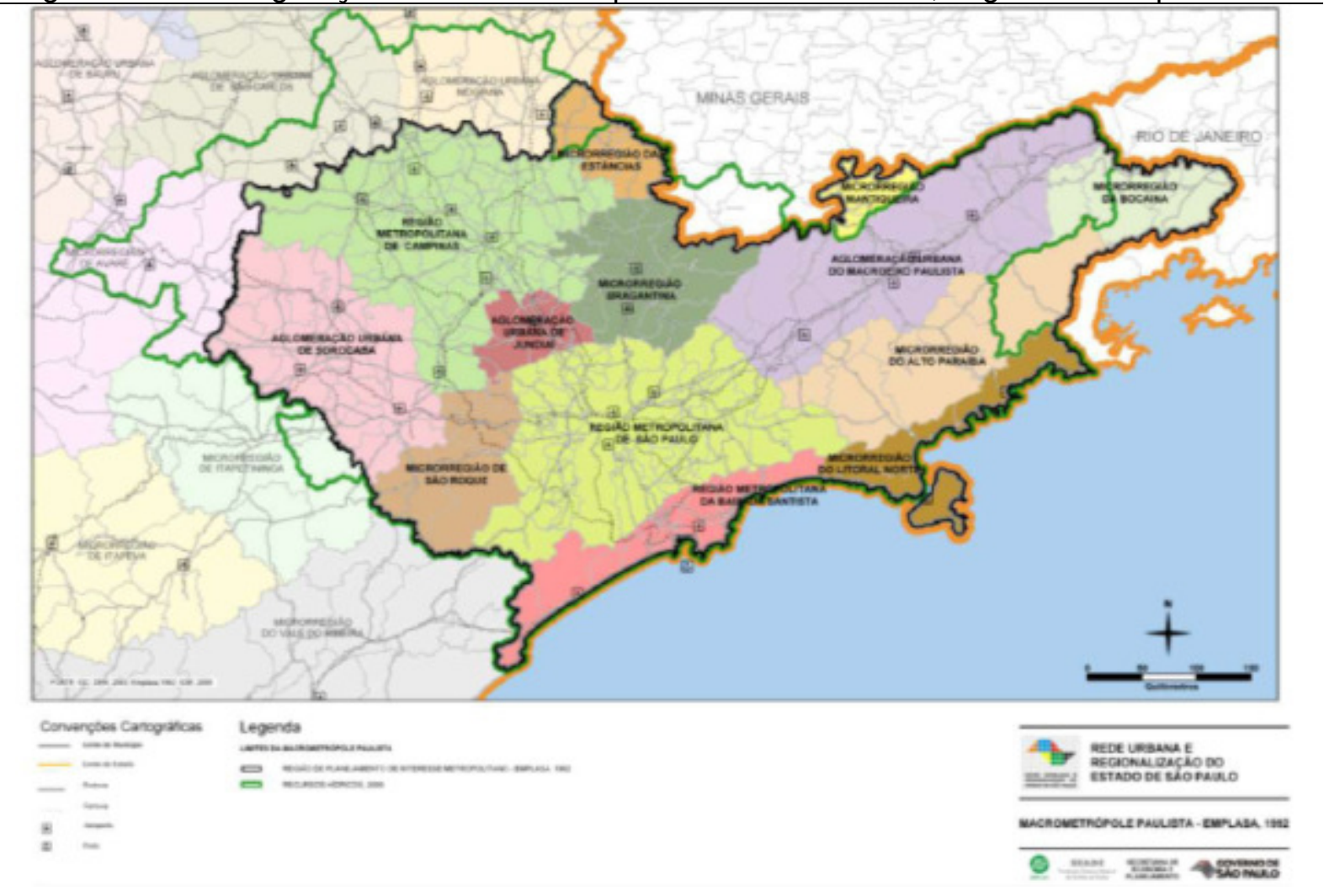

Fonte: Emplasa, 2011.

A Emplasa (2011), juntamente com o Seade, nos estudos sobre a regionalização do Estado de São Paulo e sobre a rede urbana paulista já vêm se referindo desde a década de 1990 sobre a constituição de uma Macrometrópole Paulista. Em 1992 a Emplasa considerava-a, como delineado no mapa da figura 6.4, envolvendo toda a porção nordeste do Estado incluindo as atuais regiões metropolitanas de São Paulo, Campinas e da Baixada Santista, mais as aglomerações urbanas de Jundiaí, Sorocaba, e as microrregiões de São Roque, das Estâncias, do Litoral Norte, da Mantiqueira, Bragantina e da Bocaina.

Nos recentes estudos realizados entre 2009 e 2011 a Emplasa (2011, p. 110) e o Seade reforçam a identificação do que consideram este novo fenômeno:

"[...] a Macrometrópole Paulista, que é o mais amplo e complexo sistema de cidades do País, consolidado nos últimos 10 anos. Na Macrometrópole, tudo é superlativo. São 153 municípios, que concentravam, no final da primeira década dos anos 2000, 72\% da população estadual, $80 \%$ do Produto Interno Bruto (PIB) paulista e $27 \%$ do PIB brasileiro, além de abrigar $50 \%$ da área urbanizada do Estado. Ali estão situadas as três Regiões Metropolitanas paulistas - São Paulo, Campinas e Baixada Santista -, as aglomerações 
urbanas de São José dos Campos, Sorocaba, Jundiaí e Piracicaba, além das microrregiões de Bragantina e São Roque, todas elas com elevada influência do polo principal, o Município de São Paulo. A Macrometrópole, identificada como um fenômeno urbano-regional complexo, reúne conjuntos de aglomerações urbanas e centros articulados em rede em um único processo de relações econômico-sociais. Para os especialistas, trata-se de um novo desenho urbano o uma nova escala de metropolização." (Ver Mapa da figura 6.5)

Dessa forma, a nova delimitação adotada restringe um pouco o espaço daquilo que se considerou em 1992, separando regiões de menor densidade e de relações menos intensas com as principais aglomerações da macrometrópole como São Paulo, Campinas e São José dos Campos, e inserido no contexto a Aglomeração Urbana de Piracicaba, em face da intensificação das relações e interdependência desta com a Região Metropolitana de Campinas.

Figura 6.5 - Configuração da Macrometrópole Paulista em 2011, segundo a Emplasa.

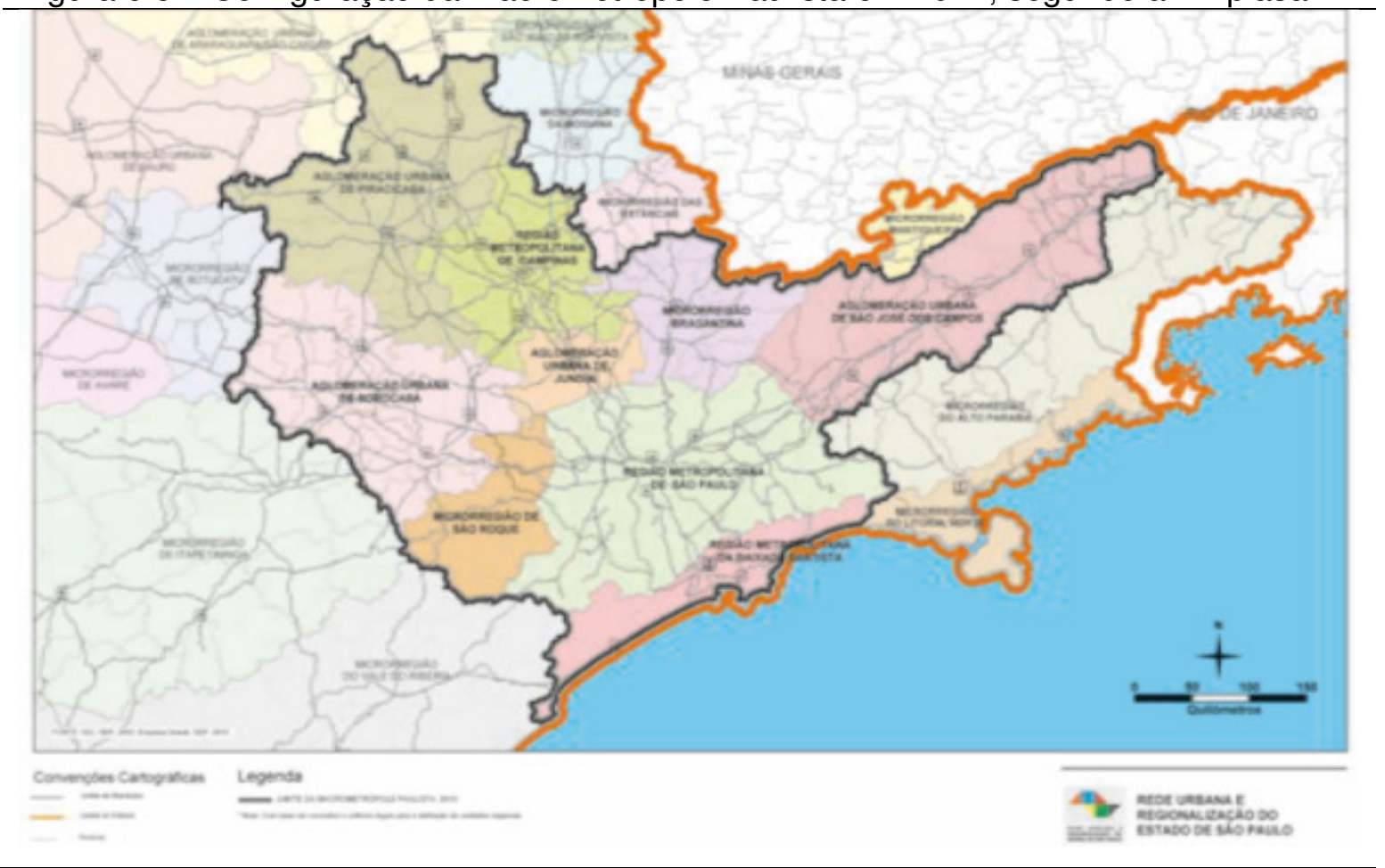

Fonte: Emplasa, 2011.

Como se pode ver, os recortes propostos para os limites da Macrometrópole ainda são divergentes, pois se ajustam aos horizontes de análise de temas específicos ou setoriais. Portanto, neste trabalho, embora tenhamos nos pautado pela regionalização adotada pelo governo de São Paulo, o recorte territorial da pesquisa também adotou uma perspectiva específica, restringindo a abrangência do 
trabalho aos municípios da Macrometrópole Paulista, definida pela Emplasa, em que efetivamente o fenômeno da dispersão urbana pode ser verificado com maior nexo causal com a influência das metrópoles de São Paulo e Campinas por meio dos principais eixos viários de dispersão.

Figura 6.6 - Área de estudo: Macrometrópole de São Paulo.

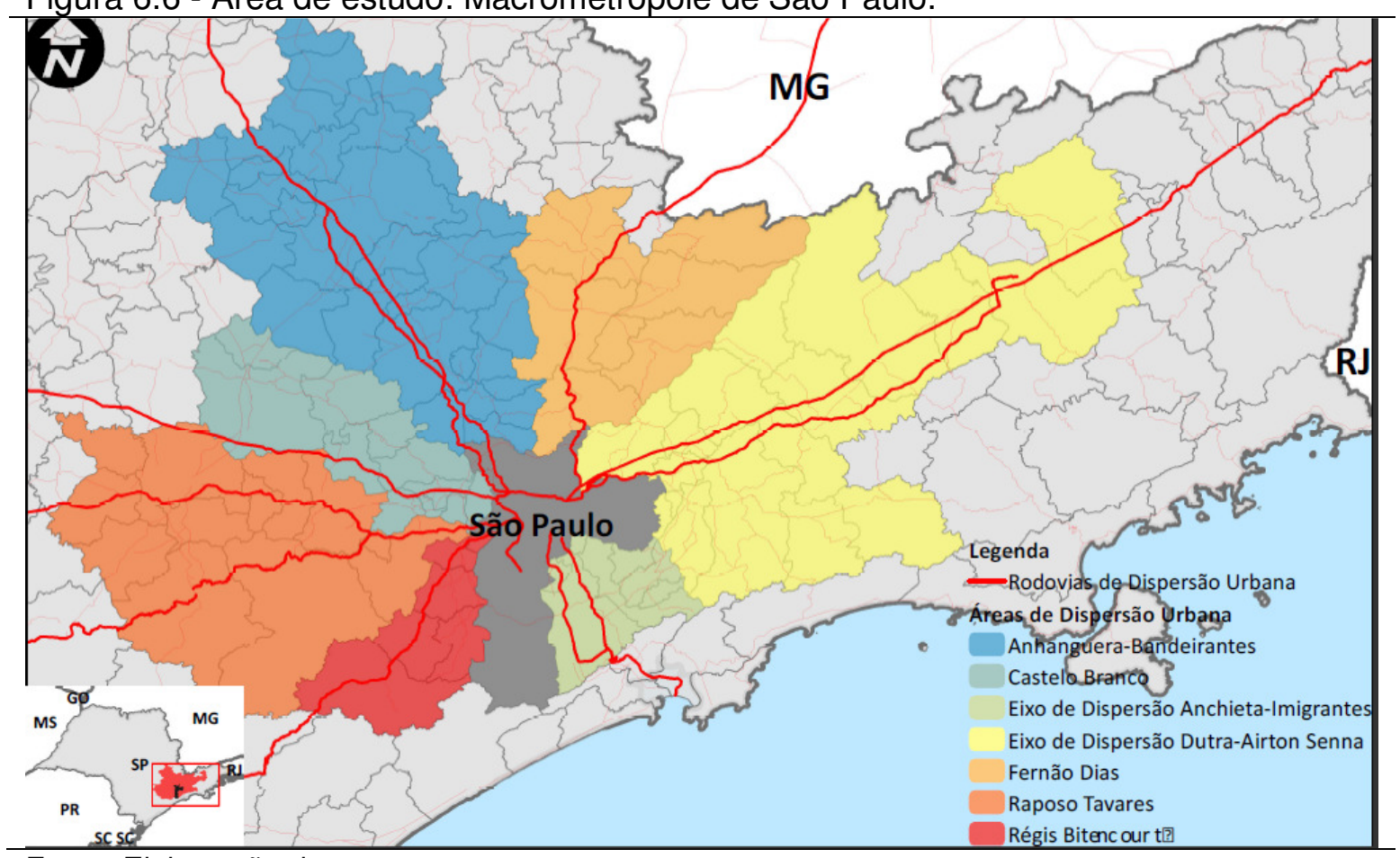

Fonte: Elaboração do autor

A figura 6.6 mostra a área de estudo adotada neste trabalho. Como mencionado, o critério adotado nessa delimitação derivou mais precisamente da observação da realidade do fenômeno de dispersão estampado nesse território de influência das cidades de São Paulo, Campinas e São José dos Campos. A observação e identificação das peças urbanas dispersas ao longo dos eixos viários, e sua intensidade de ocorrência foi a metodologia adotada para agrupar os municípios deste estudo. Foram os grandes hiatos de ocorrência da dispersão nos eixos rodoviários analisados e a distância relativa, que sugeriram o recorte territorial adotado. 
6.1.1. Método de identificação do fenômeno e análise da dispersão.

A caracterização e análise da dispersão urbana será feita tomando-se em conta os principais eixos rodoviários da dispersão. As tipologias de uso do solo serão simplificadas a fim de representar apenas o necessário para se analisar as formas de apropriação do relevo pelas peças urbanas dispersas. Assim, as atividades produtivas foram divididas em apenas três categorias, sendo que as atividades industrial, comercial e serviços (cor vermelha no mapa) foram agrupadas na categoria "áreas produtivas polarizadoras", pois atraem e demandam deslocamentos da população. Destacou-se também atividades industriais que apresentam rigidez locacional e tendem a ocorrer predominantemente nas áreas rurais, como a mineração de diversos produtos extrativos (cor lilás). Outra atividade que mereceu destaque foi a silvicultura (reflorestamento comercial), em vista de sua importância em determinados setores da macrometrópole (cor verde escuro).

As áreas urbanas e as peças urbanas residenciais dispersas foram divididas em apenas três categorias. As áreas da cidade compacta, que corresponde à sede municipal, estão distinguidas pela cor laranja. As áreas que configuram loteamentos típicos de padrão urbano de média e baixa renda da cidade compacta estão representadas com a cor amarela.Já as peças urbanas que representam os loteamentos típicos da expansão da segunda residência, ou ainda da primeira residência dentro do conceito de condomínio fechado, portanto, representando o padrão construtivo e urbanístico para as classes de renda média-alta e alta, estão destacadas das demais peças urbanas citadase representadas nos mapas pela cor verde claro.

Para essa configuração da dispersão urbana na macrometrópole paulista utilizou-se como base as imagens recentes do Google Earth(2010-2011) realçando as informações relevantes por meio de polígonos e caminhos. Dessa forma, foi possível destacar por meio dos polígonos a mancha urbana compacta e a dispersão das peças urbanas pelo território, bem como os principais elementos estruturantes do relevo como a rede hídrica principal e os principais divisores de água. Para a identificação das cotas de altitude foram utilizadas a cartografia disponível citada na bibliografia bem como a ferramenta disponibilizada no Google Earth. 
A imagem da figura 6.7 mostra a área de estudo com todas as camadas de ocupação urbana e hidrografia conforme reconhecidas nas imagens do Google Earth. Embora a escala não nos permita visualizar melhor, pode-seperceber que os pontos mais claros ou iluminados na imagem se referem às peças urbanas dispersas e quando mais agrupadas ou compactas formam as sedes dos municípios de estudo, ou seja, a área urbana da cidade compacta, representadas na cor laranja.

Figura 6.7 - Dispersão Urbana na macrometrópole paulista

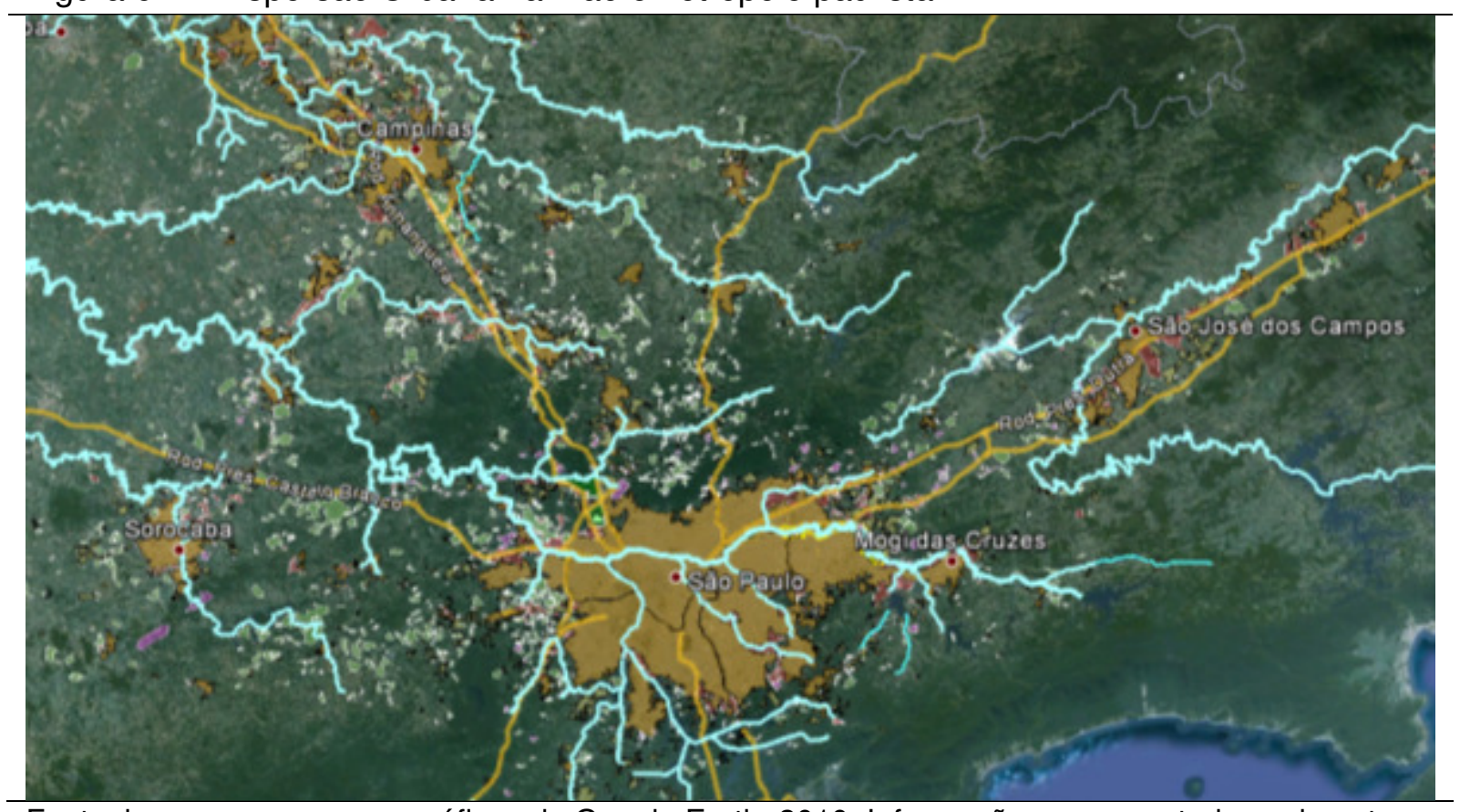

Fonte: imagem e recursos gráficos do Google Earth, 2010. Informações acrescentadas pelo autor.

\subsection{Os eixos da Dispersão Urbana}

\subsubsection{Os vetores da dispersão}

Verificando-se a disposição das peças urbanas que se dispersam em torno dos principais núcleos urbanos da macrometrópole fica evidente que essa dispersão está literalmente estruturada pelos principais eixos rodoviários que interligam esses centros - São Paulo, Campinas, São José dos Campos, Sorocaba e Santos. Percebem-se duas grandes estruturas radiais que se configuram em São Paulo e Campinas, sendo que cada uma delas produzem anéis que interligam esses eixos a partir de um afastamento relativo de seus núcleos. 
Assim, pode-se distinguir que de São Paulo partem os eixos de dispersão pelas rodovias Anhanguera (SP 330)-Bandeirantes (SP 348), Castelo Branco (BR 374), Raposo Tavares (SP 270), Regis Bittencourt (BR 116), Anchieta (SP 150)Imigrantes (SP 160), Dutra (BR 116)-Airton Senna (SP 070) e Fernão Dias (SP 010). De Campinas partem eixos em direção a São Paulo, as mesmas AnhangueraBandeirantes; a São José dos Campos - rodovia Dom Pedro I (SP 065); a ItuSorocaba - SP 075; a Jaguariúna (SP 340); a Paulínea/Cosmópolis (SP 332); a Americana/Santa Bárbara - o mesmo sistema Anhanguera-Bandeirantes.

Quanto aos anéis de interligação desses vetores destacam-se no sistema radial de São Paulo a rodovia Índio Tibiriçá (SP 031) que liga a Anchieta a Mogi das Cruzes e ao eixo Dutra; o próprio Rodoanel São Paulo. Deve-se destacar também o papel de ligação que as rodovias SP 075 (Campinas-Itú/Sorocaba) e Dom Pedro I (SP 065) representam para a interligação dos eixos Fernão Dias, Dutra, Anhanguera-Bandeirantes, Castelo Branco e Raposo Tavares.

Figura 6.8 - Vetores principais da dispersão urbana na macrometrópole paulista.

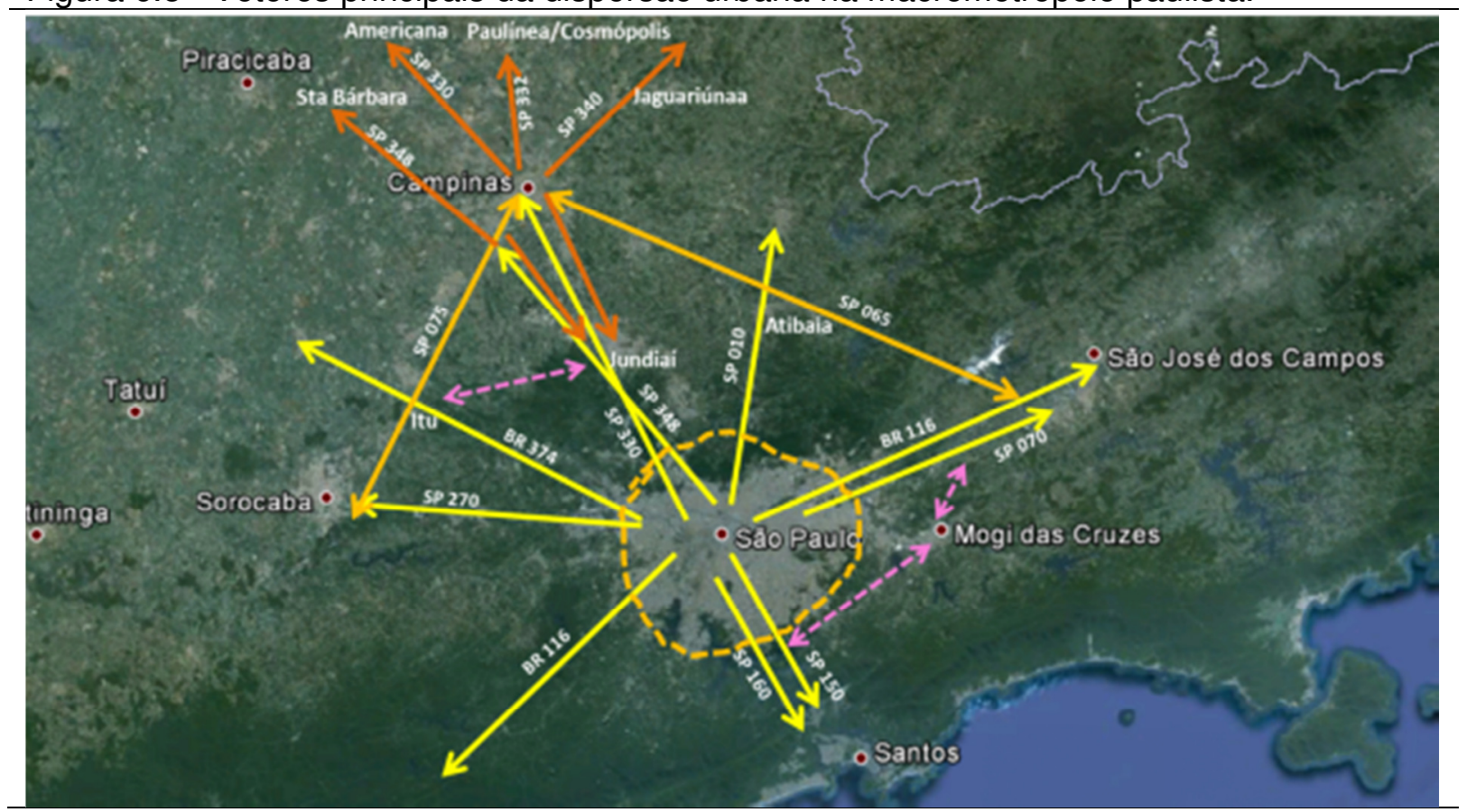

Fonte: imagem e recursos gráficos do Google Earth, 2010. Informações acrescentadas pelo autor.

Interdigitadas por rodovias de menor porte, esse é o sistema de mobilidade da macrometrópole de São Paulo por onde hoje de deslocam as funções urbanas de 
que dispersam das cidades compactas da rede urbana desta porção do estado de São Paulo.

\subsubsection{A morfologia geral da dispersão}

Em uma primeira aproximação do reconhecimento da realidade da dispersão em cada eixo rodoviário analisado podemos realçar a grande presença dos condomínios fechados e loteamentos para as camadas de mais alta renda. Eles formam o conjunto de peças ou ocupação urbana que mais se dispersam e se afastam dos eixos rodoviários principais, utilizando estradas vicinais e até estradas rurais não asfaltadas. Outro aspecto relevante é a sua maior presença ao longo dos eixos da Anhanguera-Bandeirantes, tanto próximo a São Paulo como em Campinas; e nos eixos da Raposo Tavares e da Fernão Dias. É expressiva também a sua ocorrência ao longo do eixo da Rodovia D. Pedro I, passando por Itatiba, em direção a Atibaia e Bragança Paulista.

Já os loteamentos dispersos das classes de média-baixa e baixa renda tendem a ocorrer mais frequentemente ao longo dos eixos rodoviários e das manchas urbanas da cidade compacta. Portanto, não se afastam muito dessas localizações das quais dependem - o transporte, os serviços e o emprego. A sua ocorrência é mais percebida ao longo da Rodovia Índio Tibiriçá, ao sul de São Paulo, nos municípios de Rio Grande da Serra, Ribeirão Pires, São Bernardo e Suzano. Esta rodovia faz a ligação dos eixos rodoviários do sistema Anchieta-Imigrantes com o da Dutra-Airton Senna.

Outra ocorrência significativa deste conjunto de média-baixa e baixa renda vai ocorrer na saída da metrópole ao longo das Rodovias Dutra e Airton Senna, na região de Guarulhos, Arujá e Itaquaquecetuba. É expressiva também a ocorrência na porção Sul do Município da São Paulo, na região de Parelheiros, sem, contudo, estar vinculada a um eixo rodoviário principal de saída da metrópole.

Se a dispersão de baixa renda não acontece tão significativamente ao longo do eixo Anhanguera-Bandeirantes na saída de São Paulo até Jundiaí, essa tipologia se desloca para a antiga estrada São Paulo-Campinas (SP 332 - Rodovia Tancredo Neves). É bem expressiva a dispersão nos municípios de Caieiras, Franco da 
Rocha, Francisco Morato, Campo Limpo Paulista e Várzea Paulista, fato que foi também historicamente impulsionado pelo transporte de trem de subúrbio.

Na região de Campinas a dispersão de média-baixa e baixa renda vai ocorrer mais significativamente na porção nordeste de Campinas, ao longo do eixo Anhanguera-Bandeirantes, na direção de Americana, passando por Hortolândia, Sumaré e Paulínia.

É curioso verificar a dispersão das atividades produtivas industrial, comercial e de serviços. Estas efetivamente se caracterizam por uma dispersão linear, contínua ou em forma de contas de um colar, ao longo dos principais eixos rodoviários. Nas proximidades dos principais núcleos metropolitanos essa tipologia ocorre mais adensadamente, misturando-se, muitas vezes, com os loteamentos de média-baixa e baixa renda. A dispersão destas atividades vai ocorrer mais significativamente no eixo Dutra-Airton Senna na saída da metrópole de São Paulo, região entre Guarulhos e Arujá; e em todo o percurso entre Jacareí, São José dos Campos, Taubaté e Pindamonhangaba.

Do outro lado da metrópole sua ocorrência é expressiva nas saídas pela Régis Bittencourt, Raposo Tavares e Castelo Branco, e, também, no começo da rodovia Anhanguera. Nestes vetores a característica principal é a sua proximidade com a mancha compacta. Percebe-se um hiato de sua ocorrência no meio do caminho entre uma cidade e outra. Isso deve guardar relação com a existência de transporte público para os trabalhados. Portanto, a dispersão dessas atividades é relativa, e ocorre de forma diferente da dispersão das atividades residenciais. Como já mencionado, essa forma de dispersão traz em seu DNA uma forte correlação a atratividade para um novo adensamento da mancha urbana e uma nova compactação do tecido urbano. Indústrias, distritos industriais e suas tipologias afins são raros aparecer isoladamente e distantes das sedes municipais.

Na região de Campinas pode-se argumentar que a ocorrência das tipologias industriais/comerciais fogem a essa regra descrita acima, e se diferencia da forma como ocorre nas proximidades de São Paulo. De fato, aparentemente, as peças industriais aparecem mais fragmentadas e menos contínuas ao longo dos eixos rodoviários. Essas atividades também acontecem em todas as principais saídas de 
campinas, exceto pela Rodovia D. Pedro I. Ela é muito mais frequente no vetor da Anhanguera no caminho para Americana, e ocorre de forma mais concentrada nas proximidades da entrada das cidades de Hortolândia, Sumaré e Americana, além de sua presença na saída de Campinas. Muito próxima a essa ocorrência ao longo da Anhanguera verifica-se outra ocorrência importante entre Campinas e Paulínea, mas seguido o mesmo padrão de aproximação da área urbana compacta destas cidades.

Já na saída de Campinas para Jundiaí, pela rodovia Anhanguera, a ocorrência desta tipologia produtiva aparece em um formato muito mais linear colada ao longo darodovia. Entretanto, também não foge de seu padrão de maior concentração dessas peças dispersas na proximidade das entradas para Valinhos, Vinhedo e Louveira, além de ocorrer também nas saídas de Campinas e Jundiaí.

Todos os fatos relatados podem ser relativamente observados nas imagens das figuras 5.7 a 5.12 que mostram alguns detalhes dos mapeamentos que deram suporte à pesquisa.

\subsection{A caracterização dos eixos de dispersão}

\subsubsection{O eixo Fernão Dias}

Este eixo rodoviário de dispersão interliga São Paulo, Guarulhos, Mairiporã e vai até Atibaia e Bragança Paulista. Se ramifica nas duas direções da Rodovia D. Pedro I, a que segue para a Dutra, passando por Bom Jesus dos Perdões e Nazaré Paulista, e a que segue para Itatiba-Campinas. Nas proximidades de Bragança Paulista se acessa Piracaia e Joanópolis. Este grupo de municípios é o que está na esfera de influência da Rodovia Fernão Dias.

A dispersão urbana neste eixo pode ser analisada segundo a proximidade dos principais núcleos urbanos polarizadores. Optou-se por uma regionalização do fenômeno de maneira muito generalista, não se atendo muito aos limites municipais e sim à relação de proximidade e influência das sedes municipais. Assim, o eixo Fernão Dias pode ser repartido segundo a esfera de influência local de São Paulo, Guarulhos, Mairiporã, Atibaia e Bragança Paulista. O que chamaremos de região de Atibaia corresponderá às áreas de dispersão nas proximidades da cidade de Atibaia, 
abrangendo também os municípios de Bom Jesus dos Perdões e Nazaré Paulista. A região de Bragança envolverá os municípios de Joanópolis e Piracaia. As imagens das figuras 6.9 a 6.11 mostram as regiões de dispersão acima citadas e um retrato simplificado do fenômeno. Neste mapeamento as tipologias de condomínios e loteamentos de chácaras estão agrupadas ao padrão de tipologia de condomínios fechados de média-alta renda e assinaladas na cor verde claro.

Figura 6.9 - Dispersão Urbana no vetor norte de São Paulo. Eixo da Rodovia Fernão Dias, entre São Paulo e Mairiporã.

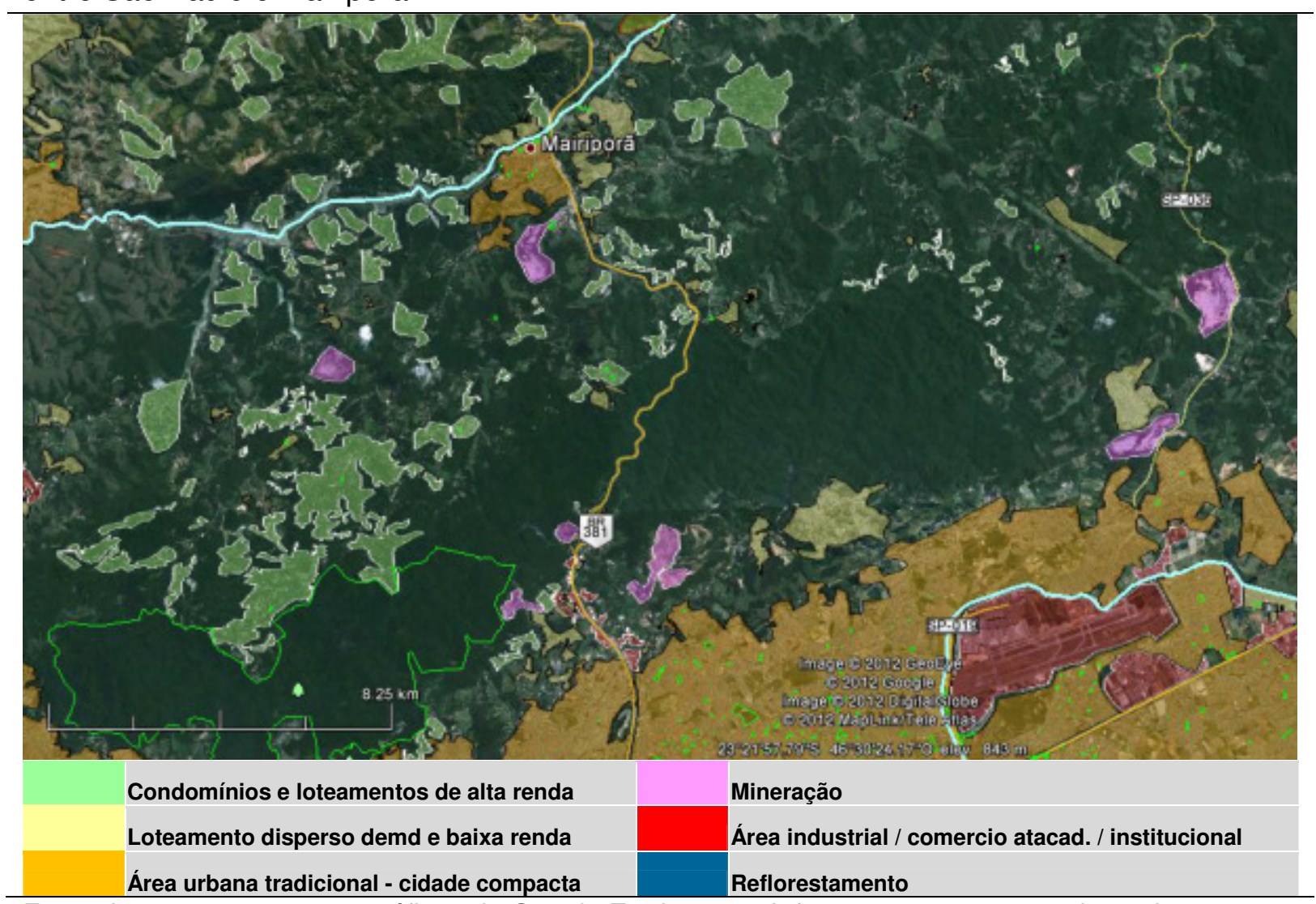

Fonte: imagem e recursos gráficos do Google Earth, 2010. Informações acrescentadas pelo autor.

Essa região de dispersão possui condições naturais bastante atrativas caracterizadas pela presença de conjuntos serranos de porte e abrangências territoriais variadas, muitos deles ainda marcados pela presença de vegetação nativa de mata atlântica em variados graus de preservação e/ou regeneração. Nas proximidades de São Paulo e Guarulhos, na divisa com Mairiporã encontra-se um dos conjuntos serranos mais significativos que é a Serra da Cantareira, que apresenta altitudes em torno de 1.000 a 1.100 metros e desnível em relação a São Paulo e Guarulhos na ordem de 300 metros, configurado por vertentes íngremes, maitas nascentes e seus anfiteatros e vegetação florestal ainda exuberante. Neste 
cenário registra-se a presença de um parque estadual - parque da Cantareira - que qualifica os espaços do entorno historicamente ocupados por loteamentos e condomínios para as camadas de mais alta renda.

A rodovia Fernão Dias corta essa região da Serra da Cantareira, saindo de São Paulo na direção de Mairiporã, e no final da subida da serra tem-se o túnel localmente conhecido como túnel da Mata Fria, que atravessa os topos dos morros que compõem a linhamento do divisor de águas das bacias do Tietê, a sul, e do Rio Juqueri, a norte.

Figura 6.10 - Dispersão Urbana no eixo da Rodovia Fernão Dias, região de Atibaia.

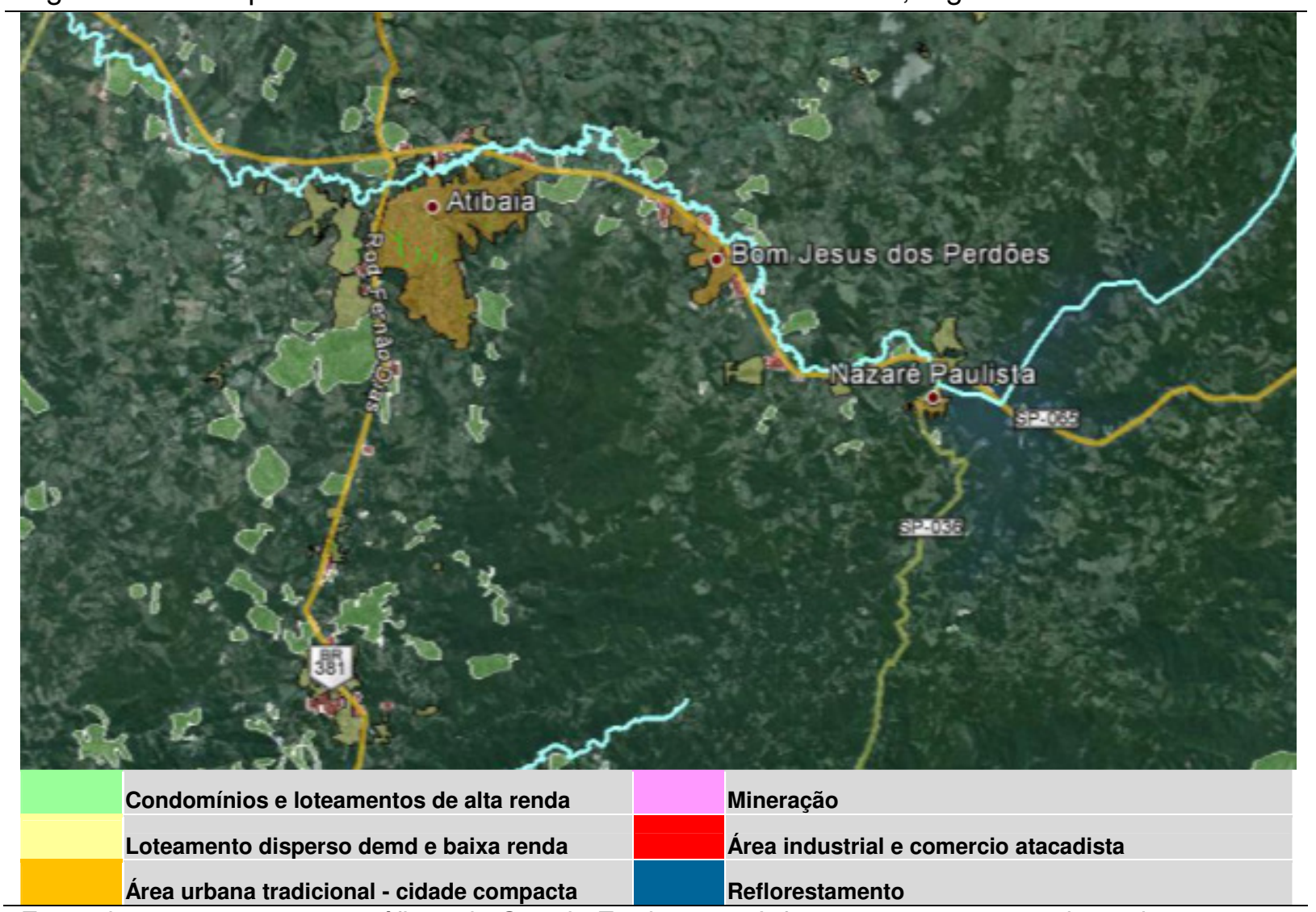

Fonte: imagem e recursos gráficos do Google Earth, 2010. Informações acrescentadas pelo autor.

Outro alinhamento serrano que se destaca na paisagem regional é o conjunto da Serra da Pedra Vermelha que separa o município de Atibaia de Mairiporã e de Bom Jesus dos Perdões. Trata-se de um expressivo maciço granítico com altitudes em torno de 1.200 metros e um pico famoso localmente - Pico da Pedra Grande com seus quase 1.400 metros de altitude, muito utilizado como ponto turístico de cunho ecológico, contemplativo e para práticas esportivas. Apresenta uma extensão 
de aproximadamente $17 \mathrm{~km}$ na direção norte-sul, dispondo-se paralelamente à leste da rodovia Fernão Dias.

$\mathrm{Na}$ região de Bragança Paulista uma série de pequenos conjuntos serranos constituem-se em divisores de águas locais das bacias do Rio Atibaia e do Jaguari, já próximos das nascentes dos referidos rios. Quase todas são sustentadas por maciços graníticos, com altitudes alinhadas em torno de 1.100 a 1.200 metros. A Serra do Juncal divide os municípios de Piracaia e Joanópolis e abriga parte das nascentes do Rio Jaguari e emoldura o reservatório do mesmo nome, que se constitui em um expressivo elemento paisagístico local. Entre Joanópolis e Nazaré Paulista sobressai a Serra do Mato Mole, um alinhamento de morros com quase 30 $\mathrm{km}$ de extensão e altitudes que variam de 1.200 a 1.400 metros. Compõe essa paisagem local o reservatório da represa de Atibainha.

Figura 6.11 - Dispersão Urbana no eixo da Rodovia Fernão Dias, região de Bragança Paulista.

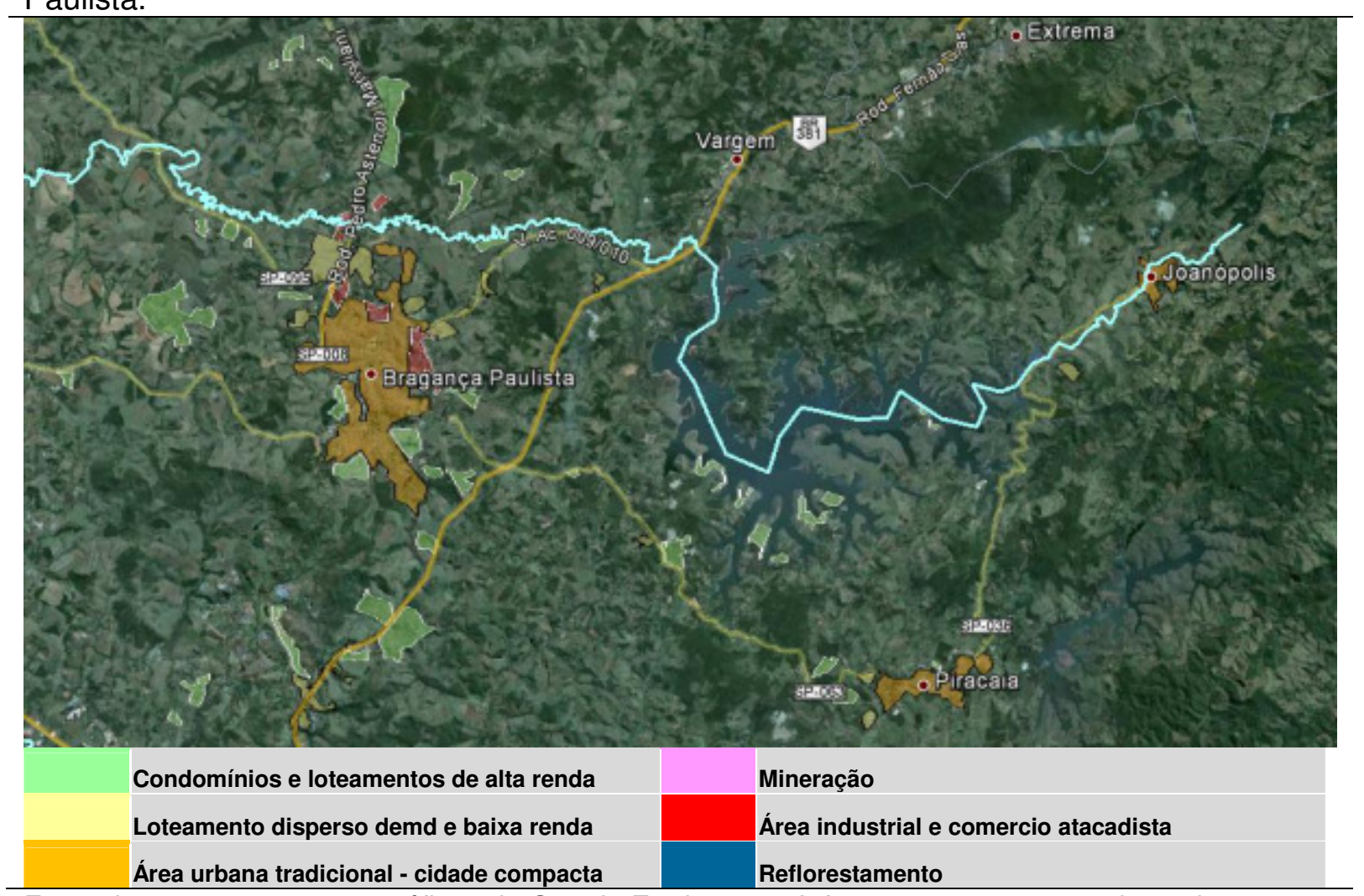

Fonte: imagem e recursos gráficos do Google Earth, 2010. Informações acrescentadas pelo autor.

Emoldurando a paisagem de Bragança aparecem as serras das Anhumas, do Leite-Sol e das Araras, esta última já na divisa com o município de Pinhalzinho e Pedra Bela. Todas têm os seus topos em torno de 1.100 metros de altitude enquanto a área urbana da cidade se situa entre 800 e 900 metros. 
A importância ambiental estratégica desta paisagem serrana que forma importantes sistemas de nascentes está refletida no delineamento de regulação ambiental do uso do solo em nível predominantemente estadual. Essa região é abrangida pelas APAs Sistema Cantareira e Piracicaba/Juquery-Mirim, em virtude de sua relevância para o abastecimento de água macrometropolitano; pela APA Bairro da Usina em Atibaia e pelo Parque Estadual da Cantareira.

Neste contexto paisagístico bastante atrativo composto por serras, represas, nascentes e matas desenvolve-se um importante eixo de dispersão urbana. Foram identificadas aproximadamente 300 peças urbanas dispersas nessa região. Destas 66\% (199 peças) representavam condomínios e loteamentos com o padrão para as faixas de média a alta renda, podendo representar $1^{\underline{a}}$ ou $2^{\underline{a}}$ residência. Neste conjunto predominam ainda as tipologias de morfologia semelhante às formas de ocupação da cidade compacta. A ocupação residencial das camadas de médiabaixa a baixa renda representou $23 \%$ (68 peças) do conjunto total de peças urbanas dispersas. O restante $11 \%$ (34 peças) formaram as peças de uso produtivo indústriacomercial ou uso institucional.

Assim, como já esperado, e em vista dos atrativos mencionados, há a predominância absoluta de dispersão de loteamentos e condomínios residenciais das faixas de média/alta renda. A maior parte destes, $46 \%$, se concentra no município de Mairiporã, seguido da região de Atibaia (36\%) e, completando o quadro, 17,5\% estão localizados na região de Bragança Paulista, Apenas 2 condomínios deste padrão foram verificados em São Paulo $(0,5 \%)$. O padrão de distribuição das peças residenciais de baixa e média renda e de tipologia similar às da cidade compacta, apresentou-se muito mais equilibrado. Do total das 68 peças urbanas $35 \%$ se localizam em Mairiporã, 31\% na região de Atibaia, $21 \%$ no início da Fernão Dias em São Paulo (10) e Guarulhos (4), e 13\% na região de Bragança Paulista.

É importante ressaltar que não está se considerando o tamanho da peça, nem se ela se compõe de um agrupamento de loteamentos residenciais distintos ou aparece isoladamente. Assim, contabilizaram-se peças de tamanhos variados. $O$ que importou foi o seu padrão de desgarramento da mancha compacta da cidadesede municipal. 
Das peças industriais mapeadas que se encontravam separadas no núcleo urbano central da cidade compacta, a distribuição também se deu de maneira mais equilibrada entre as regiões analisadas, com uma leve concentração de sua ocorrência na região de Atibaia, que representou $38 \%$ do total das peças industrias/comerciais dispersas. Mairiporã e Guarulhos ficaram com 6\% das peças cada um, São Paulo 14\% e a região de Bragança com 12\%.

Quanto à morfologia da ocupação observa-se uma grande dispersão dos condomínios de média/alta renda, e que se distanciam bastante dos eixos rodoviários principais da Fernão Dias e D. Pedro I. Já a dispersão de baixa e médiabaixa renda, segue o padrão normal desta tipologia: predominam ao longo da rodovia; trata-se de uma dispersão mais agrupada ou aglomerada; e ocorrem mais significativamente nas saídas de São Paulo/Guarulhos, e nas proximidades de Mairiporã e Atibaia. Ressalta-se a concentração que ocorre em dois trechos específicos da rodovia Fernão Dias entre Mairiporã e Atibaia. O primeiro e maior aglomerado ocorre no $\mathrm{Km} \mathrm{56}$, em Mairiporã, quase na divisa com Atibaia. Trata-se do bairro Terra Preta. Outra aglomeração, embora em menor escala, acontece no km 51, já no município de Atibaia. Nesta ocorre uma aglomeração mista de peças residenciais e industriais.

É também relevante mencionar a presença de atividade mineradora nesta região do eixo Fernão Dias. Ocorre de maneira mais incisiva o início da rodovia, à saída de São Paulo e Guarulhos. Foram cinco ocorrências mapeadas, duas em São Paulo, duas em Mairiporã e uma em Guarulhos. Trata-se de pedreiras que exploram o maciço granítico (e uma em anfibolito) que embasa a Serra da Cantareira e os seus contrafortes em Mairiporã. Colaboram para realçar a fragmentação da paisagem junto com as peças urbanas em dispersão, e causam impacto paisagístico marcante, no entanto, de forma negativa.

\subsubsection{O Eixo Anhanguera-Bandeirantes}

Este eixo rodoviário de dispersão interliga São Paulo a Campinas e desta até Americana, abrangendo também uma série de municípios ao longo da rodovia ou do entorno. Apresenta também muitas ramificações que contribuem para determinar 
uma morfologia complexa, pois extremamente fragmentada. As ramificações mais importantes correspondem aos seguintes eixos de ligação:

SP 354: Ligação Anhanguera - D. Pedro I, passando por Campo Limpo Paulista e Jarinu.

$\checkmark$ SP 360: Ligação Jundiaí - Itatiba.

$\checkmark$ SP 300: Ligação Jundiaí - Itu.

$\checkmark$ SP 332: Ligação Caieiras, Franco da Rocha, Francisco Morato, Campo Limpo Paulista, Várzea Paulista, Jundiaí, Louveira, Campinas, Paulínia, Cosmópolis, Artur Nogueira e Eng. Coelho.

$\checkmark$ SP 340: Ligação Campinas - Jaguariúna.

$\checkmark$ SP 101: Ligação Campinas - Monte Mor.

$\checkmark$ SP 304: Ligação Americana - Santa Bárbara.

Para caracterizar a dispersão ao longo deste eixo optou-se por dividi-lo em setores que segmentam as rodovias Anhanguera-Bandeirantes nos trechos de ligação das principais cidades deste eixo. Nestes trechos incluem-se também as ramificações que são acessadas a partir dessesistema. Os setores delineados são os seguintes:

$\checkmark$ Saída de São Paulo até Jundiaí: abrange os municípios de Cajamar, Caieiras, Francisco Morato, Franco da Rocha, Várzea Paulista e Campo Limpo. Inclui a ramificação para Jarinu (SP 354).

$\checkmark$ Jundiaí até Campinas: abrange os municípios de Louveira, Valinhos e Vinhedo. Inclui também as ramificações para Itupeva-Itu (SP 300) e para Itatiba (SP 360).

$\checkmark$ Campinas Norte até Americana: abrange as saídas norte de Campinas para Paulínia (SP 332); para Hortolândia, Sumaré, Nova Odessa, Santa Bárbara e Americana pela própria Anhanguera ou Bandeirantes; e para Monte Mor (SP 101).

As imagens das figuras 6.12 a 6.16 mostram as regiões de dispersão acima citadas e um retrato simplificado do fenômeno. Neste mapeamento as tipologias de condomínios e loteamentos de chácaras também se encontram agrupadas ao padrão de tipologia de condomínios fechados de média-alta renda e assinaladas na cor verde claro. 
Essa região de dispersão possui condições naturais bastante diversas, pois abrange os terrenos de estrutura geológica cristalina do Planalto Atlântico e os de estrutura sedimentar da Bacia do Paraná, no setor especifico da Depressão Periférica Paulista. Assim, no trecho inicial do percurso do sistema AnhangueraBandeirantes transita-se por um relevo de morros cristalinos, que envolve a presença de alguns conjuntos serranos significativos e proeminentes nesta paisagem como o maciço quartzítico do Pico do Jaraguá, o alinhamento da Serra dos Cristais e o conjunto da Serra do Japi. Após o município de Valinhos, já perto da chegada a Campinas, dá-se a passagem para um relevo de colinas amplas e relativamente suavizadas, pois já expressão de outro substrato geológico que responderam de maneira diversa da dos terrenos de estrutura cristalina aos processos morfodinâmicos de esculturação da paisagem.

Este fator, não muito perceptível entre os que executam projetos de loteamentos, determina, em muito, os partidos urbanísticos adotados no desenho do traçado (arruamentos) dos loteamentos e condomínios. Portanto, sutis ou profundas variações de tipologia de plantas destes loteamentos podem ser verificadas. Entretanto, pode-se dizer que, em muitos casos, elas não derivam de uma aguçada relação com as formas do relevo, que tiram partido das condições de declividade e das condições ambientais da paisagem, e, sim, apenas a modismos de arquétipos ora de cidades-jardim, ora de desenhos de traçados regulares-reticulares da concepção modernista. Não iremos nos deter ainda nesta abordagem sobre as formas de apropriação do relevo no desenho urbano dos loteamentos dispersos em análise. Interessa-nos mais nesta pesquisa a relação do conjunto desta apropriação em sua relação com os compartimentos ambientais estruturantes da paisagem.

Em decorrência destas variações geológicas-geomorfológicas e também pedológicas da paisagem deste vetor de dispersão, tem-se que o usos do solo rural tem uma história bastante diversa, o que se reflete na configuração paisagística da cobertura vegetal existente. No setor dos morros e serras cristalinas a vegetação florestal, embora extremamente degradada e fragmentada, ainda continua presente em alguns setores de vertentes ou topos de morros. Já no setor das colinas sedimentares da Depressão Periférica, em vista de sua aptidão maior para as práticas agrícolas, essa vegetação florestal é pouco presente. 
Figura 6.12 - Dispersão Urbana no Eixo Anhanguera- Bandeirantes, na saída de São Paulo, Cajamar e Caieiras.

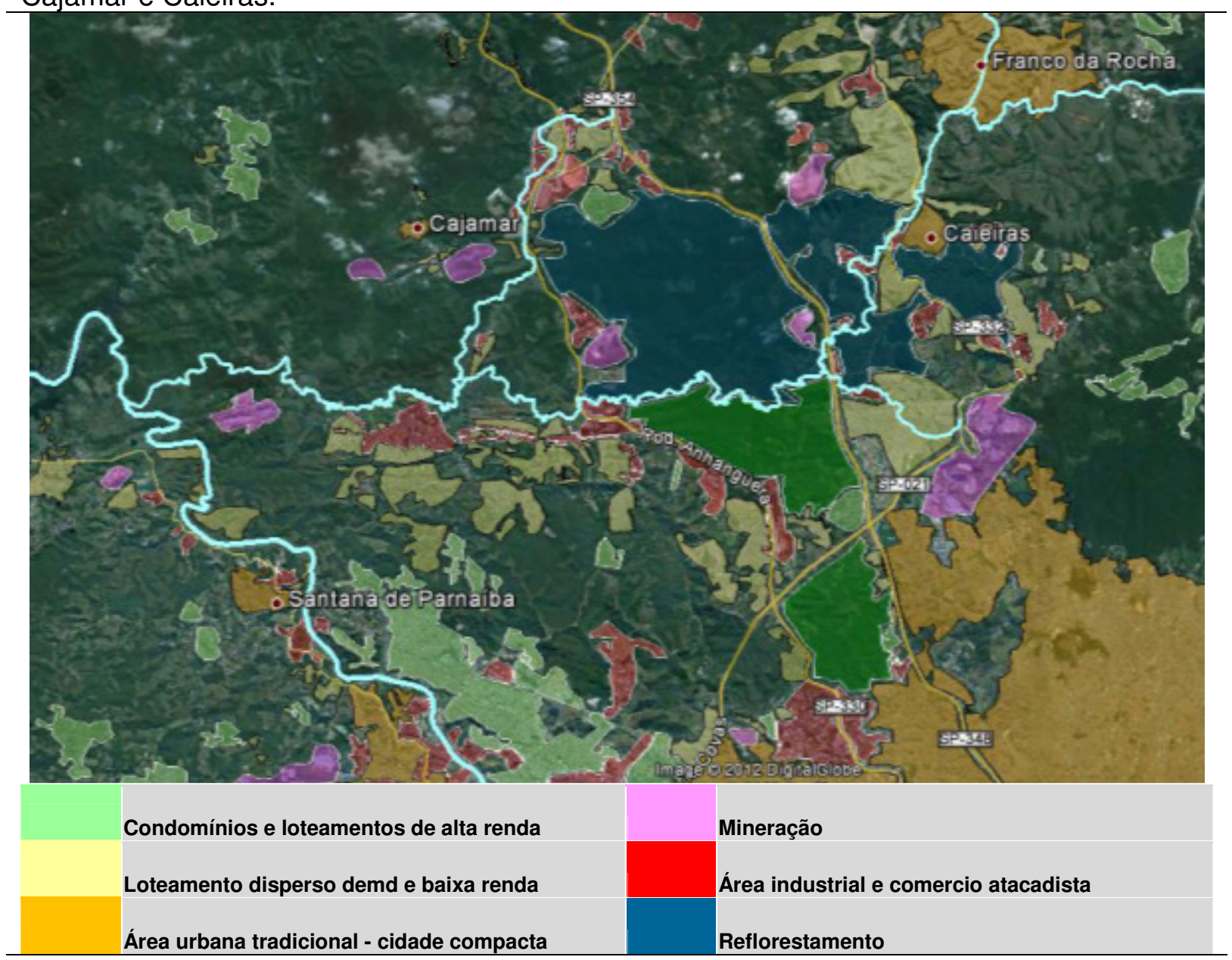

Fonte: imagem e recursos gráficos do Google Earth, 2010. Informações acrescentadas pelo autor.

Dos atributos paisagísticos deste vetor o mais importante em termos de expressão territorial é o conjunto serrano do Japi, situado nas proximidades de Jundiaí. Apresenta altitudes em torno dos 1.200 metros e seu alinhamento de topos atinge uma extensão de 18 kms. O relevo da cidade de Jundiaí, situado na sua face leste, atinge em média 760 metros de altitude, o que origina um desnível paisagístico médio de aproximadamente 400 metros. Encontra-se ainda com sua cobertura florestal relativamente preservada. Todo esse conjunto se transforma em um grande atrativo para os empreendimentos imobiliários de mais alta renda que já começam a avançar em seu entorno, sobretudo em sua vertente norte, no município de Itupeva. São rochas quartzíticas que sustentam esse conjunto paisagístico, mas não apresentam afloramentos como o que sucede no Pico do Jaraguá. 
Outro conjunto serrano importante, embora não tão expressivo como o da Serra do Japi, é o alinhamento da Serra dos Cristais, que se estende desde a Anhanguera até próximo à rodovia Fernão Dias, perfazendo uma extensão de aproximadamente $13 \mathrm{~km}$. Este conjunto serve como divisor de águas das bacias do Rio Juqueri com a do Rio Jundiaí. Está associado à falha de Jundiuvira que proporcionou a proeminência dos xistos que sustentam a maior parte do conjunto em relação ao filitos que faceiam a borda sul da vertente deste conjunto serrano. As altitudes não são tão expressivas quanto às da Serra do Japi e se situam em torno dos 800 a 1.000 metros. (IPT, 1981a)

Figura 6.13 - Dispersão Urbana no Eixo Anhanguera- Bandeirantes, região de Franco da Rocha, Francisco Morato, Cajamar e Várzea Paulista.

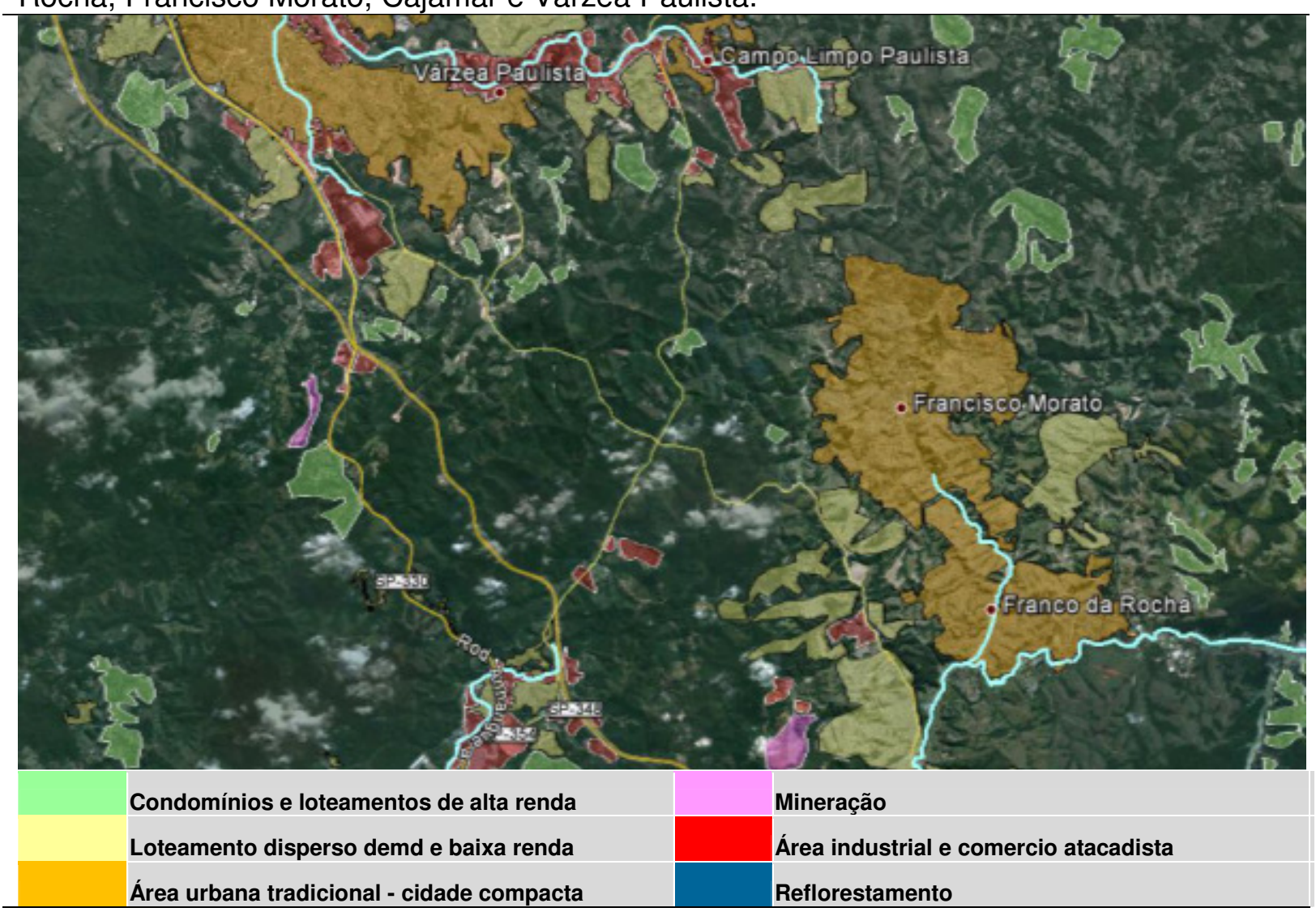

Fonte: imagem e recursos gráficos do Google Earth, 2010. Informações acrescentadas pelo autor.

Cabe também realçar a presença do Pico do Jaraguá, situado no trecho inicial do sistema Anhanguera-Bandeirantes. Os afloramentos de quartzito são os destaque deste maciço, composto ainda por filitos e granitos no entorno. As altitudes se situam em torno de 1.000 a 1.100 metros. Este conjunto faz parte do alinhamento de divisores das bacias do Tietê e Juqueri que se estende desde Santa 
Isabel até Pirituba, em São Paulo, com o nome de Serra da Cantareira, e após o maciço do Jaraguá segue até Alphaville, em Barueri.

Campinas se situa na divisa entre os terrenos cristalinos do Planalto Atlântico com os sedimentares da Depressão Periférica. Nesta paisagem, que se estende também por Indaiatuba, Salto, Itú e Sorocaba, ocorrem arenitos de granulação variada, conglomerados, siltitos, folhelhos, entre outras rochas sedimentares. Entretanto, neste setor específicoda Depressão Periférica que abrange a porção norte de Campinas, além de Paulínia e Hortolândia, rochas vulcânicas em forma de diques de diabásio originaram solos ricos para a agricultura e modificam um pouco a morfologia do relevo da região, deixando-o mais diverso em suas formas.

Figura 6.14 - Dispersão Urbana noEixo Anhanguera- Bandeirantes, região de Jundiaí.

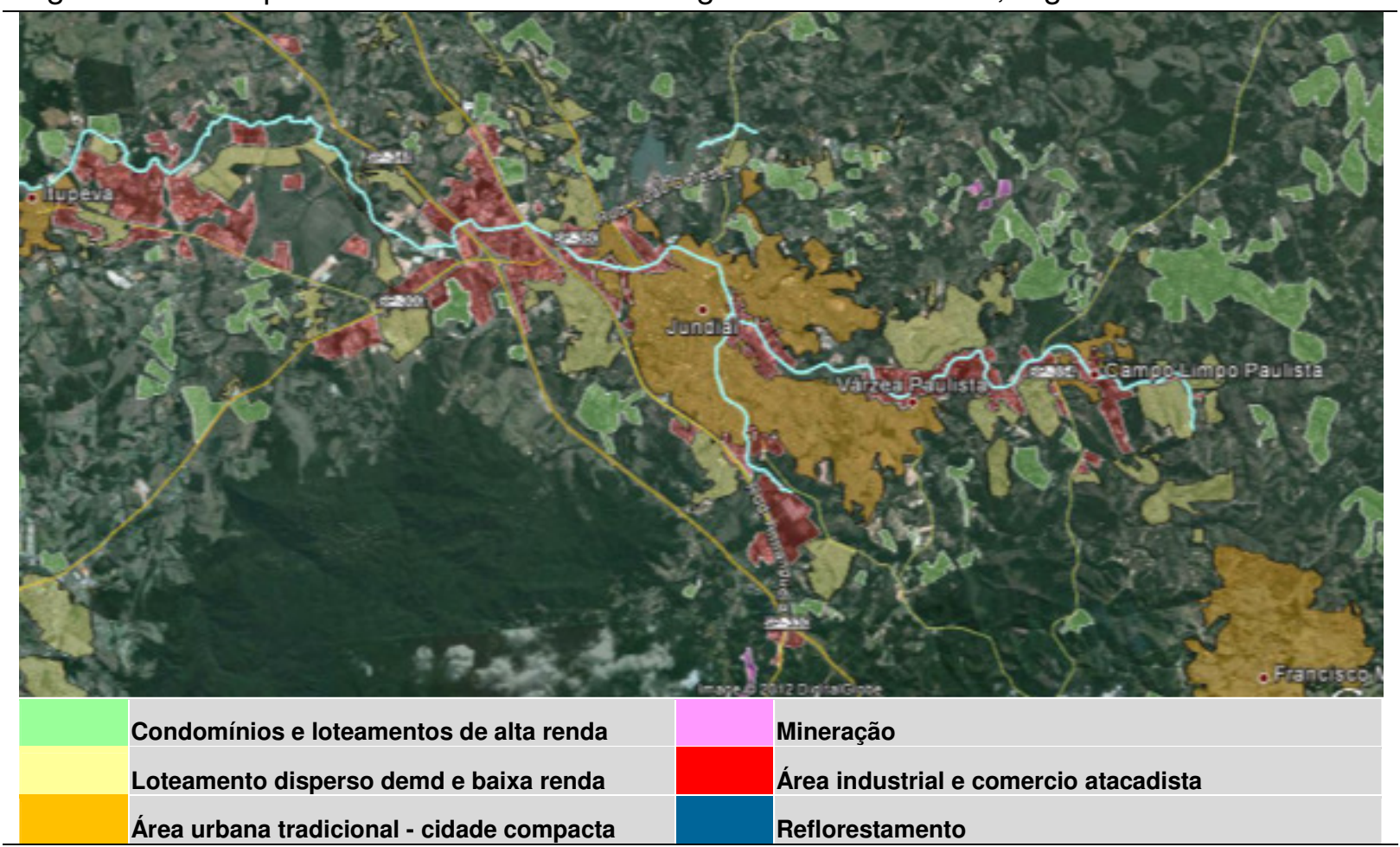

Fonte: imagem e recursos gráficos do Google Earth, 2010. Informações acrescentadas pelo autor.

Essas diferenças paisagísticas citadas também se refletem na regulação ambiental dos referidos setores. Na porção cristalina são cinco áreas sob objeto de alguma forma de proteção. São duas APAs (Jundiaí e Cajamar), dois Parques Estaduais (Juquery e do Jaraguá) e uma Estação Ecológica (Valinhos). Na região sedimentar não existem áreas de proteção regulamentadas nos níveis federal e estadual. 
Neste cenário paisagístico a dispersão urbana ao longo deste vetor rodoviário e de seus ramais ocorre seguindo uma morfologia de dispersão que revela algumas diferenças entre essas duas paisagens relatadas. Não se pode afirmar que as diferenças apresentadas no padrão morfológico da dispersão decorram somente de condicionantes físico-naturais, entretanto, deve-se lembrar que a estrutura agrária dos dois setores sempre foi muito diversa. Assim, traçados rodoviário e ferroviário, e o tamanho de propriedades rurais decorreram das aptidões relativas a cada setor.

Figura 6.15 - Dispersão Urbana noEixo Anhanguera- Bandeirantes, região de Vinhedo e Valinhos.

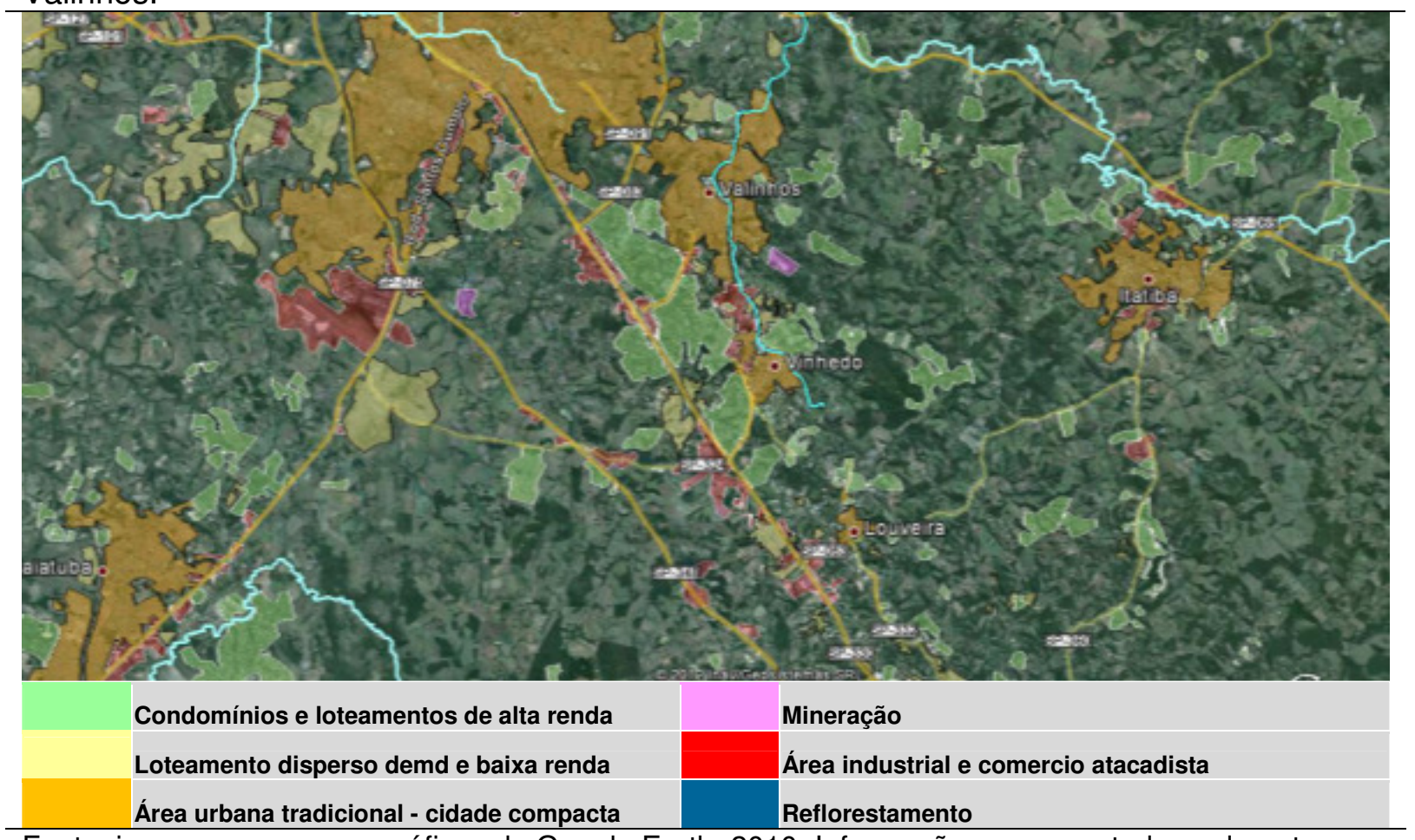

Fonte: imagem e recursos gráficos do Google Earth, 2010. Informações acrescentadas pelo autor.

O que é possível verificar nos mapas das imagens das figuras 6.12 a 6.16 é que a dispersão urbana na Depressão Periférica, entre Campinas e Americana, assume uma forma muito mais espalhada em grandes peças e com as tipologias justapostas. As peças de uso produtivo também se apresentam mais fragmentadas e espalhadas do que ocorre na região cristalina do Planalto Atlântico.

Foram mapeadas e identificadas 673 peças urbanas dispersas neste vetor. A maior parte - 45\% - corresponde aos condomínios e loteamentos de média/alta renda. Os loteamentos de média-baixa e baixa renda representaram $32 \%$ das peças 
dispersas, enquanto que as peças de uso industrial chegaram a representar $23 \%$ do total.

Como se pode observar nesses percentuais neste vetor a dispersão se dá de forma mais homogênea em relação a essas três tipologias de uso do território. A dispersão da atividade industrial é significativa, e é mais expressiva na região de Campinas-Americana, do que nas proximidades de São Paulo. Das 155 peças da tipologia industrial/comercial/institucional identificadas, $46 \%$ ocorrem na região de Campinas-Americana-Paulínia (norte de Campinas). Na região da saída de São Paulo até a entrada de Jundiaí foram identificadas $27 \%$ das peças dessa tipologia e o mesmo valor para o setor Jundiaí-Campinas. Isto significa um certo equilíbrio nessa distribuição das peças industriais, mas com uma predominância maior na região de influência de Campinas-Americana-Jaguariúna, considerando-se que os trechos analisados possuem abrangência territorial semelhante.

Figura 6.16 - Dispersão Urbana no Eixo Anhanguera- Bandeirantes, região de Campinas a Americana.

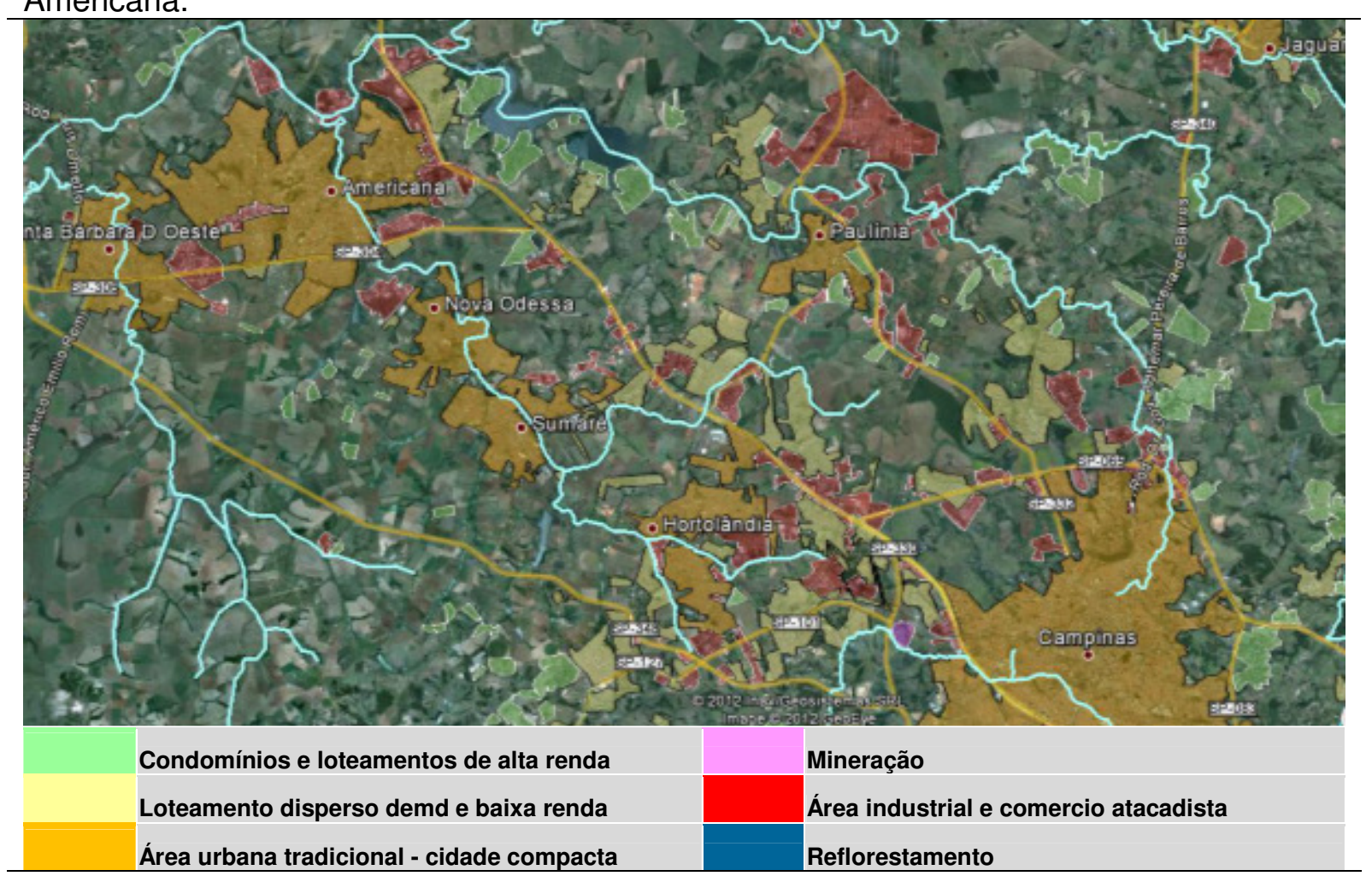

Fonte: imagem e recursos gráficos do Google Earth, 2010. Informações acrescentadas pelo autor.

Em relação aos condomínios e loteamentos residenciais para as faixas de média-alta a alta renda o desequilíbrio é marcante. Nas proximidades de São Paulo até Jundiaí verificou-se apenas $18 \%$ do total de 300 peças dispersas desta tipologia. 
A maior concentração se dá no trecho entre Jundiaí e Campinas - 43\%. Na porção norte de Campinas (Americana, Sta Bárbara, Jaguariúna, etc) foram identificadas $39 \%$ do total, entretanto, neste setor elas apresentam dimensões menores e uma maior pulverização no espaço.

Caiado e Pires (2007, p. 4-6) em estudo sobre a dispersão urbana na Região Metropolitana de Campinas registraram que entre o final da década de 1980 e 2000, 17 mil hectares de área rural foram agregados ao tecido urbano, o que havia representado um aumento $30 \%$ da área urbanizada. As autoras confirmam que a expansão recente está lastreada basicamente por empreendimentos residenciais e de comércio voltados para as camadas de média e alta renda. Apresentando dados do Graprohab revelam que, entre 1994 e 2004, foram aprovados 249 empreendimentos, com 87.772 lotes à disposição do mercado imobiliário. A área média dos lotes era de $250 \mathrm{~m} 2$ na região de Campinas e Americana e de $300 \mathrm{~m} 2 \mathrm{em}$ Hortolândia e Sumaré. Embora esses dados não se restrinjam apenas ao fenômeno da dispersão urbana, como aqui está sendo analisado, eles contribuem para se compreender melhor a dimensão da urbanização recente na RMC e sua intensa fragmentação dos tecidos urbanos que lá se verifica.

Em relação aos loteamentos dispersos de tipologia idêntica aos loteamentos da cidade compacta para as faixas de média a baixa renda, a ocorrência apresentou uma grande homogeneidade em sua distribuição, com umarelativa presença maior nas regiões entre São Paulo e Campinas. Do total de 218 peças urbanas dispersas desta tipologia, 36\% ocorreram no setor entre Jundiaí e Campinas; 35\% entre São Paulo e Jundiaí e 29\% entre Campinas-Americana-Jaguariúna.

A atividade mineradora só foi identificada no setor São Paulo-Jundiaí, com 10 ocorrências, e entre Jundiaí-Campinas, com apenas 2. Em sua maior parte se referem a pedreiras para a transformação em brita.

\subsubsection{Eixo da Rodovia Castelo Branco}

Para a análise deste eixo de expansão do processo de dispersão urbana na macrometrópole fez-se uma setorização da área de influência da rodovia Castelo Branco em 4 conjuntos, conforme descrito a seguir: 
Setor da saída de São Paulo até o Morro do Votoruna: envolve os municípios de Osasco, Carapicuíba, Barueri, Jandira, Itapevi, Santana do Parnaíba e Pirapora do Bom Jesus.

$\checkmark$ De Araçariguama até o entroncamento com a SP 075: Envolve os municípios de Araçariguama, Porto Feliz (parte).

$\checkmark$ SP 075 até Itú: setor que envolve a dispersão no município de Itú e Boituva.

$\checkmark$ SP 075 até Sorocaba: setor que envolve a dispersão no vetor leste domunicípio de Sorocaba.

Neste vetor de dispersão as condições paisagísticas se assemelham ás do vetor Anhanguera-Bandeirantes. No trecho inicial em São Paulo e Osasco até o entroncamento com a rodovia SP - 075 a rodovia Castelo Branco percorre trechos do Planalto Atlântico caracterizado pela presença de morros cristalinos e alguns conjuntos serrano, estes de menor porte do que os que ocorrem no eixo Anhanguera-Bandeirantes. Vale do Tiete neste trecho também é bastante atrativo, em que pese a poluição do rio neste trecho, pois ele se apresenta bastante encaixado por entre os morros cujas altitudes se situam entre 800 e 900 metros em média, enquanto o rio se encaixa na cota próxima a 640 metros. Portanto, em vista da proximidade entre morros e o canal do Rio Tietê, o desnível chega a 260 metros o que se reflete em vertentes com alta declividade, que dificultam, em muito, uma urbanização mais intensiva neste setor.

Após a rodovia SP-075 a Castelo Branco inicia o seu percurso sobre as colinas sedimentares areníticas da Depressão Periférica paulista. A SP-075 têm seu traçado paralelamente ao contato dessas duas estruturas geológicas da paisagem o que the confere um bom referencial de observação das diferenças das formas de relevo neste setor do território paulista. Embora os atributos paisagísticos sejam mais consideráveis no setor do Planalto Atlântico a dispersão urbana de média e alta renda ocorre de maneira muito semelhante nos dois setores de paisagem, onde o mercado imobiliário explora a aproximação da vida no campo e próxima à natureza, possível de se aproveitar, também, nas colinas da Depressão Periférica.

No setor dos morros cristalinos destacam-se no cenário paisagístico os fragmentos de matas, as vertentes íngremes, o vale encaixado do Rio Tietê e seu leito rochoso, os afloramentos de matacão granítico e quartzítico em Itu e Cabreúva, 
e o Morro do Votoruna, entre Barueri e Araçariguama. Este alinhamento de morros se destaca na paisagem da Castelo Branco e possui seus topos seus topos situados entre as cotas de 1.000 a 1.100 metros. Trata-se de um maciço granítico com aproximadamente $7 \mathrm{Km}$ de extensão que vai desde a Castelo Branco até o vale do Rio Tietê. Já é alvo de expansão urbana por meio de loteamentos de alta renda e de extração mineral por intermédio de três pedreiras instaladas nas vertentes que ficam defronte á cidade de Pirapora do Bom Jesus.

As imagens das figuras 6.17 a 6.20 mostram as regiões de dispersão acima citadas e um retrato simplificado do fenômeno. Neste mapeamento as tipologias de condomínios e loteamentos de chácaras também se encontram agrupadas ao padrão de tipologia de condomínios fechados de média-alta renda e assinaladas na cor verde claro.

Figura 6.17 - Dispersão Urbana na região entre São Paulo, Barueri e Santana do Parnaíba. Eixo Castelo Branco.

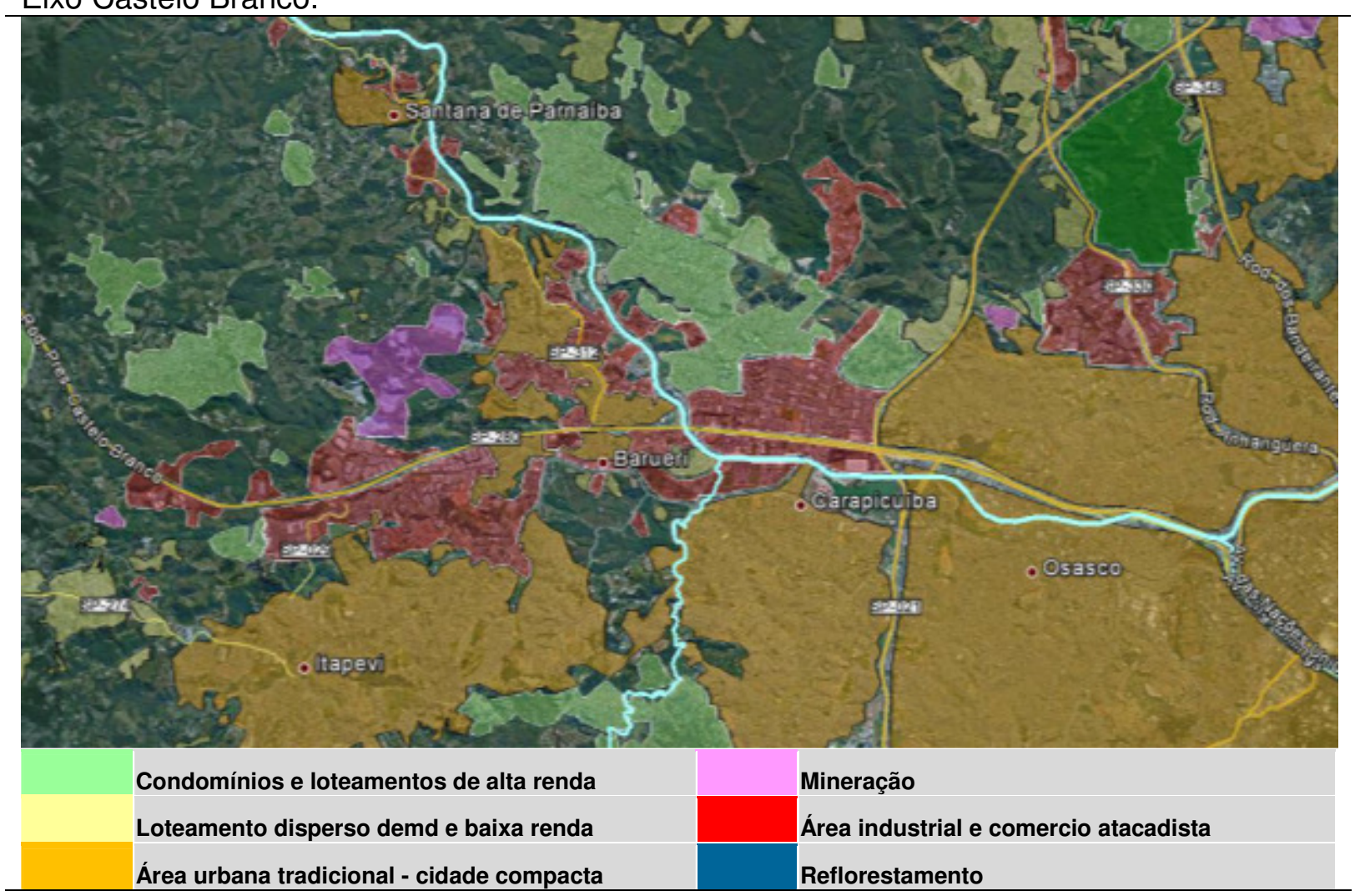

Fonte: imagem e recursos gráficos do Google Earth, 2010. Informações acrescentadas pelo autor.

Neste eixo a dispersão industrial ocorre de forma mais agrupada no trecho inicial da rodovia, nos municípios de Barueri e Itapevi. Essa concentração faz com 
que boa parte da industrialização existente faça parte da área urbana da metrópole compacta, não podendo ser mais considerada sob o enfoque da dispersão. 0 mesmo deve ser considerado na mancha urbana industrial de Alphaville e a do início da SP-312 (Estrada dos Romeiros). Nestas áreas a industrialização já se amalgamou com os loteamentos de média-alta renda em Alphaville e com os de baixa renda entre Barueri e Santana do Parnaíba.

Nesse sentido, o mesmo critério de reconhecimento da dispersão foi adotado em relação aos condomínios fechados de Alphaville. Como a maior parte destes já se encontram conurbados com áreas industriais e com o tecido urbano da cidade compacta que vem de Osasco, São Paulo e Carapicuíba, não podem mais serem considerados como fenômeno de dispersão. No entanto, foram computados como dispersão alguns loteamentos em Alphaville que se desgarram do conjunto compacto do empreendimento.

Figura 6.18 - Dispersão Urbana na região entre Araçariguama e Pirapora do Bom Jesus. Eixo Castelo Branco.

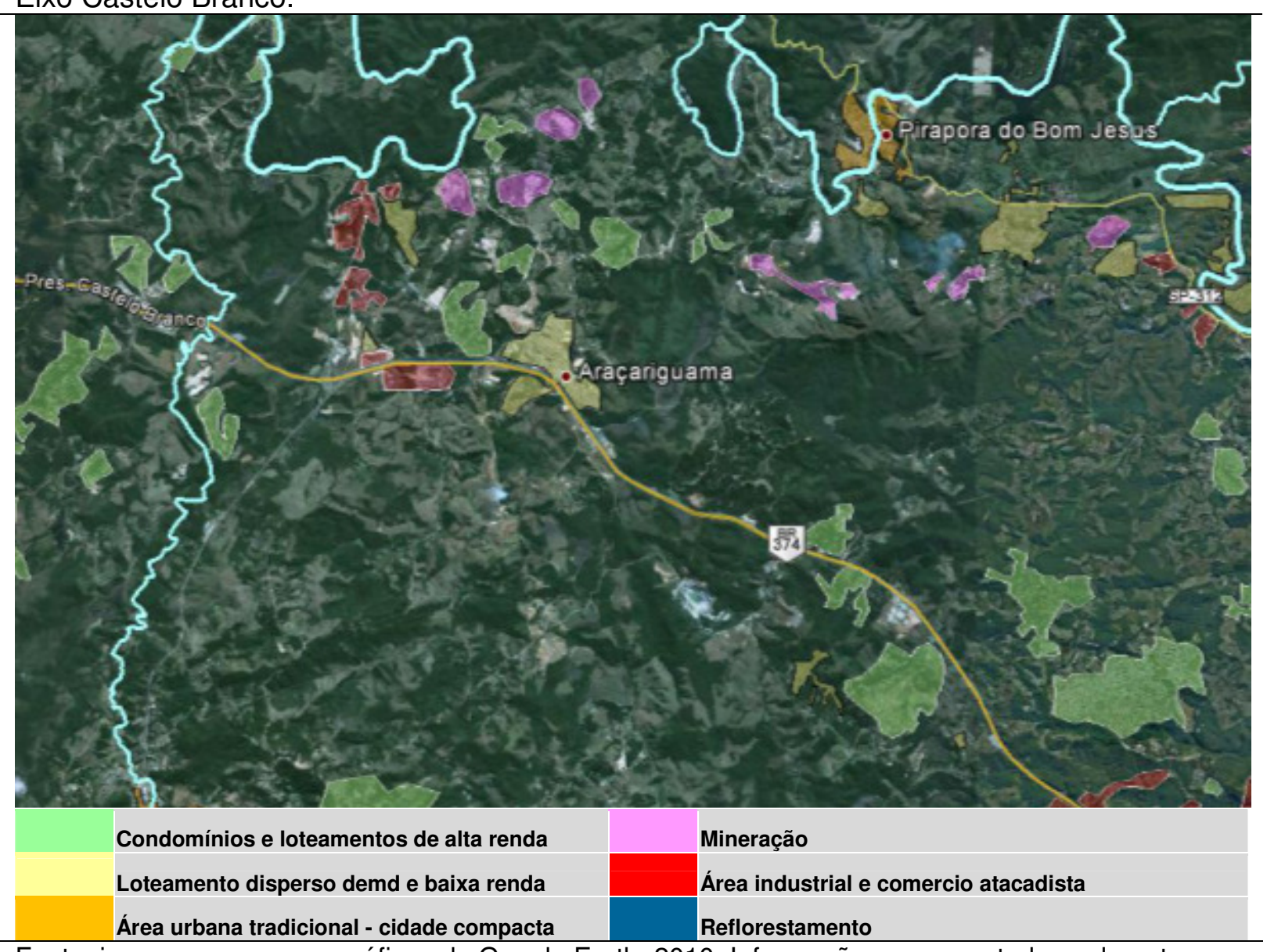

Fonte: imagem e recursos gráficos do Google Earth, 2010. Informações acrescentadas pelo autor. 
Analisando suscintamente a morfologia da dispersão neste vetor, verifica-se uma maior concentração no trecho inicial da rodovia e após o Morro do Votoruna as peças urbanas dispersa ficam mais rarefeitas e pulverizadas pela área rural. Na SP075 a dispersão volta a ficar mais intensa nas duas direções dessa rodovia - para Itú e para Sorocaba. Nessas duas áreas volta a ocorrer mais intensamente a dispersão industrial ao longo das rodovias.

Figura 6.19 - Dispersão Urbana na região entre Araçariguama, Itu e Sorocaba. Eixo Castelo Branco.

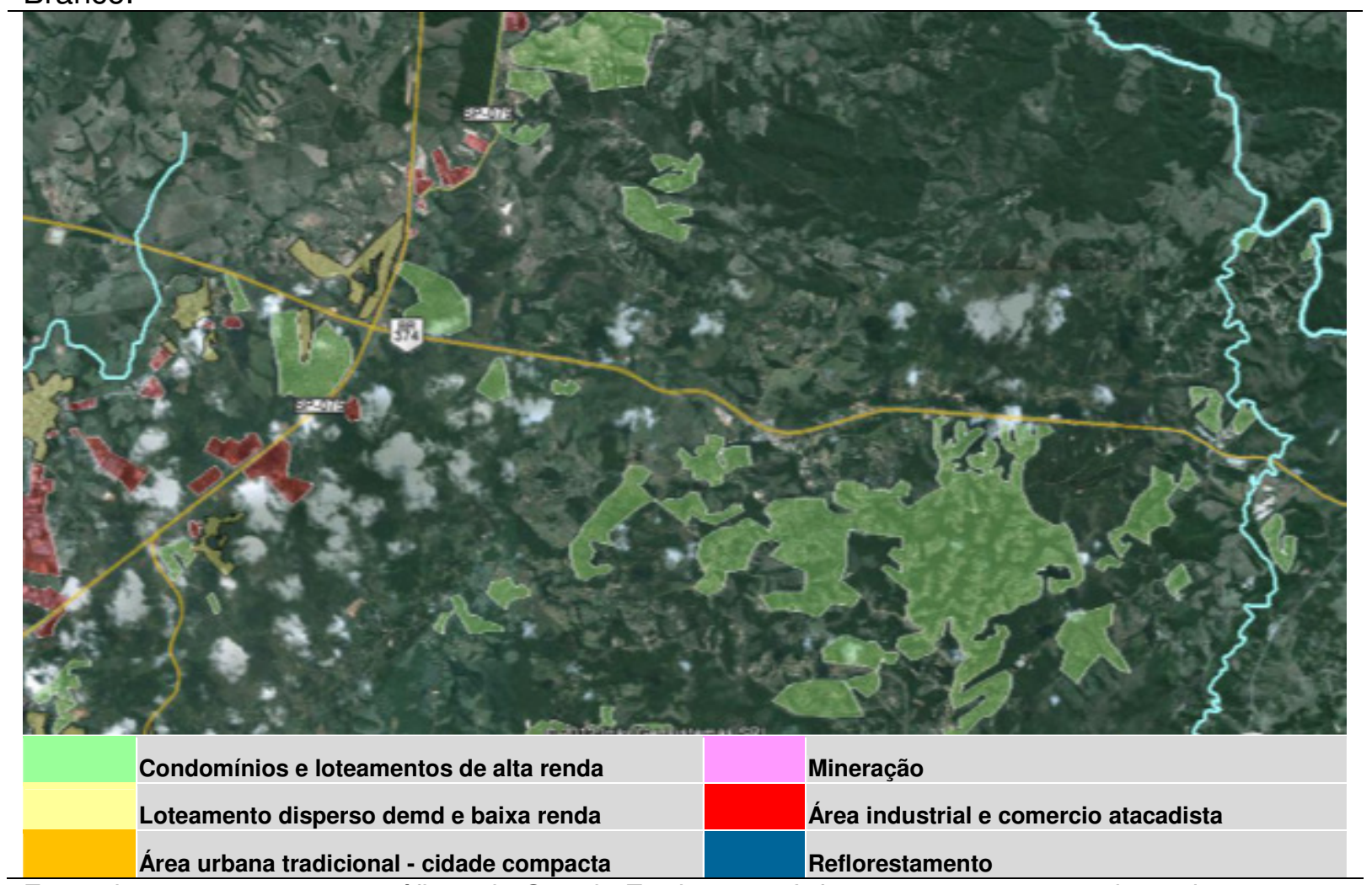

Fonte: imagem e recursos gráficos do Google Earth, 2010. Informações acrescentadas pelo autor.

Foram contabilizadas no mapeamento realizado neste estudo 165 peças urbanas dispersas. Neste vetor são os condomínios e loteamentos para média-alta renda que também predominam na dispersão. Esses condomínios correspondem a $43 \%$ das ocorrências. Sua maior concentração ocorre na região de Itú (SP 075), tendo sido registrados 24 peças dispersas, na região da saída de São Paulo em Barueri e Santana do Parnaíba (21 peças), e em terceiro lugar na região de Araçariguana (20 peças) A ocorrência na SP 075 na direção de Sorocaba foi a menos expressiva sendo contabilizados apenas 6 peças $(8 \%$ do total desta tipologia). 
As peças urbanas de baixa renda significam $27 \%$ do total das peças urbanas dispersas neste vetor. Elas se concentram no trecho inicial da rodovia, tendo sido registradas 29 ocorrências, o que significa $64 \%$ do total desta tipologia, localizadas sobretudo nos municípios de Barueri e Santana do Parnaíba. Na região de Araçariguama foi onde se encontrou o menor número de loteamentos dispersos desta tipologia.

Figura 6.20 - Dispersão urbana na região de Itu - Eixo Castelo Branco.

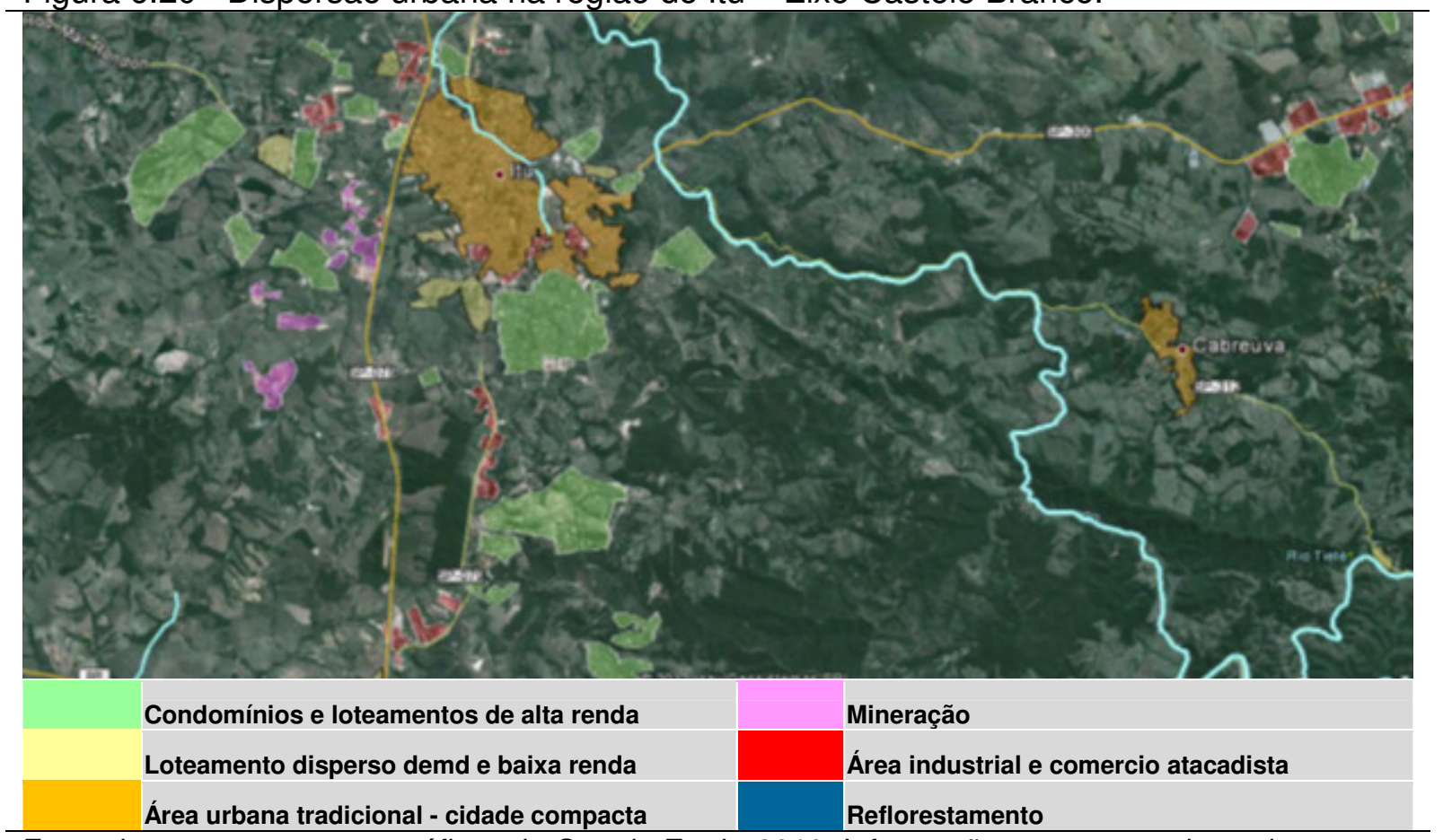

Fonte: imagem e recursos gráficos do Google Earth, 2010. Informações acrescentadas pelo autor.

A tipologia industrial representou $30 \%$ das peças urbanas dispersas contabilizadas no eixo Castelo Branco. A sua dispersão foi verificada em maior número ao longo da SP 075, nos dois sentidos - para Sorocaba e para Itu. Como já mencionado as manchas industriais mais expressivas são encontradas nas proximidades de São Paulo-Osasco-Barueri, mas estas já se encontram envolvidas pela cidade compacta. Assi é que apenas $20 \%$ da ocorrência desta tipologia em dispersão foi registrada neste setor inicial de influência da rodovia.

Outro aspecto importante a ser destacado é que a dispersão urbana neste trecho inicial de influência da Castelo Branco se ramifica em três vertentes: a da própria Castelo, a da Estrada dos Romeiros (SP 312) e a da rodovia SP 274, essa última em Itapevi. Enquanto os condomínios de alta renda ocorrem em maior quantidade no eixo castelo Branco (65\% do total deste trecho inicial da Rodovia), os 
de baixa renda vão predominar nos dois outros vetores internos da Estrada dos Romeiros (12 peças) e Itapevi (13 peças). A atividade industrial também quase não ocorre em Itapevi ao longo da SP 274. Sua ocorrência vai se concentrar nos outros dois vetores.

Deve-se registrar a grande presença de mineração neste vetor de dispersão. Foram identificadas 18 áreas de mineração. A maior ocorrência se dá na área dos morros cristalinos do Planalto Atlântico e predomina a lavra de pedra para brita. Aí foram identificadas 11 minerações (61\% do total), sendo 6 no trecho inicial da rodovia e 5 em Araçariguama. Na região de Itú, nas colinas sedimentares da Depressão periférica foram levantadas 7 lavras de argila.

\subsubsection{Eixo Raposo Tavares}

Para a análise deste eixo de expansão do processo de dispersão urbana na macrometrópole fez-se uma setorização da área de influência da rodovia Raposo Tavares em 4 conjuntos ou regiões, conforme descrito a seguir:

$\checkmark$ Regiâo de Cotia-Vargem Grande: envolve os municípios de mesmo nome.

$\checkmark$ De Ibiúna-Piedade:envolve os municípios de mesmo nome.

$\checkmark$ Região de São Roque a Sorocaba: abrange os municípios de São Roque, Mairinque, Alumínio até a chegada a Sorocaba pela rodovia Raposo Tavares.

$\checkmark$ Região de Sorocaba: abrange as saídas de Sorocaba para Votorantim, Piedade, Araçoiaba da Serra e Salto de Pirapora. A dispersão urbana que ocorre na saída para Itú foi analisada no vetor de dispersão da rodovia Castelo Branco.

Neste vetor de dispersão as condições paisagísticas se assemelham às do vetor Anhanguera-Bandeirantes e Castelo Branco. No trecho inicial em São Paulo e Alumínio a rodovia Raposo Tavares percorre trechos do Planalto Atlântico caracterizado pela presença de morros cristalinos e alguns alinhamentos serranos, quase todos de estrutura geológica granítica. Apenas na região de São Roque a ocorrência de filitos predomina. Estes alinhamentos graníticos compõem têm seus topos em cotas médias de 1.000 a 1.100 metros, denotando as características de uma superfície de aplainamento regional. Dentre os principais alinhamentos serranos destacam-se: 
$\checkmark$ Serra da Caucaia e Reserva Florestal do Morro Grande: A Serra da Caucaia se caracteriza por um maciço sustentado por rochas graníticas, com aproximadamente $15 \mathrm{~km}$ de extensão, no sentido norte-sul. A altitude média dos topos ficam em torno dos 1.000 metros. Encontra-se protegida pela existência da Reserva Florestal do Morro Grande, onde existe o reservatório de abastecimento de água da Sabesp (Pedro Beicht) nas nascentes do Rio Cotia. A área protegida perfaz aproximadamente $100 \mathrm{~km}^{2} \mathrm{e}$ abrange áreas do município de Cotia, Vargem Grande e Embu.

$\checkmark$ Serra de São Roque: de composição granítica, se estende por quase $20 \mathrm{~km}$ de extensão, com altitudes médias que variam de 1000 a 1.100 metros. Está situada na divisa de Vargem Grande com São Roque.

$\checkmark$ Morro do Saboó: Pequeno maciço de filitos com 4 km de extensão localizado nas proximidades da cidade de São Roque. Suas altitudes giram em torno de 800 a 900 metros.

$\checkmark$ Serra de São Francisco: alinhamento de morros que atingem cotas médias em torno dos 1.000 metros. Trata-se de um maciço granítico, que apresenta alguns afloramentos, com extensão aproximada de $14 \mathrm{~km}$. Abrange áreas dos municípios de Alumínio e Votorantim.

$\checkmark$ Represa de Itupararanga: reservatório de água localizado nos municípios de Alumínio, Mairinque, Ibiúna e Votorantim. Parte das nascentes que abastecem a represa estão na Serra de São Francisco. Essa represa pertence à bacia do Rio Sorocaba.

As imagens das figuras 6.21 a 6.24 mostram as regiões de dispersão acima citadas e um retrato simplificado do fenômeno. Neste mapeamento as tipologias de condomínios e loteamentos de chácaras também se encontram agrupadas ao padrão de tipologia de condomínios fechados de média-alta renda e assinaladas na cor verde claro.

A dispersão urbana neste vetor é também significativae caracteriza uma ocupação bastante fragmentada sobretudo na região de Cotia e Vargem Grande Paulista. Foram identificadas e mapeadas 339 peças urbanas dispersas das tipologias aqui abordadas. Como nas demais áreas essas peças variam muito em tamanho, tanto no que se refere ao tipo e padrão do loteamento, como por já apresentar tendências de agrupamento contíguo de loteamentos implantados em 
épocas diferentes. Neste vetor também se verifica a predominância de condomínios e loteamentos de média-alta renda, correspondendo a 52\% (176 peças) do total das peças urbanas mapeadas. Em segundo lugar registrou-se uma grande ocorrência também de loteamentos de baixa renda, demonstrando uma intensa fragmentação dessa tipologia, diferente do ocorrido nos vetores da Fernão Dias, do sistema Anhanguera-Bandeirantes e da rodovia Castelo Branco. Nesta área de influência da Raposo Tavares foi onde menos se verificou a dispersão de áreas industriais. Foram somente 28 peças dispersas mapeadas, o que significa apenas $8 \%$ do total de peças urbanas em dispersão.

Figura 6.21 - Dispersão urbana na região de Cotia e Vargem Grande Paulista - Eixo Raposo Tavares.

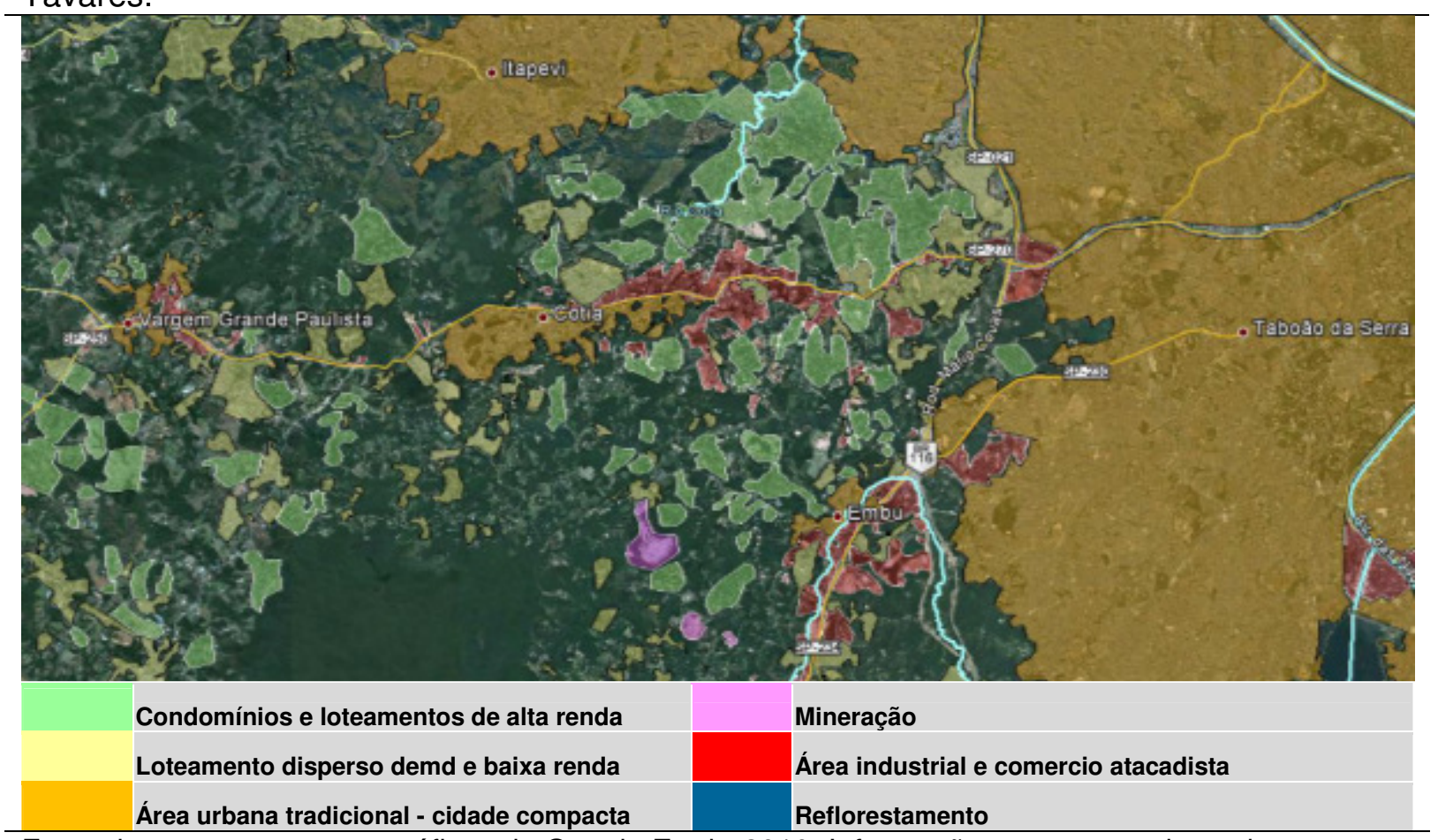

Fonte: imagem e recursos gráficos do Google Earth, 2010. Informações acrescentadas pelo autor.

Do total de 135 loteamentos de baixa-média renda dispersos que seguem o padrão da cidade compacta, $58 \%$ se concentram na região de Cotia-Vargem Grande, 19\% estão na região de São Roque-Mairinque-Alumínio, 14\% na região de Sorocaba e apenas $9 \%$ na região de Ibiúna. Dentre os 176 condomínios de alta renda também a sua maior ocorrência (42\%) se dá na região de Cotia-Vargem Grande, e a segunda na região de Ibiúna (28\%), seguida da região de Sorocaba (17\%) sendo que aí ela se dá mais na direção de Araçoiaba da Serra do que na direção de Salto de Pirapora. A dispersão industrial também é mais frequente na 
região de Cotia-Vargem Grande onde se registrou 68\% (19 peças) do total de dispersão desta tipologia.

Figura 6.22 - Dispersão urbana na região de Vargem Grande Paulista e Ibiúna- Eixo Raposo Tavares.

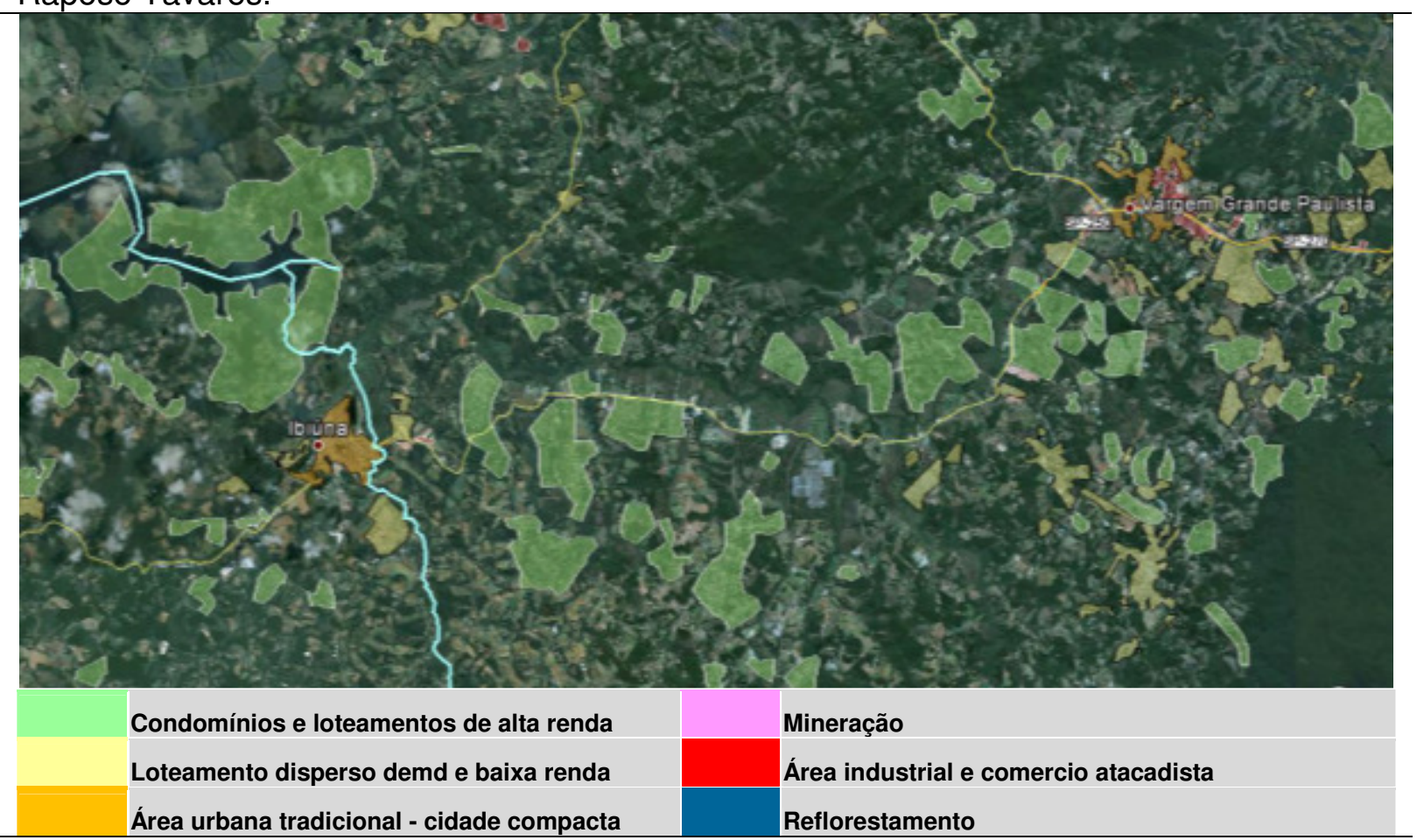

Fonte: imagem e recursos gráficos do Google Earth, 2010. Informações acrescentadas pelo autor.

Assim, é importante considerar que a dispersão neste vetor da rodovia Raposo Tavares é extremamente heterogênea quanto à sua ocorrência pelos diversos setores analisados. Este fenômeno de dispersão é muito mais intenso no trecho inicial da Raposo Tavares entre Cotia e Vargem Grande Paulista, diminuindo consideravelmente nos caminhos de Ibiúna/Piedade e de São Roque/Mairinque/Alumínio. Como se pode ver na Figura 6.21, a ocorrência da dispersão na região de Cotia-Vargem Grande é expressiva, pulverizada e equilibrada entre as tipologias residenciais de baixa e de alta renda. Do total de peças dispersas das três tipologias analisadas (339 peças) 45\% (153 peças) se concentram neste setor de Cotia/Vargem Grande. As peças dispersas da tipologia de baixa/média-baixa renda ocorrem em maior número do que as de tipologia de condomínios e loteamentos de alta renda (79 e 74, respectivamente). Assim, esse setor se configura em uma ocupação territorial complexa, multifacetada socialmente, em meio a uma paisagem rural em franca desorganização. 
Figura 6.23 - Dispersão urbana na região de São Roque, Ibiúna e Alumínio- Eixo Raposo Tavares.

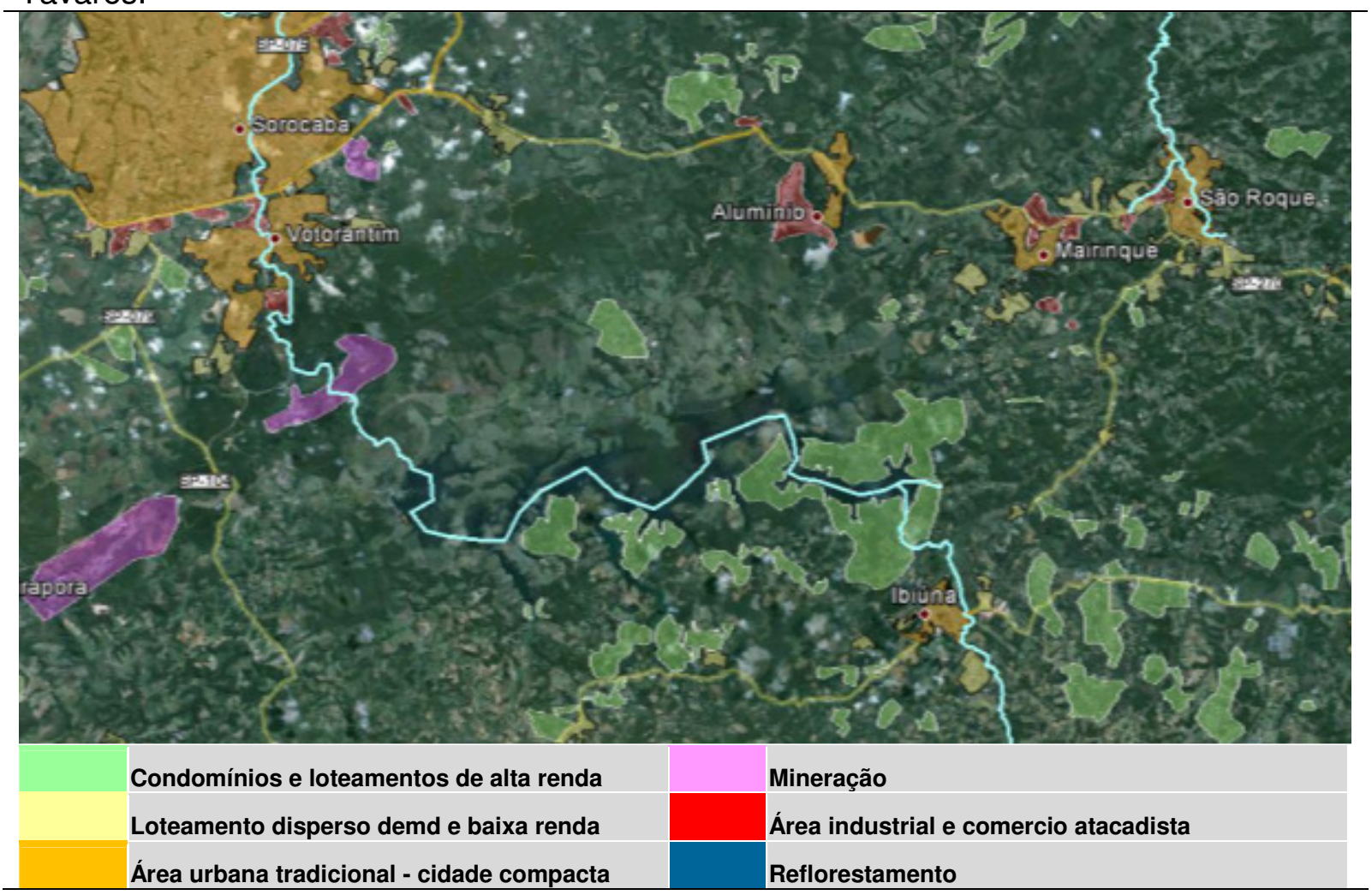

Fonte: imagem e recursos gráficos do Google Earth, 2010. Informações acrescentadas pelo autor.

Figura 6.24 - Dispersão urbana na região de Sorocaba - Eixo Raposo Tavares.

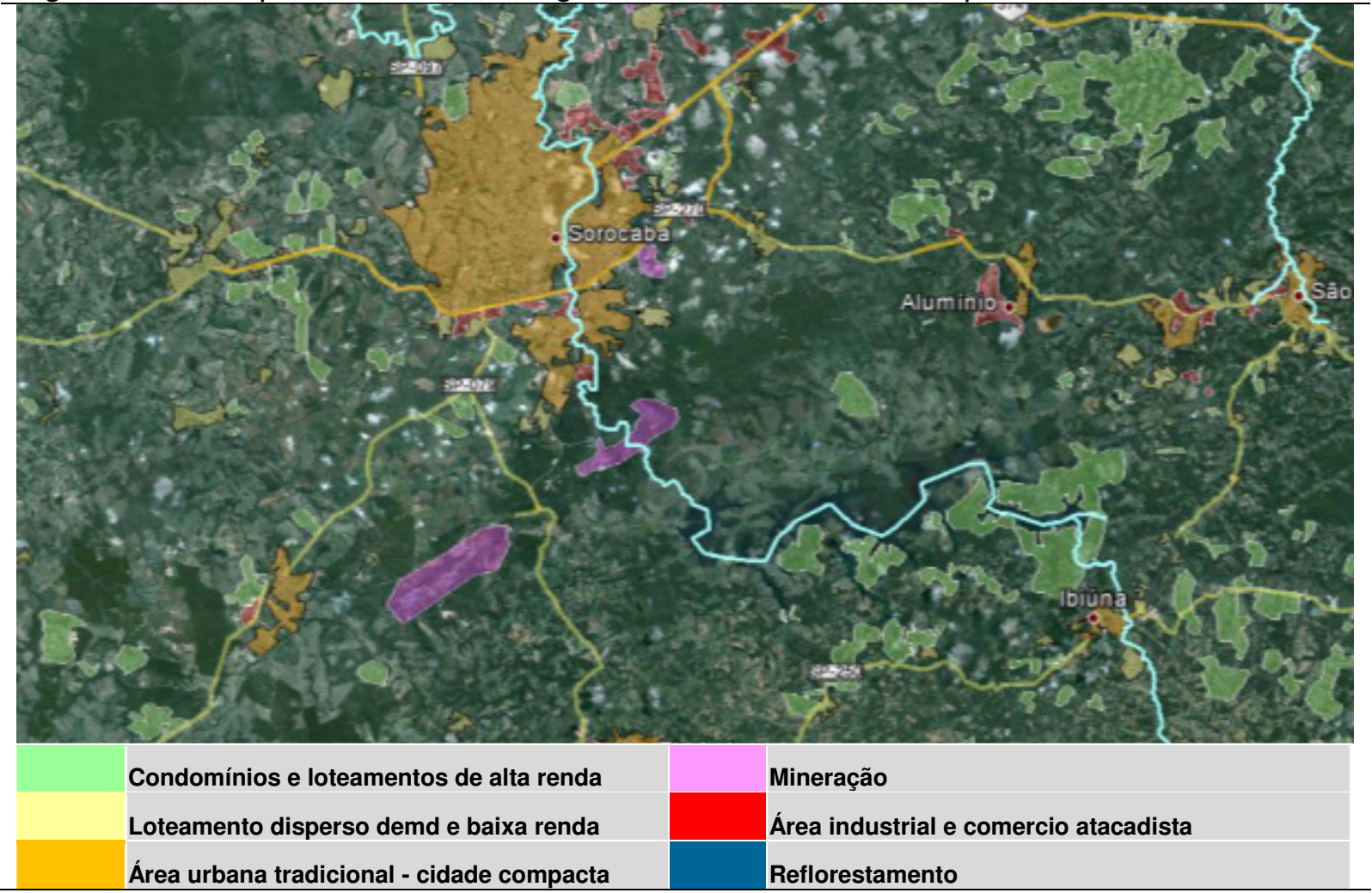

Fonte: imagem e recursos gráficos do Google Earth, 2010. Informações acrescentadas pelo autor. 
Já na região de Ibiúna verifica-se a predominância de condomínios de alta renda, que representam $77 \%$ das peças urbanas em dispersão neste setor. Ocorrem muitos condomínios de chácaras e verifica-se a tendência de se constituir peças urbanas maiores em área do que verificado em outras regiões analisadas. Nesta região foi onde se verificou o menor percentual de loteamentos de baixa renda dispersos ( $9 \%$ do total).

Na região de São Roque/Mairinque/Alumínio a situação da dispersão urbana ocorreu de forma parecida à região de Ibiúna, em quantidade, mas não quanto à distribuição das tipologias. Na região de São Roque as peças dispersas de baixa renda ocorreram em número maior que as de condomínios de alta renda. As peças de baixa renda se distribuem nas proximidades das sedes de São Roque e Mairinque.

\subsubsection{Eixo Régis Bittencourt}

A setorização da área de influência da rodovia Régis Bittencourt obedeceu praticamente os limites municipais dos quatro municípios envolvidos neste fenômeno de dispersão urbana, conforme descrito a seguir:

$\checkmark$ Embu: envolve a área total do município.

$\checkmark$ Itapecerica da Serra: envolve a área total do município.

$\checkmark$ Embu-Guaçu: município não lindeiro à rodovia Régis Bittencourt, mas tem nela um de seus acessos. Sua área de dispersão é parcialmente influenciada por um vetor rodoviário pouco expressivo ligado à expansão urbana periférica do sul do município de São Paulo - região de Parelheiros e Cipó-Marsilac - acessado pela estrada de Parelheiros. Seu acesso à Régis Bittencourt se dá pela SP-234 até Itapecerica da Serra.

$\checkmark$ São Lourenço da Serra: envolve a área do município. Fica ás margens da rodovia Régis Bittencourt.

Neste vetor de dispersão as condições paisagísticas são exclusivas das formas de relevo que configuram a paisagem do Planalto Atlântico. Os principais atributos paisagísticos estão na presença dos mares de morros, de alguns 
alinhamentos serranos e de fragmentos da mata atlântica. Rochas graníticas e migmatíticas sustentam o relevo deste trecho inicial da rodovia. Os principais alinhamentos serranos são graníticos: Serra de Taquaxiara e Serra de Itatuba. A primeira se situa a meio caminho de Embu-Guaçu a Itapecerica da Serra e tem seus topos nas cotas em torno dos 900 metros. A segunda ocorre a meio caminho de Embu a São Lourenço da Serra, e tem seus topos em torno de 1.000 metros de altitude.

Figura 6.25 - Dispersão urbana na região de Embu e Itapecerica da Serra - Eixo Régis Bittencourt .

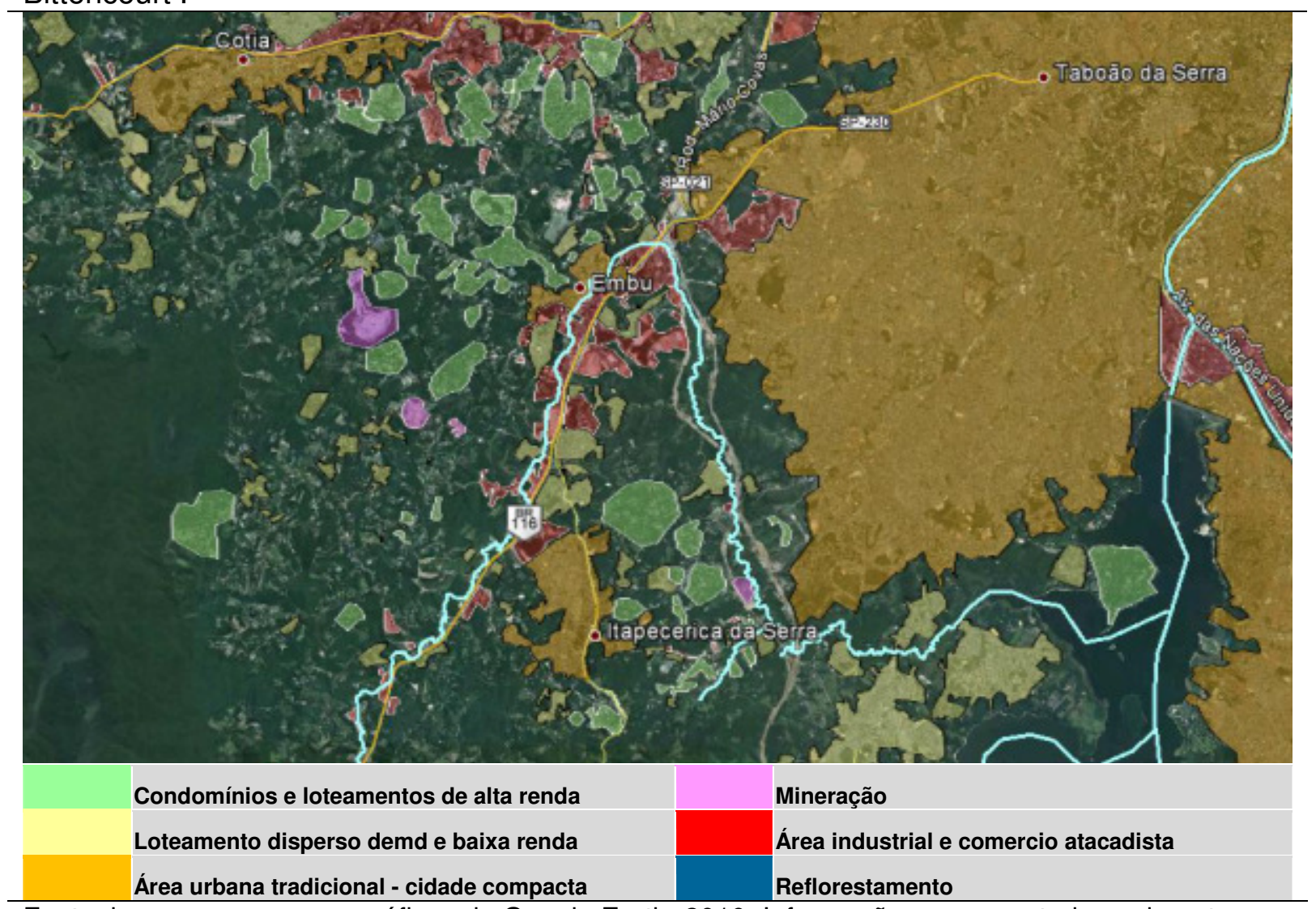

Fonte: imagem e recursos gráficos do Google Earth, 2010. Informações acrescentadas pelo autor.

As imagens das figuras 6.25 e 6.26 mostram as regiões de dispersão acima citadas e um retrato simplificado do fenômeno. Neste mapeamento as tipologias de condomínios e loteamentos de chácaras também se encontram agrupadas ao padrão de tipologia de condomínios fechados de média-alta renda e assinaladas na cor verde claro. 
Figura 6. 26 - Dispersão urbana na região de São Lourenço da Serra e Embu-Guaçu - Eixo Régis Bittencourt.

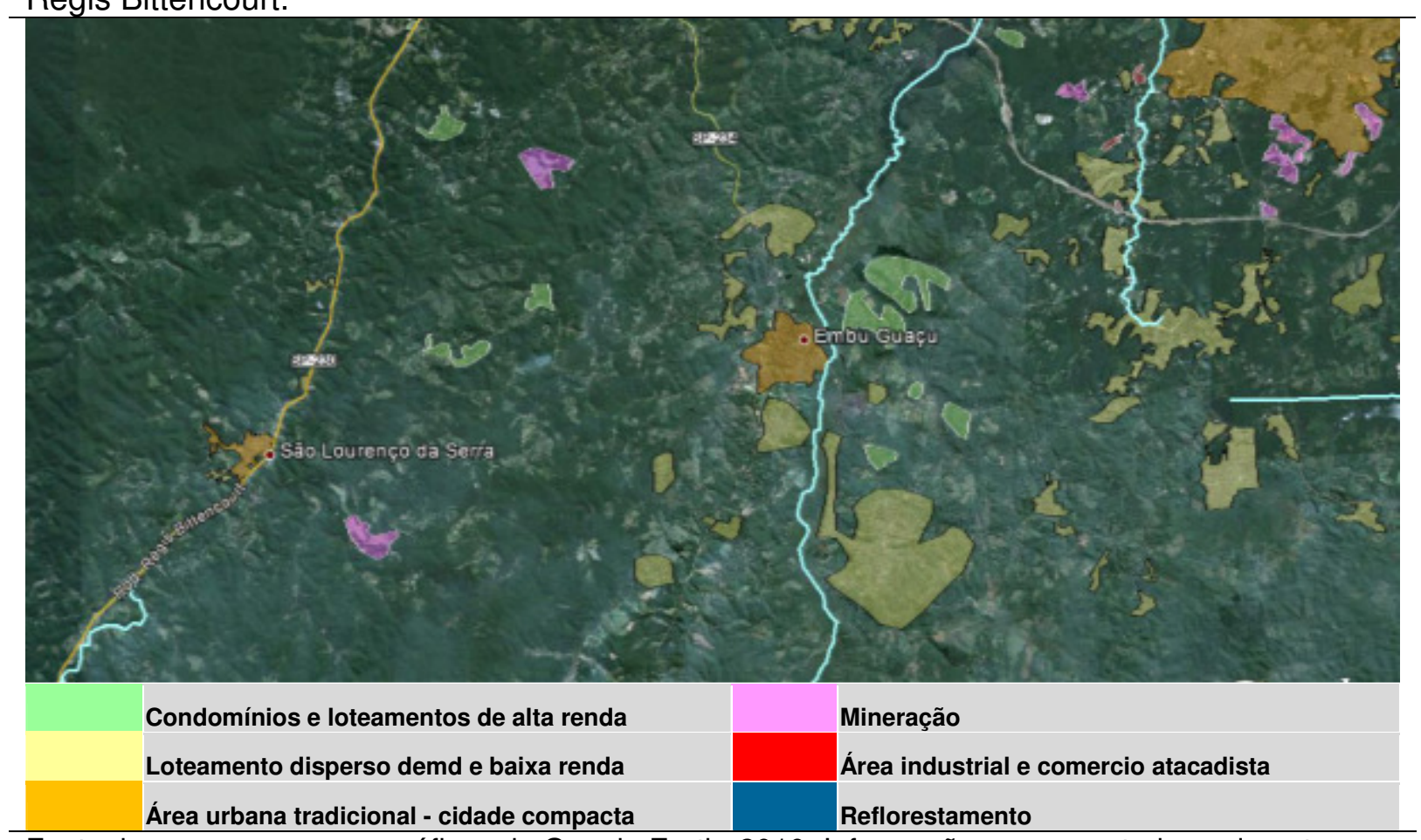

Fonte: imagem e recursos gráficos do Google Earth, 2010. Informações acrescentadas pelo autor.

Assim como no vetor da Régis Bittencourt, a dispersão urbana neste vetor não é tão expressiva como do que ocorre nos eixos Anhanguera-Bandeirantes, Raposo Tavares e Fernão Dias. Este vetor de dispersão é dominado pela presença de loteamento de baixa renda. Das 148 peças urbanas dispersas das três tipologias abordadas (ocupação residencial de baixa renda, condomínios de alta renda e área industrial/comercial/institucional) $60 \%$ se referem a loteamento de baixa renda (89 peças). Os condomínios de alta renda representam $26 \%$ da dispersão (38 peças0) e as áreas industriais 14\% (21 peças). Em todos os setores analisados a ocupação de baixa renda predomina, sendo mais significativa no setor entre Rio Grande da Serra/Ribeirão Pires até Suzano (44\% do total da ocupação de baixa renda dispersa).

A dispersão industrial só não aparece no setor Imigrantes. Nos demais ela se distribui igualitariamente - 10 peças em cada setor, sendo que entre Ribeirão Pires e Suzano ela ocorre estritamente ás margens da Rodovia Índio Tibiriçá. Não foram registradas atividade minerária neste eixo de dispersão. 


\subsubsection{Eixo Anchieta-Imigrantes}

A setorização da área de influência do vetor sul composto pelo sistema Anchieta-Imigrantes se orientou pelo estabelecimento de segmentos rodoviários entre as cidades mais influentes da região e à imposições físicas e de infraestrutura, fatos esses que se refletem em termos de acessibilidade. A dispersão foi considerada apenas no que se refere às peças urbanas dispersas além do Rodoanel. Na parte interna considerou-se que o vetor principal de expansão urbana são as ocupações urbanas adjacentes da urbanização compacta das cidades de Diadema, São Bernardo e Mauá. Considerou-se que esse vetor sul inclui a rodovia Índio Tibiriçá - SP-031, em sua ligação da Via Anchieta até o município de Suzano. Assim, definiu-se três regiões de influência de cada rodovia/cidade da seguinte forma:

$\checkmark$ Região de influência da Via Imigrantes: vai do rodoanel até a interligação Imigrantes-Anchieta no topo da Serra do Mar. Separa-se da área de influência da Anchieta em um dos braços do reservatório Rio Pequeno. Inclui os bairros rurais de Taquacetuba e Tatetos.

$\checkmark$ Região de influência da Via Anchieta: inclui as localidades Finco, Rio Grande e Varginha, nas proximidades da represa Billings, a rodovia Caminho do Mar e a rodovia Índio Tibiriçá até a cidade de Rio Grande da Serra.

$\checkmark$ Região de influência da rod. Índio Tibiriçá entre Rio Grande da Serra/Ribeirão Pires até Suzano: inclui as localidades Estância São Luís, Ipelândia e Fazenda Aya.

Este vetor de dispersão é dominado pela presença mais marcante de remanescentes de Mata Atlântica e pela represa Billings, que Ihe conferem um grande atrativo de localização para usos turísticos e residenciais. A expansão urbana periférica da metrópole neste eixo sul bordejando um dos lados da represa modificou por completo as dinâmicas urbanísticas associadas à preservação dos mananciais conforme se planejava nas décadas de 1970-80. Vários autores estudaram essa questão socioambiental ligada à preservação de mananciais, dentre eles Sporl e Seabra (1997), Sócrates, Grostein e Tanaka (1985) e Marcondes (1999). 
As imagens das figuras 6.27 e 6.28 mostram as regiões de dispersão acima citadas e um retrato simplificado do fenômeno. Também neste mapeamento as tipologias de condomínios e loteamentos de chácaras se encontram agrupadas ao padrão de tipologia de condomínios fechados de média-alta renda e assinaladas na cor verde claro.

Figura 6.27 - Dispersão Urbana na região sul de São Paulo e São Bernardo. Eixo AnchietaImigrantes.

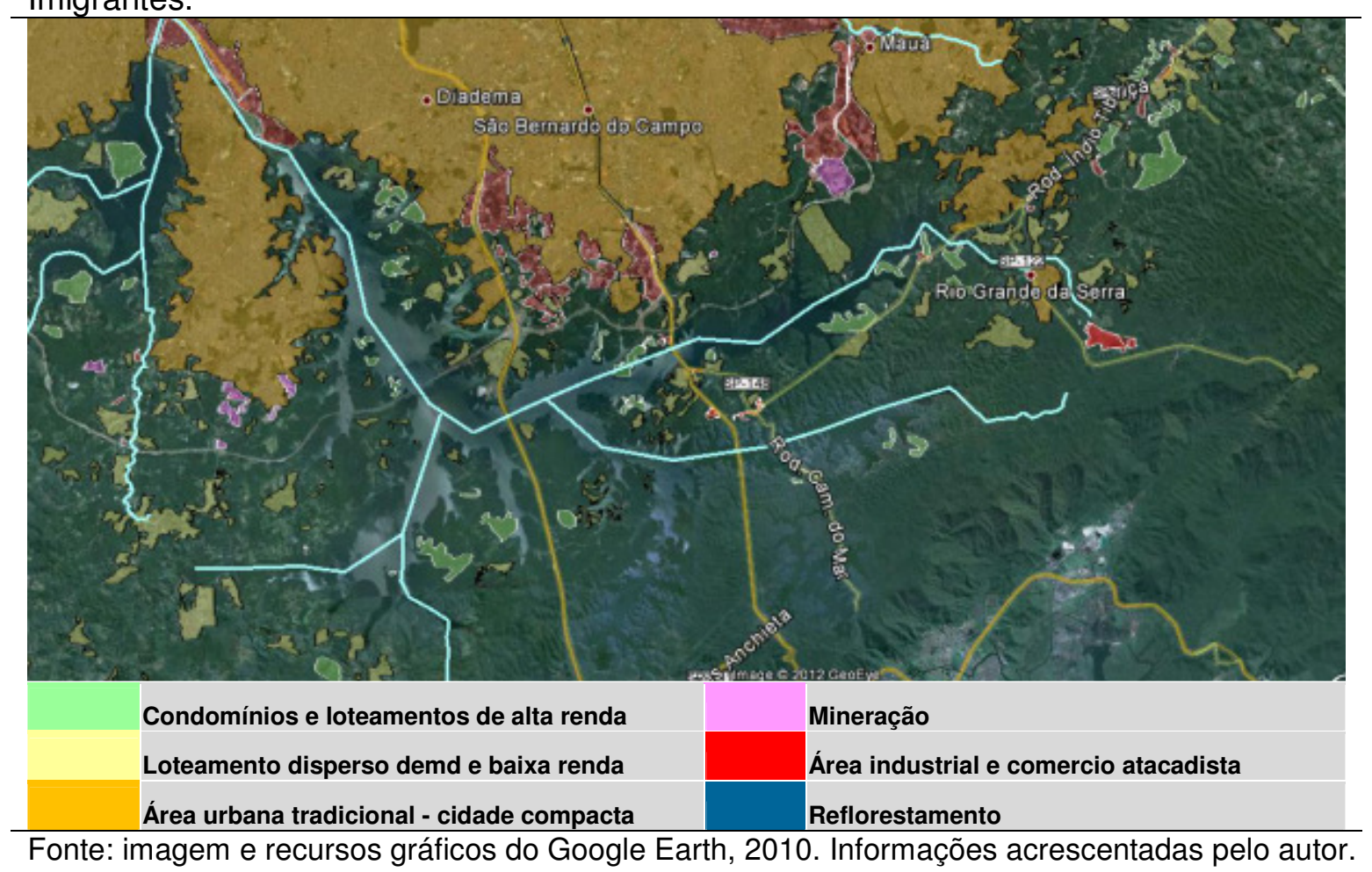

A morfologia da dispersão urbana assume configurações diversas nos três setores analisados. No setor da Imigrantes a ocupação apresenta-se bem dispersa e geralmente beirando a represa. Enquanto os condomínios e loteamentos de alta renda têm dimensões maiores, a ocupação de baixa renda apresenta-se fragmentada em agrupamentos de pequenas dimensões. No setor da Via Anchieta a alta renda também ocupa glebas às margens da represa e em conjuntos de grandes dimensões. As peças dispersas de baixa renda ocorrem mais dominantemente próximas à cidade de Rio Grande da Serra e do entroncamento da Anchieta com a Índio Tibiriçá. Já no setor da rodovia Índio Tibiriçá entre Rio Grande da Serra/Ribeirão Pires até Suzano a morfologia assume a feição de contas de colar ao longo da rodovia. Mas, essa feição só acontece com os loteamentos de baixa renda e com a ocupação industrial. Os condomínios de alta renda tendem a se afastar da rodovia. 
A dispersão urbana neste vetor só é mais expressiva no município de Embu, e se mistura com a dispersão proveniente de Cotia, da área de influência da Raposo tavares. Foram identificadas e mapeadas neste vetor de dispersão apenas 132 peças urbanas dispersas, a menor ocorrência dentre os eixos de dispersão analisados. Como nas demais áreas essas peças variam muito em tamanho, tanto no que se refere ao tipo e padrão do loteamento, como por já apresentar tendências de agrupamento contíguo de loteamentos implantados em épocas diferentes.

Figura 6.28 - Dispersão urbana na região de Mauá, Rio Grande da Serra e Suzano - Eixo Anchieta-Imigrantes (Rod. Índio Tibiriçá).

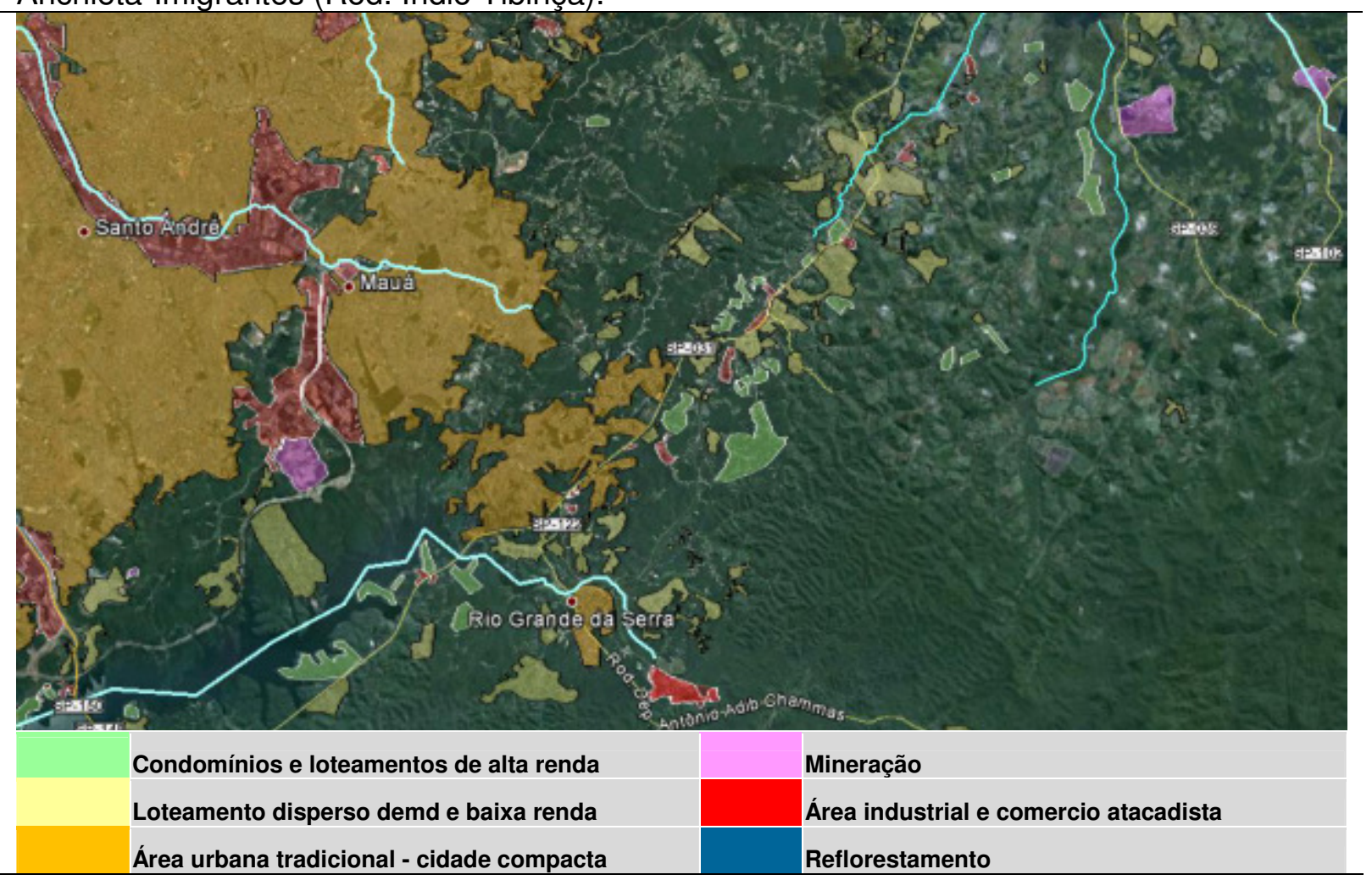

Fonte: imagem e recursos gráficos do Google Earth, 2010. Informações acrescentadas pelo autor.

Este vetor destoa dos até aqui apresentados quanto à tipologia das peças urbanas predominantes. Neste vetor predominam os loteamentos de baixa e médiabaixa renda. Em todos os municípios o número de loteamentos dispersos de baixa renda foi maior que a dispersão de alta renda, inclusive em Embu, que possui o maior número das tipologias residenciais de alta renda dentre os municípios abordados. De um total de 132 peças urbanas dispersas mapeadas neste vetor da Régis Bittencourt, 47\% correspondem à tipologia de baixa renda (62 peças). Os condomínios de alta renda significam $35 \%$ (46 peças) do total das peças em dispersão. O restante são as peças da tipologia industrial com apenas 18\% (24 
peças). Desta forma, pode-se afirmar que este vetor está envolto à expansão periférica da metrópole em um grau maior.

\subsubsection{Eixo Dutra-Airton Senna}

A setorização da área de influência do vetor composto pelo sistema DutraAirton Senna se deu pelo critério de estabelecimento de tamanhos homogêneos em área, e pela influência e início de conurbação dos principais polos com o entorno. Dessa forma, se delineou o conjunto de cidades situadas na saída da metrópole até Santa Isabel; pela região conurbada de São José dos Campos; pela conrbação em torno de Taubaté e pela região de Mogi das Cruzes, uma variante de dispersão por meio da rodovia Mogi-Bertioga. Os setores definidos possuem a seguinte conformação:

$\checkmark$ Região da saída da metrópole - Guarulhos/ltaquaquecetuba: abrange os municípios citados mais Arujá, Suzano, Guararema e Santa Isabel.

$\checkmark$ Região de São José dos Campos: inclui os municípios de Jacareí e Caçapava.

$\checkmark$ Região de Taubaté: inclui os municípios de Tremembé e Pindamonhangaba.

$\checkmark$ Região de Mogi das Cruzes: inclui Biritiba-Mirim e Salesópolis.

Este vetor de dispersão é dominado pela presença marcante das escarpas da Serra da Mantiqueira, que assume denominações locais distintas: Serra do Itaberaba, em Arujá e Santa Isabel; Serra da Pedra Branca e Serra do Mato Mole, em São José dos Campos; e Serra do Palmital, em Caçapava. Esse conjunto serrano é emoldurado ao fundo pelas escarpas da Serra da Mantiqueira atinge altitudes de 1.800 a 1.900 metros, enquanto de as serranias locais se situam em torno dos 1.000 (Pedra Branca e Palmital) a 1.300 metros (Serra do Itaberaba).

Outro elemento importante da paisagem é o Rio Paraíba do Sul e sua expressiva planície sedimentar, situada nas cotas 560 a 540 metros. Além desses, a atratividade também se sustenta na presença de imponentes espelhos d'água na forma de grandes represas de abastecimento e produção de energia: Jaguari, em Igaratá, Ponte Nova, em Biritiba-Mirim e Salesópolis, reservatório de Jundiaí, em Mogi das Cruzes. Localmente a Serra do Itapetí, com seus 1.000 metros de altitude, agrega valor paisagístico à região de Mogi das Cruzes. 
Neste cenário paisagístico a dispersão urbana ao longo deste vetor rodoviário, e de suas variantes, revela diferentes características morfológicas. Enquanto na saída da metrópole a fragmentação e a aglomeração das peças é intensa, deixando pequenos interstícios rurais, na região de Mogi a rarefação das peças urbanas de pequenas dimensões por um amplo espaço rural é a regra. De outro lado, na região do Vale do Paraíba tende-se para a constituição de uma metrópole linear, mas não nos moldes da cidade linear a que se referiu Hilberseimer em 193528. Aí, a dispersão se orienta pela geografia imposta pelo Rio Paraíba e pelas rodovias. Na região de São José a expansão das peças urbanas em dispersão tende a se estabelecer nos terrenos entre a Dutra e a Airton Senna. Na região de Taubaté, pela inexistência da rodovia Airton Senna neste trecho, a ocupação se dirige para o entornoda SP 0622 SP-170, que ligam Taubaté a Pindamonhangaba e a Tremembé. Outro fato a diferencia em muito a morfologia da dispersão na região é a presença constante de mineração na região de saída da metrópole de São Paulo.

As imagens das figuras 6.29 e 6.30 mostram as regiões de dispersão acima citadas e um retrato simplificado do fenômeno. Também neste mapeamento as tipologias de condomínios e loteamentos de chácaras se encontram agrupadas ao padrão de tipologia de condomínios fechados de média-alta renda e assinaladas na cor verde claro.

Neste vetor de dispersão foram identificados no mapeamento realizado 314 peças urbanas dispersas, desgarradas das manchas urbanas compactas das cidades-sede dos municípios. Assim como nos vetores Anchieta-Imigrantes e Régis Bittencourt, na dispersão da Dutra-Airton Senna predominam os loteamentos de baixa e média-baixa renda, que são os loteamentos típicos da ocupação da mancha urbana compacta da metrópole. Do total de peças dispersas 138 (44\%) corresponde aos loteamentos de baixa-média renda. Os condomínios e loteamentos de alta renda representam $35 \%$ (110 peças) do total.

\footnotetext{
${ }^{28}$ Ludwig Hilberseimer, propôs uma cidade ideal, em 1935, que tinha um desenho linear estruturando-se ao longo de uma via, ou rodovia. De um lado indústrias, de outro comércio e centro administrativo dentro de um cinturão verde, e atrás destes, as residências, cercadas por parques e escolas. A área agrícola vinha depois desses parques. Ver "Utopia e Cidades: proposições", de Denise Falcão Pessoa. São Paulo; Annablume, Fapesp, 2006.
} 
Figura 6.29 - Dispersão urbana na região deArujá, Itaquaquecetuba e Santa Isabel - Eixo Dutra-Airton Senna.

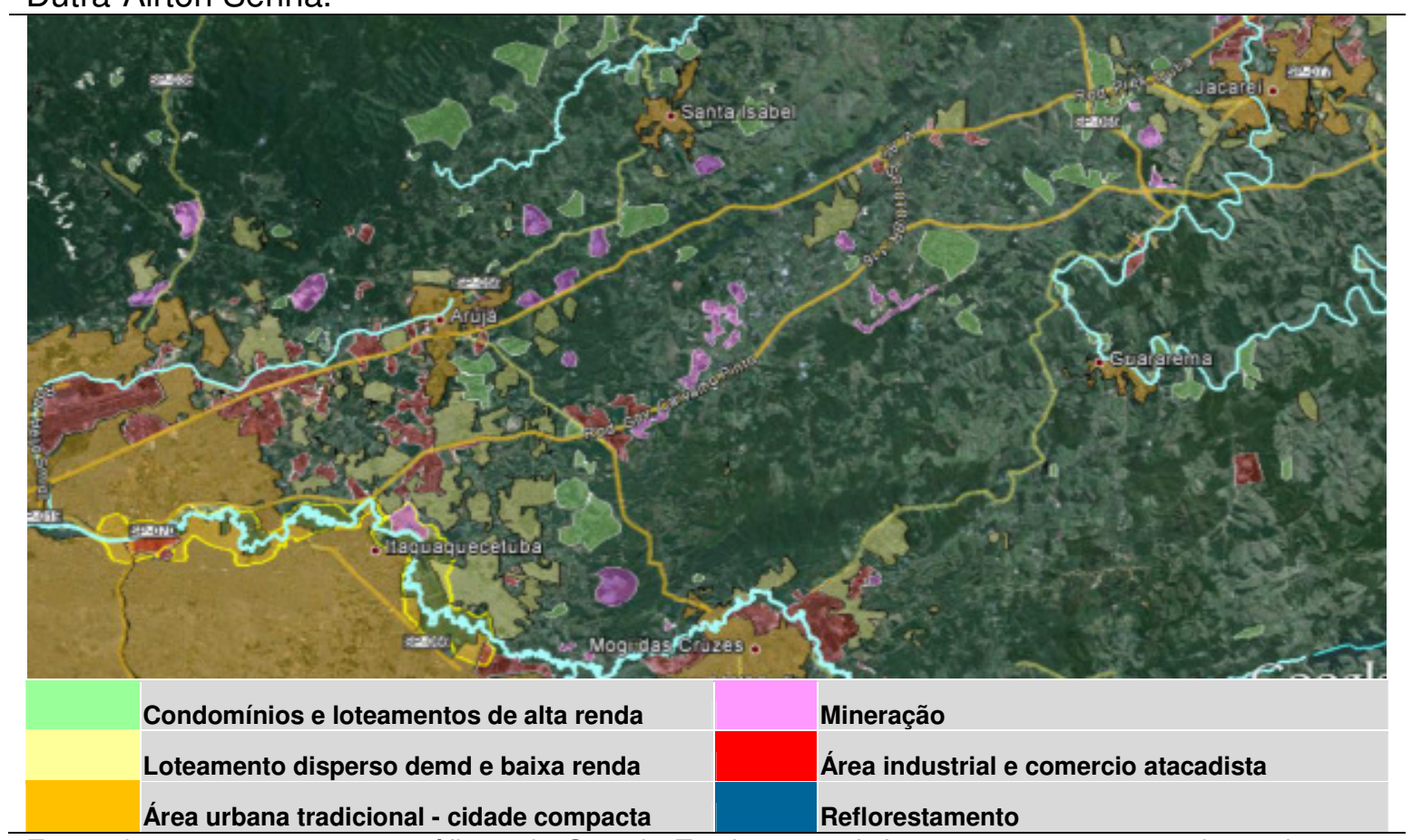

Fonte: imagem e recursos gráficos do Google Earth, 2010. Informações acrescentadas pelo autor.

Figura 6.30 - Dispersão urbana na região do Vale do Paraíba entre Jacareí e Pindamonhangaba - Eixo Dutra-Airton Senna.

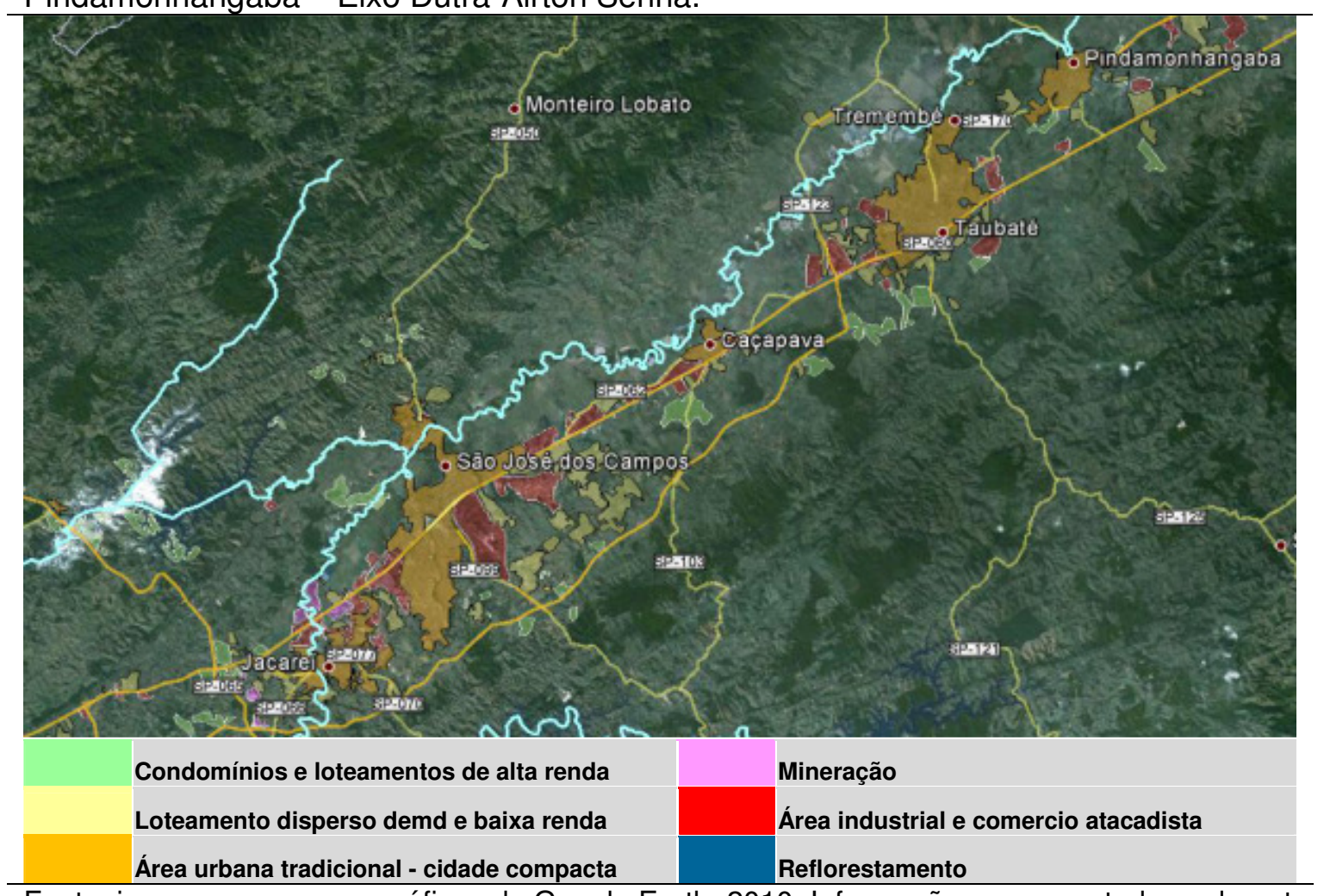

Fonte: imagem e recursos gráficos do Google Earth, 2010. Informações acrescentadas pelo autor. 
A dispersão de unidades produtivas foi significativa neste vetor. Foram identificadas 66 peças de tipologia industrial dispersas (21\% do total). No entanto, é importante realçar que a maior quantidade se verificou na região de saída da metrópole, ou seja, em Guarulhos, Itaquaquecetuba e Arujá, denotando que mesmo nessa tipologia existe a tendência a aglomeração. De certa forma, é o que ocorre na distribuição das áreas industriais ao longo do Vale do Paraíba. Como a distribuição é literalmente linear, muitas áreas já se encontram conurbadas com loteamentos residenciais e este conjunto com a antiga mancha urbana da cidade compacta. Assim, não se pode considerar mais como dispersão, mesmo que os tecidos residenciais ou industriais estejam segregados, uns pelos outros, da contiguidade com o tecido da cidade compacta.

Exceto na região da saída da metrópole, que vai de Guarulhos até perto de Jacareí, nas demais regiões o que se verificou é que os loteamentos dispersos da tipologia da cidade compacta tradicional de baixa e média-baixa renda ocorrem em maior proporção. Na região de São José dos Campos eles representam 57\% das peças dispersas. Em Taubaté, 50\%; e em Mogi das Cruzes 45\%. Já o inverso ocorreu na região de Guarulhos-Arujá-Santa Isabel. Aí se deu a maior ocorrência de loteamentos de alta renda em números absolutos e proporcionais. Foram mapeadas, ao todo, 60 peças urbanas da tipologia de condomínio/loteamento de média-alta renda, de um total de 110 da mesma tipologia, o que representa $54 \%$ do total. Em relação ao total geral deste setor, que foi de 145 peças das três tipologias abordadas, estes condomínios representaram $45 \%$ do total.

\subsubsection{O quadro geral da dispersão na Macrometrópole: a realidade como tendência}

Que o processo de dispersão urbana apresentado na atualidade é complexo, e vai muito além de se configurar apenas a sua expressão territorial, não se pode negar. Conforme tem expressado boa parte dos pesquisadores e teóricos deste fenômeno, a dispersão é, mesmo, uma tendência da urbanização atual. No entanto, o senso comum vem conduzindo a sua explicação para três preocupações adjetivas: 
$\checkmark$ Primeira, a de que o processo é predominantemente impulsionado pela dispersão de loteamentos e condomínios de $1^{\underline{a}}$ ou $2^{\text {a }}$ residência para as classes de média a alta renda;

$\checkmark$ Segunda, que este processo deriva dos problemas da vida agitada da cidade concentrada, e por isso busca-se um maior contato com a natureza;

$\checkmark$ E terceira, que acompanha o processo de dispersão industrial.

De fato esses três elementos estão presentes no processo de dispersão aqui analisado, mas também que a realidade da macrometrópole de São Paulo nos mostra variações importantes em sua expressão. A primeira dessas variantes é que, em alguns eixos de dispersão, a dispersão das classes de alta renda não é a que predomina absolutamente sobre a dispersão da baixa renda. Outra é que a dispersão industrial tende à concentração linear no espaço lindeiro às rodovias, e prioriza a proximidade com os núcleos urbanos da cidade compacta mais próxima. Nesse sentido, a dispersão dos loteamentos de baixa renda segue a tendência à aglomeração em torno da cidade compacta e das áreas de emprego industrial.

Tabela 6.1 - Quadro síntese da dispersão das peças urbanas na macrometrópole de São Paulo. Comparação horizontal - número absoluto e percentual das tipologias segundo cada eixo rodoviário, 2010-2011.

\begin{tabular}{lccccccc}
\hline Eixo rodoviário de dispersão & $\begin{array}{c}\text { loteamentos de } \\
\text { baixa e média- } \\
\text { baixa renda }\end{array}$ & $\begin{array}{c}\text { Condomínios e } \\
\text { loteamentos de } \\
\text { média-alta renda }\end{array}$ & $\begin{array}{c}\text { Uso produtivo - } \\
\text { área industrial / } \\
\text { comercial / } \\
\text { institucional }\end{array}$ & $\begin{array}{c}\text { Total } \\
\text { Geral }\end{array}$ \\
\cline { 2 - 8 } & No sobre & $\begin{array}{c}\text { \%o } \\
\text { total }\end{array}$ & No sobre & $\begin{array}{c}\text { \% sobre } \\
\text { total } \\
\text { total }\end{array}$ & No \\
\hline Fernão Dias & 68 & $23 \%$ & 199 & $66 \%$ & 34 & $11 \%$ & 301 \\
Anhanguera-Bandeirantes & 218 & $32 \%$ & 300 & $45 \%$ & 155 & $23 \%$ & 673 \\
Castelo Branco & 45 & $27 \%$ & 71 & $43 \%$ & 49 & $30 \%$ & 165 \\
Raposo Tavares & 135 & $40 \%$ & 176 & $52 \%$ & 28 & $8 \%$ & 339 \\
Régis Bittencourt & 62 & $47 \%$ & 46 & $35 \%$ & 24 & $18 \%$ & 132 \\
Anchieta-Imigrantes & 89 & $60 \%$ & 38 & $26 \%$ & 21 & $14 \%$ & 148 \\
Dutra-Airton Senna & 138 & $44 \%$ & 110 & $35 \%$ & 66 & $21 \%$ & 314 \\
Total & $\mathbf{7 5 5}$ & $\mathbf{3 6 \%}$ & $\mathbf{9 4 0}$ & $\mathbf{4 5 \%}$ & $\mathbf{3 7 7}$ & $\mathbf{1 8 \%}$ & $\mathbf{2 0 7 2}$ \\
\hline
\end{tabular}

Fonte: Elaboração e dados organizados pelo autor.

O quadro levantado nesta pesquisa para a macrometrópole de São Paulo, mesmo que apenas analisado sobre o aspecto formal da mancha, e não pelo seu conteúdo funcional explicito de constituição de uma cidade difusa, na acepção de Dematteis (1998), permite verificar algumas variações substantivas. Como 
demonstra a Tabela 6.1, a dispersão dos condomínios de alta renda é predominante no conjunto da macrometrópole. Das 2072 peças urbanas dispersas mapeadas, $45 \%$ correspondem a essa tipologia, enquanto a dispersão de baixa e média-baixa renda significou $36 \%$ do total. Entretanto variações significativas foram registradas. A dispersão de alta renda se verificou maior, em termos percentuais, nos vetores Fernão Dias (66\%), Raposo Tavares (52\%), Anhanguera (45\%) e Castelo Branco (43\%). Dessa forma, a dispersão de baixa renda foi maior nos vetores da AnchietaImigrantes (60\%), Régis Bittencourt (47\%) e Dutra-Airton Senna (44\%).

A dispersão industrial apareceu percentualmente mais expressiva nos vetores das rodovias Castelo Branco (30\%), Anhanguera-Bandeirantes (23\%) e Dutra-Airton Senna (21\%), e pouco significativa nos vetores Raposo Tavares (8\%) e Fernão Dias $(11 \%)$.

A Tabela 6.2 nos mostra outra faceta desta realidade, quando se verifica em qual vetor cada uma das tipologias abordadas foi mais expressiva numericamente. Pode-se observar que as maiores ocorrências da tipologia de baixa renda aconteceram ao longo dos eixos de dispersão da Anhanguera (29\%), em que pese ela ter sido suplantada internamente pela dispersão de alta renda, e da Raposo Tavares e Dutra-Airton Senna (18\% cada). Já as maiores ocorrências de alta renda foram registradas nos eixos Anhanguera-Bandeirantes (32\%), Fernão Dias (21\%) e Raposo Tavares (19\%).

Tabela 6.2- Quadro síntese da dispersão das peças urbanas na macrometrópole de São Paulo. Comparação dos eixos segundo cada tipologia de dispersão, 2010-2011.

\begin{tabular}{|c|c|c|c|c|c|c|c|c|}
\hline \multirow{2}{*}{$\begin{array}{l}\text { Eixo rodoviário de } \\
\text { dispersão }\end{array}$} & \multicolumn{2}{|c|}{$\begin{array}{l}\text { loteamentos de } \\
\text { baixa e média- } \\
\text { baixa renda }\end{array}$} & \multicolumn{2}{|c|}{$\begin{array}{c}\text { Condomínios e } \\
\text { loteamentos de } \\
\text { média-alta } \\
\text { renda }\end{array}$} & \multicolumn{2}{|c|}{$\begin{array}{l}\text { Uso produtivo - } \\
\text { área industrial / } \\
\text { comercial / } \\
\text { institucional }\end{array}$} & \multicolumn{2}{|c|}{ Total Geral } \\
\hline & № & $\begin{array}{c}\% \\
\text { sobre } \\
\text { total }\end{array}$ & № & $\begin{array}{c}\% \\
\text { sobre } \\
\text { total }\end{array}$ & № & $\begin{array}{c}\% \\
\text { sobre } \\
\text { total }\end{array}$ & № & $\begin{array}{c}\% \\
\text { sobre } \\
\text { total }\end{array}$ \\
\hline Fernão Dias & 68 & $9 \%$ & 199 & $21 \%$ & 34 & $9 \%$ & 301 & $15 \%$ \\
\hline Anhanguera-Bandeir. & 218 & $29 \%$ & 300 & $32 \%$ & 155 & $41 \%$ & 673 & $32 \%$ \\
\hline Castelo Branco & 45 & $6 \%$ & 71 & $8 \%$ & 49 & $13 \%$ & 165 & $8 \%$ \\
\hline Raposo Tavares & 135 & $18 \%$ & 176 & $19 \%$ & 28 & $7 \%$ & 339 & $16 \%$ \\
\hline Régis Bittencourt & 62 & $8 \%$ & 46 & $5 \%$ & 24 & $6 \%$ & 132 & $6 \%$ \\
\hline Anchieta-Imigrantes & 89 & $12 \%$ & 38 & $4 \%$ & 21 & $6 \%$ & 148 & $7 \%$ \\
\hline Dutra-Airton Senna & 138 & $18 \%$ & 110 & $12 \%$ & 66 & $18 \%$ & 314 & $15 \%$ \\
\hline Total & 755 & $100 \%$ & 940 & $100 \%$ & 377 & $100 \%$ & 2072 & $100 \%$ \\
\hline
\end{tabular}

Fonte: Elaboração e dados organizados pelo autor. 
Pela dimensão do fenômeno, e por envolver as duas metrópoles principais, São Paulo e Campinas, o eixo rodoviário Anhanguera-Bandeirantes apresentou o maior número de casos, 673 peças urbanas em dispersão, o que equivale a $32 \%$ do total. Por isso, também apresentou o maior percentual de casos de dispersão industrial - $41 \%$, contra $18 \%$ do eixo Dutra-Airton Senna. As menores ocorrências foram registradas nos eixos Régis Bittencourt e Anchieta-Imigrantes. Convém lembrar que o eixo Anchieta-Imigrantes, por ser área de industrialização antiga, tem boa parte de suas áreas industriais envolvidas pela mancha compacta da metrópole nos municípios de Diadema, São Bernardo, Santo André e Mauá.

Dessa forma, conclui-se que essa apresentação das características da dispersão urbana na macrometrópole segundo os principais eixos de dispersão foi colocada no sentido de aproximar a análise tendencial da dispersão com a análise dos impactos ambientais decorrentes. No que se vincula à compreensão das tendências de expansão/dispersão, no capítulo que se segue - 6.4 - serão abordados os parâmetros populacionais da evolução demográfica dos municípios segundo esses eixos de dispersão. Após essa abordagem, o capítulo 7 adentrará nos aspectos ambientais relativos à essa essência da dispersão urbana verificada sobre a ótica da apropriação do relevo, categoria de análise até aqui não introduzida nesse contexto analítico por opção metodológica de apresentação.

\subsection{Os eixos da dispersão urbana e a desconcentração populacional}

Sob o aspecto populacional pode-se considerar que na década de 1970 é que se inicia o processo de desconcentração populacional na RMSP e na Macrometrópolede São Paulo, esta última aqui considerada sob o ponto de vista do processo de dispersão urbana.

Como se pode verificar na Tabela 6.3, em 1970 o município de São Paulo, sozinho, detinha $59,3 \%$ de toda população dos 87 municípios da região deste estudo. Os municípios dos eixos de dispersão da Dutra-Airton Senna, AnchietaImigrantes, Anhanguera-Bandeirantes perfaziam aproximadamente $10 \%$ em cada conjunto, enquanto os municípios dos eixos Castelo Branco, Raposo Tavares e Regis Bittencourt, todos somados, juntavam o restante dos $10 \%$ da população da macrometrópole. Fica, assim, evidente a concentração do crescimento no município 
de São Paulo até então, e uma maior expressão de crescimento populacional nos eixos Dutra-Airton Senna, Anchieta-Imigrantes e Anhanguera-Bandeirantes do que nos demais eixos. É certo que ainda não se pode falar em dispersão urbana como o elemento caracterizador desse processo, mas que corresponde apenas a um vetor de crescimento das cidades, dos núcleos-sede destes municípios.

O processo de desconcentração populacional passa a ficar evidente a partir de 1970, pois se verifica a expressiva queda proporcional da população do município de São Paulo em relação aos municípios da Macrometrópole aqui analisados. A participação da população do município de São Paulo em relação ao total da Macrometrópole cai de 59,3\% em 1970, para 54,0\% em 1980, chegando em 2010 a significar 42,8\%, numa redução de 16,5 pontos percentuais no período 1970-2010.

Tabela 6.3 - Evolução da população total e \% relativo ao total da Macrometrópole nos períodos entre 1970-2010, segundo os eixos rodoviários de dispersão urbana.

\begin{tabular}{|c|c|c|c|c|c|c|c|}
\hline $\begin{array}{l}\text { Rodovias - Eixo } \\
\text { de dispersão }\end{array}$ & Indicador & 1970 & 1980 & 1991 & 2000 & 2010 & $\begin{array}{l}1970- \\
2010\end{array}$ \\
\hline \multirow{2}{*}{$\begin{array}{l}\text { Dutra - Airton } \\
\text { Senna }\end{array}$} & População Total & 990.045 & 1.814 .175 & 2.695 .244 & 3.526 .647 & 4.062 .951 & $310 \%$ \\
\hline & \% Macrometr. & $9,9 \%$ & $11,5 \%$ & $13,5 \%$ & $15,0 \%$ & $15,5 \%$ & \\
\hline \multirow{2}{*}{$\begin{array}{l}\text { Anchieta - } \\
\text { Imigrantes }\end{array}$} & População Total & 988.677 & 1.652 .794 & 2.048 .674 & 2.354 .722 & 2.549 .135 & $158 \%$ \\
\hline & \% Macrometr. & $9,9 \%$ & $10,5 \%$ & $10,3 \%$ & $10,0 \%$ & $9,7 \%$ & \\
\hline \multirow{2}{*}{ Fernão Dias } & População Total & 154.186 & 206.471 & 283.963 & 357.921 & 427.273 & $177 \%$ \\
\hline & \% Macrometr. & $1,5 \%$ & $1,3 \%$ & $1,4 \%$ & $1,5 \%$ & $1,6 \%$ & \\
\hline \multirow{2}{*}{$\begin{array}{l}\text { Anhanguera - } \\
\text { Bandeirantes }\end{array}$} & População Total & 960.961 & 1.744 .787 & 2.554 .438 & 3.258 .932 & 3.904 .439 & $306 \%$ \\
\hline & $\%$ Macrometr. & $9,6 \%$ & $11,1 \%$ & $12,8 \%$ & $13,9 \%$ & $14,9 \%$ & \\
\hline \multirow{2}{*}{ Castelo Branco } & População Total & 503.448 & 968.399 & 1.397 .537 & 1.819 .712 & 2.029 .384 & $303 \%$ \\
\hline & $\%$ Macrometr. & $5,0 \%$ & $6,2 \%$ & $7,0 \%$ & $7,8 \%$ & $7,7 \%$ & \\
\hline \multirow{2}{*}{ Raposo Tavares } & População Total & 363.468 & 563.926 & 833.393 & 1.080 .714 & 1.297 .291 & $257 \%$ \\
\hline & \% Macrometr. & $3,6 \%$ & $3,6 \%$ & $4,2 \%$ & $4,6 \%$ & $4,9 \%$ & \\
\hline \multirow{2}{*}{ Regis Bittencourt } & População Total & 101.947 & 287.464 & 465.466 & 630.566 & 742.669 & $628 \%$ \\
\hline & $\%$ Macrometr. & $1,0 \%$ & $1,8 \%$ & $2,3 \%$ & $2,7 \%$ & $2,8 \%$ & \\
\hline \multirow{2}{*}{$\begin{array}{l}\text { Município de São } \\
\text { Paulo }\end{array}$} & População Total & 5.924 .612 & 8.493 .217 & 9.646 .185 & 10.434 .252 & 11.244 .369 & $90 \%$ \\
\hline & \% Macrometr. & $59,3 \%$ & $54,0 \%$ & $48,4 \%$ & $44,5 \%$ & $42,8 \%$ & \\
\hline \multirow{2}{*}{ Macrometrópole } & População Total & 9.987 .344 & 15.731 .233 & 19.924 .900 & 23.463 .466 & 26.257 .511 & $163 \%$ \\
\hline & Macrometr. & $100 \%$ & $100 \%$ & $100 \%$ & $100 \%$ & $100 \%$ & \\
\hline
\end{tabular}

Fonte: IBGE - Censo demográfico

As regiões que apresentaram maior crescimento no mesmo período foram, na ordem, as dos eixos de dispersão das rodovias Dutra-Airton Senna, AnhangueraBandeirantes e Castelo Branco, que exibiram um crescimento percentual da população em torno de 300\% no período 1970-2010. O eixo Dutra-Airton Senna passa de 9,9\% em 1970 para 15,5\% da população do conjunto da Macrometrópole em 2010. Em segundo lugar em expressão de aglomeração aparece a região do eixo de dispersão da Anhanguera-Bandeirantes, que sobe de 9,6\% para $14,9 \%$. Ambos os grupos mostraram um crescimento contínuo na participação da população 
total, o que tanto pode revelar o dinamismo de atração e fixação de população nas áreas urbanas compactas da sede dos municípios, quanto o já evidente processo de dispersão. O eixo da rodovia Castelo Branco também apresentou um crescimento contínuo no período analisado, passando de 5,0\% em 1970 a 7,8\% em 2000, mas mantendo praticamente o mesmo percentual no período seguinte, ficando com $7,7 \%$ (2000-2010).

Já os eixos da Fernão Dias e da Anchieta-Imigrantes mantiveram quase a mesma proporção de 1970, com o segundo apresentando uma pequena queda de 9,9\% em 1970, para 9,7\% em 2010.

Os eixos de dispersão das rodovias Raposo Tavares e da Régis Bittencourt, embora partindo de patamares populacionais menores, também apresentaram um crescimento relativamente contínuo, no que tange à participação relativa da população total e também no crescimento interno. O eixo da rodovia Raposo Tavares passa de 3,6\% para 4,9\% do total da população, apresentando um crescimento de $257 \%$ no período 1970-2010. Mas o crescimento percentual mais expressivo em termos de taxa se deu no eixo da Régis Bittencourt, cuja população total do conjunto dos municípios cresceu em 628\% no período 1970-2010. Entretanto, trata-se do eixo de desconcentração-dispersão populacional menos expressivo em termos absolutos.

Assim é que os dados apresentados na tabela 6.3 se correlacionam com a análise dos mapas de dispersão urbana, que nos indicam uma maior expressividade da dispersão urbana nestes mesmos eixos de maior crescimento proporcional e absoluto da população.

Tabela 6.4 - Percentual de crescimento nos períodos entre 1970-2010, segundo os eixos rodoviários de dispersão urbana.

\begin{tabular}{lcccc}
\hline \multicolumn{1}{c}{ Rodovias - Eixo de dispersão } & $\mathbf{1 9 7 0 - 1 9 8 0}$ & $\mathbf{1 9 8 0 - 1 9 9 1}$ & $\mathbf{1 9 9 1 - 2 0 0 0}$ & $\mathbf{2 0 0 0 - 2 0 1 0}$ \\
\hline Fernão Dias & 33,91 & 37,53 & 26,04 & 19,38 \\
Anhanguera - Bandeirantes & 81,57 & 46,40 & 27,58 & 19,81 \\
Castelo Branco & 92,35 & 44,31 & 30,21 & 11,52 \\
Raposo Tavares & 55,15 & 47,78 & 29,68 & 20,04 \\
Regis Bittencourt & 181,97 & 61,92 & 35,47 & 17,78 \\
Anchieta - Imigrantes & 67,17 & 23,95 & 14,94 & 8,26 \\
Dutra - Airton Senna & 83,24 & 48,57 & 30,85 & 15,21 \\
\hline Município de São Paulo & 43,35 & 13,58 & 8,17 & 7,76 \\
\hline
\end{tabular}

Fonte: IBGE - Censo demográfico 
Já o crescimento relativo da população vem diminuindo nas últimas quatro décadas e isso se observa em todos os eixos analisados. Na década 1970-1980 o crescimento da população total dos municípios chegava a significar 60 a $80 \%$ em média da população do início da década, como pode ser observado na tabela 6.4. Em 2010 esse crescimento ficou abaixo dos 20\%, exceto nos municípios do eixo Raposo Tavares. O crescimento menos expressivo em termos percentuais se deu nos municípios do eixo Anchieta-Imigrantes (8,26\%).

\subsubsection{As taxas de crescimento anual da população}

Para balizar a compreensão das tendências de crescimento populacional de cada vetor analisado, a análise das taxas de crescimento anual da população do conjunto dos municípios, e de cada um individualmente, pode nos dar pistas de acirramento do processo de dispersão ou de sua atenuação. Essa análise também nos dá uma dimensão mais real das tendências de homogeneização ou não do crescimento e do desenvolvimento territorial, e é um elemento importante para qualificar a evolução de uma rede urbana.

Nessa análise, também é importante a correlação com índices de referência regional que possam balizar a real intensidade do fenômeno, sobretudo quando em um cenário de tendências opostas de crescimento e declínio da população. Tem-se como prática para as análises municipais a comparação com as médias do estado em que se encontram tais municípios e com a média do Brasil.

Para a análise desse indicador de crescimento demográfico utilizou-se a classificação contida no trabalho do IBGE, sobre as tendências demográficas apresentadas no censo 2000 (IBGE, 2004). Nele, as taxas médias geométricas de crescimento anual da população estão divididas em quatro faixas:

$\checkmark$ Taxas negativas: refletem perda populacional.

$\checkmark$ Taxas entre 0 e 1,5\% ao ano: refletem um crescimento baixo ou moderado e, provavelmente, abaixo do crescimento vegetativo da população.

$\checkmark$ Taxas entre 1,5 e 3,0\% ao ano: refletem um crescimento médio e indiscutível da população. 
$\checkmark$ Taxas acima de 3,0\% ao ano: refletem um crescimento alto ou acelerado da população do município.

Observando a Tabela 6.5 é possível observar que, no período 1970-80, a população dos conjuntos analisados apresentou um crescimento alto ou acelerado, inclusive o do município de São Paulo. Todos os conjuntos tiveram indicador acima das médias do Estado de São Paulo e do Brasil. A única exceção se deu no vetor Fernão Dias, que apresentou taxas medianas (2,96\%), mas muito próxima da alta, tendo também ficado abaixo da média estadual que foi de 3,67\%. Este quadro revela o forte componente migratório na direção da metrópole nesse período, fato esse que recrudesce nos períodos seguintes.

Observa-se também uma queda geral nas taxas de crescimento nessas quatro décadas analisadas, em todos os eixos de dispersão estudados. Entretanto, em muitas regiões elas se mantiveram sempre acima das médias estadual e nacional. No período 1980-91 o conjunto de municípios do eixo de dispersão da Anchieta-Imigrantes e o município de São Paulo passam a apresentar taxas de crescimento anual menores que a média do Estado e média do Brasil, e isto continua a ocorrer na década seguinte. A partir de 1980 o município de São Paulo passa a apresentar taxa de crescimento moderada, e nas duas últimas décadas se tornam baixas, ou seja, abaixo do crescimento vegetativo, o que pode indicar migração de parte da população para outros municípios.

Tabela 6.5 - Evolução da taxa de crescimento anual da população total nos períodos entre 1970-2010, segundo os eixos rodoviários de dispersão urbana.

\begin{tabular}{lcccc}
\hline \multicolumn{1}{c}{$\begin{array}{c}\text { Rodovias - Eixo de } \\
\text { dispersão }\end{array}$} & $\mathbf{1 9 7 0 - 1 9 8 0}$ & $\mathbf{1 9 8 0 - 1 9 9 1}$ & $\mathbf{1 9 9 1 - 2 0 0 0}$ & $\mathbf{2 0 0 0 - 2 0 1 0}$ \\
\hline Dutra-Airton Senna & 6,24 & 3,66 & 2,47 & 1,30 \\
Anchieta-Imigrantes & 5,27 & 1,97 & 1,27 & 0,72 \\
Fernão Dias & 2,96 & 2,94 & 2,13 & 1,62 \\
Anhanguera-Bandeirantes & 6,15 & 3,53 & 2,24 & 1,66 \\
Castelo Branco & 6,49 & 3,34 & 2,27 & 1,01 \\
Raposo Tavares & 4,49 & 3,61 & 2,39 & 1,67 \\
Regis Bittencourt & 10,92 & 4,48 & 2,80 & 1,50 \\
\hline Município de São Paulo & $\mathbf{3 , 6 7}$ & $\mathbf{1 , 2 8}$ & $\mathbf{0 , 7 9}$ & $\mathbf{0 , 7 5}$ \\
\hline Brasil & $\mathbf{2 , 4 8}$ & $\mathbf{2 , 1 2}$ & $\mathbf{1 , 4 6}$ & $\mathbf{1 , 1 7}$ \\
\hline Estado de São Paulo & $\mathbf{3 , 4 9}$ & $\mathbf{2 , 3 5}$ & $\mathbf{1 , 6 0}$ & $\mathbf{1 , 0 8}$ \\
\hline
\end{tabular}

Fonte: IBGE - SIDRA e Censo Demográfico 2010 - primeiros resultados. 
Apenas no período recente, 2000-2010, as taxas de crescimento dessas regiões da macrometrópole passam a se assemelhar às médias do Estado e do Brasil. Os municípios da área de influência das rodovias Raposo Tavares, Fernão Dias, Anhanguera-Bandeirantes e Régis Bittencourt passam a apresentar um crescimento populacional médio (entre $1,50 \%$ e 1,78\%), e ainda acima das médias do Estado e Nacional, enquanto o conjunto de municípios dos eixos da Dutra-Airton Senna, da Castelo Branco e da Anchieta-Imigrantes atingem taxas consideradas de crescimento moderado a baixo (entre $0,72 \%$ e 1,30\%). Assim, é possível afirmar que o primeiro grupo ainda revela um componente de crescimento e aglomeração persistente, o que será analisado em mais detalhe, adiante.

\subsubsection{O tamanho populacional dos municípios}

É necessário considerar que os grupos de municípios aqui estudados, segundo os eixos rodoviários de crescimento e de dispersão urbana, não são homogêneos. Observa-se grande disparidade populacional entre os conjuntos, e entre os municípios dentro de cada conjunto. A existência de cidades de porte, além da metrópole paulista, em cada vetor, também é um elemento importante de atração de população, bem como de dispersão e de desconcentração entre os municípios polarizados. Nas tabelas 6.6 a 6.12 podem ser comparados esses grupos entre si, como também em suas diferenciações internas. Mesmo em termos de composição numérica de municípios por grupo, o fenômeno de dispersão urbana, dentro da área de macrometrópole aqui considerada, ocorre em abrangência bastante diferenciada. O eixo Anhanguera-Bandeirantes foi o que abrangeu o maior número de municípios, pois quase toda a região da RM de Campinas foi agrupada neste conjunto, além dos municípios da AU Jundiaí e de parte dos municípios da RM de São Paulo. São ao todo 30 municípios considerados neste vetor. $O$ segundo maior conjunto é o do eixo de dispersão das rodovias Dutra-Airton Senna, com 18 municípios ao todo. O terceiro grupo é o da rodovia Raposo Tavares com 12, e da rodovia Castelo Branco com 11. Os demais compõem grupos com menos de 10 municípios.

Os eixos de dispersão das rodovias Anhanguera-Bandeirantes e Dutra-Airton Senna são os únicos que contam com municípios de população acima de 1 milhão 
de habitantes (Campinas e Guarulhos). Os eixos das rodovias Castelo Branco, Raposo Tavares e Anchieta contabilizam municípios com população entre 500 mil e 1 milhão (Osasco; Sorocaba; São Bernardo e Santo André; e São José dos Campos). Os eixos da Fernão Dias e Régis Bittencourt são os que agrupam municípios de menor porte. Na Fernão Dias, o menor grupo em termos populacionais, apenas Bragança e Atibaia possuem entre 100 e 200 mil habitantes; e na Régis Bittencourt, Taboão da Serra e Embu se situam na faixa entre 200 e 300 mil habitantes.

Tabela 6.6 - Evolução da população total dos municípios do eixo de dispersão da Rodovia Fernão Dias, nos períodos censitários entre 1970-2010.

\section{Eixo Rod. Fernão Dias}

\begin{tabular}{lrrrrr}
\hline \multicolumn{1}{c}{ Municípios } & \multicolumn{1}{c}{$\mathbf{1 9 7 0}$} & \multicolumn{1}{c}{1980} & \multicolumn{1}{c}{$\mathbf{1 9 9 1}$} & \multicolumn{1}{l}{$\mathbf{2 0 0 0}$} & \multicolumn{1}{c}{$\mathbf{2 0 1 0}$} \\
\hline Bragança Paulista & 63.676 & 84.050 & 108.980 & 125.031 & 146.744 \\
Joanópolis & 7.362 & 7.754 & 8.186 & 10.409 & 11.768 \\
Piracaia & 12.883 & 13.792 & 18.999 & 23.347 & 25.116 \\
Nazaré Paulista & 10.009 & 8.419 & 11.671 & 14.410 & 16.414 \\
Bom Jesus dos Perdões & 3.834 & 7.096 & 9.854 & 13.313 & 19.708 \\
Atibaia & 36.838 & 57.820 & 86.336 & 111.300 & 126.603 \\
Mairiporã & 19.584 & 27.540 & 39.937 & 60.111 & 80.920 \\
\hline Total & $\mathbf{1 5 4 . 1 8 6}$ & $\mathbf{2 0 6 . 4 7 1}$ & $\mathbf{2 8 3 . 9 6 3}$ & $\mathbf{3 5 7 . 9 2 1}$ & $\mathbf{4 2 7 . 2 7 3}$ \\
\hline
\end{tabular}

Fonte: IBGE - Censo demográfico

O eixo da rodovia Dutra-Airton Senna, em 2010, foi o que apresentou o maior contingente populacional - 4 milhões de habitantes, seguido do eixo AnhangueraBandeirantes com 3,9 milhões. Comparando-se com a quantidade de peças urbanas em dispersão analisadas no capítulo anterior, o eixo Dutra registrou menos da metade de loteamentos dispersos que o eixo da rodovia Anhanguera. O terceiro maior contingente populacional, que é o conjunto do eixo Anchieta-Imigrantes com 2,5 milhões de habitantes, registrou um dos menores números de peças em dispersão, ficando somente à frente do eixo Régis Bittencourt. Deve-se considerar, nestes termos, a pujança da dispersão nos eixos das rodovias Raposo Tavares e Fernão Dias, pois ambos possuem dentre os menores contingentes populacionais (1,2 milhão e 427 mil) e registraram o $2^{\circ}$ e $4^{\circ}$ maior número de peças urbanas dispersas. 
Tabela 6.7 - Evolução da população total dos municípios do eixo de dispersão da Rodovia Anhanguera-Bandeirantes, nos períodos censitários entre 1970-2010.

\begin{tabular}{|c|c|c|c|c|c|}
\hline \multicolumn{6}{|c|}{ Eixo Rodovias Anhanguera-Bandeirantes } \\
\hline Municípios & 1970 & 1980 & 1991 & 2000 & 2010 \\
\hline Americana & 66.316 & 121.998 & 153.840 & 182.593 & 210.701 \\
\hline Santa Bárbara d'Oeste & 31.018 & 76.628 & 145.266 & 170.078 & 180.148 \\
\hline Nova Odessa & 8.336 & 21.891 & 34.063 & 42.071 & 51.278 \\
\hline Sumaré & 23.074 & 101.851 & 226.870 & 196.723 & 241.437 \\
\hline Hortolândia & - & - & - & 152.523 & 192.225 \\
\hline Engenheiro Coelho & - & - & - & 10.033 & 15.719 \\
\hline Artur Nogueira & 10.171 & 15.932 & 28.053 & 33.124 & 44.270 \\
\hline Cosmópolis & 12.110 & 23.243 & 36.684 & 44.355 & 58.821 \\
\hline Holambra & - & - & - & 7.211 & 11.292 \\
\hline Jaguariúna & 10.391 & 15.213 & 24.999 & 29.597 & 44.331 \\
\hline Santo Antônio de Posse & 7.799 & 10.877 & 14.327 & 18.124 & 20.635 \\
\hline Pedreira & 15.053 & 21.381 & 27.972 & 35.219 & 41.549 \\
\hline Paulínia & 10.708 & 20.753 & 36.706 & 51.326 & 82.150 \\
\hline Monte Mor & 7.960 & 14.020 & 25.559 & 37.340 & 48.971 \\
\hline Campinas & 375.864 & 664.566 & 847.595 & 969.396 & 1.080 .999 \\
\hline Indaiatuba & 30.537 & 56.243 & 100.948 & 147.050 & 201.848 \\
\hline Morungaba & 5.032 & 6.528 & 8.210 & 9.911 & 11.769 \\
\hline Itatiba & 28.376 & 41.630 & 61.645 & 81.197 & 101.450 \\
\hline Valinhos & 30.775 & 48.928 & 67.886 & 82.973 & 106.968 \\
\hline Vinhedo & 12.338 & 21.647 & 33.612 & 47.215 & 63.685 \\
\hline Louveira & 6.430 & 10.322 & 16.259 & 23.903 & 37.153 \\
\hline Itupeva & 7.095 & 10.189 & 18.142 & 26.166 & 44.825 \\
\hline Jundiaí & 169.076 & 258.809 & 289.269 & 323.397 & 370.251 \\
\hline Várzea Paulista & 9.894 & 33.818 & 68.921 & 92.800 & 107.146 \\
\hline Campo Limpo Paulista & 9.156 & 21.891 & 45.387 & 63.724 & 74.114 \\
\hline Jarinu & & & & 17.041 & 23.827 \\
\hline Francisco Morato & 11.231 & 28.537 & 83.885 & 133.738 & 154.538 \\
\hline Franco da Rocha & 36.303 & 50.794 & 85.535 & 108.122 & 131.603 \\
\hline Cajamar & 10.355 & 21.942 & 33.736 & 50.761 & 64.113 \\
\hline Caieiras & 15.563 & 25.156 & 39.069 & 71.221 & 86.623 \\
\hline Total & 960.961 & 1.744 .787 & 2.554 .438 & 3.258 .932 & 3.904 .439 \\
\hline
\end{tabular}

Fonte: IBGE - Censo demográfico 
Tabela 6.8 - Evolução da população total dos municípios do eixo de dispersãoda Rodovia Castelo Branco, nos períodos censitários entre 1970-2010.

\begin{tabular}{|c|c|c|c|c|c|}
\hline \multicolumn{6}{|c|}{ Eixo Rod. Castelo Branco } \\
\hline Municípios & 1970 & 1980 & 1991 & 2000 & 2010 \\
\hline Osasco & 283.073 & 474.544 & 568.225 & 652.593 & 666.469 \\
\hline Carapicuíba & 54.873 & 185.822 & 283.661 & 344.596 & 369.908 \\
\hline Barueri & 37.808 & 75.338 & 130.799 & 208.281 & 240.656 \\
\hline Santana de Parnaíba & 5.390 & 10.098 & 37.762 & 74.828 & 108.875 \\
\hline Jandira & 12.499 & 36.043 & 62.697 & 91.807 & 108.436 \\
\hline Itapevi & 27.569 & 53.442 & 107.976 & 162.433 & 200.874 \\
\hline Araçariguama & & & & 11.154 & 17.080 \\
\hline Pirapora do Bom Jesus & 3.694 & 4.814 & 7.956 & 12.395 & 15.727 \\
\hline Cabreúva & 7.679 & 11.716 & 18.814 & 33.100 & 41.643 \\
\hline Itu & 49.091 & 74.203 & 107.314 & 135.366 & 154.147 \\
\hline Salto & 21.772 & 42.379 & 72.333 & 93.159 & 105.569 \\
\hline Total & 503.448 & 968.399 & 1.397.537 & 1.819 .712 & 2.029 .384 \\
\hline
\end{tabular}

Fonte: IBGE - Censo demográfico

Tabela 6.9 - Evolução da população total dos municípios do eixo de dispersãoda Rodovia Raposo Tavares, nos períodos censitários entre 1970-2010.

Eixo Rod. Raposo Tavares

\begin{tabular}{lrrrrr}
\hline \multicolumn{1}{c}{ Municípios } & \multicolumn{1}{c}{$\mathbf{1 9 7 0}$} & \multicolumn{1}{c}{$\mathbf{1 9 8 0}$} & \multicolumn{1}{l}{$\mathbf{1 9 9 1}$} & \multicolumn{1}{l}{$\mathbf{2 0 0 0}$} & \multicolumn{1}{c}{$\mathbf{2 0 1 0}$} \\
\hline Cotia & \multicolumn{1}{c}{ 30.924 } & 62.948 & 107.453 & 148.987 & 201.023 \\
Vargem Grande Paulista & & & 15.870 & 32.683 & 42.946 \\
São Roque & 37.049 & 49.548 & 63.900 & 66.637 & 78.873 \\
Ibiúna & 24.391 & 31.826 & 49.187 & 64.384 & 71.217 \\
Mairinque & 18.858 & 30.828 & 43.205 & 39.975 & 43.225 \\
Alumínio & - & - & - & 15.252 & 16.845 \\
Sorocaba & 175.677 & 269.888 & 379.006 & 493.468 & 586.311 \\
Votorantim & 26.932 & 53.158 & 80.728 & 95.925 & 108.872 \\
Araçoiaba da Serra & 6.557 & 8.539 & 14.544 & 19.816 & 27.323 \\
Iperó & 6.439 & 6.606 & 10.575 & 18.384 & 28.301 \\
Salto de Pirapora & 9.001 & 14.688 & 25.344 & 35.072 & 40.141 \\
Piedade & 27.640 & 35.897 & 43.581 & 50.131 & 52.214 \\
\hline Total & $\mathbf{3 6 3 . 4 6 8}$ & $\mathbf{5 6 3 . 9 2 6}$ & $\mathbf{8 3 3 . 3 9 3}$ & $\mathbf{1 . 0 8 0 . 7 1 4}$ & $\mathbf{1 . 2 9 7 . 2 9 1}$ \\
\hline
\end{tabular}

Fonte: IBGE - Censo demográfico 
Tabela 6.10 - Evolução da população total dos municípios do eixo de dispersãoda Rodovia Régis Bittencourt, nos períodos censitários entre 1970-2010.

Eixo Rod. Régis Bittencourt

\begin{tabular}{lcccrr}
\hline \multicolumn{1}{c}{ Municípios } & $\mathbf{1 9 7 0}$ & \multicolumn{1}{c}{$\mathbf{1 9 8 0}$} & \multicolumn{1}{c}{$\mathbf{1 9 9 1}$} & \multicolumn{1}{c}{$\mathbf{2 0 0 0}$} & \multicolumn{1}{c}{$\mathbf{2 0 1 0}$} \\
\hline Taboão da Serra & 40.945 & 97.656 & 160.084 & 197.644 & 244.719 \\
\hline Embu & 18.141 & 95.800 & 155.990 & 207.663 & 240.007 \\
Embu-Guaçu & 10.280 & 21.038 & 36.277 & 56.916 & 62.846 \\
Itapecerica da Serra & 25.314 & 60.473 & 93.146 & 129.685 & 152.380 \\
Juquitiba & 7.267 & 12.497 & 19.969 & 26.459 & 28.732 \\
São Lourenço da Serra & & & & 12.199 & 13.985 \\
\hline Total & & & & $\mathbf{6 3 0 . 5 6 6}$ & $\mathbf{7 4 2 . 6 6 9}$ \\
\hline
\end{tabular}

Fonte: IBGE - Censo demográfico

Tabela 6.11 - Evolução da população total dos municípios do eixo de dispersão da Rodovia Anchieta-Imigrantes, nos períodos censitários entre 1970-2010.

\begin{tabular}{|c|c|c|c|c|c|}
\hline \multicolumn{6}{|c|}{ Eixo Rodovias Anchieta-Imigrantes } \\
\hline Municípios & 1970 & 1980 & 1991 & 2000 & 2010 \\
\hline Diadema & 78.914 & 228.663 & 305.287 & 357.064 & 386.039 \\
\hline Santo André & 418.826 & 553.077 & 616.991 & 649.331 & 673.914 \\
\hline São Bernardo do Campo & 201.662 & 425.611 & 566.893 & 703.177 & 765.203 \\
\hline São Caetano do Sul & 150.130 & 163.086 & 149.519 & 140.159 & 149.571 \\
\hline Mauá & 101.700 & 205.736 & 294.998 & 363.392 & 417.281 \\
\hline Ribeirão Pires & 29.048 & 56.530 & 85.085 & 104.508 & 113.043 \\
\hline Rio Grande da Serra & 8.397 & 20.091 & 29.901 & 37.091 & 44.084 \\
\hline Total & 988.677 & 1.652 .794 & 2.048 .674 & 2.354 .722 & 2.549 .135 \\
\hline
\end{tabular}

Fonte: IBGE - Censo demográfico

Analisando-se as tabelas citadas também é importante considerar que nenhum município apresentou perda populacional no período 2000-2010, fato que ocorre em outras regiões brasileiras, inclusive em áreas metropolitanas.

Depurando um pouco mais a análise também é relevante considerar o que significa em termos de crescimento anual da população o que foi registrado nesta última década, a fim de verificar quais municípios tendem a demandar maiores esforços em termos de disponibilização de novas áreas para moradia ou de adensamento das áreas já ocupadas. Pode-se dizer que em média a população de Guarulhos cresceu na última década censitária algo em torno de 15 mil pessoas ao ano. Em segundo lugar vem Campinas com 11 mil, e na sequência Sorocaba $(9,2$ 
mil), São José dos Campos (8,8 mil) e São Bernardo do Campo (6,2 mil). São municípios que ainda guardam estoque de terras rurais para a dispersão.

Tabela 6.12 - Evolução da população total dos municípios do eixo de dispersão da Rodovia Dutra-Airton Senna, nos períodos censitários entre 1970-2010.

\section{Eixo Rodovias Dutra-Airton Senna}

\begin{tabular}{|c|c|c|c|c|c|}
\hline Municípios & 1970 & 1980 & 1991 & 2000 & 2010 \\
\hline Guarulhos & 236.811 & 532.724 & 787.866 & 1.072 .717 & 1.222 .357 \\
\hline Arujá & 9.571 & 17.487 & 37.622 & 59.185 & 74.818 \\
\hline Santa Isabel & 17.161 & 29.013 & 37.975 & 43.740 & 50.464 \\
\hline Itaquaquecetuba & 29.114 & 73.068 & 164.957 & 272.942 & 321.854 \\
\hline Mogi das Cruzes & 138.751 & 197.935 & 273.175 & 330.241 & 387.241 \\
\hline Guararema & 12.638 & 15.105 & 17.961 & 21.904 & 25.844 \\
\hline Salesópolis & 9.557 & 10.657 & 11.359 & 14.357 & 15.639 \\
\hline Biritiba-Mirim & 9.033 & 13.374 & 17.833 & 24.653 & 28.573 \\
\hline Poá & 32.373 & 52.787 & 76.302 & 95.801 & 106.033 \\
\hline Ferraz de Vasconcelos & 25.134 & 55.046 & 96.166 & 142.377 & 168.290 \\
\hline Suzano & 55.460 & 101.056 & 158.839 & 228.690 & 262.568 \\
\hline Caçapava & 30.712 & 51.353 & 66.058 & 76.130 & 84.844 \\
\hline Jacareí & 61.216 & 115.738 & 163.869 & 191.291 & 211.308 \\
\hline Igaratá & 3.686 & 4.394 & 6.292 & 8.292 & 8.831 \\
\hline São José dos Campos & 148.332 & 287.513 & 442.370 & 539.313 & 627.544 \\
\hline Pindamonhangaba & 48.222 & 69.568 & 102.063 & 126.026 & 147.034 \\
\hline Taubaté & 110.585 & 169.259 & 206.965 & 244.165 & 278.724 \\
\hline Tremembé & 11.689 & 18.098 & 27.572 & 34.823 & 40.985 \\
\hline Total & 990.045 & 1.814 .175 & 2.695.244 & 3.526 .647 & 4.062 .951 \\
\hline
\end{tabular}

Fonte: IBGE - Censo demográfico

Entretanto, Guarulhos e São Bernardo, se excetuarmos as áreas de proteção de mananciais e de serras, esses dois municípios irão demandar ações regulatórias mais efetivas contra a expansão de loteamentos nessas áreas de fragilidade socioambiental. Nesse mesmo sentido, deve-se ficar atento para as médias de crescimento anual da população de Mogi das Cruzes (5,7 mil), Indaiatuba (5,4 mil) e Jundiaí (4,6 mil), o 6ํㅡ, $9^{\circ}$ e $12^{\circ}$ maior contingente de todos os municípios estudados. Os três também tem seus territórios em áreas de relevante interesse ambiental, e isso será abordado no capitulo 7 deste trabalho. 


\subsubsection{A evolução populacional e tendências no eixo Fernão Dias}

Analisando-se a evolução das taxas de crescimento anual da população de cada município em cada eixo de expansão pode-se inferir possíveis tendências de evolução do fenômeno de dispersão urbana. No eixo Fernão Dias, que vem apresentando considerável presença de dispersão de loteamentos de alta renda, se verifica que, exceto Piracaia, todos possuem taxa de crescimento de moderada a elevada. Os dados de Mairiporã indicam que o processo de expansão e de dispersão urbana é contínuo e continua com a mesma força apresentada nas décadas anteriores. Sua taxa de $3.02 \%$, no período 2000-2010, é considerada elevada, o que pode indicar que o adensamento dos loteamentos existentes e a expansão para novas áreas terá mercado ativo neste município lindeiro a São Paulo e às áreas de proteção da Serra da Cantareira.

Os dois maiores municípios da região Atibaia e Bragança Paulista apresentaram taxas menores no período recente (2000-2010), no entanto acima das médias do estado e nacional. Os dados da tabela 6.13 induzem a afirmar que 0 processo de dispersão urbana esteve ativo em Atibaia nos períodos de 1970 a 1991, pois suas taxas estiveram acima de $4 \%$ ao ano, taxas consideradas de alto crescimento populacional. No período 1991-2000 essas taxas recrudesceram para 2,57, consideradas de crescimento médio, mas acima da média do Estado de São Paulo e do Brasil. No período seguinte ela cai para a metade $(1,30 \%)$, significando um crescimento moderado.

Entretanto, é importante atentar para as taxas elevadas de sua vizinha Bom Jesus dos Perdões, sobretudo na última década censitária quando retoma o crescimento que já era alto no período anterior (3,05\%), subindo para 4,00\%. É certo que essas taxas se referem a um município de baixo contingente populacional (19 mil habitantes), mas é relevante que de menor população da região ela agora se situa em $5^{\circ}$ lugar. É muito provável que parte dos empreendimentos imobiliários da região de Atibaia devem estar se direcionando a esse município. Boa parte dos condomínios fechados dispersos registrados nesta região se situa neste município. Essa taxa elevada na última década representou uma média de 640 novos habitantes anuais, o triplo do que se verificou nos municípios de Nazaré Paulista, Piracaia e Joanópolis. 
Tabela 6.13 - Evolução da taxa de crescimento anual da população total dos municípios no eixo de dispersão da Rodovia Fernão Dias, nos períodos entre 1970-2010.

\begin{tabular}{lccccc}
\hline \multicolumn{5}{c}{ Eixo Rod. Fernão Dias } & \\
\hline \multicolumn{1}{c}{ Municípios } & $\mathbf{1 9 7 0 - 1 9 8 0}$ & $\mathbf{1 9 8 0 - 1 9 9 1}$ & $\mathbf{1 9 9 1 - 2 0 0 0}$ & $\mathbf{2 0 0 0 - 2 0 1 0}$ \\
\hline Mairiporã & 3,47 & 3,79 & 4,17 & 3,02 \\
Atibaia & 4,61 & 4,09 & 2,57 & 1,30 \\
Bom Jesus dos Perdões & 6,35 & 3,34 & 3,05 & 4,00 \\
Nazaré Paulista & $-1,72$ & 3,32 & 2,13 & 1,31 \\
Piracaia & 0,68 & 3,25 & 2,08 & 0,73 \\
Bragança Paulista & 2,81 & 2,63 & 1,38 & 1,61 \\
Joanópolis & 0,52 & 0,54 & 2,43 & 1,23 \\
\hline Total & $\mathbf{2 , 9 6}$ & $\mathbf{2 , 9 4}$ & $\mathbf{2 , 1 3}$ & $\mathbf{1 , 6 2}$ \\
\hline
\end{tabular}

Fonte: IBGE - Censo demográfico

Há que se considerar também no quadro de crescimento populacional desse eixo é que Mairiporã, mesmo possuindo população bem inferior à de Bragança Paulista, quase a metade, nesta última década incrementou em média 2081 novos habitantes ao ano, enquanto Bragança obteve quase a mesma quantidade - 2.171 hab/ano. Essa média também foi maior que a observada em Atibaia (1,530 hab/ano) o que reforça 0 argumento de que o crescimento dessa região pode ser preocupante, tendo em vista a sua importância ambiental para o conjunto da metrópole.

\subsubsection{A evolução populacional e tendências no eixo Anhanguera-Bandeirantes}

As taxas de crescimento médio anual da população deste eixo de expansão da metrópole são impressionantes. Na década de 1970 já eram muito expressivas e continuaram altas na década seguinte. Dos 30 municípios deste eixo de expansão/desconcentração da metrópole, 13 apresentação taxas de crescimento acelerado da população, que variaram entre 5 e $16 \%$. É possível verificar, analisando-se a tabela 6.14 , tendências regionais que se verificavam àquela época $e$ que se modificaram no presente. Três setores deste vetor se configuraram nesse crescimento de ritmo acelerado. Primeiro, os municípios do entorno de São Paulo recebem o impacto do espraiamento do crescimento da capital e crescem a taxas 
acima de 7\% ao ano: Várzea Paulista (13,08\%), Francisco Morato (9,77\%), Campo Limpo Paulista $(9,11 \%)$ e Cajamar (7,80\%). Nesse movimento, deve-se considerar a contribuição dos trens de subúrbio que ligam São Paulo a Jundiaí e colaboram com os eixos rodoviários nesta expansão urbana da metrópole. Um segundo lócus de crescimento explosivo foi a região de Campinas. As taxas de crescimento variaram entre 5,5\% e 7,0\% nos municípios de Campinas, Paulínia, Indaiatuba, Vinhedo e Monte Mor, e chegou a 16\% em Sumaré, consideradas como de crescimento acelerado da população. Acrescente-se as taxas altas de Jaguariúna (3,89\%) e Itatiba (3,91\%), e se completa o quadro do entorno de Campinas, àquela época uma cidade de 375 mil habitantes. O terceiro foco de expansão se deu na região de Americana, com taxas que variaram de 6 a 10\% nos municípios de Americana (6,29\%), Santa Bárbara D’Oeste (9,47\%), Nova Odessa $(10,14 \%)$ e Cosmópolis $(6,74 \%)$. Neste momento o crescimento se dava mais como expansão das cidades sede municipal do que um movimento de dispersão, embora o fortalecimento de alguns distritos como em Hortolândia, posteriormente se desmembrariam em novas unidades administrativas.

Esse crescimento acelerado mantém o seu impulso na década seguinte (1980), apresentando apenas um leve declínio nos municípios principais, como Campinas e Americana que passam a manter taxas consideradas de crescimento médio. O entorno de São Paulo continua apresentando taxas muito altas (5 a 11\%). É interessante notar que esse crescimento acelerado não atinge Jundiaí, e sim somente o seu entorno, tanto do lado de São Paulo como de Campinas. A região de Campinas mantém quase o mesmo ritmo, mas a de Americana apresenta uma redução mais significativa, no entanto, mantém taxas consideradas de alto crescimento.

Na década seguinte, 1991-2000, quando o movimento de dispersão urbana se acentua as taxas sofrem um razoável declínio, mas sempre acima das taxas do estado $(1,60 \%)$ e do Brasil $(1,46 \%)$. O setor próximo a São Paulo mantém um crescimento alto com taxas que variam de 3 a $6 \%$. Um novo pequeno declínio se verifica na região de Campinas, com o núcleo central da metrópole em formação crescendo a taxas semelhantes com as médias estadual e nacional, mas seu entorno continua mantendo taxas consideradas de alto crescimento, o dobro das 
médias do estado e do Brasil, principalmente Indaiatuba (4,27\%), Monte Mor (4,30\%), Vinhedo (3,85\%) e Paulínia (3,80\%).

A região de Americana perde impulso e para a se aproximar das médias do estado de São Paulo.Nesse período enquanto as demais regiões diminuem um pouco o ritmo de seu crescimento, na região de Jundiaí os municípios de Louveira e Itupeva mantém o alto ritmo de crescimento que se observa desde a década de 1970, em torno de 4 a $5 \%$.

No período recente (2000-2010) verifica-se que a região de Americana se estabiliza em taxas de médio crescimento entre 2 e $3 \%$, mas ainda representando o dobro ou o triplo das médias do estado e do Brasil. O crescimento na região de Campinas se acentua sobretudo em Jaguariúna (4,12\%), Paulínia $(4,82 \%)$ e Holambra $(4,59 \%)$ com taxas elevadas. Indaiatuba e Vinhedo também continuam em um ritmo de crescimento considerado alto, o que deve manter relação com a acentuação do crescimento urbano e com a dispersão nesses municípios.

Enquanto a região próxima a São Paulo apresenta um grande declínio em suas taxas a região de Jundiaí volta a tomar impulso, com Louveira e Itupeva mantendo taxas elevadas e em crescimento em relação à década anterior $(4,51 \% \mathrm{e}$ $5,53 \%$, respectivamente). As taxas de crescimento de Jundiaí, que eram moderadas voltam a crescer passando de $1,25 \%$ a $1,36 \%$.

No entorno de São Paulo, nos municípios de Cajamar, Franco da Rocha, Francisco Morato, Campo Limpo Paulista e Várzea Paulista, embora o crescimento tenha se desacelerado, as taxas continuam a se caracterizar por um crescimento moderado a médio e acima das médias do estado e nacional. Decorre que a expansão e dispersão urbana continuarão uma tendência presente nesta região, sobretudo nos municípios de Cajamar, Franco da Rocha e Caieiras. 
Tabela 5.14 - Evolução da taxa de crescimento anual da população total dos municípios no eixo de dispersão da Rodovia Anhanguera-Bandeirantes, nos períodos entre 1970-2010.

\begin{tabular}{|c|c|c|c|c|}
\hline Municípios & $1970-1980$ & 1980-1991 & $1991-2000$ & $2000-2010$ \\
\hline Americana & 6,29 & 2,13 & 1,92 & 1,44 \\
\hline Santa Bárbara d'Oeste & 9,47 & 5,99 & 1,77 & 0,58 \\
\hline Nova Odessa & 10,14 & 4,10 & 2,37 & 2,00 \\
\hline Sumaré & 16,01 & 7,55 & $-1,57$ & 2,07 \\
\hline Hortolândia & & & & 2,34 \\
\hline Engenheiro Coelho & & & & 4,59 \\
\hline Artur Nogueira & 4,59 & 5,28 & 1,86 & 2,94 \\
\hline Cosmópolis & 6,74 & 4,24 & 2,13 & 2,86 \\
\hline Holambra & & & & 4,59 \\
\hline Jaguariúna & 3,89 & 4,62 & 1,89 & 4,12 \\
\hline Santo Antônio de Posse & 3,38 & 2,54 & 2,65 & 1,31 \\
\hline Pedreira & 3,57 & 2,47 & 2,59 & 1,67 \\
\hline Paulínia & 6,84 & 5,32 & 3,80 & 4,82 \\
\hline Monte Mor & 5,82 & 5,61 & 4,30 & 2,75 \\
\hline Campinas & 5,86 & 2,24 & 1,50 & 1,10 \\
\hline Indaiatuba & 6,30 & 5,46 & 4,27 & 3,22 \\
\hline Morungaba & 2,64 & 2,11 & 2,11 & 1,73 \\
\hline Itatiba & 3,91 & 3,63 & 3,11 & 2,25 \\
\hline Valinhos & 4,75 & 3,02 & 2,25 & 2,57 \\
\hline Vinhedo & 5,78 & 4,08 & 3,85 & 3,04 \\
\hline Louveira & 4,85 & 4,22 & 4,37 & 4,51 \\
\hline Itupeva & 3,69 & 5,38 & 4,15 & 5,53 \\
\hline Jundiaí & 4,35 & 1,02 & 1,25 & 1,36 \\
\hline Várzea Paulista & 13,08 & 6,69 & 3,36 & 1,45 \\
\hline Campo Limpo Paulista & 9,11 & 6,85 & 3,84 & 1,52 \\
\hline Jarinu & & & & 3,41 \\
\hline Francisco Morato & 9,77 & 11,39 & 4,77 & 1,46 \\
\hline Franco da Rocha & 3,42 & 5,35 & 2,37 & 1,98 \\
\hline Cajamar & 7,80 & 4,40 & 4,17 & 2,36 \\
\hline Caieiras & 4,92 & 4,50 & 6,19 & 1,98 \\
\hline Total & 6,15 & 3,53 & 2,24 & 1,66 \\
\hline
\end{tabular}

Fonte: IBGE - Censo demográfico 
6.4.5. A evolução populacional e tendências no eixo Castelo Branco.

Este eixo de expansão e dispersão urbana tem a gênese característica da expansão urbana tradicional de crescimento acelerado alternado que se espraia do núcleo central de uma metrópole. Após o crescimento intenso da sede, os municípios contíguos passam a absorver o excedente de crescimento e a apresentar taxas de crescimento acelerado e o mesmo processo se repete nas décadas seguintes na direção dos outros municípios periféricos. É o que está acontecendo nos municípios de Santana do Parnaíba, Araçariguama e Itapevi, podendo se incluir também Pirapora do Bom Jesus. A bola da vez é Santana do Parnaíba e Araçariguama, que apresentam ainda grandes espaços territoriais para a expansão urbana. As taxas de crescimento do período 2000-2010 foram altas, 4,35\% em Araçariguama e 3,82\% em Santana do Parnaíba.

Tabela 6.15 - Evolução da taxa de crescimento anual da população total dos municípios no eixo de dispersão da Rodovia Castelo Branco, nos períodos entre 1970-2010.

\begin{tabular}{lccccc}
\hline \multicolumn{1}{c}{ Municípios } & Eixo Rod. Castelo Branco & & \\
\hline & $\mathbf{1 9 7 0 - 1 9 8 0}$ & $\mathbf{1 9 8 0 - 1 9 9 1}$ & $\mathbf{1 9 9 1 - 2 0 0 0}$ & $\mathbf{2 0 0 0 - 2 0 1 0}$ \\
\hline Osasco & 5,30 & 1,82 & 1,39 & 0,21 \\
Barueri & 7,14 & 5,67 & 4,76 & 1,46 \\
Carapicuíba & 12,97 & 4,32 & 1,96 & 0,71 \\
Santana de Parnaíba & 6,48 & 14,10 & 7,08 & 3,82 \\
Itapevi & 6,84 & 7,29 & 4,17 & 2,15 \\
Jandira & 11,17 & 5,69 & 3,89 & 1,68 \\
Pirapora do Bom Jesus & 2,68 & 5,15 & 4,53 & 2,41 \\
São Roque & 2,95 & 2,34 & 0,47 & 1,70 \\
Mairinque & 5,04 & 3,12 & $-0,86$ & 0,78 \\
Cabreúva & 4,32 & 4,40 & 6,48 & 2,32 \\
Salto & & & & 1,26 \\
Itu & 4,22 & 3,41 & 2,61 & 1,31 \\
Araçariguama & & & & 4,35 \\
\hline Total & $\mathbf{6 , 4 9}$ & $\mathbf{3 , 3 4}$ & $\mathbf{2 , 2 7}$ & $\mathbf{1 , 0 1}$ \\
\hline
\end{tabular}

Fonte: IBGE - Censo demográfico

Pirapora do Bom Jesus e Itapevi registraram taxas de crescimento médio, $2,41 \%$ e 2,15\%, respectivamente. Em Itapevi observou-se no mapeamento da 
dispersão urbana uma grande ocorrência de loteamentos d ebaixa renda. Em Araçariguama parecem ser os condomínios de média e alta renda os responsáveis, em parte, pelo crescimento apresentado. Já em Santana do Parnaíba, a partir dos mapeamentos realizados, pode-se afirmar que os dois movimentos estão acontecendo em intensidades semelhantes. Deve-se analisar com cuidado a taxade 2,32\% de Cabreúva, pois se deve a um crescimento em área loteada resultante de demandas originadas no vetor da Anhanguera, como uma extensão do crescimento que se verifica em Itupeva.

6.4.6. A evolução populacional e tendências no eixo Raposo Tavares.

Neste eixo de dispersão o crescimento ocorre mais concentrado nas duas pontas da rodovia Raposo Tavares, como se pode verificar na tabela 6.16. Nas proximidades de São Paulo os municípios de Cotia e Vargem Grande vêm recebendo o crescimento espraiado da metrópole desde a década de 1970. Cotia apresentou taxas de crescimento anual acelerado entre os períodos 1970-80 e $1980-91$, com $7,37 \%$ e $\%, 49 \%$, respectivamente. Na década seguinte a taxa cai para $3,32 \%$, ainda de alto crescimento, mas percebe-se que esse crescimento se espraia para Vargem Grande, pois este município apresentou a expressiva taxa de 7,49\%. No período recente (2000-2010) as taxas ainda são altas, com Cotia apresentando $3,04 \%$ e Vargem Grande declinando bastante para uma taxa de 2,77\%, considerada de crescimento médio, mas acima do crescimento vegetativo, a indicar processos migratórios ainda evidentes.

Ibiúna, que nas décadas de 1980 e 1990 apresentou uma grande expansão de condomínios fechados, alcançou taxas de crescimento anual da população também significativas, $4,04 \%$ e 3,04\%, mas no período recente estas declinaram bastante para um padrão de crescimento moderado, semelhante às médias atuais do estado e do país. É interessante notar que essa porção central da rodovia não apresentou em nenhuma fase um crescimento acelerado, talvez porque guarda distância relativa dos dois polos de difusão da expansão urbana. 
Tabela 6.16 - Evolução da taxa de crescimento anual da população total dos municípios no eixo de dispersão da Rodovia Raposo Tavares, nos períodos entre 1970-2010.

\begin{tabular}{lc|c|c|c}
\hline \multicolumn{1}{c}{ Municípios } & Eixo Rod. Raposo Tavares & & \\
\hline Cotia & $\mathbf{1 9 7 0 - 1 9 8 0}$ & $\mathbf{1 9 8 0 - 1 9 9 1}$ & $\mathbf{1 9 9 1 - 2 0 0 0}$ & $\mathbf{2 0 0 0 - 2 0 1 0}$ \\
\hline Vargem Grande Paulista & 7,37 & 5,49 & 3,32 & 3,04 \\
São Roque & & & 7,49 & 2,77 \\
lbiúna & 2,95 & 2,34 & 0,47 & 1,70 \\
Mairinque & 2,70 & 4,04 & 3,04 & 1,01 \\
Alumínio & 5,04 & 3,12 & $-0,86$ & 0,78 \\
Sorocaba & & & & 1,00 \\
Votorantim & 4,39 & 3,13 & 2,98 & 1,74 \\
Araçoiaba da Serra & 7,04 & 3,87 & 1,93 & 1,27 \\
Iperó & 2,68 & 4,96 & 3,50 & 3,26 \\
Salto de Pirapora & 0,26 & 4,37 & 6,34 & 4,41 \\
Piedade & 5,02 & 5,08 & 3,68 & 1,36 \\
\hline Total & 2,65 & 1,78 & 1,57 & 0,41 \\
\hline Fonte: & $\mathbf{4 , 4 9}$ & $\mathbf{3 , 6 1}$ & $\mathbf{2 , 3 9}$ & $\mathbf{1 , 6 7}$ \\
\hline
\end{tabular}

Fonte: IBGE - Censo demográfico

$\mathrm{Na}$ outra ponta, na região de Sorocaba, o crescimento foi importante no período 1970 a 1991 nos municípios de Sorocaba, Votorantim, Araçoiaba da Serra e Salto de Pirapora. Nas duas décadas seguintes ele se mantém em taxas de crescimento médio, recrudescendo um pouco mais em Votorantim no período 20002010 para um crescimento moderado semelhante às médias do Brasil e do estado de São Paulo. A partir dos anos 1980 este crescimento elevado também se espraia para o município de Iperó, que apresentou no período censitário recente a mais alta taxa de crescimento anual da população deste eixo de dispersão.

6.4.7. A evolução populacional e tendências no eixo Régis Bittencourt.

Neste vetor pode-se verificar com clareza o impacto do crescimento periférico observado nas décadas de 1960 a 1980 em vários setores do entorno do município de São Paulo. No período 1970-80 este vetor de expansão foi palco de um grande afluxo migratório que pode ser observado na tabela 6.17 a partir das elevadas taxas 
de crescimento anual da população que os municípios de Embu (18,11\%), Taboão da Serra (9,08\%), Itapecerica da Serra (9,10\%) e Embu-Guaçu $(7,42 \%)$ apresentaram. Neste primeiro movimento pode-se considerar como taxas explosivas muito em virtude de um patamar populacional ainda baixo.

Nas décadas seguintes a tendência da taxa é recrudescer, mas o crescimento acelerado continua. É o que seobserva no período seguinte: taxas em torno de $5 \%$ ainda são elevadas e relevam o forte componente migratório para a região. No período 1991-2000 a expansão urbana vai se consolidando, mas pode-se considerar que eram taxas significativas, pois ainda muito acima das médias do estado e do país. No período recente o crescimento parece ter se estabilizado e não se verifica pressão de expansão urbana acelerada em nenhum outro vetor deste eixo. Excetuando Taboão da Serra que apresentou taxa de crescimento médio $(2,16 \%)$, Embu e Itapecerica apresentaram um crescimento mais moderado $(1,46 \%$ e $1,63 \%$, respectivamente). Estes dados se correlacionam com o levantamento da dispersão urbana analisados no capítulo anterior.

Tabela 6.17 - Evolução da taxa de crescimento anual da população total nos períodos entre 1970-2010.

\section{Eixo Rod. Régis Bittencourt}

\begin{tabular}{lcccc}
\hline \multicolumn{1}{c}{ Municípios } & $\mathbf{1 9 7 0 - 1 9 8 0}$ & $\mathbf{1 9 8 0 - 1 9 9 1}$ & $\mathbf{1 9 9 1 - 2 0 0 0}$ & $\mathbf{2 0 0 0 - 2 0 1 0}$ \\
\hline Taboão da Serra & 9,08 & 5,07 & 2,13 & 2,16 \\
Embu & 18,11 & 5,00 & 2,90 & 1,46 \\
Embu-Guaçu & 7,42 & 5,60 & 4,61 & 1,00 \\
Itapecerica da Serra & 9,10 & 4,41 & 3,36 & 1,63 \\
Juquitiba & 5,57 & 4,80 & 2,85 & 0,83 \\
São Lourenço da Serra & & & & 1,38 \\
\hline Total & $\mathbf{1 0 , 9 2}$ & $\mathbf{4 , 4 8}$ & $\mathbf{2 , 8 0}$ & $\mathbf{1 , 5 0}$ \\
\hline
\end{tabular}

Fonte: IBGE - Censo demográfico

6.4.8. A evolução populacional e tendências no eixo Anchieta-Imigrantes.

Os dados da tabela 6.18 traduzem a história da ocupação urbana deste vetor de expansão da metrópole que, impulsionada pela industrialização dos anos 1960 e 1970 atraiu um grande contingente migratório responsável pelas elevadas taxas de 
crescimento anual da população no período 1970-80. Como se observa na tabela citada, as taxas de crescimento nesse período se situaram entre 6,88\% a $11,23 \%$, denotando um acelerado crescimento. No período 1980-91, já em meio à crise inflacionária esse crescimento se reduz drasticamente, mas nem por isso se pode considerar um crescimento baixo. As taxas de 2,93\% de Diadema, 2,91\% de São Bernardo correspondem a um crescimento mediano mas efetivo, com crescimento vegetativo e ainda um fator migratório presente. As taxas de 4,06\% de Rio Grande da Serra e de $4,17 \%$ de Ribeirão Pires demonstram um elevado crescimento da população e, consequentemente, da expansão urbana.

Este vetor de expansão perde impulso nas décadas seguintes, o que se correlaciona com a pouca expressividade do processo de dispersão urbana, não fosse pelo seu componente socioambiental de que já mencionados no capítulo anterior. Na fase atual o crescimento dos municípios deste vetor de expansão é baixo, sobretudo nos municípios de Santo André, Diadema, São Bernardo, São Caetano do Sul e Ribeirão Pires, e isto indica que parte do crescimento vegetativo destas cidades se transforma em migração. Apenas Rio Grande da Serra apresenta crescimento mediano $(1,74 \%)$ e, em virtude de sua localização, deverá ser palco de expansão do processo de dispersão urbana no futuro.

Tabela 6.18 - Evolução da taxa de crescimento anual da população total dos municípios no eixo de dispersão da Rodovia Anchieta-Imigrantes, nos períodos entre 1970-2010.

Eixo Rodovias Anchieta-Imigrantes

\begin{tabular}{l|c|c|c|c}
\hline \multicolumn{1}{c}{ Municípios } & $\mathbf{1 9 7 0 - 1 9 8 0}$ & $\mathbf{1 9 8 0 - 1 9 9 1}$ & $\mathbf{1 9 9 1 - 2 0 0 0}$ & $\mathbf{2 0 0 0 - 2 0 1 0}$ \\
\hline Diadema & 11,23 & 2,93 & 1,58 & 0,78 \\
Santo André & 2,82 & 1,10 & 0,51 & 0,37 \\
São Bernardo do Campo & 7,76 & 2,91 & 2,18 & 0,85 \\
São Caetano do Sul & 0,83 & $-0,86$ & $-0,64$ & 0,65 \\
\hline Mauá & 7,30 & 3,67 & 2,11 & 1,39 \\
Ribeirão Pires & 6,88 & 4,17 & 2,08 & 0,79 \\
Rio Grande da Serra & 9,12 & 4,06 & 2,18 & 1,74 \\
\hline Total & $\mathbf{5 , 2 7}$ & $\mathbf{1 , 9 7}$ & $\mathbf{1 , 2 7}$ & $\mathbf{0 , 7 2}$ \\
\hline
\end{tabular}

Fonte: IBGE - Censo demográfico 
6.4.9. A evolução populacional e tendências no eixo Dutra-Airton Senna.

Este vetor, após o crescimento alto a acelerado da década 1970-80, apresentou no período 2000-2010 taxas de crescimento de padrão moderado. Excetuando-se Arujá que, com 2,37\%, apresenta um crescimento considerado médio e foi a bola da vez da pressão expansionista da mancha urbana da metrópole na última década, todas as demais regiões deste vetor apresentaram taxas inferiores a $2 \%$. Como crescimento mediano pode-se contabilizar, além de Arujá, mais 4 municípios: Ferraz de Vasconcelos, Itaquaquecetuba, Mogi das Cruzes, Guararema, São José dos Campos, Tremembé e Pindamonhangaba. Crescimento moderado se verificou em Guarulhos, Suzano, Poá, Santa Isabel, Biritiba-Mirim, Jacareí, Caçapava e Taubaté. Baixa taxa de crescimento ocorreu em Salesópolis e Igaratá.

Assim, pode-se dizer que boa parte da dispersão urbana verificada neste vetor decorre de crescimento populacional substantivo verificado nas décadas anteriores. É o que se pode observar na tabela 6.19.

O padrão de crescimento deste vetor, excetuando a região de Mogi das Cruzes que sempre obteve índices considerados de crescimento mediano, parte de um crescimento acelerado, com taxas acima de $5 \%$ e chegando a quase $10 \%$ em Itaquaquecetuba na década de 1970; declina para um crescimento alto ( 3 a $8 \%$ ) na década 1980; decai na década seguinte para um padrão de crescimento mediano, com algumas exceções como Ferraz de Vascocelos, Itaquaquecetuba e Arujá que ainda apresentam crescimento elevado.

Mogi das Cruzes vai apresentando um crescimento constante de elevado para mediano nas últimas décadas, mas nunca acelerado como nos demais setores deste vetor de expansão. 
Tabela 6.19 - Evolução da taxa de crescimento anual da população total dos municípios no eixo de dispersão da Rodovia Dutra-Airton Senna, nos períodos entre 1970-2010.

\begin{tabular}{|c|c|c|c|c|}
\hline \multicolumn{5}{|c|}{ Eixo Rodovias Dutra-Airton Senna } \\
\hline Municípios & $1970-1980$ & 1980-1991 & $1991-2000$ & $2000-2010$ \\
\hline Guarulhos & 8,45 & 3,99 & 3,13 & 1,31 \\
\hline Ferraz de Vasconcelos & 8,15 & 5,74 & 4,00 & 1,69 \\
\hline Suzano & 6,18 & 4,63 & 3,71 & 1,39 \\
\hline Poá & 5,01 & 3,75 & 2,30 & 1,02 \\
\hline Itaquaquecetuba & 9,64 & 8,48 & 5,16 & 1,66 \\
\hline Mogi das Cruzes & 3,62 & 3,27 & 1,92 & 1,60 \\
\hline Arujá & 6,21 & 7,21 & 5,16 & 2,37 \\
\hline Santa Isabel & 5,39 & 2,73 & 1,42 & 1,44 \\
\hline Guararema & 1,80 & 1,75 & 2,00 & 1,67 \\
\hline Salesópolis & 1,10 & 0,64 & 2,37 & 0,86 \\
\hline Biritiba-Mirim & 4,00 & 2,92 & 3,29 & 1,49 \\
\hline Jacareí & 6,58 & 3,21 & 1,73 & 1,00 \\
\hline São José dos Campos & 6,84 & 3,99 & 2,23 & 1,53 \\
\hline Igaratá & 1,77 & 3,32 & 3,11 & 0,63 \\
\hline Caçapava & 5,28 & 2,32 & 1,59 & 1,09 \\
\hline Taubaté & 4,35 & 1,85 & 1,85 & 1,33 \\
\hline Tremembé & 4,47 & 3,90 & 2,63 & 1,64 \\
\hline Pindamonhangaba & 3,73 & 3,55 & 2,37 & 1,55 \\
\hline Total & 6,24 & 3,66 & 2,47 & 1,30 \\
\hline
\end{tabular}

Fonte: IBGE - Censo demográfico 


\section{COMPARTIMENTOS AMBIENTAIS ESTRUTURANTES MACROMETRÓPOLE DE SÃO SAULO}

Abordar a categoria relevo nas relações entre sociedade e natureza tem sido objeto dos planejadores do espaço territorial brasileiro em diferentes escalas. $\mathrm{Na}$ escala regional, o relevo é abordado em seu conjunto de unidades ou grandes compartimentos de planalto, serranos, planícies ou bacias hidrográficas. São os grandes conjuntos que são analisados, sobretudo ante as formas de ocupação econômica - agrária. Na escala local, investiga-se a cidade e a zona rural próxima, observando-se a ocupação das vertentes, do fundo de vale, dos morros etc.

O relevo é, assim, tratado sob o prisma antropocêntrico (Casseti, 1995, p.35), como um recurso natural, o que ele desempenha para o homem. Está inserido e é parte constituinte de um território, e sua análise tem significância quando a abordagem se relaciona com o território usado, sinônimo de espaço geográfico, portanto, categoria de análise geográfica. (Santos, 2008, p.19).

O relevo deve ser entendido como herança de processos passados, naturais e sociais, e como recurso atual da sociedade e também como herança para as sociedades futuras. Nesse sentido, ganha relevância a análise das formas de ocupação e de utilização do território, e, contido dentro desta categoria, as formas de utilização e de apropriação do relevo. O relevo é o suporte da implantação dos sistemas de engenharia da sociedade, caracterizada pela implantação das infraestruturas necessárias que dão dinamismo à vida social e à produção econômica.

Como os usos são diferentes nos diversos momentos da história das sociedades, cada um carrega um peso diverso entre novidade e heranças (Santos, 2008, p.20). O uso do território se intensificou a partir do início do século passado, à medida que o crescimento populacional explodia em termos mundiais. Com a intensificação da urbanização a partir da segunda metade do século XX, um número cada vez menor de lugares passa a abrigar um número cada vez maior de pessoas, significando uma maior divisão do trabalho e, ao mesmo tempo, uma imobilização 
relativa, que é também resultado de uma fluidez aumentada no território. (Santos, 2008, p.21).

Nesse contexto, a urbanização modifica seu conteúdo, alterando e imobilizando uma maior parte do território, diminuindo e restringindo os espaços de domínio dos objetos da natureza. O relevo é apropriado cada vez mais e com mais intensidade pelos usos urbanos. No contexto da cidade moderna, da organização territorial alinhada a um controle centralizado e hierarquizado das redes urbanas, decorreu uma tendência à compactação da mancha urbana da cidade e das áreas que se metropolizavam. Já no contexto da cidade contemporânea, descentralização e dispersão caracterizam o desenho das funções e morfologia da ocupação em curso. No primeiro caso, todos os compartimentos do relevo, desde várzeas, fundos de vale, variados tipos de vertentes, topo de morros de diversos matizes, foram sendo ocupados pelos usos e funções nitidamente urbanas. No segundo caso, fragmentos do mundo rural ou natural (incluindo a $2^{2}$. natureza) vão figurando em espaços intersticiais à ocupação que se efetiva.

Como acentuou Soja (1994, p.154), "as dinâmicas do desenvolvimento metropolitano já não são, hoje, tão decididamente monocêntricas, tão determinadas por um modo singularmente polarizado de forças centrífugas e centrípetas, por um padrão de crescimento urbano que gira em torno de um centro definitivo da cidade." Disso decorre uma expansão horizontal da urbanização sem precedentes, e um impacto sobre o relevo e sobre o ambiente local também, até então, não imagináveis.

O relevo é o objeto de estudo da geomorfologia, e ao longo desse mesmo período analisado, construiu o seu constructo conceitual e objeto metodológico e, pode-se dizer, em consonância com a evolução da paisagem urbanizada derivada dessa passagem da cidade moderna para a cidade contemporânea, assim como se deu a teorização das tendências do urbanismo como construção conceitual.

A urbanização extensiva sobre o território, no contexto abordado por MonteMór (1994), também impulsionou um redirecionamento do próprio entendimento do conceito de natureza e da sua relação com a sociedade. É nesse sentido que podemos afirmar, como Santos (1994, p.15), que hoje a natureza é histórica, 
inclusive o chamado "meio ambiente" e que seu valor local se torna relativo, ou, em todo caso, relativizado. Assim é que, quando jovens, percebíamos como natureza uma paisagem rural já totalmente modificada pela ação humana.

O homem torna-se, na atualidade, um dado da valorização dos elementos naturais porque é capaz de ação. O sistema natureza ganha, assim, um novo significado. É nesse sentido que Santos (1988, p.90) argumenta que "o homem é sujeito, enquanto a terra é objeto", pois este utiliza "suas forças intelectuais e físicas contra um conjunto de objetos naturais que seleciona como indispensáveis para se manter enquanto grupo". Mas, se o homem tem poder de modificar a intensidade da ação das forças da natureza, esta também impõe aos grupos humanos a necessidade de adaptações, ou seja, em qualquer escala da intervençãohumana sobre a natureza o progresso técnico não elimina a ação da natureza e algumas das imposições territoriais, dentre elas a de certas situações do relevo (Santos, 1988, p.91) 29.

\subsection{A Compartimentação da paisagem como etapa para a síntese da paisagem e do relevo}

$\mathrm{Na}$ integração das diversas leituras temáticas que se pode extrair de uma paisagem, ou de um território, a sobreposição de cartas, mapas físicos e das infraestruturas existentes é um dos recursos utilizados para se distinguir unidades de paisagens segundo suas características físicas e critérios de homogeneidade ou heterogeneidade. Não se pode negar a certa dose de interpretação contida neste método em virtude da visão seletiva de quem analisa os diversos layers que carregam as informações daquela paisagem.

Tem-se denominado "Unidades de Paisagens" às separações e agrupamentos de tipologias afins sejam elas de padrão uniforme ou complexo. Essas unidades de paisagem são distinguidas segundo as variadas categorias selecionadas para a análise, desde as que se baseiam predominantemente nos aspectos físicos, ou em parte dos elementos físicos da paisagem, até a abordagens que incluem temas do universo social e econômico da paisagem estudada.

\footnotetext{
${ }^{29}$ O homem não comanda as intempéries, mas tem conhecimento prévio de sua eclosão. (Santos, 1988, p.92)
} 
De outro lado, na produção de sínteses interpretativas da base física, um recurso costumeiramente utilizado na Geografia Física e na Geomorfologia tem sido a compartimentação preliminar do relevo, incluindo o estudo de suas formas, como método de simplificar a leitura da paisagem observada em poucas unidades tipológicas para que delas se possam extrair elementos que se constituam em premissas de abordagens propositivas. Segundo Ab'Saber (1975), "toda paisagem possui uma certa compartimentação de relevo". Como a superfície do planeta apresenta porções de território altas e baixas, formas aguçadas ou planas, homogêneas ou complexas quanto à ocorrência de suas formas, é relativamente fácil extrair do relevo uma leitura de seus compartimentos. Numa primeira aproximação, pode-se dizer que essa está representada por aquilo que se convencionou designar por planaltos, planícies e serras.

Dessa forma, entende-se por compartimento de relevo qualquer conjunto topográfico situado entre áreas topograficamente mais elevadas, ou aqueles situados entre áreas topograficamente mais baixas. (Ab'Saber, 1975). É claro que esse primeiro escalonamento do relevo assume características internas diferenciadas em função das cotas de altitude predominantes, das estrutura superficial da paisagem e da ossatura geológica que o sustenta, bem como dos diversos arranjos de padrão de formas de relevo passíveis de ocorrer em função das dinâmicas climáticas atuais e pretéritas.

Em Geomorfologia, segundo Ab'Saber (1967), o que se pretende com a compartimentação do relevo vai um pouco além do mero escalonamento topográfico da superfície. Ele entende que "desde que se faça também o estudo dos diferentes tipos de depósitos superficiais e considerações adequadas sobre sua significação paleogeográfica" o que se almeja mesmo é um estudo da compartimentação da paisagem, sendo estes compartimentos derivados de uma gênese evolutiva desencadeada pelos processos de funcionamento da paisagem pretérita e pelos processos atuais que possam indicar tendências evolutivas futuras.

Assim, toda paisagem pode ser dividida em compartimentos, setores e unidades segundo critérios que se estabelecem para a análise a ser empreendida. 


\subsubsection{A Compartimentação Topográfica}

A compartimentação topográfica, como já mencionado, é uma técnica de abordagem do relevo e um nível de pesquisa considerado elementar na Geomorfologia, embora muitos pesquisadores desconsiderem a importância dessa análise preliminar da paisagem nos estudos geomorfológicos. É certo que, muito além do que havia expressado Ab'Saber em 1969 (p. 3), quanto ao extraordinário desenvolvimento de uma cartografia de escol e a disponibilidade de cartas topográficas e fotografias aéreas, hoje não há muito o que fazer no campo da compartimentação dos terrenos, pois as ferramentas que se dispõem facilitam sobremaneira a visualização da compartimentação topográfica de uma paisagem em um nível muito superior ao obtido pelo trânsito na área.

Ab'Saber, defensor desse método básico de pesquisa geomorfológica, explicava em 1969 a importância dessa abordagem do relevo para a interação com as disciplinas vizinhas, bem como para facilitar a compreensão do relevo e sua dinâmica pelos profissionais de diversos ramos do saber implicados com 0 planejamento e o uso do território:

"Desde que se faça ao mesmo tempo o estudo da compartimentação e das formas e o estudo da posição dos diferentes tipos de depósitos superficiais - e, considerações adequadas sobre sua significação paleogeográfica - todos os pesquisadores ficam concordes, quanto ao valor metodológico do procedimento. Em outras palavras, desde que se Ihes demonstre que o realmente pretendido é um estudo da compartimentação da paisagem, acompanhado 'pari passu' por uma prospecção superficial dos diferentes depósitos de vertentes, terraços e planícies, todos ficam plenamente de acordo sobre a validade do método. Isto porque, todos estão cientes de que somente assim conduzidos, os estudos geomorfológicos podem servir às disciplinas vizinhas e atingir a alguma coisa de mais objetivo para a restauração dos eventos que responderam pela evolução do relevo e pelas transformações globais e locais da própria paisagem (Ab'Saber, 1969, p.3-4)".

A compartimentação topográfica se relaciona, assim, com os níveis topográficos e com os depósitos superficiais ou estruturas rochosas do embasamento. E também com a posição relativa entre eles. É por isso que fica implícito no estudo da compartimentação topográfica da paisagem aspectos da própria fisiologia da paisagem. Por isso a importância e a validade do método, conforme sugeria Ab'Saber. 
$\mathrm{Na}$ Geomorfologia a compartimentação topográfica corresponde à individualização de um conjunto de formas com características semelhantes, em que se admite que tenham sido elaboradas em determinadas condições morfogenéticas ou morfoclimáticas parecidas e/ou que apresentem relações litoestratigráficas oriundas de uma mesma gênese. A interpenetração das diferentes forças ao longo do tempo leva à individualização e à caracterização das formas de relevo, da situação topográfica ou altimétrica, bem como da existência de traços genéticos comuns.

A expressividade dessas forças atuantes na elaboração do modelado depende tanto da intensidade quanto da duração dos fenômenos, e nesse sentido, a compartimentação topográfica visa evidenciar 0 resultado dessas relações processuais e respectivas implicações tectônico-estruturais registradas ao longo do tempo, que tendem a originar formas diferenciadas, em face das alternâncias climáticas e das variações estruturais. Portanto, a compartimentação topográfica visa, em suma, diferenciar conjuntos por formas e processos atuantes.

Dentre os subsídios que a compartimentação do relevo, na perspectiva geomorfológica, oferece para o planejamento territorial destacam-se a vulnerabilidade e a potencialidade. Por vulnerabilidade se considera como indicador a suscetibilidade erosiva do relevo, tanto em condições naturais quanto prognosticáveis em função de determinados usos ou tipos de ocupação. Já a potencialidade, tem a ver com determinadas individualidades que podem ser racionalmente apropriadas para fins específicos, como a destinação de áreas portadoras de depósitos de cobertura com fertilidade natural às atividades agrícolas, o potencial mineral, ou ainda morfologias especiais, como as cársticas e falhadas, voltadas a explorações turísticas.

A metodologia utilizada nos estudos de compartimentação do relevo depende da dimensão ou da escala do estudo, que deverá estar ajustada a um determinado nível taxonômico.Depende também dos objetivos e do nível de abordagem proposto para o estudo.A função da compartimentação é subdividir o relevo em unidades que permitam tratamento individual, em função de sua ordem de grandeza. Essas unidades são representadas por meio de um conjunto de formas de relevo que guardam similitude e posição altimétrica individualizada, podendo ser divididas em 
subunidades que identificam particularidades regionais, pelo posicionamento altimétrico e fatores genéticos.

A própria classificação do relevo apresentada desde os mapas escolares já se trata de uma compartimentação da paisagem. Planaltos, planícies, depressões são termos que evocam compartimentos de relevo. O Estado de São Paulo teve ao longo do século XX uma série de bons estudos sobre compartimentação topográfica, e foi o primeiro a ter um bom retrato de sua macro-compartimentaçãotopográfica, evoluída no período entre 1920e 1956 (Ab'Saber, 1969). Os grandes traços do relevo paulista estão marcados nos mapas de Ab'Saber (Esquema Morfológico, 1956); do IPT (Divisão Geomorfológica, 1981); de Ross \& Moroz da USP (Mapa Geomorfológico, 1996) e do IBGE (Compartimentos de Relevo, 2000). As três grandes unidades desse relevo - Planalto Atlântico, Depressão Periférica e Planalto Ocidental Paulista, a Ross em 1996 denominou de Unidades Morfoesculturais, caracterizam essa macro-compartimentação do relevo do estado. Cada uma delas guarda subdivisões e denominações locais, sem no entanto mudar radicalmente sua condição estrutural que lhe é dada pelas características estruturais, litológicas e geotectônicas que estão associadas à sua gênese (Ross \& Moroz, 1996). ${ }^{30}$

Os mapas geomorfológicos apresentados nas figuras 7.1 a 7.4 mostram aspectos da compartimentação do relevo do estado de São Paulo realizados pelos autores acima citados, e estão aqui inseridos com o intuito ilustrativo da variedade de formas de se representar os compartimentos de relevo, bem como aproximar o leitor à morfologia da nossa região de estudo. A nomenclatura utilizada nesta pesquisa se baseia na classificação realizada por Ross \& Moroz (Figura 7.4).

Portanto, os mapas apresentados revelam a macro-compartimentação do relevo do Estado em suas grandes estruturas. Ao ampliarmos a escala de abordagem a compartimentação topográfica vai assumindo contornos mais precisos e realçando os detalhes internos de cada morfoescultura e suas sub-unidades.

\footnotetext{
${ }^{30}$ Para Ross \& Moroz, essa unidades estruturais são chamadas de Morfoestruturas, seguindo a proposição de classificação de Gerasimov \& Mercejakov (1968), que desenvolveram os conceitos de Morfoestrutura e Morfoescultura. As grandes morfoestrutura são os cinturões orogênicos, como o do Planalto Atlântico; as Bacias Sedimentares, como a do Paraná; e as plataformas ou crátons. Essas grandes estruturas, em face racterísticas relacionadas à gênese, litologia eidade, definem na superfície terrestre padrões de relevo que lhes são inerentes (Ross \& Moroz, 1996, p. 44)
} 
Figura 7.1 - Esquema Geomorfológico do Estado de São Paulo, elaborado por Ab'Saber em 1956, com destaque para a área da Macrometrópole de São Paulo.

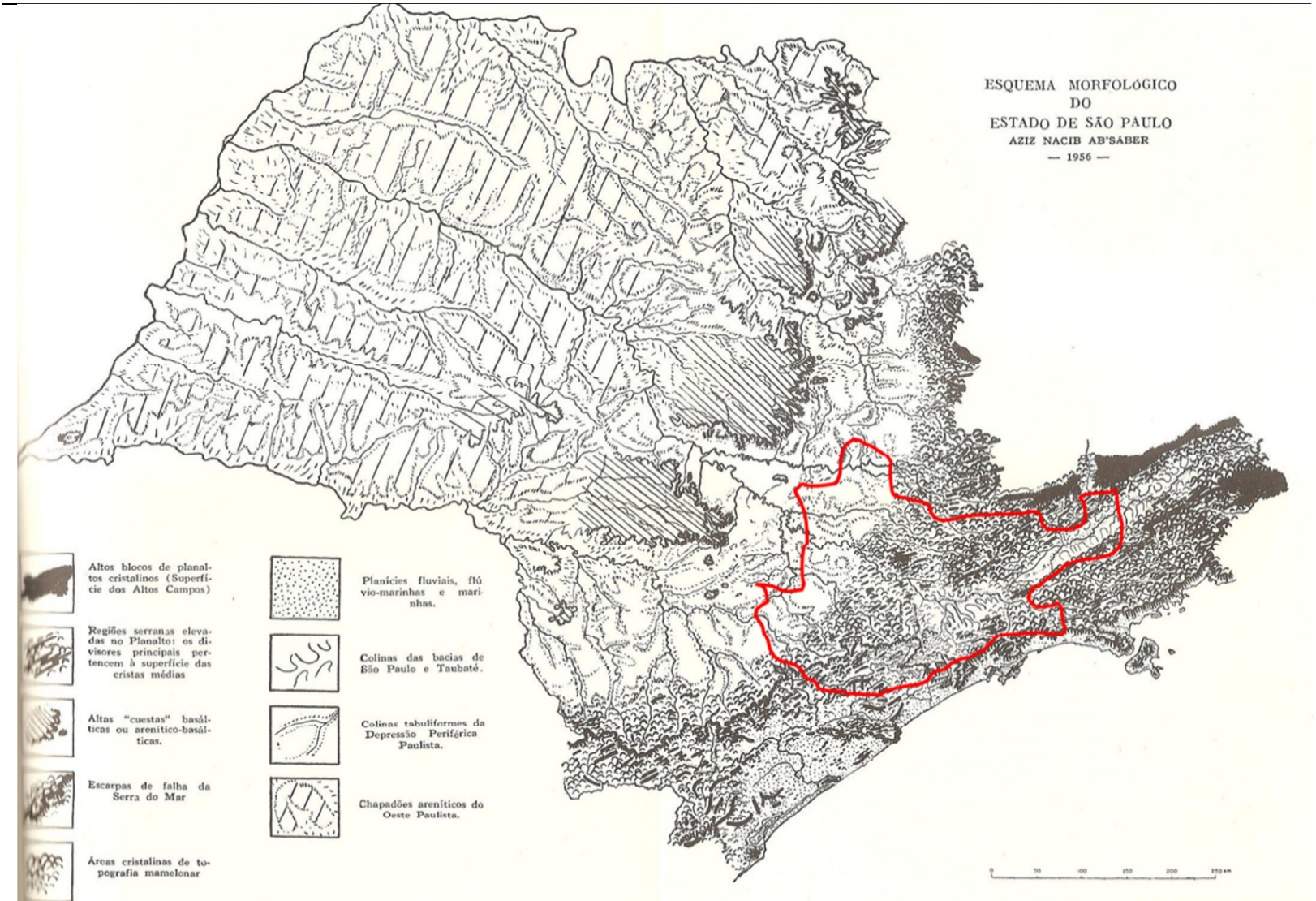

Fonte: Ab'Saber, 1958, adaptado pelo autor.

Figura 7.2 - Mapa Geomorfológico do Estado de São Paulo, IPT-1981, com destaque para a área da Macrometrópole de São Paulo.

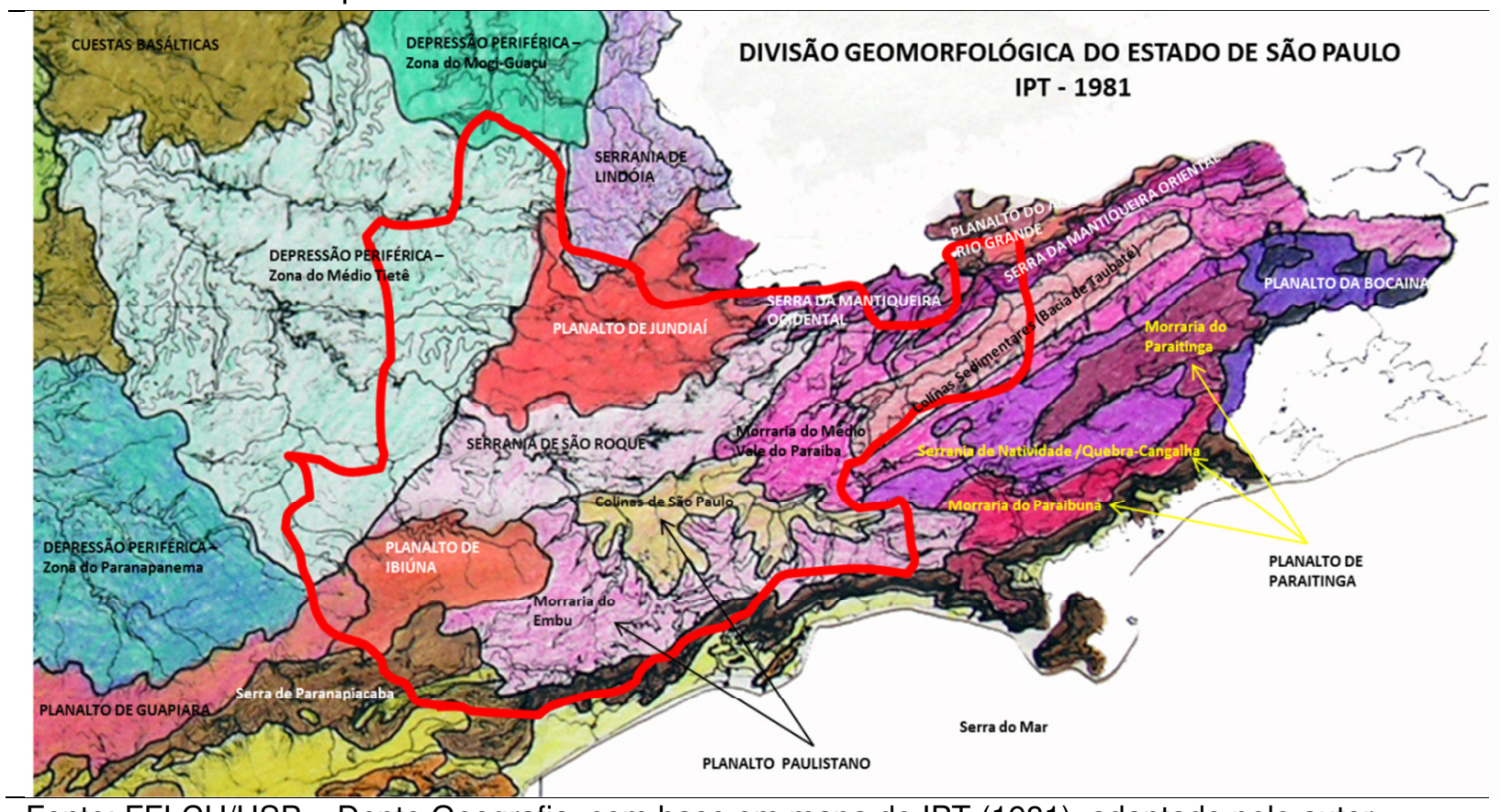

Fonte: FFLCH/USP - Depto Geografia, com base em mapa do IPT (1981), adaptado pelo autor. 
Figura 7.3 - Mapa Geomorfológico do Estado de São Paulo , IBGE-2000, com destaque para a área da Macrometrópole de São Paulo.

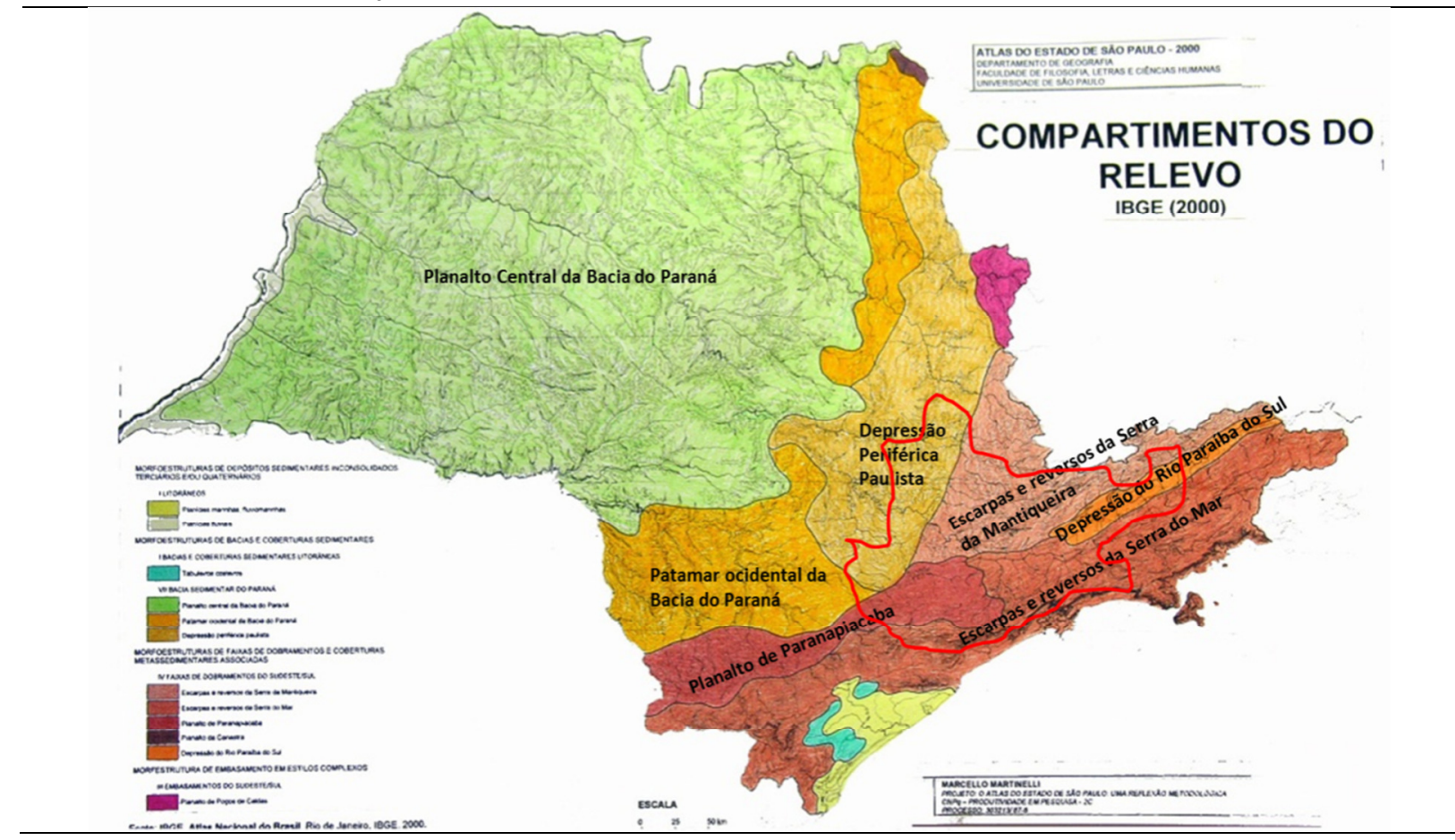

Fonte: FFLCH/USP - Depto Geografia, com base em mapa doIBGE (2000), adaptado pelo autor.

Figura 7.4 - Mapa Geomorfológico do Estado de São Paulo ,FFLCH/USP-Depto Geografia1993 (Ross \& Moroz), com destaque para a área da Macrometrópole.

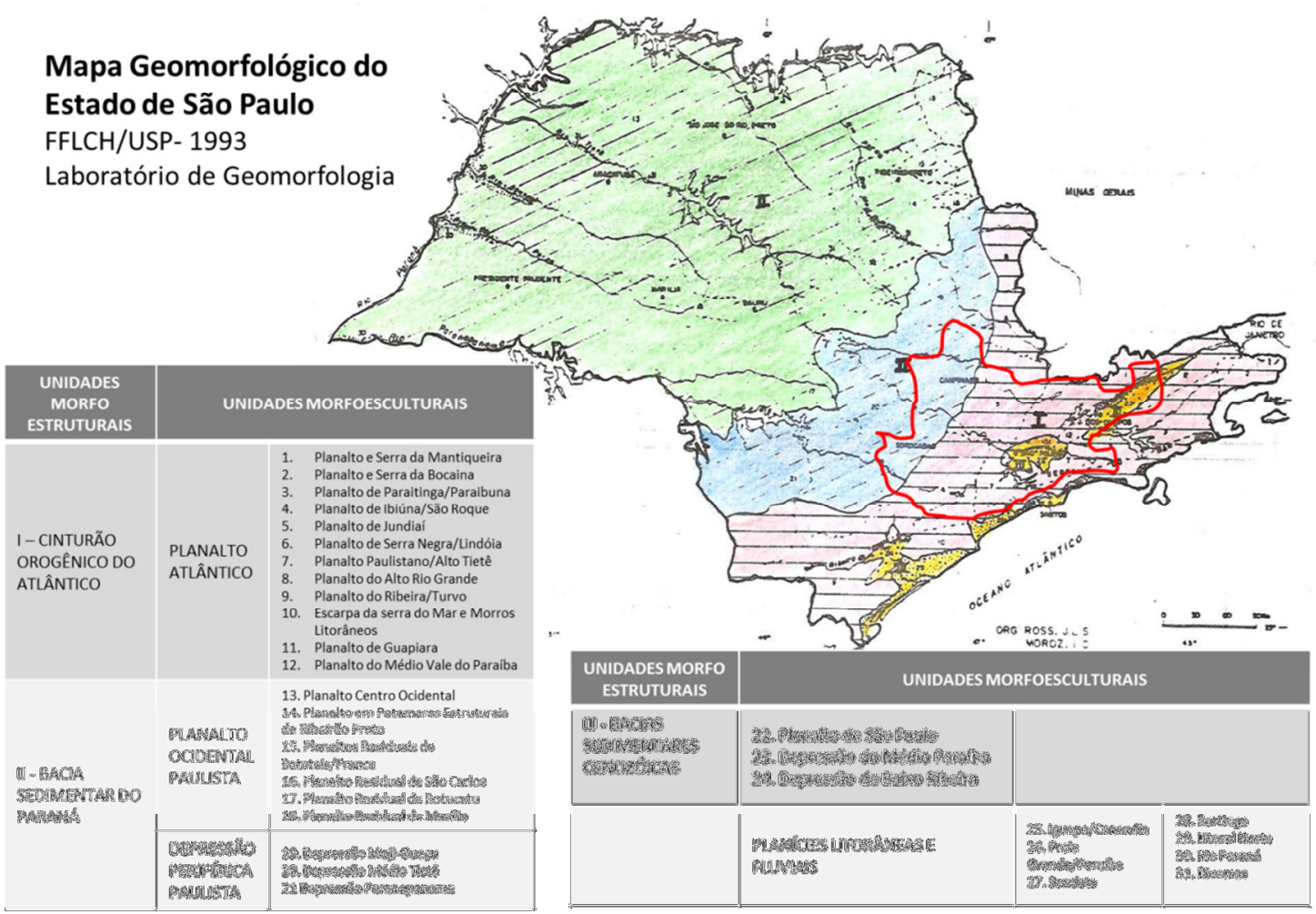

Fonte: Ross \& Moroz (1996), adaptado pelo autor. 
A elaboração de perfis dessa compartimentação topográfica é uma prática associada à elaboração da cartografia geomorfológica, facilitando a visualização dos compartimentos e a posição relativa em que se encontram. A análise e descrição das formas de relevo associadas a cada compartimento proporciona uma primeira aproximação mental e dedutiva acerca da fisiologia da paisagem em operação naquela porção do território. Evidentemente, não é possível ao pesquisador a abordagem analítica dos complexos indicadores das ações morfológicas, pedogênicas e hidrodinâmicas integradas de uma paisagem. No entanto, a simples consciência desses fatos já constitui um bom ponto de partida para iniciar o entendimento daquela paisagem.

\subsubsection{A Compartimentação Ambiental}

Diferente da compartimentação topográfica, a compartimentação ambiental introduz à compartimentação topográfica a ideia de valores de uso e de ocupação do relevo para a sociedade urbana de forma enfática. À fisiologia da paisagem, que conduz a esculturação evolutiva do relevo, associa-se o funcionamento da sociedade, por meio do funcionamento da cidade e do campo, das ações humanas e do acréscimo de formas artificiais da engenharia humana. A compartimentação ambiental, na forma aqui trabalhada, visa associar ao compartimento de relevo sua aptidão ou fragilidade em responder às funções urbanas que the quer dar a sociedade. Portanto, trata-se de um conceito eminentemente de cunho urbano, operacional para avaliar e planejar a urbanização de um território.

Não se quer dizer com isso que a compartimentação topográfica feita nos estudos de geomorfologia não relacione as fragilidades e potencialidades dos compartimentos para a sociedade. No entanto, trabalha com diretrizes gerais, enquanto a compartimentação ambiental visa subsidiar o desenho urbano e a urbanização do território com uma leitura estratégica do relevo para fins propositivos de escolha efetiva dos espaços a ocupar ou preservar.

Na realidade, as duas formas de compartimentação do relevo, a topográfica e a ambiental, parecem mesmo ser a mesma coisa. A compartimentação topográfica é uma etapa da análise ambiental. Ou seja, para se chegar a uma compartimentação 
ambiental é necessário realizar uma primeira aproximação dela, que se faz por meio de uma compartimentação topográfica minuciosa. Somente após introduz-se a análise valorativa dos compartimentos topográficos. Quais são suas potencialidades e fragilidades para responder às necessidades de uso e ocupação do solo para fins urbanos e periurbanos. Não estamos falando aqui de necessidade de preservação ambiental, pois esta faz parte das necessidades de uso do território. Hoje já é compreensível para a maior parte das pessoas que o uso intensivo dos recursos da natureza requer espaços de preservação, dos recursos e dos processos naturais.

Então, quais são os valores associados à compartimentação ambiental da paisagem? Pode-se dizer que o valor central para a sociedade é a manutenção de certa estabilidade dos processos naturais, ou seja, um equilíbrio dinâmico e dialético entre os processos urbanos e processos naturais, que permitam a sustentabilidade do território. Mas que sustentabilidade é essa? ${ }^{31}$

Se observarmos sob o ponto de vista do conceito de geossistema, de um lado há a necessidade de se garantir as propriedades sócio-reprodutoras do sistema local, ou seja, a necessidade de espaços para a reprodução social do morar, trabalhar, ter lazer, produzir alimentos e recursos materiais (mineração, silvicultura, etc, ou seja, propriedades geoeconômicas). Trata-se da dialética de vida do "animal laborans" e do "homo faber" a que referiu Arendt (2010) na década de 1950 em "A condição humana"32. Portanto, para que isto se dê, a pergunta que se faz ésobre quais são os compartimentos de relevo que possuem maior ou menor aptidão para o desempenho dessas funções necessárias à sociedade do espaço em que se está planejando o uso e ocupação? Qual é o seu potencial de uso ou de ocupação? Pode-se até relacionar a pergunta qual é a segurança de seu uso, se pensarmos na corriqueira condição de ocupação destinada às populações de baixa renda que habitam áreas alagáveis ou encostas sujeitas a riscos de deslizamentos. Acrescente-se aqui, também, a presença de valores culturais instalados no compartimento, ou ainda àqueles relativos ao próprio valor sentimental de uma paisagem natural.

\footnotetext{
${ }^{31}$ Fazemos referência à sustentabilidade em um sentido genérico, referente à manutenção de certas condições de estabilidade da vida social em relação ao ambiente, à natureza. Não é intenção entrar no mérito da discussão de sustentabilidade que, embora em voga e na moda, é bastante controverso e eivado de carga ideológica.

${ }^{32}$ Arendt, Hanna. A condição humana. Rio de Janeiro: Forense Universitária, 2010.
} 
A sustentabilidade do território também perpassa a garantia das propriedades geoecológicas da paisagem em uso e com planos de expansão. Aqui se fala das propriedades biofísicas da natureza, do qual o relevo faz parte. Trata-se de se perguntar quais compartimentos que prestam serviços ambientais importantes para a sociedade como o fornecimento de água potável, zonas de amenização climática por meio de florestas e bosques, de lagos ou abrigar reservatórios, etc. Também a necessidade de manutenção da biodiversidade dos biomas, ou as áreas de refúgios de fauna ou de sua reprodução, refúgios da flora, e outras potencialidades paisagísticas. Aqui se fala na manutenção dos recursos da natureza e também dos processos naturais.

Portanto, na análise geomorfológica da compartimentação topográfica, a fim de se compreender a cinemática da paisagem, inqueria-se a fisiologia da paisagem no que concerne a modelos predominantemente naturais ou de pouca interferência humana. Mesmo quando esta interferência existia a análise tendia à constatação e pouco à obtenção de prognósticos do futuro da paisagem.

Entendida dessa maneira, a compartimentação ambiental poderá não coincidir com o detalhamento proposto pela compartimentação topográfica. Compartimentos topográficos diferentes poderão ter a mesma função para os interesses sociais naquele momento ou naquela sociedade. Assim, poderão configurar um só compartimento ambiental.

Percebe-se, dessa forma, que a compartimentação ambiental é uma síntese da paisagem naquilo que esta interessa para a urbanização do território. Assim, compartimentos ambientais serão mais bem definidos nas áreas mais urbanizadas ou densamente povoadas, pois se faz necessário uma ordenação do uso do território para explorar as potencialidades e preservar as áreas de maior fragilidade ambiental ou necessárias à manutenção do equilíbrio urbano. Nas áreas pouco povoadas ele também pode ser importante no sentido de direcionar o crescimento e o uso do território, mas em virtude da escala tornar-se-á genérico demais. Outros instrumentos como o Zoneamento Econômico-Ecológico são mais apropriados ao planejamento territorial de grandes regiões. Nas áreas fracamente povoadas, em termos de impactos ambientais, a condição é semelhante ao que ocorria no passado 
em cidades e áreas rurais de pequena expressão populacional, em que os impactos ambientais eram plenamente absorvidos pela natureza.

A compartimentação ambiental visa entender a fisiologia de cada compartimento e sua função na paisagem, os impactos que recebe de processos desenvolvidos em outros compartimentos ou os impactos que induz ou provoca nos demais compartimentos da paisagem. Nesse sentido, interessa também, como valor ou necessidade, inquirir sobre o estágio de degradação da paisagem e do compartimento e sua situação de resiliência.

Os compartimentos assim analisados podem sugerir estratégias e índices de uso e ocupação, ou até de preservação. Revelam também suas potencialidades para outros usos que até então não haviam sido chamados a executar.

Nesse sentido, um aspecto importante na análise da compartimentação ambiental vem a ser a questão da sua abrangência em superfície, ou seja, da dimensão de cada compartimento ambiental e de sua área de influência ou de impacto, seja negativo ou positivo para a manutenção dos indicadores de qualidade ambiental.

Cabe avaliar se um compartimento sofre impactos provenientes de muitos outros,ou de uma vasta área; ou então se promove impactos a uma área relativamente grande. Nessa mensuração concorrem a análise da superfície de contato com a dinâmica do clima (radiação; chuvas; emissividade de calor; influencia na circulação do ar) e com a dinâmica da água (escoamento; infiltração; percolação; erosão laminar; erosão).

É certo que muitas vezes poderá se confundir a compartimentação ambiental da paisagem com a identificação de unidades de paisagem, conceito muito utilizado recentemente por geógrafos, arquitetos, urbanistas, biólogos e ecologistas de diversos matizes. $\mathrm{E}$ também com a definição de zoneamento ambiental e zoneamento econômico-ecológico. Ou ainda com as unidades geomorfológicas de uma paisagem, muitas vezes mais associada ao conjunto de formas de relevo homogêneas. 
De fato, todos esses estudos se baseiam também na identificação das potencialidades e fragilidades para fins de uso do território e de seus recursos para a sociedade, como subsídios à gestão do território. No entanto, há que se ressaltar diferenças de escala importantes. Como exemplo, cita-se o caso do Zoneamento Ecológico-Econômico da Amazônia Legal33 que, mesmo fundamentado nos conceitos ecodinâmicos de Tricart (1975), tendo o relevo como componente básico,foi realizado em uma base cartográfica na escala 1:250.000, portanto, uma abordagem de nível regional, relacionado grandes diretrizes de utilização do território. Neste caso, realiza-se uma macro-compartimentação topográfica da paisagem. Dentro de cada conjunto tem-se uma rede de cidades em desenvolvimento em que cada componente dessa rede realiza sua relação dialética com um relevo local pouco detalhado em seus compartimentos, em virtude da escala trabalhada (1:250.000).

Tanto a compartimentação topográfica como a compartimentação ambiental não apresentam uma escala definida, pois depende de cada situação regional e local da paisagem. Entretanto, para a compartimentação ambiental há que se ter uma finalidade de uso urbano do território, senão ela perde a utilidade e referência. Portanto, a compartimentação ambiental está intrinsecamente ligada às áreas de ocupação humana mais densa.

\subsubsection{Compartimentos ambientais estruturantes}

Com base no exposto até aqui é possível falar então de compartimentos ambientais estruturantes de uma paisagem. Estes se definem por aqueles que colaboram em maior grau para a preservação dos valores associados aos compartimentos do território estudado, sobretudo daqueles valores relativos às propriedades geoecológicas do território. Trata-se, assim, de uma avaliação estratégica do relevo e das condições físico-ecológicas para fins de ocupação e de preservação, preservação essa no duplo sentido: a dos recursos de flora, fauna, água e solos férteis, como a preservação dos processos naturais sem alterar em muito a sua intensidade normal.

\footnotetext{
${ }^{33}$ Realizado segundo orientação de Becker \& Egler (1997), sugere, por exemplo, como subsídio à gestão do território, o estudo da vulnerabilidade da paisagem natural e da potencialidade social.
} 
Traz agregado a essa identificação uma noção de escala de abrangência do compartimento estruturante dos processos naturais e urbanos, ou seja, aquele conjunto - compartimento ou setor dele - que mais interfere nos processos naturaisda região e que mais colabora na preservação do equilíbrio natural-urbano e dos recursos naturais imprescindíveis à vida da cidade, como água potável, clima ameno, entre outros. Os compartimentos estruturantes são aqueles dos quais derivam influências (positivas ou negativas) aos demais compartimentos, ou então aqueles que recebem interferência de uma vasta área, de outros compartimentos, interferência essa no duplo sentido, o de impactos diretos ou na indução de processos.

São estruturantes, também, aqueles compartimentos que possam agregar condicionantes ecológicas importantes para a preservação da flora e da fauna associada, como a criação de corredores ecológicos, a junção de áreas de concentração de nascentes e seus anfiteatros, a preservação das margens (APPs) dos mais importantes canais de drenagem, a preservação das encostas íngremes de compartimentos que interferem na circulação dos ventos, etc. Nesse sentido, um compartimento ambiental estratégico é aquele que colabora para combater a fragmentação da paisagem, no sentido da preservação dos biomas e habitats para a fauna, como também para a ocorrência dos processos naturais relativos às dinâmicas da água e do clima. Como exemplo, cita-se o escoamento superficial concentrado que se dirige para os grandes canais de drenagem; ou a preservação de áreas de recarga do lençol freático.

Qual deve ser então a posição de um compartimento estruturante na paisagem? Como já mencionado, existem compartimentos que influenciam ou impulsionam a ativação ou a intensificação dos processos naturais de outros compartimentos. Como exemplo, as regiões serranas, os grandes divisores de água, que determinam a intensidade do escoamento superficial, que interferem na circulação atmosférica, que regulam a oferta de água durante o ano, etc. Existem aqueles outros compartimentos que recebem influência dos demais, ou de uma área expressiva, como as grandes várzeas ou planícies costeiras ou embutidas em macrocompartimentos de planalto. $O$ exemplo clássico dessa influência está na 
ocorrência das cheias naturais dos rios, ou nas enchentes que impactam a vida das cidades.

Dessa forma, existem compartimentos indutores de processos e compartimentos receptores de processos, ou seja, para onde se dirigem e se concentram processos induzidos em áreas distantes, de outros compartimentos.

A mensuração do tamanho da área de influência é, de certa forma, uma tarefa mais subjetiva, pois derivaria de estudos mais complexos e detalhados da fisiologia da paisagem objeto dessa avaliação estratégica do relevo. É mais tranquila a determinação da influência indutiva ou passiva dos processos relativos à dinâmica da água, pois ela é dada e controlada, em boa parte pela delimitação das bacias hidrográficas. Nesse sentido, tanto os divisores de água quanto os fundos de vale receptores da água infiltrada, escoada ou percolada em seu entorno podem ter sua delimitação mais precisa. Para os divisores de água serão os canais principais de drenagem de seu entorno. Para os fundos de vale serão os divisores de água de seu entorno. Pode-se perceber pela descrição que essas delimitações podem se imbricar na paisagem, induzindo a avaliação da importância dessa região como um todo na preservação dos processos naturais.

Já para a dinâmica do clima essa mensuração é mais difícil, por isso torna-se mais subjetiva, devendo ser balizada por indicadores como influências na circulação atmosférica (barreiras ao vento e indução de chuvas orográficas, canalização dos ventos, na dispersão de poluentes, na conformação das ilhas de calor, nos índices de umidade relativa do ar, na mensuração da temperatura de superfície, etc).

Entre os dois elementos da paisagem citados, que configurariam compartimentos ambientais estruturantes, os divisores de água - indutores de processos - e os fundos de vale - receptores - têm-se os setores de vertentes que interligam essas duas linhas estruturantes da paisagem. Essas vertentes podem ter declividades suaves ou elevadas, e são as áreas por onde passam e se desenvolvem os processos naturais. Seriam, assim, áreas receptoras e transmissoras ao mesmo tempo, mas não somente, pois nelas também se desenvolvem processos naturaisque induzirão impactos a jusante, ou seja, distribuindo-os para outros compartimentos. Portanto, embora se configurem em 
áreas mais passíveis de ocupação urbana, quando não muito íngremes, elas também devem ser objeto de regulação da forma e intensidade de sua ocupação, quando se constituam em indutoras de processos para outros compartimentos, principalmente para aqueles considerados estruturantes.

A percepção do relevo pelo homem sempre ressaltou esses dois elementos significativos de uma paisagem - os rios e os morros, os vales e as serras. Nestes os grupos humanos buscavam definir seus caminhos, suas trilhas, aproveitando tanto os fundos de vale como os alinhamentos de divisores como percursos mais suavizados do relevo e com menores interrupções bruscas do caminho. Buscavam também tanto ora a proximidade com a água, ora a segurança das vistas de paisagem, o controle do território por meio de localizações escolhidas de eixos visuais abrangentes.

Figura 7.5 - Mapa Topográfico da Província de São Paulo - 1875.

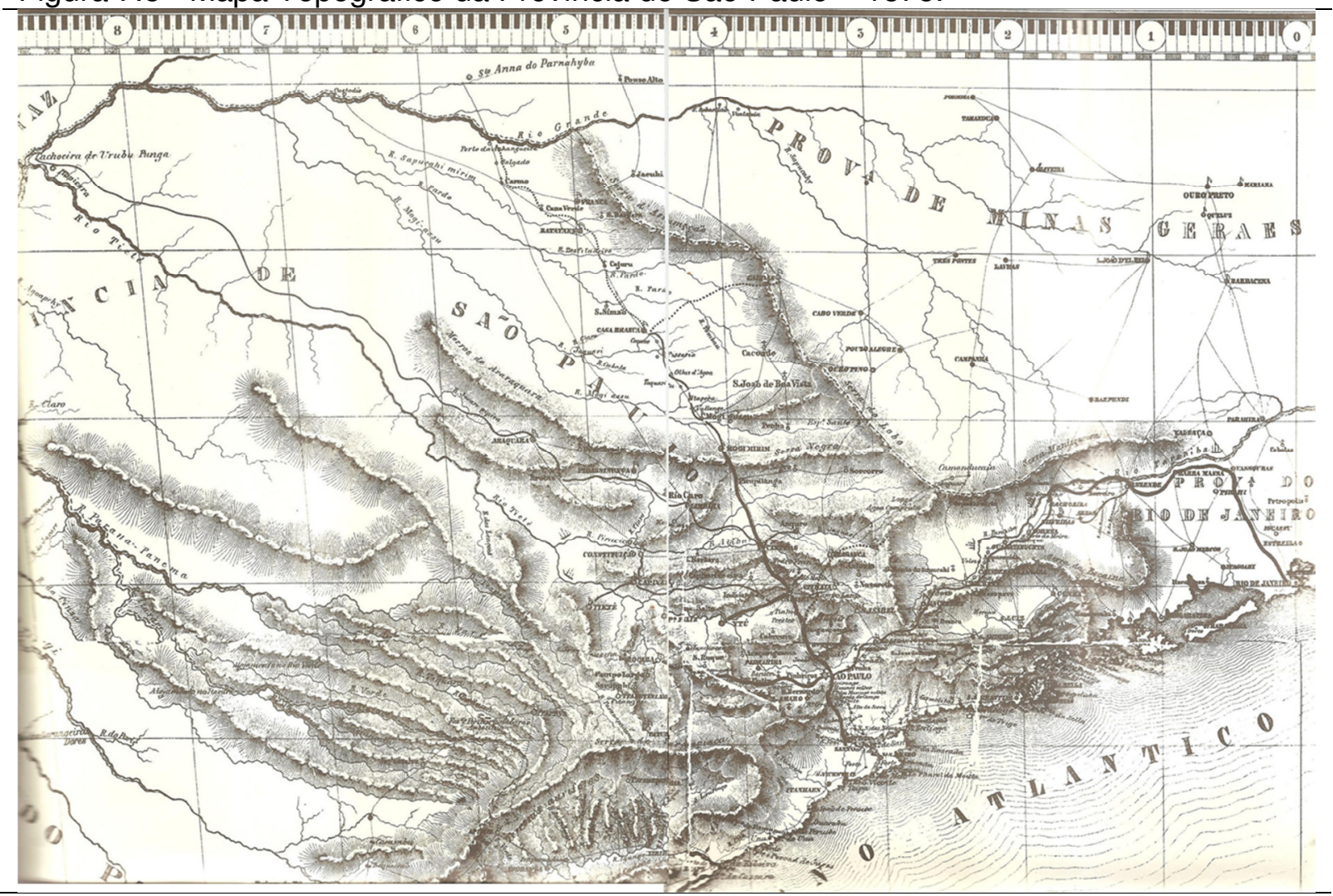

Fonte: Godoy (2007)

Nesse sentido, como ilustração, vale apreciar o mapa topográfico de 1875 , em que aparece em destaque essas grandes linhas da paisagem, que sintetizavam, para a época, as feições mais relevantes do relevo que se impunham como obstáculos ou como oportunidades. Veja-se a expressão dada ao desenho dos 
divisores de água das suaves colinas do interior, situadas na Depressão Periférica. Tratavam-se dos principais caminhos de penetração por terra para o sertão de São Paulo, livres da transposição dos afluentes do Rio Tietê e dos outros rios que tinham seu curso na direção do interior (noroeste). Ou então, a partir da passagem do Planalto AtLântico para a Depressão Periférica poderia-se atingir o interior do Brasil pelos rios navegáveis, como o Rio Tietê.

\subsubsection{Compartimentos ambientais estruturantes da macrometrópole}

Para a identificação dos compartimentos ambientais estruturantes da Macrometrópole de São Paulo foram utilizados os mapas de uso e ocupação do solo da Região Metropolitana de São Paulo e Bacia Hidrográfica do Alto Tietê, da Emplasa, na escala 1:150.000; mapas geológico e geomorfológico do IPT para o Estado de São Paulo, na escala 1:500.000; o mapa hipsométrico da Emplasa para o Estado de São Paulo, na escala 1:1.000.000; e informações analisadas e mapeadas a partir das imagens do Google Earth.

Essa identificação teve um caráter exploratório, por isso, e em face da escala trabalhada e dos objetivos assumidos na hipótese da pesquisa, não se pretendeu elaborar um mapeamento preciso da área de cada compartimento, bem como dos seus limites divisórios com outros compartimentos. O cruzamento de informações entre compartimentos ambientais estruturantes e áreas ocupadas pelas peças urbanas que se dispersam pela zona rural dos municípios teve o caráter de evidenciar tendências gerais dessa dispersão sobre o relevo, e não estabelecer criteriosamente uma análise exaustiva da compartimentação topográfica e ambiental da paisagem da macrometrópole.

A análise e identificação dos compartimentos ambientais estruturantes na macrometrópole de São Paulo foi uma tarefa que, como já frisado anteriormente, requereu conhecimentos sobre a topografia e a hidrografia da região, e também uma compreensão sobre a fisiologia da paisagem, naquilo que se refere às principais dinâmicas que caracterizam as relações do clima e da água com o relevo.

$\mathrm{Na}$ leitura estratégica do relevo para a identificação dos compartimentos ambientais estruturantes da paisagem observou-se o critério de identificar os conjuntos indutores e os receptores de processos das dinâmicas do clima e água. 
Num segundo momento, verificou-se a extensão de cada conjunto ou compartimento e a sua área de influência, principalmente no que tange à dinâmica da água, especialmente a do escoamento superficial.

Para identificar os principais compartimentos ambientais indutores de processos naturais, ou seja, aqueles potencializadores da intensidade desses processos em face da energia que dissipa, foram levantados os principais divisores de água das bacias hidrográficas existentes na área estudada, sobretudo aquelesonde se encontra maiores altitudes e desníveis topográficos. Portanto, são os divisores de água compostos pelos alinhamentos serranos e/ou de topo de morrarias que compõem uma parte desse quadro das linhas estruturantes de uma paisagem.

Mas, não são todos os divisores que satisfazem essas exigências de altitude e desnível topográfico mais pronunciado. Aliam-se a esses dois elementos a extensão do alinhamento do divisor pela paisagem e a área de influência de seus efeitos. Assim, incorporam-se a esses compartimentos ambientais estruturantes as principais áreas de concentração nascentes, os principais anfiteatros de nascentes, e os principais alinhamentos que as unem. Dessa forma, teremos satisfeitas exigências ecológicas de corredores que interligam essas áreas de concentração de nascentes. Os limites desses compartimentos de topo, quando mapeados em escala apropriada, serão dados pelas linhas de ruptura de declividade das vertentes, que incorporem os setores de topo e das encostas de alta declividade.

De outro lado, atentou-se para as principais áreas receptoras de processos naturais induzidos de outros compartimentos mais elevados. Nesse sentido, o olhar se direcionou aos fundos de vale, ou seja, para as áreas mais baixas do relevo, baixas sentido relativo, pois em relação ao entorno imediato dessas áreas. Assim, reconhecem-se os principais canais de drenagem da rede hidrográfica local e regional, ou seja, os canais coletores de cada bacia ou sub-bacia. Dessa forma, temse o segundo conjunto de linhas estruturantes da paisagem.

Os mapas das figuras 7.6 e 7.9 visam ilustrar esses elementos estruturantes da paisagem. Para melhor visualização optou-se pela utilização de uma base antiga, porém de fácil leitura. Trata-se de uma figura, publicada em 1958 no livro "A cidade 
de São Paulo: estudos de geografia urbana" organizado por Aroldo de Azevedo, referente ao mapa hipsométricoda região de São Paulo e áreas vizinhas. A Figura xx apresenta esse histórico mapa na íntegra, onde estão representadas as principais cidades, à época, as principais serras e elevações do relevo e os principais rios, além dos represamentos já existentes em 1958. Nota-se, neste mapa, que os limites da mancha urbana compacta de São Paulo ainda estavam circunscritos aos terrenos sedimentares da Bacia de São Paulo (Ver Figura 7.10).

No mapa da Figura 7.9 estão representados os principais compartimentos ambientais estruturantes que assumem uma posição de indutores de processos da natureza que perpassam pela superfície. Como já mencionado, tratam-se dos principais divisores de água do relevo, que delimitam as bacias hidrográficas aí existentes. Neste mapa já é possível perceber que alguns destes compartimentos são mais expressivos, pois formam um lineamento mais contínuo e longo, e também apresentam uma largura mais pronunciada.

Nesse sentido podem ser destacados o conjunto de serras que formam os contrafortes da Serra do Mar e o conjunto da Serra da Cantareira.

Os contrafortes da Serra do Mar constitui em uma borda de planalto cujos divisores estão alinhados entre 750 e 850 metros de altitude. Forma toda a borda Sul-Sudeste da Bacia do Alto Tietê, onde nascem os principais rios que drenam a região de São Paulo. Essas cabeceiras de drenagem se estendem por aproximadamente 140 km de Salesópolis a Embú-Guaçu.

Já o conjunto formado pela Serra da Cantareira, Serra do Itaberaba e Serra da Pedra Branca, passando pelo setor do Pico do Jaraguá e Morro Botucavarú na região de Alphaville, se caracteriza por um expressivo lineamento serrano que se estende por aproximadamente $90 \mathrm{~km}$ desde Piracaia-Igaratá até Barueri. A altitude média fica em torno de $1.100 \mathrm{~m}$ (Cantareira, Jaraguá). A Serra do Itaberaba apresenta as maiores elevações, em torno de $1.300 \mathrm{~m}$, enquanto a Serra de Pedra Branca se situa em torno de 1.000 metros. Na região de Alphaville, o Morro do Botucavarú se nivela em torno de 800 a 900 metros. 
Figura 7.6 - Hipsometria da região de São Paulo e áreas vizinhas (1958)
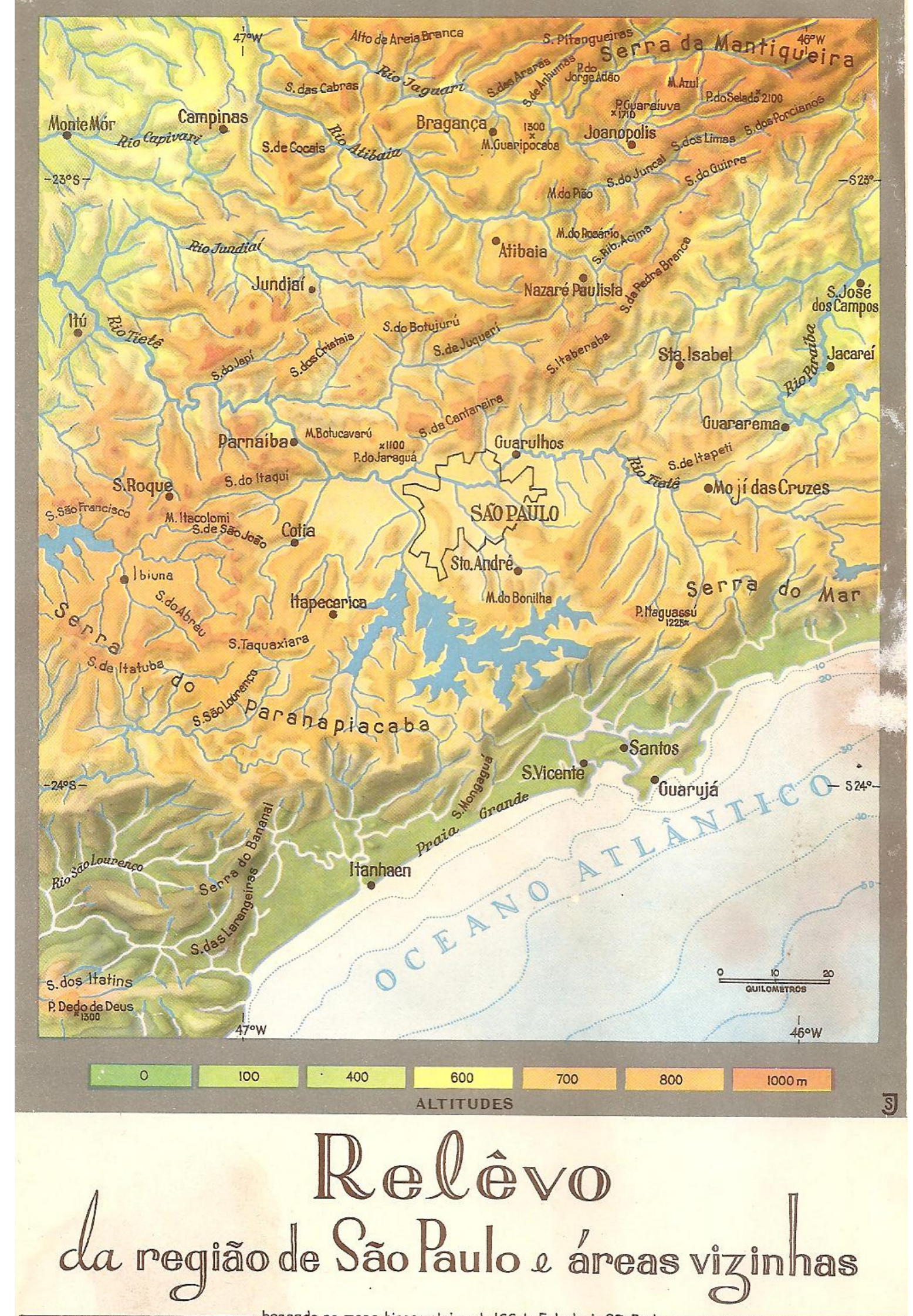

Fonte: Azevedo (1958), adaptado pelo autor. 
Um terceiro conjunto expressivo de lineamento de divisores pode ser reconhecido entre os rios Tietê-Juqueri e Jundiaí. É formado pelo conjunto de serras que se estende desde Atibaia até Jundiaí, separadas por colos estreitos ou mais alongados, mas que formam um mesmo alinhamento, constituído pelas serras da Pedra Vermelha, do Boturujú, Juqueri, dos Cristais e do Japi. As altitudes começam em torno de $1.200 \mathrm{~m}$ na Serra da Pedra Vermelha, decaem para 1.100m na Serra do Juqueri, ficam em torno de $1.000 \mathrm{~m}$ nas serras do Boturuju e dos Cristais, e se elevam novamente para $1.200 \mathrm{~m}$ na Serra do Japi.

Influências estruturais impostas pela história geológica do embasamento cristalino do Planalto Atlântico nessa região, colaboraram para a configuração de uma rede de drenagem de tipo retangular, em alguns setores que apresentam interflúvios pouco distantes. Isto pode ser observado nos divisores de água das bacias dos rios Atibaia e Jaguari; e entre o Rio Atibaia e o Rio Jundiaí. Como podese observar no mapa da Figura 7.9, esses divisores formam lineamentos razoavelmente extensos, porém estreitos. Formam compartimentos ambientais localmente importantes para os municípios de Atibaia, Bragança Paulista, Itatiba, Campo Limpo Paulista, Jarinú, Jundiaí, Louveira e Vinhedo.

O divisor de águas dos rios Atibaia e Jaguari é formado por algumas serras conhecidas localmente por Serra do Juncal, entre Piracaia e Joanópolis; Montanha Leite Sol, em Bragança Paulista; e Serra das Cabras, em Morungaba. As altitudes vão declinando desde os 1.000-1.100 metros na região das cabeceiras em Piracaia e Bragança Paulista; entre 900 e 1.000 metros na Serra das Cabras; declinando consideravelmente quando deixa os terrenos cristalinos e adentra a Depressão Periférica, ficando entre 600 e 700 metros na região de Jaguariúna.

Já o alinhamento de divisores dos rios Atibaia e Jundiaí apresenta altitudes menos expressivas, situadas entre 800 e 900 metros em média, sendo as maiores na região da Serra de Cocais entre Valinhos e Itatiba.

Outros três conjuntos de divisores devem ser destacados, pois colaboram no fechamento da configuração de divisores da Bacia do Alto Tietê e têm o atributo de confinar a mancha urbana compacta da metrópole de São Paulo, se isso fosse 
possível. Estes conjuntos formam sistemas de nascentes relativamente exorreicas, se aproximando mais do modelo de drenagem dendrítica. São eles:

- Serras de Taquaxiara, São Lourenço, Itatuba e Caucaia, entre Itapecerica da Serra, Embu-Guaçú, Juquitiba e Cotia.

- Serras de São João, São Roque, Itaqui e São Francisco, entre Barueri, Araçariguama, São Roque, Mairinque, Ibiúna e Vargem Grande.

- Serras do Itapeti e dos Monos, entre Mogi das Cruzes e Salesópolis.

As principais serras da região, assim como os principais divisores de água das bacias que drenam a região apresentam forte controle estrutural, derivado da presença de falhas ou saliência de intrusões graníticas. Além disso, a provável existência de dois ciclos erosivos antigos de aplanainamento da superfície foram objeto de investigação de muitos geólogos e geomorfólogos e estão relatados nas obras de Almeida (1958) e Ab'Saber (1958) dentre outros. O nivelamento das cristas dos principais divisores de água dessa região do Planalto Atlântico sugere a existência na história dessa paisagem de uma superfície de aplainamento em torno dos 1.100 metros e outra nivelada na faixa dos 800 metros em que se confundem com os topos das camadas terciárias da Bacia Sedimentar de São Paulo.

A maior parte do conjunto de serras que ocorre nessa região da macrometrópole de São Paulo tem constituição granítica, como se poderá verificar no mapa geológico da figura $x x$, e têm suas cristas niveladas a $1.100 \pm 50$ metros. $O$ conjunto litológico do Planalto Atlântico nessa região apresenta-se dominado por rochas graníticas e numerosas intercalações de xistos e gnaisses, restos do teto do batólito granítico, que devido à erosão diferencial de resistência dessas rochas, ressaltou, na paisagem a presença desses conjuntos serranos graníticos.

Numa escala menor escala, também em face da considerável resistência de suas rochas, dominantemente quartzíticas, destacam-se os relevos residuais que compõem um dos compartimentos ambientais estruturantes identificados na paisagem da região da macrometrópole, que é composto pelo alinhamento das Serras do Japi, dos Cristais e do Boturuju, associadas à Falha de Jundiuvira. Além dessas serras, os morros do Jaraguá e do Boturuna também apresentam 
constituição quartzítica. Cabe destacar que apenas a Serra do Japi e Morro do Boturuna apresentam nivelamento de seus topos superior às demais cristas das serras da região, situando-se em torno de 1.200 metros (Almeida, 1958).

Figura 7.7 - Serra da Cantareira, na vertente de Mairiporã,e Serra do Boturuju, região de Franco da Rocha, em 1940. Notar a ocupação esparsa, ainda, nessa época.

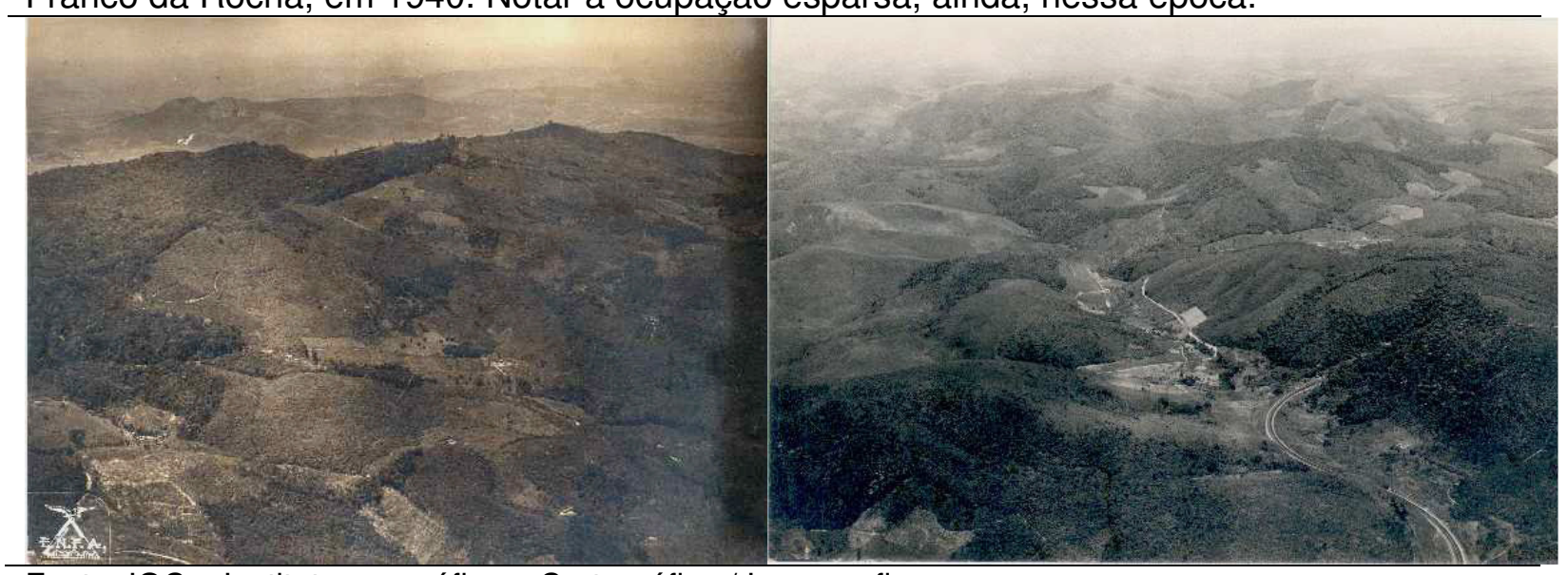

Fonte: IGC - Instituto geográfico e Cartográfico / Iconografia.

As serranias graníticas em geral, e os morros formados pelos gnaisses, xistos e migmatitos apresentam em comum uma espessa cobertura de regolito (manto de decomposição das rochas), que suaviza os perfis das vertentes, tornando pouco frequente a presença de afloramentos rochosos em seus topos. Dentre esses se ressalta o Pico da Pedra Grande em Atibaia, na Serra da Pedra Vermelha. Ocasionalmente surgem vertentes com presença de matacões, que não chegam a se constituírem em "mares de pedra", como acontece na Serra do Itaguá, atravessada pelo Rio Tietê pouco antes de adentrar as colinas da Depressão Periférica(Almeida 1958, p.119-120).

Dentre as serras oriundas de rochas predominantemente graníticas estão quase todas as identificadas no mapa da Figura xx, e podem ser conferidas também no mapa geológico citado (Figura xx). São graníticas as seguintesserras da:

- Serras da Cantareira, do Itaberaba e da Pedra Branca, nos municípios de São Paulo, Mairiporã e Guarulhos;

- Serras do Juqueri, Pedra Vermelha e Juncal, nos municípios de Mairiporã, Atibaia, Bom Jesus dos Perdões, Piracaia e Joanópolis;

- Serras de Itapeti e dos Monos, em Mogi das Cruzes e Salesópolis; 
- Serras de Itatuba e de Caucaia, nos municípios de Itapecerica, Embu, Cotia e Vargem Grande;

- Serras do Itaqui, São Roque, São João e São Francisco, nos municípios de Barueri, São Roque, Mairinque e Votorantim;

- Serras de Cocais e das Cabras, em Valinhos, Vinhedo, Itatiba e Morungaba;

- Serras do Jambeiro, do Palmital e do Quebra-Cangalha, no Vale do Paraíba.

Cabe salientar que os terrenos derivados da decomposição de rochas graníticas apresentam solo de alteração de rocha altamente suscetíveis à erosão quando exposto por cortes em obras viárias e de edificação, sem o tratamento adequado. Assim, em face das declividades das vertentes preponderantemente elevadas nessas regiões serranas, ou em suas morrarias do entorno, não são recomendados à ocupação urbana, sobretudo para loteamentos para a baixa renda que são realizados com intenso parcelamento em lotes pequenos.

Figura 7.8 - Morro do Jaraguá, em São Paulo, e Morro do Saboó, em São Roque, sustentado por quartzitos, em fotos de 1940, ainda com ocupação urbana esparsa ou inexistente nas redondezas.

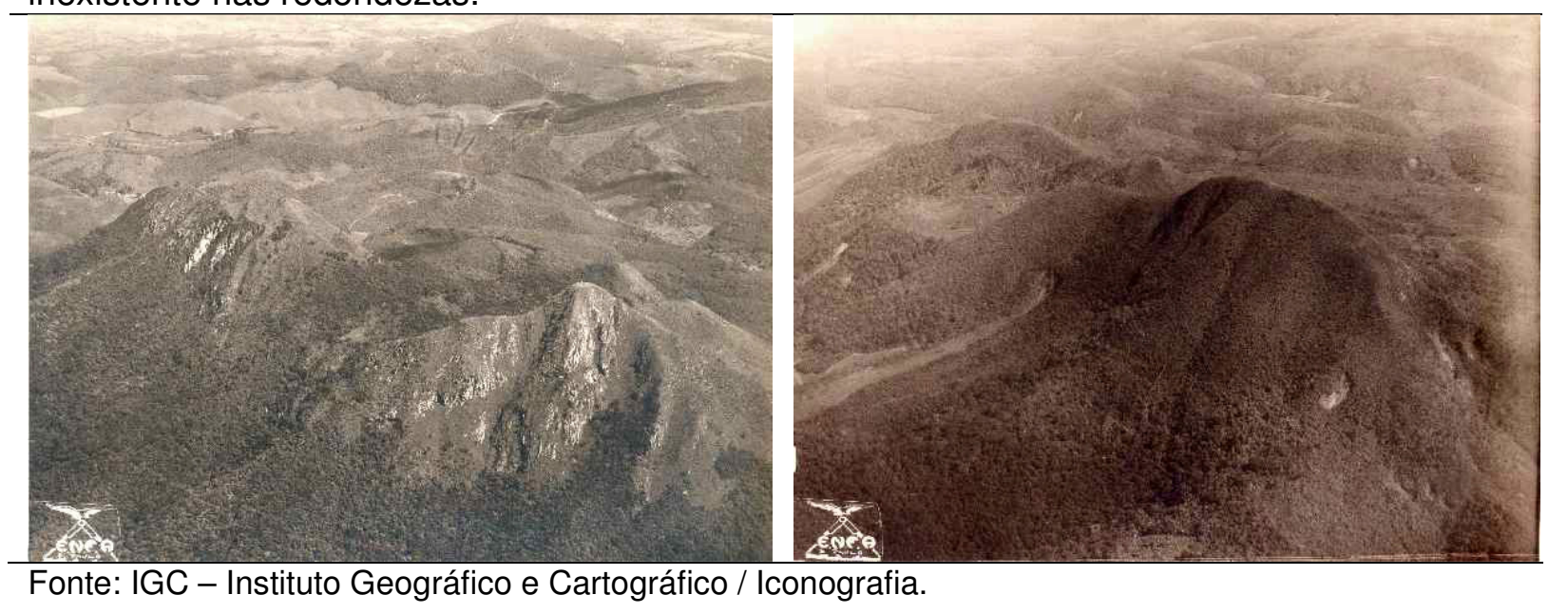

Em termos de expressão territorial de sua influência na dinâmica da água que tem rebatimentos na regularização da vazão do sistema hídrico local e regional, no predomínio do escoamento superficial e do conseqüente potencial erosivo, na existência de inúmeras nascentes e anfiteatros, na sua influência na circulação atmosférica, dentre outros fatores naturais e socioambientais, o alinhamento de divisores das serras da Cantareira, do Itaberaba e da Pedra Grande, incluindo os morros do Jaraguá e do Botucavarú, se constitui em um dos principais compartimentos ambientais da região central da macrometrópole de São Paulo. 
Figura 7.9 - desenho esquemático dos principais compartimentos ambientais estruturantes da paisagem - lineamento de divisores de água.

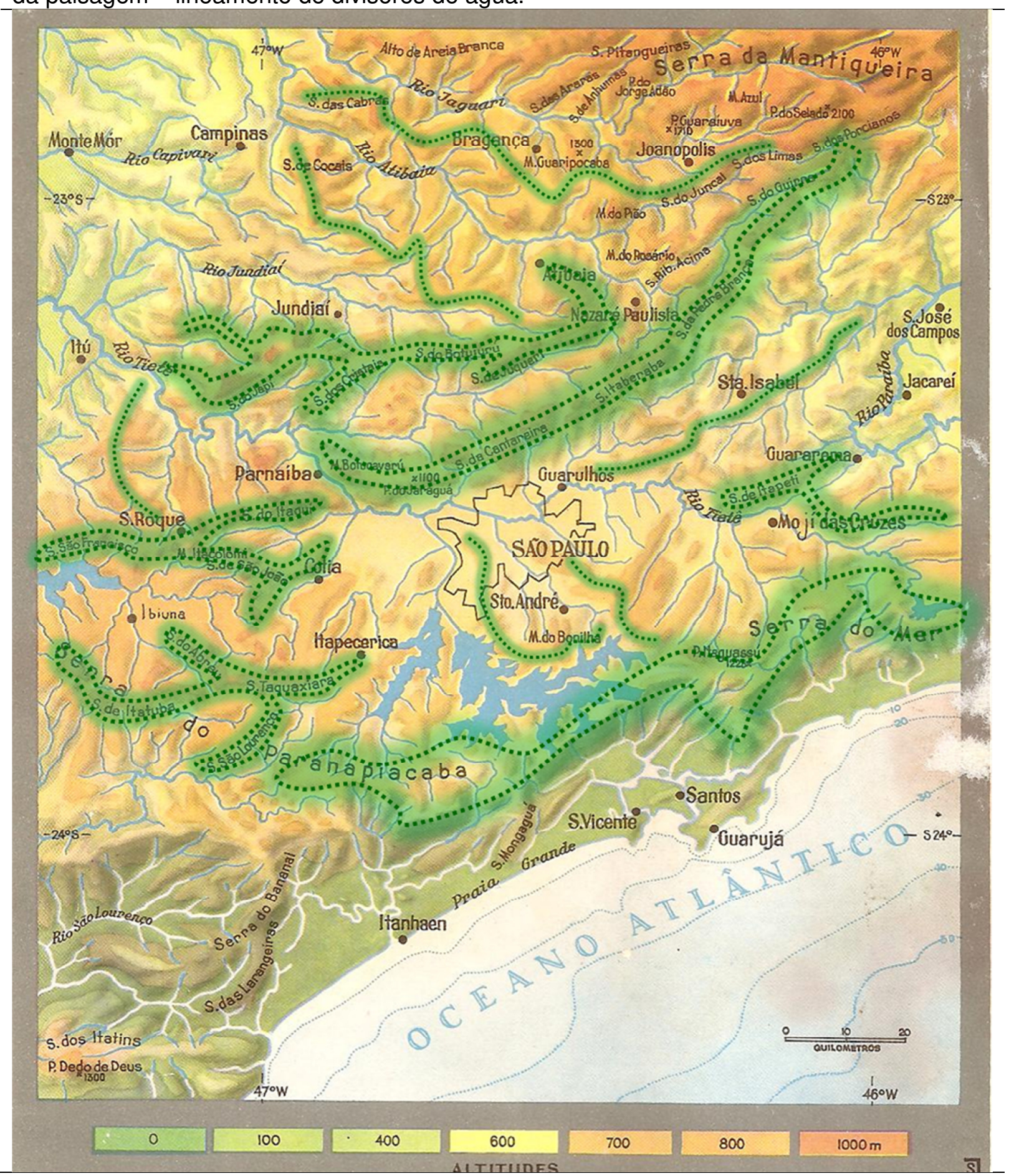

Fonte: Azevedo (1958), adaptado pelo autor.

Não cabe aqui detalhar suas características físicas e nem sua expressividade nas implicações ambientais do território, pois estas já são bem conhecidas em um número grande de publicações, duas das quais já foram citadas. Acrescente-se o fato de que boa parte de sua extensão já se encontra sobre proteção legal por meio 
da criação de unidades de conservação34. O decreto $n^{0}$ 55.662/2010 de criação do parque o Parque Estadual de Itaberaba, o Parque Estadual de Itapetinga, a Floresta Estadual de Guarulhos, o Monumento Natural Estadual da Pedra Grande, já releva a importância destes divisores para a região ao afirmar a relevância do setor nortenordeste da Serra da Cantareira para a conservação da biodiversidade, pois ao longo das últimas décadas tem sido objeto de inúmeros estudos que ressaltam a importância do Corredor Cantareira-Mantiqueira, desde a conectividade dos fragmentos florestais, às evidências de presença e deslocamento de felinos e pela necessidade de proteção dos seus recursos hídricos. Considera, também,"que o Parque Estadual da Cantareira é exemplo de manutenção de integridade florestal em região de forte pressão e expansão urbana, e vem demonstrando, ao longo do tempo, que essa categoria de unidade de conservação é a mais adequada à proteção da biodiversidade".

Estes dois compartimentos ambientais possuem suas diferenciações internas em seu percurso, que colocam questões físicas e ambientais diferentes. Os dois possuem parte de seu curso em áreas de fundo de vale encaixado nas vertentes inclinadas das colinas, morros e serras da região, onde adquirem velocidade maior em sua corrente d'água, que muitas vezes se transformaram em potencial de represamento para produção de água potável e de energia. Ambos possuem também parte de seu percurso aninhado em planícies aluviais mais expressivasque formaram setores significativos de várzeas e de terraços, sítio este muito utilizado para a ocupação urbana.

No mapa da Figura 7.13 pode-se verificar que outros quatro cursos d'água possuem expressividade na região em termos de área drenada, mas também em termos de impactos da urbanização que se densificou ao extremo nas três últimas décadas. São eles os rios Pinheiros, Jundiaí, Atibaia e Capivari.

\footnotetext{
${ }^{34}$ O Decreto no 55.662, de 30 de março de 2010, criou o Parque Estadual de Itaberaba, o Parque Estadual de Itapetinga, a Floresta Estadual de Guarulhos, o Monumento Natural Estadual da Pedra Grande. O primeiro abrange os municípios de Arujá, Guarulhos, Nazaré Paulista e Santa Isabel, com área total de 15.113,11ha (quinze mil, cento e treze hectares e onze ares) e o Parque Estadual de Itapetinga abrange os municípios de Atibaia, Bom Jesus dos Perdões, Mairiporã e Nazaré Paulista, com área total de 10.191,63ha (dez mil, cento e noventa e um hectares e sessenta e três ares).
} 
Figura 7.10 - Geologia da região da Macrometrópole de São Paulo. Notar a relação das serras existentes com a rochas graníticas (cor ver,elha no mapa).

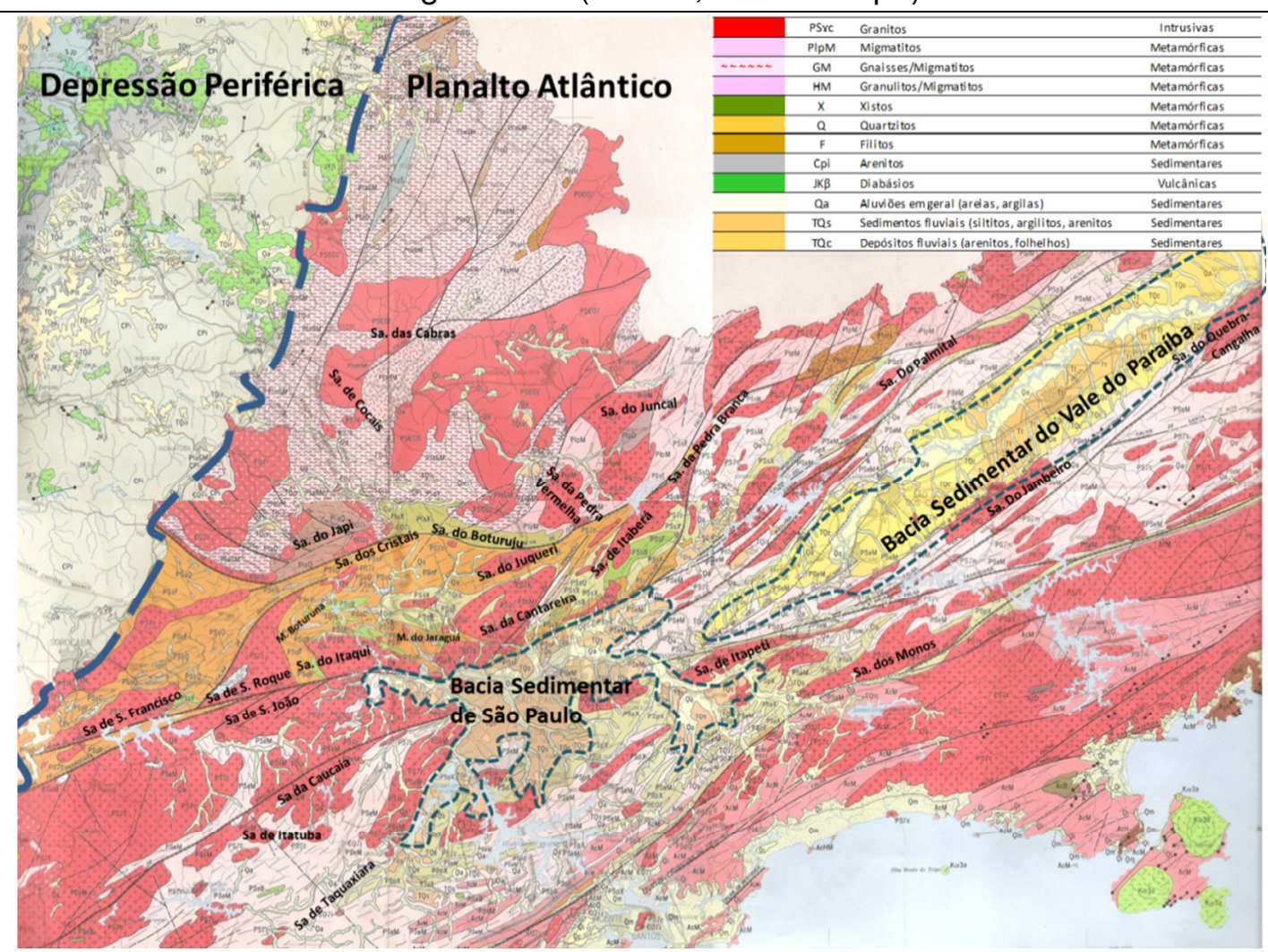

Fonte: Mapa Geológico do Estado de São Paulo, IPT-1981; Mapa Hipsométrico do Estado de São Paulo, IGC-1982; adaptado pelo autor.

Figura 7.11 - Unidades de conservação na área de estudo, 2008.

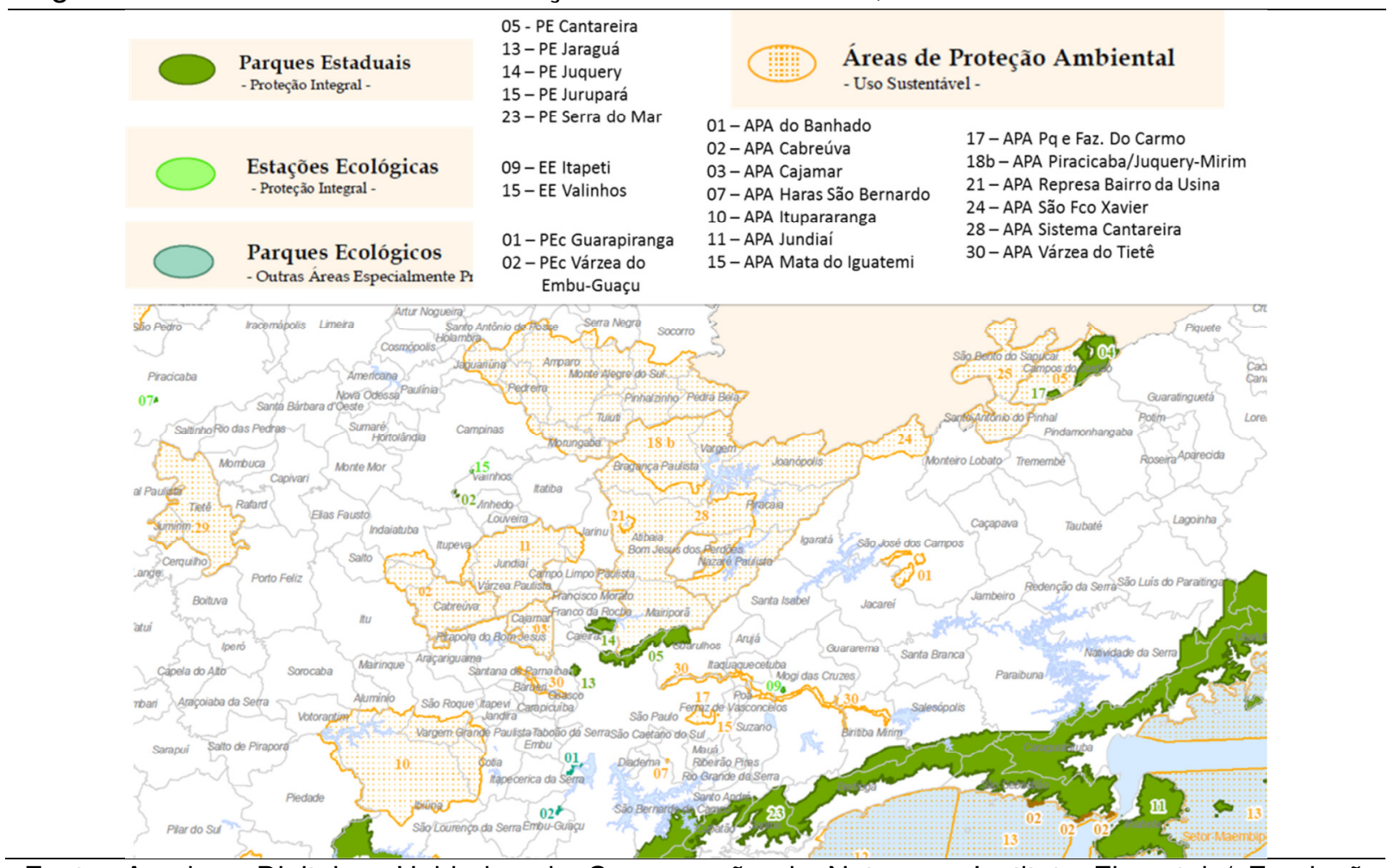

Fonte: Arquivos Digitais - Unidades de Conservação da Natureza. Instituto Florestal / Fundação Florestal, 2008 
O Rio Pinheiros, já historicamente utilizado para a produção de energia e água potável, teve o fundo de seu vale e de seus formadores utilizado para represamento a partir da década de 1910 (Represa Guarapiranga, construída em 1907). No final da década de 1920 é formada a represa Billings, com o represamento dos afluentes Jurubatuba, Rio Grande e Rio Pequeno. Trata-se, hoje, salvo pelas represas, de um rio eminentemente urbano.

Já o Rio Jundiaí, em seu pequeno cursode aproximadamente $70 \mathrm{~km}$, passa pela área urbana de 5 cidades - Campo Limpo Paulista, Várzea Paulista, Jundiaí, Itupeva e Indaiatuba, antes de desaguar no Rio Tietê. É praticamente um rio urbano, tendo poucos trechos de seu percurso livres de ocupação de suas margens. O mais grave é que apresenta uma razoável planície aluvial, em boa parte também ocupada pela mancha urbana dessas cidades. Trata-se de um compartimento ambiental importante, mas mais estruturante local do que regionalmente.

Figura 7.12 - O trecho de várzea do Rio Tietê, em São Paulo, durante a cheia de 1929; e o Rio Tietê nas proximidades de Itú (1940), em seu trecho de vale encaixado nos morros do Planalto Atlântico. Ao fundo, vê-se a silhueta da Serra do Japi.

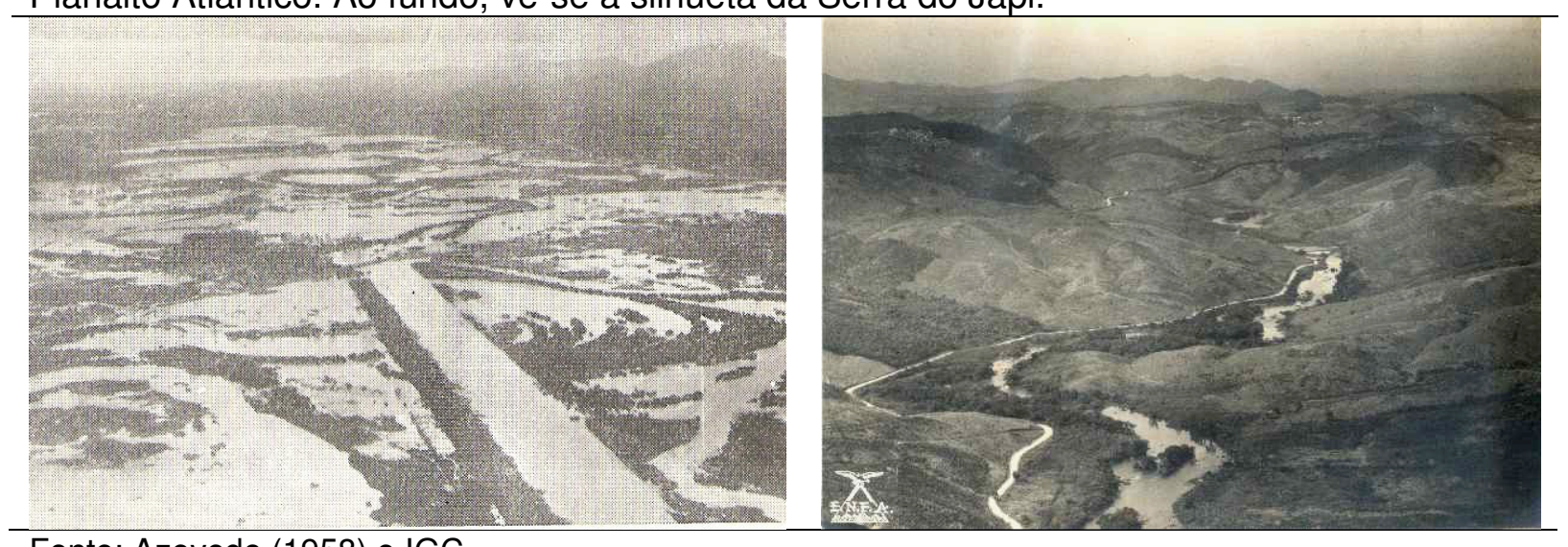

Fonte: Azevedo (1958) e IGC.

O Rio Atibaia se estende por aproximadamente $130 \mathrm{~km}$, e passa lateralmente por 5 cidades em seu alto e médio curso (Nazaré Paulista, Bom Jesus dos Perdões, Atibaia, Itatiba e periferia de Campinas). Sua planície aluvial mais expressiva, embora de pequena dimensão, ocorre entre Bom Jesus dos Perdões e Atibaia. Deve ser considerado um compartimento ambiental estruturante em face de sua extensão e área, e também pelo avanço expressivo da ocupação de loteamentos dispersos (condomímios) às suas margens. 
Figura 7.13 - Desenho esquemático dos principais compartimentos ambientais estruturantes da paisagem - lineamento de fundos de vale.

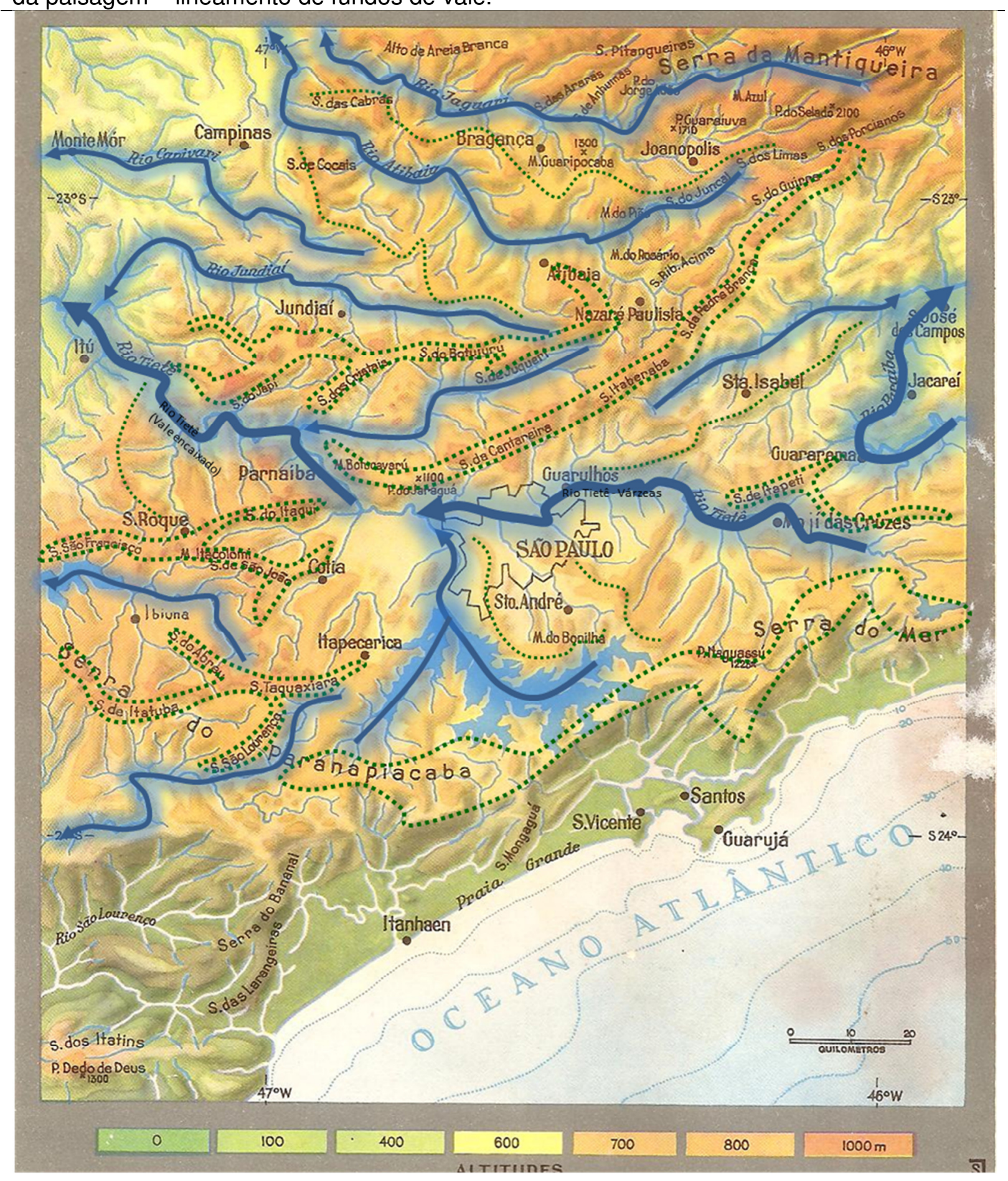

Fonte: Azevedo (1958), adaptado pelo autor.

O Rio Capivari também apresenta um percurso pequeno, comparado a outros rios da região, contando com aproximadamente $80 \mathrm{~km}$ de extensão. Destes, $70 \mathrm{~km}$ são percorridos em meio às colinas sedimentares da Depressão Periférica. 0 desnível entre o rio e seus divisores é pouco expressivo. Nasce praticamente dentro de Campinas, e antes de desaguar no Rio Tietê passa apenas por mais uma cidade 
- Monte Mór. Trata-se de um compartimento ambiental estruturante da paisagem local, que junto com as APPs de seus afluentes merecem ordenação ambiental em face de que os demais compartimentos do relevo que drena são potencialmente favoráveis aos usos urbano e rural.

Com aproximadamente $55 \mathrm{~km}$ de extensão, o Rio Juqueri drena uma área de aproximadamente $800 \mathrm{~km}^{2}$. Trata-se do coletor principal de uma importante área de nascentes, pois confinado pelas serras da Cantareira, de um lado, e do Juqueri, Pedra Vermelha e Boturuju, de outro. Hoje pode ser considerado um compartimento ambiental estruturante não só local, mas regionalmente, em face de sua posição muito próxima da metrópole e por ser um importante manancial de abastecimento para a metrópole de São Paulo. A amplitude topográfica entre divisores e fundo de vale é expressiva, o que denota a existência de setores de vertentes de alta declividade em área considerável. Abriga, também, um represamento formado pela represa Paiva Castro da Sabesp. As vertentes que drena são alvo de pressão imobiliária por ocupação de condomínios fechados de alta e média renda. Passa lateralmente pelas áreas urbanas das cidades de Mairiporã, Franco da Rocha, Caieiras, e bairros dispersos de Cajamar e Santana de Parnaíba antes de desaguar no Rio Tietê.

Já o Rio Paraíba e suas várzeas e terraços formam, também, um importante compartimento ambiental, estruturante da paisagem regional do Vale do Paraíba. Em seus $190 \mathrm{~km}$ de extensão na área abordada por este estudo, passa por 7 cidades, 5 delas lateralmente (Guararema, Caçapava, Taubaté, Tremembé e Pindamonhangaba), e 2 (Jacareí e São José dos Campos) seccionando o tecido urbano da ciadde compacta.

Müller (1969) no livro "O fato urbano na Bacia do Rio Paraíba - Estado de São Paulo", analisou notavelmente a relação que as áreas urbanas das cidades do Vale estabelecem com o Rio Paraíba. Já se tratava de um trabalho de análise de compartimentos ambientais da paisagem, embora a autora não usasse essa denominação. Traz mapas do tecido urbano de muitas cidades e identifica topograficamente os compartimentos de colinas terciárias, terraços e várzeas, e o tipo de ocupação neles reinantes e as tendências em desenvolvimento. 
Figura 7.14 - Foto e esquema topográfico que consta do livro "O Fato Urbano na Bacia do Paraíba" de Nice L. Müller. Análise de compartimentos ambientais urbanos em São José dos Campos e em várias cidades do Vale.

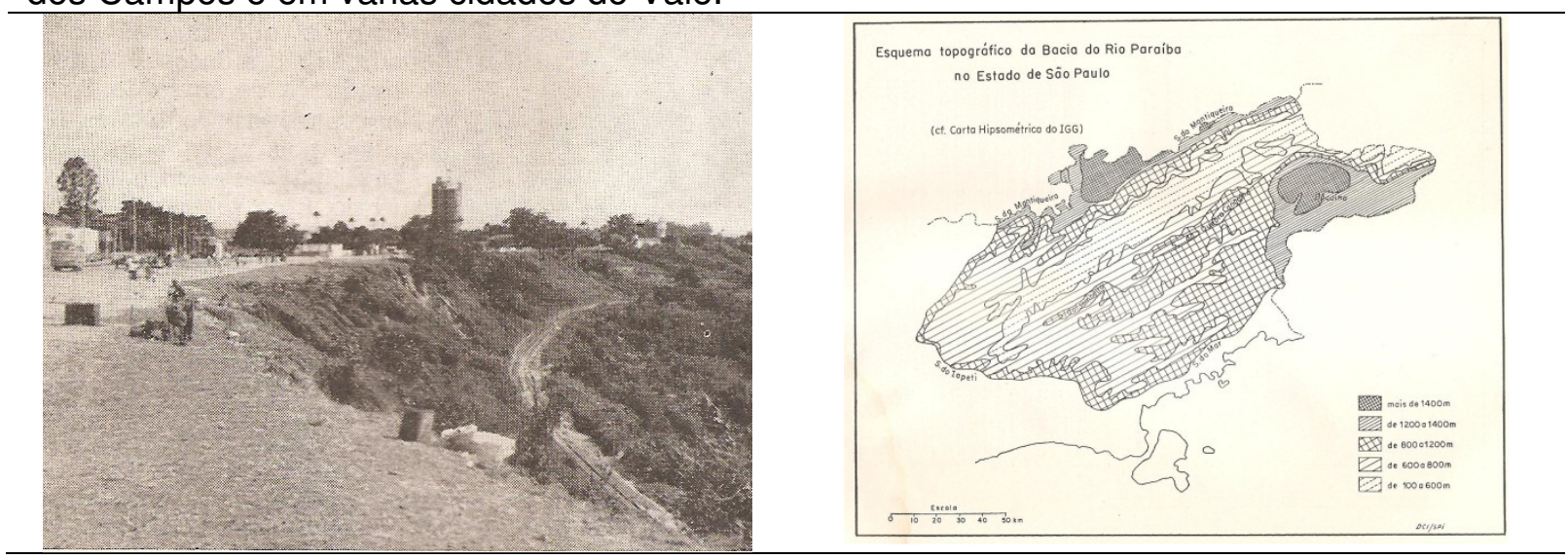

Fonte: Müller, 1969.

Alguns desses compartimentos citados já recebem alguma regulação legal. No nível estadual apenas a várzea do Embu (Embu Guaçu) teve parte do trecho do rio preservada de ocupação (128 ha), como parque estadual segundo tipologia do SNUC.

As demais áreas são reguladas por APAs - áreas de proteção ambiental que permitem uma série de tipologias de uso, e dependentes para sua real proteção de fiscalização e controle sistemático e firme do Estado, o que, sabe-se, nem sempre acontece a contento da preservação necessária, também por abranger áreas de grande povoamento e de interesses comerciais e imobiliários. Destacam-se as seguintes APAs que incluem a de regulação de fundos de vale e de várzeas, com o foco prioritário na preservação de mananciais de água potável:

$\checkmark$ APA do Banhado: com 9.100 ha, localiza-se em São José dos Campos.

$\checkmark$ APA Piracicaba / Juqueri-Mirim, ÁREA-II: com 280.000 ha; abrange os municípios de Amparo, Bragança Paulista, Campinas, Holambra, Jaguariúna, Joanópolis, Monte Alegre do Sul, Morungaba, Nazaré Paulista, Pedra Bela, Pedreira, Pinhalzinho, Piracaia, Santo Antonio da Posse, Serra Negra, Socorro, Tuiuti, Vargem Grande.

$\checkmark$ APA Sistema Cantareira:abrange os municípios de Atibaia, Bragança Paulista, Joanópolis, Mairiporã, Nazaré Paulista, Piracaia, Vargem Grande. 
$\checkmark$ APA Várzea do Tietê: com 7.400 ha; abrange Barueri, Biritiba Mirim, Carapicuíba, Guarulhos, Itaquaquecetuba, Mogi das Cruzes, Osasco, Poá, Salesópolis, Santana do Parnaíba, São Paulo, Suzano.

Mais se poderia falar sobre os compartimentos ambientais citados, sua importância, características e expressão local e regional, mas já se considera a apresentação até aqui elaborada suficiente para elucidar os propósitos de comparação entre a dispersão urbana e os compartimentos ambientais como objetivo de trazer para discussão acadêmica e profissional um instrumento metodológico de abordagem do relevo para fins de análise ambiental para 0 planejamento urbano.

O próximo tópico discorre algumas considerações sobre a fisiologia da paisagem e os indicadores que sustentam, teoricamente, a avaliação de impactos e mudanças ambientais a partir da ocupação urbana do relevo. Entendemos que esta análise deve preceder o fechamento do trabalho, a ser apresentado no último tópico quando se fará o cruzamento entre compartimentos ambientais estruturantes e dispersão urbana, como uma constatação de tendências mais ou menos satisfatórias ao equilíbrio entre processos urbanos e processos naturais.

\subsection{A Dispersão dos efeitos da urbanização nos processos naturais}

O conceito de apropriação do relevo como apropriação de uma superfície, ou seja, o por meio do uso e ocupação do solo, inclui não somente a apropriação da superfície, mas também a apropriação dos processos que nela ocorrem, e que atuam sobre essa superfície. Isto nos induz a investigar no processo de dispersão urbana como este se relaciona com a fisiologia da paisagem.

O termo "fisiologia da paisagem", conforme utilizado na Geomorfologia, se refere aos mecanismos que interagem para o funcionamento da paisagem. Esse funcionamento implica em reconhecer os processos indutores da evolução da forma da paisagem. Dá-nos uma primeira impressão de se referir apenas aos mecanismos de funcionamento da natureza. No entanto, no momento atual do processo de intervenção na paisagem acionado pelo homem, tal conceito deve ser ampliado com a incorporação dos mecanismos que configuram, tanto o metabolismo natural da 
paisagem, como também o metabolismo urbano, no sentido da interface entre os processos naturais e processos urbanos que, interagindo um sobre o outro, produzem formas e qualidades diferenciadas aos espaços humanizados.

Como categoria da análise em Geomorfologia, Ab’Sáber (1969) define a "fisiologia da paisagem" como a funcionalidade atual e global da paisagem em estudo, através do detalhamento e estudo da dinâmica climática e da hidrodinâmica dessa mesma paisagem. Ross (2000) igualmente enfatiza a importância do reconhecimento da fisiologia da paisagem para os estudos referentes às questões ambientais atuais, ao afirmar que é nesse terceiro nível proposto por Ab’Sáber "que se encaixam as pesquisas experimentais as quais, se bem conduzidas, fornecem respostas enriquecedoras para o conhecimento científico relativo às questões ambientais".

A fisiologia da paisagem deve analisar os processos em plena atividade, desde os elementos da dinâmica climática, da hidrodinâmica e das interferências introduzidas pela ação humana. Trata-se de um conteúdo de pesquisa dos mais difíceis a serem empreendidos, pois envolve a mensuração de processos em pleno desenvolvimento e sua comparação sucessiva com as mensurações anteriormente realizadas. Os indicadores assim levantados servem como modelo e como tendências, que nos oferecem a oportunidade de realizar inferências e prognoses de situações futuras. Assim empreendidas essas pesquisas e análises elas têm utilidade para o planejamento territorial e urbano.

Do encadeamento das análises sobre a fisiologia da paisagem, dois conjuntos de indicadores são relevantes para as mensurações mencionadas. Um deles se refere aos relativos à dinâmica climática. Neste campo é necessário observar os elementos os processos que dão movimento à dinâmica climática, como a precipitação (passagem da água do estado gasoso ao líquido), que é medida pelos índices de pluviosidade; a evaporação e a evapotranspiração (passagem do líquido ao gasoso), medida pela umidade relativa do ar; a radiação e a emissividade de calor pelas superfícies (transformação da radiação em calor), medida pela temperatura do ar; e pela movimentação do ar de caráter genético (massas de ar) ou local (ventos). 
O outro mensura os indicadores relativos à hidrodinâmica, que visam observar todo o movimento que a água realiza pelo sistema da paisagem, ou seja, suas atividades e seus caminhos. Inclui, nesse sentido, o estudo das águas superficiais e das águasinfiltradas no solo, em seus processos de escoamento superficial, de infiltração e de percolação no solo, e também dos locais de armazenamento e superfícies de evaporação. Devem ser incluídas também, todas as atividades impulsionadas pela ação da água, como os processos erosivos e deposicionais, bem como os processos relativos a pedogênese, como o comportamento dos solos ou do manto de alteração face a ação física e química da água, o papel da cobertura vegetal e os efeitos da ação antrópica.

Os efeitos da ação antrópica no meio urbano sobre as dinâmicas do clima, da água e da forma (morfologia do relevo) relacionam-se aos processos referentes ao metabolismo urbano e podem ser divididos em dois tipos: os que se referem ao uso da natureza como suporte e os que se referem ao seu uso como recurso. No uso como suporte tem-se os usos do solo para moradia, trabalho e lazer, fatos analisados nesse estudo sob o enfoque da dispersão de peças urbanas; e também para a circulação; além de incluir o uso de espaços para a deposição de resíduos sólidos e de efluentes. Já no uso como recurso tem-se a exploração de matérias primas para a construção civil e para a indústria (areia, argila, pedras, minerais etc.); para a produção agrícola; para a produção de energia (hidráulica, térmica) e queima de combustíveis; e, finalmente, para o abastecimento de água. Embora esses tipos de utilização da natureza se verifique em todos os quadrantes do planeta, é sobretudo nas grandes concentrações urbanas que seu uso é mais intenso e conflitivo com a dinâmica da natureza, pela sua grande demanda por espaços e de recursos necessários ao desenvolvimento do metabolismo urbano.

\subsubsection{Dispersão e apropriação do relevo: a interferência nos processos naturais}

A apropriação dos diversos tipos de compartimentos de relevo utilizados tanto na cidade compacta, como também a ser verificado na cidade dispersa, induz à interferêncianos diversos tipos de processos de funcionamento da natureza. 
A apropriação do relevo como apropriação da possibilidade de alteração da intensidade dos processos naturais a serviço do lucro ou da utilização de parcelas reduzidas da sociedade causa impacto nos processos naturais e, em decorrência, determinam problemas ambientais para toda a sociedade ou, frequentemente, para as parcelas de menor poder aquisitivo. Em locais em que essas questões ambientais se acirram, como, por exemplo, na disputa pela utilização da água, surgem as tendências a se capitalizar a natureza cobrando pelos impactos gerados, e, consequentemente, também pelos serviços ambientais prestados pela natureza.

É fato, hoje, que no Brasil e em diversos outros países a ocupação urbana tem configurado um tipo de ocupação de sítio urbano que releva um conteúdo social, diriam alguns autores, de apartamento social (Santos, 1990; Casseti 1995, p.97). Existe sim, no Brasil, uma apropriação diferenciada da superfície, e em muitos lugares ela assume um componente de classe explícito. A ocupação dos diferentes compartimentos de relevo, ou dos compartimentos ambientais que preferimos denominar ou conceituar, também pode apresentar esse componente de diferenciação de classes. Essa tendência ocorreu na cidade compacta e tende a continuar na cidade dispersa. De antemão, pode-se adiantar que o mapeamento realizado nesta pesquisa identifica claramente vetores de expansão predominantemente de alta renda e vetores de expansão predominantemente de baixa renda, como tendências de diferenciações espaciais resultantes do próprio poder de compra de cada camada da população. Flavio Villaça (1998) já havia identificado claramente esse processo como fenômeno do espaço intra-urbano, ou seja, da cidade compacta. Na dispersão urbana atual pode-se afirmar que ele continua ocorrendo, embora sob outras características.

Segundo o senso comum, e a maior parte dos dicionários, apropriar-se significatomar como propriedade, como seu; arrogar-se a posse de; apossar-se (Dicionário Aurélio, 1975). O termo apropriação do relevo, então, sugereo sentido de tomar como propriedade não somente uma superfície, mas também todos objetos e os processos que nela ocorrem.

Esse tema foi abordado em nossa dissertação de mestrado (Schutzer, 2005) e, recentemente, no livro Cidade e Meio Ambiente (2012) de nossa autoria, e já mencionado anteriormente. Entretanto, o enfoque esteve direcionado para o que 
ocorria, como apropriação do relevo, na cidade compacta. A apropriação sobre compartimentos ambientais estruturantes da paisagem do sítio urbano da metrópole, com estudo de caso em um compartimento específico do sítio urbano de São Paulo, demonstrou a correlação entre ocupação intensiva do território e do sítio urbano com os problemas ambientais da cidade. Como já mencionado na introdução, o que se pretende neste trabalho é verificar até que ponto esse processo se distribui regionalmente pela macrometrópole.

De outro lado, há que se considerar que, hoje, existem muitas normas de uso do território, e muitas restritivas a determinados tipos de ocupação. A normatização de uso do território é um processo antigo. Santos (1999) discorre sobre essa condição em 'A Natureza do Espaço". A normatização ambiental do território é um processo que praticamente se inicia com o Código das Águas na década de 1930 e posteriormente com o Código Florestal, em 1965, e atualmente em revisão. O SISNAMA - Sistema Nacional de Meio Ambiente colaborou com a identificação de alguns espaços de relevante interesse de conservação, e incluiu também espaços em áreas intensamente ocupadas pela urbanização intensiva.

O que diferencia o processo atual de ocupação urbana, do que ocorria anteriormente, não é somente um problema de escala, mas um problema de território. Trata-se de investigar se para um equilíbrio socioambientalsatisfatório dos espaços de ocupação humana é melhor espalhar essa ocupação urbana pelo território ou então concentrá-la? Esta é a questão ambiental do momento a que não se tem ainda uma resposta, uma definição. Deve-se sobrecarregar o sítio ou dispersar essa carga sobre o sistema ambiental territorial? O que fazer? O espaço regional sob o ponto de vista dos processos naturais também é regulado pela somatória de fatores locais internos nele instalados. Se os fatores de degradação da paisagem estão concentrados ou dispersos, mas possuem a mesma amplitude em área ocupada, qual será a resposta da natureza local e regional ante a modificação da intensidade dos processos naturais?

A dispersão urbana nos coloca, assim, uma outra questão que é a da dispersão das interferências nas dinâmicas naturais disseminadas pela ocupação urbana. Como na escala local da cidade compacta, essas interferências mudam os atributos locais das dinâmicas do clima e da água. Até que ponto a dispersão urbana 
pode colaborar na atenuação dessas modificações, ou a somatória dessas interferências dispersas poderão produzir o mesmo resultado que o observado na urbanização da cidade compacta?

\subsubsection{A dispersão dos efeitos na dinâmica climática da paisagem}

A importância da dinâmica climática no entendimento do funcionamento da paisagem urbana está relacionada, sobretudo, ao grau de alteração dos atributos climáticos impulsionados pela urbanização, que acabam por configurar situações de desconforto ambiental e riscos à vida urbana. Assim, na análise da urbanização concentrada na cidade compacta o cotejo entre situações climáticas urbanas excessivamente alteradas e desconfortáveis em relação ao ambiente suburbano ou rural próximo (ou mesmo em relação a ambientes urbanos mais saudáveis) era um importante mecanismo de análise da dinâmica climática no meio urbano.

A influência urbana nas condições climáticas responde a variações de caráter local, ou até sub-regional nas grandes áreas metropolitanas (Monteiro, 1976), mas que não chegam a interferir nas condições gerais da movimentação atmosférica de caráter genético e regional, e também nos controles climáticos naturais como 0 oceano, relevo, altitude, declividade, orientação e ventos. O meio urbano introduz novos controles climáticos à dinâmica natural do clima, como: os diversos tipos de uso do solo; o fluxo de veículos; a densidade populacional; a densidade de edificações; a orientação e a altura das edificações, as áreas verdes e os parques; as represas e a emissão de poluentes etc. (Tarifa, 2001, p. 48). Tais controles climáticos urbanos condicionam alterações, muitas vezes significativas, nos principais atributos do clima, sendo esses os sensores da qualidade ambiental urbana dentro dos processos da dinâmica climática. Esses processos que evidenciam o funcionamento da paisagem relacionado à interseção superfícieatmosfera são controlados pelos seguintes atributos do clima, conforme organizados por Schutzer (2012), exposto no quadro 7.1.

Mais do que a classificação climática nos interessa o conhecimento, em detalhe, de algumas dessas características descritas no quadro, pois revelam a 
movimentação da natureza na dinâmica climática, ou melhor dizendo, revelam processos da natureza.

A oferta natural de água e a disponibilidade hídrica possível do sistema ambiental de uma região ou localidade são determinados pelos índices pluviométricos anuais em sua distribuição mensal e diária. Eles permanecem estáveis ao longo do tempo, com alterações anuais e sazonais que não tendem a alterar radicalmente esse quadro de oferta dos recursos naturais vinculados a esse elemento.

Quadro 7.1: Indicadores de análise e atributos da dinâmica climática.

\begin{tabular}{|c|c|}
\hline DINÂMICA - MOVIMENTOS & ATRIBUTOS DO CLIMA \\
\hline precipitação & pluviosidade \\
\hline evaporação e evapotranspiração & umidade relativa do ar \\
\hline radiação e emissividade de calor & temperatura do ar e da superfície \\
\hline movimentação do ar & Ventos e massas de ar (frentes) \\
\hline $\begin{array}{c}\text { energia dissipada pelas atividades } \\
\text { humanas }\end{array}$ & Qualidade do ar(poluição) e temperatura \\
\hline
\end{tabular}

Fonte: Schutzer, 2012.

Portanto, esse é um importante instrumental de planejamento, sobretudo no momento em que o mundo caminha para a produção de escassez deste recurso, por fatores como o aumento do consumo e da poluição. Nas condições atuais de exploração da natureza, desmatamento, impermeabilização do solo e consumo de água tem acelerado a perda de água do sistema da paisagem de uma localidade e de uma região, através de um escoamento superficial cada vez mais veloz. Dessa forma, a água atinge com grande rapidez os canais de drenagem e sai do sistema ambiental local através dos rios. Este fato está muito presente na cidade compacta e se reflete na região circunvizinha. É certo que fatores do mundo rural como o desmatamento e determinados tipo de lavoura em encostas de maior declividade também contribuem para esse fato, mas a contribuição da urbanização, incluindo mais recentemente a profusão dos loteamentos dispersos, é ainda muito mais significativa. É correto também considerar que o represamento artificial da rede de drenagem local contribui para a amenização dessa perda de água no sistema e a sua retenção na paisagem local e regional por um tempo maior. Mas é fato que aumenta exponencialmente a perda por evaporação. 
Como a disponibilidade de água e umidade no sistema ambiental de uma região é garantida por meio do armazenamento da água da chuva no solo, na vegetação densa (sobretudo arbórea), no subsolo (manutenção do lençol freático a pouca profundidade) e na superfície, através de lagos, represas, espelhos d'água e outros reservatórios intra-urbanos, a forma da ocupação e do uso do solo urbano se transforma na questão chave da análise ambiental urbana. Assim, considerar as tipologias das peças urbanas em seu conteúdo interno quanto às respostas relativas à ocorrência dos processos naturais é tão importante quanto considerar a sua dispersão como estratégia para a atenuação dos efeitos climáticos em relação à disponibilidade de água no sistema de paisagem local e regional.

A evaporação e a evapotranspiração dependem da disponibilidade de água no sistema ambiental da localidade, ou seja, do armazenamento de água no solo, no subsolo, na vegetação e, principalmente, na superfície, através de represas, lagos, rios, espelhos d'água ou outros tipos de reservatórios. Sua ocorrência intra-urbana em escala considerável é importante fator de refrigeração climática pela sua significativa participação no aumento da umidade do ar urbano. Nas grandes áreas metropolitanas a umidade do ar diminui consideravelmente no período da tarde, devido ao aumento da temperatura do ar e da poluição nas áreas centrais, fenômeno que é conhecido como "ilhas de calor". Os índices de umidade relativa do ar decaem para situações desconfortáveis, típicas de clima deserto, mesmo em áreas de clima úmido (Lombardo, 1985). Assim, a vegetação arbórea densa é muito importante no combate aos efeitos da ilha de calor, pois transfere continuamente umidade ao ar, gerando uma amenização da temperatura pelo sombreamento que impõe ao solo.

Já a emissividade de calor está relacionada com a radiação solar, assim dependendo da localização geográfica do sítio em termos de latitude e altitude. Em contato com a superfície, a radiação se transforma em calor, que é emitido à atmosfera, interferindo no clima. Portanto, ela varia também de acordo com o tipo de superfície, ou seja, com a forma de uso e de ocupação do solo. A emissividade é consideravelmente maior nas superfícies construídas (asfalto e áreas edificadas) e menor nas áreas vegetadas e superfícies líquidas. As áreas de intensa verticalização também apresentam índices menores que as demais áreas edificadas 
devido ao sombreamento que elas produzem sobre o solo e sobre os próprios edifícios e construções. Laurie (1983) e Mascaró (2002) apresentam dados sobre o desempenho térmico de recintos urbanos que ilustram as diferenças significativas entre as superfícies tanto sob sol, como à sombra. Tarifa e Armani (2001) constataram diferenças significativas no clima e, principalmente, na temperatura, entre bairros nobres e populares de baixa renda em São Paulo, onde os fatores tamanho do lote, densidade populacional e construtiva, e tamanho das vias imprimem diferenças marcantes na paisagem, sobretudo pela possibilidade de permeabilidade do solo e arborização existentes nos bairros nobres. As áreas industriais e as vias de tráfego intensas, como as marginais dos rios Tietê e Pinheiros, também não apresentavam situações climáticas satisfatórias quanto à temperatura e poluição, enquanto os bairros verdes e áreas verticalizadas se apresentavam em situações de aquecimento mais lentas comparativamente às demais áreas.

A emissividade de calor também está relacionada à concentração das atividades urbanas, que consomem energia e liberam calor e poluentes através da queima de combustíveis de veículos e geradores de energia, como também de maquinários elétricos, processos industriais, sistemas de aquecimento central e os resíduos orgânicos das aglomerações humanas. Por isso as áreas centrais, as áreas industriais e as áreas de grande circulação de veículos (sobretudo pesados, como caminhões e ônibus) tendem a apresentar situações de temperatura e poluição mais elevadas, criando climas locais e microclimas mais desconfortáveis à população. (Azevedo, 2001).

Isto demonstra a importância e influência crescentes das atividades urbanas na derivação do clima. A forma como as atividades humanas se distribui e/ou se concentra pelo espaço da cidade, por meio dos usos residencial, industrial, comercial e de serviços, do sistema de transporte e da disposição dos resíduos, tem um forte referencial e impacto urbanístico e ambiental, devendo ser considerada no jogo de situações da ocupação do território. Em Os Climas na Cidade de São Paulo, Tarifa e Azevedo (2001), juntamente com outros autores, abordam de maneira mais integrada a relação espacial estabelecida entre clima e sociedade no âmbito urbano, 
indicando a forma como as relações processuais entre os dois ambientes (o urbano e o natural) devem ser conduzidas.

A gênese dos ventos que ocorrem numa localidade está associada, primeiramente, à circulação geral da atmosfera, que é representada pela dinâmica das massas de ar que atuam sobre o território e trazem características adquiridas (atributos climáticos) em escala macrorregional. No caso de São Paulo, e de toda a região centro-sul do país, incluem praticamente todo o continente sul-americano e o Atlântico Sul. Os fatores locais que podem influenciar a circulação de ventos gerados por essa dinâmica são as barreiras físicas naturais (relevo) e as artificiais constituídas pela verticalização e pelas atividades urbanas. A rugosidade das superfícies urbanizadas ao mesmo tempo em que impõe uma diminuição da velocidade dos ventos, em escala microclimática cria situações diferenciadas de calmaria e de formação de canyons (verticalização), que tendem a aumentar a velocidade dos ventos de maneira muitas vezes insatisfatória para os espaços livres urbanos (Spirn, 1995; Hough, 1998; Laurie, 1983). Segundo Monteiro (1976), a ilha de calor, gerada pela urbanização extensiva, "é suficiente para desencadear uma ventilação urbana, que se alterna com aquela local do quadro geoecológico e aquela mais ampla da circulação regional”.

Nas áreas quentes do globo - no mundo tropical, e mesmo nos verões quentes das latitudes médias, a ventilação é vital, ao proporcionar, além da refrigeração do ambiente, a dispersão dos poluentes. Na região metropolitana de São Paulo, o comportamento dos fluxos de vento "determina situações favoráveis ou desfavoráveis à formação da ilha de calor e ao acúmulo de poluentes na mancha urbana" (López, 2001). Lombardo (1985) constatou essa influência, juntamente com as do relevo (Espigão Central, Serra da Cantareira), na configuração do formato das ilhas de calor no período da tarde. O sítio urbano da cidade de São Paulo, seja pela sua característica geomorfológica, seja pelas temperaturas elevadas da área central, apresenta uma força de convergência dos ventos para essa área central que agrava as condições de poluição nesse espaço da cidade, sobretudo em virtude dos ventos oriundos da área industrial do $\mathrm{ABC}$, através da calha do rio Tamanduateí.

As condições climáticas de uma área urbana extensa e densamente construída são muito distintas das que ocorrem nos espaços rurais e suburbanos 
circundantes, podendo apresentar diferenças significativas de temperatura, umidade do ar, velocidade do vento e pureza do ar (Lombardo, 1985). Como exposto, o ambiente construído, em suas nuances de volume, adensamento, tipologia e espaços livres, implica um mosaico de situações de climas locais e microclimas que contém relação com a emissividade de calor absorvido da radiação solar; com as transferências de umidade através dos processos de evaporação, evapotranspiração e pluviosidade; e, por fim, com as interferências na circulação do ar regional ou local, que podem criar barreiras ou canalizações artificiais.

Vários estudos de climatologia urbana realizados em diversas cidades dos EUA e Europa demonstraram a íntima relação entre uso do solo e a elevação das temperaturas internas da cidade. Lombardo, M. (1985), em seu estudo "Ilhas de Calor nas Metrópoles", faz uma resenha sobre essas pesquisas onde fica realçada a influência do tipo de uso do solo na elevação da temperatura, e a diferenciação das condições microclimáticas entre bairros com diferentes usos e padrões de ocupação. $\mathrm{O}$ aquecimento produzido pelas atividades humanas, atividades estas sempre mais concentradas nas áreas centrais da mancha urbana, e a emissividade de calor diferenciada entre os objetos urbanos (casas, edifícios, ruas, estacionamentos, áreas industriais, espaços livres, represas, parques etc.) que é transferida para a atmosfera, proporcionam a formação de bolhas de ar aquecido e poluído em forma de ilhas sobre a região central das cidades. A elevação da temperatura na área central proporciona, em algumas situações, uma movimentação do ar em direção a essa região aquecida, carreando e concentrando poluentes. Com isto reduz-se drasticamente os índices de umidade relativa do ar, proporcionando situação de extremo desconforto térmico, de má qualidade do ar e de riscos à saúde. Essa situação, nas regiões tropicais, como é o caso de São Paulo, é mais significativa no período entre catorze e dezessete horas, conforme constatou Lombardo (1985). A amplitude térmica entre essas áreas centrais e as áreas periféricas ou rurais pode chegar a $10^{\circ} \mathrm{C}$, evidenciando o elevado ganho térmico em situações espaciais tão próximas.

Hoje, em face à dispersão urbana o que se pergunta é até que ponto essas anomalias entre a cidade compacta e as áreas periurbanas e rurais circunvizinhas persistirão com essa intensidade? Se a dispersão urbana, apoiada praticamente nas 
mesmas tipologias de desenho urbano e de ocupação do solo da cidade compacta, conforme se verificou no capítulo 5, não estaria apenas dispersando os efeitos de alterações climáticas para todo o território?

É certo que se tira uma vantagem dessa não concentração das peças urbanas, pois favorece a formação de um mosaico com usos rurais ou de áreas de preservação mais permeáveis e que proporcionam trocas de menos impactantes em relação à emissividade de calor, evapotranspiração e evaporação das superfícies. Mas há que se considerar também a necessidade de mudanças consistentes nas tipologias das peças urbanas que se dispersam, pois poderá ocorrer que, na somatória do conjunto do território os efeitos benéficos de uma não compactação urbana se anulem.

No mesmo sentido, há que se considerar que em muitas situações de dispersam observadas existe a tendência de acontecer uma nova compactação da mancha urbana, como já ocorreu em vários momentos da história da cidade de São Paulo e da metrópole.

\subsubsection{A dispersão dos efeitos na hidrodinâmica da paisagem}

O caminho que a água percorre, sobre e sob a superfície do solo, e que desencadeia os processos geológicos, geomorfológicos e ecológicos que animam a paisagem, é um dos principais elementos a serem investigados numa análise ambiental urbana e no planejamento territorial de uma cidade. Essa investigação pode ser dividida em duas frentes de análise: a primeira se refere aos movimentos da água no momento em que ela atinge o solo, ou seja, os caminhos que ela percorre. Estes movimentos podem ser mensurados através da análise do escoamento superficial; da infiltração e da percolação da água no solo; e do armazenamento da água a superfície ou no subsolo (lençol freático). A segunda frente deve se preocupar com os processos que ela desencadeia na superfície e no subsolo e são mensurados através da erosão do solo, da deposição ou sedimentação de materiais carreados pela água, da possibilidade de pedogênese e da filtragem da água.

Todos esses movimentos e processos que colaboram na sustentação do ambiente natural continuam a ocorrer no ambiente urbano, embora sensivelmente 
alterados. No meio urbano o encadeamento mais impactante em climas úmidos se refere ao ciclo do escoamento superficial, que envolve a erosão do solo, o carreamento de sedimentos e a deposição desse material nas baixadas, processo que estimula a ocorrência de situações críticas como enchentes, deslizamentos e assoreamento em geral, com suas consequências sociais e econômicas bem conhecidas. Os demais caminhos e processos são mais favoráveis ao ambiente e à economia urbana, mas que, devido à forma de utilização e apropriação do solo pela cidade, também são sensivelmente alterados.

A infiltração-percolação que reabastece o lençol freático (armazenamento no subsolo), que filtra a água, que retarda sua chegada aos canais de drenagem e proporciona vida ao solo e à vegetação, tem sua ocorrência diminuída com a impermeabilização do solo. Já o armazenamento de água fica prejudicado pela falta de espaços na superfície, devido à ocupação indiscriminada das várzeas, e no subsolo pela diminuição da infiltração; e também pela poluição, pois o abastecimento dos reservatórios de superfície fica restrito à água advinda do escoamento superficial que, por sua vez, carreia uma importante carga de resíduos das atividades urbanas das calçadas e ruas (poeiras diversas, resíduos de pneus etc.).

Portanto, a forma de ocupação urbana, ou seja, a forma do desenho urbano dos bairros residenciais, comerciais e industriais, e da relação destes com o relevo, é que determina o comportamento que irão assumir estes movimentos da água acima descritos. Assim, não será somente a compactação ou não da mancha urbana, mas também a peça urbana em si, ou seja, em seu desenho interno, que apresentam implicações ambientais importantes neste relacionamento da cidade com a dinâmica da água.

A dinâmica da água sobre a superfície tem implicações com todos os compartimentos de relevo, sejam eles divisores de água, vertentes ou planícies aluviais e várzeas. Assim, todos eles devem ser objeto de regulação de indicadores de ocupação urbana, regulação essa similar à que já ocorre por meio dos índices de taxa de ocupação do lote e taxa de permeabilidade. Entretanto, essas taxas devem ser reguladas em sua intensidade segundo as características da forma de relevo que 
a cidade ocupa, ou seja, das características dos compartimentos de relevo existentes, e não indiscriminadamente igual sobre toda a superfície.

No processo de dispersão urbana esses efeitos positivos ou negativos da relação entre tecido urbano e dinâmica da água tendem a se dispersar pelo antigo ambiente rural, assumindo a ocupação urbana, certamente, um caráter mais poroso e permeável. Isso pode sugerir um fator favorável à disseminação da dispersão. Entretanto, há que se considerar o outro lado da moeda que é o da intensificação do escoamento superficial, caso as peças urbanas dispersas impermeáveis da cidade compacta continue sendo o modelo de ocupação interna dos loteamentos.

\section{3. $O$ ideal de vida saudável próxima ao campo: o marketing verde imobiliário e a dispersão dos condomínios fechados.}

No processo de dispersão urbana para as camadas de média e alta renda está embutido um ideal de contato com a natureza, viver em meio ao verde, que pode ser considerado como um dos atributos importantes de um marketing verde imobiliário. Uma pequena pesquisa exploratória executada entre 2003 e 2004, mesmo que em relação a empreendimentos imobiliários dentro da cidade compacta, sobre os lançamentos de empreendimentos verticalizados em São Paulo35, verificou que, em 2003, de um total de 100 lançamentos, 45 \% apresentavam algum tipo de apelo verde como mais um motivo de comercialização para a satisfação do cliente. Destacava de alguma maneira uma visão de uma cidade verde, mais saudável, bem arborizada e pouco verticalizada.

Dos empreendimentos analisados, $29 \%$ apareciam sempre longe da verticalização circundante, em meio a um padrão de urbanização baixo e arborizado, apresentando vistas amplas, num ambiente claro e ensolarado. Os empreendimentos que citavam a vista como um destaque importante (9\%) apresentavam uma foto real do local ou uma fotomontagem da cidade com a arborização ou o espaço verde como um elemento de qualidade de vida. Outros $7 \%$

\footnotetext{
${ }^{35}$ Meses de Fevereiro de 2003 e Outubro de 2004Fonte: Guia Qual Imóvel - Regiões norte, sul e oeste - Editora Abril - Edições de Fevereiro de 2003 e Outubro de 2004.
} 
deram destaque ao verde através da arborização viária, ilustrando o folheto com uma foto de uma rua tranquila e bem arborizada.

Em outubro de 2004, estavam em comercialização 158 empreendimentos, sendo que, destes, 59 (37\%) apresentavam algum tipo de apelo verde. Um total de 46 empreendimentos (29\%) apresentavam fotomontagem ou ilustração de um edifício isolado numa paisagem com construções baixas e muito verde (arborização) como moldura; 8 (5\%) fizeram referência a uma rua tranquila e arborizada e 5 (3\%) deram destaque para algum tipo de vista arborizada importante e bela. O mote principal é sempre a ideia de um bairro-jardim, bem arborizado, com vistas amplas, apartamento ensolarado e claro, no entanto, não se tem certeza de quanto tempo estas condições serão mantidas na realidade.

Tabela 7.1 - Lançamentos imobiliários e a exploração da paisagem natural

\begin{tabular}{cccccc}
\hline Mês/Ano & Lançamentos & $\begin{array}{c}\text { Marketing } \\
\text { verde }\end{array}$ & $\begin{array}{c}\text { Apelo } \\
\text { Vistas }\end{array}$ & $\begin{array}{c}\text { Apelo } \\
\text { Verde }\end{array}$ & $\begin{array}{c}\text { Apelo } \\
\text { Edifício } \\
\text { isolado } \\
\text { Bairro-jardim }\end{array}$ \\
\hline FEVEREIRO/2003 & 100 & $45 \%$ & $9 \%$ & $7 \%$ & $29 \%$ \\
\hline OUTUBRO/2004 & 158 & $37 \%$ & $3 \%$ & $5 \%$ & $29 \%$
\end{tabular}

Fonte: Guia Qual Imóvel - Regiões norte, sul e oeste - Editora Abril - Edições de Fevereiro de 2003 e Outubro de 2004.

As vistas mais destacadas foram as do Parque Ibirapuera, da Serra da Cantareira, do Pico do Jaraguá; dos bairros-jardim Chácara Flora, Morumbi, Cidade Jardim e Alto da Boa Vista; do Museu do Ipiranga e Parque da Independência. Outros parques como os da Água Branca (Pq. Fernando Costa), Villa Lobos, Bosques do Tamboré também foram citados em menor escala, inclusive a Hípica de Santo Amaro - um clube privado.

O restante dos lançamentos, os que não usavam o apelo verde da paisagem, somente destacavam o paisagismo de sua área interna, ou nem isso, dando ênfase estritamente aos valores estéticos arquitetônicos e aos aspectos funcionais internos.Folhetos imobiliários de outros empreendimentos, que não constavam do Guia do Imóvel, coletados de forma avulsa no mesmo período, e que apresentavam este apelo verde, citavam ou mostravam, também com frequência, o Parque do Ibirapuera como modelo da qualidade ambiental de sua miragem. Outros destacaram os mesmos espaços já citados como os Parques da Água Branca e 
Independência, e ainda o Parque do Povo, o Parque da Aclimação e os mesmos bairros-jardins já citados anteriormente.

Dentre as frases pitorescas encontradas nos folhetos promocionais que denotam esse ideário verde e que tem na dispersão de condomínios fechados um motivo similar, podemos destacar as seguintes:

$\checkmark$ "Tenha o Ibirapuera como horizonte todos os dias..."

$\checkmark$ "Sua vista privilegiada e definitiva será uma área verde de $120.000 \mathrm{~m} 2$, com muito ar puro e tranquilidade...", referindo-se ao Parque da Água Branca.

$\checkmark$ "Venha morar em frente a dois parques do lbirapuera...", referindo-se aos Bosques do Tamboré, em Alphaville.

$\checkmark$ "Venha morar dentro de um bosque a 5 minutos do Shopping Villa Lobos..."

$\checkmark$ "230.000 m2 de muito verde e 4,5\% de área construída..."

$\checkmark$ "Última grande área verde da cidade..."

$\checkmark$ "Debruçado sobre um parque...", referindo-se ao parque do Povo, na Vila Olímpia.

$\checkmark$ "O verde de nossas matas dá o tom...."

$\checkmark$ "Uma ampla reserva de Mata Atlântica nativa."

$\checkmark$ "Por fora, as mais belas árvores ..."

$\checkmark$ "Vista permanente para Z1..."

$\checkmark$ “Um verdadeiro oásis no cenário paulistano".

$\checkmark$ "Toda a sofisticação do estilo neoclássico em frente ao Parque da Água Branca"...

$\checkmark$ "Localizado no último espaço disponível em frente ao Parque da Água Branca..."

$\checkmark$ "Viva ao lado do Parque Burle Marx...."

$\checkmark$ "More a apenas 300 metros do Parque da Aclimação..."

$\checkmark$ "Venha morar entre um bosque e uma praça..."

$\checkmark$ "Venha morar ao lado do Museu do Ipiranga...", referindo-se ao Parque da Independência.

Estas frases refletem claramente o uso intencional da natureza e das paisagens verdes da cidade como um importante apelo para a concretização de 
negócios e renda diferencial. Este apelo se dá sob enfoques distintos. Um deles se dirige auma paisagem verde real, existente, perene (ou com prazo de validade de sua existência). Outras vezes o apelo se fixa sobre uma miragem, uma paisagem verde quase fictícia, pois distante ou melhorada através de fotomontagem. Em muitos casos, a expansão da verticalização sobre antigos bairros horizontais com alto índice de cobertura vegetal se dá de maneira predatória em função da própria natureza do estilo pasteurizado que o paisagismo recente tem desenhado os espaços livres internos e externos. As árvores antigas, pouco a pouco, vão cedendo lugar ao edifício e aos seus novos usos. O privilégio dado às espécies mais atrativas visualmente como as palmeiras e alguns pinheiros e a pouca arborização das calçadas e do recuo de solo livre obrigatório dentro do terreno36, vão transformando a paisagem arborizada do antigo bairro, numa outra, bem empobrecida.

Essa situação pode ser transposta para a análise das tipologias de condomínios fechados dispersos das camadas de média e alta renda, pois o que o mercado imobiliário vende é um modelo de contato com a natureza que só se realiza na paisagem circundante, e não dentro do condomínio, pois o seu desenho imita os modelos de uso do solo urbano da cidade compacta.

Assim, pode-se afirmar que o marketing verde imobiliário vende uma paisagem que ele não ajuda a construir, nem mesmo em seu espaço de ocupação (área interna), ou seja, procura vender uma coisa que ele mesmo nega quando o empreendimento se concretiza.

\footnotetext{
${ }^{36}$ Que se transformam em estacionamentos, entrada de veículos, portaria, playground, etc.
} 


\section{PARTE III}

\section{A DISPERSÃO URBANA NOS COMPARTIMENTOS AMBIENTAIS ESTRUTURANTES DA PAISAGEM MACROMETROPOLITANA}

Neste capítulo será verificado como ocorre a dispersão urbana na macrometrópole de São Paulo em sua relação com os compartimentos ambientais estruturantes da paisagem, conforme delineados no capítulo anterior. Essa análise abordará separadamente as formas de relação com cada tipo de compartimento ambiental estruturante identificado. Os compartimentos indutores de processos - os divisores de água -, e os compartimentos receptores - os fundos de vale e várzeas. Como se tentou mostrar até aqui, estes compartimentos são os que mais possuem interface com os processos das dinâmicas do clima e da água nesta paisagem. Portanto, parece ser lógico afirmar que, para a atenuação dos impactos ambientais da paisagem esses compartimentos deveriam ser objeto de uma regulação urbanoambiental mais diretiva e incisiva ante os processos desenvolvidos pela lógica do mercado imobiliário e da permissividade das regras urbanísticas de cada municipalidade.

Assim, inicialmente este capítulo irá destacar quais compartimentos ambientais estruturantes estão sofrendo os impactos da dispersão urbana. Posteriormente, serão observados casos específicos e emblemáticos dessa ocupação, relacionando-os às três hipóteses do trabalho:

1. Avaliar até que ponto essa ocupação dispersa sobre o compartimento analisado não passa de uma etapa de uma nova compactação futura da mancha, ou de uma etapa da ocupação total do compartimento.

2. Avaliar a ocupação em si de setores destes compartimentos. Se ocupam topos ou encostas, anfiteatros de nascentes, terraços ou várzeas, área ocupada do compartimento.

3. Avaliar a qualidade ambiental do desenho das peças urbanas que se dispersam sobre esses compartimentos, ou seja, a análise de sua tipologia, 
como ela se relaciona ambientalmente com esse relevo e com os processos naturais que nele ocorrem.

Devemos alertar o leitor, de antemão, que parte dessas análises terão uma boa dose de inferências sobre possíveis tendências que vêm se apresentando a partir da percepção da evolução recente do processo de expansão urbana nos municípios da macrometrópole, especialmente nas regiões metropolitanas de São Paulo e de Campinas. Essas inferências podem indicar caminhos para pesquisas exploratórias mais aprofundadas sobre o tema geral, ou sobre a especificidade que ocorre em cada compartimento.

Figura 8.1 - Eixos estruturantes dos processos naturais na Macrometrópole de São Paulo.

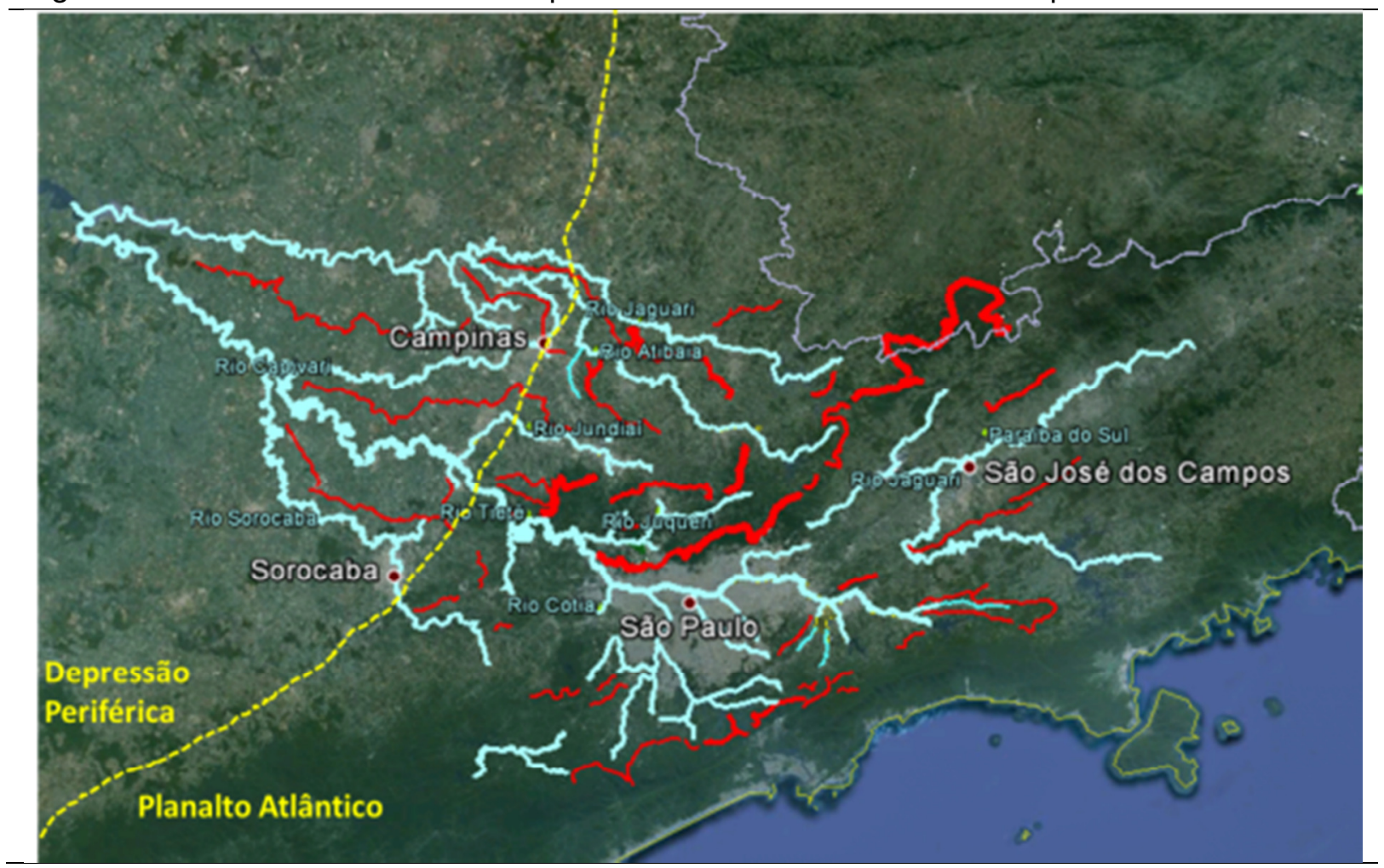

Fonte: imagem e recursos gráficos do Google Earth, 2010. Informações acrescentadas pelo autor.

\subsection{A dispersão urbana nos compartimentos serranos}

A dispersão urbana nos compartimentos serranos é bem expressiva e ocorre predominantemente por meio de condomínios e loteamentos de média-alta e alta renda. Ela é mais intensa nas serranias próximas a São Paulo e, sobretudo, nos vetores do eixo Anhanguera-Bandeirantes, Fernão Dias e Castelo Branco. Mas 
também ocorre nas serranias ou divisores de água importantes da região de Jundiaí, Campinas e São Roque.

As peças urbanas dispersas, na região da macrometrópole, que ocupam os divisores de água e as regiões serranas se estendem por todos os setores destes compartimentos, tanto nos topos, como na alta e na baixa vertente. Alguns loteamentos se estendem pelos anfiteatros de nascentes da alta vertente, configurando, assim, ocupações altamente impactantes ao ambiente, mesmo que apresentem baixa densidade e lotes grandes.

Os trechos de serras ocupados por loteamentos de baixa renda ocorrem somente nas proximidades das rodovias, enquanto os de alta renda se estendem por distâncias muito maiores.

As tipologias dos loteamentos de alta renda - os condomínios fechados variam bastante, desde aqueles que se caracterizam como chácaras de grandes lotes, como os que se assemelham aos condomínios da cidade compacta, com lotes medianos e intensamente construídos. Existem variações de permeabilidade do solo e de relação entre áreas construídas e livres, que se relacionam a essas formas de ocupação, bastante intensas.

Portanto, verificam-se situações desde altamente impactantes como medianamente impactantes. Esses impactos se caracterizam pelo desmatamento que se verifica nestes setores de encostas frágeis, pois de alta declividade; pelo aumento da impermeabilização do solo; do conseqüente aumento do escoamento superficial concentrado nas vertentes e dos processos erosivos. Dependendo da intensidade do desmatamento e da densidade da ocupação pode ocorrer maior ou menor redução do nível do lençol freático e de cota da nascente. Disto decorre indícios de perda de umidade e de reservação de água no sistema ambiental da macrometrópole por um tempo mais prolongado.

\subsubsection{O alinhamento da Serra da Cantareira (Divisor Tietê-Juqueri)}

O principal compartimento ambiental estruturante constituído pelas serras, objeto da maior ocupação pela dispersão urbana, é o alinhamento da Serra da 
Cantareira. Este se estende por aproximadamente $90 \mathrm{~km}$ desde os morros da Vacanga e Botucavarú, situados na região de Alphaville, em Barueri e Santana do Parnaíba; passa pelo conjunto do Morro do Jaraguá, em São Paulo; pela Serra da Cantareira, divisa de São Paulo com Mairiporã e Caieiras, e segue na divisa de Guarulhos com Mairiporã. Após, muda de nome para Serra do Itaberá, entre Arujá e Nazaré Paulista; e depois para Serra da Pedra Branca, entre Nazaré Paulista e Igaratá. A altitude média fica em torno de 1.000-1.100m (Cantareira, Jaraguá). A Serra do Itaberá apresenta as maiores elevações, em torno de $1.300 \mathrm{~m}$, enquanto a Serra de Pedra Branca se situa em torno de 1.000 metros. Na região de Alphaville, este alinhamento descrece em altitude até se desfazer nas proximidades da confluência do Rio Juqueri com o Rio Tietê. Neste último trecho são os morros do Botucavarú e do Vacanga que se impõem como divisores com cotas entre 800 e 900 metros.

A Figura 8.2 mostra este divisor de águas serrano dos rios Tietê e Juqueri em relação à mancha urbana metropolitana. Ele é cortado mais intensamente pela ocupação urbana na região de Caieiras, Franco da Rocha e Francisco Morato, justamente onde o divisor apresenta um colo, uma redução de altitude de seu topo, que coincide com o setor em que os granitos estão entremeados pelos filitos, rochas mais tenras que originaram relevo mais desgastado pela erosão diferencial. Enquanto o alinhamento de topos da Serra da Cantareira na divisa São PauloMairiporã se situa em torno $1000 \pm 50$ metros, nessa região, que coincide com a passagem das rodovias Bandeirantes e Anhanguera, bem como da ferrovia SantosJundiaí, o divisor desce para cotas de $850 \pm 50$ metros. Este é um fato que facilitou a passagem da infraestrutura de circulação e em decorrência da ocupação urbana e do seu adensamento.

Para da dispersão urbana neste compartimento ambiental estruturante iremos subdividi-lo em três setores distintos:

1. O setor oeste - região entre a Via Anhanguera e Alphaville - que abrange o Morro do Jaraguá, Morro do Botucaravú e Morro do Vacanga;

2. O setor central, correspondendo à Serra da Cantareira, entre a Via Anhanguera e a Estrada Guarulhos-Nazaré (SP 036);

3. O setor leste, correspondendo às serras do Itaberá e de Pedra Branca, 
Figura 8.2 - Alinhamento do divisor de águas do Tietê-Juqueri, Pico do Jaraguá, Serra da Cantareira e Serra do Itaberaba.

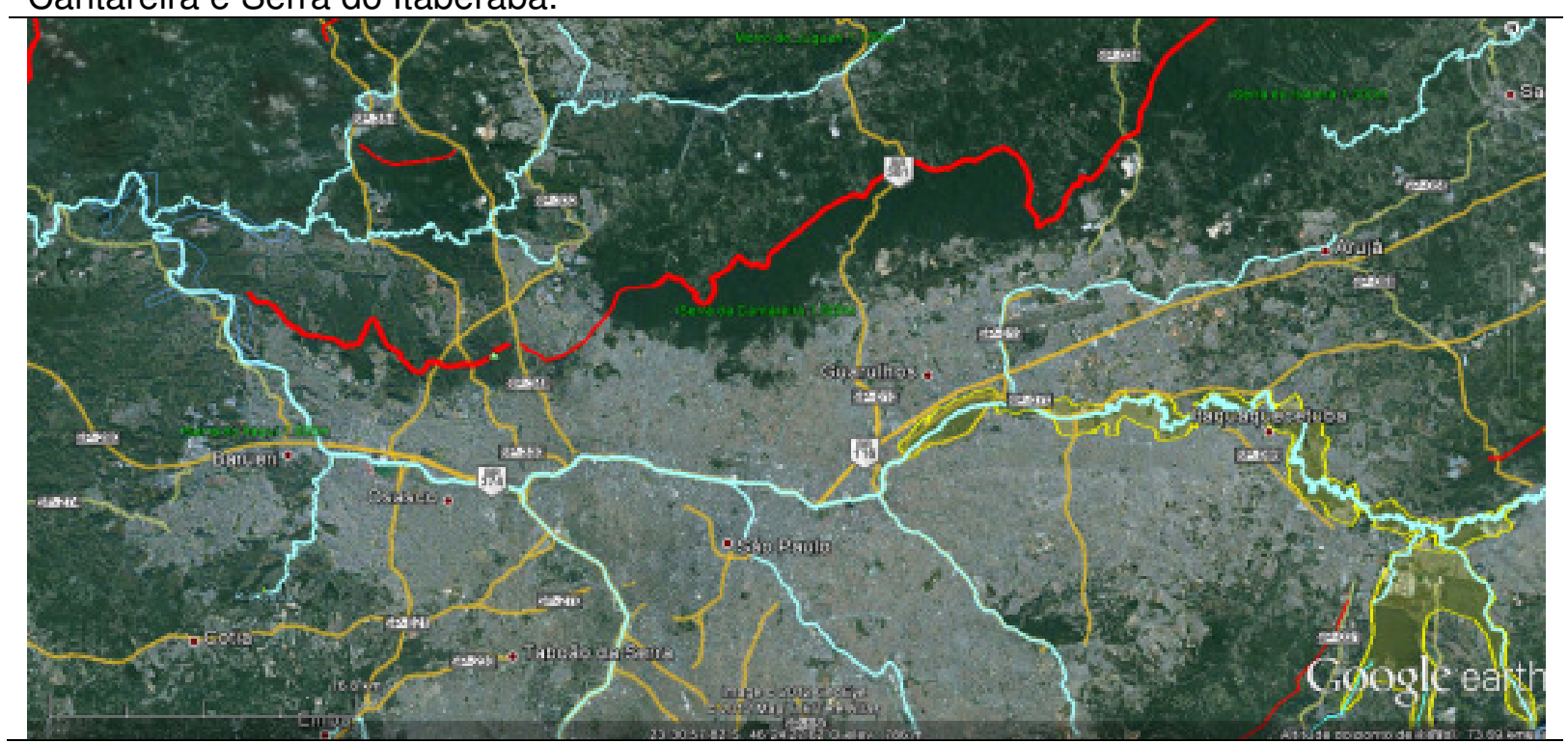

Fonte: imagem (20/07/2011) e recursos gráficos do Google Earth. Informações acrescentadas pelo autor.

No setor oeste, como se pode verificar no mapa da Figura 8.3, é possível considerar dez peças urbanas que se dispersam e ocupam os setores de topo e encostas dos morros do Vacanga e Botucavarú. Destas, oito correspondem a condomínios fechados de alto padrão, cuja expansão decorre dos negócios imobiliários atrelados ao bairro de Alphaville. Alguns apresentam contigüidade à antiga ocupação inicial de Alphaville, caso do Alpha 10 e do Residencial Valville, e também do condomínio Tamboré 10 Terras Altas. Os demais são os condomínios Tamboré 11 - Terras de Provence, o Campos do Conde e o Vila Velha, todos na vertente sul do Morro do Vacanga (vertente Rio Tietê). Na vertente norte tem-se oc condomínios Genesis I e II, além de um bairro de padrão construtivo baixo e médiano, característico da expansão periférica de baixa renda que ocorre nos municípios de Santana de Parnaíba e Cajamar, ocupando os setores de média e baixa vertente da margem esquerda do Rio Juqueri.

Existem apenas dois loteamentos de baixo padrão que ocupam o setor de alta vertente e topo dos morros do Vacanga e Botucavarú. Um deles se organiza ao lado da Via Anhanguera e o outro fica nas proximidades do núcleo urbano da sede de Santana de Parnaíba, muito próximo das expansões recentes de Alphaville. 
O tecido urbano de todas essas peças dispersas não se distancia do padrão de loteamentos da cidade compacta. Os de baixa renda apresentam infraestrutura deficiente e sua morfologia, quando ainda em fase inicial de ocupação vê-se a simbiose entre lotes pequenos e totalmente edificados e lotes ainda não ocupados com vegetação remanescente da mata ou capoeira. Já o padrão de condomínios de alta renda do conceito Alphaville apresenta os novos empreendimentos todos com terrenos pelados de arborização. Executa-se uma total raspagem da superfície para a modelagem dos arruamentos e terrenos. Nos casos de condomínios antigos e já adensados, os lotes tendem a taxa de ocupação elevada, portanto, lotes bastante impermeabilizados.

Figura 8.3 - Dispersão urbana sobre divisor Tietê-Juqueri, setor Região de Alphaville, Barueri e Santana do Parnaíba/SP.

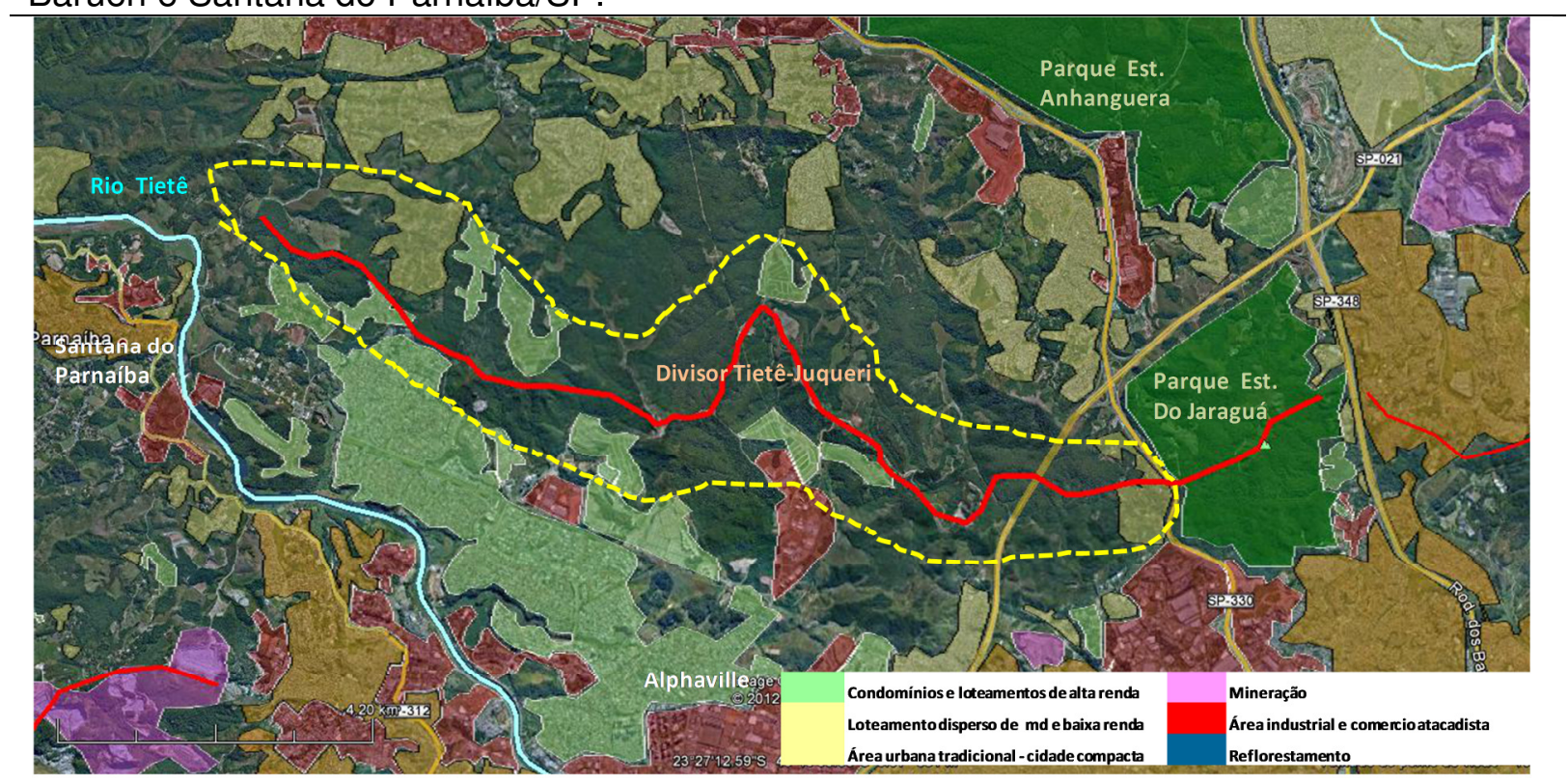

Fonte: imagem (20/07/2011) e recursos gráficos do Google Earth. Informações acrescentadas pelo autor.

Figura 8.4 - Morro do Botucavarú no trecho cortado pelo Rodoanel; e setor do Morro do Vacanga em Alphaville, e o Condomínio Genesis II.

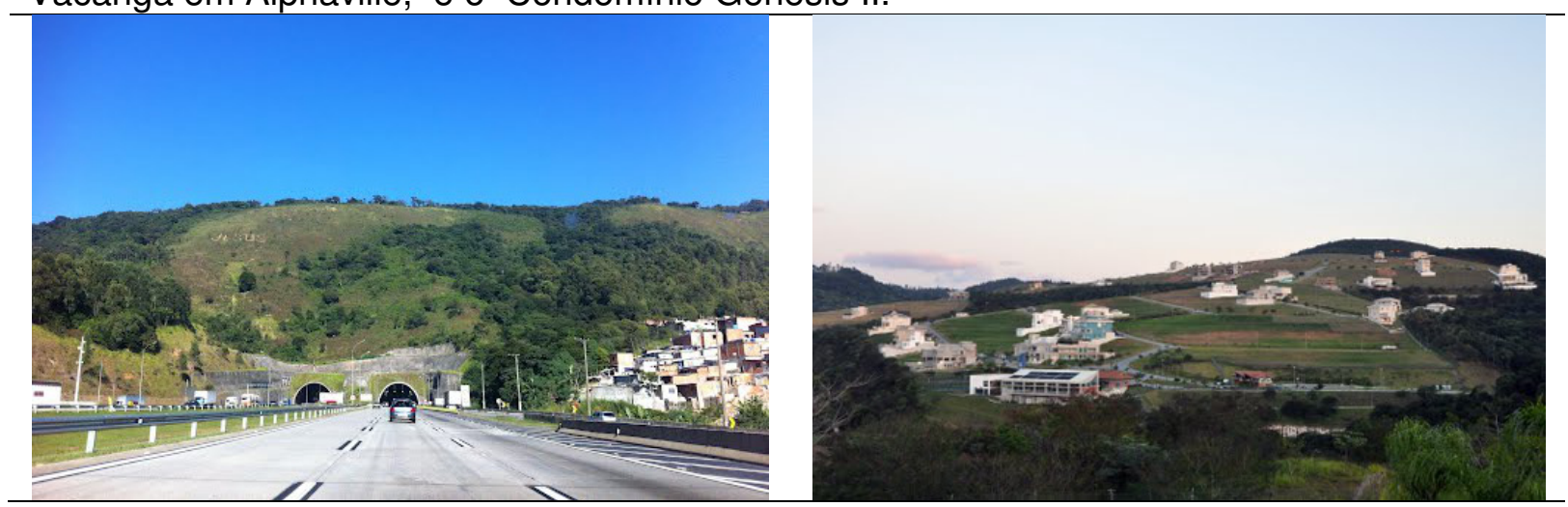

Fonte: Google Earth - Panoramio. 
Não é difícil concluir que essa dispersão urbana torna-se altamente impactante para a paisagem local e com decorrências regionais, em face da importância do alinhamento de divisores das bacias Tietê-Juqueri, em conjunto, como um compartimento ambiental estruturante da metrópole. Não só pela ocupação em si, mas pelo desmatamento decorrente, pelas tipologias de tecido urbano impermeabilizantes que aumentam as taxas de escoamento superficial e, sobretudo, a velocidade deste escoamento em face da declividade destes setores de encostas.

Infelizmente, esse divisor ficou altamente seccionado pela ocupação urbana que se compactou na região de Jaraguá e Parada de Taipas, na porção noroeste da cidade de São Paulo, segregando o totalmente o Morro do Jaraguá deste conjunto ecológico-ambiental importante, pois guardam os últimos grandes remanescentes de mata dentro da metrópole de São Paulo. Neste trecho de cidade compacta que atravessa o divisor Tietê-Juqueri trata-se de uma ocupação de padrão baixo a mediano, com presença de conjuntos habitacionais, loteamentos para as classes média e baixa, e ocorrência de ocupações irregulares e favelas. $O$ tecido urbano avança também sobre os setores de nascentes e de seus anfiteatros, e apresenta elevada taxa de ocupação dos lotes (de pequenas dimensões), configurando um comprometimento ambiental relevante para a região de São Paulo.

O próprio maciço do Jaraguá aparece com sua borda sul e leste sob pressão de ocupação de baixa renda como a que acontece na Vila Nova Esperança, na Vila Chica Luiza, na ocupação da altura do ํo 3.600 da Estrada Turística do Jaraguá, no Conj. Res. Bandeirantes, e na Vila Homero, em que um pequeno bairro de uso industrial vem sendo substituído por habitações residenciais populares, e com tendência a adensamento e crescimento. Verifica-se apenas uma ocupação de alta renda que se localiza ao lado da entrada do parque37, aproveitando-se da presença da área de proteção ambiental e da paisagem de mata atlântica que configura toda a vertente sul do maciço do Jaraguá. Trata-se de um condomínio fechado que parece fazer parte do parque.

\footnotetext{
${ }^{37} \mathrm{Na}$ Alameda Agenor Couto de Magalhães um conjunto de 8 mansões parece fazer parte da área do parque, sendo envolvido pelos limites do parque e pela continuidade da formação florestal que domina a vertente sul do Parque no Jaraguá.
} 
Figura 8.5 - Maciço do Jaraguá visto a partir da Rodovia dos Bandeirantes, com o bairro Chica Luiza no primeiro plano. Na foto ao lado, a favela Chica Luiza II,

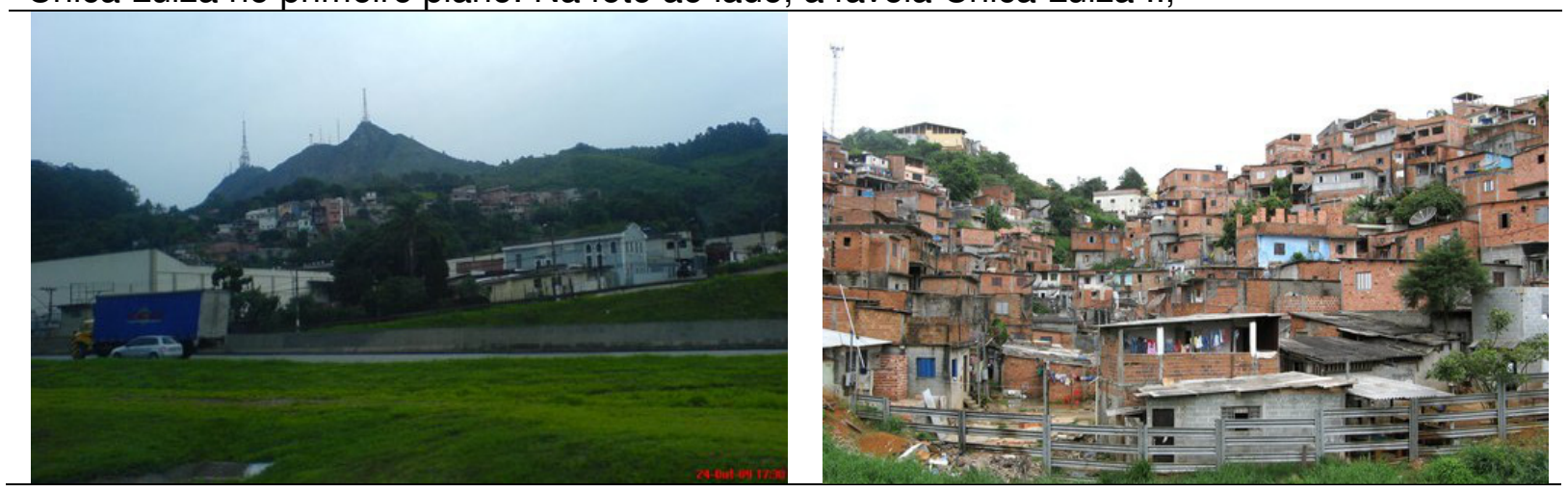

Fonte: Google Earth - Panoramio.

A vertente norte do Maciço do Jaraguá apresenta os trechos contíguos ao Rodoanel Mário Covas não protegidos legalmente, pois os limites do parque estadual terminam a $1 \mathrm{~km}$ deste anel viário. O uso da área ainda é rural, com a presença de uns poucos sítios, mas essa situação não deverá durar muito tempo, em face da estratégica posição destes terrenos que são atrativo para o mercado imobiliário, pois situados entre duas áreas de preservação paisagisticamente relevantes, como o são os Parques do Pico do Jaraguá e do Anhanguera; e também terrenos passíveis de serem acessados por três rodovias importantes (Anhanguera, Bandeirantes e Rodoanel).

Figura 8.6 - Condomínio Alpes da Cantareira e Jd. Samambaia, ocupando anfiteatro de nascentes no alto da Serra da Cantareira. Na foto ao lado, o reservatório Águas Claras e os condomínios do entorno, em setor de alta vertente da serra, no município de Mairiporã.
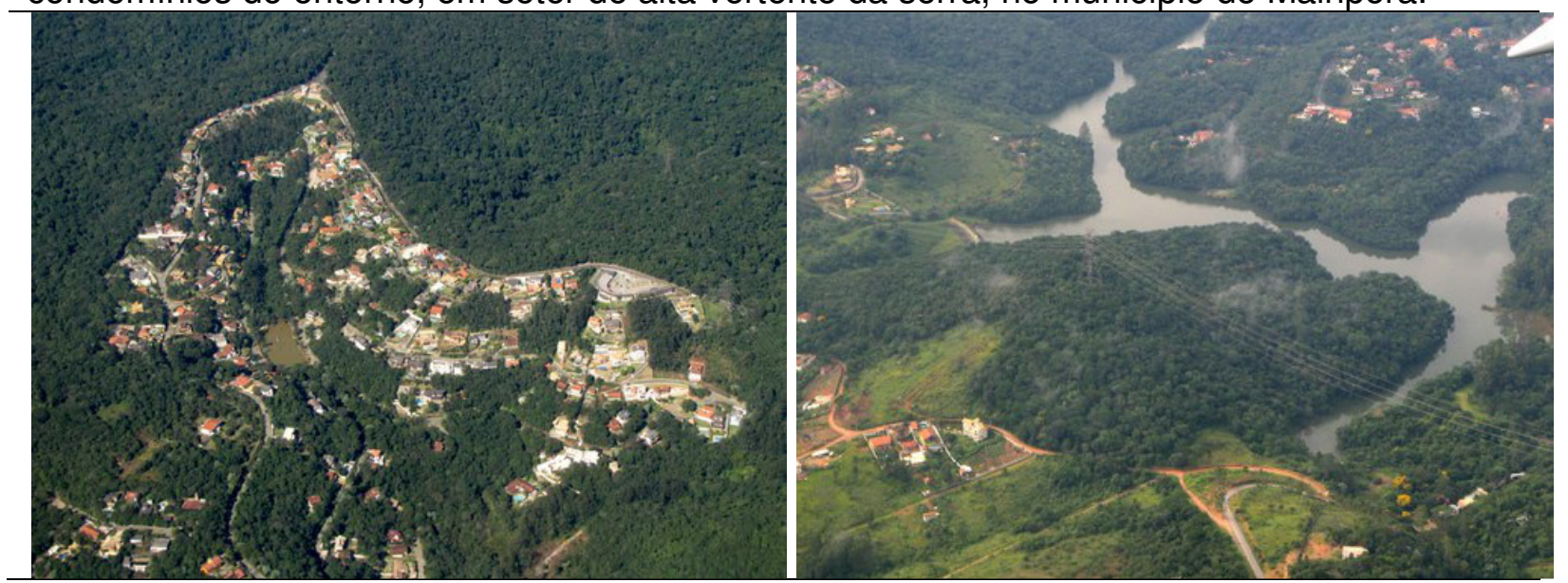

Fonte: Google Earth - Panoramio.

Já a ocupação do setor central deste divisor, que corresponde à Serra da Cantareira, é mais intensa e apresenta características um pouco diferenciadas do setor anterior, em face da própria morfologia desta serra, oriunda de um corpo 
granítico mais avantajado e com ramificações laterais mais pronunciadas, além da própria maior expressividade em altura e de apresentar escarpamento abrupto na vertente sul, a do Rio Tietê.

Como apenas a vertente voltada para o Rio Tietê foi objeto de proteção desde o início do século passado, a ocupação urbana que se dá, com seu caráter disperso, apresenta diferenças marcantes nas duas vertentes deste divisor. Assim é que na vertente norte, voltada para os municípios de Mairiporã e Caieiras, a dispersão ocupa os setores de topo e alta vertente do maciço serrano, incluindo também a média e baixa vertente, no entanto, com padrão construtivo e de renda marcantemente diferenciados. Nos setores de topo e alta vertente ocorrem em maior dominância os condomínios fechados de alta renda, que tem no Alpes da Cantareira o seu representante mais emblemático. Nos setores mais baixos da vertente dominam loteamentos de padrão médio ou baixo.

Já na vertente sul, voltada para São Paulo e Guarulhos, tanto a expansão urbana da cidade compacta quanto os loteamentos que se dispersam, ocupam o sopé da serra, ou seja, o setor de baixa vertente do maciço, galgando, em alguns pontos, trechos da vertente média. Nesta vertente, embora ocorram alguns condomínios fechados ou loteamentos de padrão médio a alto, o que predomina é a expansão de loteamentos das classes populares.

Em São Paulo, na região de Tremembé, a expansão de loteamentos ainda dispersos é expressiva, subindo a encosta da serra e atingindo a cota 800 metros, enquanto a mancha compacta da cidade de situa a 750 metros, em média. As novas ocupações são de pequenas dimensões, onde se verifica que os loteamentos de baixa renda vão seguindo a mesma tendência de alguns pequenos condomínios fechados que invadem antigos setores de floresta. Essa associação pode ser verificada no bairro Vila Albertina, no Alto da Marieta e no Jd. Ibiratiba, configurado por ocupação de condomínios fechados de médio a alto padrão; e na Vila Rosa, de onde se espalha a expansão irregular de baixa renda sobre as florestas das divisas da área do Parque Estadual da Cantareira. Essa ocupação tem seu eixo estruturado pela Av. Cel. Sezefredo Fagundes que tem seu traçado paralelo à Rodovia Fernão Dias. 
Entretanto, embora essa expansão comprometa consideravelmente a integridade já bastante ameaçada deste compartimento ambiental, essas ocupações se configuram mais como uma expansão do tecido urbano da cidade compacta e não uma efetiva dispersão urbana, no sentido de uma distinção mais duradora dessa peça urbana em relação à mancha urbana da cidade compacta.

Um pouco mais adiante, ainda pela Av. Cel Sezefredo Fagundes, uma série de peças urbanas dispersas aparecem entre essa avenida e a rodovia. São loteamentos residenciais de baixa renda, áreas industriais e cavas de mineradoras. Os loteamentos residenciais são de baixo padrão e caracterizam uma ocupação irregular. Situam-se na média vertente da serra, entre as cotas 800 e 900 metros.

Figura 8.7 - Ocupação dispersa na baixa vertente da Serra da Cantareira, na região de Tremembé, São Paulo.

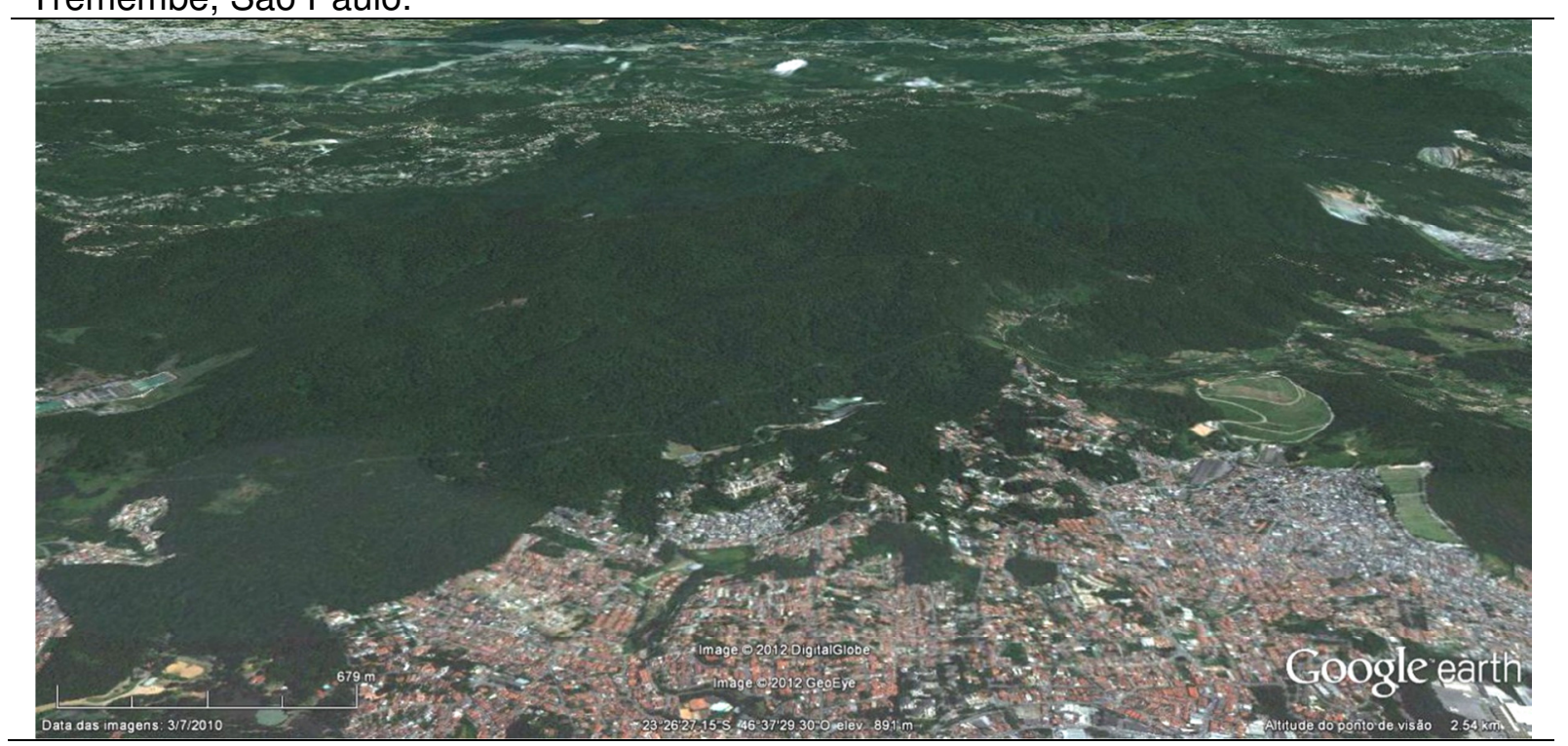

Fonte: Google Earth.

$\mathrm{Na}$ baixa vertente da Serra da Cantareira na região do município de Guarulhos, entre a Rodovia Fernão Dias e a Estrada Guarulhos-Nazaré, a dispersão urbana é nitidamente de baixa renda. Verifica-se a formação de dois grandes bairros que podem ser o embrião de novas ocupações nos setores mais elevados da vertente.

Nas proximidades do Núcleo Cabuçu do Parque Estadual da Cantareira, na estrada de acesso à entrada deste parque, uma grande ocupação de loteamentos populares se formou, configurando os bairros de Recreio São Jorge, Cabuçu, 
Chácaras Cabuçu e Jd. Monte Alto. Ocupam setores de morros da base da escarpa, no médio curso dos córregos Invernada e Cabuçu, tributários do Rio Tietê. Alguns setores desses bairros se dirigem para as divisas do parque e ocupam o sopé da vertente serrana. Enquanto o topo da serra se situa entre 1.000 e 1.100 metros de altitude, essas ocupações estão a 800-850 metros, 100 metros, em média acima das cotas da mancha compacta da cidade de Guarulhos.

No morro divisor de baixa vertente por onde correm o Ribeirão das Lavras e o Córrego Tanque Grande um grande loteamento de baixa renda se formou, originando o bairro Jd. Fortaleza. Trata-se de um bairro ainda bastante carente de infraestrutura básica, como esgoto, asfaltamento, etc, que tende a continuar sua subida à serra e o desmatamento de remanescentes de mata (capoeiras e florestas), já comprometidas pela fragmentação proporcionada pelo uso rural. A situação topográfica em relação ao topo da Serra da Cantareira é a mesma da ocupação descrita anteriormente.

Figura 8.8 - Ocupações dispersas de baixa renda na Serra da Cantareira em Guarulhos: à esquerda, bairros do Cabuçu e Recreio S. Jorge; à direita o Jardim Fortaleza.

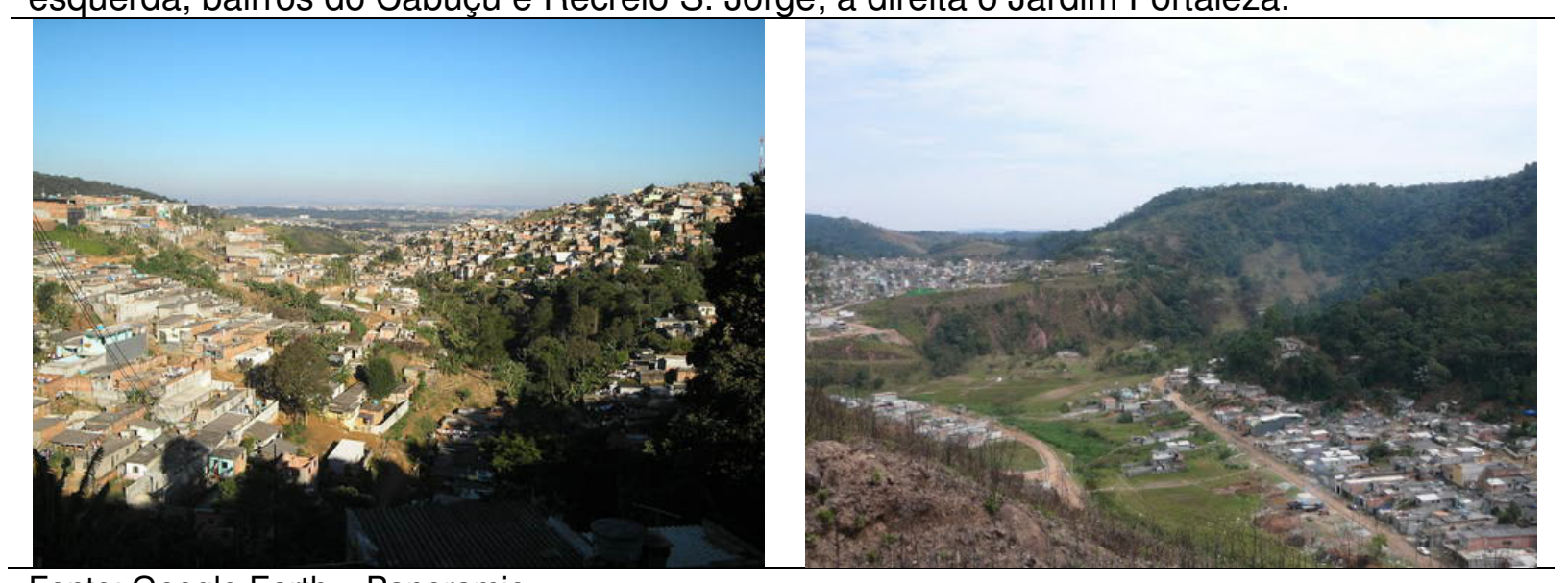

Fonte: Google Earth - Panoramio.

Passando a Estrada Guarulhos-Nazaré, outra ocupação dispersa de baixa renda ocorre de forma semelhante ás anteriores, configurando uma mesma relação topográfica com o topo da serra, aqui já denominada de Serra do Itaberá. Trata-se da ocupação do bairro Água Azul, que se estrutura ao longo da Av. Ary Jorge Zeitune, avenida essa que sobe até as proximidades das cotas altimétricas de 950 metros no bairro rural conhecido como Morro Grande. Neste setor a Serra do Itaberá tem seus topos situados entre 1.100 e 1.300 metros. 
Todas essas ocupações dispersas de baixa renda que tendem a subir a serra na região de Guarulhos devem ser foco de preocupação, tanto em relação ao seu adensamento como ponta de lança de novas expansões de padrão periférico, com prejuízos marcantes para as questões ambientais urbanas na bacia do Alto Tietê.

Já na região entre Arujá-Igaratá, na vertente, e Nazaré Paulista, no topo da Serra do Itaberá, a dispersão se dá ao longo do vele do Rio Jaguari, caracterizada por ocupação de chácaras, com baixa densidade de ocupação, e alguns condomínios residenciais de lotes médios a grandes (1.000 a 2.000 m²), porém apresentando boa situação de permeabilidade do solo. Neste setor da Serra do Itaberá a drenagem se dirige para a bacia do Rio Paraíba. Deve-se considerar que essas ocupações apnas encostam no início da parte baixa da vertente serrana, não configurando, ainda, ocupação de grande impacto para o divisor Juqueri-Paraíba do Sul.

De fato, a ocupação mais preocupante e impactante para essa região da Serra da Cantareira ocorre no topo e alta vertente voltada para o Rio Juqueri, no município de Mairiporã. De fato, trata-se de uma controversa e contraditória questão referente a essa ocupação, pelo fato de ter, na imagem de que ocupa a área uma ideia de relação harmoniosa com a natureza, de respeito ao verde da mata e à paisagem serrana. Controversa pela própria forma de ocupação das altas vertentes serranas de uma área que do outro lado é protegida, pois necessária à proteção dos mananciais da metrópole. Contraditória pela segregação social e por ter no bojo da defesa do respeito à natureza uma nítida afirmação de conteúdo de classe. A ocupação de alta renda não é contraditória com a preservação ambiental. Embora não explicitamente afirmado, é comum associar a degradação ambiental às ocupações de baixa renda.

Embora, de fato, as tipologias de ocupação das peças urbanas existentes nos altos da Serra da Cantareira permitam uma boa relação entre ambiente construído e cobertura vegetal, apresentando nitidamente uma configuração de bairro jardim, o que chama a atenção é a quantidade de loteamentos e a área serrana ocupada. Trata-se de uma forma de ocupação de alta renda muito diferenciada das congêneres mais recentes do que podemos chamar de padrão Alphaville. A implantação dos lotes e das construções é executada sem o corte excessivo da 
cobertura vegetal das matas e bosques dessa vertente serrana. A tal raspagem da superfície não é executada ao extremo como ocorre nas outras formas de ocupação.

Pode-se identificar, grosso modo, 40 peças urbanas dispersas de padrão de ocupação médio-alto para alto, e 7 de padrão médio para baixo, em uma distância de até $2,5 \mathrm{~km}$ do topo da serra, e em cotas altimétricas que se situam entre 1.0001.100 metros do topo até os 900 metros das altas vertentes. Nesse trecho o Rio Juqueri passa na cota 750 metros.

Figura 8.9 - Dispersão urbana e adensamento da ocupação sobre divisor Tietê-Juqueri, setor Serra da Cantareira, São Paulo e Mairiporã/SP.

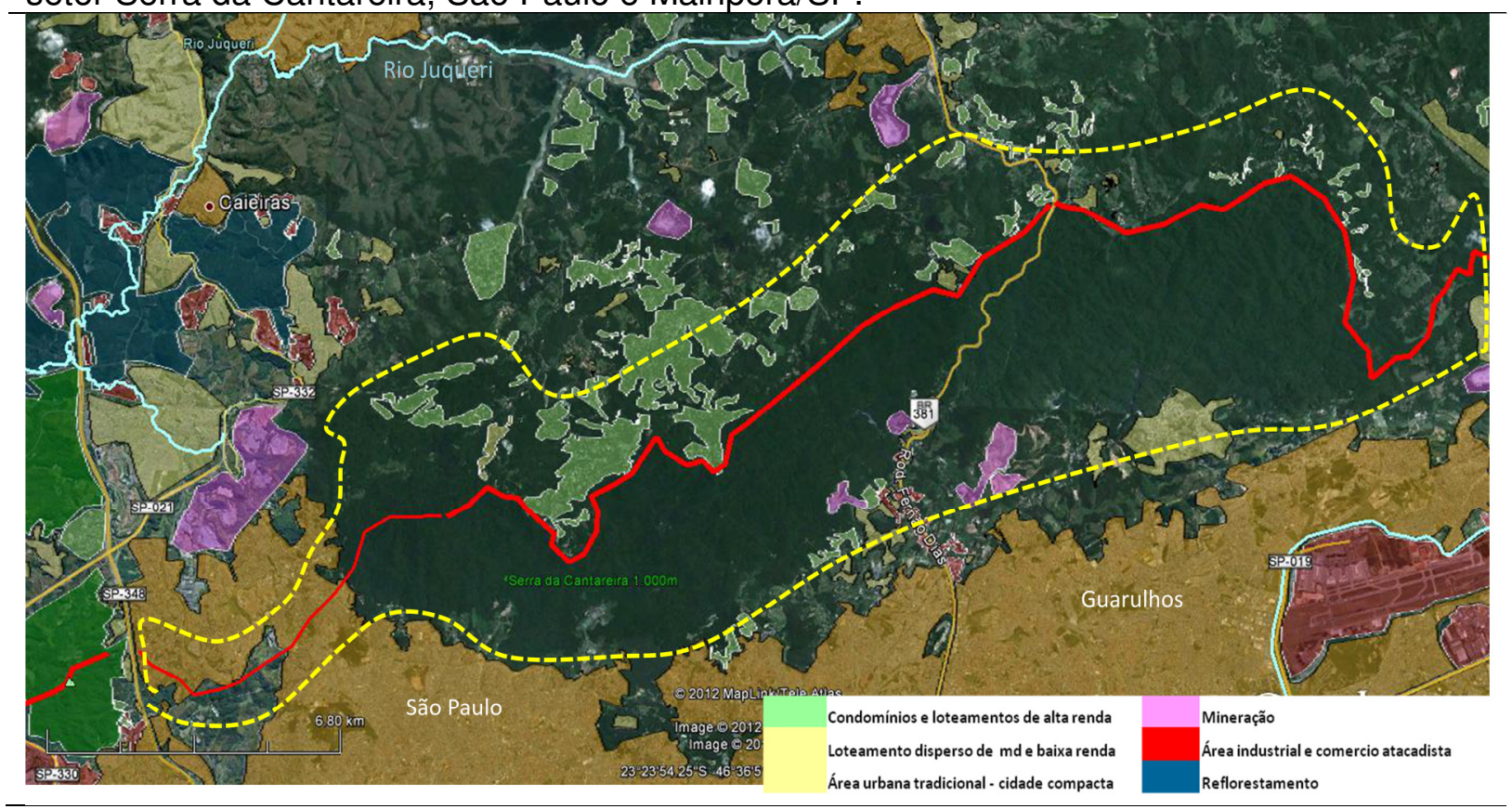

Fonte: imagem (20/07/2011) e recursos gráficos do Google Earth. Informações acrescentadas pelo

Figura 8.10 - Detalhe de ocupação de alta renda nos contrafortes da Serra da Cantareira, Mairiporã/SP: Jarim Samambaia e Alpes da Cantareira.

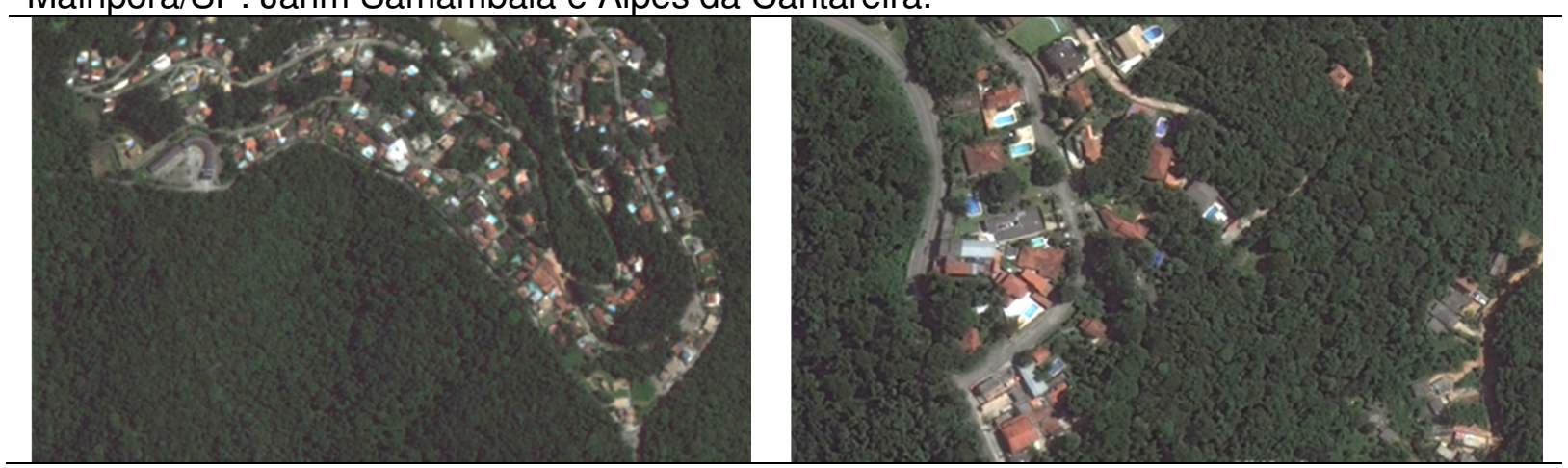

Fonte: Google Earth. Imagem de 21/12/2009 
Figura 8.11 - Detalhe de embrião de ocupação de baixa renda nos contrafortes da Serra da Cantareira em meio aos condomínios de alta renda, Mairiporã/SP.

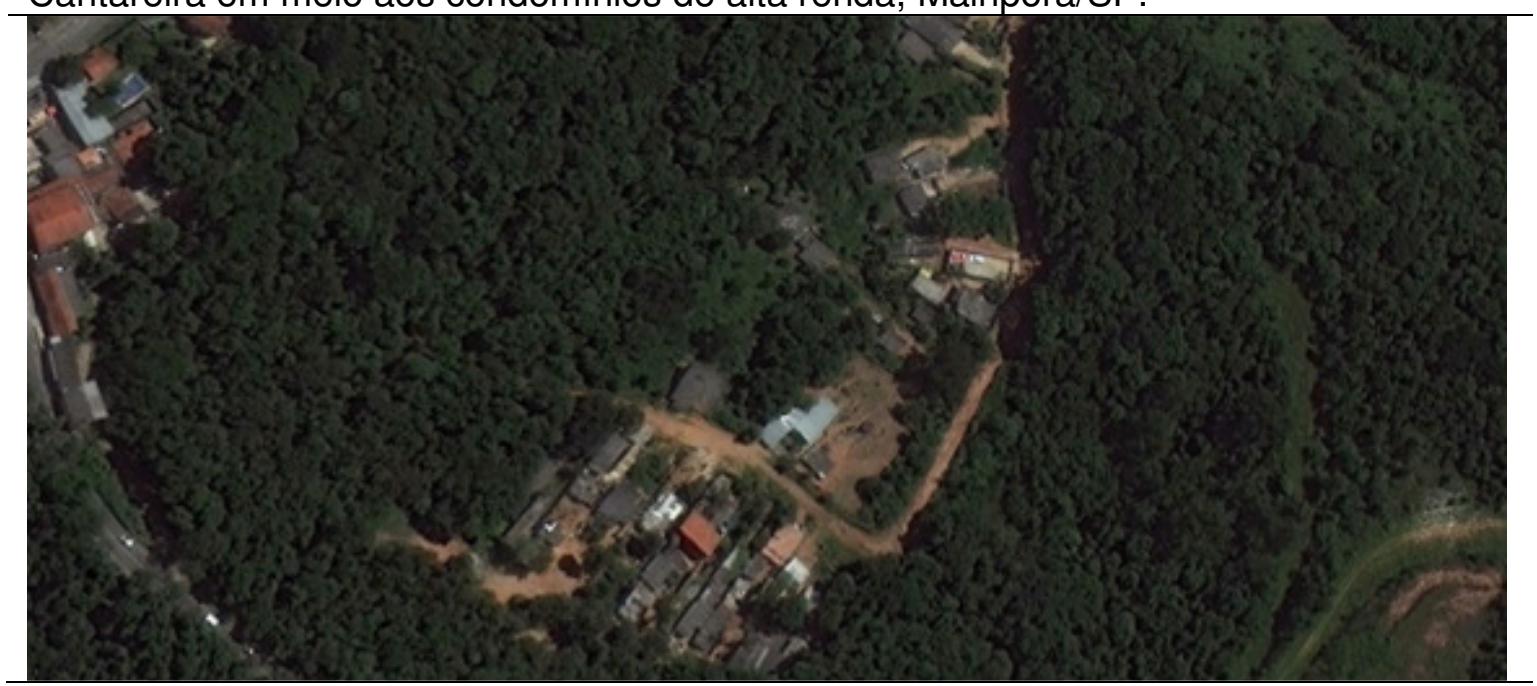

Fonte: Google Earth. Imagem de 21/12/2009

Figura 8.12 - Ocupação urbana dispersa de baixa renda na Serra da Cantareira, Guarulhos/SP: Cabuçu e Recreio São Jorge.

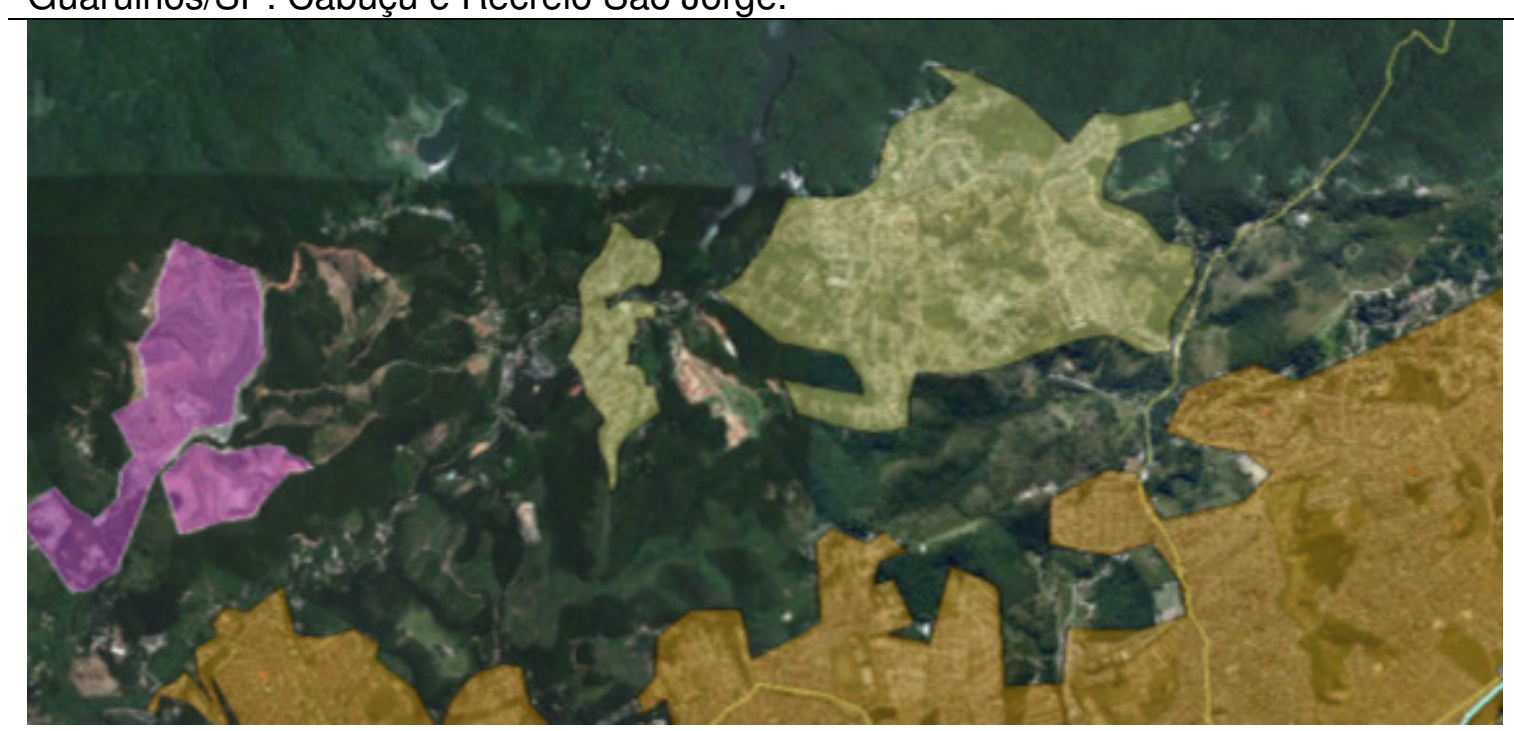

Fonte: imagem (07/03/2010) e recursos gráficos do Google Earth. Informações acrescentadas pelo autor.

Figura 8.13 - Detalhe da ocupação urbana dispersa de baixa renda na Serra da Cantareira, Guarulhos/SP. Estrada do Cabuçu - Bairro Cabuçu e Sítio Pirucaia.

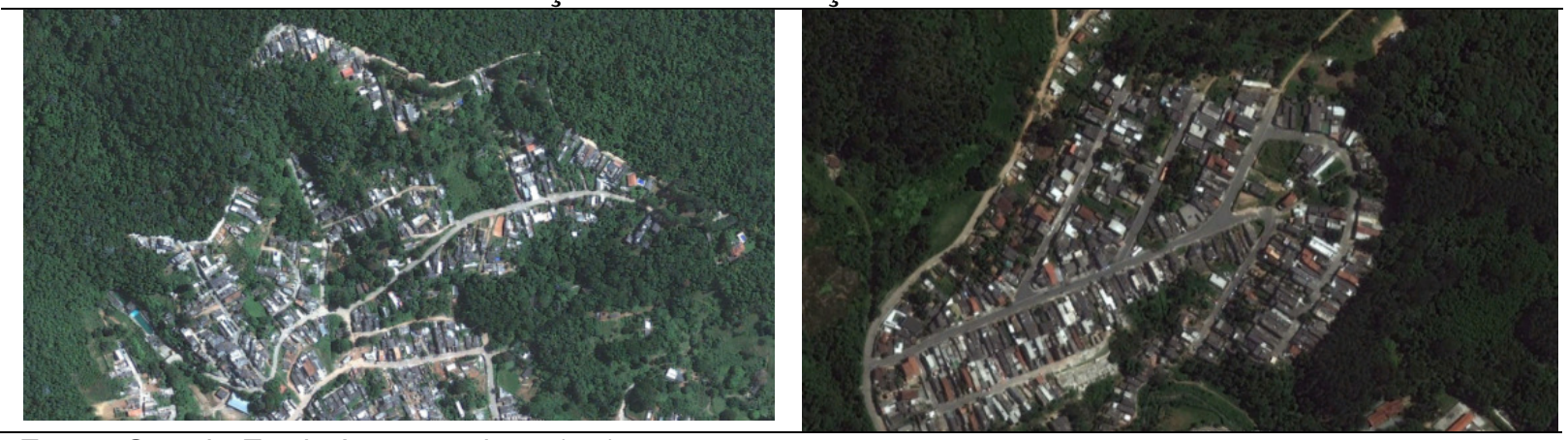

Fonte: Google Earth. Imagem de 07/03/2010 
8.1.2. O alinhamento do Divisor Juqueri-Jundiaí

O importante alinhamento de divisores das bacias do Juqueri e Jundiaí é composto pelas serras do Juqueri, Boturuju, dos Cristais e do Japi. Como já mencionado, são serras associadas a falhamentos, porém de composição litológica diferenciadas. A Serra do Juqueri é sustentada por granitos; a do Boturuju por xistos; a dos Cristais por filitos; e a do Japi dominantemente por quartizitos.

Podem ser notados (Figura 8.14) cerca de 14 peças urbanas residenciais de média a alto padrão ocupando os setores de topo e alta vertente em todo esse alinhamento. Alguns loteamentos de baixa renda e outros com área industrial ocorrem apenas ao longo das rodovias que cortam esse alinhamento, como a Anhanguera e a Fernão Dias. Os condomínios fechados e outros loteamentos de alta renda dispersos ocupam as áreas rurais intersticiais a essas rodovias, se distanciando bastante de seus eixos.

Não configuram loteamentos muito adensados e os lotes são de tamanho intermediário, tendendo a aparentar pequenas chácaras, ou aos condomínios-jardim existentes na Serra da Cantareira, em Mairiporã. Entretanto, embora a permeabilidade do solo seja satisfatória a arborização é incipiente, pois correspondem a transformação de sítios rurais já desmatados anteriormente. Portanto, os remanescentes de floresta apresentam-se bastante fragmentados e degradados.

O caso de ocupação mais emblemático ocorre na Serra do Japi, com a presença de um condomínio fechado dentro da área de preservação do Parque Estadual da Serra do Japi (Chácaras da Ermida). É grande a valorização imobiliária no entorno leste e norte da Serra do Japi, em Jundiaí e Itapuva ${ }^{38}$.

\footnotetext{
38 Notícia publicada no jornal “O Estado de São Paulo", de 04/02/2012, informa sobre o avanço de condomínios na Serra do Japi, que afeta animais, a integridade e a biodiversidade da Reserva. "De pontos altos nos limites de Jundiaí com a Serra do Japi, é possível ver o avanço de prédios e condomínios sobre as franjas da mata preservada, em fenômeno semelhante ao que já ocorreu com a ocupação da Serra da Cantareira na zona norte da capital, nos anos 1990. No distrito do Parque Eloy Chaves, ao lado da Rodovia dos Bandeirantes, por exemplo, os primeiros prédios de 10 andares começaram a chegar em 2008 e não param de se multiplicar. No mesmo bairro, condomínios com bosques de matas nativas administradas pelo Ibama também atraem famílias de paulistanos que querem morar "com vista para a serra". As placas de apartamentos à venda estão pregadas nos postes de estradas de terra da serra. Segundo ambientalistas, essa ocupação urbana próxima da serra já provoca uma "diáspora" de animais silvestres. O reflexo mais direto está na Associação Mata Ciliar, ONG que recebe em média 9,7 animais por dia achados em áreas urbanas da região....... E agora estamos ainda mais assustados com a possibilidade da chegada de hotéis. Isso vai acentuar a tentativa de fuga de animais silvestres."A Serra do Japi também conta com nascentes e mananciais que fazem parte da Bacia do Rio Piracicaba, cujo volume hídrico é usado para o abastecimento de 2 milhões de pessoas no interior e na Grande São Paulo. "A Serra do Japi é o último fragmento de Mata Atlântica antes do início do Cerrado. Por isso, tem espécies de fauna dos dois ecossistemas,
} 
Figura 8.14 - Alinhamento de divisores dos rios Juqueri-Jundiaí.

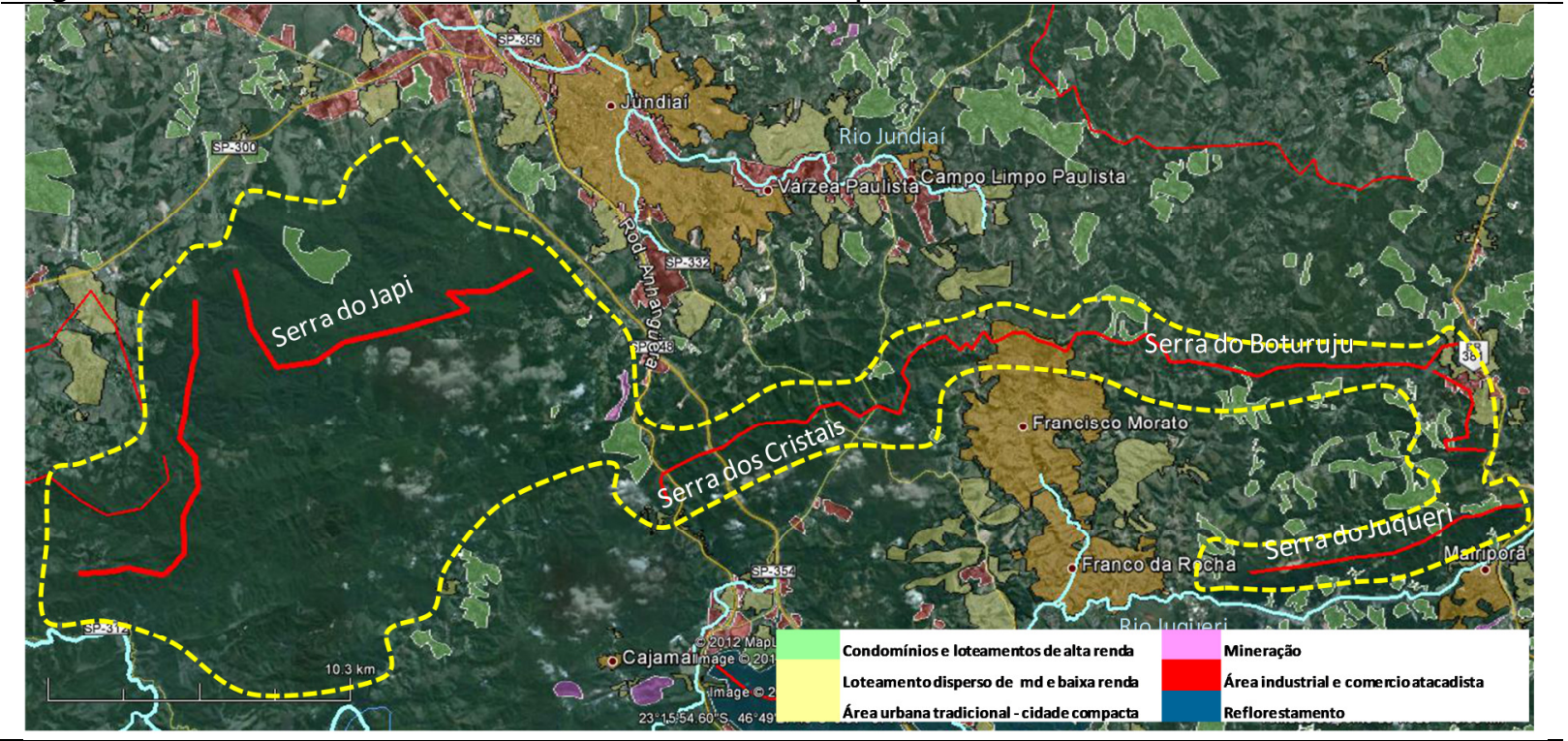

Fonte: imagem e recursos gráficos do Google Earth. Informações acrescentadas pelo autor.

Figura 8.15 - Detalhe de casas do Condomínio Chácaras da Ermida, situado no topo da Serra do Japi.
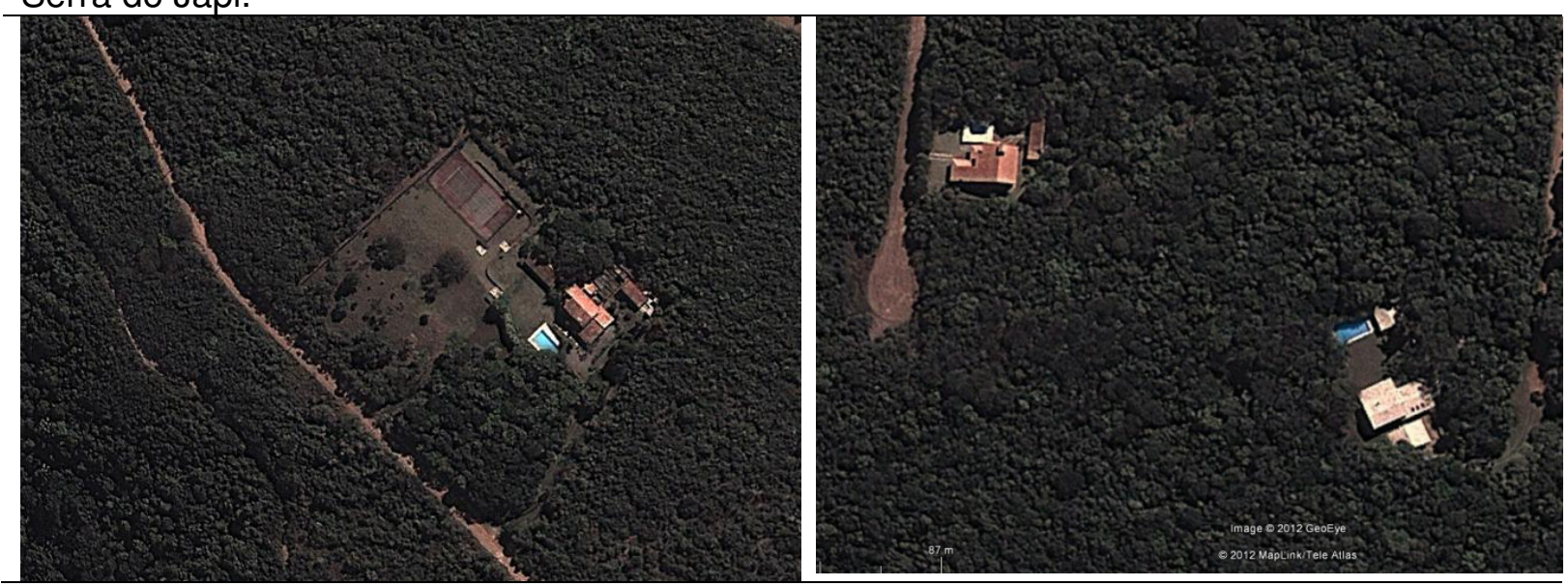

Fonte: Google Earth.

8.1.3. A dispersão nos divisores de menor abrangência regional.

Nos demais divisores, configurados por serranias de menor expressão, o processo de dispersão de peças urbanas sobre os setores de topo e altas vertentes também é significativo. A tendência é pela dispersão dos condomínios fechados ou loteamentos para as classes de média-alta a alta renda. A busca pelas vistas mais amplas da paisagem e pelos remanescentes de matas, que ocorrem em alguns

algo único no Brasil. Se a borda da serra não for congelada, todos esses animais silvestres vão acabar fugindo para áreas urbanas, correndo risco de ser mortos", completou. 
anfiteatros e setores de encosta, atraem clientela para a ocupação como $1^{\mathrm{a}}$ ou $2^{\mathrm{a}}$ residência.

Na Serra do Itaqui, no eixo de dispersão da Castelo Branco, os condomínios Aldeia da Serra, Portal da Serra e Morada do Sol se estendem desde o topo $(1.000 \mathrm{~m})$ até os setores mais baixos do sopé deste alinhamento serrano. O próprio nome dos dois primeiros já indica o que motiva a ocupação destes compartimentos ambientais serranos, na ênfase dada pelo mercado imobiliário (Figura 8.16).

Figura 8.16 - Dispersão na Serra do Itaqui.

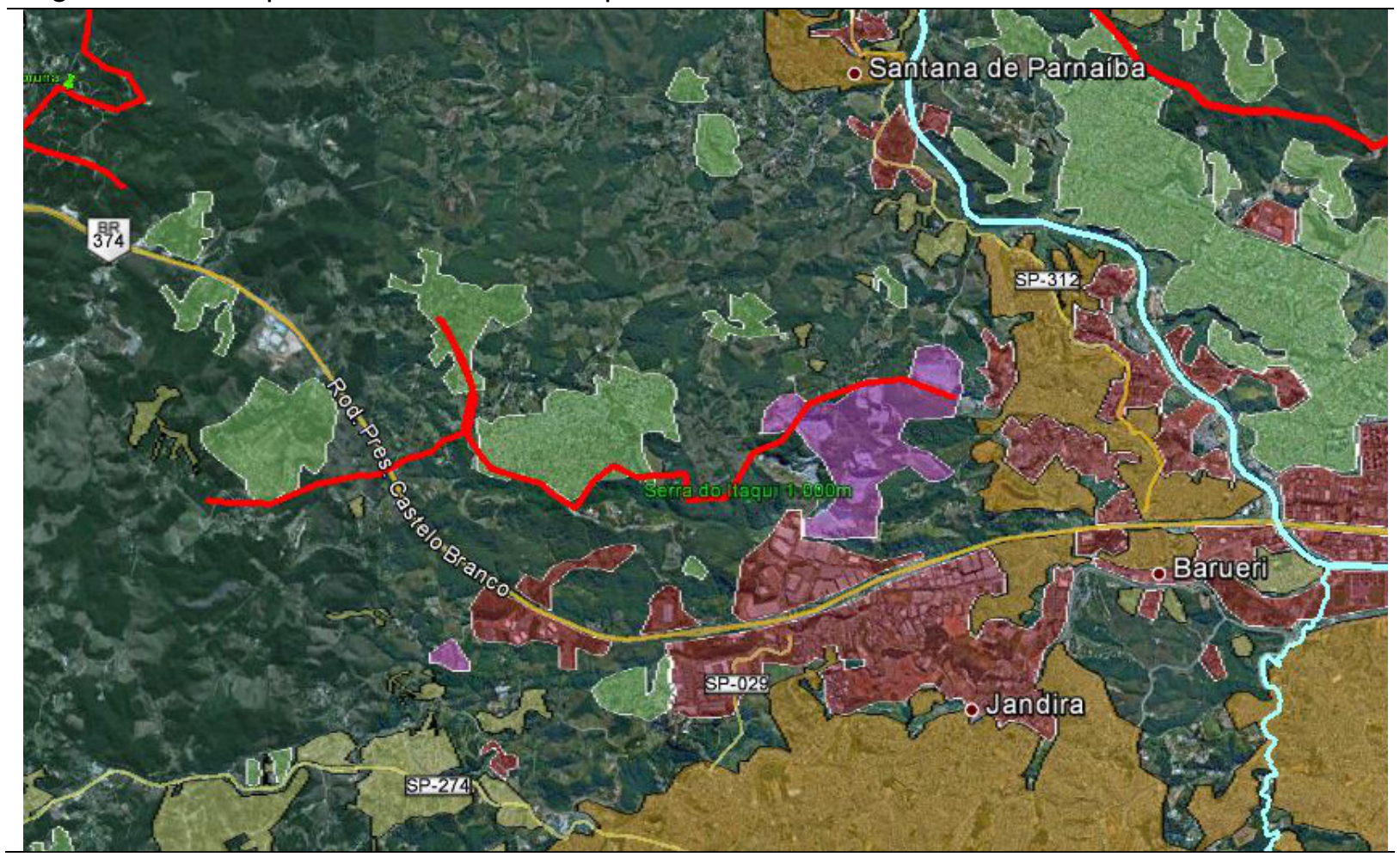

Fonte: imagem e recursos gráficos do Google Earth. Informações acrescentadas pelo autor.

Na região da Serra da Caucaia, entre Cotia e Vargem Grande, no eixo de dispersão da Rodovia Raposo Tavares, os loeametos e condomínios fechados de alta renda fazem divisa com a área protegida sob o regime de proteção dos manaciais (reservatório da Sabesp), ocupando a alta vertente desta serra. Observase também a aproximação de pequenos loteamentos de baixa renda, pulverizados nas franjas dessas vertentes (Figura 8.17). 
Figura 8.17 - Dispersão nas encostas da Serra da Caucaia.

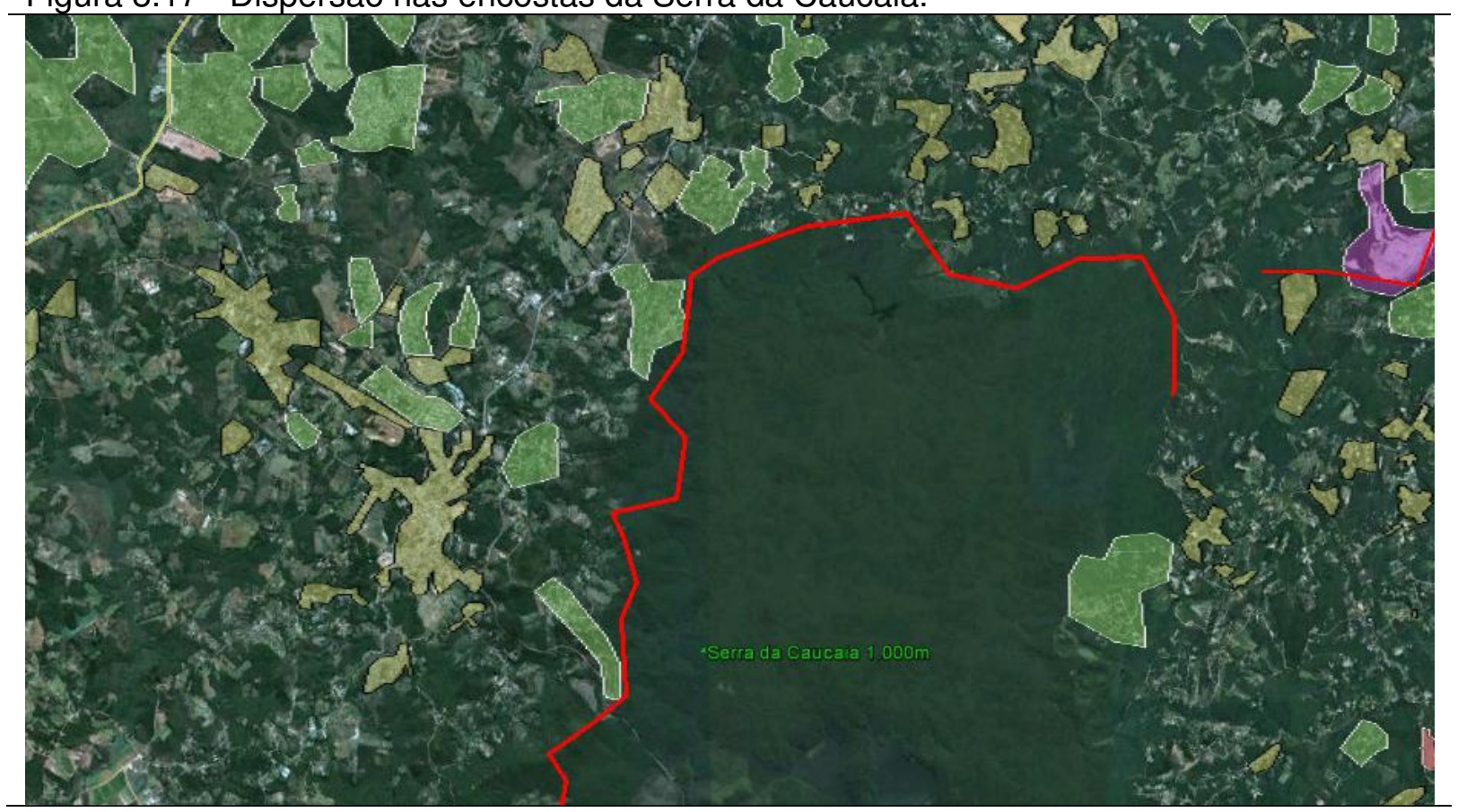

Fonte: imagem e recursos gráficos do Google Earth. Informações acrescentadas pelo autor.

Também no alinhamento de divisores dos rios Jundiaí e Atibaia, entre os municípios de Jundiaí, Louveira, Vinhedo, Valinhos e Itatiba, embora este alinhamento não se apresente como uma serrania muito pronunciada, a dispersão de condomínios fechados de alta renda de diversificados padrões de ocupação (chácaras, loteamentos residenciais) se dirige para o setor de topo e altas vertentes.

Configura-se, assim, na dispersão urbana da macrometrópole a tendência de ocupação indiscriminada de todos os compartimentos de relevo, incluindo, conforme esta pesquisa visou verificar, compartimentos ambientais estruturantes, regional e localmente, no que se refere aos compartimentos que influenciam outros compartimentos da paisagem. Nas regiões serranas analisadas, ou mesmo nos divisores de menor expressão altimétrica, a ocupação se dá dominantemente por meio dos condomínios fechados de alta renda que se pulverizam ao longo do alinhamento, enquanto a dispersão das classes populares, que ocorre em menor escala, quando ocupam esses setores se dá nas proximidades dos principais eixos rodoviários. 
Figura 8.18 - Dispersão no alinhamento de divisores dos rios Jundiaí e Atibaia.

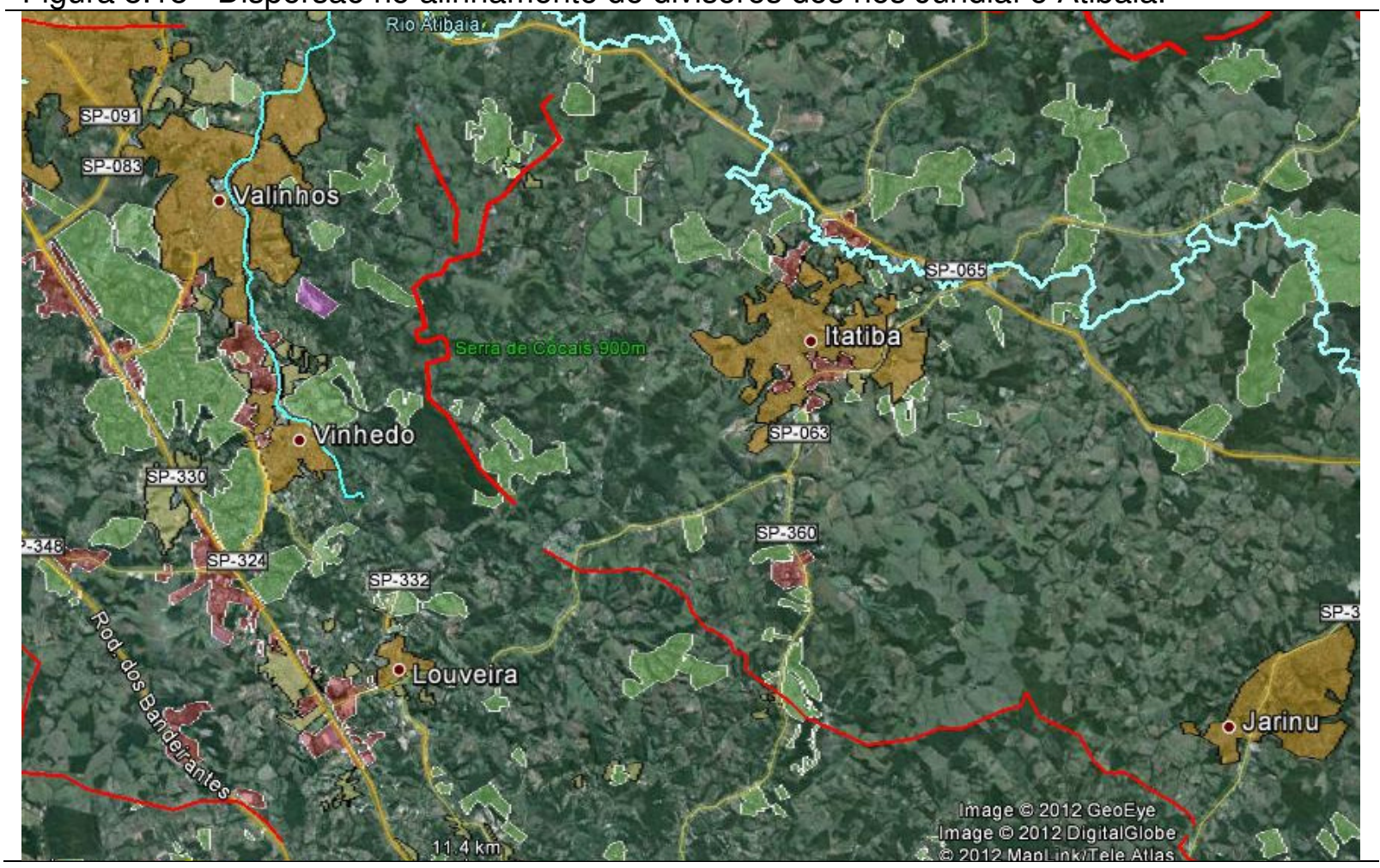

Fonte: imagem e recursos gráficos do Google Earth. Informações acrescentadas pelo autor.

\subsection{A dispersão urbana nos compartimentos de fundos de vale}

Em termos ambientais ligados aos compartimentos de fundo de vale e de várzeas, dois setores merecem atenção especial nos processos de expansão e ocupação urbana. Um deles, e já razoavelmente reconhecido pelos meios técnicos, é o compartimento de várzeas, devido à recorrência de suas cheias, que se transformam em enchentes quando ocupadas pelo uso urbano. O outro, cuja importância se configura mais recentemente em função do aumento considerável do consumo de água e do desmatamento, são as bordas dos reservatórios de água para abastecimento público.

Iremos concentrar a análise destes compartimentos ambientais estruturantes de fundos de vale, naqueles que apresentam planícies aluviais mais consideráveis. Assim, o destaque será dado às planícies aluviais do Tietê, do Rio Atibaia e do Jundiaí. Também será objeto de avaliação a situação da dispersão urbana que se dirige para as bordas dos principais reservatórios instalados nas bacias de abrangência deste estudo. 


\subsubsection{As várzeas do Tietê}

Segundo Ab'Saber (1958, p.209), na terminologia popular paulistana da primeira metade do século $X X$, todos os terrenos de aluviões recentes já eram conhecidos como várzeas, desde os brejais das planícies sujeitas à submersão anual, até as mais enxutas e menos sujeitas às inundações.

Almeida descreveu os processos que resultaram na formação da planície aluvial do Tietê da seguinte forma:

"Os processos sedimentares, que hoje se relaizam no Planalto paulistano, resultam principalmente do excesso de detritos produzidos pela profunda meteoração química e que são levados a uma rede de drenagem com capacidade de transporte diminuída, em face dos obstáculos interpostos ao curso do Tietê, ao penetrar na Província Serrana. Disso resultam planícies aluviais, de nível de base local, que se alongam pela quase totalidade do vale desse rio, no Planalto Paulistanbo, penetrando por seus afluenetse e alcançando, mesmo, seus menores subafluentes" (Almeida, 1958, p. 159).

Esses abundantes produtos de erosão das vertentes, que continuam fornecendo material até hoje, aliados ao processo de solapamento do sopé dos morros, movimentam-se para os fundos dos vales, onde nem sempre encontram condições eficientes de evacuação. Isto decorreu do fato de que a rede de drenagem do planalto sempre esteve condicionada à importante soleira granítica de Barueri. Dessa soleira para montante, o Tietê atingiu seu perfil de equilíbrio e desenvolveu um curso bastante tortuoso numa planície aluvial de nível de base que, com algumas interrpções locais, se estende até Mogi das Cruzes, e até um pouco mais a montante na direção de Salesópolis.

Hoje, todo esse processo encontra-se sujeito a um novo nível de base constituído pelas inúmeras barragens, sendo que o entulhamento de detritos se dá no fundo das represas formadas por estas barragens. 
Figura 8.19 - Várzea do Tietê, antes de chegar em São Paulo, e principais divisores de águas regionais.

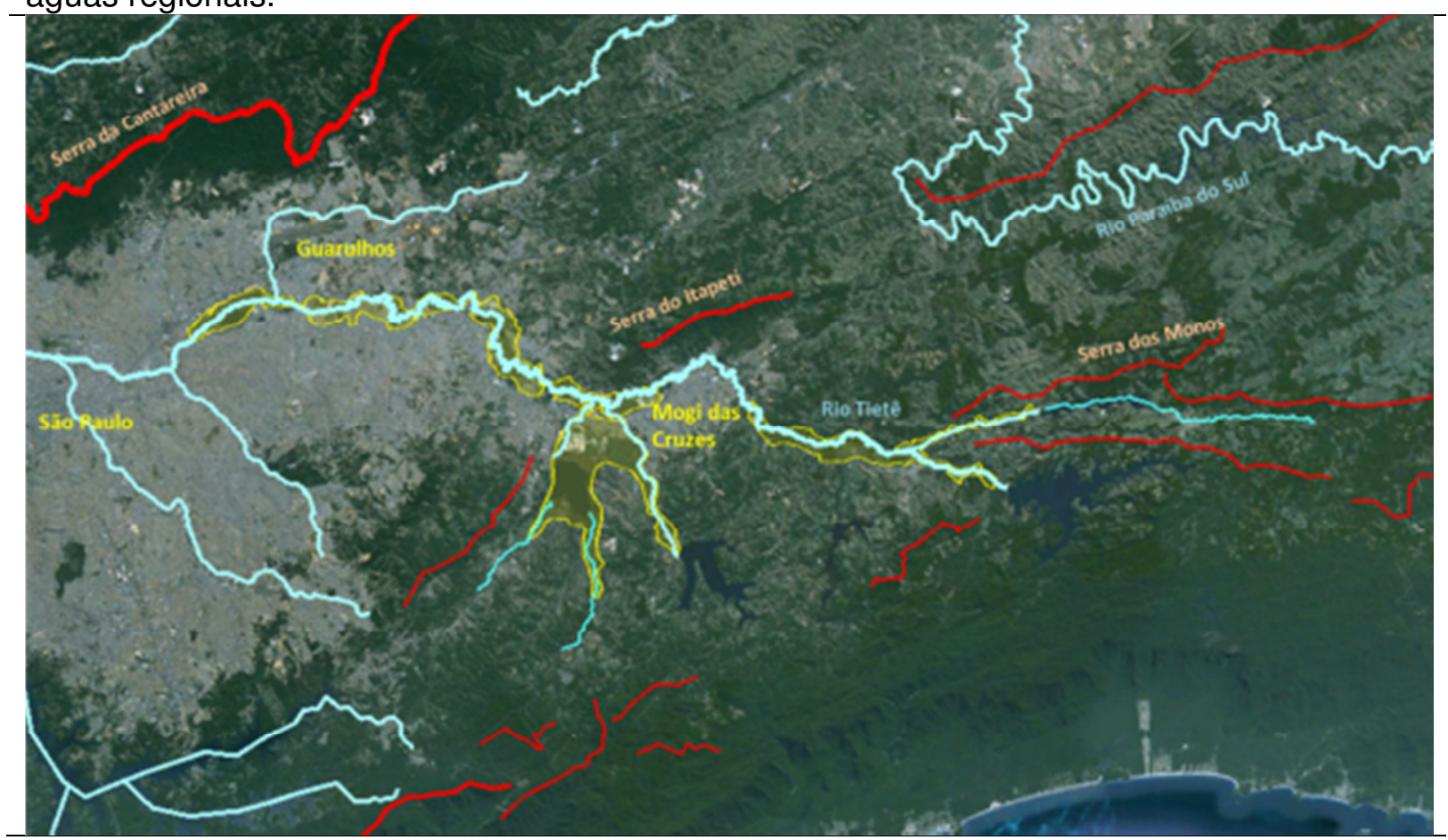

Fonte: imagem (20/07/2011) e recursos gráficos do Google Earth. Informações acrescentadas pelo autor.

De largura variável, essa planície alcança o máximo de sua lagura a sul de Vila Guilherme, quase $4 \mathrm{~km}$, trecho que se encontra hoje totalmente urbanizado, dentro da mancha compacta da cidade de São Paulo. Da barragem da Penha até Mogi das Cruzes a planície aluvial apresenta certa continuidade, passando por trechos de urbanização já consolidada e por outros ainda em consolidação. Nestes, é que s epode verificar certos aspectyos de dispersão urbana. Entretanto, é possível entrever que se trata muito mais de um processo de nova compactação da mancha do que de dispersão, como buscaremos mostrar com algumas imagens desse processo.

Pode-se diferenciar, hoje, no processo recente de consolidação urbana no entorno das várzeas do Tietê, três setores que revelam dinâmicas de ocupação em estágios diferentes. O primeiro ocorre no trecho que vai do Parque Ecológico do Tietê até Itaquaquecetuba, passando por Itaim. $O$ segundo se estende de Itaquaquecetuba até Mogi das Cruzes, passando por Poá e Suzano. E o terceiro vai de Mogi das Cruzes até as represasde Paraitinga e de Ponte Nova.

No primeiro trecho, em que pese todas as promessas de preservação de várzeas no discurso e documentos oficiais de órgãos do governo do Estado e da 
Prefeitura de São Paulo, o que vem ocorrendo é um intenso processo de ocupação dos últimos remanscentes de várzeas, que aos poucos vão confinando o curso do rio ao seu específico canal. Trata-se da expansão urbana do bairro do Itaim e Jd, Sta Helena, em processo de conurbação com a ocupação que ocorre do outro lado da várzea, no município de Guarulhos, em um processo típico de adensamento populacional, tanto por inicitaiva de loteamentos regulares e aprovados como por novas invasões de favelas. Há que se considerar a própria ação contraditória do Estado, em que algumas secretarias falam em preservação das várzeas em respeito à legislação ambiental, e outras promovem a ocupação a aprtir da implantação de conjuntos habitacionais. Esse é o caso da tragicomédia do planejamento urbano da cidade com a construção do Conjunto Habitacional do CDHU conhecido como Jd. Pantanal, que tem ficado submerso durante dias ou meses nos últimos anos, em que houveram chuvas pronunciadas nos meses de verão. No Jardim Romano, a prefeitura construiu um CEU (Centro Educacional Unificado) ao lado de outro conjunto habitacional para as camadas populares.

Nas figuras 8.20 a 8.24 pode-se verificar esse processo de ocupação das várzeas, que ilustra o movimento de cerzidura dos tecidos urbanos de São Paulo e de Guarulhos, ao partir da ocupação das últimas colinas sedimentares ainda não ocupadas e dos últimos resquícios de várzeas. Vários loteamentos irregulares foram implnatados no compartimento de várzeas nessa região como: Jd. Romano, Jd. Fiorelo, Vila Sônia, V. esperança, V. Maria Augusta, Grutas das Princesas, V. Seabra, Jd. Maia II, Favela da Paz, além do já mencionado Jd. Pantanal.

Neste setor, além da compactação da mancha por loteamentos residenciais regulares ou irregulares, a Sabesp construiu uma ETE (Estação de Tratamento de Esgoto) e houve a expansão de um distrito industrial sobre a área de várzeas. Além disso, paradoxalmente, a prefeitura de São Paulo constrói um piscinão no Jardim Romano na própria área de várzea, cuja função natural era exatamente essa de reservação temporária das águas de chuvas e de escoamento (vazão do rio) em lagoas naturais de retenção. 
Figura 8.20 - Ocupação urbana de baixa renda na várzea do Tietê, no Itaim Paulista, Zona leste de São Paulo/SP. O perímetro de linha amarela corresponde ao compartimento de várzea.

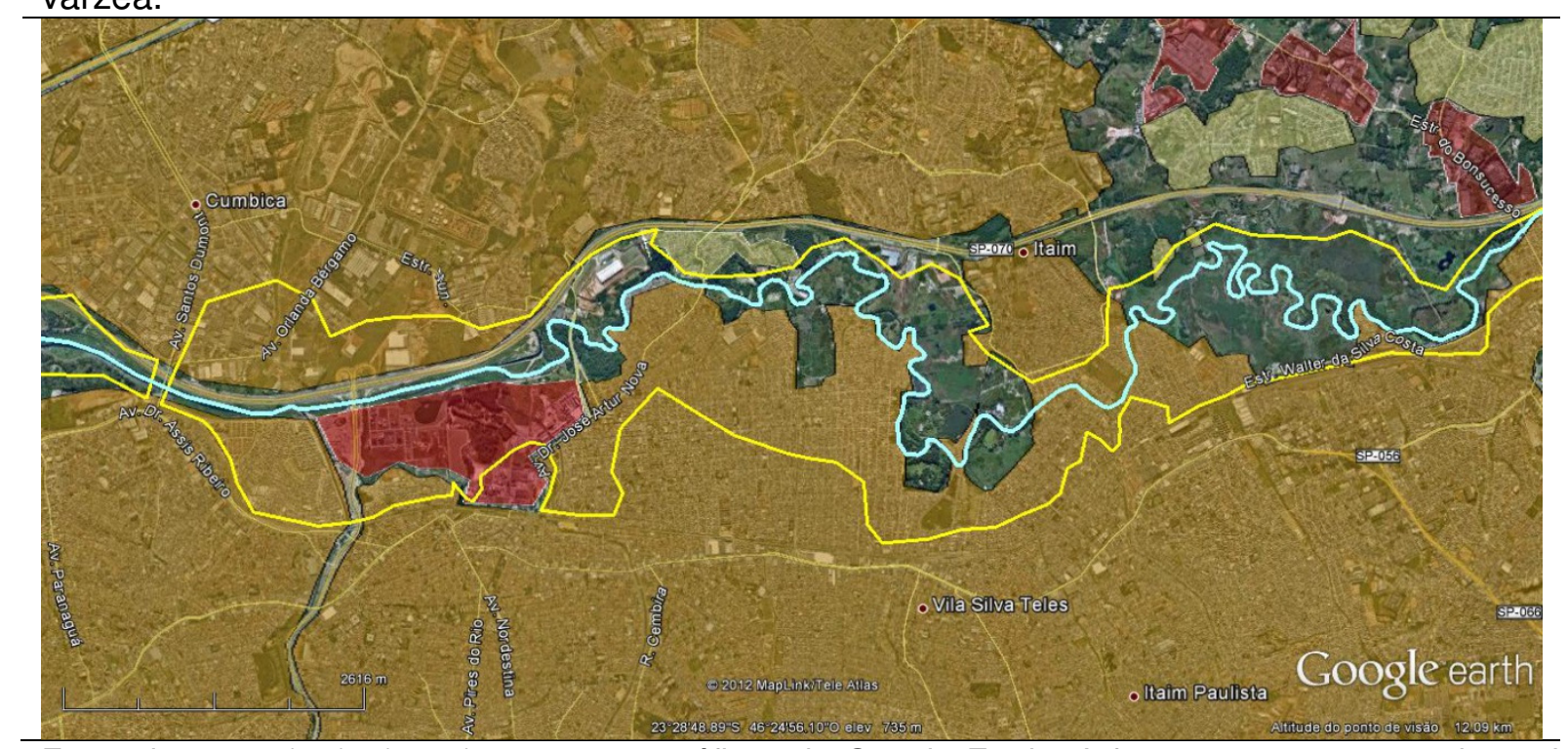

Fonte: imagem (04/03/2009) e recursos gráficos do Google Earth. Informações acrescentadas pelo autor.

Figura 8.21 - Ocupação urbana de baixa renda na várzea do Tietê, Jardim Romano/ltaim Paulista, Zona leste de São Paulo/SP.

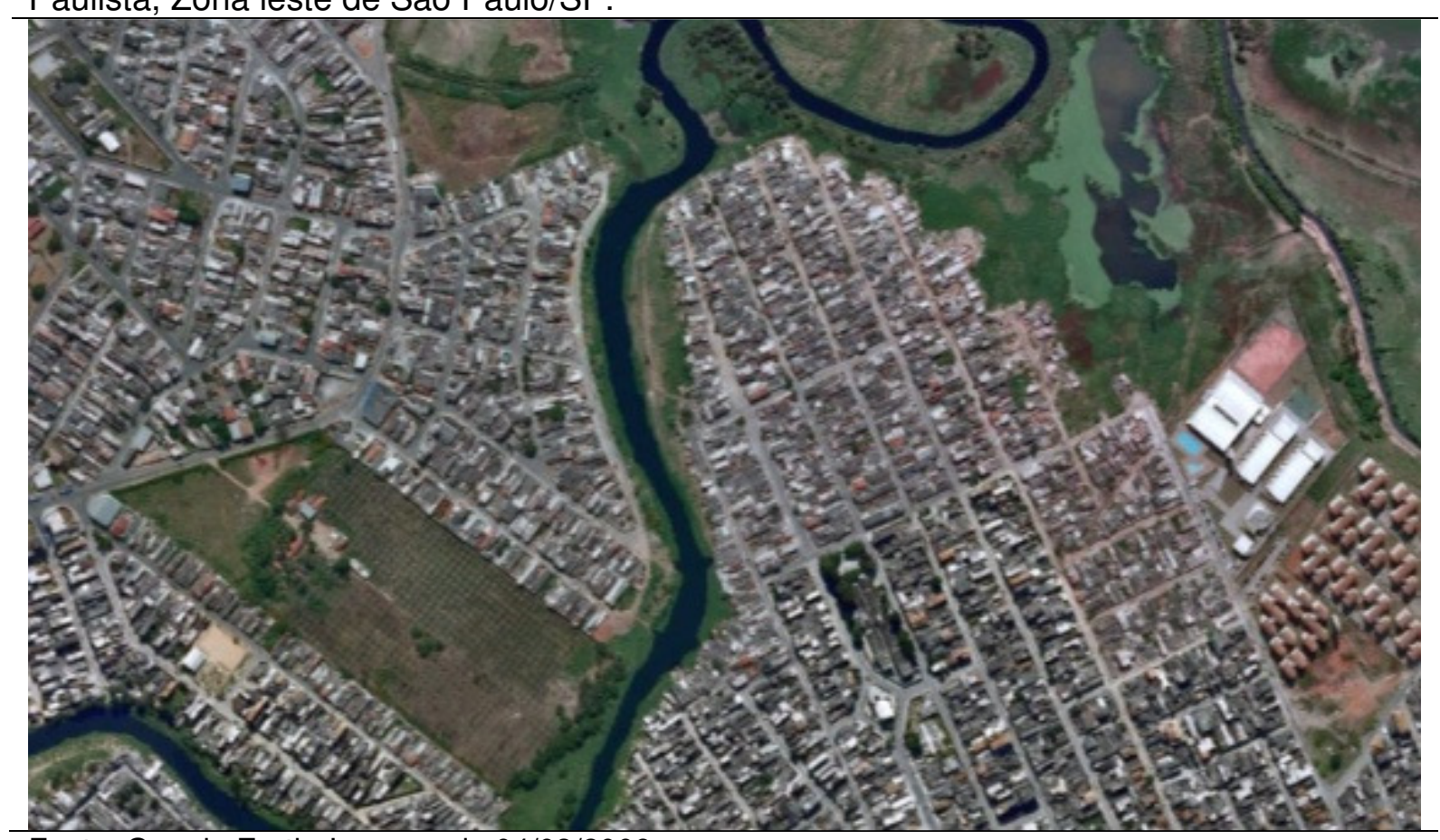

Fonte: Google Earth. Imagem de 04/03/2009 
Figura 8.22 -Detalhe da morfologia interna do loteamento no Jardim Romano/Itaim Paulista, Zona leste de São Paulo/SP.

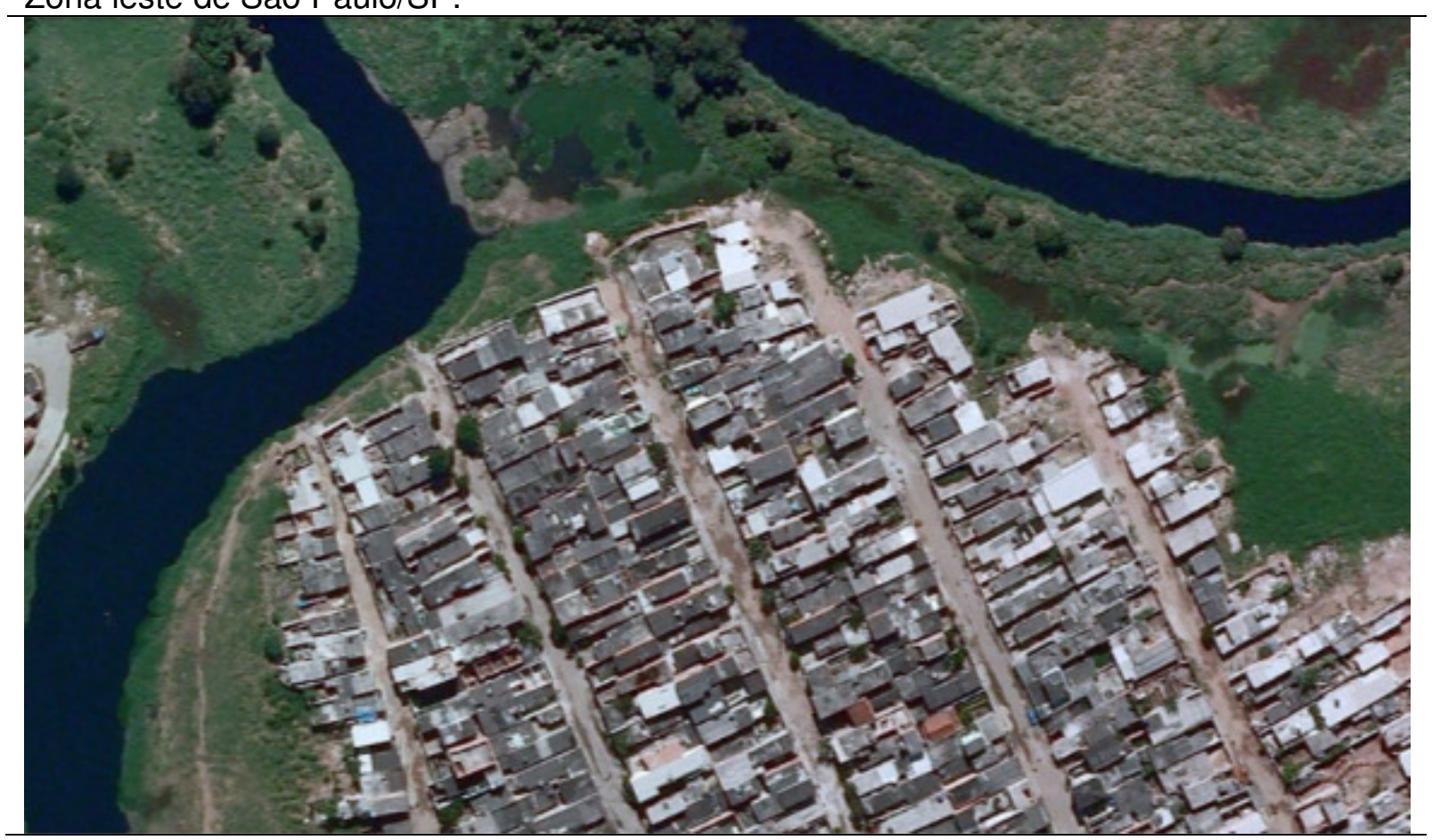

Fonte: Google Earth. Imagem de 04/03/2009.

No trecho de várzea compreendido entre os municípios de ItaquaquetubaSuzano e Mogi das Cruzes o processo de ocupação da várzea, antes de se configurar um processo de dispersão urbana, se trata mais de um processo de conurbação dos tecidos urbanos das cidades de Itaquaquecetuba, Arujá, Suzano, Poá e Mogi das Cruzes. A expansão sobre as várzeas se dá a partir de tecido urbano contíguo existente.

Nesse setor os novos usos atribuídos às várzeas se dão por meio de exploração de areia, usos antigo; bairros industriais em Suzano (Vila Maluf) e Mogi das Cruzes (V. S. Francisco), dois parques municipais (Ecológico de Itaquaquecetuba e Leon Feffer em Mogi das Cruzes), e várias expansões de bairros como no Cidade Miguel Badra e Pq. Maria Fernanda em Suzano; Jd Nova Poá em Poá.

A margem direita do Rio Tietê, neste trecho inicial de Mogi das Cruzes até Suzano, é ainda dominada pelo uso rural e mineração. 
Figura 8.23 - Ocupação urbana de baixa renda na várzea do Tietê, Itaquaquecetuba e Poá/SP. O perímetro de linha amarela corresponde ao compartimento de várzea.

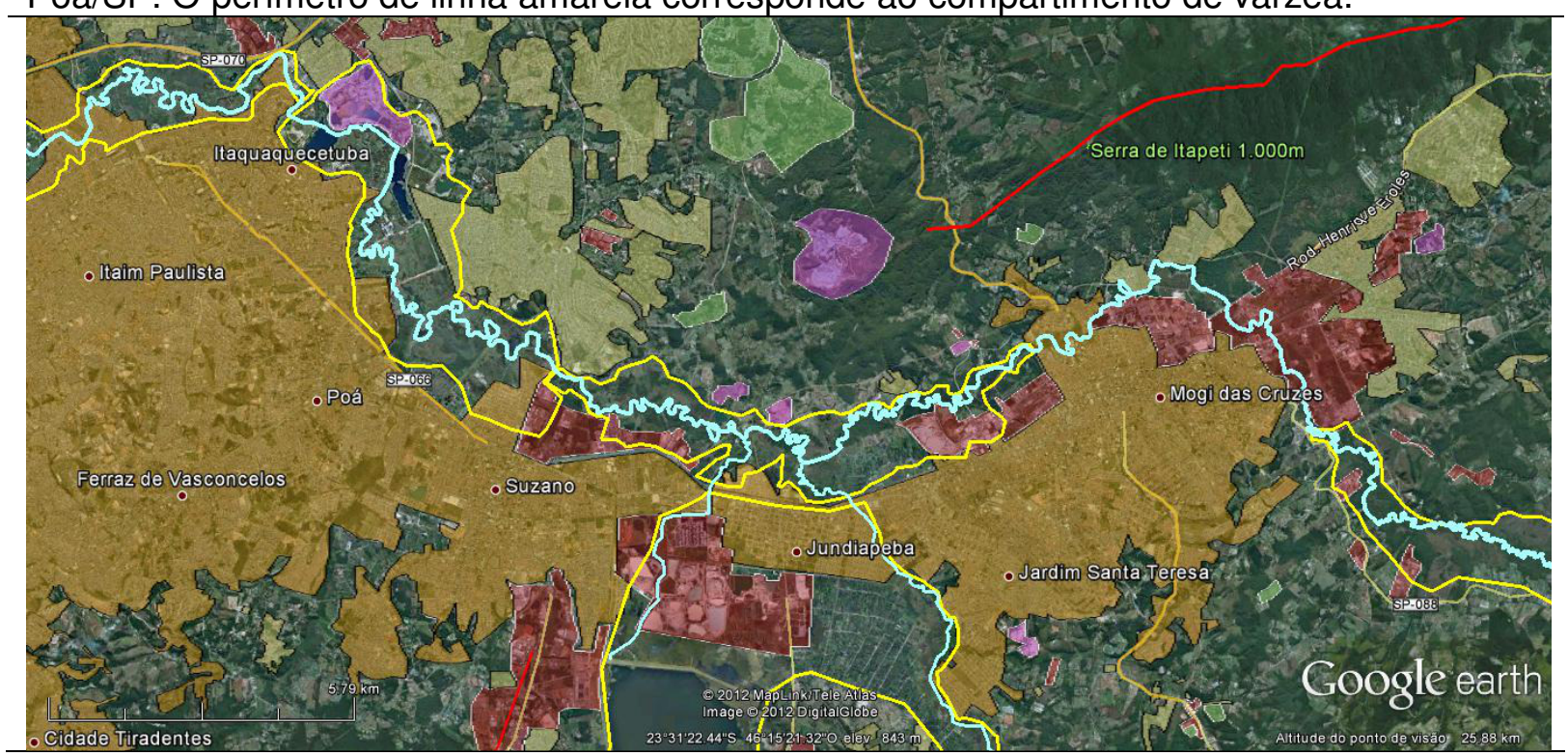

Fonte: imagem (07/03/2010) e recursos gráficos do Google Earth. Informações acrescentadas pelo autor.

Figura 8.24 - Ocupação urbana de baixa renda na várzea do Tietê, entre Mogi das Cruzes e represas de Ponte Nova e de Paraitinga. O perímetro de linha amarela corresponde ao compartimento de várzea.

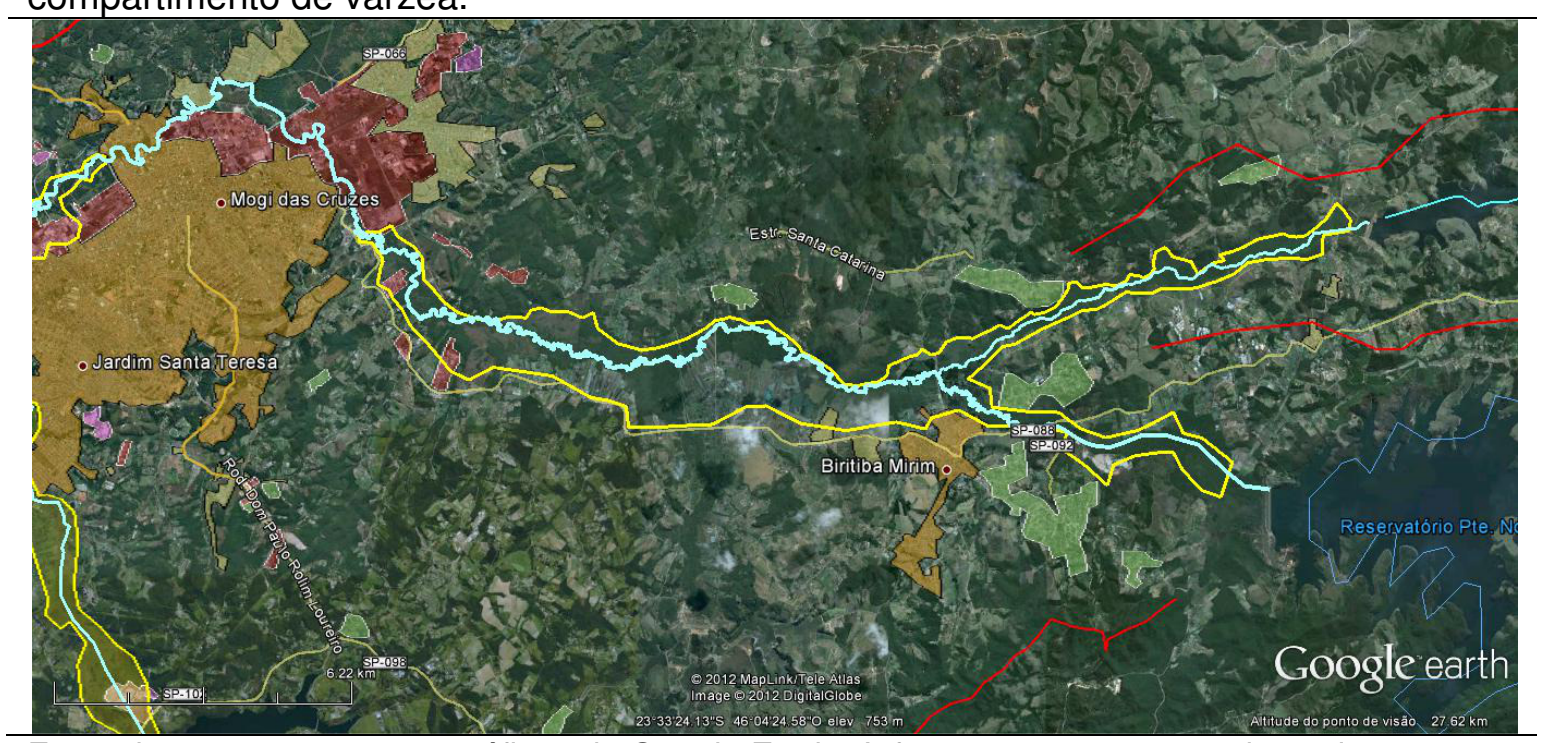

Fonte: imagem e recursos gráficos do Google Earth. Informações acrescentadas pelo autor.

No terceiro setor da várzea do Tietê, trecho que vai de Mogi a Salesópolis, a dispersão ocorre esparsamente a partir de trechos de loteamentos industriais aí instalados. Apenas em Biritiba Mirim existem duas expansões de áreas residenciais que se dirigem em parte para o compartimento de várzeas. No entanto, no perímetro urbano de Mogi das Cruzes a várzea foi sendo ocupada por usos industriais que foram unificando as ocupações residenciais dispersas além várzeas. Como ocorre 
nos demais trechos citados, loteamentos irregulares e favelas ocuparam setores de várzeas de terraços até as margens do Rio Tietê.

Dessa forma, embora a ocupação das várzeas do Tietê assuma, em alguns casos, uma fisionomia de dispersão urbana, o que se verifica efetivamente é uma tendência de cerzidura de tecidos urbanos anteriormente dispersos, ou seja, uma característica de ligação e contigüidade dos usos urbanos instalados em compartimentos de terraços e colinas.

\subsubsection{As várzeas do Rio Jundiaí.}

O Rio Jundiaí apresenta em seu percurso a formação de duas planícies aluviais mais pronunciadas, sendo a maior delas controlada por soleira granítica existente após a cidade de Itupeva. A outra planície, situada a jusante dessa mencionada, ocorre já no contato dos relevos de colinas cristalinas com as colinas sedimentares da Depressão Periférica, entre Indaiatuba e Salto, e apresenta 6 km de extensão e largura variando entre 500 metros e 1 km. Éstá delimitada por uma ferrovia, de um lado, e por área industrial do município de Indaiatuba, de outro, tendo pequenos trechos ocupados por setores dessa área industrial.

Figura 8.25 - Planície Aluvial do Rio Jundiaí e principais divisores de águas locais. Jundiaí/SP.

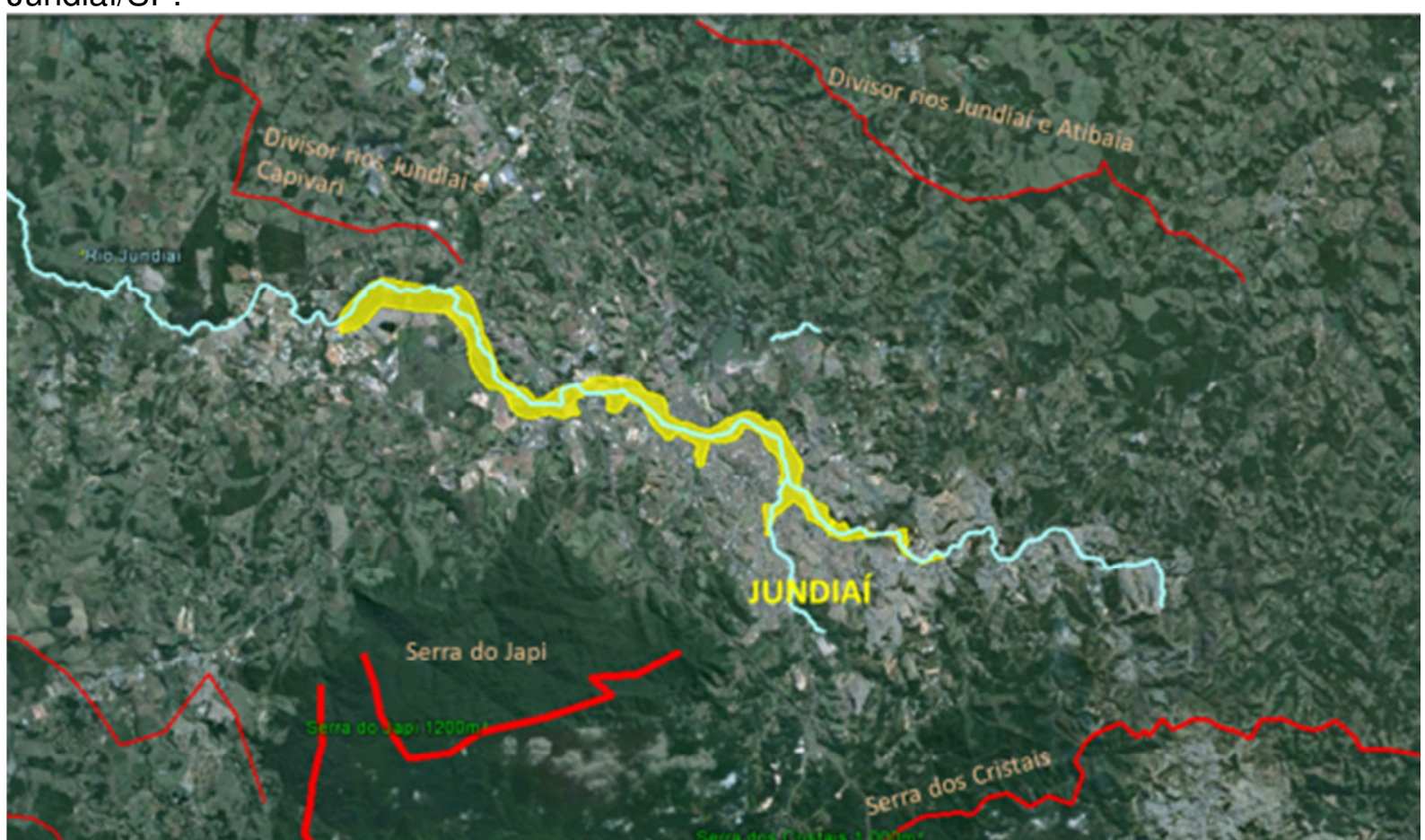

Fonte: imagem (20/07/2011) e recursos gráficos do Google Earth. Informações acrescentadas pelo autor. 
Já a planície mais extensa apresenta um percurso de aproximadamente 20 km e largura média de 500 a 600 metros. Inicia-se e Várzea Paulista e se entende até a cidade de Itupeva, passando pela área urbana de Jundiaí.

Em Várzea Paulista, essa planície aluvial tem suas várzeas ocupadas parcialmente por uso industrial, que faz a junção da mancha compacta da sede da cidade com bairro de ocupação mais recente. Esta área industrial se une com outras áreas industriais que existem a montante, na direção de Campo Limpo Paulista, ocupando o setor de fundo de vale que não formou planíciue aluvial. É essa ocupação industrial que proporcionou a conurbação dos tecidos urbanos de Várzea e de Campo Limpo Paulista.

Figura 8.26 - Ocupação urbana na planície aluvial do Rio Jundiaí entre Várzea Paulista e Itupeva (delimitada pela linha amarela).

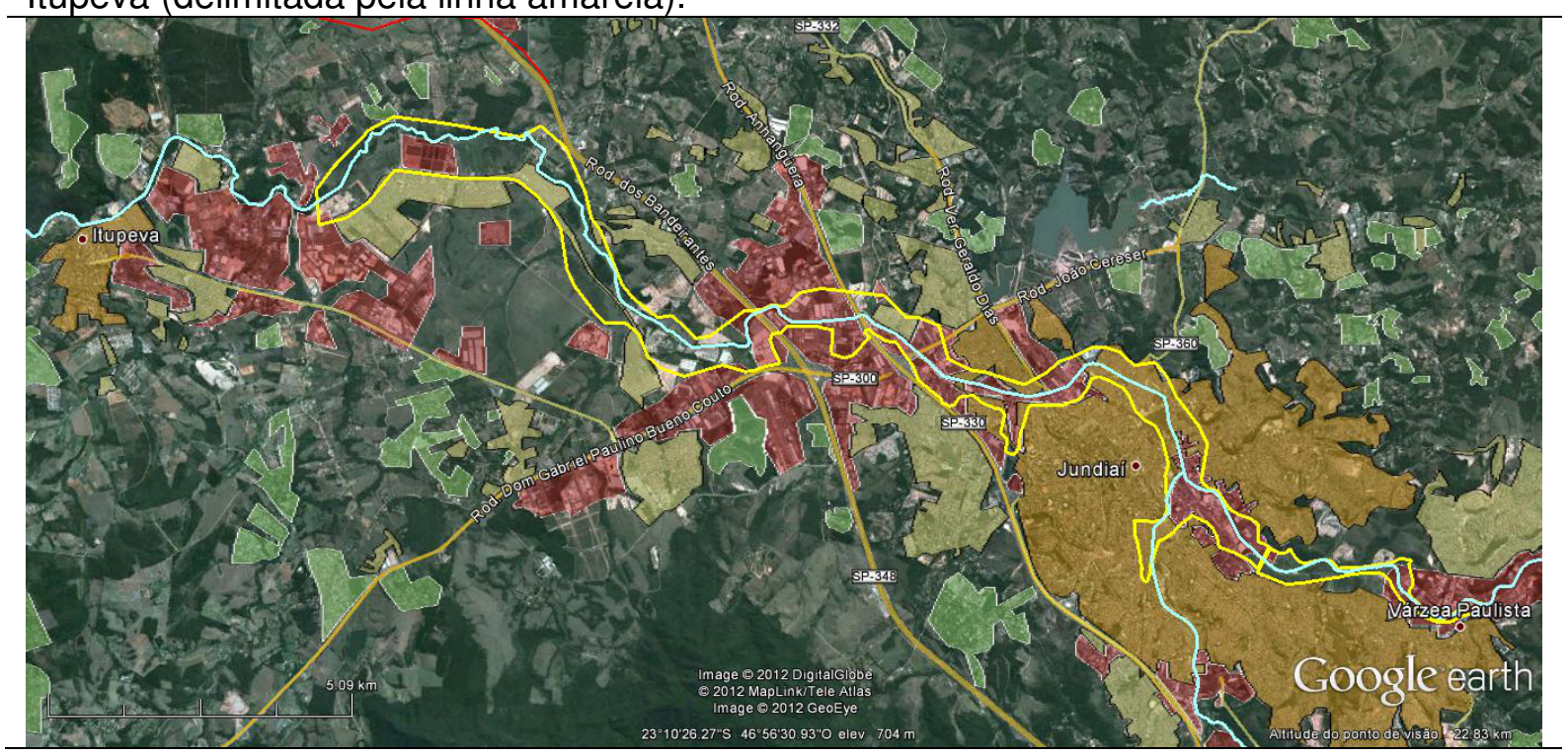

Fonte: imagem e recursos gráficos do Google Earth. Informações acrescentadas pelo autor.

Entre Várzea Paulista e Jundiaí esse compartimento de várzea apresenta um pequeno trecho (apenas $2 \mathrm{~km}$ ) livre de ocupação urbana. Após esse trecho, em todo o percurso de $11 \mathrm{~km}$ ao longo da cidade de Jundiaí, essa várzea encontra-se toda ocupada por usos industrial e bairros populares de baixo e médio padrão, incluindo conjuntos habitacionais. Trata-se de uma ocupação altamente vulnerável a eventos de enchentes em face da ocupação industrial existente a montante e do aumento da impermeabilização do solo em virtude do crescimento da área urbana da cidade, tanto a compacta como a das peças urbanas dispersas. Portanto, nesse trecho da 
cidade de Jundiaí a ocupação das várzeas promoveu a cerzidura dos tecidos urbanos da cidade compacta.

Figura 8.27 - Conjunto dop CDHU construído nas várzeas do Rio Jundiaí, em Jundiaí, e trecho da várzea ainda não ocupada por usos urbanos.

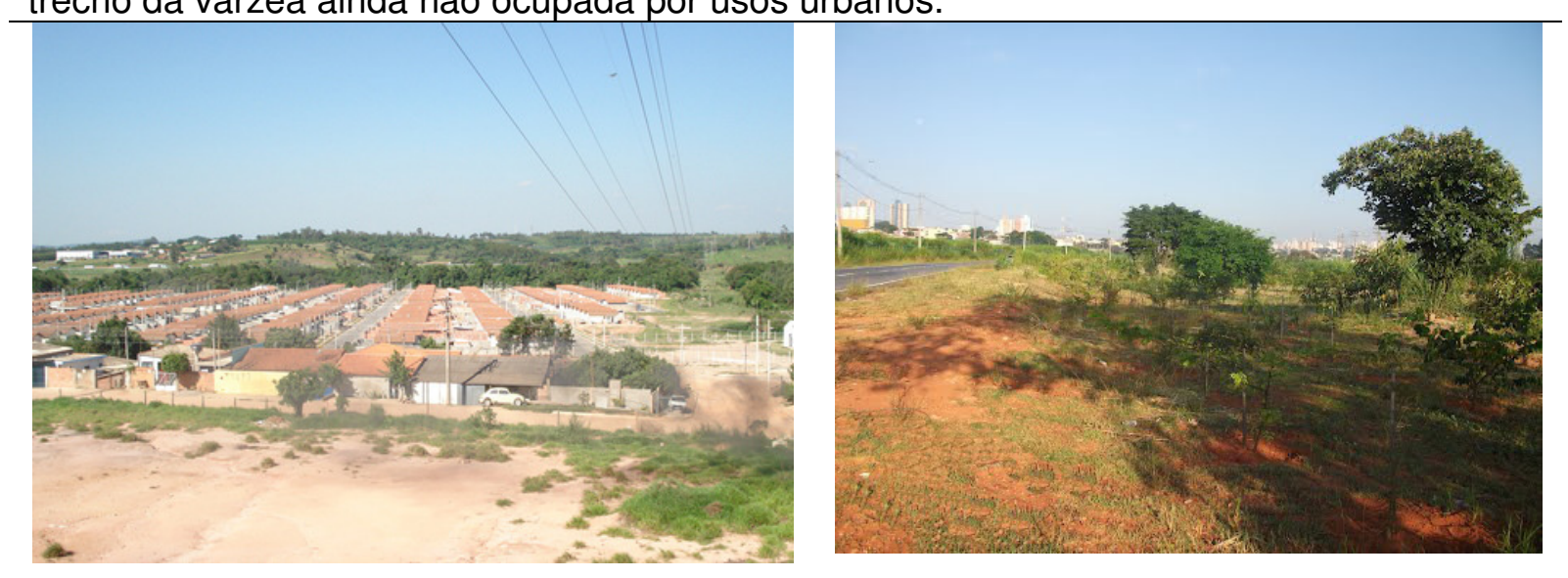

Fonte: Google Earth - Panoramio.

Após a Rodovia dos Bandeirantes, entre Jundiaí e Itupeva, essa várzea 9 km de percurso intercalando trechos sem ocupação urbana com trechos ocupados por mineração, estação de tratamento de esgoto, área industrial e bairros populares tipo CDHU e favelas. É a Avenida Jovino Furkim ou Estarda do Varjão que estrutura essa expansão urbana. Trata-se de uma efetiva dispersão urbana, mas que apresenta todos os indícios de uma futura conurbação entre os tecidos de Jundiaí e Itupeva. Uma imensa favela se estende ao longo de $3 \mathrm{~km}$ da avenida citada e, paradoxalmente, um conjunto habitacional de baixa renda foi construído pelo poder público (CDHU Novo Horizonte) em uma área sabidamente considerada de fragilidade ambiental, ocupando assim uma área de APP que a legislação ambiental orienta proteger.

Ná área urbana de Itupeva, a planície aluvial se restringe bastante em largura. No entanto, existem vários bairros instalados às margnes do Rio Jundiaí.

\subsubsection{As várzeas do Rio Atibaia.}

A planície aluvial do Rio Atibaia apresenta expressivos $30 \mathrm{~km}$ de extensão, mas uma largura média pouco pronunciada, em torno de 500 metros. Em apenas 2 $\mathrm{km}$ essa planície ficou afogada pelo represamento da Usina, que criou uma área de 
lazer de esportes náuticos. Neste trecho a rodovia D. Pedro I tem seu traçado paralelo ao Rio Atibaia.

Essa planície inicia sua formação um pouco antes da cidade de Bom Jesus dos Perdões, passa ao lado da sede de Atibaia e termina nas proximidades da Rodovia Edgar Máximo Zambotto, que liga a D. Pedro I a Jarinu. Em todo esse percurso nota-se que essas várzeas atraem tanto a ocupação de usos urbanos da cidade compacta - industrial epopular de baixa renda - como condomínios fechados de alta renda. Mas, o uso dominante ainda é de caráter rural.

Em Bom Jesus dos Perdões o setor de várzeas foi invadido por duas peças urbanas dispersas, uma de uso industrial e outa residencial, tipo condomínio fechado.

Figura 8.28 - Planície aluvial do Rio Atibaia (delimitada pela linha amarela)

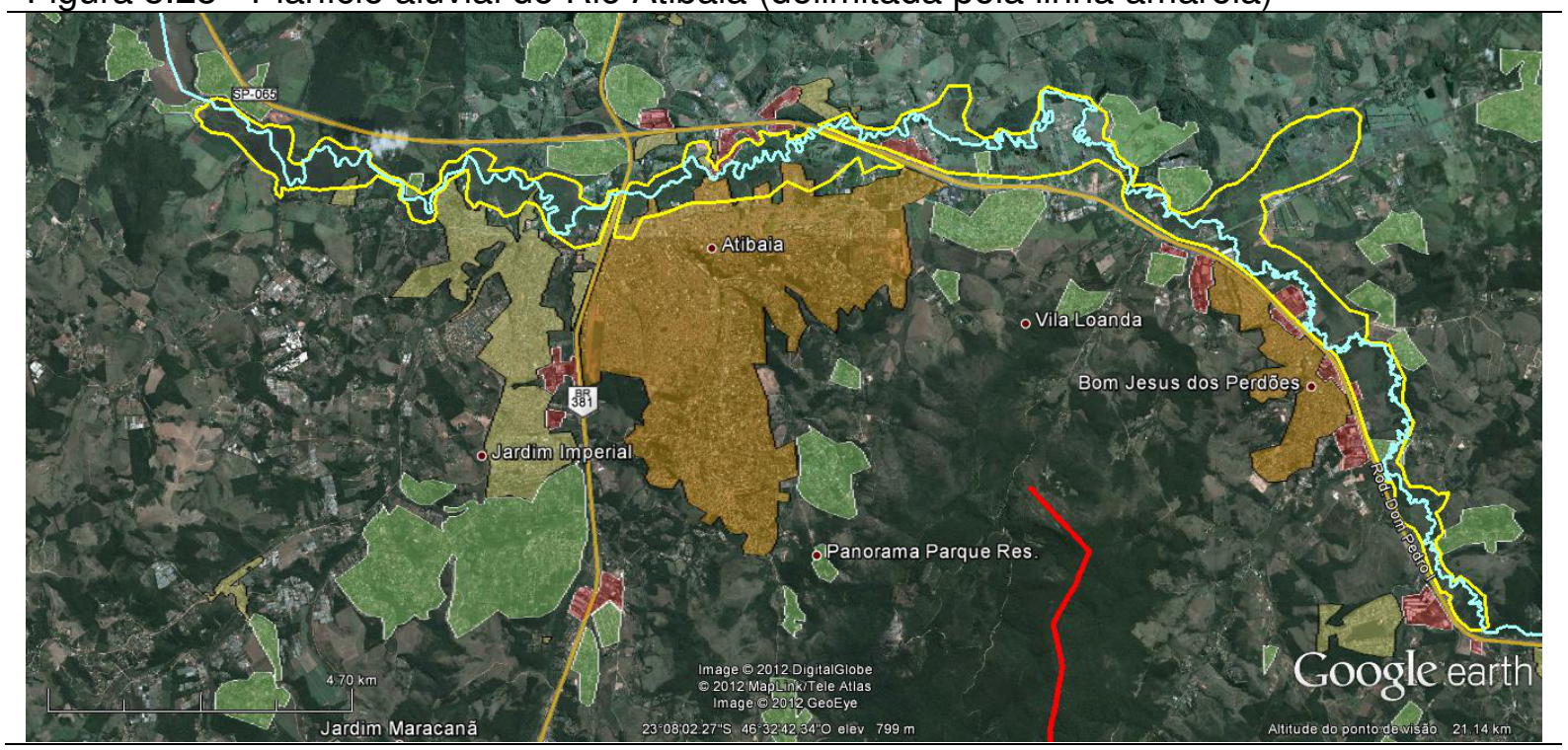

Fonte: imagem e recursos gráficos do Google Earth. Informações acrescentadas pelo autor.

No município de Atibaia a várzea apresenta todos os tipos de ocupação, de maneira esparsa e ainda pouco adensada. São sete condomínios fechados de alto padrão, de tipologia de chácaras ou semelhantes a bairros-jardimda cidade compacta. Pequenos trechos são coupados por uso industrial, disperso. Outros dois são ocupados por extensão de favelas, distantes da área central da cidade e do trecho de tecido urbano compacto. Alguns bairros da cidade de Atibaia, próximos ao centro se estenderam para setores das várzeas contíguos à sede da cidade. 
Quatro dos sete condomínios fechados citados ocupam as margens da represa da Usina, mas situados em setores de terraços ou colinas. Já o Condomínio Shambala, de alto padrão, tem a área do clube e algumas residências situadas no compartimento de várzeas.

No Bairro de Caetetuba formou-se uma expressiva ocupação popular, caracterizado por loteamentos de baixa e média-baixa renda, e presença de favelas que se dirigem para o setor de várzeas.

A vulnerabilidade de todas essas ocupações pode ser ilustrada pela Figura $x x$ que mostra a enchente ocorrida em 2009, em que as várzeas ficaram com trechos encharcados ou alagados, exercendo a sua função natural precípua dentro do contexto da fisiologia da paisagem. Entretanto, não se pode esquecer que essa vulnerabilidade é bastante diferenciada, pois abrangeu condomínios típicos de $2^{\underline{a}}$ moradia e as residências permanentes das classes populares.

Figura 8.29 - Condomínio Shambala II, ocupando trechos de várzeas do Atibaia.

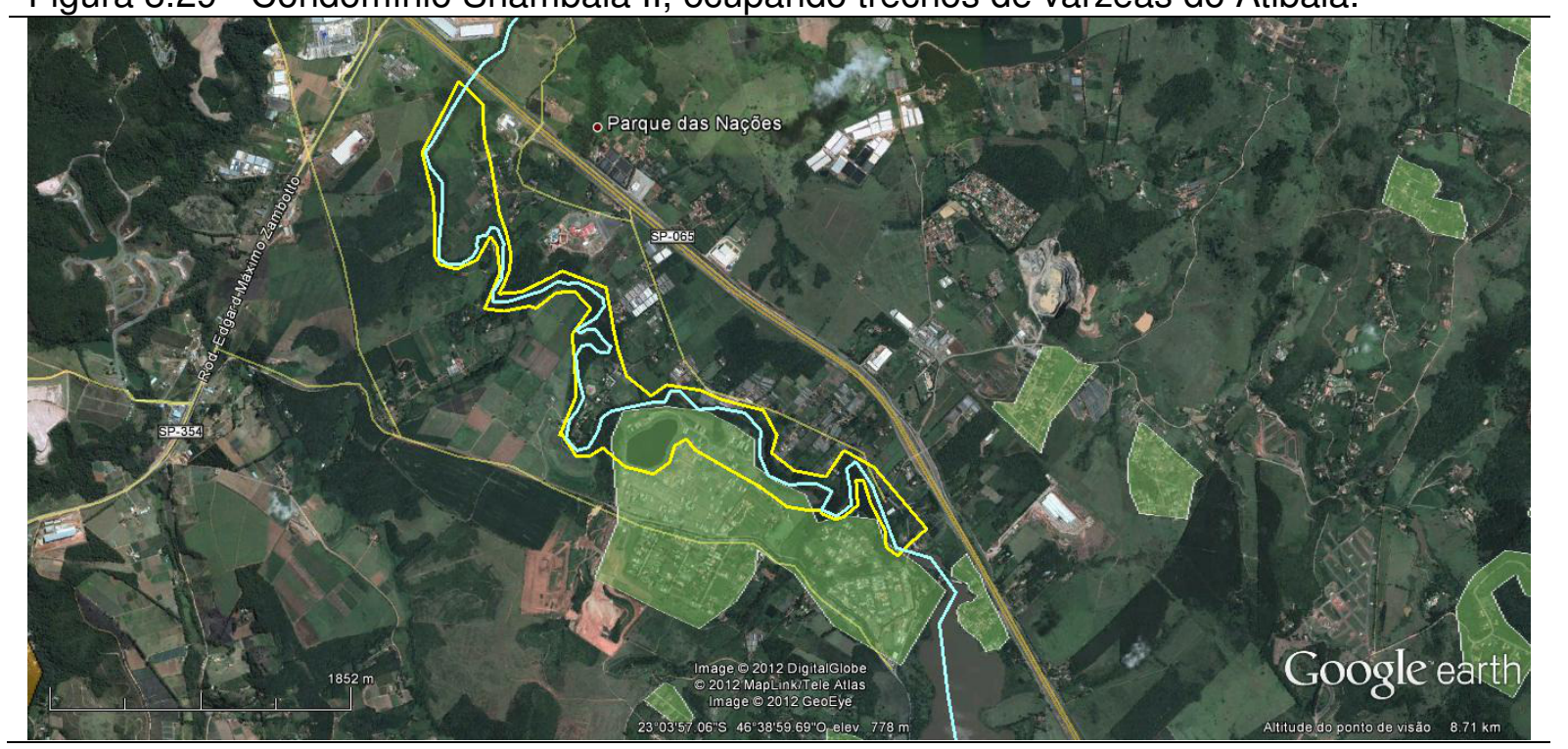

Fonte: imagem e recursos gráficos do Google Earth. Informações acrescentadas pelo autor.

Assim, diferente do que foi analisado nas outras duas planícies aluviais analisadas, essas várzeas do Rio Atibaia são objeto da ocupação dispersa que ainda não apresenta um conteúdo de conurbação, de colmatação do tecido urbano. Diferente das outras duas várzeas analisadas, nessa existe uma presença considerável de condomínios fechados de alta renda que exploram 
paisagísitcamente a relação com água, por meio da proximidade do rio, das lagoas ou de represas construídas.

Figura 8.30 - Enchente do Rio Atibaia em 2009, que alagou o setor de várzeas situadas ao lado do Jd. Suely, em Atibaia.

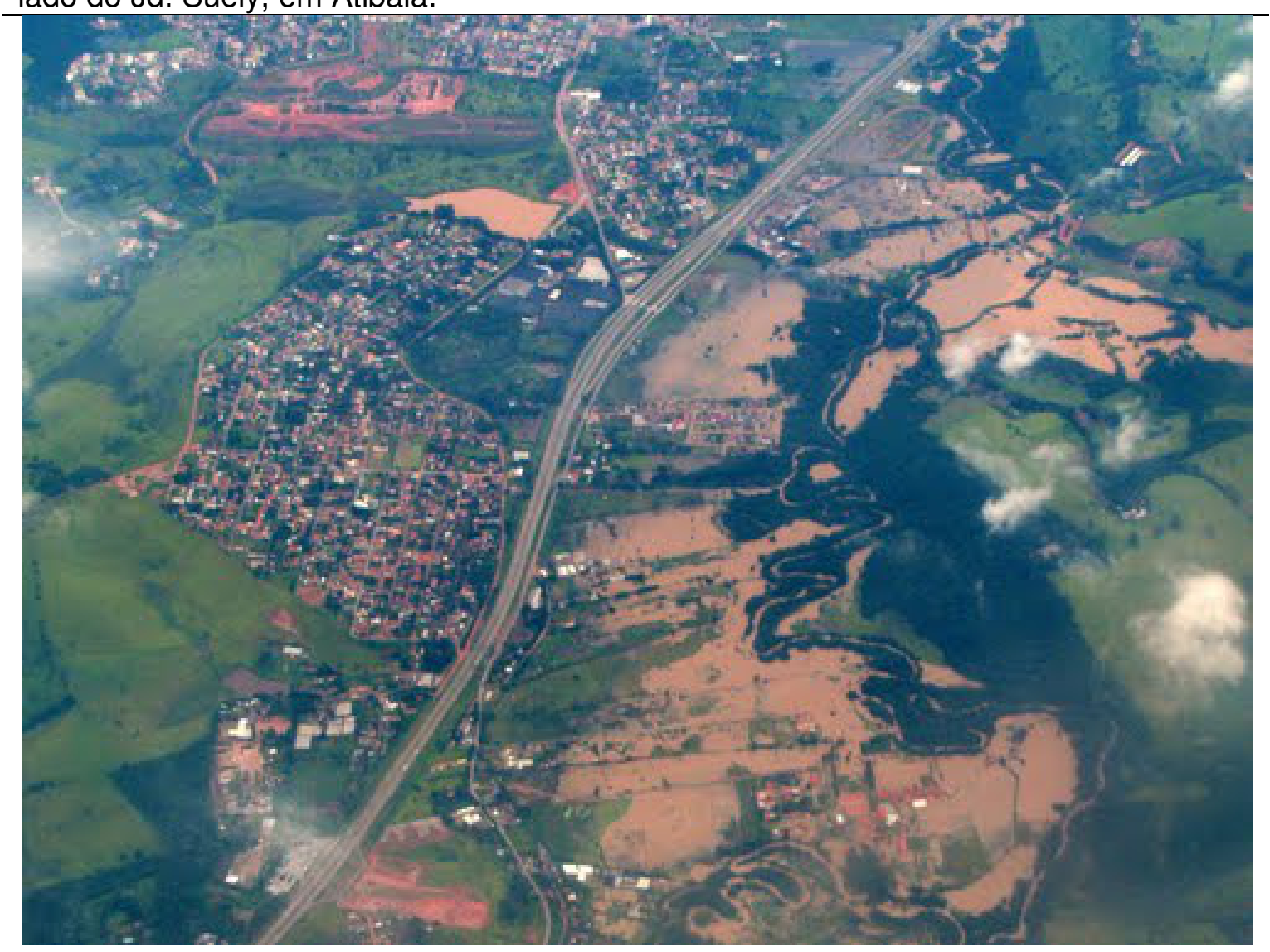

Fonte: Google Earth - Panoramio.

8.2.4. As várzeas do Rio Paraíba do Sul.

Um pouco após o cruzamento da Via Dutra com a D. Pedro I incia-se a descida dos morros do Planalto Atlântico na direção da Bacia Sedimentar do Rio Paraíba do Sul. Apresentando um desnível médio de 80 metros, atinge-se a cota de 566-568 metros, com o Rio Paraíba passando a 565 metros de altitude.

A vista para a cidade de Jacareí revela que esta tem boa parte de seu tecido urbano sobre a planície aluvial quaternária. Bairros residenciais importantes da cidade compacta de Jacareí estão assentados sobre o compartimento de várzeas (Jd. Flórida), como parte do próprio centro da cidade. A ocupação industrial também é expressiva, e ela ocorre contígua ao tecido urbano da sede. 
A ocupação da várzea do lado esquerdo da Via Dutra (sentido Rio de Janeiro) já se caracteriza pelo seu conteúdo de dispersão de usos industrial e residencial das camadas populares. Dois loteamentos de baixa renda ocupam as várzeas, sendo que um deles se situa entre cavas de exploração de areia, chegando até as margens do Rio Paraíba, praticamente 1 metro acima do leito do rio.

Em São José dos Campos a ocupação das várzeas é pouco expressiva, observando-se apenas um pequeno loteamento de alto padrão. Neste trecho em que o Rio Paraíba atravessa São José dos Campos a planície aluvial é seccionada por colinas ou terraços terciários, que servem como nível de base do trecho de planície a montante, vindo de Jacareí. Neste ponto o tecido urbano de São José encosta nas duas margens do rio.

Embora a dispersão urbana se apresente bem configurada e espalhada em São José dos Campos, ela não atinge esse setor ambiental estruturante. Espalha-se pelas colinas terciárias do entorno da cidade compacta sob todas as tipologias de peças dispersas já apresentadas (industrial, bairros de classe média e populares, e condomínios fechados das camadas de alta renda. Essa dispersão também se dirige para a morraria do sopé da Serra da Mantiqueira, no caminho de Monteiro Lobato.

A mesma situação verificada em São José em relação à planície aluvial quaternária vai ocorrer nas demais cidade do Vale do Paraíba estudadas (Caçapava, Taubaté, Tremembé e Pindamonhangaba). As várzeas não participam como suporte físico do processo de dispersão, e são utilizadas para práticas agrícolas, em especial a cultura do arroz, exploração de areia e argila, e pequenos trechos de pastagem.

\subsubsection{As bordas de represas}

Já em relação à dispersão de peças urbanas sobre as bordas de reservatórios é mais significativa em alguns dos vetores analisados. Cabe salientar que essas represas construídas predominantemente para a regularização do abastecimento de água, afogaram setores de fundo de vale encaixados e de pequenas planícies aluviais restritas. Pode-se dizer que se trata, assim, de um uso 
de interesse urbano, participante então das dinâmicas de urbanização do território. Pode ser considerado como um típico exemplo de serviços ambientais prestados por estes compartimentos de relevo.

Nesse sentido, eles ganham relevância ambiental estratégica quando implantados, passando a ser regulados por princípios de proteção de mananciais. Nos rios analisados alguns reservatórios dessa natureza foram implantados, como:

$\checkmark$ Represa de Itupararanga, no Rio Sorocaba, em Ibiúna;

$\checkmark$ Represa de Paiva Castro, no Rio Juqueri, em Mairiporã e Caieiras;

$\checkmark$ Represa do Jaguari, no rio do mesmo nome, em Igaratá;

$\checkmark$ Represa Billings, nos rios Grande e Pequeno, em Santo André, São Bernardo, Diadema e São Paulo;

$\checkmark$ Represa Guarapiranga, no rio do mesmo nome, em São Paulo;

$\checkmark$ Represa de Nazaré Paulista, Rio Atibaia e Atibainha,

$\checkmark$ Analisando-se sob a ótica da preservação e proteção de mananciais a intensificação da ocupação das bordas dessas represas poderá resultar em prejuízos ambientais consideráveis, que começam operar a partir do desmatamento que as ocupações de fins urbanos, e até de loteamentos de chácaras, realizam na sua instalação. Dentre esses prejuízos pode-se salientar a aceleração de processos erosivos, do assoreamento das represas e diminuição de volume de retenção, aumento do escoamento superficial e da carga de poluição difusa dos usos urbanos.

$\checkmark$ A ocupação das margens de represas que se verifica na macrometrópole, nesses reservatórios citados apresenta nuances distintas. De um lado, para alguns reservatórios se dirige uma ocupação dispersa das camadas de alta renda, configuradas por tipologias de chácaras ou de condomínios fechados de padrão urbano. Isso acontece predominantemente no entorno das represas de Atibaia e Atibainha; Itupararanga, Paiva Castro e Jaguari.

De outro lado, para outros reservatórios se aproximam tipologias mistas em relação ao padrão de urbanização e de renda, apresentando tanto setores dominados por loteamentos de baixa e de média renda, configurando novos bairros dispersos; como condomínios fechados de alta renda. Isso está acontecendo no entorno dos reservatórios Billings e Guarapiranga. 
Assim, nos reservatórios mais distantes da metrópole de São Paulo, são exclusivamente os condomínios fechados de alto padrão que predominam, enquanto nos reservatórios mais próximos têm-se uma atração mista, de alta e de baixa renda.

Figura 8.31 - Entorno da represa de Jaguari, Rio Jaguari, em Igaratá.

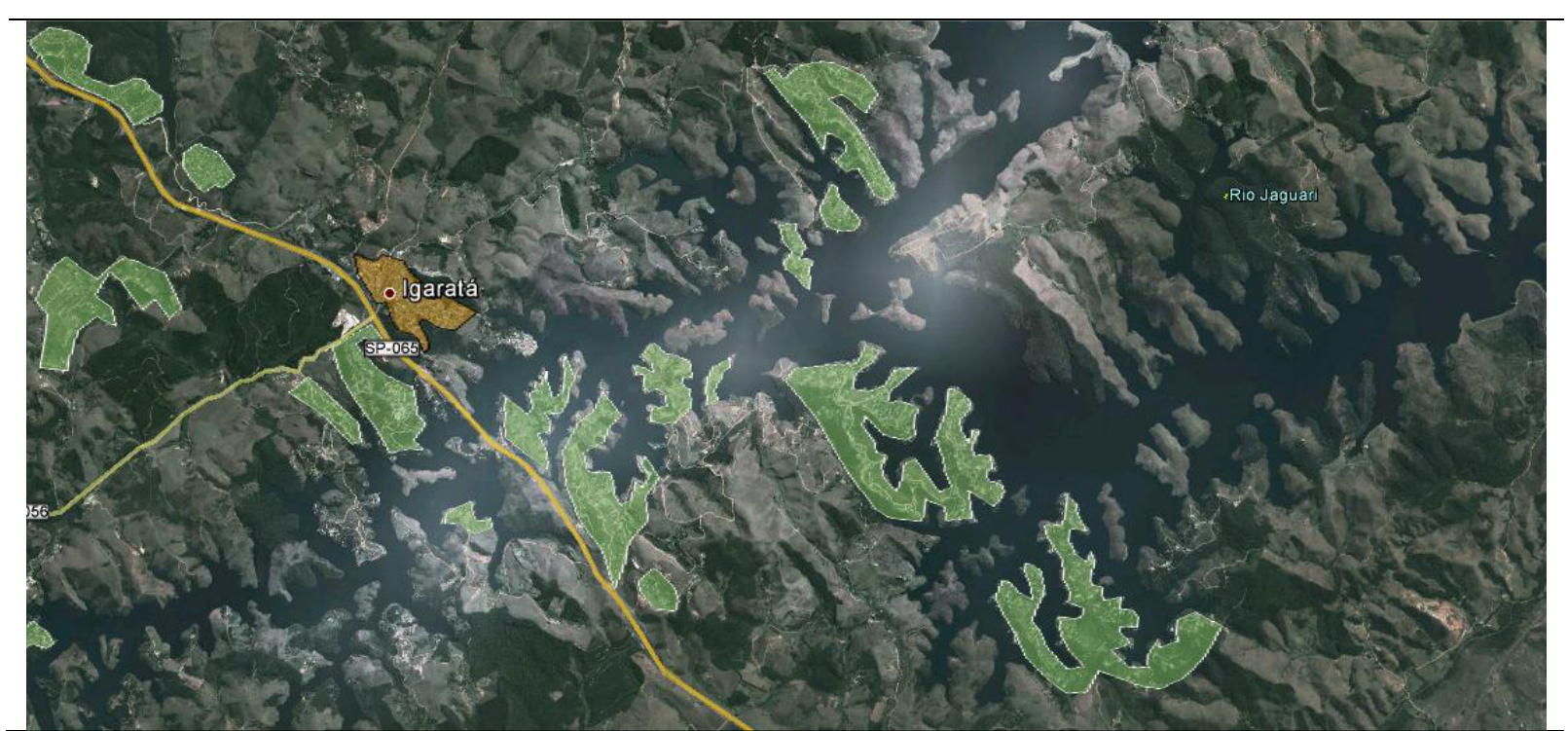

Fonte: imagem e recursos gráficos do Google Earth. Informações acrescentadas pelo autor.

Figura 8.32 - Entorno da represa Paiva Castro, Rio Juqueri, em Mairiporã.

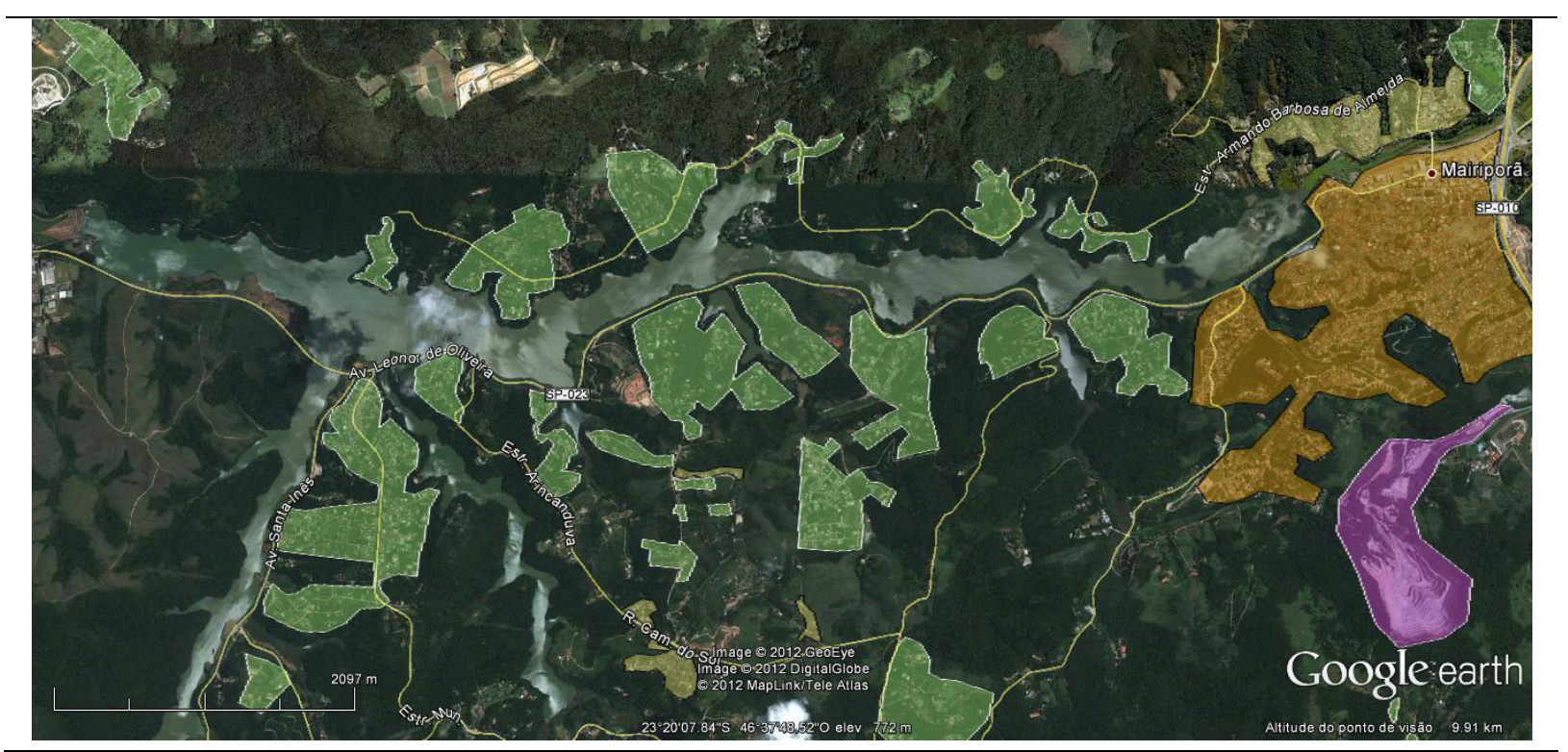

Fonte: imagem e recursos gráficos do Google Earth. Informações acrescentadas pelo autor. 
Figura 8.33 - Entorno da represa Itupararanga, Rio Soirocaba, em Ibiúna.

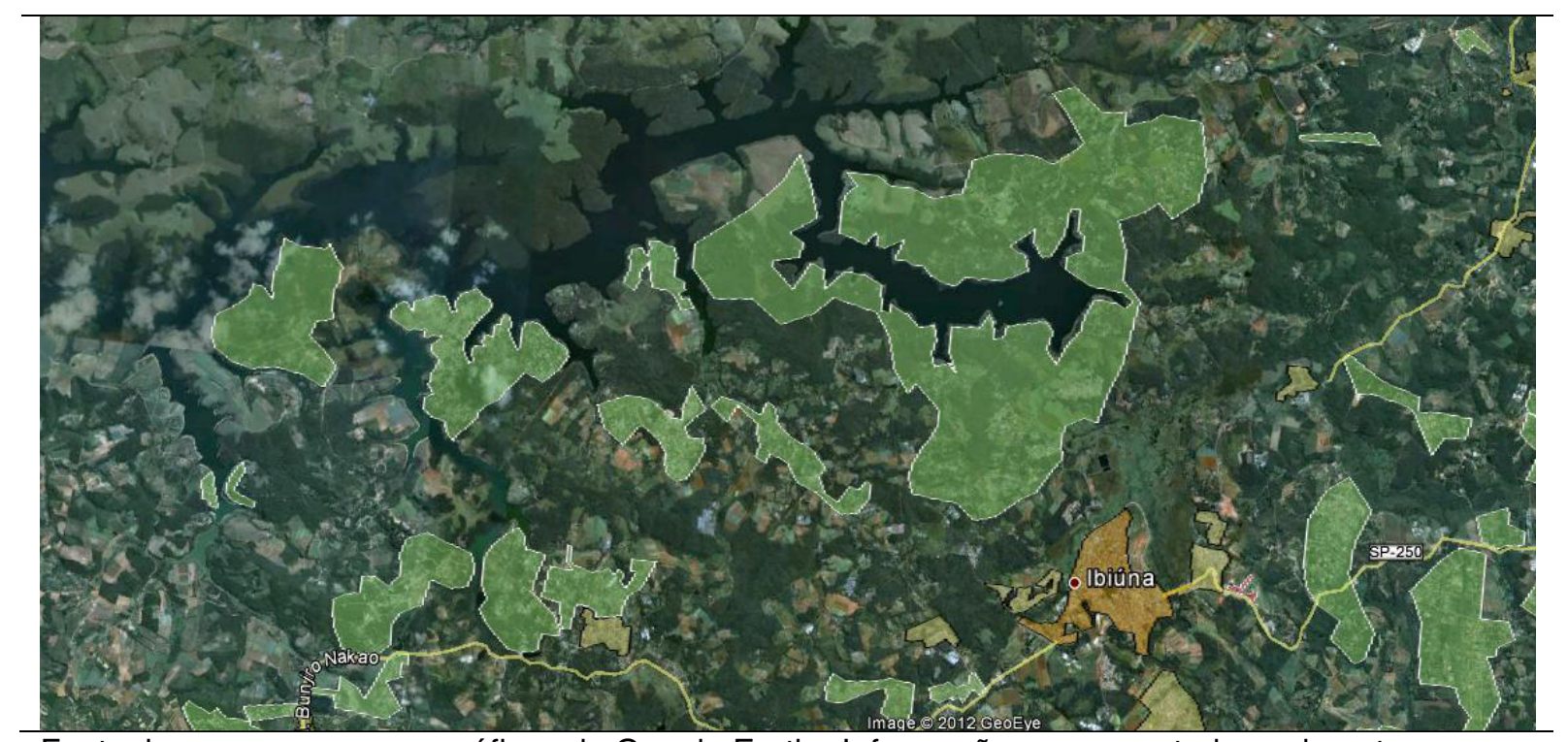

Fonte: imagem e recursos gráficos do Google Earth. Informações acrescentadas pelo autor.

Figura 8.34 - Entorno da represa de Billings, em São Paulo, São Bernardo e Santo André.

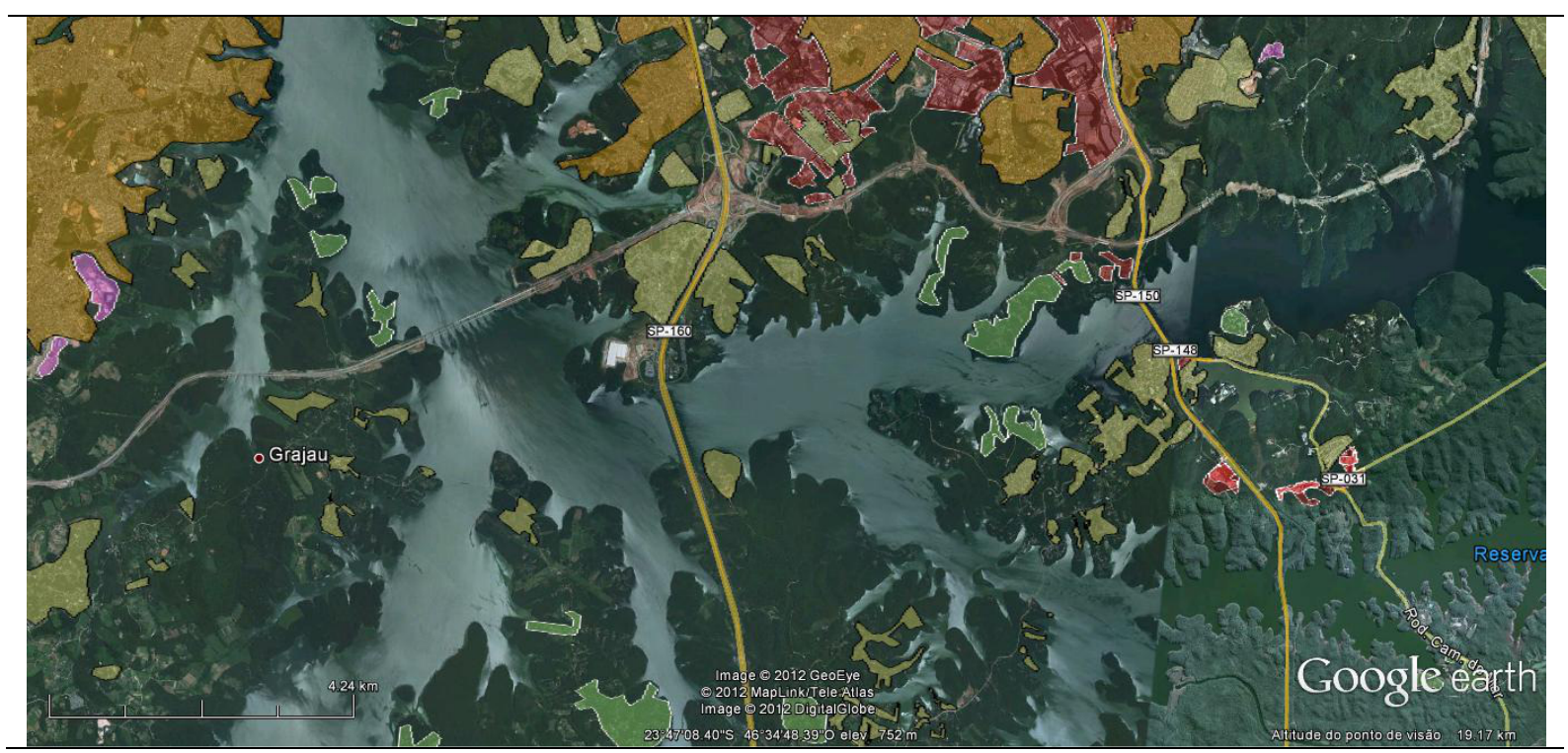

Fonte: imagem e recursos gráficos do Google Earth. Informações acrescentadas pelo autor. 


\section{CONCLUSÃO}

O processo de dispersão urbana que se verifica na Macrometrópole de São Paulo se configura por abranger tendências contraditórias entre essa nova fase de urbanização da virada do século e a questão ambiental, hoje muito mais inserida no discurso dominante de todas as práticas sociais. O ideal de sustentabilidade e de melhor relação e contato com a natureza é assimilado pelo discurso de uma nova forma de viver, de uma nova cidade, cidade esta muito mais verde e inserida na natureza. A dispersão urbana atende alguns princípios deste discurso, por separar peças urbanas através da presença de setores rurais ou outras formas de áreas verdes entre as ocupações urbanas.

Pelo que se verificou neste trabalho, as peças urbanas que se dispersam pouco se diferenciam de suas congêneres da cidade compacta, não apresentando situação de desenho urbano inovador em relação à apropriação do sítio em que se instalam, e nem mesmo em suas qualificações internas de permeabilidade do solo, preservação de anfiteatros de nascentes, cobertura vegetal, ou áreas de preservação contíguas que evitassem, no futuro, a conurbação com outras peças urbanas dispersas, além de outros atributos de caráter mais ecológico.

O fato é que, semelhante ao que aconteceu na cidade compacta, que se adensa indiscriminadamente a partir da ocupação de todos os compartimentos ambientais de um sítio ou de um território, o processo de dispersão atual não faz muita distinção entre os diversos compartimentos que ocupa. A dispersão está se dirigindo para todos os setores de relevo da macrometrópole, dos mais favoráveis aos mais frágeis, dos mais relevantes ambientalmente aos menos impactantes. Assim, é que se verificou que essa dispersão se dirige para setores geomorfológicos estratégicos para a regulação ambiental do território, como o são os principais alinhamentos serranos e as principais várzeas da rede de drenagem da região.

Alguns outros aspectos que se relacionam com a ecologia da paisagem é que essa dispersão também acentua a fragmentação da paisagem e da cobertura vegetal, dificultado a regeneração florestal e a recuperação de possíveis corredores de flora e fauna. Paradoxalmente, ante a diminuição dos espaços de natureza 
promovidos pela intensa urbanização do território, os últimos remanescentes se tornam o alvo do contraditório interesse da sociedade em se aproximar dessas áreas de amenidades. A vinculação de interesses do mercado imobiliário e das camadas de alta renda se apropria de áreas de relevante interesse ambiental, em que não existem garantias de controle de adensamento dessa ocupação no futuro.

Em muitos casos verificados nessa dispersão que ocorre na macrometrópole de São Paulo, conforme expresso por Limonad (2007), está implícito nesse processo a tendência de conurbação, ou seja, a dispersão como linha de frente de uma nova conurbação. E isso fica evidente no continuado processo de ocupação das várzeas, no duplo sentido: um de dispersão, galgando novos setores; e outro de cerzidura de tecidos anteriormente dispersos, realizados não somente em colinas e morros, mas também e inclusive nos frágeis e importantes comparimentos de várzeas.

Dessa forma, é possível perceber que, ante a mudança de escala dessa nova forma de urbanização do território, faz-se necessário, também, uma mudança de escala do planejamento territorial urbano e do planejamento ambiental urbano. Verificou-se que existem questões locais e outras que são regionais, entretanto a apropriação do relevo na região se dá por meio de vinculações de interesses locais. Assim é que esses alinhamentos ambientais importantes, composto pelas serras e várzeas, vão sendo ocupados e fragmentados visual e ecologicamente.

Os dados da dispersão urbana e as taxas de crescimento populacional evidenciaram que a situação é preocupante no alinhamento da Serra da Cantareira, pois os municípios de Mairiporã e Santana do Parnaíba apresentaram taxas de crescimento populacional elevadas, acima de 3\%, o que pode indicar que a pressão para a ocupação desses setores de amenidades paisagísticas tende a continuar.

O mesmo se pode dizer para a pressão que deverá continuar, e aumentar, no compartimento ambiental estruturante da paisagem composto pelos divisores dos rios Juqueri e Jundiaí. A Serra do Japí, embora regulada por leis de proteção, já vem sofrendo pressão pela ocupação de seu entorno. As taxas de crescimento anual da população de Itupeva $(5,5 \%)$ e Cabreúva $(2,3 \%)$ foram elevadas no período 2000 2010, fato preocupante em termos ambientais. 
O estudo verificou algumas diferenças importantes na relação entre dispersão/concentração com os compartimentos ambientais estruturantes. No caso dos alinhamentos serranos o processo de dispersão é evidente. Já em relação aos fundos de vale, e notadamente sobre as várzeas, a tendência é pela conurbação do tecido urbano, ou seja, por uma nova compactação pela junção de antigas peças dispersas.

Como também explicitado, os principais vetores de dispersão continuam ocorrendo estruturados ao longo das rodovias Anhanguera-Bandeirantes, Raposo Tavares e Fernão Dias, o que coloca em evidência a pressão sobre os compartimentos ambientais dos principais divisores da rede de drenagem das bacias do Juqueri, Jundiaí, Atibaia e Tietê.

Portanto, é possível afirmar que a dispersão urbana, na forma como vem ocorrendo na Macrometrópole de São Paulo, deverá acirrar os problemas ambientais já existentes, pois agrega tendências de apropriação do relevo preocupantes em termos ambientais para a região como um todo, tanto em termos de ocupação dos compartimentos ambientais estruturantes da macrometrópole, como também em termos do próprio desenho dos tecidos urbanos que se dispersam, que pouco agregam valores ambientais, pois pouco se diferenciam dos tecidos similares da cidade compacta.

De outro lado, a tentativa de abordagem estratégica do relevo para fins de planejamento de uso e ocupação do território, empreendida a partir de categorias da análise geomorfológica, revela situações que merecem maior reflexão e que visam colaborar na distinção de para onde se deve dirigir a expansão urbana em sua interface com os processos naturais. De outro lado, essa abordagem estratégica do relevo, que se sustenta na tríade clássica da pesquisa geomorfológica - a compartimentação do relevo, a estrutura superficial e a fisiologia da paisagem acena para a orientação de aprofundamento das pesquisas e da discussão sobre esses compartimentos ambientais estruturantes, que poderão revelar detalhes empíricos mais contundentes acerca dos problemas ambientais futuros da macrometrópole de São Paulo. 


\section{REFERÊNCIAS BIBLIOGRÁFICAS}

AB'SABER, A.N. O sítio urbano de São Paulo, In: A Cidade de São Paulo Estudos de Geografia Urbana, v.1. Organizado por Aroldo de Azevedo. São Paulo: Cia Editora Nacional, 1958.

Da participação das depressões periféricas e superfícies aplainadas na compartimentação do Planalto Brasileiro. Tese de livre-docência FFLCH/USP. São Paulo, FFLCH, 1965.

Bases geomorfológicas para o estudo do quaternário no Estado de São Paulo. Tese FFLCH/USP. São Paulo, FFLCH, 1968.

. Um conceito de Geomorfologia a serviço das pesquisas sobre o Quaternário. In: Geomorfologia, 18. São Paulo, IGEOG/USP, 1969.

Aspectos do planejamento do uso e ocupação do solo. In: Cong. Bras. de Geol. de Eng., 4 -B.H - Anais. Belo Horizonte, ABGE, 1984.

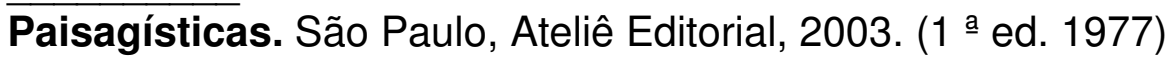

ABRAMOVAY, R. Agricultura familiar e desenvolvimento territorial. Reforma Agrária - Revista da Associação Brasileira de Reforma Agrária - vols. 28 nํs 1,2 3 e 29, no1 - Jan/dez 1998 e jan/ago 1999. Disponível em: econ.fea.usp.br. Acessado em Outubro de 2008.

ABREU, A.A. A teoria Geomorfológica e sua edificação: análise crítica. Revista Instituto de Geografia/USP, 4, pp 5-23. São Paulo: Depto de Geografia/USP, 1983.

Significado e propriedades do relevo na organização do espaço. Boletim de Geografia Teorética, 15. São Paulo: Depto de Geografia/USP, 1985.

Considerações a respeito dos fundamentos conceituais das classificações geomorfológicas utilizadas no Brasil. Boletim de Paulista de Geografia, 63. São Paulo: AGB São Paulo, 1986.

Ação antrópica e propriedades morfodinâmicas do relevo na área metropolitana de S. Paulo. In: Orientação. São Paulo, n. 7, IGEOG/USP, 1986.

Do páteo do colégio ao planalto paulistano: problemas geomorfológicos emergentes do Município de São Paulo. In: Problemas Geológicos e Geotécnicos na RMSP. São Paulo, Abas/ABGE/SBG-SP, 1992.

O papel do clima na evolução do relevo: a contribuição de Julius Büdel. Revista Depto Geografia, 19, pp 111-118. São Paulo: Depto de Geografia/USP, 2006.

Geomorfologia do sítio urbano de São Paulo. Edição fac-similar 50 anos da Tese de doutoramento - FFLCH/USP. São Paulo: Ateliê Editorial, 2007. 
ALMEIDA, F.F.M. O Planalto Paulistano. In: A Cidade de São Paulo - Estudos de Geografia Urbana,v. 1. Organizado por Aroldo de Azevedo. São Paulo: Cia Editora Nacional, 1958.

AMARAL, C. \& FEIJÓ, R.L. Aspectos ambientais dos escorregamentos em áreas urbanas. In: Reflexões sobre a Geografia Física no Brasil. Antonio Carlos Vitte e Antonio José Teixeira Guerra (orgs), p. 193-224. Rio de Janeiro: Bertrand Brasil, 2011.

ANTROP, M. Sustainable Landscapes: contradiction, fiction or utopia? In: Landscape and Urban Planning, 75, 2006, p. 187-197. Disponível em http://www.scribd.com/doc/22642775.Acesso em 20/02/2010.

ARANTES, O. Urbanismo em fim de linha. E outros estudos sobre o colapso da modernidade arquitetônica. São Paulo: EDUSP, 1998.

ASSIS, L.F. Do território à multiterritorialidade: reflexões sobre o lazer e o turismo em segundas residências no nordeste brasileiro. In: Geousp - Espaço e Tempo, nr 26, PP 45-58. São Paulo: FFLCH/USP, 2009.

AZEVEDO, A. (org). A Cidade de São Paulo: estudos de geografia urbana. São Paulo: Cia Editora Nacional, 1958.

AZEVEDO, T.R. Os fluxos de calor gerado pelas atividades humanas. In: Os climas na cidade de São Paulo: teoria e prática. Org. José Roberto Tarifa e Tarik R. de Azevedo. São Paulo, USP, 2001.

BADARÓ, R.S.C. Campinas: o despertar da modernidade. Campinas: Área de Publicações CMU/UNICAMP, 1996.

BERMAN, M. Tudo que é sólido desmancha no ar - A aventura da modernidade. São Paulo: Cia das Letras, 1986.

BERTALANFFY, L.V. Teoria Geral dos Sistemas. Petrópolis: Vozes, 1973.

BERTRAND, G. Paisagem e Geografia Física Global: Esboço Metodológico. Caderno de Ciências da Terra, n. 13, trad. Olga Cruz. São Paulo, FFCLH/USP, 1972. (publicação original de 1968).

Uma Geografia Transversal e de travessias: o meio ambiente através dos territórios e das temporalidades. Georges e Claude Bertrand. Org. Messias Modesto dos Passos. Maringá: Ed. Massoni, 2007.

BHERING, I.G.A. Condomínios fechados: os espaços da segregação e as novas configurações do urbano. Dissertação de Mestrado. Belo Horizonte: UFMG, 2002.

BICUDO, P.M. Loteamentos fechados e condomínios deitados. In:Brasil: estudos sobre a dispersão urbana. Nestor Goulart Reis (org). p. 369-399. São Paulo: FAU/USP, 2007. 
BOLÒS Y CAPDEVILA, M. Problemática actual de los estudios de paisaje integrado. Revista de Geografia, vol 11, oㅡ 1-2, 1977. Disponível em www.raco.cat/index.php/RevistaGeografia/article/viewFile/45940/567766.

BORSDORF, A. Hacia La ciudad fragmentada. Tempranas estructuras segregadas em La ciudad latinoamericana. Scripta Nova, Revista Eletrônica de Geografia y Ciências Sociales, vol VII, nr. 146. Barcelona: Universidad de Barcelona, 2003. Disponível em www.ub.es/geocrit/sn/sn-146 (122).htm

BOTELHO, R.G.M. Bacias Hidrográficas Urbanas. In: Geomorfologia Urbana, Antônio José Teixeira Guerra (org), p. 71-116. Rio de Janeiro, Bertrand Brasil, 2011.

BRAGA, R. Cidades médias e aglomerações urbanas no Estado de São Paulo: novas estratégias de gestão territorial. Anais do X Encontro de Geógrafos da América Latina -20 a 26 de março de 2005. São Paulo: Universidade de São Paulo, 2005.

CAIADO, A.S.C.; PERILLO, S. Um olhar demográfico sobre o processo de dispersão urbana no Estado de São Paulo. Trabalho apresentado no XVI Encontro Nacional de Estudos Populacionais, realizado em Caxambu- MG - Brasil, de 29/9 a 03/10/2008. Disponível em www.abep.nepo.unicamp.br/ encontro2008/docspdf.

CAIADO, M.C.S. e PIRES, M.C.S. Expansão recente na Região Metropolitana de Campinas: dispersão e novas formas urbanas. In:Brasil: estudos sobre a dispersão urbana. Nestor Goulart Reis (org). p. 81-112. São Paulo: FAU/USP, 2007.

CAIADO, A.S.C.; SANTOS, S.M.M. Fim da dicotomia rural-urbano? Um olhar sobre os processos socioespaciais. In: São Paulo em Perspectiva, 17 (3-4): 115124. São Paulo: Fundação Seade, 2003.

CAIADO, M.C.S.; PIRES, M.C.S. Expansão recente na Região Metropolitana de Campinas: Dispersão e novas formas urbanas. In:Brasil: estudos sobre a dispersão urbana, p. 81-112. São Paulo: FAU/USP, 2007.

CAMPOS, N.; KRAHL, M.F.L. Territorialidade: Elo entre o espaço rural e o espaço urbano. In: Território, ambiente e políticas públicas espaciais. Marília Steinberger (org). Brasília: Paralelo 15 e LGE Editora, 2006.

CANDIDO, D.H. e NUNES, L.H. Influência da orografia na precipitação da área entre o Vale do Rio Tietê e a Serra da Mantiqueira. Geousp-Espaço e Tempo, no 24, p. 8-27. São Paulo: FFLCH/USP-Depto Geografia, 2008.

CARNEIRO, C.D.R. e SOUZA, J.J. Mapeamento Geomorfológico em escala de semidetalhe da região de Jundiaí-Atibaia. Revista Brasileira de Geomorfologia, no 2, p. 17-30. Campinas: Unicamp, 2003.

CASSETI, V. Ambiente e Apropriação do Relevo. São Paulo, Ed. Contexto, 1991.

CASTELLS, M.I. A sociedade em rede. São Paulo: Ed. Paz e Terra, 1999. 
CAVALHEIRO, F.; RUEDA, J.R.J.; JESUS, N. de. Compartimentação do meio físico da área da Serra do Japi - Jundiaí (SP) em zonas de fragilidade quanto à degradação. GEOUSP-Espaço e Tempo, № 11, pp.85-100. São Paulo: FFLCH/USP- Depto de Geografia, 2002.

CHOAY, F. O urbanismo. São Paulo: Ed. Perspectiva, 2002 (1르 ed. 1965).

CHORLEY, R.J. A geomorfologia e a Teoria dos Sistemas Gerais. Notícia Geomorfológica, vol 11, nr 21, pp 3-22. Campinas: 1971.

CHRISTOFOLETTI, A. Impactos no meio ambiente ocasionados pela urbanização no mundo tropical. In: O Novo mapa do Mundo - Natureza e Sociedade de hoje: uma leitura geográfica. Orgs. Souza, Maria Adélia \& Santos, Milton. São Paulo, p. 127-138, Hucitec, 1994.

Aplicabilidade do Conhecimento Geomorfológico nos Projetos de Planejamento. In: Geomorfologia: uma atualização de bases e conceitos. Org. Antônio José Teixeira Guerra e Sandra Baptista da Cunha. Rio de Janeiro, Bertrand Brasil, 2001.

COATES, D.R. Urban Geomorphology. Colorado: The geological Society of América, 1976.

COELHO, M.C.N. Impactos ambientais em áreas urbanas: teorias, conceitos e métodos de pesquisa. In: Impactos Ambientais urbanos no Brasil, Antonio José Teixeira Guerra e Sandra Baptista da Cunha (orgs). Rio de Janeiro: Bertrand Brasil, 2011. (1를 edição: 2000)

COELHO NETO, A.L. Hidrologia de Encosta na Interface com a Geomorfologia, In: Geomorfologia: uma atualização de bases e conceitos. Org. Antônio José Teixeira Guerra e Sandra Baptista da Cunha. Rio de Janeiro, Bertrand Brasil, 2001.

A interface florestal-urbana e os desastres naturais relacionados à água no macicço da Tijuca: desafios ao planejamento urbano numa perspectiva sócio-ambiental. Revista do Departamento de Geografia, № 16, p. 4660. São Paulo: FFLCH/USP-Depto Geografia, 2005.

COLTRINARI, L. A urbanização na bacia sedimentar de São Paulo: Itaim Paulista e Itaquera. In: Carlos, Ana Fani Alessandri; Oliveira, Ariovaldo Umbelino, orgs. Geografias das metrópoles, p. 167-180. São Paulo: Contexto, 2006.

CONTI, J.B. Clima e meio ambiente. São Paulo, Editora Atual, 1999.

Resgatando a "fisiologia da paisagem". Revista Depto Geografia/USP, 14. São Paulo: FFLCH/USP, 2001.

COSTA, H.S.de M (org) - Novas periferias metropolitanas - a expansão metropolitana em Belo Horizonte: dinâmica e especificidades no eixo sul - Belo Horizonte: C/Arte, 2006. 
Natureza e mercado imobiliário na redistribuição espacial da população metropolitana: notas a partir do eixo sul de Belo Horizonte. XIV Encontro Nacional de Estudos Populacionais. Caxambú: ABEP, 2004. Disponível em www.abep.nepo.unicamp.br

COSTA, H.S.M.; Monte-Mór, R.L.M. Expansão Metropolitana, dispersão urbana e condomínios horizontais na Região metropolitana de Belo Horizonte. In: Brasil: estudos sobre a dispersão urbana, p. 139-164. São Paulo: FAU/USP, 2007.

COSTA, L.M.S.A (org.). Rios e Paisagens Urbanas em cidades brasileiras. Rio de Janeiro: Viana \& Mosley, Ed. Prourb, 2006.

CUNHA, S.B. Canais Fluviais e a questão ambiental. In: A Questão Ambiental: diferentes abordagens, Sandra Baptista da Cunha e Antônio José Teixeira Guerra (orgs), p. 219-238. Rio de Janeiro, Bertrand Brasil, 2007.

DAVIS, W.M. The Geographical Cycle. Journal, London, 14, p.481-504, 1899.

DEBRASSI, T.M.F.B. Uma introdução à discussão da dispersão urbana na região de Sorocaba. In: Brasil: estudos sobre a dispersão urbana. Nestor Goulart Reis (org). p. 401-419. São Paulo: FAU/USP, 2007.

DEMATTEIS, G. Surburbanización y periurbanización: ciudades anglosajonas y ciudades latinas. In: MONCLUS, J. F. La ciudad dispersa: surburbanización y novas periferias. Barcelona: CCCB, 1998 Disponível em www.etsav.upe.es/personals/monclus/cursos2002/dematteis.htm.

DINES, M. Climatologia urbana e o desenho das cidades: Insumos para o planejamento da metrópole paulistana. São Paulo: FAU/USP, 1991.

DOMINGUES, A. Urbanização difusa em Portugal. In: Dispersão Urbana - Diálogo sobre pesquisas Brasil-Europa. In: Brasil: estudos sobre a dispersão urbana. Vol. Palestras, p. 15-231. São Paulo: FAU/USP, 2007.

DRAMSTAD, W.E., OLSON J.D. y FORMAN R.T.T. Landscape Ecology Principles in Landscape Architecture and Land-Use Planning. Cambridge, Massachusetts: Harvard University Graduate School of Design, 1996.

DREW, D. Processos interativos homem-meio ambiente. São Paulo, Bertrand Brasil, 1986.

EMPLASA - Empresa Paulista de Planejamento Metropolitano S/A. Rede Urbana e Regionalização do Estado de São Paulo. São Paulo: Emplasa, 2011.

FARAH, F. Habitação e encostas. São Paulo; IPT, 2003.

FAU/USP. Cidades Jardins; a busca do equilíbrio social e ambiental 1898-1998. 3" Bienal Internacional de Arquitetura, 1997. São Paulo: FAU/USP, 1998.

FELS, E. El hombre economizante como estructurador de la tierra. Barcelona: Ediciones Omega, 1955. 
. Geomorfologia Antropogenética. Boletim Geográfico, № 144, de 1958, p. 354-357. Rio de Janeiro: IBGE, 1958.

FINATI, R. Condomínios empresariais em áreas metropolitanas do Estado de São Paulo: uma nova estratégia imobiliária. In: Geousp - Espaço e Tempo. Edição Especial, pp 11-28. São Paulo: FFLCH/USP, 2009.

FISHMAN, R. Urban utopias in the Twentieth Century.Londres: MIT Press, 1982.

FONT, A. Dispersão e difusão na região metropolitana de Barcelona. In: Dispersão Urbana - Diálogo sobre pesquisas Brasil-Europa In: Brasil: estudos sobre a dispersão urbana. Nestor Goulart Reis. p. 61-73. São Paulo: FAU/USP, 2007.

FRANCO, M.A.R. Planejamento ambiental para a cidade sustentável. São Paulo: Anablume, 2000.

Desenho Ambiental: uma introdução à arquitetura da paisagem com o paradigma ecológico. São Paulo: Anablume, 1997.

FUNDAÇÃO SEADE. Sumário de dados do MSP, 1990. São Paulo: Fundação Seade, 1990.

FURLAN, S.A. Paisagens sustentáveis: São Paulo e sua cobertura vegetal. In: Geografias de São Paulo 2 - A metrópole do século XXI. Orgs. Carlos \& Oliveira. São Paulo: Contexto, 2004.

FUSALBA, J. P. El concepto de paisaje y su aplicación em El planeamiento territorial y ambiental. In: Geografia, tradições e perspectivas: interdisciplinaridade, meio ambiente e representações, pp 139-158. Orgs. Amália Inês Geraiges de Lemos e Emerson Galvani. Buenos Aires: CLACSO e São Paulo: Expressão Popular, 2009.

GODOY, J.F. (1826-1902). A província de São Paulo: trabalho estatístico, histórico e noticioso. Edição fac-simile de 1875. São Paulo: Imprensa Oficial do Estado de São Paulo: FUNDAP, 2007.

GONÇALVES, L.F.H \& GUERRA. Movimentos de massa na cidade de Petrópolis, Rio de Janeiro. In: Impactos ambientais urbanos no Brasil, Guerra, A.J. e Cunha, S.B (orgs), p. 189-252. Rio de Janeiro: Bertrand Brasil, 2011.

GOUDIE, A. The human impact on the natural environment. Oxford: Basil Blackwll, 1990.

GRAEFF, O.R. Licenciamento ambiental urbano. In: Geomorfologia Urbana, Antônio José Teixeira Guerra (org), p. 189-226. Rio de Janeiro, Bertrand Brasil, 2011.

GREGORY, K.J. A natureza da geografia física. Rio de Janeiro: Bertrand do Brasil, 1992.

GUATTARI, F. As três ecologias. São Paulo: Papirus, 1990.

GUERASIMOV, I. et al. La sociedad y el medio natural. Moscou, Progresso, 1983. 
GUERRA, A.J. e CUNHA, S.B (orgs). Impactos ambientais urbanos no Brasil. Rio de Janeiro: Bertrand Brasil, 2011.

GUERRA, A.J.T. Processos Erosivos nas Encostas. In: Geomorfologia: uma atualização de bases e conceitos. Org. Antônio José Teixeira Guerra e Sandra Baptista da Cunha. Rio de Janeiro, Bertrand Brasil, 2001.

Encostas e a questão ambiental. In: A Questão Ambiental: diferentes abordagens, Sandra Baptista da Cunha e Antônio José Teixeira Guerra (orgs), p.191-218. Rio de Janeiro, Bertrand Brasil, 2007.

. Encostas Urbanas. In: Geomorfologia Urbana, Antônio José Teixeira Guerra (org). Rio de Janeiro, Bertrand Brasil, 2011.

GUERRA, A.J.T. \& MARÇAL, M.S. Geomorfologia Ambiental. Rio de Janeiro: Bertrand Brasil, 2012.

HARVEY, D. Condição Pós-Moderna. São Paulo: Edições Loyola, 1989.

HONDA, W.S. Atributos que condicionam o desenvolvimento de loteamentos residenciais fechados. Dissertação (Mestrado), ESCOLA POLITÉCNICA /USP. São Paulo, EP/USP, 2008.

HOUGH, M. Naturaleza y ciudad: planificación urbana y procesos ecológicos. Barcelona: Gustavo Gili S. A., 1998. (1ª ed. 1995)

IBGE. Censo Demográfico de 2010. Disponível em www.ibge.gov.br.

IBGE. Tendências Demográficas: uma análise dos resultados da amostra do Censo Demográfico de 2000. Estudos e Pesquisas - Informações Demográficas Socioeconômicas, № 13. Rio de Janeiro: IBGE, 2004.

INDOVINA, F. La città diffusa. Veneza: DAEST, 1990.

La nuova dimensione urbana: L'arcipelago metropolitano, In: MARCELLONI, M. Questioni della città contemporânea. Milano: FrancoAngeli, 2005.

KING, L.C. A geomorfologia do Brasil Oriental. Revista Brasileira de Geomorfologia, 18 (2). Rio de Janeiro: IBGE, 1956.

LAMAS, J.M.R.G. Morfologia urbana e desenho da cidade. Lisboa: Fundação Calouste Gulbenkian, 2000 ( $1^{\underline{a}}$ ed. 1993)

LANGENBUCH, J.R. A estruturação da Grande São Paulo - Estudo de Geografia Urbana. Rio de Janeiro: IBGE, 1971.

LE CORBUSIER. Urbanismo. São Paulo: Martins Fontes, 1992 (1를 ed. 1925)

LARRABURE, S.P. O fenômeno da 2a. Residência: o caso do Rio Grande entre os estados de São Paulo e Minas Gerais. In: Geousp - Espaço e Tempo. Edição Especial, pp 93-105. São Paulo: FFLCH/USP, 2009. 
LAURIE, M. Introducion a la Arquitectura del Paisage. Barcelona: Gustavo Gilli, AS ,1983.

LEFF, Enrique. Ecologia y capital: racionalidad ambiental, democracia participativa y desarrollo sustentable. Cidade do México: Siglo Veintiuno, 1994. (1 ${ }^{\text {a }}$ ed. 1986)

Ecologia, Capital e Cultura. Blumenau: Edifurb, 2000.

LENCIONI, Sandra. Da cidade e sua região à cidade-região. In: Silva, José Borzacchiello da; Lima, Luiz Cruz; Elias, Denise, orgs. Panorama da geografia brasileira. São Paulo: Annablume, 2006.

Uma nova determinação do urbano: o desenvolvimento do processo de metropolização do espaço. In: Carlos, Ana Fani Alessandri; Lemos, Amélia Inês Geraiges Lemos, orgs. Dilemas urbanos : novas abordagens sobre a cidade. São Paulo: Contexto, 2003.

Reestruturação urbano-industrial no Estado de São Paulo: a região da metrópole desconcentrada. In: Santos, Milton; Souza, Maria Adélia Aparecida de; Silveira, Maria Laura, orgs. Território: globalização e fragmentação, 332 p.. São Paulo: Hucitec/Annablume, 2002.

LIMONAD, E. Urbanização dispersa: mais uma forma de expressão urbana? Revista Formação, no 14, vol. 1. Disponível em www4.fct.unesp.br/pos/geo/revista/artigos. Acessado em novembro 2008.

No todo acaba en Los Angeles ¿Un nuevo paradigma: entre la urbanización concentrada y dispersa? In Revista Bibliográfica de Geografía y Ciencias Sociales, vol XII, no 734. Barcelona: Universidad de Barcelona, 2007.

. "Você já foi à Bahia, nêga? Não! Então vá! Antes que acabe..." Planejamento, urbanização e turismo no litoral do nordeste brasileiro, tendências e perspectivas. Scripta Nova - Revista Electrónica de Geografía y Ciencias Sociales. Vol. XII, nº 270 (55). Barcelona: Universidad de Barcelona, 2008.

LOMBARDO, M.A. Ilha de calor nas metrópoles: o exemplo de São Paulo. São Paulo: Hucitec, 1985.

LÓPEZ, C.C. O vento. In: Os climas na cidade de São Paulo: teoria e prática. Org. José Roberto Tarifa e Tarik R. de Azevedo. São Paulo: USP, 2001.

LUHMANN, N. Sociologia como teoria dos sistemas sociais (1970). In: O pensamento de Niklas Luhmann. José Manuel Santos (org). Covilhã/Portugal: Universidade da Beira Interior, 2005. Disponível em www.lusosofia.net. Acesso em $30 / 07 / 2011$.

LYLE, J.T. Design for Human Ecosystems. New York: Van Nostrand Reinhold, 1985.

MAGALHÃES, F.N.C.; LINHARES, L.R.F. e MONTE-MÓR, R.L.M - Urbanização extensiva e desconcentração espacial no Eixo Sul do entorno metropolitano de 
BH. In:Novas Periferia Urbanas - a expansão metropolitana em Belo Horizonte. Heloísa Soares M.Costa (org). Belo Horizonte: C/Arte, 2006.

MARCONDES, M.J.A. Cidade e natureza: proteção dos mananciais e exclusão social. São Paulo: Studio Nobel - EDUSP, 1999.

MARQUES, J.S. Ciência Geomorfológica. In: Geomorfologia: uma atualização de bases e conceitos. Org. Antônio José Teixeira Guerra e Sandra Baptista da Cunha. Rio de Janeiro, Bertrand Brasil, 2001.

MARTINS, A.A.C. Novos pólos territoriais motivados pela dispersão urbana. 0 cenário do Distrito Federal. Vitrúvius-Arquitextos,077.04ano 07, out 2006. Disponível em www.vitruvius.com.br.

MASCARÓ, L.E.A.R. Vegetação Urbana. Porto Alegre: L.Mascaró \& J. Mascaró, 2002.

MCHARG, I.L. Proyectar com la naturaleza. Barcelona: Gustavo Gili, 2000. (1aㅡ ed.1967)

MENDONÇA, J.G. Segregação e mobilidade residencial na região Metropolitana de Belo Horizonte. Tese de doutorado. Rio de Janeiro: UFRJ-IPPUR, 2002.

MENEGASSE Velásquez, L.N.. Efeitos da urbanização sobre o sistema hidrológico: aspecto da recarga no aqüífero freático e escoamento superficial. Tese de doutorado. São Paulo: IGC/USP, 1996.

MEYER, R.M.P. et al. São Paulo Metrópole. São Paulo: Edusp, 2004.

MEYER, R.M.P. O urbanismo: entre a cidade e o território. SBPC - Ciência e Cultura. Vol. 58, no 1. São Paulo: Jan-Mar. 2006. Disponível em: http://cienciaecultura.bvs.br/scielo.php.

MITICA, H. Tecidos urbanos dispersos na Região Metropolitana de Campinas. In:Brasil: estudos sobre a dispersão urbana. Nestor Goulart Reis (org), p. 77-91. São Paulo: FAU/USP, 2007.

MONCLÚS, F.J. Suburbanizacion ynuevas periferias - Perspectivas Geográficourbanísticas. In: (org) La Ciudad Dispersa. Barcelona, Centre de Cultura Contemporânea de Barcelona, 1998, pp. 143-167.

MONTE-MÓR, R.L. O que é o urbano, no mundo contemporâneo. 14p. (Texto para discussão ; 281). Belo Horizonte: UFMG/Cedeplar, 2006.

"Urbanização extensiva e lógicas do povoamento: Um olhar ambiental". In: Milton Santos, Maria Adélia A. de Souza e Maria Laura da Silveira. Território: Globalização e fragmentação. São Paulo, Hucitec/Anpur, 1994.

MONTEIRO, C.A.F. Teoria e Clima Urbano. São Paulo: IGEOG/USP, 1976.

Geossistemas: a história de uma procura. São Paulo: Contexto, 
MUNFORD, L. The natural history of urbanization. In: Man's Role in Changing the face of the Earth. Sauer; Bates; Munford (orgs), p. 382-400. Chicago: University of Chicago, 1956.

NIR, D. Man, a geomorphological agent: an introduction to anthropic geomorphology. Jerusalém: Ketem Pub. House, 1983.

NUCCI, J.C. \& CAVALHEIRO, F. Cobertura vegetal em áreas urbanas - Conceito e Método. Geousp - espaço e tempo, № 6. São Paulo: FFLCH/USP, 1999.

NUCCI, J.C. Qualidade Ambiental e Adensamento urbano. São Paulo: Humanitas, FFLCH/USP, 2001.

OKE, T.R. City Size ande the urban heat island.Atmospheric Environment. Vol $7 p$. 769-779, 1973.

.Evapotranspiration in urban areas and its implications for urban climate planning. In: Conference teaching the teachers on building climatology, 1973. Stockholm: The national Swedish Institute for Building Research, 1973b

OLIVEIRA JORGE, M.C. Geomorfologia Urbana: Conceitos, Metodologias e Teorias. In: Geomorfologia Urbana, Antônio José Teixeira Guerra (org). Rio de Janeiro, Bertrand Brasil, 2011.

OSEKI, J.H. \& ESTEVAM, A.R. A fluvialidade em rios paulistas. In: Rios e Paisagens Urbanas em cidades brasileiras, Costa, L.M.S.A (org). Rio de Janeiro: Viana \& Mosley, Ed. Prourb, 2006.

OTTONI, D.A.B. Cidades-Jardins de amanhã. São Paulo: Hucitec, 1996.

PEIXOTO, M.D.C. Licenciamento Ambiental e expansão urbana: um estudo em Nova Lima, Região Metropolitana de Belo Horizonte/MG. Dissertação de Mestrado. Belo Horizonte: UFMG, 2005.

PELLEGRINO, P.R.M; GUEDES,P.P.; PIRILLO,F.C.; FERNANDES,S.A. A paisagem da borda: uma estratégia para a condução das águas, da biodiversidade e das pessoas. In: Rios e Paisagens Urbanas em cidades brasileiras, Costa, L.M.S.A (org). Rio de Janeiro: Viana \& Mosley, Ed. Prourb, 2006.

PELOGGIA, A. O Homem e o Ambiente Geológico: Geologia, Sociedade e Ocupação Urbana no M. S. Paulo. São Paulo:Xamã Editora, 1998.

PENCK, A. Morphological analysis of land forms: a contribuition to physical geology. London: Macmillan, 1953.

PENTEADO ORELLANA, M.M. A geomorfologia no contexto social. Geomorfologia e planejamento. São Paulo, IGEOP-USP, 1981.

PEREIRA, R.R. Planejamento Territorial: suas implicações para a promoção da saúde e da justiça ambiental. In: Geousp - Espaço e Tempo, nr 26, pp 19-27. São Paulo: FFLCH/USP, 2009. 
PETRONE, P. São Paulo no século XX. In: A cidade de São Paulo: estudos de geografia urbana. Org. Aroldo de Azevedo,v. II, cap. III. São Paulo: Cia Editora Nacional, 1958.

PINTO, C. R. Mairiporã: perifização e conflitos ambientais na Região

Metropolitana de São Paulo. Dissertação de Mestrado: São Paulo: Universidade Presbiteriana Mackenzie, 2007.

PINTO-CORREIA, T; CANCELA D'ABREU, A; OLIVEIRA, R. Identificação de unidades de paisagem: metodologia aplicada a Portugal Continental. Finisterra, XXXVI, 72, 2001, pp. 195-206.

PITOMBEIRA, S.C. Algumas considerações em torno do zoneamento. In: Temas de Direito Urbanístico 5. Coord. M.R.T. Dissinger. São Paulo Imprensa Oficial do Estado e Ministério Público do Estado de SP, 2007.

PORTAS, N. Contar uma história, propor algumas hipóteses de trabalho e a reflexão.In: Dispersão Urbana - Diálogo sobre pesquisas Brasil-Europa In:Brasil: estudos sobre a dispersão urbana. Nestor Goulart Reis (org.), p. 49-58. São Paulo: FAU/USP, 2007.

PRANDINI, F.L.et al. Atuação da cobertura vegetal na estabilização de encostas. Uma resenha crítica. In: Anais II Congresso Brasileiro de Florestas Tropicais Mossoró. São Paulo: IPT, 1976.

QUEVEDO NETO, P.S. Dinâmica e qualidade da paisagem na área de transição urbano-rural. In: Geografia Rio Claro, v. 31, n. 2, p. 257-268, maio/ago. 2006. Rio Claro: FFLCH, 2006.

REBOUÇAS, A.C.; BRAGA, B.; TUNDISI, J.G. Águas doces no Brasil. São Paulo: Escrituras, 1999.

REBOUÇAS, A.C. Condições de uso e proteção das águas subterrâneas. In: Problemas Geológicos e Geotécnicos na Região Metropolitana de São Paulo,p. 7787. São Paulo: ABGE/IPT, 1992.

Águas subterrâneas. In: Águas doces no Brasil. Rebouças, A C.; Braga, B.; Tundisi, J. G.,p. 117-151. São Paulo: Escrituras, 1999.

REIS, N.G. Sobre a dispersão urbana em São Paulo. In: Dispersão Urbana Diálogo sobre pesquisas Brasil-Europa In:Brasil: estudos sobre a dispersão urbana, p. 35-48. São Paulo: FAU/USP, 2007.

REIS, N.G. (org) - Notas sobre a urbanização dispersa e novas formas de tecido urbano. São Paulo: Via das Artes, 2006.

(org) - Sobre dispersa urbana. São Paulo: Via das Artes, 2009.

RODRIGUES, C. Urbanização e intervenções no meio físico na borda da Bacia Sedimentar de São Paulo: uma abordagem geomorfológica. Dissertação de mestrado. São Paulo: Depto Geografia/FFLCH/USP, 1990. 
Qualidade Ambiental Urbana: Como avaliar? In: Rev. Depto. Geografia. São Paulo, n. 11, FFLCH-USP, 1997.

A teoria geossistêmica e sua contribuição aos estudos geográficos e ambientais. Revista do Depto de Geografia, 14, 69-77. São Paulo: FFLCH/USP, 2001.

Morfologia original e morfologia antropogênica na definição de unidades espaciais de planejamento urbano: exemplo na metrópole paulista. Revista do Depto de Geografia, 17, pp 101-101. São Paulo: FFLCH/USP, 2005.

ROHDE, G.M. Epistemologia Ambiental. Uma abordagem filosófica-científica sobre a efetuação humana alopoiética. Porto Alegre, EDIPUCRS, 1996.

ROSS, J.L.S. A qualidade da água subterrânea no espaço urbano da Grande São Paulo. Dissertação de mestrado. São Paulo, FFLCH-USP, 1981.

. Análises e sínteses na abordagem geográfica pelo planejamento ambiental. In: Revista do Departamento de Geografia, no ${ }^{-}$9.. São Paulo: FFLCH/USP-Depto de Geografia, 1995.

2000.

Geomorfologia, Ambiente e Planejamento. São Paulo, Contexto,

Geomorfologia aplicada ais EIA-RIMA. In: Geomorfologia e Meio Ambiente. Rio de Janeiro: Bertrand Brasil, 2000a.

. Geomorfologia Ambiental. In: Geomorfologia do Brasil, Sandra Baptista da Cunha e Antonio José Teixeira Guerra (orgs), p. 351-388. Rio de Janeiro: Bertrand Brasil, 2000b.

. Ecogeografia do Brasil: subsídios para o planejamento ambiental. São Paulo: Oficina de Textos, 2006.

Avaliação do impacto humano da urbanização em sistemas hidrogeomorfológicos. Desenvolvimento e aplicação de metodologia na Grande São Paulo. In: Revista do Departamento de Geografia, № 20. São Paulo: FFLCH/USPDepto Geografia, 2010.

ROSS, J.L.S.; MOROZ, I.C. Mapa Geomorfológico do Estado de São Paulo. In: Revista do Departamento de Geografia, № 10. São Paulo: FFLCH/USP-Depto Geografia, 1996.

ROSS, J.L.S.; DEL PRETTE, M.E. Recursos hídricos e as bacias hidrográficas: âncoras do planejamento e gestão ambiental. In: Revista do Departamento de Geografia, № 12. São Paulo: FFLCH/USP-Depto Geografia, 1998.

ROUGERIE, G. \& BEROUTCHACHVILI, N. Géosystèmes et Paysages: Bilan et methodes. Paris: Armand Colin Éditeur, 1991.

SABATÉ, J. Proyecto Territorial. In: La Práctica del Urbanismo. Luis Moya (coord), Capítulo 7, p.207-236. Madri: Editorial Síntesis, 2009. 
SANTOS, Á.R.; NAKAZAWA, V.A. Erosão e assoreamento na RMSP. In: Problemas Geológicos e Geotécnicos na RMSP. São Paulo: p. 177-194, IPT, 1992.

SANTOS, M. Espaço e Sociedade. São Paulo: Vozes, 1982.

. Metamorfoses do espaço habitado. São Paulo: Hucitec, 1988.

Paulo: Nobel, 1990.

Metrópole corporativa fragmentada: o caso de São Paulo. São 1992: A redescoberta da natureza. São Paulo: IGEOG/USP, 1992.

. O Retorno do Território. In: Território, Globalização e Fragmentação. Orgs. M. Santos, Maria Adélia Souza e Maria Laura Silveira. São Paulo: Hucitec, 1994.

A natureza do espaço: técnica e tempo; razão e emoção. São Paulo: Hucitec, 1999.

Da Totalidade ao Lugar. São Paulo: Edusp, 2012.

SÃO PAULO, Governo do Estado. O Desafio Metropolitano. Série: Documentos 1. Secretaria dos Negócios Metropolitanos. São Paulo: EMPLASA, 1976.

SAUER, C.O. The Agency of the man on the Earth. In: Man's Role in Changing the face of the Earth. Sauer; Bates; Munford (orgs), p. 49-69. Chicago: University of Chicago, 1956.

SCHUTZER, J.G. Cidade e Meio Ambiente: a apropriação do relevo no desenho ambiental urbano. Dissertação de Mestrado. São Paulo: FAU/USP, 2005.

Cidade e Meio Ambiente: a apropriação do relevo no desenho ambiental urbano. São Paulo: Edusp, 2012.

SEABRA, O. Os meandros dos rios nos meandros do poder - Tietê e Pinheiros: valorização dos rios e das várzeas na cidade de São Paulo. - Tese de doutorado. São Paulo: FFLCH/USP, 1987.

SECCHI, B. - Primeira Lição de Urbanismo. São Paulo: Perspectiva, 2006.

A cidade do Século XXI. São Paulo: Perspectiva, 2009.

SILVA, J.P \& RODRIGUES, C. Expansão Urbana e evolução geomorfológica em remansos de reservatórios: análise comparativa de duas bacias hidrográficas em Guarapiranga, São Paulo. VI Simpósio Nacional de Geomorfologia. Goiania. 2006.

SOBRAL, H.R. O meio ambiente e a cidade de São Paulo. São Paulo: Makron Books, 1996.

SÓCRATES, J.R.; GROSTEIN, M. D.; TANAKA, M. A cidade invade as águas. Qual a questão dos mananciais. São Paulo: FAU/USP, 1985. 
SOCTCHAVA, V.B. O estudo dos geosistemas. Métodos em questão, nr 6. São Paulo: Depto Geografia/USP, 1977.

Por uma teoria de classificação geossistêmica da vida terrestre. Biogeografia, nr 14. São Paulo: Instituto de Geografia/USP, 1978.

SOJA, E.W. Geografias Pós-Modernas: a reafirmação do espaço na teoria social crítica. Rio de Janeiro: Jorge Zahar Editor, 1989.

O Desenvolvimento Metropolitano Pós-Moderno nos EUA: virando Los Angeles pelo avesso. In: Território, Globalização e Fragmentação. Orgs. M. Santos, Maria Adélia Souza e Maria Laura Silveira. São Paulo: Hucitec, 1994.

: Blackwell Pub., 2004, c2000.

Postmetropolis : critical studies of cities and regions. Malden, MA

SOUZA, M.B.; MARIANO, Z.F. Geografia Física e a questão ambiental no Brasil. Geousp - Espaço e Tempo, 23, PP. 77-98. São Paulo: FFLCH/USP,2008.

SOUZA, M.A.A. A identidade da Metrópole: a verticalização em São Paulo. São Paulo: Hucitec, 1994.

Cidades Médias e Desenvolvimento Industrial - uma proposta de descentralização matropolitana. Série Estudos e Pesquisas, 17 - Secretaria de Economia e Planejamento do Estado de São Paulo. São Paulo: SEPLAN, 1978.

SPIRN, A.W. O Jardim de Granito: a natureza no desenho da cidade. São Paulo: Edusp, 1995.

SPORL, A.; SEABRA, O.C.L. - A Lei de Proteção aos mananciais $\mathbf{x}$ a prática social de ocupação da Bacia do Guarapiranga. In: Revista do Departamento de Geografia. São Paulo: n. 11, FFLCH-USP, 1997.

SPÓSITO, M.E.B. A Questão Cidade-Campo: perspectivas a partir da cidade. In: Cidade e Campo: Relações e contradições entre o urbano e rural, Sposito, M.E.B e Whitacker, A.M., pp. 111-130. São Paulo: Expressão Popular, 2006.

Novas formas de produção do espaço urbano no estado de São Paulo. In: Brasil - estudos sobre dispersão urbana. Nestor Goulart Reis (org.), p. 728. São Paulo: FAU/USP, 2007.

Descontinuidades territoriais e novas morfologias urbanas no estado de São Paulo. In: Dispersão Urbana - Diálogo sobre pesquisas BrasilEuropa. In:Brasil: estudos sobre a dispersão urbana, p. 93-109. São Paulo: FAU/USP, 2007.

STEINBERGER, M. e AMADO, T.M. O espaço Urbano no Zoneamento Econômico Ecológico: Esboço metodológico. In: Território, ambientte e políticas públicas espaciais. Marília Steinberger et alli. Brasília: Paralelo 15 e LGE Editora, 2006. 
STOCKINGER, G. Sistemas Sociais - A teoria Sociológica de Niklas Luhmann. Robertexto.com, Portal de Recursos para estudantes. Textos de Sociologia. Disponível em www.robertextos.com. Acesso em 28/06/2011. Disponivel em PreTextos, desde 22/12/1997.

TANAKA, M.M.S. São José dos Campos: Áreas urbanizadas dispersas 1970 a 2000. In:Brasil: estudos sobre a dispersão urbana. Nestor Goulart Reis (org),p. 2980. São Paulo: FAU/USP, 2007.

TARIFA, J.R. \& AZEVEDO, T.R. (orgs) Os climas na cidade de São Paulo: teoria e prática. São Paulo: USP, 2001.

TARIFA, J.R. \& ARMANI, Gustavo. Os Climas "Naturais", In: Os climas na cidade de São Paulo: teoria e prática. Org. José Roberto Tarifa e Tarik R. de Azevedo. São Paulo: USP, 2001.

.Os Climas "Urbanos", In: Os climas na cidade de São Paulo: teoria e prática. Org. José Roberto Tarifa e Tarik R. de Azevedo. São Paulo: USP, 2001.

TATSCH, J.D. Evidências do efeito de urbanização sobre a temperatura em Campinas e Ribeirão Preto - SP. In: XV CBMET: Anais Rio de Janeiro: Sociedade Brasileira de Meteorologia, 2008. Trabalho de evento. Rio de Janeiro: XV CBMET, 2008.

TAUK, S.M. Análise ambiental: uma visão multidisciplinar. São Paulo, UNESPFAPESP, 1991.

THOMAS, W.L. (Ed). Man's Role in Changing the face of the Earth. Wernner-gren Foundation. Chicago: University of Chicago, 1956.

TINEU, R. Os efeitos do espraiamento das industrias da Região Metropolitana de São Paulo sobre o território do interior paulista. In: Geousp - Espaço e Tempo. Edição Especial, pp 127-142 . São Paulo: FFLCH/USP, 2009.

TREVISAN, F.L. e PAES, M.T.D. Conservação ambiental e Urbanização. As contradições socio-espaciais na área de proteção municipal de Campinas. Revista Terra Livre, oㅡ 32, p.31-46. São Paulo: AGB, 2009.

TRICART, J. Ecodinâmica. Supren, Fund. Rio de Janeiro, IBGE, 1977.

.Principés et Méthods de la Géomorphologie. Paris: Masson, 1965.

TRINDADE JÚNIOR, S.C. A cidade dispersa: os novos espaços de assentamentos em Belém e a reestruturação metropolitana. Tese de Doutorado, FFLCH/USP. São Paulo: FFLCH, 1998.

TROPPMAIR, H. Ecossistemas e Geossistemas do Estado de São Paulo. Boletim de Geografia Teorética, vol. 13, nr 25, pp 27-36,. Rio Claro: UNESP, 1983

VENTURI, L.A.B. Recurso Natural: a construção de um conceito. Geouspespaço e Tempo, no 20, p. 09-17. São Paulo: FFLCH/USP-Depto Geografia, 2006. 
VILLAÇA, F. Espaço intra-urbano no Brasil. São Paulo: Studio Nobel, 1998.

VITTE, A.C. Os fundamentos Metodológicos da Geomorfologia e sua Influência no Desenvolvimento das Ciências da Terra. In: Reflexões sobre a Geografia Física no Brasil. Antonio Carlos Vitte e Antonio José Teixeira Guerra (orgs), p.23-48. Rio de Janeiro: Bertrand Brasil, 2011.

WAIBEL, L. Capítulos de Geografia Tropical e do Brasil. Rio de Janeiro: IBGE, 1958.

WENDEL, H. A cidade e a natureza: a apropriação, a valorização e a sofisticação da natureza nos empreendimentos imobiliários de alto padrão em São Paulo. Geousp-Espaço e Tempo, no 20, p. 65-77. São Paulo: FFLCH/USPDepto Geografia, 2006.

Cartografia

GOOGLE EARTH 5.0. Disponível em: http://earth.google.comm/. Acesso de 2009 a 2012.

IPT/SP. Carta de aptidão física do assentamento urbano - Cartografia geotécnica aplicada ao planejamento na Grande São Paulo. São Paulo: IPTSHDU-EMPLASA, 1990.

IPT/SP. Mapa Geológico do Estado de São Paulo (1:500.000). São Paulo: IPT, 1981a.

IPT/SP. Mapa Geomorfológico do Estado de São Paulo (1:500.000). São Paulo: IPT, 1981b.

EMPLASA. Hipsometria do Estado de São Paulo - 1982 (1:1.000.000). São Paulo: Emplasa, 1982. 